MACIR BERNARDO DE OLIVEIRA

\title{
A UTILIZAÇÃO DA TECNOLOGIA DA INFORMAÇÃO E A CRIAÇÃO DE VALOR NAS ESTRATÉGIAS DE NEGÓCIOS NA INDÚSTRIA DA SAÚDE
}

São Paulo

2008 
MACIR BERNARDO DE OLIVEIRA

\section{A UTILIZAÇÃO DA TECNOLOGIA DA INFORMAÇÃO E A CRIAÇÃO DE VALOR NAS ESTRATÉGIAS DE NEGÓCIOS NA INDÚSTRIA DA SAÚDE}

Tese apresentada à Escola Politécnica da Universidade de São Paulo para obtenção do título de Doutor em Engenharia

São Paulo 
MACIR BERNARDO DE OLIVEIRA

\section{A UTILIZAÇÃO DA TECNOLOGIA DA INFORMAÇÃO E A CRIAÇÃO DE VALOR NAS ESTRATÉGIAS DE NEGÓCIOS NA INDÚSTRIA DA SAÚDE}

Tese apresentada à Escola

Politécnica da Universidade de São

Paulo para obtenção do título de

Doutor em Engenharia

Área de Concentração

Engenharia da Produção

Orientador:

Prof. Dr. Fernando J. B. Laurindo

São Paulo

2008 
Este exemplar foi revisado e alterado em relação à versão original, sob responsabilidade única do autor e com a anuência de seu orientador.

São Paulo, de janeiro de 2008.

Assinatura do autor

Assinatura do orientador

FICHA CATALOGRÁFICA

Oliveira, Macir Bernardo de

A utilização da tecnologia da informação e a criação de valor nas estratégias de negócios na indústria da saúde I M.B. de Oliveira. -- ed.rev. -- São Paulo, 2008.

$388 \mathrm{p}$.

Tese (Doutorado) - Escola Politécnica da Universidade de São Paulo. Departamento de Engenharia de Produção.

1. Operações de serviços 2. Tecnologia da informação 3. Estratégias de negócios 4 . Criação de valor 5 . Indústria da saúde $\mathbf{I}$. Universidade de São Paulo. Escola Politécnica. Departamento de Engenharia de Produção II. t. 
Dedico aos meus pais.

Pela orientação, quanto aos caminhos.

Pela liberdade, quanto às escolhas. 


\section{AGRADECIMENTOS}

Ao professor Fernando Laurindo, pela confiança depositada desde o início, a qual permitiu esta jornada de conhecimento, que, juntamente como sua orientação segura e esclarecedora, ampliou meus horizontes.

Aos meus professores da produção POLI-USP, em especial do GTI (Grupo de Tecnologia da Informação), pelas aulas, pelos debates, pelas idéias e pelos bons momentos de aprendizado.

Aos professores Mitsuru Yanaze e Márcia Terra (banca de qualificação) pela atenção e pelas enriquecedoras recomendações que, certamente, tornaram mais suave esta aventura ao novo saber.

Aos amigos, Denise Curi, pelo apoio para o início deste projeto e Antônio Tonini e Gilberto Perez por compartilharem longas conversas pelos caminhos da metodologia.

Aos executivos e suas respectivas empresas (estudo de caso), que gentil e pacientemente despenderam horas de conversas, relatando como criam valor utilizando a TI.

Aos que, de alguma forma apoiaram este trabalho, ensinando, discutindo, opinando, informando e, enfim, compartilhando tantos momentos difíceis e, ao mesmo tempo, felizes: um grande abraço.

Também agradeço e peço desculpas aos mais próximos, por sacrificarem tantos momentos por minha causa e pelas inúmeras vezes que ouviram: "agora não".

A todos, meus sinceros agradecimentos, por ajudarem a construir o alicerce de uma formação acadêmica. 
"Quanto mais eu treino, mais sorte eu tenho!" Gary Player 


\section{RESUMO}

O objetivo deste trabalho é analisar situações em que a tecnologia da informação (TI) contribui para o desenvolvimento de estratégias de negócios, envolvendo interrelação e cooperação entre empresas no setor da saúde. O estudo baseia-se na análise das operações de serviços em uma rede de valor (grupo determinado de empresas) no setor da saúde. Esta análise é realizada por meio de técnicas estratégicas, buscando compreender como e por que a tecnologia da informação pode ser utilizada como um fator diferenciador e decisivo na escolha de estratégias de negócios. As estratégias de negócios obtêm vantagem competitiva na medida em que criam valor, aumentando a eficiência e/ou eficácia das empresas. Este valor pode ser mais bem percebido e até aferido ao se analisar as interações em uma rede de valor em que a empresa está inserida. O levantamento de dados deste trabalho tem respaldo no método exploratório cuja função, entre outras, é obter informações sobre possibilidades práticas de realização de pesquisas em situações de vida real. Utilizam-se, ainda, de levantamento bibliográfico, pesquisas de documentos e dados em geral, tendo como fonte principal um estudo de caso múltiplo, englobando empresas de uma rede de valor no setor da saúde. Os resultados da pesquisa demonstram que o uso da TI permite ampliar os pontos fortes da empresa, além de suas oportunidades no ambiente externo e propicia também formas alternativas de atuação das empresas no mercado, gerando possibilidades para o desenvolvimento de novas estratégias ou modelos de negócios.

Palavras-Chave: Operações de Serviços. Tecnologia da Informação. Estratégia de Negócios. Criação de Valor. Indústria da Saúde. 


\begin{abstract}
The purpose of this study is the analysis of cases where information technology (IT) helps the development of business strategies. It involves the inter-relation and cooperation among companies in the health care sector. This study is based on the analysis of service operations in the health care sector (a particular group of companies) by means of strategic techniques. It addresses the reasons why information technology may be used as a decisive differentiating factor in the selection of business strategies. Business strategies result in competitive advantages as they create value and thus increase business efficiency and/or effectiveness. Such value may be perceived and measured when the chain of values, the value system, the supply chain, and most of all, the network of values where the company is encased, are analyzed. Data collection for this study is supported by the exploratory method whose function,among others, is getting information about the practical possibilities of carrying out researches in real life conditions. This study also makes use of bibliographic research, documents research and generic data. The main source of data is a multi-case study encompassing health care enterprises. Data obtained in this research show that IT application may amplify the company strong points as well as its business opportunities in the market. It also opens up alternative forms of market actuation and raises new possibilities for the development of new strategies and business models.
\end{abstract}

Key-words: Service Operations. Information technology. Business Strategy. Creation of Value. Health Care Industry. 


\section{LISTA DE FIGURAS}

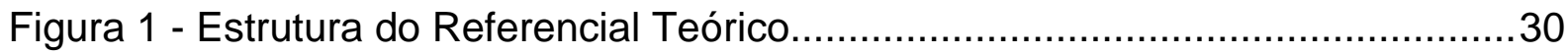

Figura 2 - Modelo de Processo de Serviço ……................................................ 38

Figura 3 - Formas de Utilização da Internet nos Negócios.......................................59

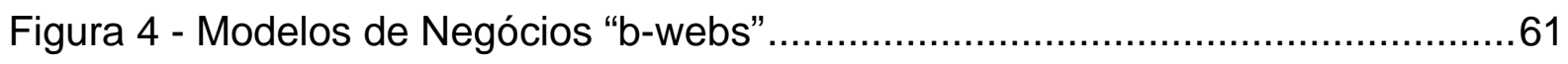

Figura 5 - Determinantes da Vantagem Competitiva Nacional ................................81

Figura 6 - Forças que Dirigem a Concorrência na Indústria .....................................83

Figura 7 - A Cadeia de Valores Genérica .............................................................99

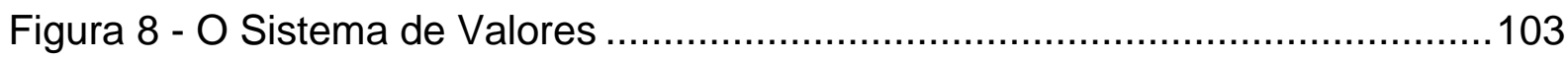

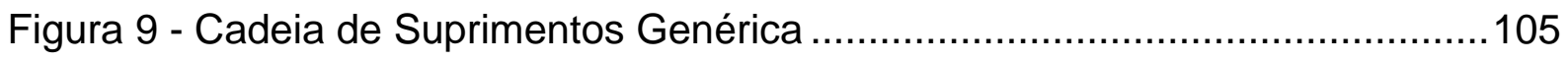

Figura 10 - Participantes e Relacionamento na Cadeia de Valor na Saúde.............116

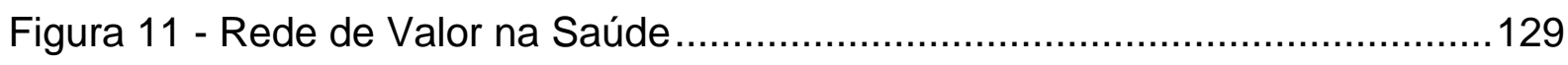

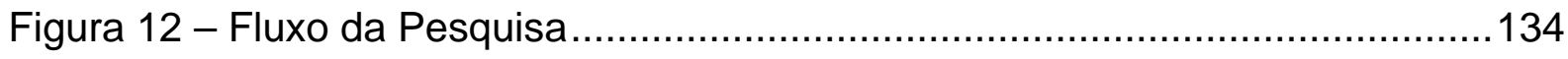

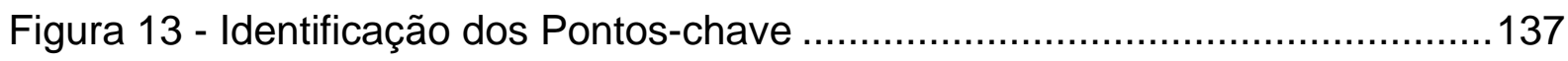

Figura 14 - Síntese das Contribuições da TI em Serviços ......................................141

Figura 15 - Avaliação das Contribuições da TI .....................................................143

Figura 16 - Matriz de Criação de Valor (Eficácia e Eficiência) em Operações de

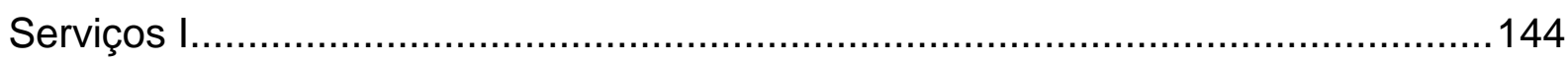

Figura 17 - Modelo Decorrente da Análise Qualitativa ........................................144

Figura 18 - Matriz de Criação de Valor (Eficácia e Eficiência) em Operações de

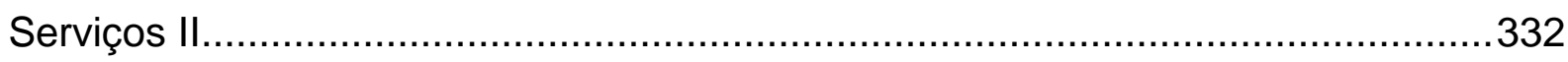

Figura 19 - Rede de Valor na Saúde e o Uso da TI ..............................................341 


\section{LISTA DE QUADROS}

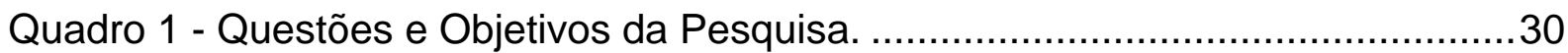

Quadro 2 - Principais Características dos tipos de "b-webs"...................................63 Quadro 3 - Estratégias de Mediação e Direcionadores de Negócios, utilizando a TI. .65

Quadro 4 - Formas de Reação Competitiva em Operações de Serviços..................67

Quadro 5 - Etapas e Procedimentos da Pesquisa...............................................136

Quadro 6 - Contribuições da TI nas Operações de Serviço na Saúde.....................140

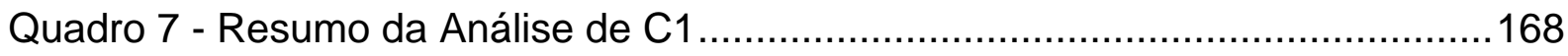

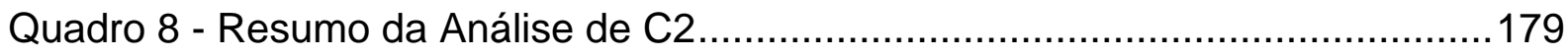

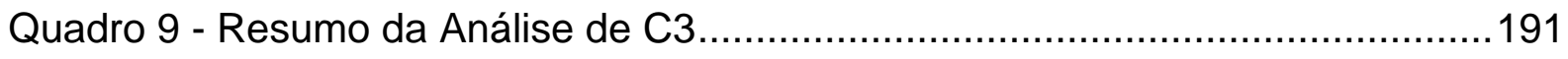

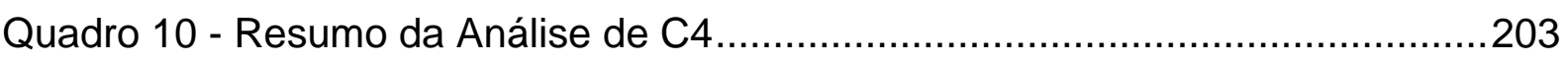

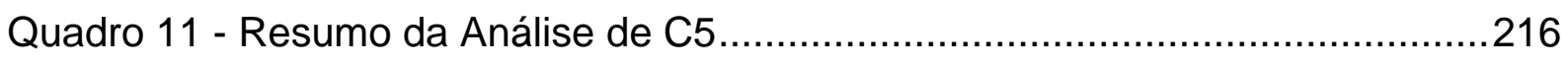

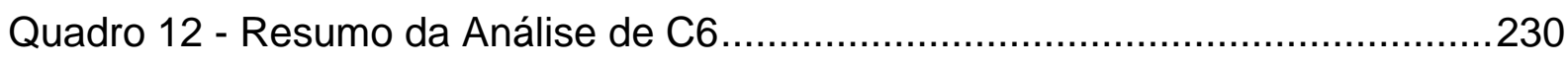

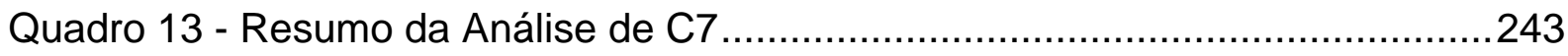

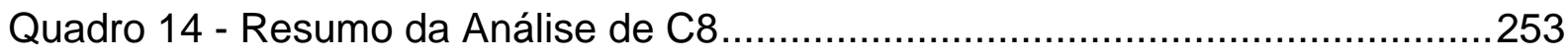

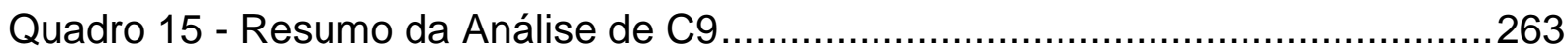

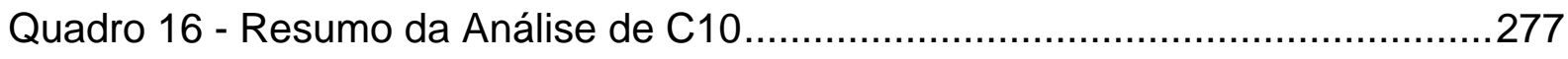

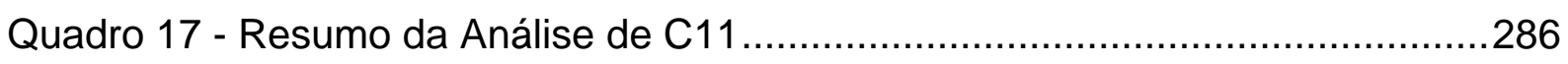

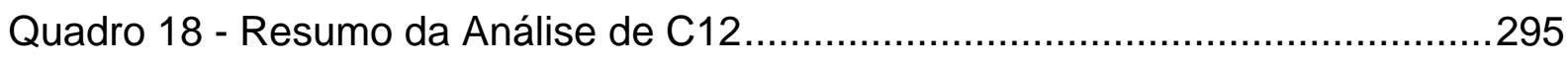

Quadro 19 - Resumo da Análise de C13 .........................................................

Quadro 20 - Resumo da Análise de C14 .........................................................

Quadro 21 - Síntese da Análise dos Casos.................................................................

Quadro 22 - Análise Geral dos Casos - Tabela Consolidada................................324

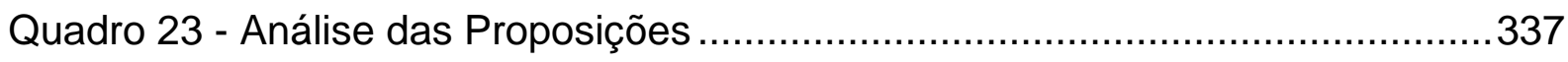

Quadro 24 - Formas de Utilizar a TI que Concorrem Entre Si ou que se

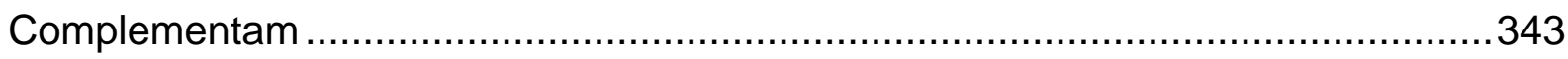

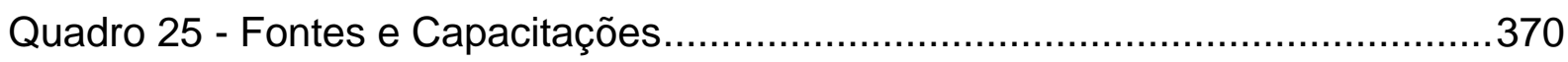

Quadro 26 - Direcionadores de Negócios Utilizando a TI ....................................373 


\section{LISTA DE GRÁFICOS}

Gráfico 1 - Análise da Eficácia nas Operações de Serviços Utilizando a TI - I .......327 Gráfico 2 - Análise da Eficácia nas Operações de Serviços Utilizando a TI - II.......328 Gráfico 3 - Análise da Eficiência nas Operações de Serviços Utilizando a TI - I ....330 Gráfico 4 - Análise da Eficiência nas Operações de Serviços Utilizando a TI - II....330 


\section{SUMÁRIO}

1 INTRODUÇÃO E OBJETIVOS .19

1.1 A PROBLEMÁTICA DA INDÚSTRIA DA SAÚDE NO MERCADO NACIONAL E A TECNOLOGIA DA INFORMAÇÃO. 21

1.1.1 As Operações de Serviços e a Tecnologia da Informação na Indústria da Saúde .23

1.2 OBJETIVOS .27

1.3 ESTRUTURA DO TRABALHO. 28

2 OPERAÇÕES DE SERVIÇO - CONCEITOS E CARACTERÍSTICAS 31

2.1 CONCEITO DE SERVIÇO 31

2.2 CARACTERÍSTICAS BÁSICAS DE SERVIÇOS ...................................32

2.2.1 Intangibilidade nos Processos em Serviço................................................35

2.2.2 Diferenças no Processo de Produção de Serviços......................................35

2.2 SERVIÇOS PROFISSIONAIS, SERVIÇOS DE MASSA E LOJA DE SERVIÇOS .36

2.4 SERVIÇOS, NOVA ECONOMIA E TI 39

2.5 PRODUÇÃO DE SERVIÇOS 39

2.5.1 Operações de Serviço na Saúde e a utilização da TI .42

3 A NOVA ECONOMIA E A TECNOLOGIA DA INFORMAÇÃO .........44

3.1 TRANSFORMAÇÕES, MUDANÇAS E TURBULÊNCIA AMBIENTAL ... 45

3.2 A TRANSPARÊNCIA NAS EMPRESAS E O PODER DO CLIENTE ......46

3.3 A REVOLUÇÃO DA INFORMAÇÃO E A UTILIZAÇÃO DA TI................47

3.4 A UTILIZAÇÃO ESTRATÉGICA DA TI ............................................. 49

4 ESTRATÉgIAS DE NEgócios E A TECNOLOGIA DA INFORMAÇÃO. .52

4.1 ESTRATÉGIAS DE NEGÓCIOS......................................................52

4.2 ESTRATÉGIAS DE NEGÓCIOS E O USO DA TI ..................................55

4.2.1 Direcionadores de Negócios, utilizando a TI .............................................64

5 VANTAGEM COMPETITIVA........................................................69

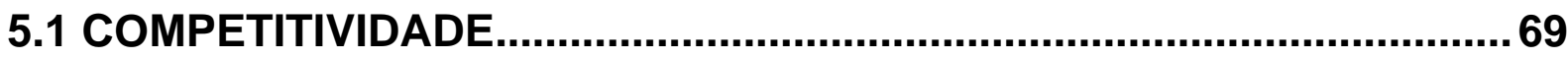


5.2 VANTAGEM COMPETITIVA E O AMBIENTE EXTERNO DAS EMPRESAS

5.3 VANTAGEM COMPETITIVA E O AMBIENTE INTERNO DAS EMPRESAS. .73

5.4 VANTAGEM COMPETITIVA E O AMBIENTE EXTERNO E O AMBIENTE INTERNO DAS EMPRESAS................................................................... 76

5.5 VANTAGEM COMPETITIVA E A TECNOLOGIA DA INFORMAÇÃO ....77 5.6 MODELO DE AVALIAÇÃO DO AMBIENTE EXTERNO .........................8 80

5.6.1 Análise do Macroambiente - O Modelo do Diamante (PORTER, 1999) .....80

5.6.2 Análise do Microambiente - O Modelo das Cinco Forças (PORTER, 1999b) .81

5.7 MODELO DE AVALIAÇÃO DO AMBIENTE INTERNO. .84

5.7.1 Análise do Ambiente Interno - As Fontes e Capacitações (BARNEY, 1995) .84

5.7.2 Análise do Ambiente Interno - As Competências Essenciais (PRAHALAD e HAMEL, 1990) . .85

6. CRIAR VALOR .88

6.1 CRIAR VALOR EM SERVIÇOS 91

6.1.1 Eficiência e Eficácia 93

6.1.1.1 Eficiência e Eficácia em serviços 93

6.1.1.2 Eficiência e eficácia no uso da tecnologia da informação .95

7 AMPLIANDO O VALOR EM SERVIÇOS. .98

7.1 CADEIA DE VALOR .98

7.2 SISTEMA DE VALOR 103

7.3 CADEIA DE SUPRIMENTOS. 104

7.4 REDES DE VALOR 107

7.4.1 Conceitos e Características de Redes de Valor 108

7.4.2 Redes de Valor e Vantagem Competitiva. 110

7.4.3 As alianças como Ferramentas Estratégicas

7.5 CADEIA DE VALOR NA SAÚDE E O RELACIONAMENTO COM OUTROS PARCEIROS 113 


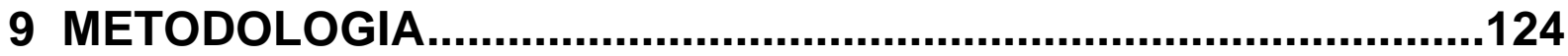

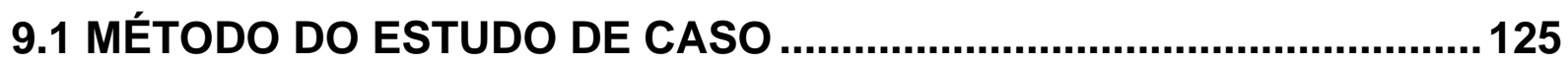

9.2 PLANO DE AÇÃO PARA O ESTUDO DE CASO .................................127

9.2.1 Seleção dos Casos.............................................................................127

9.2.1.1. Critérios para seleção dos casos ....................................................127

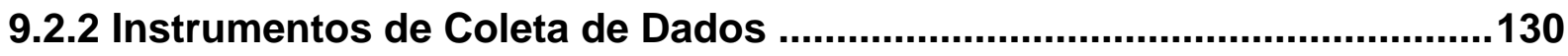

9.2.3 Protocolos (procedimentos e circunstâncias)...........................................130

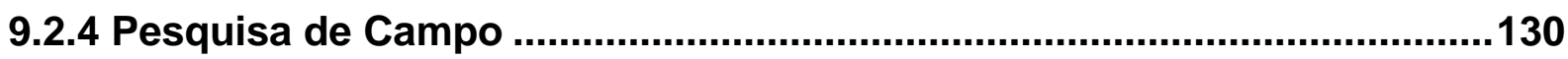

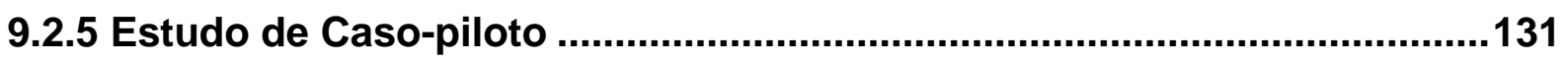

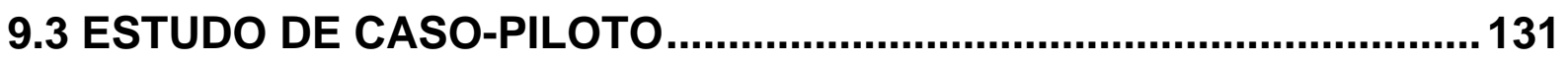

9.3.1 Atividades realizadas no Estudo de Caso-piloto.......................................132

9.3.2 Roteiro preliminar para o Estudo de Caso-piloto ......................................132

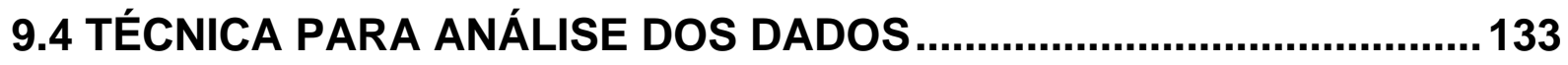

9.4.1 Modelo para Descrição dos Dados ..............................................................134

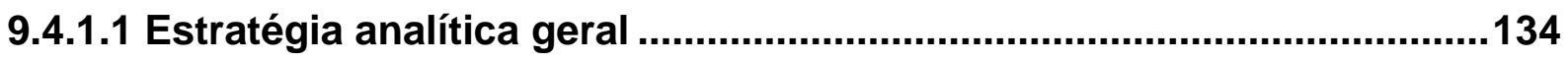

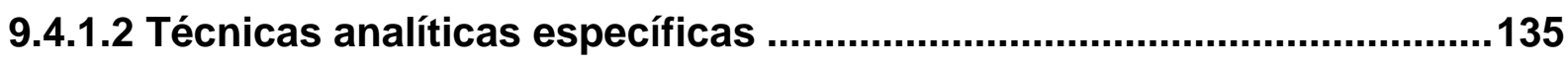

9.3.1.3 Modelo para interpretação dos dados da pesquisa ..............................142

9.3.1.3.1 Avaliação das contribuições da TI em relação às operações de serviços, utilizando escalas (baixo, médio e alto) grau de contribuição da TI nas Operações de Serviços........................................................................142

9.3.1.3.2 Matriz de criação de valor em serviços.............................................143

9.3.1.3.3 Modelo decorrente da análise qualitativa ...........................................144

9.3.1.4 Modelo para avaliar os resultados da pesquisa .....................................145

10 DESCRIÇÃO DOS DADOS DA PESQUISA...................................146

10.1 EMPRESA 1 (C1) - INTERNAÇÃO DOMICILIAR .............................147

10.1.1 Formas de Contribuição da $\mathrm{TI}$ - Categorias ..........................................149

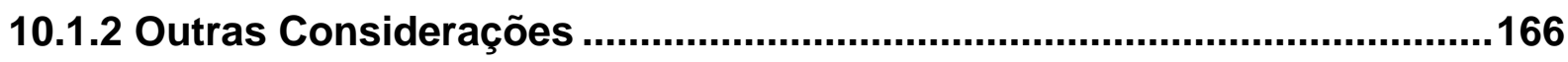

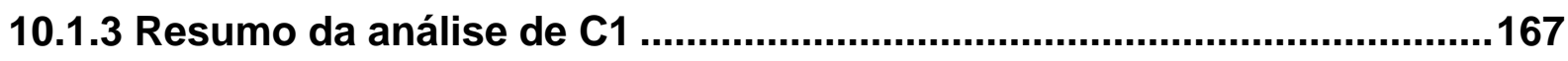

10.2 EMPRESA 2 (C2) - HOSPITAL GERAL DE ALTA COMPLEXIDADE168

10.2.1 Formas de Contribuição da TI - Categorias ........................................170

10.2.2 Outras Considerações de C2 …...........................................................177

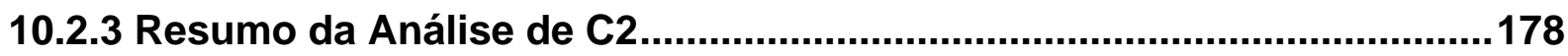


10.3 EMPRESA 3 (C3) - HOSPITAL ESPECIALIZADO DE ALTA

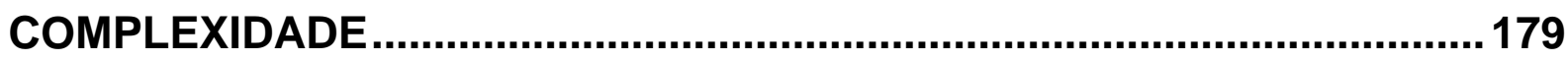

10.3.1 Formas de Contribuição da TI - Categorias ...........................................180

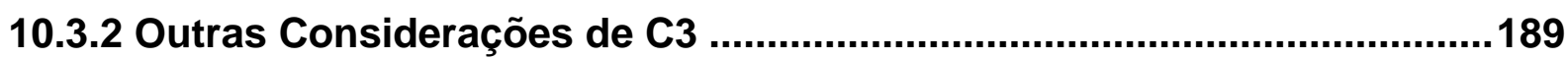

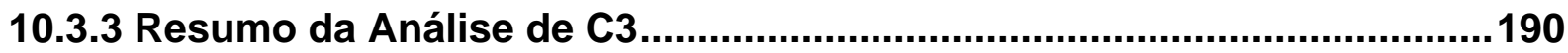

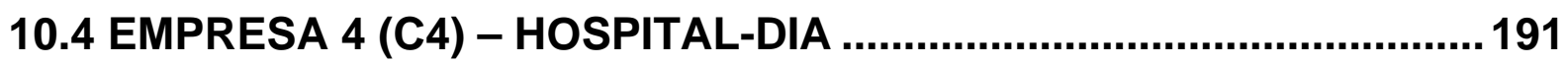

10.4.1 Formas de Contribuição da TI - Categorias ...........................................193

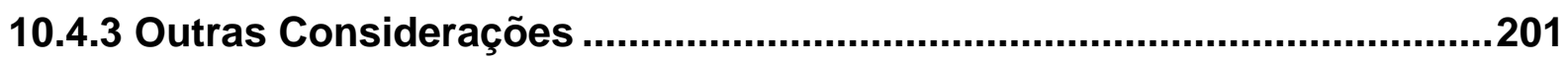

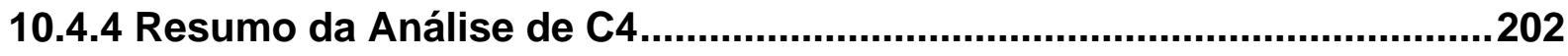

10.5 EMPRESA 5 (C5) - LABORATÓRIO DE ANÁLISES CLÍNICAS E

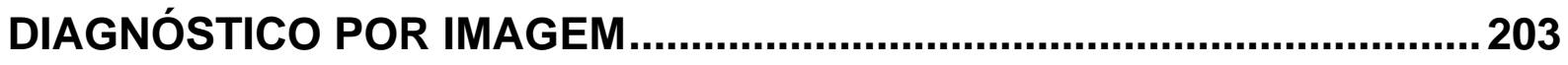

10.5.1 Formas de Contribuição da TI - Categorias .........................................205

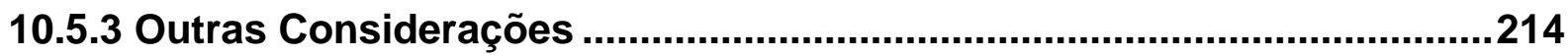

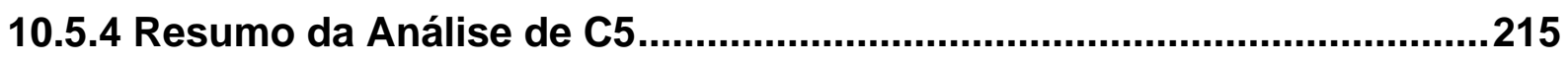

10.6 EMPRESA 6 (C6) - EMPRESA DE SERVIÇOS MÉDICOS.................. 216

10.6.1 Formas de Contribuição da TI - Categorias ...........................................218

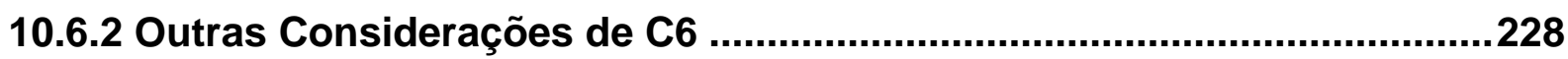

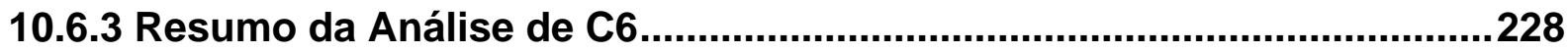

10.7 EMPRESA 7 (C7) - PLANO DE SAÚDE.......................................... 230

10.7.1 Formas de contribuição da $\mathrm{TI}$ - Categorias .........................................232

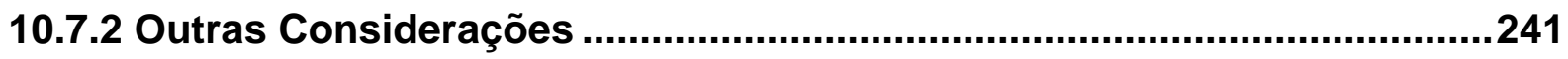

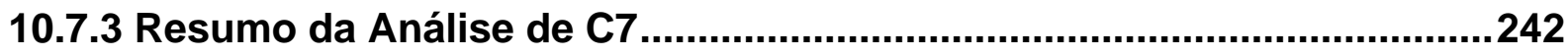

10.8 EMPRESA 8 (C8) - EMPRESA FARMACÊUTICA .............................243

10.8.1 Formas de Contribuição da TI - Categorias .........................................245

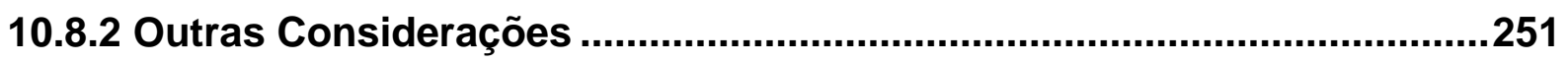

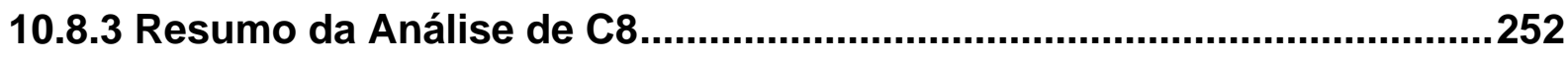

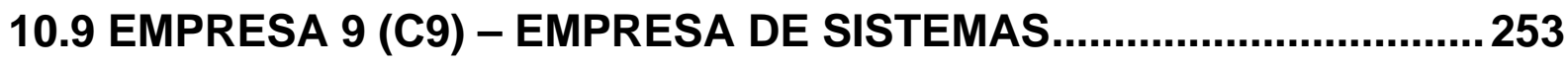

10.9.1 Formas de Contribuição da TI - Categorias ............................................25

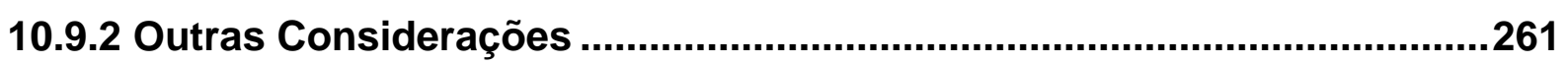

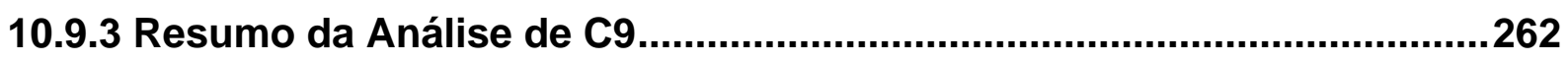

10.10 EMPRESA 10 (C10) - EMPRESA DE GERENCIAMENTO DE

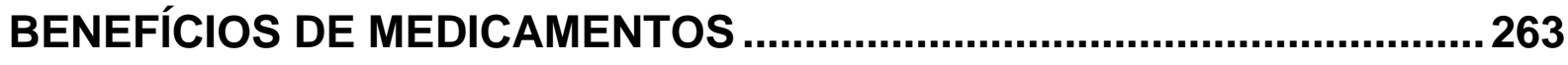

10.10.1 Formas de Contribuição da TI - Categorias ..........................................266 
10.10.2 Outras Considerações 275

10.10.3 Resumo da Análise de C10 .276

10.11 EMPRESA 11 (C11) - EMPRESA DE EQUIPAMENTOS E SOFTWARES MÉDICOS. 277

10.11.1 Formas de Contribuição da TI - Categorias 279

10.11.2 Outras Considerações 284

10.11.3 Resumo da Análise de C11 285

10.12 EMPRESA 12 (C12) - EMPRESA DE GESTÃO DE DOCUMENTOS 286

10.12.1 Formas de Contribuição da TI - Categorias 288

10.12.2 Outras Considerações 294

10.12.3 Resumo da Análise de C12. 294

10.13 EMPRESA 13 (C13) - EMPRESA DE SISTEMAS E SERVIÇOS PARA INSTITUIÇÕES DE SAÚDE .................................................................. 295

10.13.1 Formas de Contribuição da TI - Categorias ......................................297

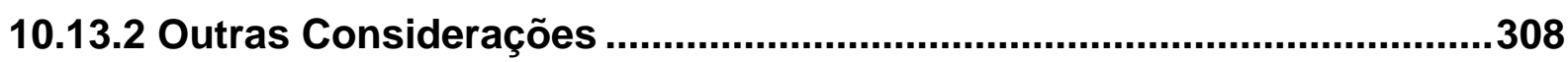

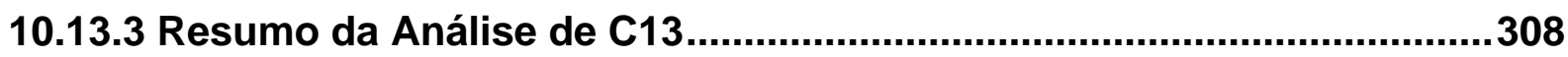

10.14 EMPRESA 14 (C14) - EMPRESA DE SERVIÇOS DE INFORMÁTICA (CONECTIVIDADE). 310

10.14.1 Formas de Contribuição da TI - Categorias 312

10.14.2 Outras Considerações 318

10.14.3 Resumo da Análise de C14. .318 10.15 SÍNTESE DA ANÁLISE DOS CASOS (PROCESSOS POR CATEGORIAS).. 320

11 INTERPRETAÇÃO DOS DADOS DA PESQUISA .........................322

11.1 AVALIAÇÃO DAS CONTRIBUIÇÕES DA TI EM RELAÇÃO ÀS OPERAÇÕES DE SERVIÇOS, UTILIZANDO ESCALAS (BAIXO, MÉDIO E ALTO) GRAU DE CONTRIBUIÇÃO NAS OPERAÇÕES DE SERVIÇOS... 322 11.1.1 Avaliação das Contribuições da TI - Análise Geral dos Casos - Tabela Consolidada. 324

11.1.1.1 Avaliação das Contribuições da TI para a Eficácia. 325

11.1.1.2 Avaliação das Contribuições da TI para a Eficiência. 328 
11.2 MATRIZ DE CRIAÇÃO DE VALOR EM SERVIÇOS. 330

11.3 MODELO DECORRENTE DA ANÁLISE QUALITATIVA (APLICAÇÕES E COMENTÁRIOS) . 333

12 ANÁLISE DOS RESULTADOS DA PESQUISA..........................335

12.1 REDE DE VALOR NA SAÚDE E O USO DA TI................................339

13 CONCLUSÕES E RECOMENDAÇÕES FINAIS............................344 REFERÊNCIAS BIBLIOGRÁFICAS ..............................................348

GLOSSÁRIO ..............................................................................358

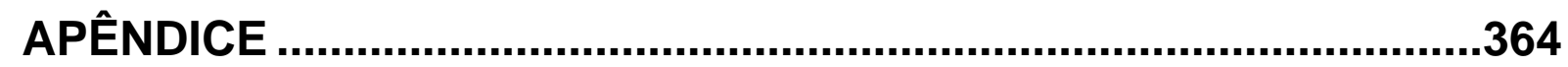




\section{INTRODUÇÃO E OBJETIVOS}

No novo mundo da economia do conhecimento (KIM e MAUBORGNE, 2002), que acelera o processo de globalização dos mercados, nunca a palavra mudança foi tão expressiva como agora. Esta é a nova dinâmica do mundo digital e globalizado que se apresenta na nova economia (TAPSCOTT, 1998), ou também conhecida como economia do conhecimento (KIM e MAUBORGNE, 2002). As terminologias são muitas, porém as abordagens são semelhantes. Conforme Laurindo (2005): "A tecnologia da informação (TI) é vista como o fator de viabilização desta integração em abrangência mundial, bem como a criação de novas estratégias de negócio, de novas estruturas organizacionais e de novas formas de relacionamento entre empresas e entre empresas e seus consumidores".

O estudo que por ora se apresenta neste trabalho procura trazer alternativas para o desenvolvimento de estratégias de negócios, utilizando a TI no setor da saúde. Esta reflexão tem por finalidade contribuir para o empreendimento de novos negócios e estratégias de negócios com maior vantagem competitiva.

Diariamente, cresce o índice de informação e conhecimento entre os agentes que compõem o ambiente competitivo do mercado: concorrência, compradores e fornecedores e, com isto, altera-se constantemente o poder de negociação entre eles (SEYBOLD e MARSHAK, 2000). Neste sentido, observa-se uma mudança nas características da disputa mercadológica. Os concorrentes estão transformando-se. O foco da disputa já não é tão evidente: novas regras aparecem e desaparecem a todo o momento. Novos entrantes e produtos substitutos estão derrubando tradicionais barreiras de entrada consolidada no mercado e assumindo posições importantes em algumas áreas, influenciada pelos efeitos desta economia digital (PORTER e MILLAR, 1985). Se, por um lado, a nova economia cria ou altera o ambiente competitivo (Id., Ibid.), por outro, as empresas também impõem mudanças, apresentando alternativas inovadoras de se competir, utilizando a TI (BARNEY et al., 2003), (WADE e HULLAND, 2004). Estas alternativas visam a valorizar os recursos das empresas, tornando-os mais valiosos, raros, difíceis de imitar, entre outros elementos, que contribuem com a vantagem competitiva (BARNEY, 1995).

Com o surgimento da Internet, a ascensão da multimídia, a rapidez da globalização, o ritmo aumenta na medida em que o novo conhecimento, a criação de 
idéias e a difusão global aceleram-se. Diante deste quadro, as empresas continuam com as velhas fórmulas reativas, incrementais ou imitativas. Para que as empresas sejam competitivas neste novo contexto, elas devem inovar valor e desenvolver novas estratégias de negócios, buscando alternativas neste ambiente altamente competitivo, (KIM e MAUBORGNE, 2002).

Conforme Tapscott (2001), uma estratégia de negócio ou um modelo de negócio refere-se à arquitetura de uma empresa, especificamente como se desdobram os recursos relevantes para criar valor a clientes diferenciados.

O sucesso de uma estratégia de negócio depende de quanto esta nova forma de atuar no mercado cria valor. Este valor deve sempre estar subordinado à ótica do cliente, que cada vez tem mais poder e, portanto, determina o valor que pretende receber (SEYBOLD e MARSHAK, 2000). As expectativas dos clientes estão crescendo rapidamente, abastecidas pela força da Internet. Para atender estas exigências, as empresas estão desenvolvendo estratégias baseadas em redes de valor, buscando atender de forma mais rápida, precisa e personalizada (BOVET e MARTHA, 2000). Estes autores falam da transformação dos clientes e da necessidade de que os processos sejam redesenhados de fora para dentro para atender aos anseios desses consumidores, os quais poderão ser melhor compreendidos e atendidos com a ajuda da TI.

A criação de valor é a visão de fora para dentro, é a visão de valor sob a perspectiva do cliente (MAGRETA e STONE, 2002). Este ponto de vista norteará os aspectos sobre criação de valor a ser desenvolvido neste trabalho, delimitando a questão do valor sob a ótica do cliente, que oscila sempre entre duas bases, eficiência e/ou eficácia, conforme nos sugerem Magreta e Stone (2002); Porter (1989); Zarifian (2001a) entre outros.

Segundo Drucker (1963): "Eficiência é fazer corretamente as coisas. Eficácia é fazer as coisas corretas". Com o passar do tempo, observam-se várias formas de se interpretar os conceitos: eficiência e eficácia e a questão do valor. Houve momentos em que a criação de valor pendeu para a eficiência: fazer mais com menos, tornando produtos acessíveis a um maior número de clientes. Depois, criar valor passou a ser relacionado com o que o cliente valorizava, mudando a ênfase para a eficácia. Mais adiante, os conceitos eficiência, eficácia e valor serão apresentados de forma mais detalhada e também explicados sob o ponto de vista dos serviços e da $\mathrm{TI}$. 


\subsection{A PROBLEMÁTICA DA INDÚSTRIA DA SAÚDE NO MERCADO NACIONAL E A TECNOLOGIA DA INFORMAÇÃO}

"A crise da saúde no Brasil vem de longa data e continua presente no dia-adia da sociedade" (COUTO FILHO, 2005). Segundo este autor, problemas como filas nos hospitais e postos de saúde, essencialmente no serviço público, além da falta de leitos, equipamentos, medicamentos, materiais, etc., refletem com precisão este quadro. O fato é que há escassez de recursos financeiros, materiais e humanos para manter o sistema de saúde, operando com eficiência. Pagamentos com atraso por parte do Ministério da Saúde, valores abaixo do custo pagos pelo SUS (Sistema Único da Saúde) aos seus conveniados, são apenas alguns dos fatores que contribuem para os problemas econômicos do setor. O SUS despende atualmente de $\mathrm{R} \$ 31$ bilhões ao ano para suprir o direito à saúde de 145 milhões de habitantes, enquanto, segundo estatística da Abramge (Associação Brasileira de Medicina de Grupo) e Fenaseg (Federação Nacional das Empresas de Seguros Privados e de Capitalização), despende-se o mesmo valor para cuidar de 35 milhões de beneficiários do setor privado.

Dados oficiais de 1993, comparados a 2001, demonstram que o número de leitos disponíveis no país sofreu uma sensível redução. Neste espaço, inferior a uma década, a população apresentou um crescimento de cerca de 6 a 7\% e a oferta por leitos no mercado, por sua vez, foi reduzida em quase 3\%, conforme Panorama Setorial da Gazeta Mercantil (2005). A saúde pública vem sendo duramente criticada pelos usuários do sistema, os quais reclamam das longas filas, da demora nos exames e na marcação de consulta (Tabonense, 2006). Segundo Chao (2003), além dos inúmeros problemas listados, uma das carências nos sistemas de saúde do país é a má-distribuição de médicos especialistas, que torna ainda mais discrepante a assistência aos pacientes em geral. Dados do Conselho Federal de Medicina revelam a má distribuição de médicos especialistas, fortemente concentrados nas regiões Sul e Sudeste do país (COUTO FILHO, 2005).

No setor privado, há um esforço da indústria da saúde no sentido de desenvolver produtos e serviços a custos menores, para satisfazer as necessidades dos tomadores de serviço. Os tomadores de serviço, também conhecidos por convênios médicos ou por operadoras de saúde, são formados pelos planos de 
saúde, seguro saúde, cooperativas de saúde, autogestões e outros. Estas mudanças vêm tornando o mercado mais competitivo e dinâmico. Isto permitiu que novos entrantes participassem do negócio e que se iniciasse uma grande reviravolta com a profissionalização e novas formas de gestão no segmento. Nos últimos anos, observaram-se a formação de blocos e a concentração de empresas por meio de fusões e parcerias. A entrada de competidores estrangeiros acelerou ainda mais este processo no setor da saúde. O propósito das mudanças foi buscar oportunidades neste mercado ainda pouco explorado. Assim, as empresas seguiram alguns caminhos comuns como aumento de tamanho, de escala e de especialização, visando ao maior poder de barganha e, conseqüentemente, lucratividade e sustentabilidade nos negócios, (KLENK, 2000), (VILLELA, 2000) e (ASSUMPÇÃO, 2000).

Segundo a Pesquisa Nacional por Amostra de Domicílios (PNAD) do IBGE de 1998, publicada no site Saúde Total (2006), o Brasil possuía, na ocasião, 39 milhões de pessoas cobertas por plano de saúde, com maior cobertura nas áreas urbanas e um pouco superior nas mulheres e pessoas na faixa entre 40 a 64 anos. Isto significa que menos de um quarto da população possui cobertura pelo sistema privado de saúde; o restante está sujeito ao sistema público, o que agrava ainda mais o problema da saúde no país. Existe, ainda, uma grande preocupação com o crescimento no número de idosos no país. Atualmente, existem 14 milhões de idosos e estima-se que, em 2045, este número quadruplique. Este fato irá onerar ainda mais o sistema de saúde nacional, tanto no setor público quanto no privado. Uma das alternativas para este problema será a prevenção de doenças, focando na saúde dos pacientes "O Estado do Paraná, 2006".

É corrente a afirmação, nas empresas de saúde, que todas as partes envolvidas no negócio devem lucrar com a saúde, e não com a doença dos usuários (HERZOG, 2006). Seguindo esta tendência, a Intel (grande fabricante mundial do setor de tecnologia), informa que um dos seus focos de atuação no Brasil e no mundo será o setor da saúde. A empresa também prevê um crescimento substancial na população idosa e acredita que o setor da saúde oferecerá oportunidades importantes para o desenvolvimento de projetos da empresa (TEIXEIRA Jr., 2006).

Em uma visão mais geral do negócio ou do problema da saúde, pode-se observar que grandes empresas do setor de medicina de grupo e seguro saúde e compradores de serviços de saúde vêm apresentando resultados negativos em suas 
operações. Empresas tradicionais estão sucumbindo e desaparecendo; nos últimos anos, mais de 1000 empresas saíram do mercado. Uma alternativa utilizada por uma grande empresa de medicina de grupo no Brasil foi o fechamento de unidades no exterior e também a verticalização de suas operações no Brasil. A verticalização, neste caso, o desenvolvimento de atividades de prestação de serviços com rede própria de atendimento à saúde, utilizando centros clínicos, médicos, laboratórios e hospitais, teve, como justificativa, o controle de despesas e melhoria da eficiência, (SALOMÃO, 2006).

Conforme matéria publicada em "O Estado do Paraná" (2006), outras empresas como hospitais, que vendem serviços para a medicina suplementar (privada), também demonstram preocupação com a crise no setor e a necessidade de se adequar à nova realidade. Algumas instituições estão procurando atuar de acordo com sua vocação, focando na utilização da tecnologia; algumas outras, por meio de nichos mais atraentes; outras, ainda, por meio de fusões ou acordos operacionais entre os prestadores de serviço, etc.

\subsubsection{As Operações de Serviços e a Tecnologia da Informação na Indústria da Saúde}

Ao se analisar o uso da TI na indústria da saúde, pode-se obter importantes contribuições, considerando que este é um ambiente com muitos problemas e pouco explorado sob esse aspecto, como foi visto anteriormente. Chao (2003) entende que os problemas da saúde (custos crescentes e recursos escassos) devem contar com o apoio da tecnologia da informação, mais especificamente com as ferramentas da telesaúde. Conforme este autor, as dimensões continentais do país acentuam ainda mais a discrepância entre as regiões. O desenvolvimento de serviços virtuais, como, por exemplo, ambulatórios para prover facilidades a distância no atendimento de patologias diversas em todas as regiões do país, pode contribuir para minimizar estes problemas. Este autor explica que os serviços no setor da saúde estão em constante mudança e a TI vem sendo utilizada cada vez mais pelas instituições neste processo de transformação. Estas formas diferenciadas de se atuar são as novas ferramentas que as empresas deverão utilizar para atender à crescente exigência dos clientes, e, assim, aumentar sua vantagem competitiva no mercado. Neste contexto, o uso da TI, em saúde, vem apresentando crescimento substancial 
nos últimos anos.

Muitas instituições privadas do setor da saúde no Brasil utilizam a TI em aplicações administrativas, porém um número pequeno delas a utiliza para gerar novas estratégias de negócios (OLIVEIRA e LAURINDO, 2004). Estas ações têm permitido um nível de diferenciação importante a estas instituições, que pode ser entendido como vantagens competitivas (PORTER, 1989) e, conseqüentemente, garantia de sobrevivência. Assim, preparar-se em relação aos novos entrantes ou aos produtos substitutos é uma garantia de sustentabilidade no mercado da saúde. Conforme Kanamura (2004), as características acima abrangem tanto o setor público como o setor privado. Como em qualquer setor que tem recursos insuficientes, a questão na saúde é a mesma: definição de prioridades. Este fato significa que na escolha entre a TI e outros recursos, aquela nem sempre tem sido prioridade, e isto pode estar ampliando os problemas de escassez de recursos e falta de controle. Rothenberg (1995) explica que a inovação na saúde se limita aos instrumentos médicos e equipamentos de diagnóstico e a outras tecnologias, que, em geral, são reembolsáveis pelos tomadores de serviço na saúde (planos, seguros, cooperativas e outros do setor). Para trazer mudança significativa no negócio, os investimentos deverão sair do âmbito tradicional e invadir os processos organizacionais e a gestão, infere este autor.

Já faz cinco anos desde que se traçou o genoma humano e quase 40 anos que os especialistas na saúde terminaram o primeiro transplante bem-sucedido do coração - mas, no setor da saúde, o uso da TI ainda é muito limitado. Enquanto muitas outras indústrias mostram que trabalhar com a informação digital tem menor custo, é mais rápida e mais exata do que usar registros manuscritos, os hospitais e médicos em geral insistem em utilizar o tradicional papel, (Relatório BOOZ ALLEN, 2005). Neste relatório, podem-se encontrar afirmações de especialistas da saúde de que o sistema de arquivamento de papéis está ultrapassado. Se estes dados pudessem ser disponibilizados em meio digital, além de a informação ser mais rápida e precisa, evitando duplicidade de procedimentos e, conseqüentemente, de custos, poderia ser realizado um monitoramento da saúde no país, evitando ou prevendo epidemias, bioterrorismo, entre outros.

Analisando o quadro da saúde, sob um ponto de vista mundial, podem ser encontradas muitas semelhanças em relação aos problemas da saúde no Brasil, que envolve inclusive corrupção. Conforme Relatório Global sobre Corrupção (2006), 
existem provas de subornos e fraudes em todos os sistemas de saúde, que vão de pequeno furto ou extorsão a importantes distorções da política de saúde e de financiamentos mediante pagamentos feitos a responsáveis. No setor privado, é muito claro o conflito de interesses (TEISBERG, PORTER e BROWN, 1999) entre tomadores de serviços (planos de saúde em geral) e prestadores de serviços (médicos, clínicas, laboratórios, diagnóstico por imagem, hospitais, outros). Assim sendo, a transparência torna-se fundamental para um maior entendimento entre os envolvidos. Conforme Scoott e Struder (2003), os consumidores querem controlar mais e ajudar nas escolhas, o que comumente não acontece, pois desconhecem os sinuosos caminhos da indústria da saúde. O autor explica que muitas vezes na história da saúde de grupo, a participação dos pacientes causou impacto significativo e positivo. Skinner (2003) afirma que a TI pode contribuir muito com este processo. Ele defende que se a TI fosse utilizada a exemplo de outras indústrias, avançando para além das atividades de retaguarda e operações tradicionais, buscando focar nas competências da empresa, possibilitaria ganhos de eficiência e eficácia. Quinn e Baily (1994) pensam da mesma forma e consideram que o conflito de interesse no setor tem causado problemas de eficiência no sistema. Segundo estes autores, o medo de um atendimento não adequado incita os médicos indubitavelmente a sobreutilizar alguns sistemas diagnósticos e procedimentos de tratamento. Os autores afirmam que isto poderia ser diferente, pois a TI tem permitido respostas de emergência mais rápidas, diagnósticos mais cedo, reduzindo o número de procedimentos invasivos. Carvalho e Laurindo (2003) comentam que há uma tendência da utilização da TI não apenas nas operações existentes, mas viabilizando estratégias empresariais. Este fato demonstra que a TI evoluiu de uma orientação tradicional de suporte administrativo para um papel mais estratégico, criando mais valor.

Skinner (2003) insiste sobre a sinergia que se poderia obter com o uso estratégico da TI. Segundo ele, desde os gerentes de departamento, médicos e executivos seniores, o valor da TI tem sido pouco compreendido e pouco debatido. Conforme este autor, a ênfase pelo tema se justifica, pois o setor da saúde enfrenta desafios severos semelhantes a outras indústrias no passado, que utilizaram a $\mathrm{TI}$ como facilitador para reverter seus desafios. Os investimentos em TI na saúde em geral não foram feitos nas áreas de sustentação dos processos centrais do negócio, neste caso, em clínica. Os departamentos, tais como laboratório, radiologia, farmácia 
e outros têm sido automatizados por muito tempo, mas as unidades de cuidado, as clínicas e os serviços cirúrgicos, estão apenas começando a usufruir da TI, (SKINNER, 2003). Conforme Laurindo (2005), a Internet possibilitou que o mercado virtual se tornasse realidade e, com isto, novas formas de cooperação e relação entre empresas puderam ser viabilizadas. Teisberg, Porter e Brown (1999:433) pensam da mesma forma que os autores anteriormente citados:

\begin{abstract}
A premissa enganosa subjacente à boa parte do debate sobre a reforma da assistência médica é a percepção da tecnologia como inimigo. Pressupondo que a tecnologia impulsiona os custos, os reformadores negligenciam a importância central da inovação ou, pior ainda, tentam desacelerar seu ritmo.
\end{abstract}

Nestes termos, muitas oportunidades de negócio podem estar sendo negligenciadas e buscar estas alternativas será uma forma inteligente de as empresas conseguirem sustentabilidade neste ambiente altamente competitivo.

Neste contexto, o problema da pesquisa é "como analisar novas formas para as operações de serviço na saúde, utilizando a TI em um cenário em que a demanda esta cada vez mais exigente e os recursos mais escassos". "Como identificar se a TI pode colaborar para alterar esta situação e de que forma isto pode ser possível?"

O que se pressupõe neste trabalho é que as novas formas de se atuar ou as estratégias de negócios que utilizam a TI propiciarão vantagem competitiva às empresas na medida em que contribuírem na solução dos problemas acima citados.

Muito se diz da importância da TI na saúde, porém explicar de que forma ela pode ser mais bem utilizada, ainda é um questão importante a ser respondida. Estas e outras questões fazem parte da contribuição que este trabalho pretende trazer no campo das operações de serviço na saúde e o uso da TI no desenvolvimento de estratégias de negócios. Assim, na seqüência, serão apontadas as principais questões da pesquisa que devem ser respondidas neste estudo.

Questões da Pesquisa:

1 - Como e por que utilizar a TI para criar maior valor (eficiência e/ou eficácia) nas operações de serviços na saúde?

2 - Como e por que a TI amplia as oportunidades e/ou competências nas operações de serviço na saúde? De que forma este efeito pode aumentar as possibilidades de êxito competitivo das empresas? 


\subsection{OBJETIVOS}

Laurindo (2005) apresenta um quadro bastante esclarecedor sobre o impacto estratégico da TI. O autor descreve que o impacto da TI não está restrito a questões de organização interna das empresas, mas também para além das fronteiras destas, abrangendo os consumidores, concorrentes e redes com outras empresas. $\mathrm{O}$ autor afirma que embora no âmbito internacional muito já tenha sido feito, a realidade brasileira ainda necessita ser estudada com maior atenção. Neste caso, propõe uma agenda de estudos, na qual serão destacados dois itens, que vão ao encontro dos objetivos deste trabalho, ou seja:

- verificar qual o papel da TI (em especial a Internet) ao viabilizar estratégias de negócios preexistentes, envolvendo inter-relação e cooperação entre empresas;

- $\quad$ estudar o papel da TI (em especial a Internet) em viabilizar novas estratégias de negócios, envolvendo inter-relação e cooperação entre empresas.

Assim, este estudo tem como objetivo compreender como a TI contribui para o desenvolvimento de estratégias de negócios, envolvendo inter-relação e cooperação entre empresas no setor da saúde; Identificar a partir das vantagens competitivas das empresas, o nível de contribuição da TI na criação de valor (eficiência e/ou eficácia) em operações de serviços.

Como objetivos específicos podem ser destacados os seguintes itens:

1. analisar formas para a organização das operações de serviços utilizando a TI em uma rede de valor no setor da saúde;

2. compreender como desenvolver estratégias de negócios de maior valor (eficiência e/ou eficácia), que propiciem vantagem competitiva aos seus executores no setor da saúde.

O desenvolvimento do trabalho justifica-se na medida em que se propõe a analisar alternativas que permitam o desenvolvimento ou identificação de estratégias de negócios, utilizando a tecnologia da informação no setor da saúde. Como se sabe, este setor faz parte da infra-estrutura básica de qualquer nação, compreendêlo torna-se vital para o seu desenvolvimento gerando melhores perspectivas para prestadores de serviço e usuários, o que permite sua sustentabilidade. Este fato torna-se mais importante na medida em que a "nova economia" transforma o 
mercado e cria novas possibilidades de atuar e competir. Neste caso, desenvolver pesquisas que otimizem os processos de escolhas e, conseqüentemente, propiciem estratégias de negócios que criam valor, deverá contribuir para alavancar o setor da saúde.

Conforme Perez (2006), as contribuições em uma pesquisa devem se dar em, pelo menos, três frentes distintas no que tange ao conhecimento, que, por sua vez se complementam. São elas:

- em nível prático: entender as operações de serviço que criam valor e conseqüentemente direcionar esforços a elas no sentido de maximizar os resultados da empresa;

- em nível metodológico: fornecer uma linha de raciocínio que possa ser replicada;

- em nível teórico: apresentar diversos autores e abordagens que se complementam e que juntos ganhem formas diferentes de se compreender o problema apresentado.

\subsection{ESTRUTURA DO TRABALHO}

Inicialmente, será realizada uma abordagem conceitual das operações de serviços, complementada por operações de serviços na saúde. O intuito é introduzir as características específicas do setor de serviços e serviços na indústria da saúde.

Na seqüência, será apresentada a nova economia e a TI na saúde. Estes conceitos deverão contribuir para contextualizar o ambiente em transformação, em que se insere a discussão deste trabalho.

Depois, serão abordadas estratégias de negócios e o uso da $\mathrm{Tl}$, construindo novas formas de se atuar no mercado, em busca da vantagem competitiva. A proposta é mostrar que ao se juntarem operações de serviços na saúde e a utilização estratégica da TI obtém-se opções de se explorar o mercado: as novas estratégias de negócios.

Após isto, serão apresentadas alternativas para se diagnosticar vantagens competitivas no mercado. Nesta parte, serão utilizadas as premissas de que o sucesso de uma estratégia de negócio deve apoiar-se em oportunidades externas ou em competências internas das empresas. A primeira delas discorrerá sobre as 
possibilidades de se obter vantagem competitiva a partir das oportunidades do ambiente externo das empresas (micro e macro ambiente), conforme os conceitos da escola da Organização Industrial (CONNER, 1991). A outra abordagem descreverá as características do ambiente interno das empresas, buscando as forças como recursos internos das empresas para obter vantagens competitivas no mercado: a Visão Baseada no Recurso (BARNEY, 1995).

Não será objeto, deste trabalho, distinguir qual das duas abordagens é a mais adequada, o que já foi apresentado por diversos autores. O que se pretende é demonstrar com base na análise nestes modelos estratégicos, como e por que a $\mathrm{TI}$ cria valor no setor da saúde. Neste caso, a criação de valor pode ocorrer a partir de um determinado ambiente externo ou a partir de um recurso interno das empresas e, conseqüentemente, como o TI permite desenvolver estratégias de negócios na saúde.

$\mathrm{Na}$ seqüência, será apresentado o conceito de criar valor utilizado neste trabalho. O conceito de criar valor se apóia nas questões relacionadas à eficiência $e$ à eficácia e que por meio de uma e/ou de outra, pode-se obter vantagem competitiva.

O último passo apresentará os conceitos da Cadeia de Valor, Sistema de Valor, Cadeia de Suprimentos e Redes de Valor, os quais deverão permitir que se faça uma aferição da criação de valor, por meio das possíveis interações. A lógica dos conceitos do modelo teórico deste trabalho, que norteia seu desenvolvimento, pode ser observada na Figura 1 - Estrutura do Referencial Teórico. Veja também o Quadro 1 - Questões e Objetivos da Pesquisa. 


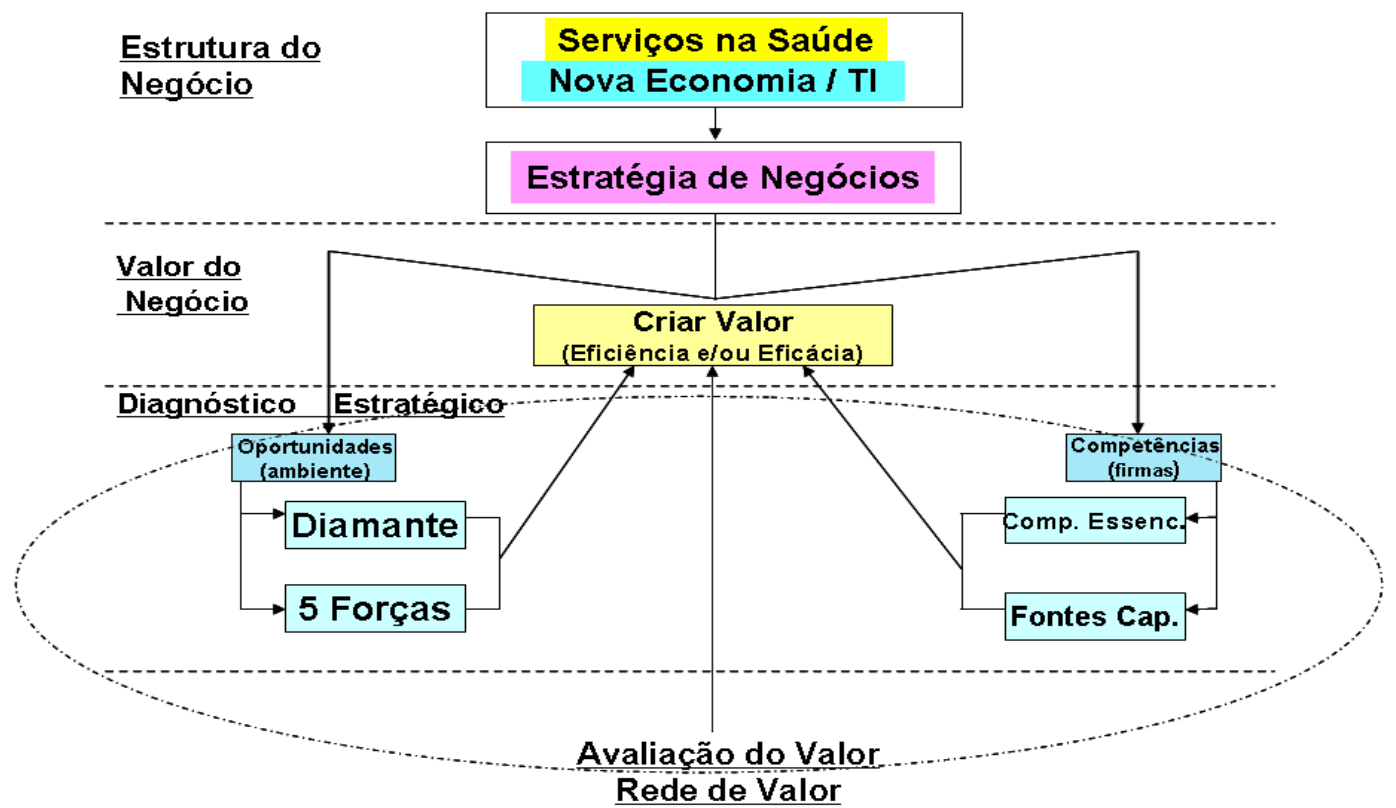

Figura 1 - Estrutura do Referencial Teórico

\section{QUESTÕES DA PESQUISA}

1 - Como e por que utilizar a TI para criar maior valor (eficiência e/ou eficácia) nas operações de serviços na saúde?

2 - Como e por que a TI amplia as oportunidades e/ou competências nas operações de serviço na saúde? De que forma este efeito pode aumentar as possibilidades de êxito competitivo das empresas?

\section{OBJETIVOS DA PESQUISA}

Compreender como a tecnologia da informação contribui para o desenvolvimento de estratégias de negócios, envolvendo inter-relação e cooperação entre empresas no setor da saúde. Identificar a partir das vantagens competitivas das empresas, o nível de contribuição da TI na criação de valor (eficiência e/ou eficácia) em operações de serviços.

Como objetivos específicos podem ser destacados os seguintes itens:

1 analisar formas para a organização das operações de serviços utilizando a TI em uma rede de valor no setor da saúde;

2 compreender como desenvolver estratégias de negócios de maior valor (eficiência e/ou eficácia), que propiciem vantagem competitiva aos seus executores no setor da saúde. 


\section{OPERAÇÕES DE SERVIÇO - CONCEITOS E CARACTERÍSTICAS}

\subsection{CONCEITO DE SERVIÇO}

Da definição do conceito "serviço" até as formas de se criar valor ao cliente final, observa-se a complexidade que envolve a atividade de prestação de serviços. Se, por um lado, existem interpretações variadas sobre o conceito de serviço, por outro lado, desenvolver parâmetros para entender e avaliá-lo, não é uma tarefa simples. Na seqüência, serão apresentados alguns conceitos de serviço, que serão úteis para se obter uma idéia da complexidade deste campo, e que contribuirão para delimitar o estudo em questão.

Hill (1977) faz a seguinte definição sobre o conceito de serviço:

Um serviço pode ser definido como uma mudança na condição de uma pessoa ou de um bem pertencente a um agente econômico, que vem à baila como resultado da atividade de outro agente econômico, por acordo prévio, ou seja, solicitação da pessoa ou agente econômico anteriores.

Gadrey (2001) propõe um enriquecimento do enunciado de Hill (1977) acima e faz o seguinte comentário sobre conceito de serviço:

(...) uma atividade de serviço é uma operação que visa a (sic) uma transformação do estado de uma realidade $C$, possuída ou utilizada por um consumidor $B$, realizada por um prestador de serviços $A$, a pedido de $B$, e com freqüência relacionada a ele, não chegando, porém à produção de um bem que possa circular economicamente independente do suporte $\mathrm{C}$.

Conforme este autor, a diferença entre as duas definições reside na precisão com que se determina que o "resultado não pode circular economicamente independente de C".

As duas interpretações acima abordam as operações nos serviços e a eficiência deles. Como exemplo, poderia ser citado o atendimento em uma unidade de emergência de um hospital e os processos pelos quais estão sujeitas e que refletem a quantidade de pacientes atendidos. Uma outra abordagem, que vai além da questão da eficiência e que incorpora também a questão da eficácia, avaliaria também se foi resolvido o problema do paciente. Resolver o problema do paciente significa se a experiência permitiu que ele tivesse uma melhora na saúde, diferentemente da abordagem anterior que foca a questão da doença. A partir desta 
avaliação, é necessária uma abordagem profunda sobre a questão de serviços, cuja preocupação abrange também este segundo ponto de vista.

No entender de Zarifian (2001), os pesquisadores Hill (1977) e Gadrey (2001) fazem uma abordagem sobre a produção dos serviços (plural), diferentemente de sua proposta, que é compreender no que consiste "produzir serviço" (singular). Assim, o autor não propõe uma definição sobre serviço, mas sugere que esta deva ser simples para se poder construir ao redor dela um conjunto de elocubrações que a possa enriquecer. Segundo ele, o ponto primordial, o valor de serviço, deve ser o ponto de partida. Como valor em serviço, Zarifian (2001a) sugere que este valor possa ser gerado de duas formas: 1) valor de serviço a partir das conseqüências (efeitos): neste caso, avaliam-se a utilidade, a justiça, a solidariedade e a estética, e 2) valor de serviço a partir dos recursos: o papel fundamental da competência profissional. Uma abordagem de valor condiciona a outra. "Não se avalia a eficiência em si mesma, não se faz uma avaliação restrita à empresa", (ZARIFIAN, 2001a: 119). O autor explica que a eficiência deve ser avaliada em função das conseqüências esperadas pelos clientes-usuários e, por isso, a avaliação da eficiência depende das avaliações feitas sobre suas conseqüências.

Por fim, este autor ainda propõe a seguinte definição: "O serviço é uma organização e uma mobilização, o mais eficiente possível, de recursos para interpretar, compreender e gerar a mudança perseguida nas condições de atividade do destinatário do serviço" (ZARIFIAN, 2001a:119).

Como se percebe, o tema é bastante complexo. Julgar algo que não existe antes de ser experimentado que, em geral, é indesejado por quem adquire, muitas vezes torna-se vago e de difícil compreensão. Estas abordagens, variações e características serão retomadas e mais bem exploradas ao longo deste trabalho.

\subsection{CARACTERÍSTICAS BÁSICAS DE SERVIÇOS}

Analisando as características dos serviços, notam-se muitas possibilidades em que o nível de serviços aos clientes pode sofrer variação e, com isto, tornar uma empresa mais ou menos competitiva. Entre estas características, podem-se citar: intangibilidade, inseparabilidade e perecibilidade. Para melhor compreensão, serão estudadas abaixo, separadamente, cada uma característica. 
Intangibilidade. Para Gianesi e Correa (1996), o que fazer para criar valor com algo que não se vê, não se sente, não se ouve, não pode ser tocado, antes de ser consumido? A intangibilidade é uma das principais características dos serviços. Como minimizar o risco do comprador, se ele está comprando apenas uma promessa, a qual ele só poderá experimentar após a compra? Como adequar o nível de serviços para que se minimize esta sensação de risco? Lovelock e Wright (2006) apresentam as seguintes constatações: como os serviços são intangíveis, em geral são difíceis de avaliar. Neste aspecto, os clientes buscam pistas tangíveis da natureza do serviço. O quão impressionado não ficaria um cliente ao visitar um amigo em um hospital onde o terreno e o prédio são mantidos em perfeitas condições, a decoração interior é mais animadora do que institucional e o pessoal é mais amistoso e usa uniformes elegantes e imaculadamente limpos, assim eles complementam.

Inseparabilidade. Serviços necessitam da presença do cliente para serem produzidos, explicam Gianesi e Correa (1996) e mencionam que este fato apresenta um grande número de variáveis em que o nível de serviços deve ser planejado, medido e controlado exaustivamente. Entre algumas variáveis, podem ser destacadas as seguintes: a) participação - o cliente vai consumir junto com 0 funcionário, e é necessário treinamento, motivação e tudo que for possível para que o cliente perceba a qualidade no serviço; b) avaliação do processo e resultado - a qualidade do processo é observada na hora pelos clientes; C) operações descentralizadas - ao longo da experiência do cliente em um estabelecimento qualquer ele pode ter diversos tipos de interação com diversas pessoas. Sincronizar estas atividades e manter um nível de qualidade de serviços adequado é muito importante. Sobre a inseparabilidade, que envolve a produção simultânea ao consumo, Lovelock e Wright (2006) fazem distinções entre encontros de alto nível de contato entre clientes e organizações de serviços e encontros de baixo nível de contato. Quando se observam categorias relacionadas a serviço nas pessoas ou nos bens das pessoas e o nível de tangibilidade de cada um deles, observa-se o mínimo de contato necessário para a oferta de um serviço, conforme explicado anteriormente. O fato é que esta também pode ser uma decisão gerencial, em que se pode reduzir ou aumentar o contato com o cliente de acordo com a estratégia desenhada pela empresa para se conquistar o cliente. Algumas empresas do setor da saúde estão utilizando a tecnologia para minimizar e/ou eliminar o contato com as 
pessoas, para simplificar a entrega do serviço e reduzir os impactos negativos da produção simultânea ao consumo.

Perecibilidade. Para Gianesi e Correa (1996), como não se pode estocar um serviço, regular a oferta à demanda é uma das atividades que devem ser perseguidas exaustivamente pelo estrategista em serviços. Os serviços são altamente perecíveis; é impossível estocar um leito de hospital que não foi ocupado no final de semana ou um não-comparecimento a uma consulta do dia anterior, para serem negociados em momentos de maior demanda. Na mesma linha, Lovelock e Wright (2006) explicam que as operações de serviços criam um estoque perecível que não pode ser armazenado para venda posterior como, no exemplo, dos leitos. $\mathrm{O}$ uso da capacidade produtiva, em especial, na área da assistência médica, é um dos segredos para o êxito neste ramo de atividade. O fato é que em serviços processados com pessoas, como em saúde, não raro impõem espera indesejada aos seus clientes, como forma de evitar o excesso de oferta. Os agendamentos, por exemplo, visam a minimizar filas, mesmo assim nem sempre resolvem. Poupar tempo do cliente melhora sua experiência no serviço e, conseqüentemente, dá mais vantagem competitiva ao prestador de serviços. Resolver esta equação de adequação da demanda à oferta é um grande desafio para os profissionais de serviços.

Lovelock e Wright (2006) explicam, ainda, que as características dos serviços acima apresentados: intangibilidade, inseparabilidade, perecibilidade e ainda variabilidade, aceitas prioritariamente no meio acadêmico, simplificam o mundo real. Para eles, as diferenças básicas entre bens e serviços devem ser complementadas e, portanto, apresentam as seguintes características: os clientes não obtêm propriedade; os produtos dos serviços são realizações intangíveis; envolvimento dos clientes no processo de produção; as pessoas como parte do produto; maior variabilidade dos insumos e produtos operacionais; mais difícil de os clientes avaliarem; ausência de estoques; importância do tempo e diferentes canais de distribuição, os sistemas de entrega podem envolver canais eletrônicos e físicos. Conforme estes autores, nesta última característica, e também em outras, entre as citadas por eles, nota-se um efeito importante dos avanços tecnológicos nos serviços. Os clientes agora são capazes de atender a si mesmos, em lugar de demandar a assistência de um funcionário. Isto tem causado mudanças importantes no setor da saúde. 


\subsubsection{Intangibilidade nos Processos em Serviço}

Entre as características dos serviços acima citadas, a intangibilidade é a que mais distingue serviços de produtos. Bowen e Ford (2002) expõem as principais diferenças entre serviços e manufatura, considerando que estas diferenças são causadas, principalmente, pela questão da intangibilidade.

1- Diferenças na avaliação da organização de serviço:

a) controle subjetivo da eficácia organizacional. A avaliação é subjetiva e está relacionada à satisfação e à lealdade do cliente (como medir a eficácia de um tratamento psiquiátrico, por exemplo);

b) controle subjetivo da eficiência organizacional. Ao se determinar exatamente as entradas e saídas (inputs e outputs) em serviços, é importante considerar a co-produção do cliente. Duas questões relevantes estão relacionadas com estes itens: a entrada é fornecida com a co-produção do cliente, e os clientes oscilam muito e variam em suas decisões, gerando demandas diferentes.

2 - Diferenças na estratégia da produção do serviço:

a) controle da qualidade do serviço. Em função da produção simultânea ao consumo, as falhas nos serviços não podem ser corrigidas como na manufatura, elas devem ser reparadas no momento do atendimento; em bens, são reparados por especialistas em operações de retaguarda (back office);

b) controle da capacidade e demanda. Como os serviços são altamente perecíveis (não podem ser armazenados), deve haver um controle adequado da demanda para que não se opere com capacidade ociosa, gerando perdas.

\subsubsection{Diferenças no Processo de Produção de Serviços}

A produção de serviços também apresenta diferenças importantes em relação à manufatura que alteram as formas de se conduzir as estratégias de produção de serviços. Conforme Bowen e Ford (2002), os principais itens são os seguintes: 
a) controle do processo de produção para acomodar a co-produção do cliente. Considerar a importância no desenho do processo da co-produção, envolvendo cliente e empregado;

b) controle do ajuste da produção para acomodar a co-produção do cliente. Considerar que na manufatura há uma distância como prestador de serviço, ou seja, a produção é protegida, pois é realizada longe do cliente. Em serviços, tem-se a questão da inseparabilidade, portanto é junto ao cliente;

c) controle dos empregados da produção para acomodar clientes como coprodutores. Deve-se sempre considerar a convivência entre empregado e cliente;

d) controle dos clientes como co-produtores. Processo de produção deve considerar a co-produção. Considerações: 1) capacidade de os funcionários reagirem aos diferentes clientes; 2) encontro com o cliente: saber lidar com as questões de incerteza; 3) impedimento - pelas firmas de manufatura - de o cliente estar no nível técnico (nas máquinas, nos equipamentos, e outros); a necessidade da transparência, pois nos serviços, isto não pode ser feito.

\subsection{SERVIÇOS PROFISSIONAIS, SERVIÇOS DE MASSA E LOJA DE SERVIÇOS}

As possibilidades de oferta de um serviço variam muito. Neste caso, o grau de intangibilidade de um serviço e outro podem ser muito diferentes. Podem-se observar serviços com alto grau de intangibilidade como, por exemplo, um serviço de aconselhamento médico por telefone. Por outro lado, têm-se serviços como de clínicas de diagnóstico, instaladas em prédios suntuosos e que realizam exames de diagnóstico por imagem em equipamentos sofisticados de alto valor financeiro. Nos dois casos, o que se pretende é meramente um diagnóstico para facilitar a prescrição médica. Considerando estas questões, Silvestro (1999) faz uma descrição dos serviços em relação ao processo, os quais podem ser classificados pelo menos de três formas distintas: profissionais, massa e lojas de serviço. Cada um causa interesses diferentes da gerência e que a estratégia de serviços, 0 controle e a medida de desempenho diferirão significativamente entre os três.

1 - Serviços profissionais. Participação freqüente e ativa do cliente no processo para definição do serviço, detalhando suas exigências individuais. $O$ 
desafio-chave é adaptar-se às mudanças dos clientes, como especificações, entrega dos projetos, entre outros. Enfatiza a dificuldade de avaliação do serviço pelo cliente, que, às vezes, confunde preço baixo com qualidade e, por esta razão, considera a questão de controle de custo como chave. Corrêa e Caon (2002) citam os serviços médicos, como uma consulta ou uma cirurgia, como exemplos de serviços profissionais.

2 - Serviços de massa. As especificações do serviço são elaboradas antes da participação do cliente no processo, de forma pouco personalizada, devendo entender as expectativas dos clientes. Correa e Caon (2002) complementam Silvestro (1999): algumas características destes serviços são: atendimento a grande número de pessoas de forma padronizada, visando a ganhos de escala. O contato que se tem é praticamente com a tecnologia e com as instalações. A ênfase no controle em geral é feita nas operações de retaguarda. Alguns exemplos: fornecimento de energia elétrica, de água e de gás.

3 - Loja de Serviços. A loja de serviços, conforme modelo da Silvestro et al. (1992), apresenta um meio termo entre os serviços de massa e os serviços profissionais. O cliente interfere de forma discreta no processo da operação de serviços. Já Correa e Caon (2002) explicam que a região intermediária entre os extremos é longa e bastante variada e inferem que é onde se encontra a maioria das operações de serviços. Estas operações tratam de um volume intermediário de clientes e estão a meio caminho das variáveis: customização, ênfase em pessoas versus ênfase em equipamentos e intensidade de contato.

Na matriz proposta (Figura 2 - Modelo de Processo de Serviço), Silvestro et al. (1992) correlacionam o volume de produção com diversas características do processo de produção, como as seguintes dimensões de serviços: foco em equipamento ou pessoas; nível de contato com o cliente; grau de valor agregado na linha de frente; nível de decisão (julgamento) da linha de frente; grau de customização do serviço; foco no processo ou no produto. O modelo apresenta três tipos de serviços e afirma que a estratégia e a avaliação das operações destes tipos de serviços serão muito diferentes: serviços profissionais (dificuldade de avaliação do serviço pelo cliente), serviços de massa (especificações de serviço são elaboradas antes do cliente no processo de forma pouco personalizada) e lojas de serviço. 


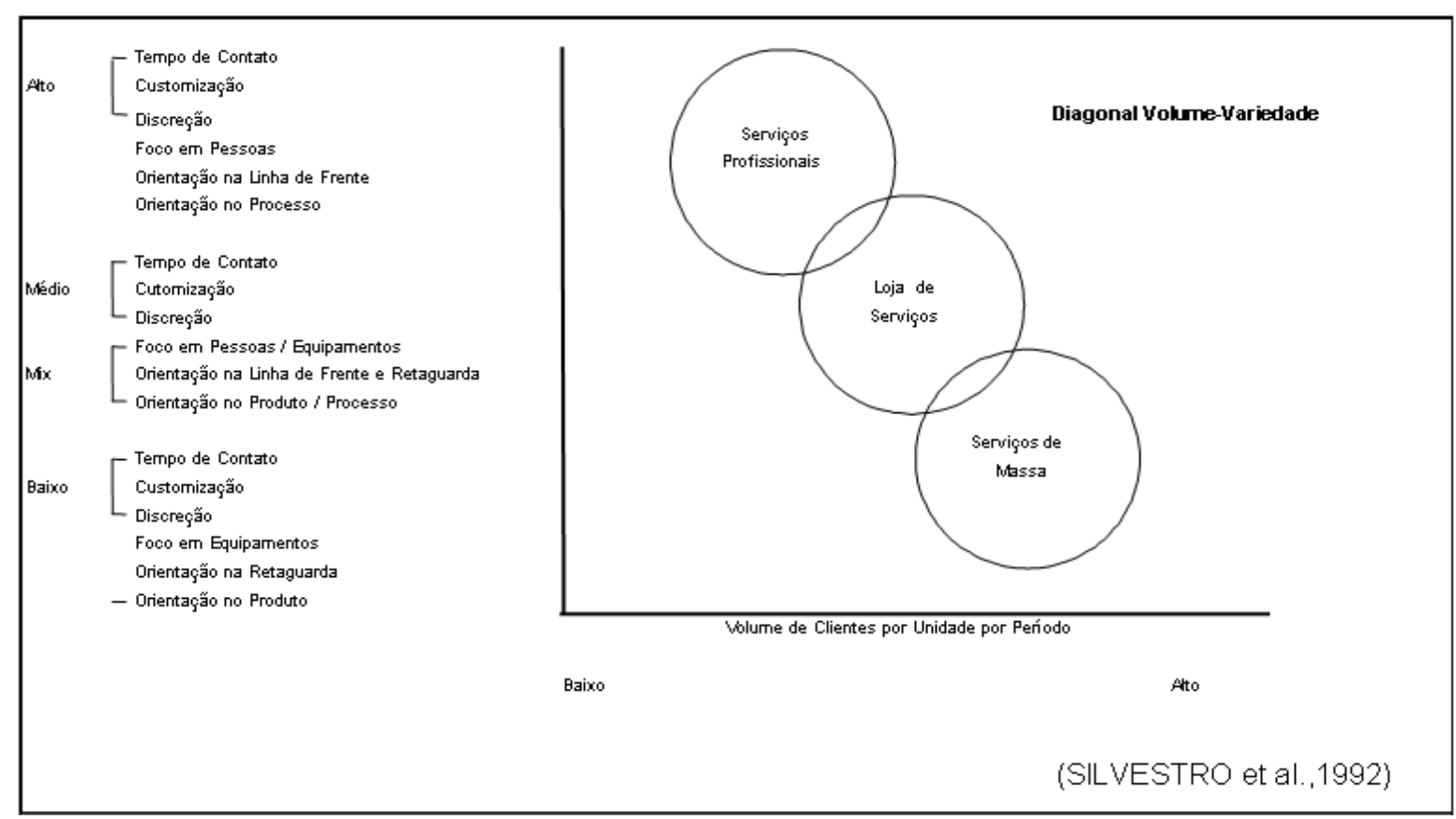

Figura 2 - Modelo de Processo de Serviço

O modelo do Processo de Serviço de Silvestro et al. (1992) busca o balanço entre volume de atendimento a clientes por unidade de período e "variedade", entendida como a capacidade de exercer discernimento na linha de frente para customizar o processo.

Este modelo de análise busca posicionamento estratégico que traga eficácia de custos para serviços. Se o serviço se posicionar mais à direita, demonstra baixo foco estratégico, tentando processar grandes volumes de serviço com projeto de processo que exige alta padronização. Se estiver à esquerda, pode estar perdendo oportunidades de negócio por excessiva customização.

A partir deste modelo, pode-se avaliar a questão do serviço sobre o ponto de vista da eficiência e da eficácia, o que pode contribuir muito para entender a questão das operações de serviço e, conseqüentemente, o processo de criação de valor, (OLIVEIRA et al., 2005). Conforme Correa e Caon (2002:73): "A tecnologia da informação em muitas situações está representando na verdade um 'achatamento' da diagonal, expandindo suas possibilidades verticalmente". O efeito do "achatamento" significa que a TI pode contribuir tanto para reduzir os efeitos dos serviços de massa, com baixo ou nenhum grau de personalização, e torná-los mais customizados. Por outro lado, a TI pode contribuir para que se obtenha maior escala 
em situações personalizadas, típicas de serviços profissionais, (OLIVEIRA et al., 2005).

\subsection{SERVIÇOS, NOVA ECONOMIA E TI}

Barney et al. (2001) sugerem que deve haver uma nova forma de se pensar nas operações de serviços na nova economia, considerando a utilização da TI. Os aspectos acima, que vão desde as características dos serviços, passando pelos efeitos da intangibilidade nas operações e depois pelos tipos de serviço, são passíveis de serem mudados, reinventados, realizados de outras formas, graças ao impacto da nova economia e o uso das ferramentas da TI. Com a velocidade das mudanças, em que as tecnologias baseadas na Internet estão por toda parte, é impossível ficar alheio a isto sob o ponto de vista da competição e da gestão. Muitas variáveis na nova economia apontam para a dependência de informações nas operações e, portanto, de sistemas de informação e tecnologia que propiciam eficácia e eficiência no processamento de informações. Conforme estes autores, neste novo contexto, são fundamentais o uso da $\mathrm{TI}$ e o conceito de redes nas operações de serviços.

\subsection{PRODUÇÃO DE SERVIÇOS}

Zarifian (2001) faz uma interessante abordagem, demonstrando a convergência entre o setor industrial e o setor de serviços. Segundo este autor, o setor industrial descobre e incorpora a noção de "serviço", o setor dos serviços industrializa seus modos de funcionamento. Para entender melhor esta convergência, o autor propõe falar sobre a produção industrial do serviço, enfatizando os três grandes universos da produção: a) da concepção das novas tecnologias e dos novos produtos ou serviços; b) dos grandes sistemas técnicos que asseguram a produção material destes produtos ou serviços (as fábricas na indústria, as unidades técnicas nos serviços); c) da relação direta com os clientes ou usuários, que permite estruturar o contato com estes últimos (as agências comerciais e redes comerciais).

Conforme o autor, estes universos: 
(...) têm ofícios profissionais e necessidades de organização que permanecem distintos (...), porém os mesmos acreditam que (...) a eficiência futura da empresa depende amplamente da qualidade da cooperação entre estes três universos, e, portanto, de uma convergência e a complementaridade nos seus objetivos e na maneira de trabalharem e se organizarem, (ZARIFIAN, 2001:71).

Gianesi e Corrêa (1994: 21) concordam com o autor acima e comentam que a questão da industrialização do serviço tem implicações fundamentais na competitividade das empresas. Para que estas não se tornem vulneráveis à competição internacional, é necessário que se desenvolvam conceitos e técnicas para as operações de serviço, com a mesma ênfase que se tem dado à manufatura.

De maneira similar, porém observando sob outro ponto de vista, KingmanBrundage et al. (1995) comentam sobre a necessidade da evolução da produção dos serviços. Os autores informam que, com base em suas experiências e descobertas, foram levados a questionar a estrutura funcional tradicional e o enfoque departamental encontrado na maioria das empresas de serviços. Estes autores entendem que os gerentes em particular são cada vez mais desafiados a desenhar sistemas de serviço que se adequem aos desejos dos clientes, em vez de se fecharem em seus departamentos, priorizando os resultados para uma área específica da empresa. O que se percebe é que o conceito de conjunto em serviços ainda é pouco explorado. As melhorias na eficiência e eficácia das empresas ainda são perseguidas de forma pontual, limitando-se a áreas funcionais, como vendas, operações ou atendimento a cliente. Os gerentes estão despreparados para assumir uma integração funcional de toda a empresa, o que faz com que não se maximize os resultados nos serviços oferecidos. O modelo da lógica dos serviços, propostos por Kingman-Brundage et al. (1995) é uma ferramenta analítica que visa a ajudar a conceber o serviço por inteiro, de forma indivisível. O modelo da lógica do serviço demonstra como e por que um sistema unificado de serviço trabalha melhor. $\mathrm{O}$ modelo da lógica do serviço é integrativo e colaborativo e reconhece que as necessidades de clientes são freqüentemente complexas e requerem uma equipe totalmente integrada. O modelo possui três variáveis, lógicas internas (do cliente, da técnica, do empregado), que, segundo os autores, devem estar integradas, para que o negócio se desenvolva em serviços de maior produtividade e qualidade aos clientes em geral.

Quanto à lógica do cliente, questiona-se: "O que o cliente está tentando fazer e por quê?", "Quais as expectativas dos clientes?". O cliente como consumidor, 
argúi: "Como se consegue o que se quer?". O cliente como co-produtor, questiona: "Qual é o seu papel e como deve ser desempenhado?".

Quanto à lógica da técnica, pergunta-se: "Como os serviços prestados são produzidos e por quê?". A lógica técnica deve ser consistente com o conceito do serviço.

Quanto à lógica do empregado, argúi-se: "O que os empregados estão tentando fazer e por quê?". Há também outras questões importantes que abordam: precisão do "Job description"; avaliação das práticas de seleção e treinamento e avaliação das práticas de incentivo, compensação e gerenciamento.

Em suma, o modelo propõe uma alternativa para as empresas que necessitam deslocar-se do modelo departamentalizado, para o de negócio integrado. No modelo tradicional departamentalizado, as áreas competem entre si; no de negócio integrado, o foco está em fornecer experiências de serviço de qualidade, que oferecem alternativas mais adequadas para se competir no setor de serviços.

Como pôde ser observado, o processo de industrialização dos serviços envolve modernas técnicas que há muito a indústria da manufatura vem desenvolvendo e a integração das operações, propiciando um valor único ao cliente, pois não é mais novidade para as empresas. Assim, gera-se uma melhor experiência com serviços. Aprofundando um pouco mais o estudo nas características das operações de serviços, poder-se-ia ainda direcionar o estudo para análise das lacunas (gaps) existentes entre o serviço esperado pelo cliente e o serviço percebido (PARASURAMAM, 1986). Entre uma situação e outra, existem inúmeras passagens que envolvem fluxos de informações e prestação de serviços que, por mais que sejam controlados, são passíveis de desvios. Desde o serviço esperado, que nasce das necessidades pessoais dos clientes, das experiências anteriores, da propaganda informal, tem-se um longo caminho a ser percorrido pela empresa que deverá desenvolver os fluxos para entregá-lo. Este processo passará da percepção da gerência em relação à experiência do consumidor para a execução, muitas vezes em diversas áreas do local de prestação de serviços, os quais irão acumulando desvios. Todas as questões apresentadas comprometem não apenas o desempenho da empresa, mas também sua eficácia, minimizando o valor criado. Com o acirramento da competitividade no setor da saúde, torna-se fundamental a 
busca destas alternativas para se garantir a sobrevivência e sustentabilidade das empresas.

\subsubsection{Operações de Serviço na Saúde e a utilização da TI}

As operações de serviços na saúde apresentam algumas peculiaridades em relação aos serviços em geral. Estas especificidades influenciam fortemente 0 desenho de uma estratégia de negócio neste setor, no que se relaciona à criação de valor. Considerando que uma experiência positiva em relação a um tratamento da saúde seria não a ter, ou seja, "não ficar doente", parte-se da idéia de que o serviço deverá satisfazer uma necessidade apenas e não um desejo, variável que também afetará a forma de se avaliar a criação de valor. Além desta, há várias outras características que tornam o setor complexo e de difícil compreensão. Scott e Struder (2003) comentam que a complexidade é algo inerente ao negócio na saúde.

A existência de um número elevado de intermediários não permite uma relação direta e simples de causa e efeito. Este fato acentua ainda mais os efeitos acima apresentados, pois existem muitas camadas a montante e a jusante da cadeia de valor do prestador de serviço. Hesket et al. (1997) complementam dizendo que a complexidade dos serviços na saúde é evidente e compreensível. Há muitos intermediários para permitir um foco simples ou de causa e efeito. Por exemplo, há pelo menos dois clientes diferentes para uma simples transação, envolvendo um consulta médica. O paciente seria um, o plano ou seguro saúde outro. Pode-se pensar ainda nas empresas que pagam as mensalidades do plano de saúde, como um terceiro cliente e aí por diante. Estes fatos criam dificuldades no desenvolvimento de estratégias de negócios, utilizando a TI. Problemas básicos entre usar ou não a TI nas operações para infra-estrutura administrativa, ainda pairam sobre as empresas. O que pensar sobre novas formas de se executar operações de serviços se as convencionais ainda estão em estágio incipiente? Conforme Skinner (2003), o tema precisa ser mais bem debatido, pois o ambiente está em constante mudança. Assim como em outras indústrias, a TI trará ganhos importantes para a eficiência e eficácia das empresas, tanto nas operações de linha de frente (front office) como nas de retaguarda (back office). Muitas barreiras devem ser vencidas, como já foi dito, entre elas está a complexidade da indústria: de um hospital para outro se encontram objetivos e processos muito diferentes (SKINNER, 2003). 
No que se refere à falta de padronização, desde o vocabulário até as métricas utilizadas, isto traz muitos problemas ao setor. No que se refere à questão da economia de escala, este assunto é difícil e árido quando se observa sob a ótica da indústria da saúde, aliás, os serviços profissionais, como um todo, apresentam estas peculiaridades. Segundo Silvestro (1999), estas características podem ser mudadas, reestruturando-se algumas formas de se desenvolver o negócio, utilizando a TI, por exemplo. Estas, entre outras variáveis, além da falta de profissionais especializados em TI na saúde, a falta de hábito em redesenhar processos e, finalmente, os baixos investimentos na reestruturação da gestão do negócio, trazem outras complicações para o setor.

Por outro lado, na medida em que os consumidores aumentam seu nível de informação, também adquirem mais poder (SEIBOLD, 2000). Este é um dos efeitos da nova economia, que transforma cada vez mais o comportamento dos consumidores.

Na área de cuidados com a saúde, já existem correntes que consideram esta tendência importante e que deve ser analisada com muita atenção. Conforme Morath (2003), deve-se considerar cada vez mais o paciente como parte do sistema do cuidado. Está havendo uma mudança de decisão: os pacientes por meio de seus tomadores de serviço (planos e seguros de saúde em geral) exigem novas métricas e padrão mais elevado de contabilização que atenda a todos os interessados.

No mercado Norte-Americano, os pacientes e clientes em geral questionam constantemente o aumento crescente dos custos. Segundo Morath (2003), este processo é irreversível. Quinn e Baily (1994) fazem uma importante observação sobre a questão da informação e o uso da TI, aos clientes em geral. Conforme os autores, medir a qualidade de serviços não é tarefa simples. Assim, eles fazem a seguinte interrogação: Quanto vale uma informação antecipada?; "Quanto vale um diagnóstico médico mais preciso?"; "Quanto vale um resultado de exame em tempo real (on-line)?". Tudo isto é difícil de ser medido. De acordo com eles, a qualidade final de um serviço pode não ser conhecida, até mesmo depois de o cliente ter passado pela experiência, como cirurgia, odontologia e outros. Qualidade final pode depender de vários fatores, inclusive sorte ou informação, sobre como foi realizado o serviço. Nestes termos, a TI pode ser primordial nos serviços da saúde, pois, em geral, os resultados dos serviços carregam muitas informações. 


\title{
3 A NOVA ECONOMIA E A TECNOLOGIA DA INFORMAÇÃO
}

A Nova Economia ou Economia do Conhecimento pode ser entendida como uma economia cuja abordagem privilegia as idéias, o conhecimento, a informação, a inovação de valor entre outros (TAPSCOTT, 1998 e 2001) e (KIM e MAUBORGNE, 2002). Esta situação tem trazido grande impacto na economia tradicional (ou economia de produção). Entender o impacto destas transformações pode ser muito importante para a sobrevivência das empresas em um mundo globalizado, em que as mudanças são cada vez mais velozes.

Wertheim (2001) comenta sobre a força da tecnologia e o crescimento dos usuários:

\begin{abstract}
Essa abrangência não pode ser explicada meramente pela disponibilidade da tecnologia. As pessoas não adotam uma tecnologia simplesmente porque ela existe. (...) as pessoas só adotam uma tecnologia quando ela está em consonância com um desejo latente. A simples escala do interesse despertado pelo ciberespaço sugere haver aqui desejos intensos em ação.
\end{abstract}

Alan Kay, apud Tapscott (1998), descreve de forma ímpar esta tendência digital cada vez mais presente nos dias de hoje e que tende a se acentuar ainda mais: "A tecnologia só é tecnologia para a gente que nasceu antes dela ser inventada". Para os jovens, estas tecnologias não são novas ou velhas - são da mesma geração que eles. "É como o ar", diz Coco Conn também citado por Tapscott (1998); para eles, não há assunto mais importante para pais, professores, políticos, profissionais de marketing, líderes empresariais e ativistas sociais do que entender o que é que a nova geração pensa fazer com a competência digital. Como se percebe, um novo contexto mercadológico vem surgindo, impulsionado pela TI. Esta mudança interfere, principalmente, na forma das empresas apresentarem-se ao mercado, em suas estratégias de negócios, visando também a atender as transformações de seus clientes. Daqui para frente, os novos consumidores e públicos de interesse em geral poderão participar cada vez mais e interferir nos processos de troca com as empresas. Portanto, escolher os melhores caminhos no mercado, as melhores estratégias a serem adotadas pelas empresas, não serão o bastante. Os estrategistas deverão considerar que, na nova economia, as exigências serão outras, todos os interesses deverão ser considerados para se maximizar o valor para o grupo. 
Farrell (2003) constata que, de fato, houve uma Nova Economia nos anos 90, porém, diferente do anunciado naquela época. Além do avanço da Internet, a Nova Economia ocorreu pela intensificação da competição dos negócios e como resultado explosivo da inovação gerencial. A autora explica que realmente houve um crescimento na produtividade em alguns setores na economia norte-americana, porém se nota uma pequena relação entre produtividade e desempenho da TI. A produtividade, nestes setores, foi obtida pela contínua inovação, que os administradores foram obrigados a fazer em suas empresas a fim de protegerem suas receitas e seus lucros em face de uma forte competição. E conclui que foi, portanto, a inovação em produtos, práticas de negócios e tecnologia, que orientou os ganhos de produtividade. Tanto quanto a produtividade se eleva, a competição se intensifica, trazendo uma nova onda de inovação. A verdadeira nova economia é o círculo virtuoso de competição, de inovação e de crescimento. Porter e Millar (1985: 83) fazem a seguinte menção sobre essa questão: "A Tecnologia da Informação está passando de roldão por toda a economia. Nenhuma empresa escapa de seus efeitos. Reduções drásticas no custo de obtenção, processamento e transmissão das informações estão alterando a maneira como fazemos negócios." Correa e Caon (2002: 400) arrematam: "A chamada 'nova economia' vem se caracterizando pelo surgimento de empresas que atacam as empresas concorrentes tradicionais, e que estão constantemente em busca de novas tecnologias que substituam ou melhorem antigos processos".

\subsection{TRANSFORMAÇÕES, MUDANÇAS E TURBULÊNCIA AMBIENTAL}

Sobre transformações e mudanças, Porter e Millar (1985: 89) já apresentavam uma idéia precisa sobre este processo e de sua força: "A transformação tecnológica está expandindo os limites das possibilidades das empresas com maior rapidez do que a capacidade dos gerentes para explorar oportunidades." Figueiredo (1997) explica que, no passado, as organizações eram complexas e os postos de trabalho, muito simples. Atualmente, as organizações foram simplificadas e os postos de trabalho tornaram-se complexos. Segundo este autor, isto ocorre em função da disponibilidade cada vez maior da TI nas empresas.

O ambiente de negócios das empresas está mudando. As empresas estão olhando para fora de suas organizações, buscando estabelecer conexões 
eletrônicas com clientes, fornecedores, distribuidores, grupos de indústria e mesmo com concorrentes. O propósito desta ação é manter-se sintonizado com o mercado, ampliar as comunicações de negócios e crescer de forma saudável, mantendo a sustentabilidade (ALBERTIN, 2000). Falar de mudança é falar de globalização. Conforme Bossidy e Charan (2004), a globalização não é uma coisa nova. Esta vem acontecendo, em função da integração das atividades de negócios entre os países. Esta integração foi impulsionada pela TI, em especial a Internet, e só aconteceu quando as empresas começaram a olhar para fora de suas organizações, buscando estabelecer conexões com clientes, fornecedores, e assim por diante.

\subsection{A TRANSPARÊNCIA NAS EMPRESAS E O PODER DO CLIENTE}

Transparência é, no momento, a palavra mais utilizada pela nova economia, diz Tapscott (2005) e acrescenta que esta se tornou a força motriz das mudanças que estão moldando o mundo empresarial.

Este autor explica que a transparência vai muito além dos regulamentos e informações financeiras obrigatórios. Os grupos de interesse das empresas desejam saber como a empresa se comporta perante seus funcionários, produtos responsáveis, comunidade, meio ambiente e tudo que possa afetar seu funcionamento. Atualmente, os consumidores conseguem avaliar o verdadeiro valor de produtos e serviços e até participar das estratégias de suas empresas, diferentemente do passado, em que as empresas mantinham fechadas a 'sete chaves' seus planos estratégicos. Na medida em que a transparência fica mais evidente, caem custos da desconfiança, custos de procura e qualquer outro que esteja ligado ao relacionamento. Conforme Scott e Struder (2003), no setor de saúde tem-se um bom exemplo. Os pacientes querem e necessitam além do que é normalmente medido e apresentado pelas empresas de medicina suplementar. Cada vez mais os pacientes exigirão saber a lógica do sistema para poderem participar melhor e fazer com que isto gere uma experiência positiva para eles. Os autores concluem que as empresas deverão ser as responsáveis em criar parcerias com os pacientes em cada processo dos serviços na saúde. As empresas serão cada vez mais desafiadas com técnicas novas de se fazer conexão com seus clientes, num momento em que as tecnologias e o acesso às informações não param de expandirse. 
A experiência tem demonstrado que o mercado mundial está em constante transformação. Assim, tanto empresas como clientes e consumidores devem reciclar-se, com o propósito de estarem inseridos nessa economia, (TAPSCOTT, 1998). Quanto à conexão com os seus clientes (Id., Ibid.), dá uma noção de como isto está acontecendo, e como será ainda mais importante no futuro ao apresentar suas constatações sobre o que ele chamou de Geração Net. Esta "nova geração" é excepcionalmente curiosa, adaptável e com orientação global. Estes jovens de hoje serão os consumidores e também os gestores de amanhã e provocam dizendo aos gestores tradicionais o quão isto poderá afetar suas estratégias.

Toda esta transparência vem gerando cada vez mais poderes aos consumidores. Conforme Ohmae (1998): "Hoje o livre acesso às informações está tornando as pessoas mais exigentes, pois todos podem adquirir o conhecimento sobre tudo que acontece no mundo". Estas informações vão desde preços e características de produtos e serviços, como em que condições aqueles produtos foram fabricados. Um estudo da IBM Business Consulting Services (GAGNON e CHU, 2006) aponta para as tendências do aumento cada vez maior do poder dos consumidores. Segundo eles, em decorrência do maior acesso à informação, cresce a transparência nos negócios que afetam diretamente o cliente. Com a capacidade de obter informações onde, como e quando quiserem, os consumidores estão cada vez mais exigentes. O crescimento do acesso à rede mundial de computadores e às novas tecnologias sem fio tem ampliado o acesso às informações de forma onipresentes. Isto tem permitido que o cliente tome decisões de forma mais racional. Desta forma, entender as transformações no comportamento de seus consumidores será importante para as empresas responderem adequadamente às suas necessidades.

\subsection{A REVOLUÇÃO DA INFORMAÇÃO E A UTILIZAÇÃO DA TI}

Vários autores, ao mencionarem o fenômeno da TI (em especial, a Internet), não raro utilizam o termo "revolução". Este termo demonstra uma ruptura nas formas de pensar e fazer as mais variadas atividades, que se estendem desde uma simples comunicação até complexas redes de relacionamentos e novos negócios. Antes de se falar em revolução da informação, é importante esclarecer o que é TI. Nestes termos, serão apresentadas duas abordagens conceituais, que vão ao encontro dos 
propósitos deste estudo, e são elas: "Como tecnologia da informação, consideramse todas as formas que processam informações, entre elas os computadores, tecnologia de comunicações, automação e outros." (PORTER e MILLAR, 1985). A segunda abordagem:

O conceito de Tecnologia da Informação (TI) é mais abrangente do que os de processamento de dados, sistemas de informação, engenharia de software, informática ou o conjunto de hardware e software, pois também envolve aspectos humanos, administrativos e organizacionais. (LAURINDO, 2002: 19).

A revolução da informação é também revolucionária, porque faz confrontar com exigências para as quais ainda não se está preparado (NOBREGA, 2002). Esta revolução possibilitou a aceleração no processo de globalização dos mercados e vem causando mudanças e transformações nos processos de troca e de criação de valor. Assim como este autor, diversos outros utilizaram a expressão "revolução" para enfatizar a importância da informação em si e também como esta vem transformando as formas de se fazer negócios no mercado. Turban (apud TOLEDO, 2004) diz que a revolução da informação está gerando mudanças na forma de se fazer negócios e que as novas regras ainda não foram estabelecidas. Os sistemas de informação possibilitam novas estratégias competitivas, mudando a configuração das empresas e de seus relacionamentos. Para Toledo (1999), está revolução está na forma de se realizar negócios causados pela TI, em especial a Internet, pois tem permitido às empresas apresentarem desempenho superior, e nem sempre as organizações tradicionais e bem estabelecidas saem na frente. Porter e Millar explicam que a revolução da informação está afetando a competição de três maneiras vitais: 1) mudando a estrutura setorial; 2) gerando vantagem competitiva ao proporcionar novas formas de as empresas se apresentarem no mercado, e 3) criando novos negócios, a partir dos negócios ou operações já existentes da empresa. Corrêa e Caon (2002) falam da explosão da conectividade como responsável pela revolução das estratégias de negócios nos anos 90. Para eles, o desenvolvimento da TI neste período pode ser classificado como extraordinário e este tem norteado as empresas para esta revolução. Neto (2005) diz que a emergência da chamada economia digital, fundamentada na TI, vem revolucionando o mundo dos negócios e mudando o rumo das estratégias das empresas. Johnson (2001) lembra que "a revolução digital vai sem dúvida transformar as bolsas de valores, a pesquisa nas bibliotecas e os perfis de crédito, como os gurus vêm 
prevendo há anos nas páginas de economia". Tapscott (1998) diz, então, que os jovens "digitais" são revolucionários, mas não gastam retórica ao dizê-lo. Diferentemente dos jovens dos anos 60, não falam tanto, eles fazem. Por último, pode-se citar Porter e Millar (1985), que afirmam que a relevância da revolução da TI não seria algo questionável. O que deve ser discutido agora são as formas de se utilizá-la.

O objeto deste trabalho é o estudo da TI como agente criador de vantagem competitiva no mercado e, portanto, gerador de oportunidades de negócios no setor da saúde. Segundo Porter (1989), se algo pode gerar uma vantagem competitiva é por que este está criando maior valor. Macgee e Prusak (1994) dizem que não é a tecnologia que cria valor, mas o seu uso. Um uso eficaz da TI está relacionado com a forma de como ela está alinhada às estratégias da empresa, com a forma de que ela cria valor para o cliente, conforme explica Laurindo (2002). Neste caso, pode-se dizer que a satisfação do cliente é um importante indicador de desempenho na avaliação do desenvolvimento das estratégias de negócios que utilizam a TI. Mais uma vez depara-se com a questão do valor, porém com o ganho não apenas para o cliente, mas também para a empresa. A empresa, ao satisfazer as necessidades do cliente, obtém maior vantagem competitiva, graças à revolução da informação.

\subsection{A UTILIZAÇÃO ESTRATÉGICA DA TI}

A revolução da informação leva a novas formas de se criar valor que, por sua vez, geram vantagem competitiva e podem ser utilizadas de forma estratégica no mercado.

A TI não deve ser apenas uma ferramenta, mas um jeito novo de fazer as coisas. A grande contribuição da TI não tem sido para a administração; ela tem ocorrido para as operações. Com as afirmações acima, Drucker (1995) dá uma demonstração de como a TI pode contribuir com os negócios das empresas. O autor explica que as empresas são feitas para criar valor. Para tanto, são necessárias informações que permitam aos executivos tomarem decisões corretas. Estas informações provêm de quatro conjuntos de métricas de diagnóstico: informações básicas, informações de produtividade, informações sobre competências e informações sobre alocação de recursos escassos. Os quatro tipos de informação contam apenas com o negócio atual. Elas orientam as táticas e, com relação às 
estratégias, ainda é preciso as informações sobre o macro e o micro ambiente das empresas. Um sistema de informação adequado deve incluir questionamentos a essas premissas, integrando tecnologias isoladas de diferentes finalidades para dar suporte aos conceitos de negócios. Este sistema tornaria possível o diagnóstico do negócio, a definição da estratégia e a tomada de decisões. Drucker (1995) valoriza as informações para as empresas, aliás mais do que isto, afirma que as informações são o próprio negócio. Transportando este ponto de vista para o setor da saúde, a importância aumenta ainda mais, pois uma das características principais desta indústria é justamente o diagnóstico, seguido da prescrição. Municiar o setor com dados, ou melhor, informações, integrando-as, deverá gerar um ganho substancial em seus custos e na sua qualidade.

Tapscott (1998) concorda com Drucker (1995) e explica que, na chamada sociedade da informação, o verdadeiro ativo não é a informação, mas o conhecimento. Segundo ele, informações existem em abundância, mas não o conhecimento. O conhecimento é informação que cria valor para a organização. Turban et al. (2003) são ainda mais incisivos, inferindo que as empresas já não podem mais trabalhar com "flutuações da informação". É necessário saber tudo no menor tempo possível para que as informações cheguem logo nos decisores. Segundo os autores, as tecnologias de informação podem reduzir este intervalo de tempo a quase nada.

Por outro lado, Kedrovsky (2004) explica que além das fronteiras da organização, a TI também pode colaborar com clientes por meio de fluxo de informações customizadas, que avisam no meio da inundação de informações da Internet. Como exemplo, pode ser citado o serviço on-line de doadores da Secretaria da Saúde do Estado de São Paulo que além, de tornar transparentes as informações referentes aos doadores de órgãos, informam os pacientes sobre sua posição na fila de espera (BARATA, 2006).

Muitas são as formas de se abordar o mercado de forma estratégica usando a TI. Isso se dá internamente ou criando conexões com clientes, fornecedores, concorrentes, parceiros, entre outros. O importante é saber que a TI tem diversas aplicações, que podem criar valor para as empresas, como foi visto anteriormente. Negligenciar as opções de se explorar estratégias de negócios é reduzir as possibilidades de se obter êxito no mercado. Por fim, expõem-se uma apresentação do moderno papel da TI que fundamenta o que foi dito: 
A TI evoluiu de uma orientação tradicional de suporte administrativo para um papel estratégico dentro da organização. Ela não só sustenta as estratégias de negócios existentes, mas também permite que se viabilizem novas estratégias empresariais. O papel da TI como arma estratégica competitiva tem sido discutido e enfatizado, principalmente pelas novas possibilidades de negócios que ela proporciona. (LAURINDO, 2002). 


\section{ESTRATÉGIAS DE NEGÓCIOS E A TECNOLOGIA DA INFORMAÇÃO}

\subsection{ESTRATÉGIAS DE NEGÓCIOS}

Porter (1996: 61-68) lembra que a estratégia delineia um território em que a empresa procura diferenciar-se. E complementa: "A estratégia tem a ver com escolhas: não se pode ser tudo para todos". Assim, acredita-se que a escolha deva ser feita e divulgada a todos os colaboradores para que os esforços sejam realizados na mesma direção. O papel da estratégia é apresentar a melhor opção de caminhos possíveis para uma organização seguir, considerando principalmente as forças do negócio e as oportunidades do ambiente. Ainda segundo Porter (1996): “A essência da formulação de uma estratégia competitiva é relacionar uma companhia ao seu meio ambiente". Novamente, verifica-se a importância do sistema de informações no planejamento estratégico, em que o autor sugere o relacionamento da companhia ao seu meio ambiente. Sobre o tema ambiente, transformações e estratégia encontram-se em Ansof (1993: 75) as seguintes palavras: "Estratégia é uma ferramenta potencialmente muito poderosa para lidar com as condições de mudança que cercam a empresa(...)"

Assim como Porter (1996), Markides (1999) também acredita que estratégia envolve escolhas, conforme conceito acima, porém este autor delimita as escolhas em três dimensões: quais clientes focar, quais produtos oferecer, e que atividades realizar. Para o autor, uma companhia será bem sucedida se ela escolher uma posição estratégica diferenciada, que irá distingui-la de outros competidores. "A origem mais comum de estratégias falhas é a incapacidade de fazer escolhas claras explícitas nestas três dimensões", (MARKIDES, 1999).

Rangan (2003) explica que estratégia se relaciona com a alocação e maximização de recursos. Pode-se dizer que a estratégia deve levar à vitória, à conquista, a derrotar o adversário. Mas, quando se pensa sobre estratégia, o que se faz é alocar recursos escassos e finitos para tentar maximizar certas coisas. Falando em essência da estratégia, ela tem de responder a três perguntas. A primeira é: “ O que a empresa produz, que produtos ou serviços ela deve fazer?"; a segunda é: “ Para quem ela faz produtos e oferece serviços?"; a terceira é: "Como fazer o produto 
ou serviço: sozinha, em parceria com outro, terceirizando mediante franquia?". As três têm a ver com alocação de recursos, porque não dá para fazer tudo para todo mundo, mas a alocação de recursos é só a primeira parte. Como se vê, Markides (1999) e Rangan (2003) também elencam elementos semelhantes no que diz respeito à formulação da estratégia, ou mais especificamente, às dimensões ou às perguntas que ela deve responder: O quê? Para quem? Como?

Rangan (2003) ainda complementa: "A segunda parte é a maximização desses recursos. Primeiramente, tenta-se maximizar o lucro (o fluxo de caixa das atividades); o lucro tem de ser suficientemente alto para satisfazer o acionista e agregar valor econômico, obtendo um retorno acima do custo de capital. Uma segunda dimensão é o crescimento, porque não basta ter apenas lucro, é preciso ter também crescimento, por vários motivos substantivos - quanto mais, melhor, se a empresa não crescer, os concorrentes a ultrapassam, além de atrair os melhores talentos e vários motivos avaliativos - que dizem como a empresa foi avaliada. A terceira dimensão é a sustentabilidade, a sobrevivência em longo prazo". Por fim, Rangan (2003) apresenta as forças motrizes mais importantes que para ele impulsionam o crescimento rentável e sustentável: a inovação e internacionalização. Assim, percebe-se que os dizeres de Rangan (2003) vão ao encontro de Christensen (2001) e também de Porter (1999a) quanto à questão da inovação e da internacionalização. Em relação à inovação como motor propulsor da estratégia, Christensen (2001) explica que o motivo de muitas empresas de sucesso fracassarem é que o mesmo motivo que as tornaram líderes dificultam que elas desenvolvam tecnologias de ruptura e, portanto, inovadoras. "As tecnologias de ruptura trazem ao mercado uma proposição de valor muito diferente daquela disponível até então". Conforme o autor, "produtos baseados nessas tecnologias são geralmente mais baratos, mais simples, menores e freqüentemente mais convenientes de usar". Sobre internacionalização, Porter (1999a) afirma que as nações obtêm sucesso em uma indústria em particular porque o ambiente doméstico é o mais avançado, dinâmico e desafiador. A competitividade de uma nação depende da capacidade de sua indústria de se inovar. Desta forma, companhias superam seus melhores concorrentes em todo o mundo por causa da pressão e dos desafios e se beneficiam do fato de ter em casa rivais fortes, fornecedores agressivos e clientes exigentes. Este caminho inovação-internacionalização, além de inibir a entrada de novos competidores no mercado doméstico, garante a presença 
nos mercados internacionais e contribuem para a rentabilidade, crescimento e sustentabilidade das empresas. Pode-se acrescentar ainda que os serviços, objeto de estudo deste trabalho, é um campo importante para o desenvolvimento de inovações. Gadrey et al. (1995) demonstram o quanto o setor de serviços pode contribuir com a inovação nas empresas em geral. Características como intangibilidade, entre outras questões valorizadas na inovação dos produtos em geral são há muito um campo de domínio dos profissionais de serviço.

Sintetizando, pode-se dizer que estratégias envolvem escolhas. Como foi dito antes, escolhas que podem diferenciar uma empresa de seus concorrentes e que Ihe dêem vantagem competitiva. Estas vantagens podem também advir das opções: O quê? Para quem? Como atender os clientes?. Ao atendê-los de forma diferenciada, específica e única, a empresa inova. Esta inovação poderá permitir a internacionalização e, conseqüentemente, o crescimento e a sustentabilidade.

Peck e Jutner (2000) fazem uma interessante abordagem das estratégias coletivas, que nada mais é do que estender a estratégia de atuação da empresa no mercado para um grupo de empresas. Esta estratégia, segundo os autores, reduz o custo da desconfiança entre os participantes (fornecedores e compradores), o que pode causar vantagens para o grupo. As estratégias coletivas melhoraram a habilidade de cada competidor de predizer e compreender as ações dos outros. Ao compartilharem informações e sistemas comuns, as empresas podem prevenir-se de concorrentes nestes tempos de incerteza ambiental, inibindo a entrada de novos competidores.

Finalmente, entende-se que seja valiosa para este trabalho uma derradeira conceituação sobre estratégias, que são justamente as estratégias de negócios, termo que freqüentemente tem sido utilizado como sinônimo de modelo de negócios (TAPSCOTT, 2001). Portanto, “Um modelo de negócios é um conjunto de suposições sobre como uma organização vai operar ao criar valor para todos os participantes dos quais depende, e não apenas a seus clientes", (MAGRETA e STONE, 2002, p.49). De forma simplificada, pode-se dizer que os modelos de negócios auxiliam a compreender e a gerenciar o sistema que cria valor, neste caso, o objetivo maior de qualquer gestor ou organização.

Bovet e Martha (2001) sustentam que as redes de valor (empresas que trabalham em rede, como se fossem um único negócio), vão além das cadeias de suprimentos tradicionais, pois uma rede de valor é o modelo de negócio. Esta 
abordagem vai ao encontro das estratégias coletivas, comentadas anteriormente por Peck e Jutner (2000). Os autores explicam que as redes de valor representam um tipo inédito de modelo de negócios. Esta rede de valor difere de uma cadeia de suprimento eficiente ou da moderna tecnologia da informação, pois definem a estratégia comercial geral da empresa. (BOVET e MARTHA, 2001).

Hamel e Valikangas (2003) explicam que, no passado, havia uma suposição por parte dos executivos que um modelo de negócios era praticamente imutável; considerava-se que as empresas, trabalhando com rigor, buscando melhorias, obteriam sucesso. Atualmente, mudar é fundamental. Para as grandes empresas, o sucesso contínuo não se apóia mais na manutenção daquilo que vinham realizando, mas sim na resiliência. Resiliência, conforme estes autores, é a capacidade de reinventar modelos e estratégias de negócios à medida que as circunstâncias mudam. O comentário define claramente o ambiente competitivo em que as empresas estão envolvidas na nova economia ou na economia do conhecimento: o ambiente de mudanças. Considerar que as estratégias de negócios deverão se adaptar a estes novos tempos é fundamental para o sucesso das empresas.

\subsection{ESTRATÉGIAS DE NEGÓcIOS E O USO DA TI}

Drucker (1995) considera que foram superestimadas as possibilidades de "modelos de negócio" gerados pelos próprios computadores, os quais poderiam tomar decisões e até mesmo estarem aptos para conduzir boa parte do negócio. E complementa que também se subestimou grosseiramente as novas ferramentas, apenas se pensou nelas como meios de fazer melhor o que os executivos já vinham fazendo. As novas ferramentas e os modelos de negócio relacionam-se entre si, permitindo uma nova visão do negócio de várias formas:

- como geradoras de recursos, no sentido de que as organizações transformam custos em resultados;

- como elo numa cadeia econômica, que administradores devem entender como um todo para administrar seus custos;

- como organizações societárias para geração de valor;

- como criadores e criaturas de desenvolvimento material, área externa às organizações em que as oportunidades e os resultados estão presentes, mas 
também onde as ameaças ao sucesso e sobrevivência de qualquer negócio se encontram.

Conforme Porter e Millar (1985):

A tecnologia da informação está transformando o modo de operação das empresas e afetando todo o processo de criação de produtos. Ademais, está reformulando o próprio produto: a totalidade do pacote de bens físicos, de serviços e de informações oferecidos pelas empresas, de modo a criar valor para os compradores.

Considerando o que foi falado sobre a complexidade da saúde, a colocação de Porter e Millar (1985) em relação à transformação tecnológica e à expansão dos limites da empresa com maior rapidez que a capacidade dos gerentes explorarem as novas possibilidades, fica ainda mais fácil de ser compreendido. Estas novas possibilidades a serem exploradas se constituem em uma questão importante a ser considerada no desenvolvimento de estratégias de negócios na saúde.

A transformação do modo de operação das empresas pela TI permite que se crie valor ao cliente final e este fato enriquece as possibilidades de se atuar no mercado. Rangan e Adner (2001) explicam que: "As opções emergem da tecnologia, escolhas de estratégia. Essa é a razão pela qual se realça que embora a tecnologia e estratégia são complementos fortes, eles não são substitutos". Os autores reiteram a importância de se ter a TI como uma ferramenta, conforme Drucker (1995) e Porter e Millar (1985) e também que a TI deve ser sempre uma escolha entre várias possibilidades estratégicas, para se atuar no mercado.

McFarlan (1998) comenta que "em muitos casos, a nova tecnologia trouxe uma oportunidade singular para uma empresa redistribuir seus ativos e repensar sua estratégia". Segundo ele, a tecnologia proporcionou às empresas novas ferramentas, que contribuem com os ganhos e com a participação no mercado. Um dos ganhos principais foram os sistemas que conectam clientes e fornecedores; este, entre outros, vem contribuindo com a vantagem competitiva de muitas empresas. Em relação às oportunidades criadas pelo uso da TI com conexões, mais especificamente com a Internet, Laurindo (2005) concorda e acrescenta que "a existência de mercados eletrônicos pode ser tanto uma ameaça como uma oportunidade para os intermediários". A questão é como estas empresas vão organizar-se e fazer esse uso da TI. Gilbert (2003) explana a cerca das oportunidades de ruptura e a forma que as tecnologias inovadoras e novos modelos 
de negócio têm efetivamente derrubado empresas e líderes empresariais e provavelmente vão continuar a fazê-lo. Explica que ao invés de destruição, a história de rupturas é outra: em todos os segmentos alterados por alguma ruptura, o efeito final foi positivo, com um crescimento do mercado como um todo. Uma oportunidade de ruptura cria um novo espaço no mercado, que não quer ser servido da maneira tradicional pelos concorrentes já estabelecidos. É difícil para as empresas estabelecidas reconhecerem oportunidades com seus sistemas existentes porque os novos clientes são inicialmente diferentes, assim como a maneira com que usam os produtos. As oportunidades de ruptura criam novos mercados, antes de invadir os já estabelecidos e também se sabe que os novos entrantes geralmente não começam como concorrentes a empresas já estabelecidas. Os novos entrantes atendem novos clientes que não puderam achar nada que os satisfizesse no mercado tradicional.

As três fases da ruptura podem ser divididas da seguinte forma: a inovação cria um novo mercado não concorrente e independente do negócio estabelecido; o novo mercado se expande e diminui o crescimento do negócio estabelecido; a inovação disruptiva, tendo crescido muito com o tempo, reduz significantemente o tamanho do mercado antigo.

Gilbert (2003) finaliza dizendo que, nesta era de mudanças rápidas, as empresas não têm mais períodos de 35 anos para procurar novas oportunidades por ruptura. Por outro lado, elas têm muito mais tempo do que imaginam procurando no lugar certo, onde novos clientes estão encontrando soluções para problemas anteriormente não atendidos.

Estas soluções, segundo Kim e Mauborgne (2002), também conhecidas como inovação de valor, são a essência da estratégia na economia do conhecimento. Ela deve ter o apoio das táticas apropriadas para prolongar e maximizar o potencial de inovação para gerar lucros, distânciando-a da competição. Assim, inovar valor é algo que emerge de uma oportunidade de ruptura da qual pode ser apoiada pela TI que, por sua vez, permite que se escolham novas estratégias de negócios.

Em relação às estratégias de negócios e à tecnologia da informação, em especial a Internet, Rangan (2003) entende que a Internet reafirma a importância de dar atenção ao crescimento rentável que gera a sustentabilidade. Como em tudo existe um processo de aprendizado, em que há muitos erros e também oportunidades para crescer com rentabilidade e sustentabilidade. Decisões estratégicas e que determinam o crescimento e a sustentabilidade passam por três 
itens: o que é fabricado, para quem é fabricado e como é fabricado. Conforme o autor, esta é a dinâmica em todos os negócios. A Internet deverá influenciar esses três aspectos, principalmente no futuro, mas tais decisões, em última análise, são sempre definidas à luz da estratégia e, dessa forma, coloca a seguinte indagação: "São questões tecnológicas? Sim, mas não é a tecnologia quem decide. É a estratégia quem decide e aí se pode minimizar a possibilidade de erros". O autor defende o uso da Internet, afirmando que se ela for utilizada de forma estratégica será de grande utilidade para as empresas crescerem de forma rentável e sustentável. Menciona, ainda, sobre inovação sensata, de internacionalização sensata, e questiona: "mas de onde vem o lucro, o crescimento rentável?" Ele explica que o lucro vem da vantagem de produção, da vantagem de produto e da presença ou vantagem geográfica, e é essa conjunção que garante o crescimento rentável, afirma. Pode-se ter lucro nesta área de conjunção, da justaposição, com a nova geografia, novos mercados e uma boa conjunção da vantagem de produção e do produto. Mas apenas uma das vantagens isolada não proporciona lucro, assim como sem inovação também não existe internacionalização. Nesse contexto, qual é a utilidade da Internet? Na seqüência (Figura 3 - Formas de Utilização da Internet nos Negócios), podem ser observadas diferentes abordagens no mercado e a utilidade da tecnologia da informação. 


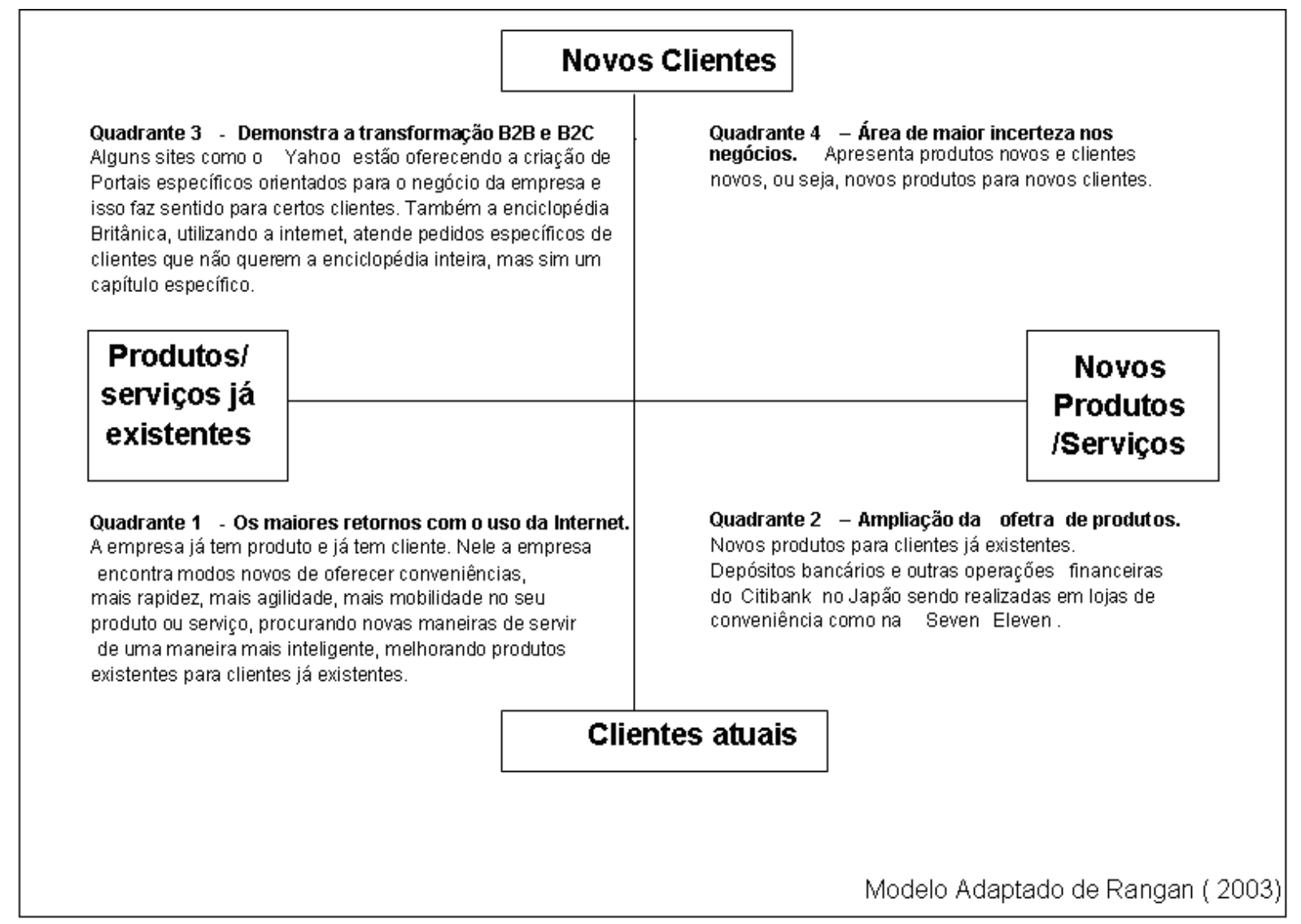

Figura 3 - Formas de Utilização da Internet nos Negócios

Rangan (2003) apresenta acima diversas possibilidades e oportunidades de se explorar o mercado, usando a TI. Porém, Rangan e Adner (2001) fazem um alerta importante sobre o erro de se achar que a tecnologia é estratégica. Segundo eles, a tecnologia complementa a estratégia. Não adianta a Internet fazer parte das estratégias de negócios da empresa, se a ela não criar valor. Além desta, os autores apresentam outras concepções incorretas que devem ser refletidas, para que se entendam melhor as estratégias de negócios na Internet. São elas: a questão da vantagem competitiva dos First Mover; os cuidados com o marketing um a um; a idéia falsa de crescimento, gerando soluções para os clientes e, conseqüentemente, a perda de foco; o setor $B 2 B$ ou $B 2 C$; os sócios alavancam o negócio desde que alinhados; o nascer global, tecnologia é estratégica.

Em um estudo bastante interessante, Tapscott et al. (2001) apresentam os conceitos de redes de negócios, ou $b$-webs, em que os autores traçam um perfil de cinco tipos diferentes de modelos de negócios, com base na utilização da TI. Segundo os autores, tudo isso é possível por causa da Internet: uma tecnologia de comunicação profunda, rica e publicamente disponível, que está possibilitando que 
uma nova arquitetura de negócio desafie a empresa da era industrial como a base de uma estratégia competitiva. Tapscott et al. (2001:17) apresentam algumas características das redes de negócios, as conhecidas b-webs, segundo estes autores: "Em b-webs, conjuntos de colaboradores interligados em redes, fluidos - às vezes, altamente estruturados; às vezes, amorfos - se reúnem para criar valor para os clientes e riqueza para seus acionistas". E complementa "as redes de negócios (b-webs) estão inventando novas propostas de valores, transformando as regras da concorrência e mobilizando pessoas e recursos em níveis de desempenho sem precedentes". A nova economia e suas ferramentas de TI são campos férteis para o nascimento cada vez maior de redes de negócios e a cada nova rede de negócio mais cresce a nova economia.

Como se nota, a procura de objetivos comuns ou, por outro lado, a criação de valores para o grupo, é a característica mais forte das redes de negócios e, portanto, fonte geradora de sinergia aos seus participantes.

Tapscott et al. (2001) apresentam cinco tipos de redes de negócios (Figura 4 Modelos de Negócios "b-webs"), os quais permitem uma classificação por estratégias de negócios e levam a uma segmentação ou mapeamento, que é um dos objetivos deste estudo. Os cinco tipos de $b$-webs citados pelo autor são os seguintes: Ágora, Agregação, Cadeia de Valor, Aliança e Rede Distributiva. Os parâmetros são: controle econômico e integração de valor, os quais definem as características fundamentais dos cinco tipos básicos de $b$-webs. 


\section{Modelos de Negócios ("b-webs")}

\section{PRECIFICAÇÃO DINÂMICA \\ Liquidez - converter bens \\ em um preço desejável}

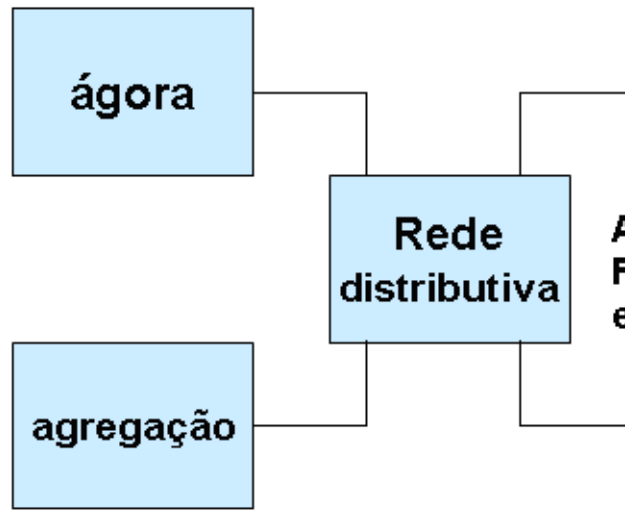

SELEÇÃO E PRATICIDADE

Otimização da Seleção,

org., preço, pratic da parceria
CRIATIVIDADE

Colaboração criativa p/ uma meta compartilham. comum.

aliança

ALOCAÇÃO / DISTRIBUIÇÃo Facilitar o intercambio e a entrega de informações

cadeia de valor

INTEGRAÇÃO DO PROCESSO Design ou entrega de um prod. integrado que atenda necess.

(TAPSCOTT et al., 2001).

Figura 4 - Modelos de Negócios "b-webs"

Na seqüência, serão apresentados os cinco tipos de redes de negócios, com base em Tapscott et al. (2001), visando a um maior aprofundamento conceitual sobre o tema:

- Ágora. É um tipo de rede de negócio em que compradores e vendedores se encontram para negociar livremente e atribuir valor aos bens. Uma Ágora facilita o intercâmbio entre vendedores e compradores, os quais, em conjunto, descobrem um preço por meio de negociação a vista. Em uma Ágora muitos participantes vendedores podem levar seus bens ao mercado, o que beneficia muitos participantes compradores com uma grande quantidade de ofertas. Além destas características, também podem ser observadas questões como praticidade, baixos custos de distribuição e marketing, abundância de informações entre outros. Proposta de valor das Ágoras: "Ágora, um lugar real ou virtual onde compradores e vendedores se reúnem para descobrir coletivamente o preço de um bem ou serviço". (TAPSCOTT et al., 2001: 39). Os autores complementam que a rede mundial de 
computadores permite que as Ágoras sejam locais de reuniões ilimitados. Este fato transforma seus mecanismos de precificação dinâmica e abre mercados mais eficientes - e dinâmicos.

- $\quad$ Agregação. Os Agregadores são tipos de redes de negócios que oferecem grande variedade de produtos e serviços, com integração de valor. Os Agregadores são empresas que buscam oferecer uma solução total aos seus usuários. Estas empresas conduzem o negócio com uma atividade principal, agregando uma série de outras empresas que oferecem serviços como busca especializada, comparação de preços, seguros, entre outros até financiamento de imóveis. Proposta de valor das Agregações: "De todos os elementos da proposta de valor das Agregações, a organização tem sido a maior promessa de inovação". (TAPSCOTT et al., 2001: 85).

- $\quad$ Cadeia de Valor. Segundo Tapscott (2001:33): "Em uma Cadeia de Valor, o provedor de contexto estrutura e dirige uma rede $b$-web para produzir uma proposta de valor altamente integrada". Nestes casos, a empresa que encabeça a Cadeia de Valor tem, como função, projetar produtos, serviços ou tecnologias centrais, coordenar processos através da $b$-web, promover 0 marketing e gerir relacionamentos. Ainda segundo o autor, os outros participantes executam outras atividades como fabricação e inclusive atendimento domiciliar aos clientes. Proposta de Valor: "é o design e a entrega de um produto ou serviço integrado que atenda a um conjunto específico de necessidades do cliente." (TAPSCOTT et al., 2001:122).

- $\quad$ Aliança. "Uma Aliança, a mais etérea das $b$-webs, busca uma alta integração de valor sem controle hierárquico. Seus participantes projetam bens e serviços, criam conhecimento ou simplesmente produzem experiências dinâmicas e compartilhadas" (TAPSCOTT et al., 2001:34). O autor cita o exemplo da PalmPilots, em que quanto mais consumidores decidem comprar este equipamento, mais desenvolvedores decidem criar aplicações, possibilitando, assim, um ambiente propício à formação de Alianças. Proposta de Valor: "é a colaboração criativa em favor de uma meta que seja compartilhada por toda uma comunidade de colaboradores". (TAPSCOTT et al., 2001:140)

- $\quad$ Rede Distributiva. As Redes Distributivas são as empresas que permitem o tráfego, armazenagem, tratamento de dados e outros serviços que dão suporte às redes de negócios. "Além da malha viária, dos serviços postais, das companhias telefônicas e de energia elétrica da economia industrial, as Redes Distributivas incluem as operadoras de redes de dados, as novas empresas de logística e os 
bancos" (TAPSCOTT et al., 2001: 35). Proposta de Valor: "a proposta de valor central de uma rede distributiva é facilitar o intercâmbio e a entrega de informações, bens e serviços" (TAPSCOTT et al., 2001:171).

Na seqüência, apresentam-se, no Quadro 2, as Principais Características dos tipos de "b-webs".

\begin{tabular}{|c|c|c|c|c|c|}
\hline & Ágora & Agregação & $\begin{array}{c}\text { Cadeia de } \\
\text { valor }\end{array}$ & Aliança & $\begin{array}{c}\text { Rede } \\
\text { Distributiva }\end{array}$ \\
\hline Tema Principal & $\begin{array}{l}\text { Precificação } \\
\text { dinâmica }\end{array}$ & $\begin{array}{ll}\begin{array}{l}\text { Seleção } \\
\text { praticidade }\end{array} & \mathrm{e} \\
\end{array}$ & $\begin{array}{l}\text { Integração do } \\
\text { processo }\end{array}$ & Criatividade & $\begin{array}{ll}\text { Alocação } & \text { I } \\
\text { distribuição }\end{array}$ \\
\hline $\begin{array}{ll}\text { Proposta de } \\
\text { Valor }\end{array}$ & $\begin{array}{lr}\text { Liquidez } & - \\
\text { converter } & \text { os } \\
\text { bens em } & \text { um } \\
\text { preço } & \\
\text { desejável } & \end{array}$ & $\begin{array}{l}\text { Otimização da } \\
\text { seleção, } \\
\text { organização, } \\
\text { preço, } \\
\text { praticidade da } \\
\text { parceria e do } \\
\text { atendimento }\end{array}$ & $\begin{array}{l}\text { Design ou } \\
\text { entrega de um } \\
\text { produto ou } \\
\text { serviço } \\
\text { integrado que } \\
\text { atenda a um } \\
\text { conjunto } \\
\text { específico de } \\
\text { necessidades } \\
\text { do consumidor }\end{array}$ & $\begin{array}{l}\text { Colaboração } \\
\text { criativa para } \\
\text { uma meta } \\
\text { compartilhada } \\
\text { para uma } \\
\text { comunidade de } \\
\text { contribuintes }\end{array}$ & $\begin{array}{l}\text { Facilita } 0 \\
\text { intercâmbio e a } \\
\text { entrega de } \\
\text { informações } \\
\text { bens e serviços }\end{array}$ \\
\hline $\begin{array}{ll}\begin{array}{l}\text { Papel do } \\
\text { Cliente }\end{array} & \text { do } \\
\end{array}$ & $\begin{array}{ll}\text { Player } & \text { do } \\
\text { Mercado } & \\
\end{array}$ & Comprador & $\begin{array}{l}\text { Propulsor de } \\
\text { Valor }\end{array}$ & Contribuinte & $\begin{array}{l}\text { Remetente/ } \\
\text { beneficiário }\end{array}$ \\
\hline $\begin{array}{l}\text { Foco do } \\
\text { Conhecimento }\end{array}$ & $\begin{array}{l}\text { Timing } \\
\text { Informações de } \\
\text { mercado }\end{array}$ & $\begin{array}{l}\text { Segmentação } \\
\text { de mercado } \\
\text { Ofertas de } \\
\text { fornecedor } \\
\text { Atendimento }\end{array}$ & $\begin{array}{ll}\text { Inovação } & \\
\text { Gestão da } \\
\text { cadeia de } \\
\text { suprimentos }\end{array}$ & $\begin{array}{l}\text { Comunidade } \\
\text { Criatividade } \\
\text { Padrões } \\
\text { papéis }\end{array}$ & $\begin{array}{l}\text { Otimização da } \\
\text { rede } \\
\text { Visibilidade e } \\
\text { transparência }\end{array}$ \\
\hline $\begin{array}{l}\text { Processo } \\
\text { Principal }\end{array}$ & $\begin{array}{l}\text { Descoberta do } \\
\text { preço }\end{array}$ & $\begin{array}{l}\text { Requer } \\
\text { parceria }\end{array}$ & $\begin{array}{ll}\begin{array}{l}\text { Design } \\
\text { produto }\end{array} & \\
\text { Gestão da } \\
\text { cadeia de } \\
\text { suprimentos }\end{array}$ & Inovação & Distribuição \\
\hline Exemplos & $\begin{array}{l}\text { Classificados } \\
\text { no Yahoo! } \\
\text { eBay } \\
\text { Priceline } \\
\text { AdAuction } \\
\text { NASDAQ } \\
\text { MetalSite } \\
\text { FreeMarkets }\end{array}$ & $\begin{array}{l}\text { Amazon.com } \\
\text { Chemdex } \\
\text { HomeAdvisor } \\
\text { Webvan } \\
E^{\star} \text { Trade } \\
\text { Travelocity } \\
\text { WSJl }\end{array}$ & $\begin{array}{l}\text { Cisco Sistems } \\
\text { Dell Computer } \\
\text { General } \\
\text { Motors } \\
\text { Celestica } \\
\text { Bidcom }\end{array}$ & $\begin{array}{l}\text { America Online } \\
\text { NetNoir } \\
\text { Linux } \\
\text { MP3.com } \\
\text { Wintel }\end{array}$ & \begin{tabular}{|l} 
Enron \\
UPS \\
AT\&T \\
Wells Fargo \\
Internet
\end{tabular} \\
\hline
\end{tabular}

(TAPSCOTT et al, 2001:30)

Quadro 2 - Principais Características dos tipos de "b-webs"

Existem inúmeras possibilidades de se classificar os modelos de negócios, que variam com as características da empresa, grau de virtualização e grau de integração que a tecnologia permite, entre outros. Para este estudo, foram apresentados os dois modelos acima, pois contemplam diversas observações desenvolvidas neste trabalho e certamente contribuirão para o pensamento 
estratégico de negócios. A seguir, serão apresentados alguns direcionadores de negócios utilizando a TI.

\subsubsection{Direcionadores de Negócios, utilizando a TI}

Novas tecnologias de informação, tal como redes de banda larga, comunicações móveis e a Internet, têm apresentado potencial para o desenvolvimento de novos negócios. Com base em Andal-Ancion et al. (2003), podem ser observados, no Quadro 3 - Estratégias de Mediação e Direcionadores de Negócios, utilizando a TI, três estratégias de transformação digital em negócios tradicionais: 


\subsubsection{Reações Competitivas em Operações de Serviços, utilizando a TI}

No Quadro 4 - Formas de Reação Competitiva em Operações de Serviços, destacam-se as reações organizacionais, utilizando a TI para obter maiores oportunidades ou ampliar os pontos fortes das empresas.

\begin{tabular}{|l|l|}
\hline \multicolumn{1}{|c|}{ Agrupamentos (Unidades de Significado) } & Categorias \\
Formas de contribuição da TI & \\
\hline $\begin{array}{l}\text { Implementar sistemas que possam impactar positivamente suas } \\
\text { operações, garantir seu sucesso ou sobrevivência. Sistemas que ofereçam }\end{array}$ & Sistemas \\
vantagens estratégicas ao atender os objetivos organizacionais, permitindo \\
que as empresas aumentem a fatia do mercado, para negociar com maior \\
eficiência com os fornecedores ou impedir que os concorrentes invadam \\
seus mercados. Impacto nas operações para: aumentar poder de barganha \\
com clientes e/ou fornecedores, criar barreiras de entrada, substituir \\
produtos existentes.
\end{tabular}


coordenação entre as diversas partes envolvidas).

As aplicações variam desde a transferência eletrônica de fundos entre compradores e fornecedores até a comercialização baseada na Internet, redes de informações baseadas em intranet e extranet para suporte inter e intra-organizacional.

Intercâmbio de produtos, serviços, informações e outros.

Comércio

eletrônico e

redes de

informação

Adaptado de Turban et al. (2003)

Quadro 4 - Formas de Reação Competitiva em Operações de Serviços.

As categorias acima apresentadas, sob pontos de vista diferentes, podem ser corroboradas por outros autores. Entre eles, pode-se citar Rockart (1979) e as questões relacionadas aos fatores críticos de sucesso com o uso da TI. Este autor lista os seguintes itens: estrutura da indústria, estratégia competitiva, posicionamento da empresa, localização geográfica, ambiente e fatores circunstanciais. Ohmae (1985), ao listar as categorias de critérios para identificar fatores básicos de êxito, menciona as seguintes categorias: posição no mercado; reputação da empresa, produtividade, implantação comercial, tecnologia; know-how, custos; capacidade de investimentos. McFarlan (1988) aborda o impacto estratégico da TI, com base na estrutura da indústria de Porter (1986), propondo os seguintes questionamentos: A TI pode estabelecer barreiras à entrada de novos competidores no mercado? A TI pode influenciar trocas de fornecedores, bem como alterar o poder de barganha? A TI pode alterar a base da competição (baseada em custo, diferenciação ou enfoque)? A TI pode alterar o poder de barganha nas relações com os compradores? A TI pode gerar novos produtos ou produtos substitutos?

Porter e Millar (1985) elencam as formas em que a revolução da informação está alterando a competição. São eles: mudança na estrutura setorial, alterando as regras da competição, gerando vantagem competitiva ao proporcionar às empresas novos modos de superar o desempenho dos rivais e disseminando negócios inteiramente novos. Ainda, segundo estes autores, as mudanças afetarão fortemente as alternativas de se criar valor, impactando, portanto, a cadeia de valor das empresas, as formas com que estas executam as atividades e como elas se relacionam entre si.

Tapscott et al. (2001) abordam as questões relacionadas à tecnologia da informação, em especial a Internet, como os novos propulsores da economia. Os autores falam das redes de negócios e as possibilidades de todo tipo de relacionamento entre as empresas, utilizando a $\mathrm{TI}$, que permitiram a criação de cinco 
estratégias de negócios diferentes, que eles nomearam da seguinte forma: Ágora, Agregação, Cadeia de Valor, Alianças e Redes Distributivas. Cada um destes negócios atua de formas diferentes no mercado. Identificam-se acima também práticas semelhantes, que se enquadram nas categorias citadas.

Rangan (2003) faz uma outra abordagem sob aspectos que podem ser observados em negócios, utilizando a TI. Segundo ele, existem formas de se utilizar a TI em produtos existentes para clientes atuais, no desenvolvimento de novos produtos para clientes atuais, no desenvolver de novos clientes para produtos existentes ou, ainda, em novos produtos para novos clientes, faixa de maior incerteza no uso da TI. Por último, Laurindo (2002) apresenta um modelo para análise da eficácia da TI nas empresas, o qual cobre vários dos aspectos acima apresentados. O autor divide o modelo de análise em dois grupos: fatores estruturais da empresa e fatores referentes à organização da $\mathrm{TI}$, cujas abordagens se assemelham em alguns aspectos às categorias apresentadas. 


\section{VANTAGEM COMPETITIVA}

\subsection{COMPETITIVIDADE}

Conforme Barney (1995 e 2001), muito se fez para compreender as fontes de vantagem competitiva para as empresas. Este esforço tem-se concentrado nas oportunidades e ameaças do ambiente externo e nas forças e fraquezas do ambiente interno. O fato é que várias ferramentas foram desenvolvidas para avaliar as oportunidades e ameaças, porém, no campo das forças e fraquezas, pouco se fez para avaliar internamente as empresas. Esta proposta de aumentar a importância do ambiente interno cresceu e se ampliou sendo conhecida como Visão Baseada no Recurso e aos poucos ganhou muitos entusiastas. Conner (1991), ao comparar diversas teorias, coloca também a Visão Baseada no Recurso, como um novo campo teórico. Segundo a autora, a Visão Baseada no Recurso tem características específicas diferentes das teorias da organização industrial. A teoria da firma incorpora ou rejeita pelo menos um elemento principal das escolas anteriores, explica Conner (1991).

Ao longo do tempo, a discussão mudou de rumos. Não se discutia mais se a Visão Baseada no Recurso era uma nova teoria. A discussão era se estas empresas que utilizavam os conceitos da Visão Baseada no Recurso eram mais ou se eram menos rentáveis do que as outras que se baseavam nas teorias mais relacionadas ao ambiente externo. Os primeiros trabalhos nesta área foram apresentados por Schmalesee (1985) e Rumelt (1991); depois deles, vários outros autores apresentaram modelos, cujo objetivo era avaliar as variáveis responsáveis pela rentabilidade das empresas. As abordagens foram as mais diversas, desde a alteração das variáveis analisadas, assim como tamanho, tipo de amostra, região analisada, entre outros. Schmalesee (1985) apresenta três variáveis, as quais, segundo ele, influenciam na rentabilidade das empresas: o setor a que pertence a corporação de que faz parte e sua participação de mercado. Em seu estudo, o autor encontra evidências que o setor a que as empresas pertencem, explica a maior rentabilidade das empresas. Anos depois, Rumelt (1991) aprimora o estudo de Schmalesee, acrescentando outras variáveis. Este autor passa a avaliar da seguinte forma: o efeito setor, o efeito corporação, o efeito ano (período analisado) e, 
finalmente, o efeito unidade de negócio ou a análise interna dos recursos das empresas. Neste segundo estudo, o efeito unidade de negócios apresenta efeito maior que o efeito setor. McGahan e Porter (1997) também apresentam estudo similar. Numa primeira abordagem, alteram a base de dados e analisam apenas as empresas manufatureiras, encontrando o efeito empresa superior ao efeito setor. Em uma segunda abordagem, incluindo diversos setores, McGahan e Porter (1997) percebem que o efeito unidade de negócio fica reduzido sob a ótica das empresas de manufatura. Estes resultados vêm apoiar a principal conclusão de Schmaleseee (1985): os efeitos da indústria contribuem substancialmente para a rentabilidade de negócios específicos e trazem à tona a afirmação de Rumelt de que os efeitos da indústria estável têm pouca influência. As análises indicam que a manufatura, a qual tem sido focalizada em outros estudos, é exceção. As generalizações sobre economia como um todo que se baseiam nos resultados da manufatura subestimam a importância dos efeitos da indústria e da corporação, e superestimam a importância dos efeitos de segmentos específicos. Em estudo sobre os determinantes da rentabilidade das empresas de manufatura em Valencia Espanha, desenvolvido por Cortés e Azorin (2001), acrescenta-se mais um elemento ao campo de estudo. Os autores analisaram que além das questões relacionadas à estrutura do setor industrial e a questão dos recursos e capacidades, também deve ser levada em conta a questão do território em que estas empresas estão instaladas. Segundo os autores, o território envolve variáveis macroeconômicas que, por sua vez, afetam a rentabilidade da indústria. Para estes autores, o efeito território apresenta discreta influência na rentabilidade das empresas nesta região; os recursos e capacidades das unidades de negócio se apresentam como os maiores responsáveis pela rentabilidade das empresas. Caloghirou et al. (2004) apresentam um estudo sobre o impacto dos fatores da indústria e dos fatores da empresa no desempenho do negócio, tanto para grandes empresas como para pequenas e médias empresas de manufatura na Grécia. Dois resultados foram obtidos: uma evidência significativa de que os fatores da empresa exercem um forte impacto no desempenho tanto nas pequenas e médias empresas como nas grandes; e ensaios de impactos causados por indicadores específicos que determinam diferenças no desempenho entre as pequenas e médias empresas e as grandes. O modelo encontrado sugere que uma ação crítica no sucesso e desenvolvimento de empresas não é inicialmente a seleção de crescimento da indústria e nichos de 
produtos (fatores da indústria) mas, sim, na escolha das capacidades organizacionais internas (fatores específicos das empresas).

Para este estudo, vantagem competitiva será considerada como uma situação privilegiada de um competidor em relação aos seus concorrentes e aquilo que the dê maiores chances de êxito no mercado. Esta vantagem pode decorrer de alternativas do ambiente externo, buscando oportunidades no mercado, conforme McGahan e Porter (1997), Schmalesee (1985) entre outros. A vantagem competitiva também poderá ocorrer a partir do ambiente interno ou por meio dos recursos internos das empresas, conforme defendem diversos teóricos entre eles: Barney (1995), Prahalad e Hamel (1990), Rumelt (1991), Cortés e Azorin (2001), e Caloghirou et al. (2004) entre outros.

Neste caso, serão apresentadas, na seqüência, várias abordagens teóricas, demonstrando que tanto o ambiente externo, como o ambiente interno das empresas, propiciam alternativas de atuação no mercado, as quais permitem obter vantagens competitivas e maiores lucros para as empresas.

\subsection{VANTAGEM COMPETITIVA E O AMBIENTE EXTERNO DAS EMPRESAS}

Recentes pesquisas afirmam que o setor tem preponderante intervenção no funcionamento de empresas individuais. Vários estudos, ao explicarem a diferença entre eles, mostram que a lucratividade média do setor possui índice muito significativo. Não se contesta que a análise do setor é de vital importância para o desempenho na formulação das estratégias das empresas, (MONTGOMERY e PORTER, 1998). Em prosseguimento, alguns autores apresentam abordagens semelhantes, demonstrando as oportunidades do ambiente externo:

Mintzberg et al. (2000) expõem a cerca da necessidade de utilizar todas as escolas do pensamento estratégico e não somente uma ou outra, deixando explícito que é importante seguir pelas necessidades do mercado e não pelos conceitos internos.

Para Markides (1999), o sucesso se origina de uma posição estratégica incomparável, mas explica que a singularidade não deve durar para sempre. Os competidores não irão apenas imitar as posições mais atrativas, mas criar novas 
posições estratégicas, que combinem uma proposta de valor viável "o que é", "como" e para "quem"? Pode ser um novo segmento de consumo: um novo "quem". Uma nova forma de produzir ou distribuir: um novo "como". Ou ainda uma nova proposição de valor: um novo "o quê". Assim, gradualmente estas novas posições alteram as posições existentes.

Embora Markides enfatize fortemente o ambiente externo, o autor também oscila no campo da inovação, fazendo uma abordagem de dentro para fora. Pode-se encontrar também em Markides (2004) a seguinte afirmação sobre o ambiente:

Nenhuma estratégia permanece única para sempre. Como a indústria muda,
surgem novas posições estratégicas para desafiar posições existentes de
supremacia. Mudando as condições surgem novas posições estratégicas
para desafiar posições existentes de supremacia. Mudando as condições da
indústria, mudam as necessidades dos consumidores e também a posição
dos competidores.

Bethlem (1999: 159) comenta sobre a importância do monitoramento do meio ambiente no qual a empresa está inserida, para o aumento de suas possibilidades de sucesso. "As empresas que vão se desenvolver, ou mesmo sobreviver, serão as que tiverem a capacidade de se adaptar rapidamente às características diferentes que o meio ambiente em mudança for apresentando".

Fischmann e Almeida (1991: 57), concordando com os autores anteriormente citados, fazem o seguinte comentário: "É importante analisar o ambiente da empresa para identificar as oportunidades e ameaças, os pontos fortes que devem ser aproveitados e os pontos fracos com os quais se deve tomar cuidado". Complementam dizendo que o ambiente de uma organização é tudo aquilo que influencia no seu desempenho; eles podem ajudar ou atrapalhar, por isto devem ser monitorados para evitarem riscos e se aproveitarem as oportunidades.

Iansiti e Levien (2004) propõem, ainda, o conceito de ecossistema de negócios ou da rede de negócios em que a empresa está inserida. Eles destacam o papel das empresas-alicerce, que deveriam encorajar o sucesso das outras empresas de seu ecossistema. Conforme estes autores, o importante, para a estratégia de uma empresa, seria descobrir com quais empresas a dependência seria maior no futuro. O ecossistema seriam, então, as empresas, com as quais a dependência seria maior; poderiam, em alguns casos, ser semelhantes ao conceito de setor ou indústria, utilizado na economia. 
Por último, Toledo (1999:1) acrescenta a importância da TI para as empresas desenvolverem seus negócios de forma rentável, a partir do ambiente externo. "A atenta observação do ambiente econômico e setorial é, sem dúvida, uma das melhores fontes de descoberta de novos negócios". Para o autor, muitos produtos e serviços foram criados a partir das oportunidades do ambiente externo, ou seja, do mercado. O impacto da TI tornou mais dinâmico o mercado, obrigando as empresas a se adaptarem a este novo contexto. O autor cita, como exemplo, os serviços de Office banking, que foi quase uma imposição do mercado, que exigia maior agilidade nas decisões financeiras. Esta é a face transformadora da TI, em especial da Internet, que promove uma verdadeira mudança na maneira de realizar negócios das empresas em geral.

\subsection{VANTAGEM COMPETITIVA E O AMBIENTE INTERNO DAS EMPRESAS}

Hamel e Prahalad (1995) trouxeram importante contribuição entre os autores que defendem que os recursos internos das empresas contribuem fundamentalmente para o sucesso das escolhas estratégicas das empresas. Estes autores enfatizam a construção mais do que o downsizing, o crescimento orgânico mais do que os acordos de negócios. E, ainda, a redefinição do setor mais do que a reengenharia de processos, a possibilidade em longo prazo mais do que a viabilidade em curto prazo, a alavancagem de recursos mais do que a alocação de recursos e a luta mais do que a vitória. Estes são alguns pontos defendidos pelos autores, que afirmam que as empresas devem inventar o futuro, construir sua base de negócios, inovando sua proposta de valor ao mercado. Esta nova proposta de valor deverá ampliar o mercado, excedendo as expectativas dos clientes, criando produtos e serviços não imaginados. Esta proposta deve sair de dentro da empresa, em que cada funcionário devidamente incentivado, crescendo com a empresa, deverá colaborar com esta nova forma de pensar o processo. Fazer destas diferenças um novo espaço competitivo para geração de novas riquezas e vantagens para a empresa em geral é o objetivo principal dessa proposta.

Hamel (1996) aborda a estratégia como um processo revolucionário de dentro das empresas onde estas devem quebrar paradigmas e alcançar novos mercados e, 
por conseguinte, o sucesso. Conforme o autor, em qualquer indústria existem três tipos de empresas: as fazedoras de regras (carros-chefe que constroem a indústria); as seguidoras de regras (seguem as demais); as quebradoras de regras (reescrevem as regras, descontentes, radicais e revolucionárias da indústria). Neste ambiente de turbulência, os revolucionários da indústria têm sido bem recebidos, enquanto as grandes empresas são recebidas com muita hostilidade. Segundo ele, as fortalezas que protegiam as oligarquias da indústria estão caindo com o peso da desregulamentação, do aumento do nível tecnológico, da globalização e das mudanças sociais.

Contador (2004) propõe 17 estratégias competitivas, comparando com duas de Porter, e explica: "Das cinco forças determinantes da atratividade da indústria, o modelo concentra-se na rivalidade entre empresas existentes. Em lugar da cadeia de valores de Porter, propõe a análise interna da empresa por meio das armas da competição." O autor complementa que as diferenças básicas entre o modelo de Porter e o de Campos e Armas de Competição estão no grau de detalhe e que, enquanto um faz uma abordagem de posicionamento no setor, o outro recomenda que se desenvolvam as forças internamente e as use como vantagem competitiva no mercado.

A capacidade de algumas empresas de internacionalizar com estratégias competitivas de sucesso, segundo Fay (1996), também tem respaldo em seus recursos únicos. O autor cita dois casos de sucesso: Wall-Mart (TALO et al., 1992 apud FAY, 1996) e AT\&T (PLEVAL et al.,1994 apud FAY, 1996), demonstrando como estas duas empresas de sucesso e com vantagem competitiva internacional conquistaram espaço em diversos países, usando seus recursos internos. No caso do Wall-Mart, sua competência essencial reside na capacidade logística rara da companhia, que confirma a importância de capacidades como uma fonte potencial de vantagem competitiva, tendo um valor importante na redução de custos da empresa. Este é um sistema raro porque combina as pessoas, os veículos de entrega, e os sistemas de comunicação, entre outros. É difícil de imitar a comunicação constante necessária entre fornecedores, centro de distribuição e saídas de vendas alcançadas pelo investimento da companhia num sistema privado de comunicações de satélite. Este conjunto de recursos permite ao Wal-Mart levar uma proposta de valor relacionada a preço baixo, imbatível no mercado. No caso da $A T \& T$, seus recursos humanos relacionados diretamente à estratégia do negócio lhe 
conferem uma capacidade rara de atuar no mercado. Seus mecanismos de recompensa aos funcionários são projetados para aumentar a motivação pessoal enquanto simultaneamente os resultados são alcançados. "Esta certamente é uma vantagem competitiva sustentável", comenta o autor.

Conforme apresentado, os tipos e as formas de recurso e como as empresas utilizam estas competências para competir com vantagem no mercado são as mais variadas possíveis. Em um estudo de Galbreath e Galvin (2004), os autores fazem um levantamento sobre quais recursos importam e dão vantagem ao competidor. Os autores descobrem que além dos recursos tangíveis, os recursos intangíveis e também as interações e combinações com outros recursos dão vantagem competitiva às empresas. Estas conclusões vão ao encontro dos dois exemplos: Wall-Mart e ATeT, anteriormente citados.

A teoria da Visão Baseada no Recurso faz uma distinção útil entre a tecnologia de informação e sistemas de informação. A anterior é baseada em ativos, enquanto a última abrange uma mistura de ativos e capacidades formadas ao redor do uso produtivo da tecnologia de informação, (WADE e HULLAND, 2004). Ao falar do uso da TI e sistemas de informação como fonte de recursos para as empresas, mais uma vez se nota que as interações e outras vantagens intangíveis são cada vez mais importantes no mundo de negócios. Duhan et al. (2001) também fazem uma abordagem baseada em recursos intangíveis; neste caso, o conhecimento. De acordo com estes autores, as pequenas e médias empresas em geral são incapazes de reestruturar a indústria, obtendo vantagens competitivas, pois atuam em mercados equilibrados, em que os competidores são semelhantes e têm dificuldades de influenciar os preços ou as quantidades no setor. Segundo o estudo, notou-se que algum sucesso foi alcançado nestas empresas no desenvolvimento de novos produtos e mercados, incorporando sistemas de informação e tecnologia da informação. Um fato importante encontrado é que, em geral, as utilizações destas ferramentas atingem apenas as áreas operacionais, não as estratégicas como, por exemplo, desenvolvimento de um novo modelo de negócio. O que os autores concluem é que a Visão Baseada no Recurso, no contexto das pequenas e médias empresas do conhecimento é, na maior parte, inexplorada e o papel de sistemas de informação é do mesmo modo não utilizado.

A tendência de se utilizar cada vez mais recursos intangíveis individualmente ou ampliando o nível de serviços com parceiros, conforme foi demonstrado, fica 
cada vez mais evidente. Kim e Mouborgne (2002) enfatizam que, no contexto da economia do conhecimento, utilizar os recursos internos das empresas para inovar valor torna-se mais importante do que buscar a vantagem competitiva, com base na concorrência. Solicitados para desenvolver uma vantagem competitiva, os gerentes se empenham em conhecer o que os concorrentes fazem e se empenham em fazer melhor, logo o pensamento estratégico volta-se para a concorrência. Assim, muitas vezes após despender este esforço, consegue-se apenas uma melhoria incremental, não inovação. Para eles, "A nova economia propõe a teoria do crescimento endógeno, em que o crescimento e a inovação surgem no interior de um sistema." Segundo os autores, o principal argumento desta teoria aplica-se à empresa. Na economia do conhecimento, as inovações não são mais exógenas (de fora para dentro); são criadas com idéias e conhecimento dentro de um sistema.

\subsection{VANTAGEM COMPETITIVA E O AMBIENTE EXTERNO E O AMBIENTE INTERNO DAS EMPRESAS}

Assim como há teóricos que acreditam que as maiores opções para a rentabilidade das empresas está no ambiente externo, há também os que pensam que esta vantagem deve ser encontrada no ambiente interno das empresas. Há, no entanto, uma terceira linha de teóricos, que acredita que o equilíbrio entre o ambiente interno e externo é quem determina a vantagem competitiva dos competidores.

HITT et al. (2003) explicam que há dois modelos principais daquilo que a empresa deve fazer para obter lucros acima da média do mercado. São eles: ambiente externo e ambiente interno.

Quanto ao ambiente externo, os retornos acima da média são auferidos quando ela identifica um setor atraente e é bem-sucedida na implantação da estratégia ditada pelas características desse setor;

Quanto ao ambiente interno (recursos e capacidades únicos), este modelo pressupõe que toda empresa adote uma coleção de recursos e capacidades únicos que determinarão sua estratégia.

Embora os autores apresentem os dois modelos acima, eles enfatizam que um complementa o outro: "A competitividade e os retornos acima da média apenas 
serão gerados se as competências essenciais (identificadas por meio do estudo do contexto interno da empresa) forem ajustadas às oportunidades (determinadas mediante estudo do ambiente externo da empresa)", (HITT et al., 2003: 132).

Assim como os autores acima, tem-se uma lista extensa de teóricos que defendem este ponto de vista, da qual serão citados alguns. Bossidy e Charan (2004) dizem que as pessoas não confrontam as realidades externas (mercado, clientes, concorrentes, políticas de regulamentação ou governamentais e outros) e as internas (habilidades e o comportamento da empresa) e que isto pode levar a conseqüências graves para o desempenho das empresas. Segundo eles, este comportamento acaba surpreendendo as empresas, principalmente neste contexto de mudança constante como é o mercado atualmente. Os autores complementam que "só depois de cristalizar as realidades do ambiente externo e associá-las ao seu conjunto de metas financeiras, você poderá pensar em estratégias, atividades operacionais, seleção e desenvolvimento de pessoal, processos e estrutura organizacional, (BOSSIDY e CHARAN, 2004). Nas palavras de Zaccarelli (1996: 26), percebe-se a concordância dos pontos de vista entre os autores: "A situação com maior potencial para a estratégia produzir sucesso da empresa é quando se tem, simultaneamente, um bom negócio e alta funcionalidade interna". Costa Filho e Toledo (1999) também nesta linha sugerem que o monitoramento ambiental deve ser uma atividade contínua e não pontual. Sobre a análise interna, deve-se desenvolver um ambiente que propicie a inovação, pois, em geral, este processo é abafado, restrito ou mesmo sufocado pelas estruturas das grandes empresas. Por fim, Yanaze (2004: 43), em seu modelo de análise de negócios, que inclui o que o autor chama de análise dos Inputs, Throughputs e Outputs, diz:

O primeiro e importante passo para uma correta aplicação do Marketing e seu mix no processo gerencial de uma empresa implica uma rigorosa avaliação dos recursos disponíveis, das condições internas para aplicá-los da melhor forma e uma correta percepção do contexto externo e dos objetivos a serem alcançados. Em suma, uma análise dos Inputs, Throughputs e Outputs da empresa.

\subsection{VANTAGEM COMPETITIVA E A TECNOLOGIA DA INFORMAÇÃO}

Conforme apresentado anteriormente, na medida que a $\mathrm{TI}$ vem sendo utilizada pelas empresas, cresce o que se tem chamado de nova economia 
(TAPSCOTT, 1998, 2001) ou economia do conhecimento (KIM e MAUBORGNE, 2002). Este é um processo sem fim, pois para se competir neste novo contexto digital e estar totalmente conectado, cada vez mais utilizar-se-á a TI como ferramenta competitiva.

Porter e Millar (1985) explicam que a TI tem consumido uma parcela cada vez maior do tempo e dos investimentos das empresas. Com isto, os executivos vêm tomando maior consciência de sua importância e despendendo maiores esforços com esta questão, não deixando apenas sob a responsabilidade exclusiva de profissionais da área. Na medida em que as empresas percebem que seus rivais estão utilizando a TI para obter vantagem competitiva, os executivos passam a envolver-se diretamente com a questão da Tecnologia.

Na mesma obra, Porter e Millar (1985) fazem importantes constatações em relação às aplicações estratégicas da $\mathrm{TI}$, que são fundamentais para a vantagem competitiva das empresas. Em prosseguimento, serão conhecidas algumas delas:

- $\quad$ a TI está mudando a própria natureza da competição, transformando produtos e processos;

- a TI está alterando as regras da competição: 1 - mudando a estrutura setorial; 2 - alavancando a vantagem competitiva das empresas; 3 - disseminando novos negócios;

- a TI está alterando a estrutura setorial ao aumentar o poder dos compradores, o poder dos fornecedores, dependendo de quem a utiliza; ao elevar ou derrubar barreiras de entrada, permitindo ou barrando a entrada de novos entrantes; ao permitir o surgimento de produtos substitutos, ampliando ou reduzindo a rivalidade no setor;

- a TI está afetando os relacionamentos de negociação entre compradores e fornecedores e todas as formas da empresa se relacionar internamente e externamente;

- a TI está gerando efeitos importantes sobre a vantagem competitiva, no custo, como na diferenciação;

- a TI está afetando a questão do escopo competitivo, ao propiciar a coordenação de atividades em termos regionais, nacionais e globais e ampliando a vantagem competitiva das empresas. 
Tapscott et al. (2001), ao comentarem as vantagens competitivas da TI, explana a respeito da vantagem colaborativa, fazendo uma alusão às vantagens de conexão e possibilidades de integrar diversas empresas em um mesmo negócio. Este termo, de certa forma, justapõe-se às estratégias coletivas (PECK E JUTNER, 2000), em que a TI traz uma importante contribuição, aumentando a confiança entre os participantes, ao otimizar os custos de transação. Moscarola e Vargas (1998), apud Freitas et al. (2001) mencionam que as vantagens não são inerentes à TI ou da Internet; é a forma que as utiliza que permite que se obtenha um diferencial competitivo no mercado. Complementam estes autores da seguinte forma: "A simples presença na Internet não é considerada como vantagem competitiva, mais sim sua capacidade de utilizar os recursos disponíveis em rede para comunicar-se com seus clientes, parceiros, fornecedores, tudo isto em coerência com a estratégia geral da empresa". Quer-se dizer que as alianças entre empresas cada vez mais ganham importância, ao serem utilizadas de forma estratégica, e que a TI contribui definitivamente com a vantagem competitiva das empresas.

Adiante, será abordada de forma mais intensa a importância do uso da TI nas alianças e nas redes de empresa na criação de valor e, de fato, na vantagem competitiva.

Por hora será apresentada uma abordagem final sobre cooperação, princípio básico para a formação de redes e alianças que relacionado à criação de valor dão uma idéia da importância da TI. Conforme Silva Junior (2004): "As competências essenciais não estão à venda no mercado aberto. Quando essas habilidades podem ser aprendidas com um parceiro, internalizadas e exploradas além dos limites da própria aliança, elas passam a ter um valor ainda maior". Castells (2003) complementa o assunto, dando a abrangência e as perspectivas que cabem à TI em relação às estratégias de negócios. Para ele, a história da criação e do desenvolvimento da TI, em especial da Internet, é a história de uma aventura humana extraordinária. $\mathrm{O}$ autor se deslumbra com as possibilidades que esta nova ferramenta traz e ainda afirma que ela inaugura um novo mundo ao subverter valores estabelecidos. E, ainda sintetiza que a TI, em especial a Internet, "reforça também a idéia de que a cooperação e a liberdade de informação podem ser mais propícias à inovação do que à competição e os direitos de propriedade" (CASTELLS, 2003: 13). 


\subsection{MODELO DE AVALIAÇÃO DO AMBIENTE EXTERNO}

Para este estudo, foram selecionados - intencionalmente - dois modelos que pudessem diagnosticar o ambiente externo das empresas. Estes modelos foram escolhidos por sua representatividade no campo da estratégia, tanto no uso conceitual quanto no cotidiano das empresas e também pelo seu formato prescritivo que permite avaliar o desempenho das empresas que utilizam a TI na indústria da saúde.

\subsubsection{Análise do Macroambiente - O Modelo do Diamante (PORTER, 1999)}

No Modelo do Diamante, Porter (1999) analisa os fatores macroambientais que afetam a competição, sendo destacados quatro aspectos: as condições dos fatores de produção; as condições da demanda; os setores correlatos ou de apoio e a estratégia, a estrutura e a rivalidade das empresas de um território. A partir da análise das quatro pontas do diamante, tem-se um diagnóstico e as condições para se competir.

1 - As Condições dos Fatores. Nesta ponta do diamante, o autor faz uma distinção entre os fatores herdados e os fatores desenvolvidos e aproveitados por um setor. Segundo o autor, uma nação não herda, mas sim cria os mais importantes fatores de produção - como especialização de recursos humanos ou base científica.

2 - As Condições de Demanda. Quanto mais sofisticada e exigente a demanda, mais as empresas são pressionadas para melhorar e inovar. O tamanho da demanda interna é menos relevante do que seu grau de sofisticação, o qual pressiona a inovação das empresas.

3 - Os Setores Correlatos ou de Apoio. Quanto mais desenvolvidos forem os setores que apóiam a produção, melhores as condições de se produzir. Quanto mais desenvolvidos os fornecedores internos, melhor será o desempenho das empresas a jusante.

4 - Estratégia da Empresa, a Estrutura e a Rivalidade. Uma forte rivalidade enérgica pode fomentar a inovação e melhoria de cada empresa.

Conforme Porter (1999:194), cada um dos quatro atributos contribuem para a vantagem da região em que está sendo analisada. As pontas do diamante se 
complementam formando um sistema, conforme Figura 5 - Determinantes da Vantagem Competitiva Nacional.

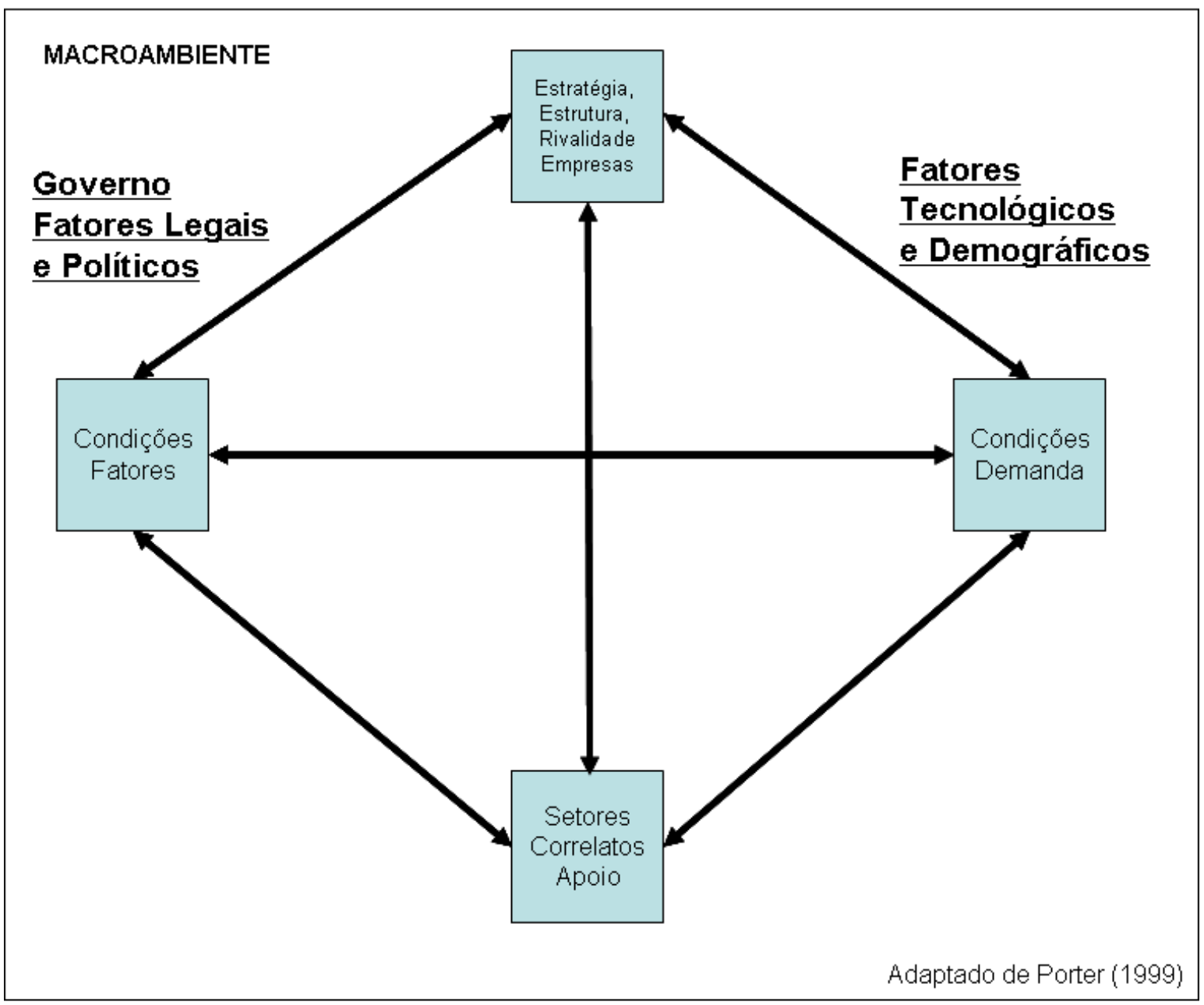

Figura 5 - Determinantes da Vantagem Competitiva Nacional

\subsubsection{Análise do Microambiente - O Modelo das Cinco Forças (PORTER, 1999b)}

No Modelo das Cinco Forças, Porter (1999b) analisa os fatores microambientais que afetam a competição em uma dada indústria. A partir da análise das Cinco Forças, tem-se um diagnóstico e as condições para se competir naquele setor.

"A essência da formulação de uma estratégia competitiva é relacionar uma companhia ao seu meio ambiente. (...) a intensidade da concorrência em uma indústria não é uma questão de coincidência ou de má sorte" (PORTER,1999b: 27). O autor deixa claro que a formulação de estratégia é uma questão de escolhas e 
que estas devem ser feitas de modo a potencializar os negócios de uma empresa em determinado mercado.

A concorrência em uma indústria tem raízes em sua estrutura econômica básica e vai bem além do comportamento dos atuais concorrentes. O grau da concorrência em uma indústria depende de cinco forças competitivas básicas, que são: os clientes; os fornecedores; os entrantes em potencial; os produtos substitutos e os concorrentes, que são mais ou menos ativos, dependendo do setor. O conjunto destas forças determina o potencial de lucro final na indústria, que é medido em termos de retorno em longo prazo sobre o capital investido (PORTER, 1986 e 1999b).

Na seqüência, será abordada cada uma das Cinco Forças:

Ingressantes Potenciais. "A seriedade da ameaça da entrada depende da expectativa dos entrantes em relação às barreiras existentes e à reação dos concorrentes" (PORTER, 1999b: 29). As principais barreiras de entrada que os concorrentes podem impor aos novos entrantes são as seguintes: economia de escala, diferenciação de produto, exigências de capital, desvantagens de custo, independente do tamanho (curva de aprendizagem, curva de experiência), acesso a canais de distribuição, política governamental.

Fornecedores. As circunstâncias em que os fornecedores se tornam poderosos são: o ambiente é dominado por poucas empresas e fornecedores são mais concentrados do que os compradores; o produto do fornecedor é exclusivo ou, pelo menos, diferenciado ou ele desenvolveu custos de mudança; o fornecedor não está obrigado a competir com outros produtos nas vendas do setor; o fornecedor representa uma ameaça concreta de integração para frente, invadindo o setor dos compradores; o setor não é um comprador importante.

Compradores. As circunstâncias em que os compradores se tornam poderosos são: os compradores ficam concentrados ou compram em grandes volumes; os produtos adquiridos no setor pelos compradores são padronizados ou não diferenciados; os produtos adquiridos no setor pelos compradores são componentes dos produtos dos compradores e representam parcelas significativas de seus custos; os lucros dos compradores são baixos, criando um forte incentivo para redução de custos de suas compras; os produtos do setor não são importantes para a qualidade dos produtos ou serviços dos compradores; o produto do setor não 
economiza o dinheiro do comprador; os compradores representam uma ameaça concreta de integração para trás, incorporando o produto do setor.

Produtos Substitutos. "(...) quanto mais atrativa for a opção excludente preçodesempenho oferecida pelos produtos substitutos, mais rígidos serão os limites impostos ao potencial de lucro do setor" (PORTER, 1999b: 38).

Rivalidade entre os concorrentes existentes. "A rivalidade entre os concorrentes assume a forma usual de manobras pelo posicionamento - a utilização de táticas como competição no preço, introdução de produtos e combates publicitários" (PORTER, 1999b: 39). A rivalidade intensa está relacionada com vários fatores como: quando os concorrentes forem numerosos, quando as condições de tamanho e do poder forem semelhantes entre os concorrentes; quando for lento o crescimento do setor; quando os custos fixos são elevados ou o produto é perecível; quando os aumentos de capacidade ocorrem em grandes saltos; quando as barreiras de saída são altas; outros.

Segundo este autor, as forças competitivas (Figura 6 - Forças que Dirigem a Concorrência na Indústria) afetam o desempenho das empresas em um determinado setor e podem fazer com que estas obtenham melhores chances de êxito neste mercado ou não.

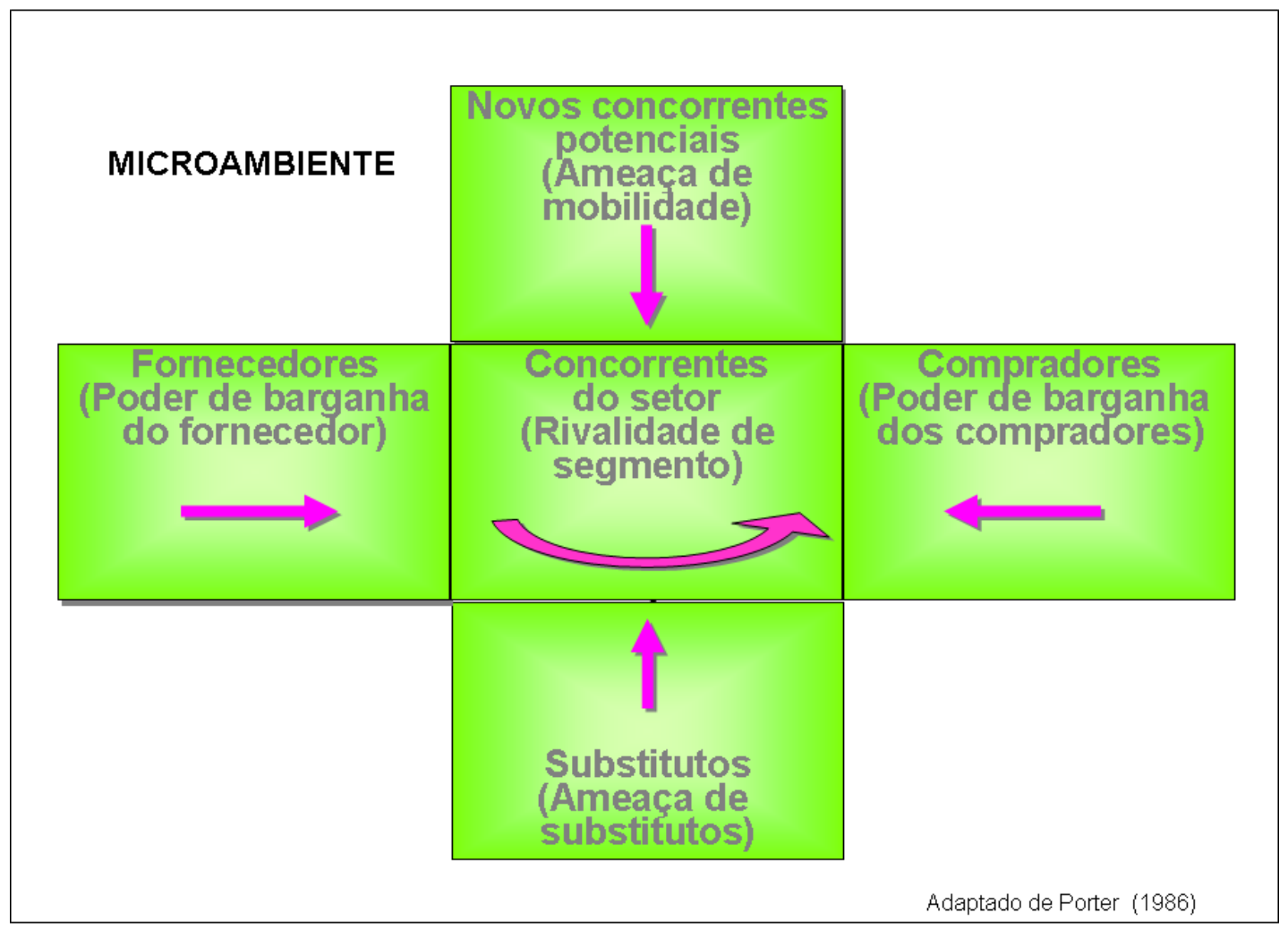

Figura 6 - Forças que Dirigem a Concorrência na Indústria 


\subsection{MODELO DE AVALIAÇÃO DO AMBIENTE INTERNO}

Para este estudo, foram selecionados - intencionalmente - dois modelos que pudessem diagnosticar o ambiente interno das empresas. Estes modelos foram escolhidos por sua representatividade no campo da estratégia, tanto no uso conceitual quanto no cotidiano das empresas e também pelo seu formato prescritivo que permite avaliar o desempenho das empresas que utilizam a TI na indústria da saúde.

\subsubsection{Análise do Ambiente Interno - As Fontes e Capacitações (BARNEY, 1995)}

A questão do valor, a questão da raridade, a questão da imitação e a questão da organização são variáveis analisadas no modelo proposto por Barney (1995). O autor citado foi um dos precursores da Visão Baseada no Recurso, ampliando o campo teórico da estratégia. As fontes e as capacitações dão uma visão das forças internas e do nível de competitividade das empresas no mercado. Estas características são analisadas de forma a abrangerem diversas áreas das empresas em que são observados em última instância o que, de fato, a empresa oferece de singular ao mercado. Qual o valor criado em determinada fonte, o quão raro é este valor que os clientes estarão dispostos a pagar mais por ele? Este valor é facilmente imitável ou não? O quão sustentável é esta vantagem? Qual a capacidade da empresa detentora destes diferenciais em relação à organização, capitalizar-se adequadamente com as fontes que têm, mantendo a inovação e sustentabilidade? Na sequência, será feita uma abordagem sobre cada um destes aspectos, baseado em Barney (1995).

A questão do Valor. A questão a ser respondida é se as fontes e as capacitações ou os recursos da empresa agregam valor, permitindo que ela explore oportunidades e/ou neutralize ameaças no mercado em que atua. Como podem ser utilizadas as forças tradicionais de maneiras novas a fim de explorar as oportunidades e/ou neutralizá-las? Conforme o autor, os recursos das empresas não são valiosos "no vácuo", mas somente quando exploram oportunidades e/ou neutralizam ameaças. 
A questão da Raridade. Se várias empresas concorrentes detêm um determinado recurso ou capacitação, então este recurso provavelmente não será uma fonte de vantagem competitiva para nenhuma delas. Ao invés disso, os recursos e capacitações valiosos, mas comuns (não raros) são fontes de igualdade competitiva. Para avaliar as implicações destes recursos deve-se perguntar: Quantas empresas concorrentes já possuem esses recursos e capacitações valiosos?

A questão da Imitação. Uma empresa que possui recursos e capacitações valiosos e raros pode obter uma vantagem competitiva sustentável na medida em que seus recursos forem difíceis de serem imitados. A imitação é crucial para se entender a habilidade dos recursos e capacitações em gerar vantagens competitivas sustentáveis. A imitação pode ocorrer de pelo menos duas maneiras: duplicação e substituição.

A questão da Organização. Uma empresa está devidamente organizada para explorar o potencial competitivo completo de seus recursos e capacitações? Inúmeros componentes da organização de uma empresa são relevantes ao se responder à questão da organização, incluindo sua estrutura formal de informações, seus sistemas explícitos de controle de gerenciamento, e suas políticas de compensação.

A proposta de Barney (1995) é que se utilize o modelo das Fontes e Capacitações para se criar vantagem competitiva sustentável em função dos recursos e capacitações únicos que uma empresa desenvolve para competir no seu ambiente. Para descobrir esses recursos e capacitações, deve-se buscar, dentro das empresas, os recursos valiosos, raros e difíceis de imitar, e então explorá-los por sua organização.

\subsubsection{Análise do Ambiente Interno - As Competências Essenciais (PRAHALAD e HAMEL, 1990)}

As Competências Essenciais são os mananciais do desenvolvimento de novos negócios. Elas devem ser o centro da estratégia em nível de empresa (PRAHALAD e HAMEL, 1990). Os autores descrevem a essência da estratégia sob uma ótica das forças internas nas organizações. Segundo eles, os gerentes devem tomar a liderança no que diz respeito à fabricação de produtos básicos e aumentar 
a participação mundial de consumidores por meio de estabelecimento de marcas. Estando apta para concorrer por uma hierarquia básica de competências, garantindo produtos básicos e unidades de negócios, a empresa terá, assim, garantida uma estratégia nesse mercado.

Os autores chamam a atenção para uma questão básica para as organizações: Vocês são bons em quê? Recomendam que haja foco por parte das empresas e busquem a vantagem competitiva pelo diferencial em que a empresa se destaca.

O modelo sugere que as competências essenciais são o aprendizado coletivo na organização, especialmente ao coordenar as diversas habilidades de produção e ao integrar as múltiplas correntes e tecnologias. A proposta é harmonizar o knowhow da organização e utilizá-lo na organização do trabalho e na entrega do valor ao cliente.

Uma questão importante enfatizada pelos autores é que as competências essenciais não diminuem com o uso. Ao contrário dos recursos físicos, que deterioram com o tempo, as competências se desenvolvem, à medida que são aplicadas e compartilhadas.

Os autores apontam três caminhos para se identificar as competências essenciais nas empresas:

a) uma competência básica fornece acesso potencial a uma enorme variedade de mercados;

b) uma competência básica deve oferecer uma contribuição significativa aos benefícios visíveis auferidos pelos consumidores dos produtos finais.

c) uma competência básica deve ser difícil de ser imitada pelos concorrentes. E será difícil, se for uma complexa combinação de tecnologias individuais e conhecimentos especiais de produção.

Assim como existem competências básicas, também existem produtos básicos e produtos finais - uma corporação deve saber se está ganhando ou perdendo em cada plano. Os produtos básicos são os componentes ou subconjuntos que realmente contribuem para valorizar o produto final. Uma empresa pode ter uma forte participação de mercado em um produto básico (um componente de um produto final qualquer), por exemplo: motor de carro. Sem que necessariamente sua marca (exemplo: automóveis Honda) que é o produto final (marca), seja a de maior participação no mercado. 
Prahalad e Hamel (1990) concluem que as competências essenciais são mananciais do desenvolvimento de novos negócios. O centro da estratégia da empresa devem ser elas. Os gerentes devem ganhar a liderança da fabricação de produtos essenciais e capturar a participação global por meio de programas para estabelecimento de marca, tendo como meta o aproveitamento de economias de escopo. A empresa está apta a lutar somente se for como uma hierarquia de competências essenciais, produtos essenciais e unidades de negócios, centradas em mercados. 


\section{CRIAR VALOR}

Criar valor para um negócio implica em criar valor para os clientes, funcionários, acionistas e todos os públicos de interesse da empresa (MAGRETA e STONE, 2002). Para estes autores, a questão fundamental na criação de valor é observar de fora para dentro, os clientes definem o valor. $E$ complementam: "A criação de valor é o princípio que anima a gestão moderna e sua principal responsabilidade" e enfatizam: “... a primeira e mais importante missão da gestão é a criação de valor", (MAGRETA e STONE, 2002: 27). Esta é a importância de se considerar o ponto de vista do cliente. Aparentemente simples, o conceito de valor assume várias formas, que variam entre o menor custo ou o melhor benefício, que de outra forma pode ser entendido como eficiência e eficácia. Compreender o conceito de valor, do ponto de vista dos clientes, segue as tendências da nova economia ou economia do conhecimento (TAPSCOTT, 1998) e (KIM e MAUBORGNE, 2002). O que se quer dizer é que neste novo contexto econômico, que envolve fortemente a TI, o cliente cada vez mais tem poder (SEIBOLD e MARSHAK, 2000) e (TAPSCOTT, 2001): o poder do conhecimento. Assim, as empresas devem considerar cada vez mais esta visão de fora para dentro, que tem ditado os rumos do mercado.

Conforme Kim e Mauborgne (2002), o conceito de inovação de valor é consistente com a noção de "destruição criativa" de Schumpeter. Consistente no sentido de que se trata da criação de um valor fundamentalmente novo e superior, que torna irrelevante o que já existe e como é realizado. Com isto, os autores consideram fundamental criar novas formas de se criar valor ou inovar o valor, neste contexto da economia do conhecimento. Normann e Ramírez (2005) descrevem as novas formas de se criar valor, que se identificam com o que foi apresentado pelos autores acima. "A competição global, os mercados em constante transformação e as novas tecnologias estão dando espaço, do ponto de vista qualitativo, para novas formas de se criar valor", (NORMANN e RAMÍREZ, 2005: 54). Para eles, as opções à disposição das empresas, dos clientes e dos fornecedores, estão proliferando-se cada vez mais e intensamente.

As novas formas de se criar valor incluem não apenas ofertas mais inteligentes mas também quando tornam seus clientes e fornecedores mais 
inteligentes proporcionam maior eficiência e eficácia. Para isso, as empresas têm de estar sempre reavaliando e redefinindo suas competências e relacionamentos a fim de manterem seus sistemas maleáveis de criação de valor, renovados e receptivos. "Na nova lógica de valor, esse diálogo entre competências e clientes explica a sobrevivência e o sucesso de algumas empresas e a decadência e o fracasso de outras" (NORMANN e RAMÍREZ, 2005: 62). Assim, fica clara, para estes autores, a importância do relacionamento com fornecedores e clientes na criação de valor, expondo que as ofertas de uma empresa têm maior valor enquanto os clientes puderem usá-las como insumos para alavancar sua própria criação de valor.

Silva Jr (2004) tem o mesmo entendimento sobre criação de valor a qual está relacionada à aliança, a empresa deve ter em perspectiva dois aspectos básicos: como criar e como capturar o valor da cooperação. Silva Jr (2004) entende “(...) a captura do valor como a propriedade sobre o estoque de conhecimento desenvolvido para utilização presente e futura por cada parceira". Na mesma linha de raciocínio, Yanaze (2007) explica que nenhum empreendimento está isolado do ambiente e do mundo em que se acha inserido, que o relacionamento interno e externo depende da comunicação para acontecer e ser mantido. Comunicação, para este autor, é uma das formas de se criar valor da empresa para o mercado, juntamente com o produto, precificação e distribuição adequados.

Sobre criação de valor, conhecimento e parcerias, Tapscott (2005) afirma que o meio empresarial passa por uma mudança histórica. Nesse processo, o capital humano se torna imprescindível, na medida em que se interconecta e se estende além das fronteiras tradicionais da empresa. Esse capital humano se utiliza das habilidades e capacidades do indivíduo, como as competências, o intelecto, a criatividade e o know-how que cada um deles possui. Cria-se, com isto, valor aos clientes.

Drucker realçou em 1993 que o conhecimento não é meramente outro fator de produção qualquer como o trabalho, o dinheiro e a terra - atualmente é o único recurso significativo. Por isso o trabalhador do conhecimento é o maior ativo de todas as organizações. (DRUCKER, 1993 apud TAPSCOTT, 2005).

Drucker (1995) retoma o assunto sobre criação de valor, abordando, desta vez, não o conhecimento, mas, agora, as informações, matéria-prima do conhecimento. O autor explica que as empresas são feitas para criar valor e não controlar custos e isto não é refletido nas métricas tradicionais. Estudantes de 
contabilidade aprendem a fazer balanços que retratam o valor de liquidação de uma empresa, mas empresas não são administradas para serem liquidadas, mas sim para criar valor. Neste contexto, Drucker (1995) recomenda que para se criar valor são necessárias informações que permitam aos executivos tomar decisões corretas. Essas informações provêm de quatro conjuntos de métricas de diagnóstico: informações básicas (fluxo de caixa, projeções de liquidez, estoques); informações de produtividade (eficiência da empresa); informações sobre competências (fazer algo que os outros não conseguem fazer), e informações sobre alocação de recursos escassos (exemplos: capital e pessoas talentosas). Além destas informações no campo tático, as quais contribuem para que se crie valor na empresa, o autor sugere ainda que se considerem outras informações importantes para o campo estratégico: informações sobre o ambiente, sobre mercados, sobre consumidores e não consumidores; sobre tecnologia em sua própria indústria e em outras; sobre finanças internacionais e sobre mudanças na economia global. Para o autor, criar valor nasce de informações internas e informações externas da empresa. Estas informações permitem entender melhor o negócio para a definição da estratégia e a tomada de decisão e, logo, criar valor ao cliente.

Das formas de se criar valor apresentadas, Seybold e Marshak (2000: 62) trazem uma proposição que de certa forma sintetiza o que se pretendeu dizer: "Os clientes mantêm-se fiéis à sua empresa por causa do valor que ela lhes oferece." Ao perceber que o valor que as empresas Ihes ofertam não é mais satisfatório, os clientes simplesmente abandonam-na e procuram novas alternativas que thes ofereçam uma melhor relação custo-benefício. Conforme Yanaze (2007), pode-se ver o valor sob diversos ângulos e a questão da percepção do valor pelo cliente, o que é fundamental para o negócio da empresa. Em comunicação, por exemplo, usase muito o conceito de imagem da empresa, imagem esta que ela passa e suscita em diferentes públicos. Neste caso, consegue-se justificar rede de valor, por exemplo, nos fatos comunicáveis, em que se adequa a comunicação a toda a rede, gerando maior qualidade e produtividade nas operações internas e externas da empresa. Ao longo da história dos negócios, o que se percebe é que o valor assumiu muitas formas. Conforme explica Magreta e Stone (2002), houve um tempo, no início do século passado, quando a Ford Company oferecia automóveis a U\$ 750 , enquanto o preço médio de mercado girava em torno de U\$5.000. Isto criou um valor substancial pelos custos reduzidos. Muitos anos depois, este modelo 
também entrou em declínio quando a rival GM passou a oferecer veículos diferenciados, com maiores benefícios, mas também com preços maiores, criando mais valor. Em resumo, pode-se perceber que a eficiência foi muito importante até um dado momento, porém não foi suficiente: era necessário também ser eficaz, fazer as coisas certas de acordo com as necessidades do cliente. Assim, em relação a criar valor, o que se nota nos exemplos da Ford e GM e nos conceitos anteriormente citados, criar valor deve ser algo de fora para dentro da empresa. Criar valor é entender e atender as expectativas dos clientes e, com isto, criar valor também aos grupos de interesse da empresa envolvida. O que se viu nesta visão de fora para dentro foi a que a questão da eficiência e da eficácia tem sido muito explorada como base para a criação de valor. Esta será, portanto, a forma que se considerará valor neste trabalho.

\subsection{CRIAR VALOR EM SERVIÇOS}

Zarifian (2001) apresenta duas abordagens genéricas sobre valor: valortrabalho, que se baseia no modelo Taylorista, o qual fundamenta o valor com base na eficiência; valor-desempenho, que tem forte influência do modelo japonês, o que representa valor sob uma forma de desempenhos (custo, qualidade, variedade, inovação). Esta segunda abordagem de certa forma também se assemelha com a segunda abordagem feita por Magreta e Stone (2002), a qual leva em conta a eficácia. Com base nas duas abordagens apresentadas acima, Zarifian (2001: 103) propõe que se observe o valor sob dois pontos de vista:

1. Abordagem do valor a partir das conseqüências: "O serviço é uma transformação nas condições de atividade do destinatário, cujas conseqüências (efeitos) são consideradas válidas e positivas por este último e/ou pela coletividade";

2. Abordagem do valor a partir dos recursos: "O serviço é a organização e a mobilização mais eficiente possível de recursos visando a interpretar, a compreender e a produzir a transformação mencionada acima".

No primeiro, abordagem do valor com base nas conseqüências, o autor propõe que se estabeleça algum parâmetro para que se realize um juízo avaliativo do valor. As avaliações propostas são: avaliação de utilidade (avaliação do quanto o serviço produz de resultados úteis à atividade do destinatário); avaliação de justiça 
(ocorre principalmente em serviços públicos e considera a questão da igualdade de acesso aos serviços para todos); avaliação de solidariedade (considera questões relativas à integração social, à qualidade de vida coletiva, à cooperação, assim como à ajuda mútua, na atividade profissional ou na vida social como um todo); avaliação estética (considera as mudanças que o serviço provoca sobre uma pessoa em relação a uma obra de arte, como um quadro ou um filme).

No segundo caso, abordagem do valor a partir dos recursos, Zarifian (2001: 119) explica: "Não se avalia a eficiência em si mesma, não se faz uma avaliação restrita à empresa. A eficiência deve ser avaliada em função das conseqüências esperadas pelos clientes-usuários e, por isso, a avaliação da eficiência depende das avaliações sobre suas conseqüências". Conforme o autor, alguns elementos que envolvem a competência profissional devem ser identificados para facilitar estas avaliações, são eles: identificar e conhecer a atividade do cliente-usuário (interpretar e compreender as expectativas do cliente-usuário, entender para atender); interpretar e compreender (identificar os problemas do cliente para gerar uma solução adequada); desenvolver as condições da compreensão (a compreensão se dá muito além do relacionamento momentâneo, mobilizar toda a experiência dos empregados de uma empresa); produzir uma solução (produzir a transformação das condições de atividade do destinatário do serviço, com eficiência dos recursos da empresa); gerar a transformação (não basta elaborar a solução, é necessário efetuar a transformação das condições de atividade do cliente-usuário).

Outra abordagem sobre a criação de valor e não menos importante que as anteriores, porém ainda mais etérea pode ser encontrada em Bowen e Ford (2002). Para estes autores, a avaliação da qualidade e do valor encontra-se inteiramente na mente do cliente. Segundo este raciocínio, torna-se difícil mensurar, pois não é uma questão que a contabilidade de custos possa apresentar números sobre a eficiência. Aliás, as medidas tradicionais de eficiência e eficácia devem ser revistas (suplantadas por medidas subjetivas para avaliar a experiência do serviço). Como se observa, a questão do valor assume diversas formas e significados, em geral oscilando entre a questão da eficiência e da eficácia, enfim conforme observa Bowen e Ford (2002), é muito difícil medir um serviço utilizando apenas critérios objetivos. 


\subsubsection{Eficiência e Eficácia}

Conforme Drucker (1963): "Eficiência é fazer corretamente as coisas. Eficácia é fazer as coisas corretas". Com o passar do tempo, observam-se as várias formas de se interpretar estes conceitos. Magreta e Stone (2001) explicam que, no auge do ciclo de prosperidade, após a Segunda Guerra Mundial, o marketing tinha um destaque especial no campo da gestão. A eficiência continuava sendo valorizada, porém a eficácia, o fazer as coisas certas, valorizadas pelos clientes, passava a ser mais importante que o desempenho.

Como já foi explicado, houve um tempo em que criar valor era ser eficiente: fazendo mais com menos. Isto tornava os produtos acessíveis ao maior número possível de consumidores. Depois, começou-se a pensar em que o cliente valorizava: a visão do cliente, ou seja, dava-se a ênfase na eficácia. Nota-se que o caminho para se entender o processo de criação de valor passa pelas questões de eficiência e eficácia, porém mais uma vez se percebe que não existe uma linearidade quanto à percepção dos clientes. Nesta linha, julga-se necessário apresentar estas questões sob outros dois importantes pontos de vista, que estão sendo discutidos neste trabalho: serviços e tecnologia da informação.

\subsubsection{Eficiência e Eficácia em serviços}

Para Bowen e Ford (2002), o controle da eficiência e da eficácia em serviços é muito subjetivo. Quanto à eficiência, existe uma dificuldade para se determinar as entradas, inputs, e, as saídas, outputs, pois, em primeiro lugar, não se pode esquecer que as entradas são fornecidas com a co-produção do cliente; em segundo, que os clientes oscilam, variando em suas formas de agir e decidir perante um serviço qualquer, alterando o tempo e as formas da prestação do serviço. Assim, clientes devem ser satisfeitos com a experiência do serviço. Importante considerar que um serviço eficiente com nenhum cliente não é eficaz, enfatiza o autor. Quanto à eficácia, ou fazer a coisa certa, os autores expõem que a medida mais adequada é a satisfação e a lealdade dos clientes.

Pode-se encontrar em Gadrey (2001) uma série de explicações sobre a produtividade nas empresas de serviços. Estas explicações demonstram que a 
produtividade deve ser relacionada com a eficiência e também com a eficácia. A experiência do usuário com o serviço deve ser considerada, pois, caso contrário, não se pode considerar o serviço prestado, logo a produtividade é menor. Segundo o mesmo autor, as formas tradicionais de medição da produtividade muitas vezes distorcem os resultados, é necessário considerar não apenas a questão da eficiência, mas também da eficácia. É necessária uma avaliação multicritério, que possa contemplar todas as variáveis que abordam desde aspectos técnicos ou industriais, como comerciais e financeiros, de relacionamento, cívicos e ecológicos de criatividade e inovação e de imagem e reputação, sugere. Zarifian (2001) lança a hipótese de que a eficiência depende amplamente da qualidade da cooperação do universo da concepção do serviço, pelo universo do sistema técnico e pelo universo do contato com os clientes, modelo que ele chama de "Os três universos da produção de serviços".

Na mesma linha de Gadrey (2001), descrito acima, Silvestro (1999) chama a atenção para que se obtenha um balanço ótimo em variedade-volume, ou eficiência e eficácia, para obter-se maior competitividade em serviços. A adoção de estratégias de custo, priorizando a padronização e a produtividade em geral, negligencia oportunidades de variação na oferta do serviço, o que pode levar à perda de competitividade. Por outro lado, a personalização excessiva pode gerar custos elevados, o que também deixa as empresas em desvantagem competitiva.

No setor da saúde, Teisberg, Porter e Brown (1999) explicam que uma questão que esteve sempre ausente sob assistência médica é como conseguir redução drástica de custo e sustentável em longo tempo. A indagação é como fomentar abordagens novas sobre prevenção e tratamento de doenças, novos meios de prestar serviços e sobre eficiência das instalações. Segundo estes autores, a resposta está na lição que as empresas aprenderam durante as últimas décadas a respeito dos imperativos da competição. A competição impele as empresas a fornecerem cada vez mais valor aos clientes. O indutor fundamental desta qualidade e redução de custos é a inovação. Dessa forma, os autores apresentam alguns pontos interessantes que podem ser muito úteis para se entender a questão da eficiência e da eficácia nos serviços na área da saúde.

- $\quad$ estudos mostram que o atendimento de melhor qualidade em geral é de custo inferior, devido à eficiência das equipes médicas experientes, à menor incidência de complicações e à superioridade dos resultados em longo prazo. Esta afirmação 
contradiz com as formas tradicionais de contratação de serviços no setor da saúde. Como foi dito, por falta de métricas adequadas, entende-se maior eficiência é igual a menor custo, quando:

- $\quad$ os planos de saúde e as seguradoras mais eficientes têm poucos incentivos para reduzir os preços, pois esta ação não contribui para ampliar a participação no mercado. O atual sistema torna os pacientes insensíveis ao preço. Ao desenvolverem formas de compensação nos preços em função da utilização, poder-se-iam obter resultados diferentes;

- $\quad$ o paciente, em alguns sistemas gerenciados, não tem escolha em muitas modalidades de decisões, tornando difíceis as opções de menor custo, ou melhor, benefício oferecido pelo sistema;

- a fragmentação dos clientes no setor dificultam seu poder de barganha e isto torna-se um impeditivo quanto à exigência de melhorar a qualidade e, ao mesmo tempo, de reduzir custo. Os trâmites burocráticos e não padronizados e os controles excessivos sobre utilização dos serviços de saúde tornam os custos administrativos altos, contribuindo para onerar ainda mais o custo total;

- $\quad$ o acesso à informação pelos clientes de assistência médica poderia melhorar as decisões e, por sua vez, pressionariam os provedores para aprimorar o desempenho médico e reduzir os custos;

- a falta de informações na assistência médica gerenciada, também prevalece e os gestores adotam critérios seletivos de prestadores de serviço, baseados no preço e não no atendimento ou resultado do tratamento;

- o desenvolvimento de sistemas de informação, assim como indicadores de resultados específicos que atendam a complexidade do setor, é fundamental.

\subsubsection{Eficiência e eficácia no uso da tecnologia da informação}

Conforme Laurindo (2002), "no âmbito da TI, eficiência está relacionada aos aspectos internos da atividade, enquanto eficácia prende-se ao seu relacionamento com a empresa e os possíveis impactos na sua operação e estrutura". A eficiência, sob o ponto de vista da tecnologia da informação, foca na questão da otimização do desempenho por parte da empresa como, por exemplo, reduzindo erros de 
programação e, portanto, aprimorando a qualidade e precisão de resultados. Em relação à eficácia no uso da $\mathrm{TI}$, o autor complementa:

(...) consiste em implantar ou desenvolver sistemas que melhor se adaptem às necessidades dos usuários, da área de negócios e da empresa, que sejam consistentes com a estratégia global da corporação, que melhor contribuam para aperfeiçoar as atividades e as funções desempenhadas pelos usuários e ainda tragam ganhos em competitividade e produtividade para a empresa (LAURINDO, 2002).

O'Brien (2003) apresenta um comentário que corrobora com autor acima, enfatizando a importância da eficiência e eficácia para o sucesso de um sistema de informação. Enquanto a primeira deve minimizar custos, tempo e uso de recursos de informação; a segunda deve apoiar as estratégias de uma organização, colaborar nos processos, reforçar as estruturas e culturas organizacionais e aumentar o valor comercial do empreendimento.

Como se percebe em Laurindo (2002) e O'Brien (2003), a utilização da TI de forma a otimizar os negócios e o processo de escolhas estratégicas das empresas é a forma mais eficiente e eficaz e de se criar valor que esta pode gerar. Tapscott (1997) estende um pouco mais o valor da TI, esclarecendo que o resultado final da utilização da TI é uma maior produtividade e eficácia organizacional neste momento, pois ao passo que novas tecnologias são introduzidas, seu impacto será muito maior nas organizações. A partir do momento que a TI propicia maior eficiência às pessoas, passando a fazer mais em menor espaço de tempo, economiza-se tempo para se investir na eficácia pessoal (TAPSCOTT, 1997). E isto amplia em muito os ganhos com a TI, quando observados no contexto dos trabalhadores do conhecimento (DRUCKER, 1993 apud TAPSCOTT, 2005) ou da economia do conhecimento, conforme Kim e Mauborgne (2002).

A questão do paradoxo da produtividade da TI há muito vem sendo debatido, porém, como já foi explicada anteriormente, nestes novos tempos da era digital, a preocupação não é mais se a TI ajuda, mas sim de que forma ela pode ser utilizada. Quinn et al. (1994) comentam que as métricas utilizadas para se avaliar a produtividade no setor de serviços são no mínimo inadequadas. Segundo eles, como em qualquer nova tecnologia, existem alguns erros sérios de avaliação. Os dados existentes de produtividade, em geral, não capturaram elementos importantes de qualidade de serviços como, por exemplo, satisfação dos clientes. Como medir o quanto a Tl afetou a longevidade de pacientes em um hospital? Isto não se obtém 
anotando simplesmente o número de procedimentos realizados. As medidas de produtividade ignoram muitas dimensões importantes de desempenho que são críticos aos clientes e aos gerentes. As medidas de produtividade normalmente não refletem o "custo alternativo" de o que teria acontecido sem os investimentos em $\mathrm{Tl}$, e esta é uma questão importante a ser debatida. Por fim, Quinn e Baily (1994) explicam que apesar da inabilidade de governo e indústria de medir em condições financeiras o crescimento de produtividade, induzido pelo uso da TI em serviços, por todas as contas aumentou o desempenho substancialmente em serviços. Como o propósito não é estender a questão do paradoxo da produtividade, mas apenas uma breve menção de Willcocks e Lester (1996), os quais complementam os autores anteriormente citados. Para a avaliação dos benefícios da TI, critérios e métricas apropriados devem ser utilizados e, acima de tudo, a passagem da cultura de avaliação do tipo "controle pelos números" para uma avaliação focada na melhoria da qualidade. Com tudo isso, vê-se que há não só questões tecnológicas, mas questões humanas no paradoxo da produtividade.

Corrêa e Caon (2002) fazem uma associação da questão da tecnologia e gestão, dando uma idéia de como uma deve ser utilizada a serviço da outra, na busca da eficiência e da eficácia, criando valor para as empresas. A nova realidade competitiva prioriza a variedade de opções e a customização, substituindo o antigo foco na gestão de operações que buscava vantagem competitiva na eficiência, flexibilidade de produção e rapidez de resposta que só está sendo possível graças aos novos métodos de gestão e à tecnologia.

No assunto sobre criação de valor em serviços utilizando a TI, é bastante providencial se reiterar a importância da visão de fora para dentro, ou seja, a visão do cliente. Nestes termos, Bowen e Ford (2002) foram bastante precisos com o tema, expondo que clientes devem ficar satisfeitos com a experiência do serviço. Um serviço eficiente com nenhum cliente, não é eficaz. Não adianta forçar o uso da máquina se esta não for amigável com o cliente: ele só usa se for ajudá-lo. A proposta é usar a eficiência com flexibilidade, gerar eficácia ao encontro da demanda heterogênea dos clientes; esta, aliás, deve ser uma boa métrica para poder compreender o cliente e atendê-lo melhor. 


\section{AMPLIANDO O VALOR EM SERVIÇOS}

\subsection{CADEIA DE VALOR}

Para Porter (1989), não se cria valor apenas com uma atividade, mas com um conjunto de atividades. Um conjunto de atividades e fluxos de informação entre uma empresa e seus fornecedores, produção, comercialização, entrega e serviços, o que ele chama de cadeia de valor. Cada atividade deve ser observada como uma fonte para se criar valor ao produto. Tão importante quanto às atividades, são os elos entre elas, que podem ampliar ou reduzir o valor criado. O conceito da cadeia de valor aborda a questão do valor por inteiro: o cliente compra uma experiência, compra um conjunto de atividades que é entregue em formato de produto ou serviço.

Conforme Porter e Millar (1985), a cadeia de valor é o conjunto das atividades tecnológicas e economicamente distintas que a empresa utiliza para realizar seus negócios. Cada uma destas atividades seria uma "atividade de valor" (componentes físicos e de processamento de informações). A cadeia de Valor compõe-se de uma série de atividades independentes conectadas pelas ligações presentes sempre que uma atividade afetar o custo ou a eficiência de outras atividades. Agregar valor nesta cadeia, de maneira mais significativa que seus concorrentes torna a empresa mais competitiva. Segundo estes autores, a vantagem competitiva surge fundamentalmente do valor que uma empresa tem condições de criar para seus compradores em sua cadeia de valor. Esta vantagem se dá sob dois aspectos: preços inferiores que a concorrência ou benefícios singulares (diferenciação). "O modelo da Cadeia de Valor (Figura 7 - A Cadeia de Valores Genérica) é uma forma sistemática para examinar se todas as atividades executadas por uma empresa do modo como elas interagem são satisfatórias e necessárias para a vantagem competitiva" (PORTER, 1989: 35).

As atividades de valor podem ser divididas em dois grupos: atividades primárias e atividades de apoio. As atividades primárias são as atividades relacionadas com a criação física dos produtos e são divididas em cinco categorias genéricas: logística interna, operações, logística externa, marketing e vendas e serviço. As atividades de apoio - que sustentam as atividades primárias e a si 
mesmo, são divididas da seguinte maneira: aquisição, desenvolvimento de tecnologia, gerência de recursos humanos, infra-estrutura da empresa.

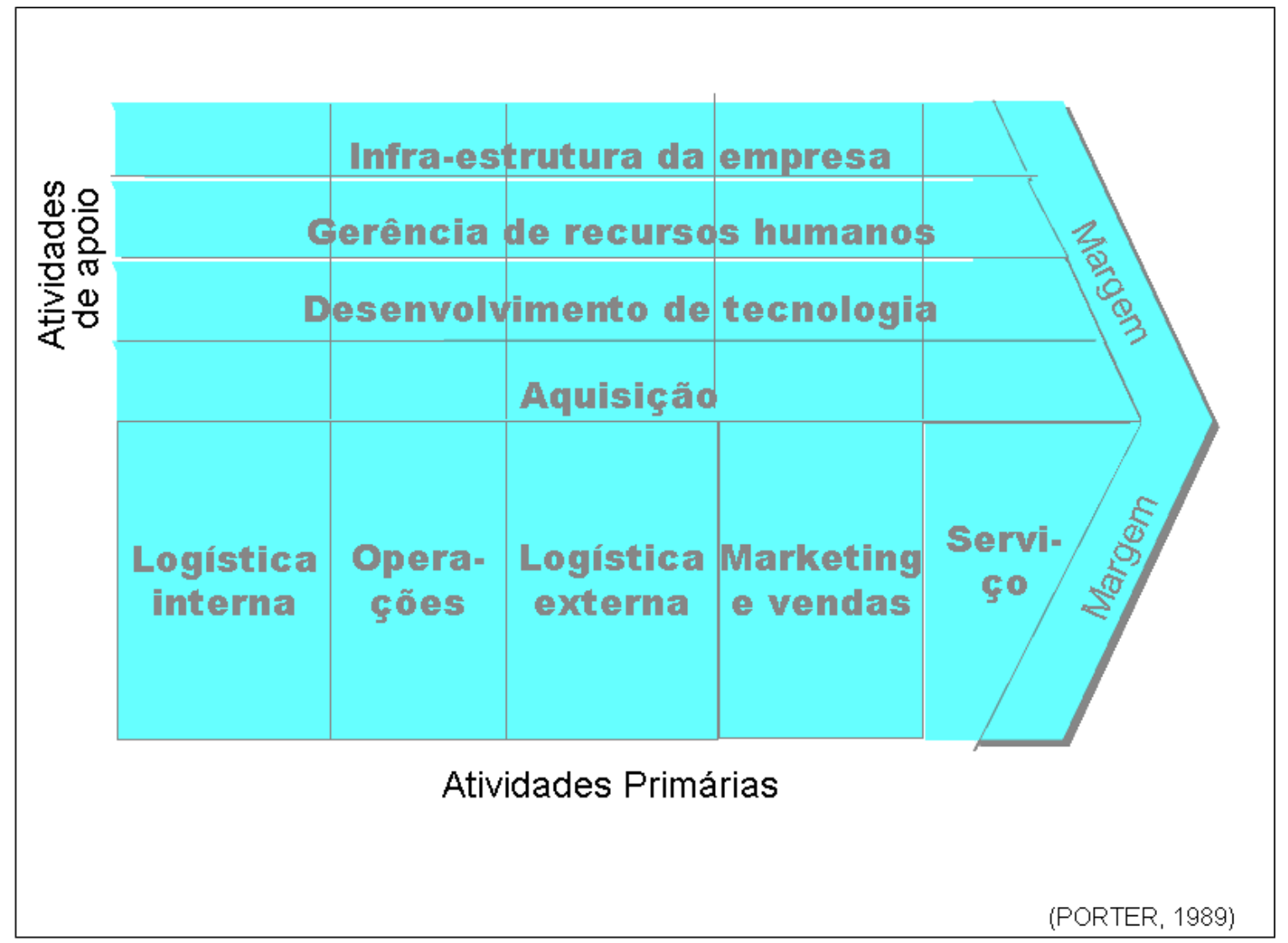

Figura 7 - A Cadeia de Valores Genérica

Quanto mais integrada for a Cadeia de Valor, maior será o valor criado pela empresa. A soma de valores de cada uma das operações em uma organização forma o grande valor que a esta cria para seus clientes. Segundo Porter (1989), "Inter-relações entre unidades empresariais podem ter uma influência poderosa sobre a vantagem competitiva, reduzindo o custo ou acentuando a diferenciação".

A habilidade de coordenar os elos na cadeia de valor freqüentemente reduz 0 custo ou aumenta a diferenciação. Existem elos mais óbvios, que se concentram nas atividades primárias e de apoio e elos mais sutis, que funcionam com uma preparação do serviço no estágio anterior ao que será utilizado. A administração dos elos é mais importante que a administração da própria atividade, pois o cliente tem sua experiência no conjunto das atividades, conforme explica Porter (1989).

Porter (1989) apresenta, ainda, em seu Modelo da Cadeia de Valores, os direcionadores de custo e os condutores de singularidade, os quais são utilizados para aferir o desempenho da Cadeia de Valor da empresa analisada. Um dos 
propósitos de incluir os direcionadores neste trabalho é utilizá-los para medir o desempenho das empresas, comparando o modelo tradicional com empresas que utilizam a TI em suas estratégias de negócios. Esta parte será apresentada mais adiante na fase de interpretação e resultados deste trabalho.

\section{Direcionadores de Custo na Cadeia de Valor}

- $\quad$ Economia de escala (tecnologia, tamanho de lote);

- $\quad$ Aprendizagem (aumento de eficiência);

- $\quad$ Padrão utilizado da capacidade;

- $\quad$ Elos (grau de integração das áreas);

- Inter-relações (compartilhar atividades com empresas do mesmo grupo);

- Integração (grau de verticalização);

- $\quad$ Momento oportuno (custo oportunidade);

- $\quad$ Políticas discricionárias (arbitrárias);

- $\quad$ Localização (afetando o custo);

- Custos em geral.

Condutores de Singularidade na Cadeia de Valor

- Escolhas de políticas (atividades a serem executadas e como serão executadas). Desempenho e característica, serviços fornecidos, intensidade de uma atividade adotada;

- $\quad$ Elos (fornecedores e canais);

- $\quad$ Oportunidade ( $1^{\circ}$. a adotar " $X$ ", pioneirismo);

- Localização (acessibilidade);

- Inter-relações (compartilhar atividades com empresas do mesmo grupo);

- $\quad$ Aprendizagem (know-how superior);

- Integração (nível de verticalização tornando singular);

- $\quad$ Fatores institucionais (marca).

Várias abordagens foram realizadas sobre cadeia de valor, todas fazendo referência a um conjunto de atividades interligadas, em geral dentro de uma mesma organização, mas, algumas vezes, referindo-se a atividades além dos limites de uma organização. Na seqüência, serão apresentadas algumas destas abordagens. 
Figueiredo (1997) utiliza o termo Cadeia de Valor de duas formas: interna e externa da organização.

a) cadeia de valor interna, a qual decompõe nas suas diversas atividades, caracteriza essas atividades, identifica as suas inter-relações e esclarece as ligações que devem manter com o meio envolvente;

b) cadeia de valor externa da organização, que caracteriza a forma como esta se integra no meio envolvente (clientes, fornecedores e concorrentes).

Drucker (1995) faz uma abordagem semelhante à de Figueiredo (1997), mostrando que saber qual é o custo das atividades não é o bastante. Para ter sucesso no mercado global cada vez mais competitivo, a empresa precisa saber o custo de toda sua cadeia de valor e deve trabalhar com os outros membros da cadeia para administrar os custos e maximizar os resultados. As companhias estão começando pelo custeio de dentro de suas organizações para o controle de todo o processo econômico, em que até a maior empresa é apenas um elo com as outras. Drucker (1995) comenta que umas empresas sempre substituirão outras em relação à vantagem competitiva no mercado. Empresas desconhecidas e pequenas derrubam líderes estabelecidos. A explicação sempre dada é: estratégia superior, tecnologia superior, marketing superior, ou manufatura eficiente. O que não se percebe é que o novo entrante também desfruta de uma significativa vantagem competitiva em custo, usualmente em torno de 30\%. A razão é sempre a mesma: a nova empresa consegue enxergar e administrar o custo de toda a cadeia de valor em vez de analisar apenas seu próprio custo (DRUCKER, 1995).

Há também os autores que levantam a questão das cadeias de valor em serviços, afirmando que, pela sua natureza não linear, elas devem ser tratadas de forma diferente. Na visão de Pitta e Laric (2004), a cadeia de valor, assim como a cadeia de suprimentos em serviços, não são processos seqüenciais como na manufatura, por isto os autores preferem chamar de redes de valor. Explicam que as redes de valor devem ligar as várias partes interessadas no sistema da empresa ou das empresas em questão. Estas redes, como já foi dito, não são nem lineares nem seqüenciais, e poderiam ser circulares ou interativas. Elas seguem o fluxo da informação disseminada por meio da rede de conexões entre os vários participantes e é da otimização desta rede valor que se cria mais valor. Estes autores ainda comentam que os serviços variam em diversos fatores importantes. O mais importante, na perspectiva da cadeia de valor, é o nível da customização que o 
serviço fornece, além do grau de participação de um prestador ou de um consumidor e a incerteza subjacente do processo básico. Na manufatura, muitos daqueles fatores são suportados pelas fórmulas e pelas métricas que permitem um grau de precisão. Nos serviços, as métricas são menos precisas, porém a cadeia de valor do serviço pode ser mais complexa.

Um outro ponto de vista é apresentado por Dunhan et al. (2001), que comentam as dificuldades de se utilizar os conceitos da cadeia de valor de Porter e Millar (1985), em pequenas e médias empresas de serviço, em especial empresas baseadas no conhecimento. Para eles, há duas razões principais que devem ser consideradas como limitações para se aplicar este modelo. A primeira diz respeito à natureza interativa do processo, em que é difícil medir o resultado de todo o processo de uma só vez. A segunda refere-se à importância das pessoas no processo, significa que o conhecimento tende a ficar concentrado nas pessoas e não no conjunto de atividades.

Como já foi comentado, o que se pretende apresentar neste trabalho são formas de se criar valor utilizando a TI, que por sua vez derivam de estratégias de negócio ou formas de se realizar coisas diferentemente do modelo tradicional. Carvalho e Laurindo (2003) explicam que a TI permitiu que as empresas ampliassem o leque de oportunidades no que se refere à integração de suas atividades. Esta nova forma de se atuar no mercado tem propiciado um impacto estratégico significativo para as empresas. Assim, a idéia de se reinventar o valor com a cadeia de valor é totalmente adequada a este trabalho. Normann e Ramírez (2005) explicam que algumas empresas obtêm sucesso não apenas agregando mais valor para seus clientes, mas reinventando o valor. Neste ambiente competitivo tão volátil, a estratégia não pode ter respaldo em um conjunto de atividades estáticas na cadeia de valor, mas acompanhar mudança constante do próprio sistema de criação de valor.

A seguir, serão apresentados os conceitos sobre sistema de valor (relacionamento entre uma ou mais empresas) e cadeias de suprimentos (relacionamento entre empresas desde a origem da matéria-prima até o consumidor final). Os dois conceitos contribuem para uma melhor compreensão do fluxo operacional das empresas. Após a apresentação destes conceitos, será apresentada uma visão sobre rede de valores e, por fim, a Cadeia de Valor na saúde e o relacionamento com outros participantes. 


\subsection{SISTEMA DE VALOR}

Em uma visão mais abrangente também se pode dizer que o valor pode relacionar uma ou mais empresas e suas cadeias de valor. Porter e Millar (1985) apresentam o conceito de sistema de valor na Figura 8 - O Sistema de Valores.

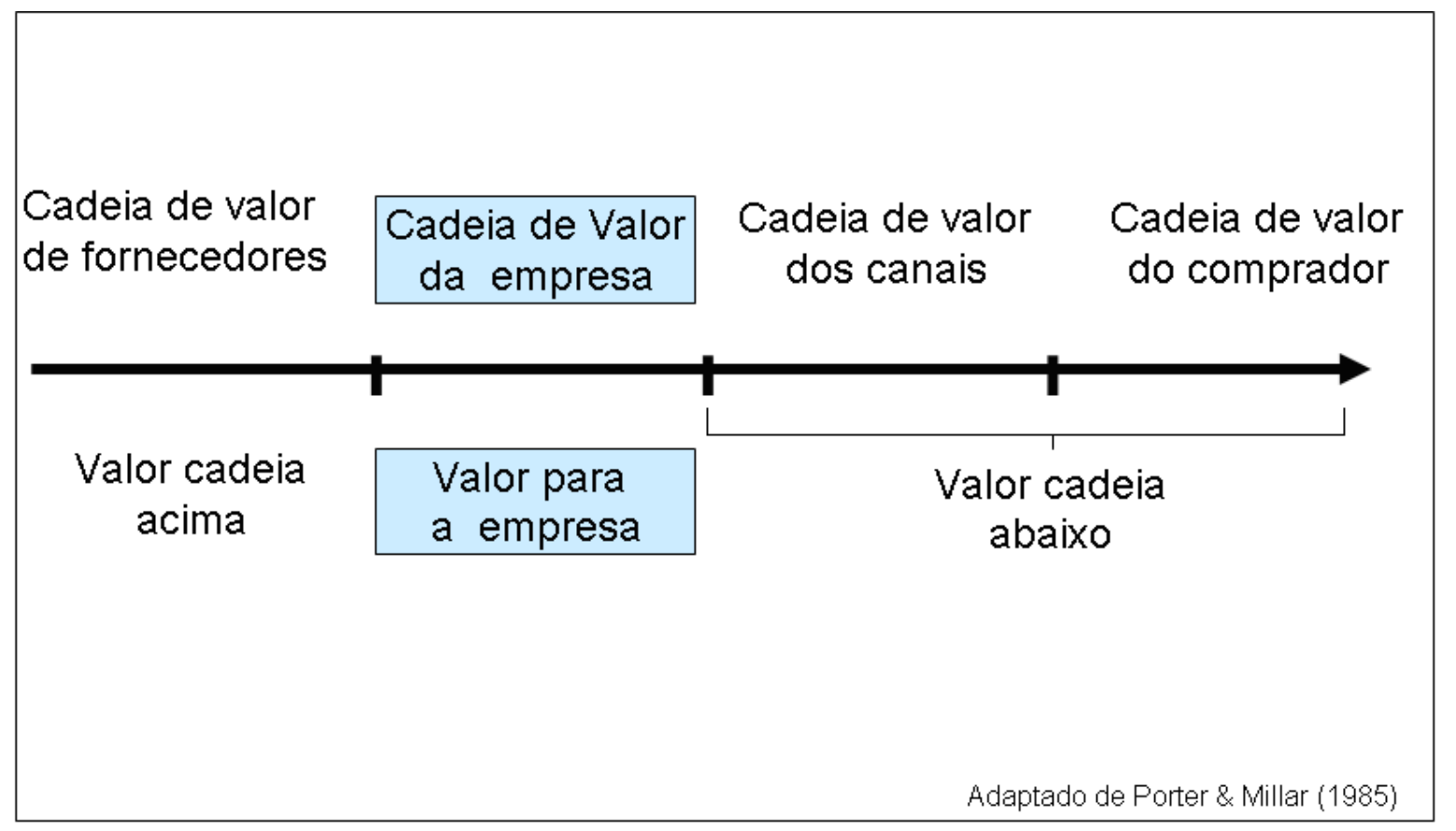

Figura 8 - O Sistema de Valores

Para estes autores, quando a Cadeia de Valor de uma empresa em um setor mais específico está inserida num fluxo mais amplo de atividades, denomina-se sistema de valores. "Esse sistema de valores inclui a cadeia de valores dos fornecedores, que fornece insumos (como matérias-primas, componentes e serviços de terceiros) à cadeia de valores da empresa" (PORTER e MILLAR, 1985: 86).

Assim como na cadeia de valor, os elos entre as atividades são de fundamental importância para o sistema, pois reduzem custos, integrando as atividades da empresa, dos fornecedores e dos distribuidores, criando a vantagem competitiva. A TI tem permitido que a natureza dos elos e a própria atividade sejam desempenhados de formas diferentes, criando ainda mais valor aos seus participantes. As atividades que criam valor de alguma forma usam a Tl, como, por exemplo, a logística na programação de entregas, preços dos transportes, entre outros. 


\subsection{CADEIA DE SUPRIMENTOS}

Um pouco mais além, considerando as cadeias de valor de empresas desde a matéria-prima até o produto final acabado, incluindo os serviços e todas as formas de integração para se obter um produto ou serviço final, tem-se o que se denomina de cadeias de suprimentos (SLACK et al., 2002). Conforme Olave e Neto (2005), a projeção da Cadeia de Valor como uma estrutura analítica surge do trabalho de Porter (1989) e serve de base para o gerenciamento moderno da cadeia de suprimentos. Turban et al. (2003: 330) conceituam da seguinte forma: "Uma cadeia de suprimentos abrange o fluxo de materiais, informações, pagamentos e serviços, desde fornecedores de matérias-primas até fábricas, depósitos e consumidor final". Para eles, uma cadeia de suprimentos também inclui as organizações e os processos que criam e entregam produtos, informações e serviços aos consumidores finais.

Conforme estes autores, as metas do moderno gerenciamento da cadeia de suprimentos são reduzir a incerteza e os riscos na cadeia de suprimentos, diminuindo o nível de estoques, e otimizando outros processos relacionados à duração do ciclo, os processos comerciais e o atendimento ao cliente. Em resposta a algumas pressões competitivas da economia global, várias empresas estão percebendo as vantagens de se realizar alianças, inclusive com empresas concorrentes. A intenção é otimizar o resultado do gerenciamento da cadeia de suprimentos, tornando cada etapa da cadeia o mais eficiente possível, melhorando as formas de comunicação e coordenação entre as atividades e as diversas partes envolvidas. Na Figura 9 - Cadeia de Suprimentos Genérica - pode-se observar uma cadeia de suprimentos genérica. 


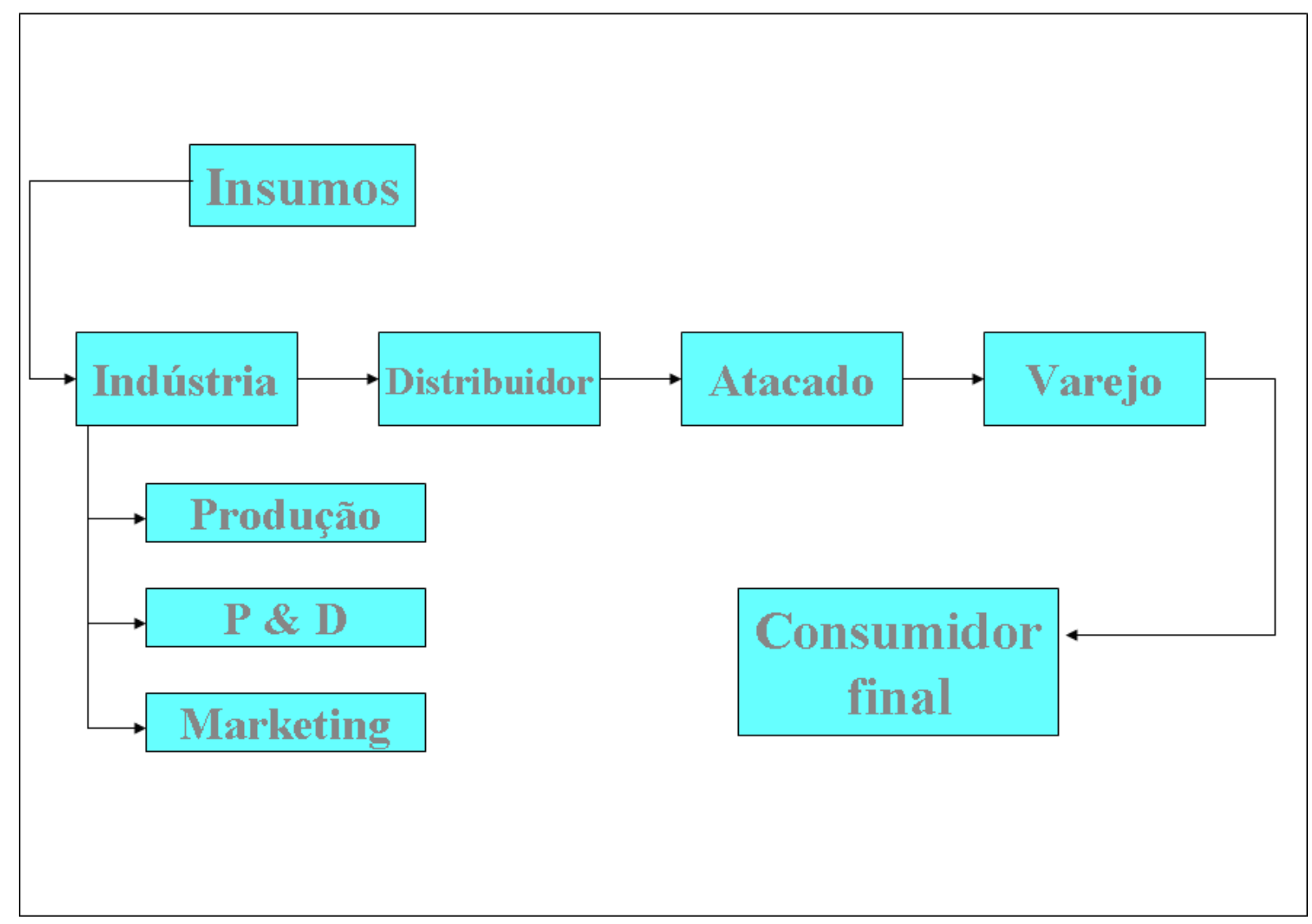

Figura 9 - Cadeia de Suprimentos Genérica

Ellram (2004) explica que a gerência da cadeia de suprimentos está relacionada com a administração de informações, de processos e de bens e insumos dos fornecedores até o cliente final. $\mathrm{O}$ autor destaca várias diferenças entre bens $\mathrm{e}$ serviços, especialmente em relação à cadeia de suprimentos. Neste caso, como as empresas de serviço são, em geral, fragmentadas, fica difícil realizar ou estruturar uma cadeia de suprimentos. A administração descentralizada típica do setor de serviços também torna mais difícil seu gerenciamento. Compradores de serviços devem estar atentos aos impactos de suas atividades na cadeia de suprimentos e os fornecedores de serviço, na cadeia de suprimentos deles. Cada um destes processos executados corretamente reduz a incerteza inerente na cadeia de suprimentos e conduz a melhores resultados.

Corrêa e Caon (2002: 359) também comentam sobre as peculiaridades da cadeia de suprimentos em serviços: "A exemplo das redes de suprimentos nas quais circulam predominantemente materiais com existência física, as empresas de serviços também têm de gerenciar redes de fornecimentos que podem ser tão ou mais complexas que as redes de operações que produzem produtos". Estes autores 
enfatizam que "o mais forte tipo de aliança é aquele em que se estabelecem as parcerias de cadeia de valor, como cadeias de fornecedores e clientes" (CORRÊA e CAON, 2002: 367). Neste caso, empresas com diferentes competências se complementam para gerar um valor maior ao cliente final.

As cadeias de suprimentos têm sido vistas como companhias interdependentes coordenadas coletivamente e como unidades de negócios autônomas e sensíveis ao mercado. Ao adotar uma perspectiva sistêmica, as cadeias de suprimentos podem ser interpretadas como uma configuração de alianças em que sócios individuais focalizam em estágios específicos da cadeia e, com suas competências distintas, para que contribuam com a vantagem competitiva do grupo (PECK e JUTTER, 2000). Uma tendência que cada vez mais se acentua é o nível de serviços nas cadeias de suprimentos, pois este possibilita que se estendam os benefícios do gerenciamento da cadeia de suprimentos até o cliente final. Pitta e Laric (2004) destacam que esta característica contribuiu muito com o marketing das empresas, em especial quanto à questão do relacionamento entre os parceiros, que possibilitam a criação de produtos para o cliente final.

Para Chandrashekar e Schary (1999), toda uma rede conectada com as ligações eletrônicas podem ser consideradas "virtual". Entretanto, uma cadeia de suprimentos virtual abrange freqüentemente as ligações muito mais do que eletrônicas. Representa, para tanto, uma estrutura de organização que facilite fluxos eficientes e eficazes de bens físicos e informação em uma forma sem emenda. $O$ que distingue a corrente virtual da cadeia de suprimentos tradicional é sua flexibilidade inerente de adotar e adaptar-se rapidamente às mudanças no ambiente de negócio.

Como se viu, existe um ponto em comum entre os autores citados, trata-se da redução de incertezas na cadeia de suprimentos como forma de se criar mais valor e ampliar a vantagem competitiva, por meio de parcerias. Assim, pode-se encontrar em Bovet e Martha (2000) a seguinte constatação, a qual eleva o conceito de cadeia de suprimentos para redes de valor, em que as parcerias são inerentes ao conceito. Para estes autores, a cadeia de suprimentos tradicional é linear, opera com velocidade reduzida e tem de adivinhar a demanda do cliente e, então, tentar satisfazê-lo com produtos unificados e serviço na média. A movimentação na cadeia de suprimentos gera gargalos e ações de retrabalho. Velocidade e melhorias de desempenho são possíveis dentro destes sistemas rígidos, seqüentes, mas só às 
margens. E por eles serem dirigidos por demanda prevista, não demanda real, é necessário inventariar toda cadeia de suprimentos. Décadas depois de introduzido o conceito de "puxar" pela demanda, ainda se trabalha com cadeias de suprimento tradicionais, sendo que estas cadeias continuam "empurrando" automóveis, eletrodomésticos, vestuário, bens eletrônicos, equipamento empresarial, materiais de construção, móveis e outros bens fabricados, porta afora, na esperança de que alguém Ihes comprará (BOVET e MARTHA, 2000).

\subsection{REDES DE VALOR}

Castells (2003) ensina que "a formação de redes é uma prática humana muito antiga, mas as redes ganharam vida nova em nosso tempo, transformando-se em redes de informação energizadas pela Internet". O autor comenta que as redes, devido às suas flexibilidades e devido à adaptabilidade próprias, possuem vantagens extraordinárias, pois elas servem como ferramentas de organização. Assim, essas características são fundamentais para se sobreviver e prosperar num ambiente em rápida transformação.

Johnson (2003) faz uma analogia entre redes, o comportamento de um formigueiro, o cérebro humano, as cidades e os modernos softwares. Para ele, nestes exemplos, o todo pode ser maior que a soma das partes. $O$ autor explica que as redes formam os sistemas auto-organizados, nos quais se dispensa a presença de um controle centralizado para haver ação. Alem disso, são emergentes, pois surgem de um nível de elementos relativamente simples em direção a formas de comportamentos mais sofisticados. Os usuários que entram nas páginas da rede mundial de computadores estão atrás de seus negócios e o próprio sistema aprende por observação sobre os gostos destes usuários. Assim como as formigas cortadeiras, quanto maior for o número de histórias individuais de navegantes rastreados pelo programa, mais inteligente ele se torna e mais organizado fica. "O computador mistura os milhões de avaliações de seu banco de dados, procura por padrões de apreciação e rejeição e depois relata para o usuário o que encontrou." Este é o novo mundo das redes de valor, que esboça apenas uma pequena idéia das alternativas de uso no convívio diário e nos negócios, pois as possibilidades são tantas, que seria impossível prevê-las. 
A rede é muito mais que outras tecnologias em desenvolvimento; apresenta algo qualitativamente novo - sem precedente - poderoso meio de comunicação universal, infinitamente rico e interativo. A rede, presente em todos os lugares, logo estará conectada a todos os negócios, às funções de negócios e à maioria das pessoas do planeta (TAPSCOTT, 2001a). Tapscott (2001) infere ainda mencionando que as oportunidades estratégicas da nova década são alavancar a Internet e os investimentos em TI e, com isto, estender a empresa além de suas tradicionais fronteiras, formando empresas em redes. O surgimento destes novos conceitos de negócios inclui parceiros, trabalhadores a distância, fornecedores, distribuidores e consumidores mediante de uma rede global segura. O novo modelo se baseia na inclusão e não na exclusão das empresas no negócio. A otimização do modelo está relacionada à integração de parceiros, fornecedores e clientes a esta rede e na confiança entre os participantes. "Na economia digital, as empresas não competirão em isolado, mas em grupos, inseridas em comunidades de negócios. Por isso, a chave para a competitividade estará nas competências em criar redes e novos modelos organizacionais" (TAPSCOTT, 2001).

\begin{abstract}
O contexto, ou rede de valor, no qual uma empresa compete, tem profunda influência em sua habilidade para tomar posições e concentrar os recursos necessários e na capacidade para superar os obstáculos tecnológico e organizacional que impedem a inovação (CHRISTENSEN, 2001: 58).
\end{abstract}

As empresas estão inseridas nas redes de valor, seus produtos são componentes dentro de outros produtos e, por conseguinte, dentro dos sistemas de uso final. Este fato afeta os clientes finais e, portanto, não deveriam ser pensados como unidades autônomas, mas sim com um complemento ou parte do todo. Pitta e Laric (2004) explicam que a Cadeia de Valor é compreendida a partir de diversas Cadeias de Valor possíveis e, desse modo dão forma a uma rede dos relacionamentos, melhor que a seqüência associada habitualmente com a cadeia de valor. Isto compreende realmente uma rede de valor.

\title{
7.4.1 Conceitos e Características de Redes de Valor
}

O acelerado processo de mudança ambiental, impulsionados por clientes mais exigentes, Internet e tecnologia digital, crescente pressão competitiva e globalização, tem feito com que as empresas se adaptem e reinventem as formas de atender o mercado para que possam sobreviver. Conforme Bovet e Martha (2001), o 
conceito de rede de valor não poderia ser mais oportuno para se adequar a este novo contexto de transformação e às novas exigências das empresas.

Rede de Valor é um modelo de negócios que utiliza os conceitos da cadeia de suprimentos digital para obter a maior satisfação do cliente e a lucratividade da empresa. É um sistema rápido e flexível, alinhado e conduzido pelos mecanismos de escolha dos novos clientes (BOVET e MARTHA, 2001: 2).

Para estes autores, a rede de valor difere do termo cadeia de suprimento, pois a primeira trabalha com o conceito de parcerias e alto desempenho entre cliente/fornecedores e fluxo de informações; a última, com o conceito tradicional de fluxos de materiais, produtos e informações. Bovet e Martha (2001) apresentam cinco características que distinguem os negócios da rede de valor sobre o modelo de negócios tradicional, baseado no conceito da cadeia de suprimento. São eles: Alinhada com o cliente, Cooperativa e sistemática, Ágil e flexível, Fluxo rápido e Digital. Estes itens serão mais bem explicados no item redes de valor e vantagem competitiva, mais adiante.

"No contexto organizacional, o crescente número de parcerias tem levado ao fortalecimento e à ampliação da consciência da importância das redes - de valor, de conhecimento, de suprimentos, configurando o que se convencionou chamar de sociedade em rede" (DORNAS e MILAGRES, 2005). O ponto de vista destes autores, quanto ao uso estratégico do conceito de redes, coincide com as afirmações acima.

As redes de informação são as que mais evoluíram, em função do crescimento da $\mathrm{TI}$ e das telecomunicações. Este movimento tem transformado o ambiente de negócios e, conforme exposto anteriormente, estas transformações têm demandado adaptações por parte das empresas, para que consigam sustentabilidade.

Os agentes econômicos precisam alterar seu comportamento na busca de compartilhamento de recursos, destacando-se, dentre estes, o conhecimento, como aquele capaz de gerar vantagens competitivas sustentáveis. Estes fluxos de conhecimento devem propiciar que as empresas sejam mais rápidas e flexíveis e que possam, com isto, gerar respostas mais rápidas ao mercado. Por último, Dornas e Milagres (2005) afirmam que as empresas brasileiras estão ainda um pouco distantes desta nova realidade, no que se refere a trabalhar e a usufruir todos os benefícios, inerentes às redes de valor. Esta afirmação tem respaldo em um estudo 
de empresas nacionais, as quais se apresentam em estágio inicial de seu processo de integração com os demais elementos de cadeias produtivas em que estão inseridas. No contexto das cadeias produtivas, estas empresas precisam reformular estratégias que envolvam todos os elos, buscando maior cooperação, geração e compartilhamento do conhecimento.

\subsubsection{Redes de Valor e Vantagem Competitiva}

Analisando as redes de valor e seu impacto na vantagem competitiva das empresas, podem-se observar ganhos tanto no campo estratégico como no campo tático. Fleury e Fleury (2005) fazem uma relação entre o conjunto de conhecimento e o papel da liderança das empresas. Por essa analogia, expõem que quanto mais estratégico o conhecimento, maior será a liderança destas empresas para se imporem como líderes no setor empresarial. Se o conhecimento for bastante técnico (ou produtivo), ele terá maior capacidade de posicionar-se no setor operacional. Se esses aspectos não tiverem relevância para a empresa, esta não terá suporte para manter-se e, provavelmente, ruirá.

Silva Junior (2004) comenta a importância das parcerias para a competitividade, pois estas podem beneficiar-se de Economias de custo - as organizações eliminam duplicidade de procedimentos; Economia de risco - as empresas reduzem as incertezas no desenvolvimento e na aplicação de soluções; Economias de escala e escopo - as empresas combinam e ampliam mercados ou bases de clientes ou maximizam processos de compras e uso de matérias-primas; e Economias de aprendizagem - as empresas compartilham antigos conhecimentos e geram novos conhecimentos. Como se vê, tanto no campo estratégico como no tático, as oportunidades de se obter vantagem competitiva são inúmeras.

Bovet e Martha (2001) apresentam algumas características que fazem parte das redes de valor e são semelhantes às vantagens apresentadas por Silva Junior (2004). São elas: cliente alinhado com a empresa; ambiente de colaboração entre fornecedores e clientes agilidade e escala - produção flexível, distribuição e fluxos de informação; fluxo rápido - ciclos curtos do pedido a entrega, inexistência de inventários, datas de entrega segura: digital - sistema de informação interligado de forma eficiente e eficaz em toda a rede. Estas vantagens permitem que as redes de valor adquiram controle estratégico com a utilização de um ou mais dos seguintes 
mecanismos: uma marca de rede de valor que pareça diferenciada aos olhos dos clientes; um elo com os clientes que os mantenha em uma relação satisfatória; um conjunto de sólidos relacionamentos com os parceiros de fornecimento; um modelo inovador que coloque os serviços de uma empresa na vanguarda; um preço baixo com o qual a concorrência considere difícil equiparar-se.

Estes artifícios servem para proteger os lucros das empresas, explicam os autores. Por um lado, aumentam os laços com os fornecedores e, por outro, com os clientes: juntos aumentam a distância dos concorrentes. Na mesma linha dos autores acima, Neto (2005) menciona acerca da importância das redes dinâmicas de cooperação e da alavancagem competitiva para as pequenas e médias empresas participantes. Estas redes de cooperação apresentam dois objetivos: alavancar a competitividade dos parceiros desta rede; possibilitar a exploração de novas oportunidades de mercado em âmbito global.

\subsubsection{As alianças como Ferramentas Estratégicas}

Goulart e Arruda (2003a) afirmam que as alianças foram a melhor estratégia escolhida pelas empresas para se manterem no mercado competitivo. Por intermédio de sistema ou relacionamento cooperativo, as alianças são alicerçadas e os seus parceiros se unem para compartilhar recursos e capital, ganhar competência e distribuir conhecimento, além de outros fatores que permitem acesso ou bloqueio à concorrência.

Fleury e Fleury (2005) explicam que existem empresas que se organizam em relações horizontais, havendo uma simetria de poder. Com o desenvolvimento de acordos de interesse mútuo, estabelecem-se alianças estratégicas, nas quais ocorre o compartilhamento de informações e de recursos para atingir objetivos de interesse comum. Segundo estes autores, "no processo de formação de cadeias e redes, a posição de cada empresa é em função do tipo de competência e conhecimentos por ele dominado". O que se quer dizer é que quanto mais integradas forem as empresas da rede de valor, maior poderá ser o comando e a posição dela no grupo.

Nakano (2005) explica que a condição para uma empresa participar de uma rede de valor é que ela necessite e tenha algo de valor para oferecer, que seja de interesse dos demais participantes: informação, serviço ou produto. Quanto mais se explorar os recursos de rede, maiores as possibilidades de êxito das empresas, os 
quais estão relacionados com o conhecimento que tem as empresas, que são fruto deste relacionamento. As empresas que não se engajarem ficarão em desvantagem, pois competirão em desigualdade em relação às empresas que participam em redes de valor.

Goulart e Arruda (2003) observam que com o conhecimento cada vez mais sofisticado e disperso, as empresas deverão buscá-lo além das fronteiras da sua organização; nestes casos, as parcerias possibilitadas pelas redes de valor serão fundamentais para as empresa se manterem competitivas. Os autores complementam, afirmando que o desafio está não somente no desenvolvimento de soluções originadas por meio do conhecimento, mas na forma que este conhecimento será utilizado. Esse conhecimento deve advir de seus clientes, fornecedores e parceiros diversos, sem os quais nenhuma solução seria efetivada isoladamente por eles. Há, portanto, nesse meio, uma rede de compartilhamento entre os elementos envolvidos, em que há um fluxo de informação e de transmissão de conhecimento. A partir dessa cultura de compartilhamento, torna-se necessária a criação de metodologias das empresas (e para as empresas). Com isso, elas terão suporte básico de acesso ao monitoramento e acesso do conhecimento, além de mobilização e integração de alianças, que são fundamentais em toda fase do processo produtivo.

A TI tem facilitado o processo de formação de parcerias, ou melhor, é o alicerce das redes de valor. Conforme O'Brien (2003), "as empresas estão se tornando empreendimentos interconectados". Seja pela forma de se integrarem às atividades internas ou externas, as empresas já não agem ou escolhem caminhos individualmente, mas por meio de estratégias coletivas (PECK e JUTNER, 2000). No processo de redes de valor, se as empresas conectadas ou as alianças de empresas são o alicerce do processo, portanto é fundamental saber onde está o cliente. Nesta construção, ele é atividade-fim, todo o resto é meio. Será que as empresas estão conseguindo identificar o cliente e entregar adequadamente o valor criado?

Para Seybold e Marshak (2000), todas as empresas possuem clientes. Mas se perguntar quem são eles, a resposta geralmente é incompleta. Porém, o cliente real é o cliente final do produto ou serviço que a empresa produz. Portanto, o cliente como pessoa ou empresa que usa o produto, e não a que o distribui ao usuário, nem necessariamente quem paga por ele. 


\subsection{CADEIA DE VALOR NA SAÚDE E O RELACIONAMENTO COM OUTROS PARCEIROS}

Como se observou em Porter (1989), a Cadeia de Valor é descrita como um processo linear e seqüencial, começando pela matéria-prima e terminando nos usuários finais. Os serviços na saúde, como a maioria dos serviços, têm diversas características que tornam ainda mais complexa uma adaptação simples desta vista linear e seqüencial da Cadeia de Valor (PITTA e LARIC, 2004). Os autores acrescentam, ainda, a esta Cadeia de Valor na saúde o relacionamento com outros parceiros. Estas características permitirão que seja apresentada, mais adiante, uma rede de valor na saúde que será adaptada deste modelo.

De acordo com Burns et al. (2002), as camadas que envolvem os serviços na saúde incluem cinco etapas: 1 - pagadores (governo, empregadores, indivíduos, grupos representantes de empregados como cooperativas e outros); 2 intermediários (seguradoras, planos de saúde, cooperativas, autogestões, outros); 3 - fornecedores (hospitais, clínicas, médicos, centros de diagnóstico, ambulatórios, farmácia, outros); 4 - compradores (inclui uma variedade dos revendedores tais como distribuidores de materiais e medicamentos, distribuidores de equipamentos, outros); e 5 - produtores (indústria farmacêutica, indústria de materiais, indústria de equipamentos, fornecedores de serviços da tecnologia de informação, outros).

O estudo acima faz um mapeamento dos vários grupos que estão divididos em camadas distintas e que vão desde a produção de insumos até a entrega do serviço ao cliente final. Estes grupos, como será explicado adiante, têm envolvimento com os pacientes das mais variadas formas, dificultando não apenas a padronização de procedimentos, mas principalmente uma previsão das operações de serviço, o que invariavelmente compromete a qualidade destes serviços. Burns et al. (2002) comentam que este é um setor em transformação e que se percebem muitos movimentos de integração vertical, entre clínicas, hospitais e centros de diagnóstico e também de integração horizontal, por meio de fusões, formando grandes grupos.

O sistema da entrega de valor nos serviços na saúde é compreendido pelas etapas que precede a entrega do serviço e efetivamente o tratamento do paciente, conforme explicado acima. Os elementos que estão contidos nestas etapas incluem 
a equipe de funcionários, médicos e todas as pessoas que contribuem para apoiar 0 serviço, a limpeza, a alimentação, a tecnologia, os insumos e outros (PITTA e LARIC, 2004). Com base nestes autores, serão apresentadas, na seqüência, diversas outras especificidades da Cadeia de Valor na saúde.

Características Específicas da Cadeia de Valor na Saúde

1 - A participação do pacientes. A participação dos pacientes na co-produção do serviço afeta extremamente o resultado objetivo da Cadeia de Valor. Na medida em que os pacientes facilitam o diagnóstico, informando os sintomas, facilitam que se realize uma prescrição ou processo otimizado para seu tratamento. Esta participação afeta de três formas diferentes:

1.1 - Custo em fornecer o tratamento correto. Na medida em que o paciente não consegue descrever seus sintomas com clareza, os processos de diagnóstico (exames de laboratório e imagens), em geral, são realizados. Este fato faz com que o paciente tenha de percorrer diversas áreas da instituição e, inclusive, deslocar-se para unidades externas. Desta forma, a demora em um atendimento pode gerar um agravamento da situação o que implicará em experiência diferente em uma cadeia de valor diferente.

1.2 - A saúde total e a aptidão física e mental do paciente são importantes. A preexistência de problemas relacionados com a saúde pode gerar procedimentos de maior custo para se conseguir resultados desejados.

1.3 - Nem todos os tratamentos são livres de risco. O tratamento para determinadas doenças pode ter os efeitos colaterais que são negativos em seu impacto na qualidade de vida do paciente e na satisfação total. Assim, um tratamento médico objetivo, tal como uma amputação de um membro, pode impactar na qualidade de vida do paciente. Deste modo, pacientes idosos podem exigir maior atenção dos cuidadores, em relação a outros pacientes.

2 - O impacto na quantidade de participantes na Cadeia de Valor. O número dos participantes que fazem parte nos serviços de saúde depende do processo prescrito do tratamento e afetam extremamente o resultado da Cadeia de Valor. Se o processo requerido começa e termina com o mesmo fornecedor, por exemplo, um paciente e um médico, tem-se uma situação. Se o processo se move para incorporar e envolver os participantes adicionais, por exemplo, um exame de raios- $X$ ou uma cirurgia, tem-se uma outra situação muito diferente da primeira. 
2.1 - Cada prestador de serviço na unidade de saúde tem uma relação administrativa e burocrática com o paciente, antes deste receber o serviço específico. Os contatos podem variar muito, passando por recepcionistas, enfermeiras, médicos generalistas, médicos especialistas, técnicos de imagem, outros.

2.2 - Existem serviços que estão subordinados ao atendimento médico como, por exemplo, um enfermeiro que faz algumas perguntas, pesa o paciente, analisa a febre ou o batimento cardíaco. Algumas vezes a necessidade de exames pode envolver prestadores de serviço externo e, neste caso, nova visita ao médico será necessária. Nos casos mais complicados que envolvem procedimentos cirúrgicos, algumas vezes é necessário mudar novamente para outra cadeia de valor. Se um acidente de automóvel provocar a necessidade do cuidado de saúde, pode haver serviços médicos de emergência envolvidos; às vezes, combinando polícias e bombeiros e, quando necessitado, uma ambulância ou um helicóptero e paramédicos.

2.3 - Em relação ao reembolso do tratamento, este exige muitas transações entre o prestador de serviço na saúde e o paciente. Muitas vezes para obter-se esse reembolso, isto requer o esforço e a informação que afetam o resultado da Cadeia de Valor.

2.4 - O processo de transferência de informação dentro da cadeia, nos termos da exatidão e da eficiência, determina o valor total derivado da cadeia de valor. A disponibilidade da informação médica, seu processamento oportuno entre fornecedores de serviço e a exatidão da transmissão impactam na Cadeia de Valor e são críticas para que o sistema funcione. A cadeia também é afetada pela natureza confidencial e sensível da informação, considerando que a informação deve ser guardada e controlada. Ao contrário da maioria das Cadeias de Valor na indústria em que o fluxo da informação é correlacionado positivamente com o fluxo do valor, na saúde, devem-se incluir os dados, que são considerados pessoais e confidenciais.

Pitta e Laric (2004) apresentam um modelo para a Cadeia e Valor nos serviço de saúde (Figura 10 - Participantes e Relacionamentos na Cadeia de Valor na Saúde). Conforme explicado, o modelo apresenta uma Cadeia de Valor que não é nem linear e nem seqüencial, mas que pode ser circular ou interativa, conforme 
explicam os autores. Segue geralmente um fluxo de informação que quanto mais desobstruído, melhores resultados poderão ser obtidos. Esta Cadeia de Valor pode ser compreendida desde um relacionamento paciente-médico, até diversas outras situações, chegando a aproximadamente a sete etapas. Principia-se com o contato com o médico, passando pela internação e até cirurgias complexas, ocorrendo internações em unidade de terapia intensiva e, depois, acertando a conta com o plano ou seguro saúde, entre outros.

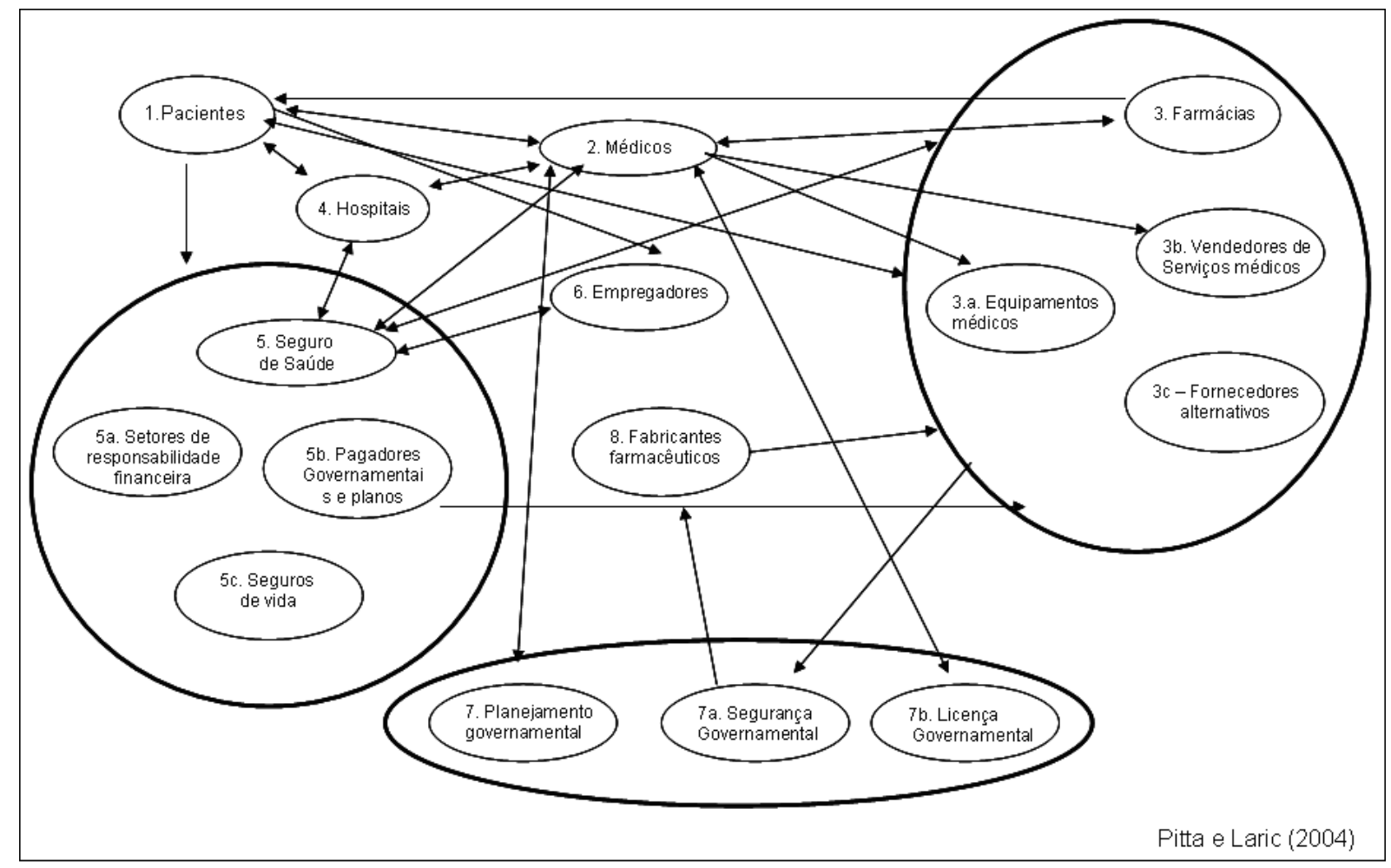

Figura 10 - Participantes e Relacionamento na Cadeia de Valor na Saúde

O que se conclui é que se um elemento da cadeia de valor tiver problemas, afetará a rede inteira da entrega do valor e provavelmente afetará o resultado ao paciente. Um resultado incorreto de um teste de diagnóstico ou uma cirurgia no órgão errado terá um impacto crucial no sistema inteiro da entrega do cuidado de saúde. Cada membro da cadeia deve ser bem-sucedido e deve considerar que só poderá criar valor se todos os membros estiverem sincronizados e em sintonia nesta complexa rede de relacionamentos que pertence os serviços na saúde.

Teisberg, Porter e Brown (1999) trazem à luz uma indagação, que nem a complexidade da medicina é capaz de explicar: Por que há um aumento da demanda por serviços de saúde onde existem quantidades maiores de 
profissionais? Além disto, também não se tem explicação por que os médicos com disponibilidade de tempo e instalações geram maior demanda por exames e procedimentos e até cirurgias a pacientes menos graves. Como se constata, o simples fato de se ter maior oferta gera um número maior de procedimentos. Os mesmos autores lembram que as variáveis são muitas no serviço na saúde que, ao se observarem as questões relacionadas, por exemplo, ao pagamento pelos associados, isto torna a compreensão da cadeia de valor de serviços na saúde uma tarefa ainda mais difícil: " $\mathrm{Na}$ maioria dos setores, os consumidores exercem a decisão de compra e pagam pelos produtos e serviços. Na assistência médica, segregam-se a decisão de compra, o pagamento e a recepção dos serviços." (TEISBERG, PORTER, BROWN, 1999: 442). Os autores explicam que este fato é conseqüência de muitos tipos de clientes no sistema. Têm-se os empregadores que pagam a assistência médica para seus funcionários, os pacientes que recebem o tratamento, os médicos que determinam o tratamento a seus pacientes; têm-se as empresas de plano de saúde, seguro saúde entre outras. Todos estes clientes tornam o sistema irregular, não linear e altamente complexo. 


\section{DESENVOLVIMENTO DAS PROPOSIÇÕES DO TRABALHO}

Em prosseguimento, serão apresentadas algumas premissas, as quais darão respaldo para a construção das proposições a serem analisadas neste trabalho.

Porter e Millar (1985) apresentam um estudo bastante esclarecedor sobre a utilização da TI como forma de se obter vantagem competitiva. Segundo os autores, a TI está alterando as regras da competição de três maneiras:

a) transformando a estrutura setorial: a TI é capaz de mudar as cinco forças competitivas que determinam em conjunto às cinco forças setoriais: poder dos compradores, poder dos fornecedores, ameaça dos novos entrantes, ameaça dos produtos substitutos e rivalidade entre os atuais concorrentes;

b) alavancando a vantagem competitiva: as organizações podem obter maior vantagem competitiva por meio da TI. Isto pode ocorrer de três formas: redução de custos, diferenciação e escopo competitivo, e

c) criando novos negócios: a TI está dando origem a setores completamente novos, de três maneiras: viabilizando novos negócios; difundindo novos negócios, por meio da demanda derivada de novos produtos, e criando novos negócios dentro de setores tradicionais, com oferecimento de sua capacidade ociosa.

A seguir, serão mencionados diversos dos aspectos apontados por Porter e Millar (1985), no que tange aos três itens demonstrados pelos autores.

Ao comentar sobre a intensificação da globalização dos mercados, do crescimento da competição e da cooperação, Freitas et al. (2001) inferem sobre as várias tecnologias que contribuem para a alteração no cenário dos negócios, entre elas a Internet. A tecnologia altera e dinamiza processos, estruturas e também culturas, com mudanças que oferecem um novo canal de comunicação com o mercado. Este canal, segundo eles, possibilita a criação de organizações virtuais e contribui para que haja um controle, um monitoramento, ou uma maximização das possibilidades em ambientes turbulentos. Bovet e Martha (2001) esclarecem sobre a velocidade de mudança no mundo e como isto está propiciando oportunidades para algumas organizações, e desafios para as empresas se manterem, para outros. Segundo eles, o conceito de rede de valor não poderia ser mais oportuno, pois amplia o valor dos negócios das empresas. Na medida em que aumenta a confiança entre os participantes, pois trabalham como se fossem uma só empresa em rede, 
reduzem custos de busca, inventários e outros custos de transação, envolvendo fornecedores, compradores e até concorrentes parceiros. Um estudo da Booz Allen Hamilton e da Escola de Wharton (2005) explica os benefícios de se trabalhar de forma integrada ou em rede, com fornecedores, clientes e os mais diversos públicos do setor da saúde. O estudo acentua que, para o sucesso, todos devem trabalhar de forma integrada, envolvendo-se tanto na execução, quanto na distribuição do valor. Neste estudo, os consultores fizeram projeções sobre um possível sistema digital universal dos registros médicos. Em seguida, citam-se algumas características e formas de se utilizar a TI nas operações de serviço no setor da saúde, conforme o estudo.

- Uso da TI na coleta de informação clínica. A informação clínica essencial não está freqüentemente disponível em situações preliminares do cuidado. Tais dados são uma fonte principal dos erros médicos, os quais poderiam ser impedidos, tendo registros eletrônicos acessíveis e exatos do paciente. Esta ação também eliminaria a duplicação de serviços, assim como a repetição de testes.

- Inovação na oferta. A informação é a espinha dorsal para o fluxo de informação na indústria da saúde. Ela poderá fornecer uma plataforma para necessidades de longo prazo, atendendo necessidades de clientes, de fornecedores e para todos no sistema.

- Melhora da qualidade e de redução de custos. Atualmente, o custo administrativo de um plano de saúde gira em torno de $20 \%$ dos custos totais. Estima-se que possa ser reduzido a 10\% deste valor.

Rothenberg (1995) dá seu aval acerca do estudo supracitado, reiterando a importância de se trabalhar em rede em um setor complexo como o da saúde. Segundo ele, a viabilidade econômica e a sobrevivência de sistemas de serviços de saúde dependem, em parte, das suas habilidades de usar redes de informação e tecnologias relacionadas, criando vantagens para o competidor. Na mesma linha de raciocínio, O’Brien (2003) destaca que um dos valores estratégicos da Tl é seu papel na realização de melhorias importantes nos processos de uma empresa. Este autor destaca que estas melhorias, quando relacionadas a seus processos, podem reduzir custos, melhorar a qualidade e aprimorar o atendimento ao cliente. Os investimentos em $\mathrm{Tl}$ permitem que se desenvolvam novos produtos e serviços ou processos exclusivos, o que gera acesso a novos mercados ou segmentos específicos. 
A partir dos processos, o que se pretende é desenvolver produtos ou serviços personalizados e adaptados conforme a necessidade ou o desejo do cliente. De Sordi (2003) diz que, para se obter estas formas de valor, que oscilam entre a maior qualidade ou o menor custo, as empresas devem conciliar a padronização das linhas de produção (elemento-chave para a redução de custos) com a diferenciação necessária à personalização. Tanto num caso quanto no outro, o autor recomenda a aplicação da TI como solução. Correa e Caon (2002) concordam com De Sordi (2003) e complementam que TI altera substancialmente os elementos do pacote de serviço oferecido aos clientes, especialmente os que são intensivos em informação. Para tanto, estes autores citam os serviços do Laboratório Fleury, que disponibilizam resultados pela Internet, permitindo, por exemplo, que o histórico de exames dos clientes (com laudo evolutivo) fique acessível aos médicos a qualquer momento e em qualquer local onde haja acesso à Internet. Além disso, estes resultados são indexados ao nome do médico, que passa a checar resultados de exames pedidos por ele, na medida em que ficam prontos. Com este método, o médico ganha maior flexibilidade, pois tem a opção de analisar os resultados dos exames, no horário que melhor Ihe convier. Os autores ainda comentam sobre a grande influência da TI em tornar os estocáveis mais intensivos em informação. Como exemplos disso, os autores citam as empresas de seguro-saúde, que avisam seus pacientes por meio de pagers, sobre o horário de tomarem medicamentos, evitando que o estado do paciente se agrave, caso ele não tome este procedimento. Uma das conseqüências desse método é a redução de custos.

Quinn et al. (1994) explicam que os investimentos em TI são estratégicos, pois eles podem mudar o posicionamento de uma empresa no mercado, redefinindo a natureza básica da companhia e até garantindo sua sustentabilidade, em função de transformações do ambiente. Muitas vezes estas mudanças não afetam necessariamente a diferenciação ou o custo, mas os fatores intangíveis, como respostas aos clientes, flexibilidade operacional e imagem no mercado.

Eustace (2003) comenta sobre a questão da erosão da Cadeia de Valor, ou seja, da troca dos valores tangíveis por valores intangíveis, o que está dirigindo as empresas a uma busca efetiva para fatores novos de diferenciação e de influência no mercado. Nestes tempos de nova economia, os fatores intangíveis, baseados em informação, têm propiciado melhores alternativas para minimizar este processo de erosão da Cadeia de Valor. Assim, o autor recomenda que se busquem alternativas 
de conectividade cujas possibilidades de arbitragem sejam numerosas e certamente estejam gerando vantagem competitiva às empresas. As vantagens podem vir com 0 uso da TI, tornando a Cadeia de Valor mais eficiente e eficaz (PITTA e LARIC, 2004).

Na mesma linha destes autores, Chandrashekar e Schary (1999) explanam a respeito da importância da cadeia de suprimentos virtual, o que propiciará trajetos múltiplos entre vários sócios (empresas que atuam para produzir um determinado bem ou serviço), a fim de se alcançar clientes individuais. Estas cadeias de empresas deverão mudar de parceiros ou processos, se for necessário, para atingir a flexibilidade e entregar um maior valor ao cliente final.

Como se observa, as possibilidades de utilização da TI são diversas. Isto significa que também são variadas as possibilidades de se desenvolver estratégias de negócios. É necessário descobrir como e por que a TI cria valor e, a partir disto, redesenhar o negócio na saúde.

Em geral, as informações sobre vantagens competitivas utilizando a $\mathrm{TI}$ no campo da saúde são escassas: encontram-se poucas recomendações genéricas. Nos dizeres de Rothenberg (1995), as redes de informação centradas no paciente afetarão a indústria nas seguintes áreas humanas e de interação do negócio: reorganização do trabalho, criação de novas comunidades eletrônicas de negócios, eliminação de intermediários, padronização de processos e remoção das barreiras de tempo e lugar. E, mais recentemente em Chao (2003), podem ser encontradas indicações de que a TI contribui para aumentar a produtividade (eficiência) nas operações de serviço na saúde, reduzindo custos, mas também aumentado eficácia, propiciando melhor atendimento (atingimento, abrangência, especialização, outros).

Para Lieber (2003), a TI deverá transformar os serviços na saúde. A questão é que, conforme The Institute of Medicine nos Estados Unidos, seu valor potencial não é debatido, o que Lieber concorda. Assim como Skinner (2003), Lieber entende que a TI é importante quando sustenta ou participa na construção da competência central dos serviços na saúde. A tecnologia por si só é apenas uma ferramenta, seu valor depende da forma como é usada.

Teisberg, Porter e Brown (1999), ao tratarem do mercado norte americano, deixam claro que o uso da TI deve ter outro rumo e deve ser encarado de forma diferente do que está sendo conduzida atualmente no setor da saúde. Segundo eles, 
o debate nacional identifica a tecnologia como o inimigo. O foco se concentra em como cortar as gorduras e eliminar os desperdícios do sistema vigente pelas reformas, como alianças para a compra de planos de saúde, redes consolidadas e limites para remédios e dispositivos. Os autores aconselham que a reforma da assistência médica deve iniciar pelo incentivo à inovação médica, assim como inovação na gestão. Não se devem confundir ações esporádicas visando à maior eficiência, com uma estratégia sustentável de custos.

Para Porter e Millar (1985: 106): "A relevância da revolução da informação não é algo questionável. A pergunta não é se a TI exercerá um impacto expressivo sobre a posição competitiva da empresa; ao contrário, a dúvida é quando e como ocorrerá o choque." Ao dizer isto, estes autores explicam que as empresas que anteciparem o poder da TI estarão no controle dos eventos. As demais serão apenas seguidoras, aceitando as mudanças, ficando em desvantagem competitiva.

Pode-se responder a uma dessas perguntas, com base nos conceitos teóricos anteriormente apresentados, o “quando” vai acontecer. Já está acontecendo. Como ocorrerá o choque é um das respostas que se está perseguindo neste estudo. Além do "como", o "por que" acontecerá desta forma? Estas indagações devem ser respondidas por esta pesquisa. Os conceitos apresentados permitem que se façam as seguintes proposições para o estudo em questão:

\section{Proposições da pesquisa:}

A TI tem potencializado as mudanças do sistema de saúde e este fato vem gerando uma série de transformações nos negócios nesta indústria. Estas transformações vêm ocorrendo no ambiente interno das empresas, em que estas detêm o controle das variáveis e também ocorrem no ambiente externo (micro e macro), cujas variáveis são "incontroláveis". O que se percebe é que as possibilidades de mudança utilizando a TI crescem a cada dia e, certamente, aumentam as alternativas para as empresas atuarem no mercado. Neste contexto, levantaram-se as seguintes proposições, que serão análise neste trabalho:

Proposição 1 - O uso da TI amplia as oportunidades, por meio de um monitoramento participativo entre empresas em uma rede de valor na saúde, causando integração do grupo, melhoria do nível de serviços e/ou redução de custos de transação.

No ambiente tarefa ou no ambiente competitivo, realizar um monitoramento 
participativo facilita conhecer as forças e as fragilidades de cada participante. Monitorar o ambiente de forma mais próxima, por meio de parcerias e alianças com fornecedores, compradores e inclusive concorrentes, amplia as oportunidades e permite, desta forma, criar propostas de valor superior, com benefícios para todos. A utilização da TI deve permitir que profissionais da saúde e prestadores de serviços em geral, assim como produtores de insumos, possam trabalhar mais próximos, como parceiros, como uma grande rede conectada. Os participantes desta rede poderão utilizar suas vantagens de informação na saúde ao rever a forma de se prestar serviços, poderão ir além de suas funções como intermediários na produção, na compra, na venda de serviços de saúde, ao desenvolver produtos e serviços ou processos exclusivos utilizando a TI.

Proposição 2 - O uso da $\mathrm{Tl}$ aumenta os pontos fortes do negócio da empresa em uma rede de valor na saúde e possibilita gerar vantagem competitiva por meio do aumento da qualidade e/ou produtividade;

As operações de serviço na saúde e suas características inerentes como intangibilidade, co-participação nos serviços (inseparabilidade), variabilidade, perecibilidade, entre outros, podem ser ajustadas mais facilmente com o aumento da produtividade e da qualidade simultaneamente, ampliando os recursos das empresas.

Proposição 3 - As diversas formas de aplicação da TI, principalmente em setores como a saúde em que a intensidade de informação nos processos e nos serviços oferecidos é substancial, têm tornado a demanda exigente. Este fato exige formas alternativas de atuação das empresas para se criar valor (eficiência e/ou eficácia) no mercado com a finalidade de novos negócios.

Os meios de comunicação, assim como a TI tem contribuído para que a população esteja cada vez mais bem atualizada, em relação a produtos, serviços e empresas no setor da saúde. Consumidores mais informados exigirão mais e mais de seus prestadores de serviço. Assim, novas formas de relacionamento, com enfoque na saúde e não nas doenças tenderão a aumentar as possibilidades de novos negócios neste setor. A TI deverá ser uma ferramenta fundamental para estes novos caminhos que se abrem ou, em outras palavras, para as escolhas estratégicas das instituições. 


\section{METODOLOGIA}

O levantamento de dados deste trabalho tem respaldo no método exploratório cuja função, entre outras, é obter informações sobre possibilidades práticas de realização de pesquisas em situações de vida real (SELLTIZ et al., 1974). O estudo utilizará levantamento bibliográfico, pesquisas com pessoas experientes na área da saúde, documentos e dados estatísticos em geral, tendo como fonte principal um estudo de caso múltiplo, englobando empresas do setor da saúde. O estudo pretende responder questões relacionadas ao impacto do uso da TI nas operações de serviços na saúde.

\section{Questões da Pesquisa:}

Conforme Yin(1988) e Eisenhardt (1989), os estudos de caso são importantes para responder questões típicas: "como" e "por que", num contexto de complexidade operacional e administrativa, em que, as respostas a estas questões certamente contribuirão para construir ou aprimorar a teoria. As questões para a solução do problema da pesquisa desenvolvida são as seguintes:

1 - Como e por que utilizar a TI para criar maior valor (eficiência e/ou eficácia) nas operações de serviços na saúde?

2 - Como e por que a $\mathrm{Tl}$ amplia as oportunidades e/ou competências nas operações de serviço na saúde? De que forma este efeito pode aumentar as possibilidades de êxito competitivo das empresas?

As respostas a estas questões contribuirão para se atingir os objetivos da pesquisa.

\section{Objetivos da Pesquisa:}

Compreender como a TI contribui para o desenvolvimento de estratégias de negócios, envolvendo inter-relação e cooperação entre empresas no setor da saúde; Identificar, a partir das vantagens competitivas das empresas, o nível de contribuição da TI na criação de valor (eficiência e/ou eficácia) em operações de serviços. 
Como objetivos específicos, podem ser destacados os seguintes itens:

1 analisar formas para a organização das operações de serviços utilizando a TI em uma rede de valor no setor da saúde;

2 compreender como desenvolver estratégias de negócios de maior valor (eficiência e/ou eficácia), que propiciem vantagem competitiva aos seus executores no setor da saúde.

$\mathrm{Na}$ seqüência, reiteram-se as proposições, as quais serão analisadas no estudo de caso múltiplo, com empresas de uma rede de valor na saúde.

Proposição 1 - O uso da TI amplia as oportunidades, por meio de um monitoramento participativo entre empresas em uma rede de valor na saúde, causando integração do grupo, melhoria do nível de serviços e/ou redução de custos de transação;

Proposição 2 - O uso da TI aumenta os pontos fortes do negócio da empresa em uma rede de valor na saúde e possibilita gerar vantagem competitiva por meio do aumento da qualidade e/ou produtividade;

Proposição 3 - As diversas formas de aplicação da TI, principalmente em setores como a saúde em que a intensidade de informação nos processos e nos serviços oferecidos é substancial, tem tornado a demanda exigente. Este fato exige formas alternativas de atuação das empresas para se criar valor (eficiência e/ou eficácia) no mercado com a finalidade de novos negócios.

\subsection{MÉTODO DO ESTUDO DE CASO}

O assunto retratado: "O uso da TI e a Criação de Valor (eficiência e eficácia) nas Estratégias de Negócios na Indústria da Saúde" estende-se além dos limites de uma organização específica qualquer, abrangendo questões cotidianas de mercado em geral. Considerando esta peculiaridade do tema, que permite que um estudo local possa ser observado e replicado, não apenas para os segmentos analisados, mas para toda a indústria da saúde, optou-se por desenvolver este trabalho pelo método do estudo de caso. O objetivo é construir uma base de referência, utilizando 
a TI, que possibilite ampliar os conhecimentos sobre as estratégias de negócios na saúde.

A análise intensiva e a compreensão como um todo do assunto investigado complementam o estudo de caso em que se evidencia a importância da compreensão dos assuntos investigados para se obter uma visão mais abrangente do todo, ou seja, um diagnóstico (YIN: 1988).

Bruyne (1991: 225) conduz a uma especificação da possibilidade acima citada, ao comentar que alguns pesquisadores utilizam o estudo de caso com intento de exploração; outros, são essencialmente descritivos e finalmente: “(...) outros perseguem um objetivo prático e freqüentemente utilitário, seja porque visam a estabelecer o diagnóstico de uma organização ou a fazer sua avaliação, seja porque procuram prescrever uma terapêutica ou mudar uma organização". Complementando estes autores, Fachin (1993:48) descreve as funções de um estudo de caso: "sua principal função é a explicação sistemática das coisas (fatos) que ocorrem no contexto social, que geralmente se relacionam com uma multiplicidade de variáveis". No trabalho, a explicação sistemática dos fatos faz-se indispensável para se entender a multiplicidade das variáveis que envolvem os assuntos sobre estratégia de negócios, para apresentar um diagnóstico e, finalmente, para propor alternativas otimizadas.

Goode e Hatt (1968:422) fazem uma definição do método utilizado, clarificando ainda mais suas características: "O estudo de caso, portanto, não é uma técnica específica. É um meio de organizar os dados sociais preservando o caráter unitário do objeto social estudado. Expresso diferentemente, é uma abordagem que considera qualquer unidade social, como um todo".

Conforme Eisenhardt (1989), os estudos de caso servem principalmente para proporcionar descrição, testar teorias e gerar teorias. Estes três corroboram a necessidades da pesquisa, a qual se desenvolve em um campo complexo e pouco explorado no que diz respeito ao uso da tecnologia da informação nas operações de serviço na saúde. Conforme já explicado por Skinner (2003), embora muito já tenha sido falado sobre TI e estratégias de negócios, pouco foi discutido sobre este assunto na área da saúde. A complexidade é um dos elementos deste setor; o outro, e não menos problemático, é o fato de que a melhor experiência em serviços de saúde, seria não tê-la. Neste caso, os estudos permitirão descrever o fenômeno, demonstrando as circunstâncias em que este acontece, gerando novas teorias. 


\subsection{PLANO DE AÇÃO PARA O ESTUDO DE CASO}

O plano de ação é fundamental para que se obtenham resultados satisfatórios em um estudo de caso e este deve conter alguns passos (EISENHARDT, 1989); (VOSS, 2002); (YIN, 1988), entre eles, podem ser citados os seguintes itens, os quais nortearão a pesquisa a ser desenvolvida.

\subsubsection{Seleção dos Casos}

Os casos devem ser selecionados de forma a propiciar o maior grau de generalização possível da pesquisa, permitido um maior grau de validade externa. Os casos não devem ser escolhidos de forma randômica, mas sim de forma que se possa ter o maior número de variação do tema. A seleção deve ter como objetivo a replicação do estudo ou ainda que se possa gerar uma teoria emergente. O número de casos selecionados deve estar relacionado às respostas das questões que se pretende com a pesquisa, ou então quando o retorno do aprendizado é baixo.

\subsubsection{Critérios para seleção dos casos}

No estudo em questão, foram selecionados intencionalmente 14 casos de forma que possam representar ou participar de diversas camadas de uma rede de valor na saúde, dando maior representatividade ao estudo. As empresas escolhidas deviam conter alta intensidade de informação, em seus produtos ou processos (PORTER e MILLAR, 1985) e também apresentar alto impacto nos negócios no presente ou futuro, de acordo com o grid estratégico de McFarlan (1984). Em síntese, as empresas deviam utilizar a TI de forma diferenciada, de forma a criar valor (eficiência e/ou eficácia) em uma ou mais áreas em que atuava e assim obter vantagem competitiva com seu uso.

Utilizou-se o benchmarking que, segundo Yanaze (2007: 2), é um artifício bastante usado em diagnósticos preliminares. O autor explica que: "trata-se de eleger uma situação ideal - as características modelares e comprovadamente eficazes de uma empresa - que sirva de padrão comparativo para as características das próprias empresas e as de seus concorrentes". 
O instrumento de investigação utilizado foram entrevistas com especialistas da área de TI e do setor da saúde de instituições de grande porte do país.

Com base nos critérios expostos, o estudo de caso foi conduzido nas empresas abaixo relacionadas:

Caso 1 (C1) - Internação domiciliar (estudo de caso piloto)

Caso 2 (C2) - Hospital geral de alta complexidade

Caso 3 (C3) - Hospital especializado de alta complexidade

Caso 4 (C4) - Hospital-dia

Caso 5 (C5) - Laboratório de análises clínicas e de diagnóstico por imagem

Caso 6 (C6) - Empresa de serviços médicos

Caso 7 (C7) - Plano de saúde

Caso 8 (C8) - Empresa farmacêutica

Caso 9 (C9) - Empresa de sistemas

Caso 10 (C10) - Empresa de gerenciamento de benefícios farmacêuticos

Caso 11 (C11) - Empresa de equipamentos e softwares médicos

Caso 12 (C12) - Empresas de gestão de documentos

Caso 13 (C13) - Empresa de sistemas e serviços para instituições do setor de saúde Caso 14 (C14) - Empresa de serviços de informática (conectividade)

Obs. Os casos C1 a C8 são empresas usuárias de Tl; os casos C9 a C14 são empresas fornecedoras de TI.

Na Figura 11 - Rede de Valor na Saúde, observa-se uma Rede de Valor na Saúde, em que os casos estudados estão distribuídos em diferentes níveis. 


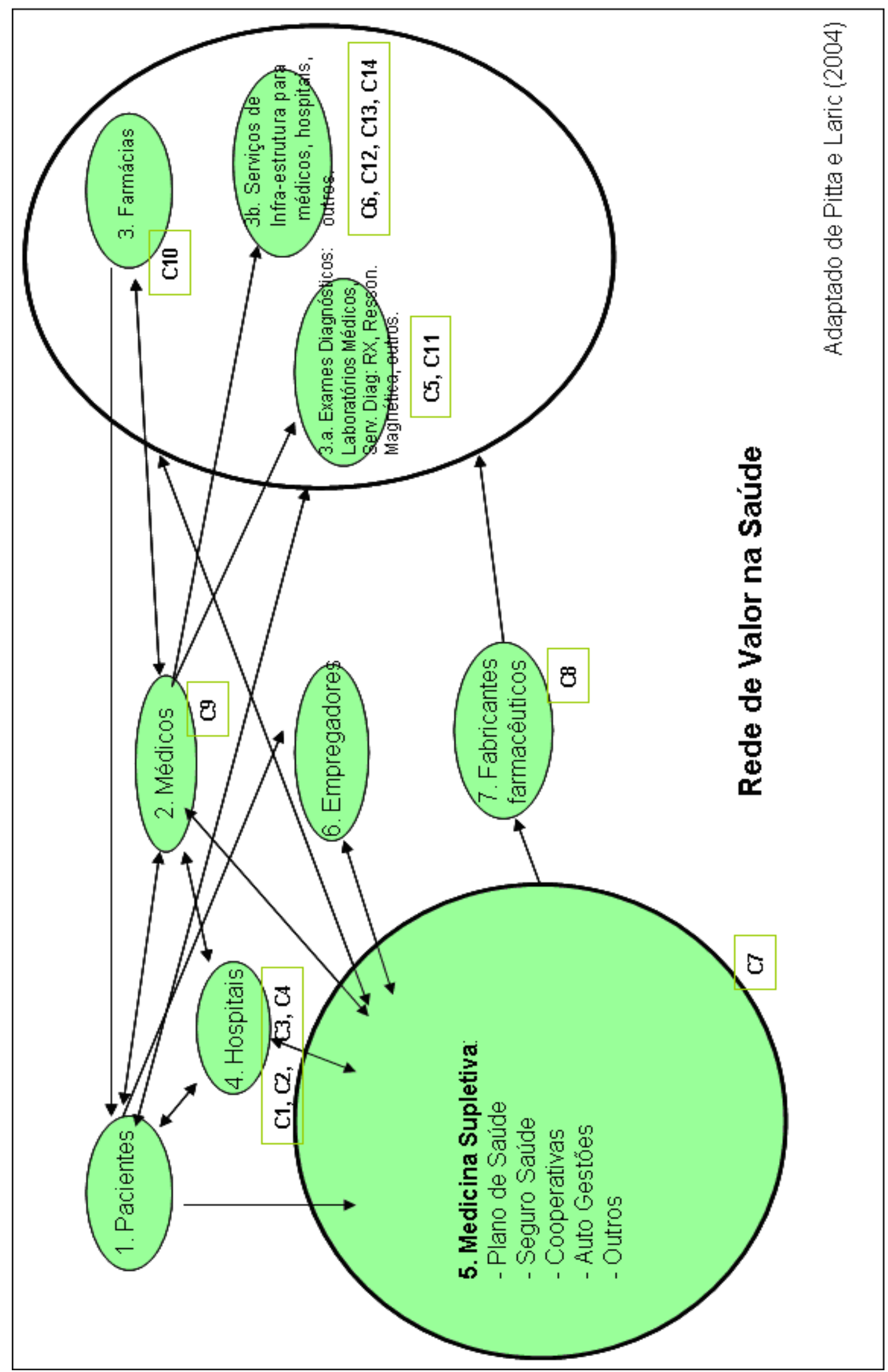

Figura 11 - Rede de Valor na Saúde 


\subsubsection{Instrumentos de Coleta de Dados}

Ocorre a combinação de diversos métodos de coleta de dados: entrevistas estruturadas, semi-estruturadas e não estruturadas, interações, observações, análise documental, outros. Deve haver uma combinação de evidências qualitativas e quantitativas, enriquecendo os dados da pesquisa.

É importante salientar que todas as entrevistas foram gravadas com o consentimento dos entrevistados. Após transcrição seguida de análise, uma versão preliminar foi elaborada e encaminhada ao entrevistado.

\subsubsection{Protocolos (procedimentos e circunstâncias)}

Contém os procedimentos e regras gerais, indicando onde obter as informações e quem as fornecerá. Também faz parte dos protocolos um roteiro para as questões com a finalidade de orientar a pesquisa de campo.

As entrevistas foram realizadas com especialistas com conhecimento nas áreas de negócios, tecnologia da informação e processos em geral e divididas em três partes:

1) o negócio e o uso da Tl;

2) as fontes de vantagem utilizando a $\mathrm{Tl}$;

3) a avaliação das unidades de significado (agrupamento prévio dos assuntos).

O roteiro da pesquisa, parte dos apêndices deste trabalho, foi utilizado para orientar o pesquisador na abordagem dos assuntos investigados. O roteiro abrangeu aspectos externo e interno da empresa investigada e avaliou de que forma a tecnologia da informação (como e por que) cria valor (eficiência e/ou eficácia) nas operações de serviços em uma rede de valor na saúde.

\subsubsection{Pesquisa de Campo}

A pesquisa de campo deve buscar as seguintes questões: pontos comuns e pontos que diferenciem uma situação de outra e também as diferenças de um caso e 
outro. Novas abordagens devem ser acrescentadas na medida em que se evolui na curva de aprendizagem do assunto. Novos métodos de coleta poderão ser incluídos se forem necessários, porém se for possível evitá-los, melhor.

A pesquisa de campo foi realizada entre os meses de agosto de 2006 a maio de 2007.

\subsubsection{Estudo de Caso-piloto}

Um estudo de caso-piloto também contribui para que se fizessem ajustes na pesquisa que contribuiu para otimizar o resultado final do trabalho.

Antes de se iniciar o trabalho definitivo, segundo os autores acima citados, deve o pesquisador buscar o melhor método possível para aplicar em seu trabalho. Portanto, o conselho é de que o pesquisador inclua um estudo-piloto para que o referido método seja o mais otimizado possível.

Para tanto, foi realizado um estudo de caso-piloto para que fossem realizados eventuais ajustes nos procedimentos e regras gerais, assim como nos protocolos da pesquisa, garantindo a validade externa da pesquisa.

\subsection{ESTUDO DE CASO-PILOTO}

Para o estudo de caso piloto, recomenda-se uma empresa que apresente características importantes e evidentes em relação ao estudo.

Neste caso, optou-se por uma empresa com uso intensivo da Tl em suas estratégias de negócio em, pelo menos, uma das áreas em que atua. Esta empresa também permitiu que se realizasse uma abordagem ampla, envolvendo os mais diversos aspectos, inclusive acesso a fontes secundárias o que permitiu um estudo longitudinal do caso.

Após a escolha, analisaram-se detalhadamente as operações de serviços, visando a entender seus processos e procedimentos, antes e após utilização da TI. Estas análises permitiram uma melhor visualização do grau de eficiência e eficácia da $\mathrm{TI}$ e de como e por que a TI é utilizada dessa maneira e qual valor a TI está gerando a seus públicos de interesse. 
O estudo de caso piloto contribuiu consideravelmente para ajustar a metodologia da coleta e descrição dos dados e inclusive a formatação inicial da interpretação dos dados.

\subsubsection{Atividades realizadas no Estudo de Caso-piloto}

Os estudos das fontes de evidência foram: entrevistas, documentação, observação direta e descrição e análise dos processos e procedimentos.

\subsubsection{Roteiro preliminar para o Estudo de Caso-piloto}

O roteiro para a pesquisa de campo (Apêndice A) foi desenvolvido a fim de diagnosticar a atratividade do mercado, os pontos fortes da empresa e o impacto da $\mathrm{TI}$, mediante análise do ambiente externo e interno da empresa. Considerando estas variáveis, optou-se em dividir esta etapa da seguinte maneira:

\section{A - Diagnóstico Estratégico}

Foram selecionados itens e os elementos do ambiente externo e ambiente interno do caso estudado. A listagem dos itens considerou um conjunto exaustivo de alternativas, mutuamente exclusivas, conforme recomenda Rasiel (2000), que é a forma básica e muito útil para se iniciar um processo de solução de problemas.

Para selecionar os itens, foram utilizados alguns modelos e técnicas estratégicos, apresentados no estudo conceitual deste trabalho. Os modelos e técnicas visam a analisar ambiente estratégico da organização (externo e interno) e contribuem para levantamento de dados sobre o assunto e serviram também de base para o roteiro da pesquisa. São eles:

\section{Análise do Ambiente Externo}

Modelo do Diamante - Análise Macroambiente (PORTER,1999).

Modelo das Cinco Forças - Análise Microambiente (PORTER, 1986).

Análise do Ambiente Interno

Modelo das Fontes e as Capacitações (BARNEY, 1995)

Modelo das Competências Básicas (PRAHALAD e HAMEL, 1990). 
A análise dos elementos do ambiente externo e do ambiente interno da empresa, com base na aplicação dos modelos estratégicos citados, propiciaram um julgamento de oportunidades e competências geradas ou não pela utilização da TI.

Os ajustes foram possíveis após a aplicação do estudo de caso-piloto.

\subsection{TÉCNICA PARA ANÁLISE DOS DADOS}

Em primeiro lugar, será apresentado o modelo para a descrição dos dados da pesquisa, abordando o exame dos dados: identificação dos pontos-chave (roteiro), formação das unidades de significado (agrupamento por assunto) e o processo utilizado para formação de categorias. Em segundo, será apresentado o modelo utilizado para a avaliação das contribuições da TI em relação às operações de serviços, utilizando escalas (baixo, médio e alto) e o modelo decorrente da análise completa, permitindo, assim, a interpretação dos dados. Em terceiro lugar, serão apresentados os resultados da pesquisa: a análise das proposições.

O fluxo utilizado (Figura 12 - Fluxo da Pesquisa) vai ao encontro do proposto por Yin $(2005,137)$, que faz os comentários para esta fase da pesquisa: "a análise dos dados consiste em examinar, categorizar, classificar em tabelas, testar ou, do contrário, recombinar as evidências quantitativas e qualitativas para tratar as proposições iniciais de um estudo". Eisenhardt (1989) e Voss (2002) corroboram com este ponto de vista. 


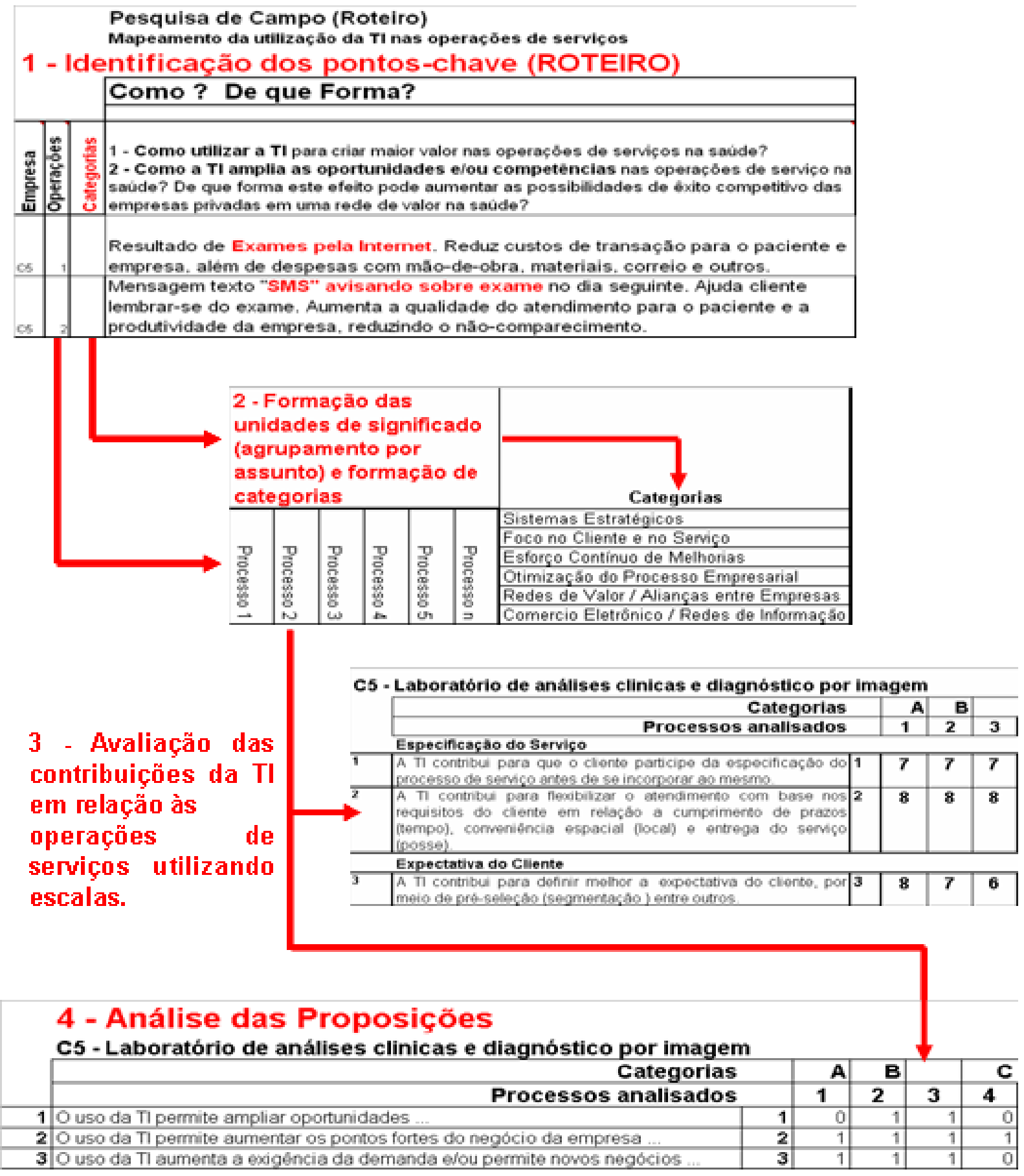

Figura 12 - Fluxo da Pesquisa

\subsubsection{Modelo para Descrição dos Dados}

\subsubsection{Estratégia analítica geral}


Conforme Yin (2005), a análise dos dados deve adotar uma estratégia analítica geral, a qual estabelece as prioridades do que deve ser analisado e por quê. $O$ autor sugere três caminhos:

a) baseando-se em proposições teóricas: os objetivos e o projeto originais do estudo basearam-se presumivelmente em proposições, que, por sua vez, refletiram o conjunto de questões da pesquisa, as revisões feitas na literatura e as novas proposições ou hipóteses que possam surgir. As proposições, neste caso, norteariam todo o trabalho, dando forma ao plano de coleta de dados e as estratégias analíticas utilizadas;

b) explanações concorrentes: esta estratégia é semelhante à anterior, porém define e testa explanações concorrentes que, por sua vez, incluirão evidências de outras influências na pesquisa;

c) descrições de caso: desenvolver uma estrutura descritiva a fim de organizar o estudo de caso, ou seja, uma descrição propriamente dita.

Neste trabalho, optou-se em seguir a primeira estratégia, baseando-se em proposições teóricas que, conforme apresentado anteriormente, fundamentaram as novas proposições, que foram utilizadas neste trabalho. Eisenhardt (1989) propõe também que as análises ocorram em dois momentos: análise dentro dos casos e análise realizando cruzamento de dados entre os casos. Estes dois procedimentos, juntamente com o explanado por Yin (2005), foram utilizados neste estudo. O passo seguinte, conforme recomenda Yin (2005), foi a escolha das técnicas analíticas específicas, elaboradas para tratar os problemas da pesquisa e estão relacionadas à validade interna (estabelecer relação causal entre as variáveis dependentes e independentes) e validade externa da pesquisa (grau de generalização da pesquisa).

\subsubsection{Técnicas analíticas específicas}

Entre as técnicas analíticas utilizadas em estudos de caso, podem-se citar as seguintes alternativas (Yin: 2005): adequação ao padrão, construção de explanação, análise de séries temporais, modelos lógicos e síntese de casos cruzados.

No que se refere à adequação ao padrão, a comparação de um padrão fundamentalmente empírico com outro de base prognóstica (ou com várias outras 
previsões alternativas). O intuito é compará-los e avaliar a coincidência dos padrões, como reforço à validade interna: no que se refere à construção da explanação, o objetivo desta técnica é realizar uma explanação do caso; no que permeia à análise de séries temporais, o objetivo é conduzir análises temporais, geralmente em experimentos e em pesquisa quase-experimentais; no que prende a modelos lógicos, este estipula deliberadamente um encadeamento complexo de eventos ao longo do tempo; no que se estabelece a síntese de casos cruzados, esta técnica trata cada estudo de caso individual como um estudo separado, que podem ter sido analisados previamente.

Para o estudo em questão, adotou-se a técnica analítica de Adequação ao Padrão. Esta técnica compara um padrão fundamentalmente empírico com outro com base prognóstica ou com várias previsões alternativas (TROCHIM apud YIN, 2005). Eisenhardt (1989) e Voss (2002) apresentam técnicas de análise específicas semelhantes, como alternativa para a validade interna e externa da pesquisa.

Conforme a técnica de Adequação do Padrão, os procedimentos realizados seguiram as seguintes etapas e a ordem descritas no Quadro 5 - Etapas e Procedimentos da Pesquisa.

\begin{tabular}{|l|l|l|}
\hline Etapas & \multicolumn{1}{|c|}{ Procedimentos } & \multicolumn{1}{|c|}{ Técnica de Adequação } \\
\hline $1^{\circ}$ & Identificação dos pontos-chave (roteiro) & Padrão empírico \\
\hline $2^{\circ}$ & $\begin{array}{l}\text { Formação das unidades de significado } \\
\text { (agrupar por assunto) e Formação de } \\
\text { Categorias }\end{array}$ & $\begin{array}{l}\text { Padrão com base } \\
\text { prognóstica (ou com várias } \\
\text { outras previsões alternativas) }\end{array}$ \\
\hline $3^{\circ}$ & $\begin{array}{l}\text { Avaliação das contribuições da TI em } \\
\text { relação às operações de serviços } \\
\text { utilizando escalas. }\end{array}$ & $\begin{array}{l}\text { Comparação do padrão } \\
\text { empírico com o padrão de } \\
\text { base prognóstica (avaliação } \\
\text { utilizando escalas) }\end{array}$ \\
\hline $4^{\circ}$ & Análise das proposições & $\begin{array}{l}\text { Avaliar os itens em relação } \\
\text { às proposições: 0 - Refuta; } \\
1 \text { - Corrobora. }\end{array}$ \\
\hline
\end{tabular}

Quadro 5 - Etapas e Procedimentos da Pesquisa 
Com relação ao processo de pesquisa formulado, definiu-se como variável dependente, os processos, procedimentos e ações decorrentes da utilização da tecnologia da informação que criavam valor. Estes processos foram levantados com base em um roteiro (Apêndice - A), cuja aplicação teve como propósito principal entender como e por que a TI cria valor (eficiência e/ou eficácia) em operações de serviço em uma rede de valor na saúde. O pressuposto criação de valor fez com que o entrevistador conduzisse a investigação de forma a entender como a TI gera vantagem competitiva para a empresa. Conforme explicado nas questões da pesquisa, foram abordados aspectos relacionados ao ambiente externo das empresas, buscando entender como e de que forma as oportunidades eram geradas pela TI. Para tanto, serão citados aspectos relacionados ao ambiente interno das empresas e os pontos fortes gerados pela TI. A Figura 13 - Identificação dos Pontos-chave demonstra as formas como os dados foram estruturados para serem analisados.

\begin{tabular}{|c|c|c|c|}
\hline \multicolumn{4}{|c|}{$\begin{array}{c}\text { Pesquisa de Campo (Roteiro) } \\
\text { Mapeamento da utilização da TI nas operações de serviços } \\
1 \text { - Identificação dos pontos-chave (ROTEIRO) }\end{array}$} \\
\hline \multirow{2}{*}{\multicolumn{2}{|c|}{ 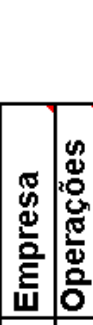 }} & \multirow[b]{2}{*}{ 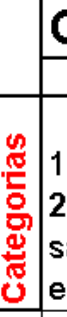 } & Como ? De que Forma? \\
\hline & & & $\begin{array}{l}1 \text { - Como utilizar a TI para criar maior valor nas operações de serviços na saúde? } \\
2 \text { - Como a TI amplia as oportunidades e/ou competências nas operações de serviço na } \\
\text { saúde? De que forma este efeito pode aumentar as possibilidades de êxito competitivo das } \\
\text { empresas privadas em uma rede de valor na saúde? }\end{array}$ \\
\hline$C 5$ & & & $\begin{array}{l}\text { Resultado de Exames pela Internet. Reduz custos de transação para o paciente e } \\
\text { empresa, além de despesas com mão-de-obra, materiais, correio e outros. }\end{array}$ \\
\hline$C 5$ & 2 & & $\begin{array}{l}\text { Mensagem texto "SMS" avisando sobre exame no dia seguinte. Ajuda cliente } \\
\text { lembrar-se do exame. Aumenta a qualidade do atendimento para o paciente e a } \\
\text { produtividade da empresa, reduzindo o não-comparecimento. }\end{array}$ \\
\hline
\end{tabular}

Figura 13 - Identificação dos Pontos-chave

Etapa 2 - Formação das unidades de significado (agrupamento por assunto) e formação de categorias

Com base nos dados levantados, foram realizados agrupamentos para se formar em unidades de significados e, por conseguinte, as categorias. A redução dos dados em categorias simplifica e facilita o entendimento dos dados levantados (VOSS, 2002). Os agrupamentos deixaram algumas evidências, as quais foram 
possíveis identificar categorias apresentadas na bibliografia apresentada. Neste caso, utilizaram-se, como base para a formação das categorias, as explicações de Turban et al. (2003), sobre as reações das organizações diante do novo quadro competitivo que se apresenta, em função do impacto da TI nos negócios.

Conforme apresentado anteriormente, diversos autores apontam um quadro de competição acirrada e muitas transformações mercadológicas, conseqüência, em parte, pela utilização da TI pelas empresas. A nova economia ou economia digital (TAPSCOTT, 1998), economia do conhecimento (KIM e MAUBORGNE, 2002), ou ainda a era da informação (TURBAN, et al, 2003), segundo estes autores, estão transformando este ambiente competitivo.

Conforme Turban et al. (2003), este contexto impõe pressões sobre as empresas e exige respostas reativas a pressões já existentes ou pró-ativas a uma pressão esperada. Assim, a TI assume uma relevância cada vez maior diante deste quadro de transformações. Na seqüência, serão apresentadas, com base em Turban et al. (2003), as categorias, que geraram os agrupamentos (unidades de significado), que foram utilizadas neste trabalho.

Categorias:

A. sistemas estratégicos;

B. foco no cliente e no serviço;

C. esforço contínuo de melhorias;

D. otimização do processo empresarial (reengenharia do processo do negócio),

D1 - reengenharia do processo do negócio;

D2 - negócios gerados pela TI ou em processo de gestação;

E. redes de valor e alianças entre empresas;

F. comércio eletrônico e redes de informação.

As categorias acima, apresentadas no Capítulo 4, no Quadro 4 - Formas de Reação Competitiva em Operações de Serviços, foram utilizadas para facilitar a classificação de Como e de que forma as empresas criam valor em uma rede de valor na saúde, utilizando a TI para obter maiores oportunidades ou ampliar seus pontos fortes. 
Após o agrupamento, as formas de reação (reativas ou pró-ativas), apresentadas, foram avaliadas, em relação à eficiência e à eficácia. A finalidade foi demonstrar por que estas operações que utilizam a TI geram vantagem competitiva às organizações, considerando o viés eficácia e/ou eficiência, conforme definido anteriormente.

Etapa 3 - Avaliação das contribuições da TI em relação às operações de serviços, utilizando escalas.

Para se realizar esta avaliação, definiu-se, como variável independente, as formas em que a TI contribui para a eficácia e eficiência em operações de serviço. Para tanto, utilizou-se uma base prognóstica, relacionada a operações de serviços em que se conceitua e se definem padrões para serviços profissionais e serviços de massa, desenvolvido por Silvestro (1999). Este quadro conceitual foi adaptado e suas variáveis permitiram realizar um julgamento da eficácia e da eficiência no uso da TI nas operações de serviços em uma rede de valor na saúde. A análise e as notas referentes ao grau de concordância foram obtidas a partir da pesquisa de campo, junto aos entrevistados. Na seqüência, o Quadro 6 - Contribuições da TI nas Operações de Serviço na Saúde. 


\section{Contribuições da TI nas Operações de Serviços na Saúde}

\begin{tabular}{|c|c|c|c|}
\hline \multirow[t]{3}{*}{\begin{tabular}{l|l}
1 & Tempo de contato com o cliente \\
\end{tabular}} & 1 e 2 & \multicolumn{2}{|r|}{ Especificação do Serviço } \\
\hline & & 1 & \begin{tabular}{|l|} 
A TI contribui para que o cliente participe da especificação do processo de \\
serviço antes de se incorporar neste processo.
\end{tabular} \\
\hline & & 2 & $\begin{array}{l}\text { A TI contribui para flexibilizar o atendimento com base nos requisitos do cliente } \\
\text { em relaçăo a cumprimento de prazos (tempo), conveniência espacial (local) e } \\
\text { entrega do serviço (posse). }\end{array}$ \\
\hline \multirow[t]{3}{*}{2 Nivel de personalização do atendimento } & 3 e 4 & & Expectativa do Cliente \\
\hline & & 3 & $\begin{array}{l}\text { A TI contribui para definir melhor a expectativa do cliente, por meio de pré- } \\
\text { seleçäo (segmentaçäo) entre outros. }\end{array}$ \\
\hline & & 4 & $\begin{array}{l}\text { A TI contribui para facilitar a avaliaçẫo da qualidade dos serviços prestados } \\
\text { (percepçäo do cliente) em funçâo da infra-estrutura: grau de tangibilidade, } \\
\text { variabilidade, outros. }\end{array}$ \\
\hline \multirow[t]{5}{*}{\begin{tabular}{l|l}
3 & Grau de formalidade no atendimento \\
\end{tabular}} & \multirow[t]{5}{*}{5 a 8} & \multicolumn{2}{|r|}{ Relacionamento com Cliente } \\
\hline & & 5 & $\begin{array}{l}\text { A TI contribui para que se desenvolvam relacionamentos de longo prazo entre } \\
\text { clientes e equipe de funcionários elou com a organizaçäo. }\end{array}$ \\
\hline & & 6 & $\begin{array}{l}\text { A TI contribui para aumentar o relacionamento e conseqüentemente a lealdade } \\
\text { (otimizando os resultados) na empresa, na medida que ajuda na soluçäo de } \\
\text { problemas do cliente. }\end{array}$ \\
\hline & & 7 & $\begin{array}{l}\text { A TI contribui para otimizar o tempo dos funcionários para que estes dediquem } \\
\text { maior atençâo ao cliente visando a ganhos do marketing "boca a boca". }\end{array}$ \\
\hline & & 8 & $\begin{array}{l}\text { A TI contribui para que o cliente associe o seu uso como sinônimo de maior } \\
\text { qualidade no serviço, criando oportunidades para maior diferenciaçăo. }\end{array}$ \\
\hline
\end{tabular}

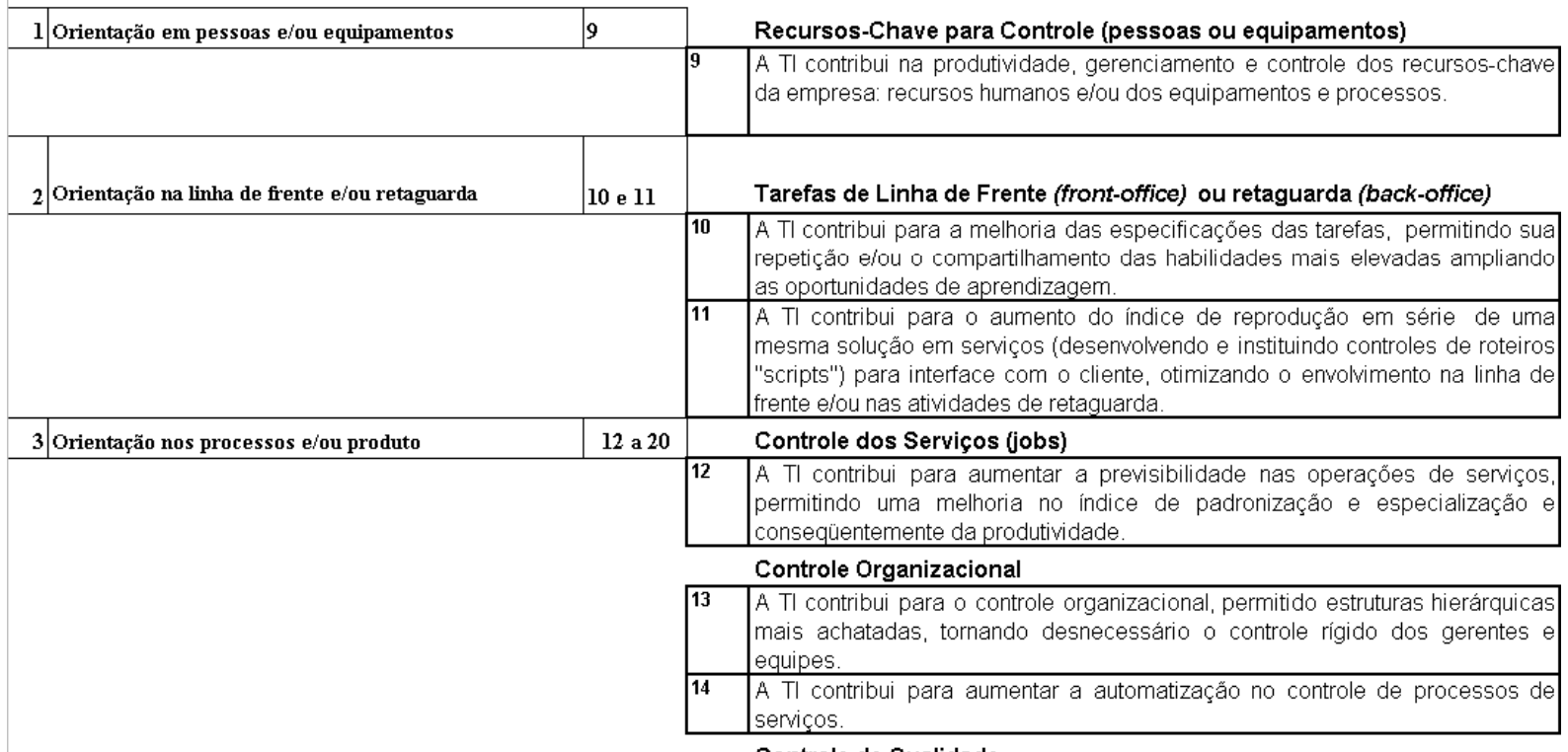

\section{Controle de Qualidade}

\begin{tabular}{l|l}
\hline 15 & A TI contribui para atenuar a necessidade de julgamento profissional rotineiro,
\end{tabular} diluindo a responsabilidade dos gerentes no controle de qualidade, permitindo um aumento na procedimentalizaçẫo.

\section{Controle de Custos}

16 A Tl contribui para o controle dos custos de mão-de-obra e/ou de outros recursos.

17 A TI contribui no controle de custos da mão-de-obra e na avaliaçäo da lucratividade individual dos serviços mesmo em situaçôes em que haja uma complexidade de rotas que os clientes podem fazer no processo.

Capacidade de Gerenciamento

\begin{tabular}{|l|l|}
\hline 18 & $\begin{array}{l}\text { A TI permite otimizar a capacidade produtiva da mão de obra disponivel elou } \\
\text { dos recursos e equipamentos nas empresas de serviços. }\end{array}$ \\
\hline 19 & $\begin{array}{l}\text { A TI permite flexibilizar a capacidade operacional com as variaçóes da } \\
\text { demanda. }\end{array}$ \\
\hline
\end{tabular}

\section{Fontes de Flexibilidade}

20 A TI permite ampliar as opçôes de flexibilidade nas operaçôes de serviços relacionadas a negociaçăo de data de entrega, rotação em equipes de trabalho, transferência de equipes de funcionários entre unidades, ajustes nas equipe de funcionários (meio período, provisória), outros 
Etapa 4 - Análise das proposições e resultados da pesquisa

Para realizar a análise das proposições, utilizaram-se as seguintes pontuações: 1 - confirma e 0 - refuta. No final, apresenta-se um quadro, demonstrando os percentuais em que as proposições foram confirmadas ou refutadas.

A Figura 14 - Síntese das Contribuições da TI em Serviços - apresenta de que forma as análises foram realizadas para entender por que a TI cria valor nas operações de serviços na saúde. Neste caso, utilizaram-se 8 proposições, abordando aspectos que refletissem a contribuição da TI para a eficácia do negócio. Também foram utilizadas 12 proposições, abrangendo características relacionadas à eficiência, conforme definições no referencial teórico.

Ao analisar as operações de serviço nos casos estudados, corroborando ou refutando as proposições relacionadas às características de serviços, fez-se uma engenharia reversa nas formas de se organizar as estratégias de negócios das empresas. Esta engenharia reversa, aplicada em casos que apresentaram vantagem competitiva no mercado com o uso da TI, propiciou que se retirassem do estudo formas e arranjos de operações de serviços em que a TI casou valor: eficiência e/ou eficácia.

\section{Síntese das Contribuições da TI em Serviços}

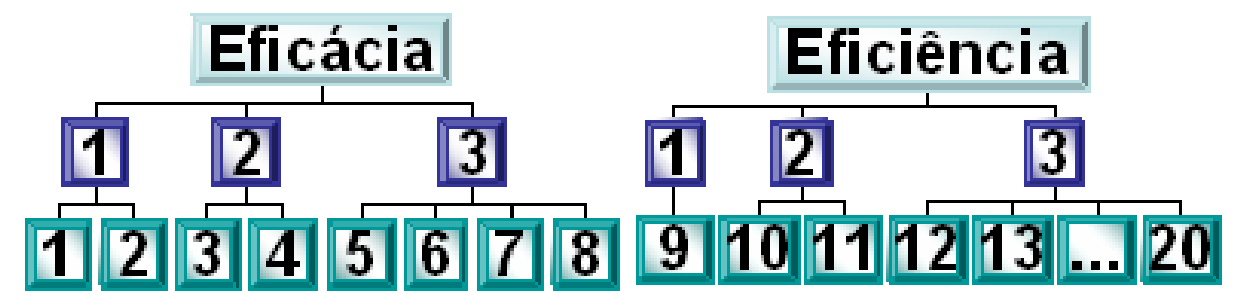

\begin{tabular}{|lc|}
\hline EFICACIA & Questōes \\
1 Tempo de Contato com Cliente & 1 e 2 \\
2 Ilivel de per sonalisação do atendimento & 3 e 4 \\
3 Grau de formalidade no atendimento & $5,6,7$ e 8 \\
EFICIENCIA & \\
1 Foco na orientação de Pessoas e/ou Equipamentos & 9 \\
2 Foco na Orientação da Linha de Frente e/ou Retaguarda & 10 e 11 \\
3 Foco na Orientação de Processos e/ou Produto & 12 a 20 \\
\hline
\end{tabular}

Figura 14 - Síntese das Contribuições da TI em Serviços 


\subsubsection{Modelo para interpretação dos dados da pesquisa}

\subsection{Avaliação das contribuições da $\mathrm{TI}$ em relação às operações de serviços, utilizando escalas (baixo, médio e alto) grau de contribuição da TI nas Operações de Serviços.}

Para avaliação das variáveis dependentes em relação às variáveis independentes (Etapa 3, veja abaixo na Figura 15 - Avaliação das Contribuições da TI), utilizaram-se escalas baseada no método Lickert. Conforme (LAKATOS e MARCONI, 1982: 94), este método permite realizar avaliações sobre o grau de concordância ou favorabilidade em uma situação ou questão. Os questionamentos utilizados nas avaliações foram divididos em dois grupos distintos: eficácia e eficiência, sendo que estes, por sua vez, divididos em três subgrupos cada. Cada subgrupo contém vários itens (questões), somando um total de vinte variáveis independentes.

As respostas a esta avaliação, por meio de escalas, explicam como as operações em serviços que utilizam a TI criam valor. A Proposta é partir de uma situação em que se cria vantagem competitiva, utilizando a TI (Etapa 1). A partir disto, deve-se classificar, sob o ponto das reações das empresas com elas utilizaram a TI no mercado (Etapa 2). Na Etapa 3, utilizaram-se situações em que operações de serviço criam mais ou menos valor com o uso da TI nas operações de serviços (avaliação utilizando escalas). O trabalho realizado se assemelha ao processo de engenharia reversa, a partir de uma situação ideal ou satisfatória (do ponto de vista da competitividade), chega-se ao como e por que ocorre, com o uso da TI em operações de serviços. Os resultados obtidos (Etapa 4) representam os porquês da TI criar valor, a partir da análise das proposições, que será apresentado junto com os resultados da pesquisa. 


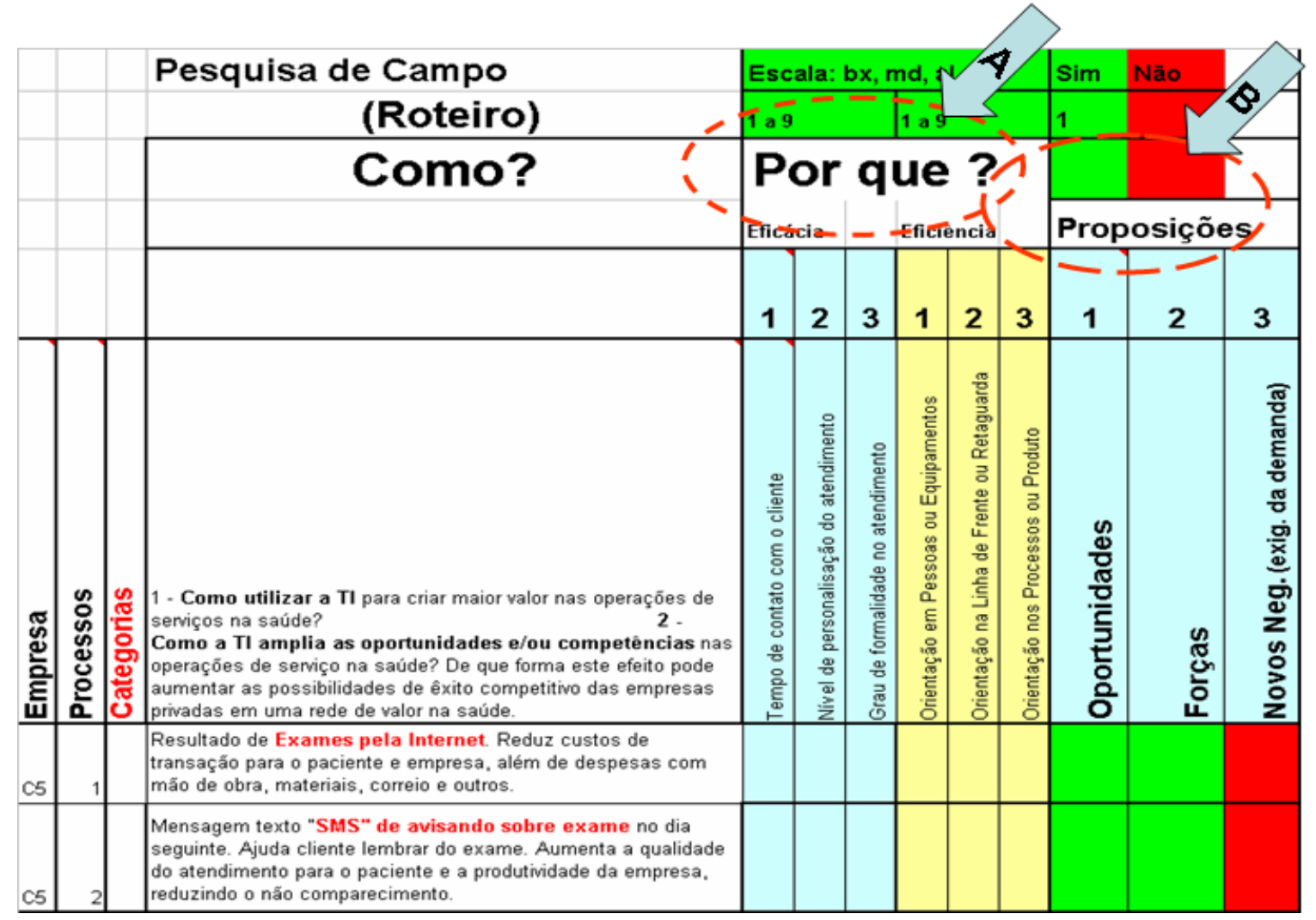

Figura 15 - Avaliação das Contribuições da TI

\subsection{Matriz de criação de valor em serviços.}

Na Figura 16 - Matriz de Criação de Valor (Eficácia e Eficiência) em Serviços I (OLIVEIRA, SILVA E LAURINDO, 2005) apresenta no eixo de $\mathrm{Y}$, o resultado da avaliação das características dos serviços sobre o ponto de vista da eficácia (média das avaliações dos itens 1, 2 e 3). O eixo X apresenta o resultado da avaliação das características dos serviços sobre o ponto de vista da eficiência (média das avaliações dos itens 5,6 e 7 ). 


\section{Matriz de Criação de Valor (Eficácia e Eficiência) em Serviços}

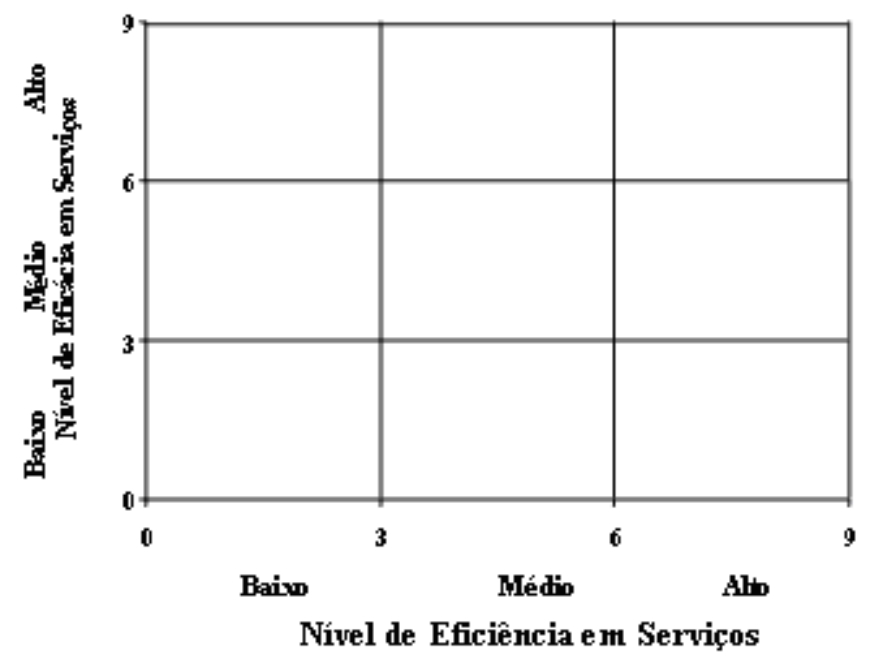

(OLIVEIRA, SLLVA E LAURINDO, 2005)

Figura 16 - Matriz de Criação de Valor (Eficácia e Eficiência) em Operações de Serviços I

\subsection{Modelo decorrente da análise qualitativa}

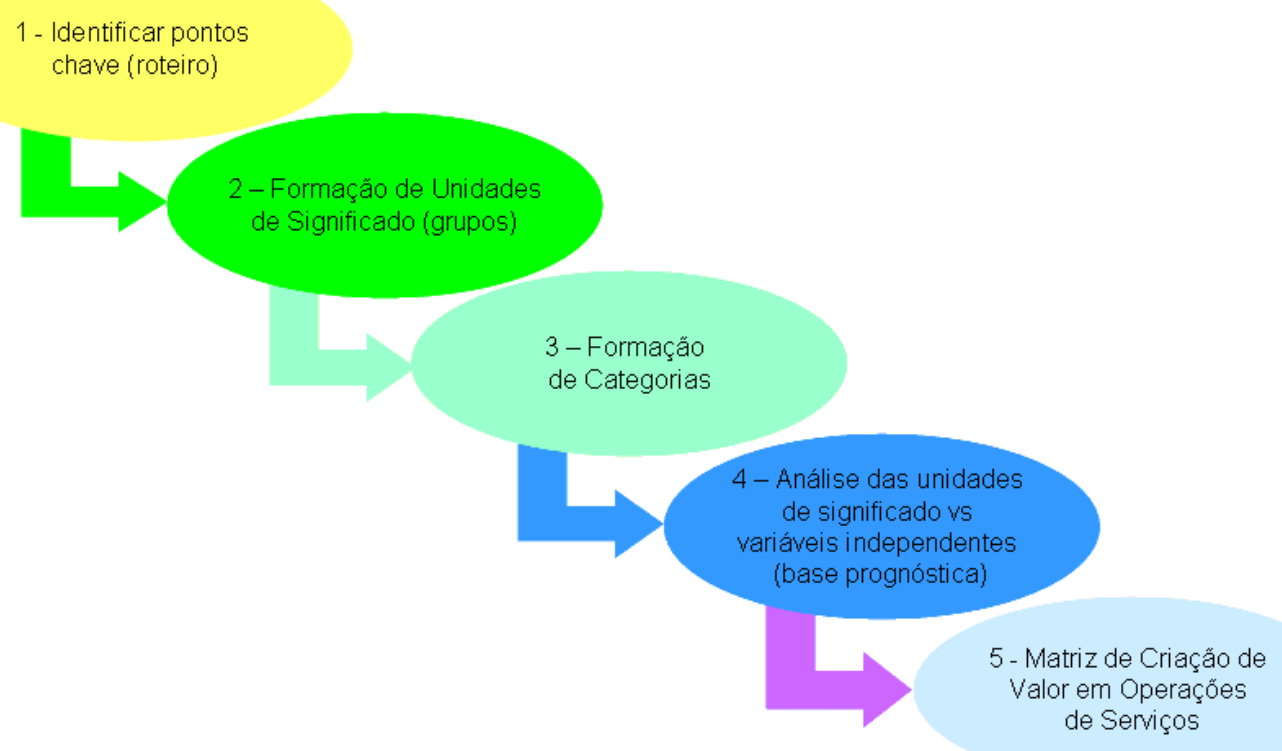

Figura 17 - Modelo Decorrente da Análise Qualitativa 
Este trabalho foi desenvolvido conforme passos apresentados na Figura 17 Modelo Decorrente da Análise Qualitativa. São eles:

1 - identificação dos pontos-chave (roteiro): foi realizada com base na pesquisa de campo, conduzida mediante um roteiro previamente estruturado. Realização do levantamento em que as operações de serviços utilizam a TI e, dessa forma, obtém vantagem competitiva;

2 - formação das unidades de significado (grupos): com base nos dados levantados, foram realizados agrupamentos para se formar as unidades de significados;

3 - formação de categorias: os agrupamentos deixaram algumas evidências, as quais foram possíveis identificar categorias na bibliografia apresentada;

4 - análise das unidades de significado, contrapondo às variáveis independentes (base prognóstica): neste passo, foram utilizados os itens que formam as unidades de significado (operações de serviços que utilizam a TI para criar valor, extraídas da pesquisa de campo) e avaliadas em relação às variáveis independentes, quanto ao grau de concordância ou favorabilidade, utilizando escalas;

5 - matriz de criação de valor (eficiência e eficácia) em operações de serviços: utilizou-se uma matriz para facilitar a compreensão do diagnóstico realizado.

\subsubsection{Modelo para avaliar os resultados da pesquisa}

Conforme apresentado Figura 15 - Avaliação das Contribuições da TI do item anterior (seta B), os itens devem ser relacionados às proposições e avaliados em 0 (zero) refuta a proposição apresentada, ou 1 (um) corrobora com a proposição apresentada (Etapa 4). Ao final, obtém-se a proporção dos itens analisados que refutam ou corroboram com as proposições, assim como as explicações de como o fenômeno ocorre. 


\section{DESCRIÇÃO DOS DADOS DA PESQUISA}

Conforme explicado, os casos apresentados a seguir fazem parte de uma rede de valor na saúde, a qual foi previamente delimitada para efeito deste estudo. Ao se desenvolverem os casos, não se pretendeu realizar uma auditoria nas empresas em relação à utilização da TI em suas operações de serviços, mas apenas compreender como esta utilização propiciava vantagem competitiva para elas. Em cada um dos casos, será realizada uma breve apresentação da empresa seguida de um comentário sob quais áreas, processos, ferramentas, formas de aplicação, outros, a TI está sendo analisada. Com exceção do "empregador", todos os outros integrantes da rede de valor apresentada anteriormente na Figura 11 - Rede de Valor na Saúde fazem parte da amostra que será descrita a seguir. Embora não integre a amostra, o empregador faz parte de vários outros negócios citados no estudo.

O primeiro caso a ser apresentado trata-se do estudo de caso-piloto. Escolhido intencionalmente, a empresa apresenta características importantes e evidentes em relação ao estudo, no caso, o uso intensivo da TI em suas estratégias de negócio em pelo menos uma das áreas em que atua. Esta empresa também aprovou que fosse realizada uma abordagem ampla, envolvendo os mais diversos aspectos, inclusive acesso a fontes secundárias o que possibilitou um estudo longitudinal do caso. As fontes secundárias permitiram que se avaliassem indicadores antes e depois da utilização da TI, demonstrando as variações no desempenho dos processos.

A primeira análise, conforme explicado anteriormente, foi muito útil para se estruturar a pesquisa de campo em si e também a formatação da descrição dos casos. Buscou-se explorar o máximo possível todas as fontes de evidência no casopiloto, demonstrando como encaminhar as entrevistas, ao seguir os protocolos e o roteiro preestabelecido. Este caso-piloto será apresentado na íntegra, processo a processo e com os subitens dos processos. Nos demais estudos de caso da pesquisa, buscaram-se sintetizar as informações, entendendo que, a partir de certa subdivisão dos processos (classificação e categorização), o padrão de respostas torna-se repetitivo e, portanto, desnecessário e, desta forma, não há perdas de conteúdo nos resultados da pesquisa. 
As alterações no roteiro foram mínimas, pois se limitaram a ajustar a forma de abordar os assuntos. No estudo-piloto, entrevistaram-se vários profissionais de diferentes áreas da empresa (TI, operações, marketing, recursos humanos), de níveis hierárquicos variados, separadamente. Notou-se que as respostas, quanto ao uso da $\mathrm{TI}$ nos negócios da empresa, apresentaram várias semelhanças, independentemente da área ou do profissional entrevistado. Neste caso, optou-se em conduzir a investigação de forma mais simplificada ou menos detalhada em relação às áreas. Considerou-se que esta opção não prejudicaria o resultado da pesquisa, pois o padrão de respostas no que diz respeito à criação de valor com o uso da TI foram muito parecidas, sem considerar a área ou o nível hierárquico. Por outro lado, optou-se por utilizar um maior número de casos, levando-se em conta que uma investigação mais horizontalizada, abrangendo negócios e processos diferentes, traria maior contribuição aos objetivos deste trabalho.

Como se observará a seguir, as descrições de alguns casos serão mais extensas que outros. O motivo destas variações está relacionado aos diferentes tipos de empresas analisadas e a forma com que estas utilizam a TI em suas operações de serviços para obter vantagem competitiva. Isto explica porque alguns casos apresentam um número maior de processos analisados que outros.

\subsection{EMPRESA 1 (C1) - INTERNAÇÃO DOMICILIAR}

\section{Dados da empresa}

\begin{tabular}{|l|lr|}
\hline Faturamento anual da empresa: & $R \$ 8.000 .000,00$ \\
\hline $\begin{array}{l}\text { Número de funcionários da } \\
\text { empresa: }\end{array}$ & & 32 \\
\hline Funcionários terceirizados: & & 300 \\
\hline Funcionários de TI da empresa: & & 1 \\
\hline Funcionários de TI terceirizados: & Área de aplicação da TI estudada \\
que gera vantagem competitiva & eletrônico, ficha eletrônica) nas operações \\
para empresa: & de serviço de internação domiciliar. \\
\hline $\begin{array}{l}\text { Estratégia competitiva genérica e } \\
\text { escopo de atuação da empresa no }\end{array}$ & $\begin{array}{l}\text { A empresa oferece serviços de maior valor } \\
\text { agregado que a média dos competidores }\end{array}$ \\
\hline
\end{tabular}




\begin{tabular}{|l|l|}
\hline mercado: & $\begin{array}{l}\text { neste segmento. A empresa foca em nichos } \\
\text { de mercados sensíveis a diferenciação } \\
\text { (seguradoras, autogestões e planos de } \\
\text { saúde diferenciados). Na medida em que } \\
\text { oferece um benefício maior que os } \\
\text { concorrentes, isto lhe dá vantagem } \\
\text { competitiva e permite que a empresa } \\
\text { pratique preços acima da média do } \\
\text { mercado. }\end{array}$ \\
\hline
\end{tabular}

\section{Principais Características da Empresa}

C1 é uma empresa nacional, especializada em atendimento domiciliar e atende principalmente no estado de São Paulo, há pelo menos 12 anos. Além de atendimento domiciliar, a empresa oferece outros serviços, como gerenciamento e acompanhamento hospitalar de pacientes.

Tem como principais clientes: seguro saúde, autogestões, planos de saúde, assim como clientes particulares e grandes empresas. Conta com 30 funcionários contratados e cerca de 280 cooperados e uma ampla rede terceirizada. A parte terceirizada, considerada parceiros da instituição, é formada por: terapeutas ocupacionais, fisioterapeutas, fonoaudiólogos, dentistas, nutricionistas, psicólogos, farmacêuticos, assistentes sociais e médicos, além de toda a estrutura hospitalar oferecida por prestadores de serviços.

Entre as especialidades oferecidas pela empresa, podem-se citar: Assistência ao ostomizado; Orientações para autocuidados; Assistência materno-infantil: cuidados gestacionais, neonatais e pediátricos; Curativos em lesões (feridas) agudas e/ou crônicas - tratamento especializado; Assistência médica e de enfermagem, com supervisão 24 horas; Serviço de nutrição enteral e parenteral; Ventilação mecânica e oxigenoterapia e outros.

A empresa atua ainda como uma divisão responsável por toda a logística de distribuição de medicamentos, equipamentos e materiais hospitalares, além de outros produtos essenciais ao tratamento de seus pacientes assistidos.

Alguns diferenciais podem ser observados como, por exemplo: direcionamento de especialistas para cada caso e treinamento intensivo. A disciplina e profissionalismo da equipe têm respaldo em suas conquistas e premiações no 
setor da saúde. O atendimento e a priorização às necessidades do cliente estão presentes nas operações desta empresa.

\section{Uso da TI}

Todas as operações de serviço são realizadas com o apoio da TI. Desde o atendimento ao paciente feito por médicos, enfermeiros e outros profissionais, médico na residência até serviços de laboratório de análises clínicas e análise por imagem são terceirizados. A utilização também é feita na parte da dispensação e requisição de medicamentos e materiais na farmácia, antes e após o atendimento do médico na prescrição. O sistema é todo integrado, inclusive, informando o que o cliente tem direito ou não, quando do atendimento de pacientes vindo pelo convênio. A empresa possui baias para enfermeiras supervisoras, que dão apoio a distância ao pessoal de campo.

A empresa realiza todo o acompanhamento de pacientes, utilizando software próprio (prontuário eletrônico) e equipamento móvel (smartphone), que permite lançar dados da residência dos pacientes e gerenciar as informações em tempo real pela central da empresa. Este sistema possibilita integrar, via WEB, toda a rede de profissionais envolvidos com o paciente, desde a evolução do quadro clínico, incluindo resultados de exames de laboratório, diagnóstico por imagens, até gerenciamento de insumos e solicitação de mão-de-obra.

\subsubsection{Formas de Contribuição da TI - Categorias}

As contribuições da TI nas operações de serviços, que são as questões da pesquisa listadas abaixo (como? de que forma? e por quê?), puderam ser observadas em várias situações. Entre elas, destacaram-se alguns exemplos, que serão apresentados na seqüência, separados por categorias. Entre as categorias, podem-se citar:

A. sistemas estratégicos;

B. foco no cliente e no serviço;

C. esforço contínuo de melhorias;

D. otimização do processo empresarial (reengenharia do processo do negócio),

D1 - reengenharia do processo do negócio;

D2 - negócios gerados pela TI ou em processo de gestação; 
E. redes de valor e alianças entre empresas;

F. comércio eletrônico e redes de informação.

Questões da pesquisa:

1 - Como e por que utilizar a TI para criar maior valor (eficiência e/ou eficácia) nas operações de serviços na saúde?

2 - Como e por que a $\mathrm{TI}$ amplia as oportunidades e/ou competências nas operações de serviço na saúde? De que forma este efeito pode aumentar as possibilidades de êxito competitivo das empresas?

A seguir, haverá apresentação dos dados do estudo de caso-piloto e, na seqüência, do item 10.2 em diante, com apresentação dos demais casos da pesquisa. No início, serão destacadas as categorias. Dentro das categorias, em seguida, serão apresentadas as variáveis dependentes, que sofreram o impacto da TI. E, por último, a análise desta variável, que será dividida em três partes, demonstrando como, de que forma e por que a TI cria valor.

A - Sistemas estratégicos.

- Equipamento Móvel

O uso da Tl em operações na saúde por si denota inovação e contribui para diferenciar a oferta da empresa ao mercado. A utilização de equipamento móvel (smarthphone) e um software que substitui o prontuário eletrônico tradicional no local de atendimento do paciente permitem maior versatilidade ao prestador de serviço (médico, enfermeiro, fisioterapeuta, outros) em campo.

As informações são transmitidas em tempo real e são disponibilizadas na $W E B$, tornando possível que todas as partes da rede de valor obtenham informações sobre determinado paciente ou sob outro ponto de vista naquela prestação de serviços.

O desenvolvimento desta operação facilita a avaliação dos serviços prestados pela transparência das informações e conduz à redução do risco do contratante. Contribui também para que se otimize o tempo da mão-de-obra nas atividades não relacionadas aos cuidados médicos, ampliando o contato com o paciente. Permite, ainda, que se ampliem e agilizem as formas de controle das operações relacionadas à especificação das tarefas e à reprodução em série de uma solução. 
B - Foco no cliente e no serviço

- Gerenciamento do relacionamento com clientes e parceiros

O uso da TI no processo de gerenciamento do relacionamento com clientes e/ou parceiros: pacientes, médicos, prestadores de serviços, fornecedores, fonte pagadora, outros é essencial. Esta operação de serviços tem como finalidade compreender como os clientes/parceiros desenvolvem suas atividades na rede de valor e como atendê-los mais adequadamente.

As ferramentas de $\mathrm{TI}$ colaboram para otimizar a cadeia valor dos profissionais que atuam a montante e jusante da empresa estudada, na medida que reduzem custos de transação e fomentam parcerias duradouras.

Ao informar o perfil e as necessidades dos clientes, torna-se possível sua participação na especificação dos processos antes que eles aconteçam. Torna possível flexibilizar o atendimento no que se refere a tempo, a local e a espaço. Facilita que se defina melhor a expectativa do cliente, atendendo de forma mais personalizada. Estes elementos propiciam a solução de problemas do cliente que, por sua vez, aumentam a lealdade, permitindo relacionamentos em longo prazo, o que ampliam as margens da empresa. Por outro lado, como a essência em empresas de serviço são os recursos humanos, seja ele o cliente, co-participante ou o colaborador, isto aumenta a produtividade da empresa. Ao conhecer melhor o cliente, melhora-se a previsibilidade sobre suas necessidades. Ao agrupá-los em segmentos, podem-se gerar soluções padronizadas e facilidade de procedimentalização, assim como melhoria na curva de aprendizagem.

\section{C - Esforço contínuo de melhorias}

- Controles e avaliação nos programas individuais de tratamento por paciente

Cada paciente possui metas que são estabelecidas com base em protocolos. Todos os dados disponibilizados pelos médicos são fichas em formato de relatórios que simplificam as informações contidas no prontuário físico do paciente. Estes relatórios possuem procedimentos, prescrições, resultados de exames, digitalização de imagens de diagnóstico, entre outros, os quais os médicos lançam tanto do local onde está sendo tratado o paciente ou de um local qualquer que ele possa acessar a Internet. Todas estas informações ficam à disposição das pessoas autorizadas a 
acessar o sistema: prestadores de serviços, tomadores de serviço, médico responsável da empresa em que o cliente faz parte, outros. Com a disponibilização das informações, quaisquer dos envolvidos que possuam acesso ao processo poderão realizar uma avaliação dos serviços prestados.

Ao se medir e disponibilizar os dados juntamente com indicadores adequados, pode-se controlar e gerir melhor toda a operação. A gestão da operação passa a ser visível a todos os participantes que podem fazer sugestões e trazer ganhos para o processo a qualquer momento. Além da facilidade de interpretação dos relatórios pela organização das informações, também se tem o ganho referente à leitura do texto digitado em relação ao texto manuscrito, o qual pode gerar problemas de entendimento. A integração facilita muito o entendimento da situação e propicia um ganho importante de tempo, aumentando a velocidade de resposta.

O acompanhamento dos pacientes, utilizando a TI, aumenta a produtividade da operação, pois todos os dados estão dispostos a facilitar o monitoramento e a evolução do paciente. Isto facilita a gerência e o controle dos recursos-chave, como mão-de-obra, equipamentos e processos. As tarefas estão especificadas, permitindo repetição, maior aprendizagem e, quando possível, com mecanismos à prova de falhas. No processo de aprendizagem, criam-se soluções, que podem ser replicadas por meio de roteiros predefinidos. Quanto aos controles das atividades específicas, exames, procedimentos diferenciados, outros, utiliza-se a TI para acessar o histórico do paciente, aumentando a previsibilidade e, portanto, minimizando imprevistos inerentes a este tipo de operação de serviços.

\section{- Monitoramento de pacientes}

Uso da TI, em especial em pacientes crônicos ou nos que demandam cuidados especiais (alta complexidade), permite adequar à oferta de serviços em relação aos cuidados.

Ao se monitorarem os casos, pode-se priorizar o atendimento. Na medida em que se dedica esforços intensivos em determinado tipo de paciente, podem-se obter melhores resultados para a saúde dele, minimizando o tempo de tratamento e efetivamente reduzindo custos.

O acompanhamento de programas individuais, anteriormente explicados, tem características semelhantes ao monitoramento de pacientes crônicos, com algumas diferenças, que serão comentadas a seguir. Na medida em que as informações de 
campo (atendimento domiciliar pelos profissionais de saúde da empresa) chegam à central da empresa, as informações são consolidadas, para que se obtenha um quadro geral dos pacientes. A partir deste quadro, podem-se fazer as priorizações, atendendo os casos mais urgentes. Esta ação flexibiliza o atendimento com base nas necessidades dos clientes e, por outro lado, amplia as fontes de flexibilidade das operações de serviços da empresa em relação a prazos de entrega, à rotação de equipes, a outros ajustes com funcionários, a equipes e, inclusive, à utilização de equipamentos.

\section{- Consolidação e disponibilização de informações}

Utilizar a TI para consolidar e disponibilizar informações em formato digital, sobre a evolução do tratamento médico do paciente.

Ao consolidar informações e analisá-las em um formato padronizado, tem-se uma interpretação mais sistêmica do histórico da saúde do paciente. Este fato, em geral, elimina retrabalhos que despendem recursos como, por exemplo, solicitar um exame que já foi realizado e ainda está na data de validade.

De posse das informações completas sobre o paciente, além dos controles e instruções que ele deverá sofrer, os profissionais de saúde que estão acompanhando o caso têm menor necessidade de serem controlados com rigidez e, com isto, conseguem-se desenvolver operações de serviços com estruturas hierárquicas mais achatadas.

- Fonte de evidência dos procedimentos realizados

Uso da TI, como fonte de evidência (prova) dos procedimentos realizados como sistema de monitoramento em tempo real, permite que as partes (prestadores de serviço e fonte pagadora) avaliem conjuntamente se os protocolos médicos estão sendo seguidos e, com isto, eliminam-ne dúvidas em relação à heterogeneidade dos casos, inerente ao setor da saúde.

Mesmo que haja patologias semelhantes e conseqüentemente protocolos e condutas a serem seguidas, ainda assim um paciente pode diferir de outro no que se refere à recuperação. $\mathrm{A} \mathrm{TI}$, neste caso, contribui com uma análise simultânea à evolução do tratamento do paciente, permitindo que as partes interajam e compreendam melhor como foram conduzidos os procedimentos. 
Com as informações disponíveis em formato digital na WEB e em tempo real, os clientes (fonte pagadora) têm maior facilidade para compreender como os serviços estão sendo realizados e, assim, podem monitorar a distância o desempenho e as formas com que as operações estão ocorrendo. Esta transparência melhora o relacionamento entre as partes envolvidas, propicia melhores soluções aos problemas e gera maior diferenciação no serviço prestado. A apresentação de protocolos nos equipamentos móveis e como eles foram seguidos, ainda que não se possa avaliar serviço a serviço, demonstram a padronização e a procedimentalização das operações, importantes fontes de evidência do que foi realizado.

- Transparência no processo de prestação de serviços

Utilizar a TI para tornar mais transparente o processo de prestação de serviços, facilita acordos comerciais. A transparência no processo permite que se observe passo a passo o que ocorre com os pacientes e com os serviços e insumos utilizados.

Da mesma forma que a empresa que oferece os serviços gerencia a operação, o tomador de serviço também acompanha os procedimentos em tempo real. A transparência permite que os operadores e os tomadores de serviço não superestimem e nem subestimem as necessidades de um tratamento. Este encontro de interesses aproxima todos os interessados no processo, em especial o paciente que se beneficiará de respostas mais rápidas no seu tratamento.

Conforme explicado no item anterior, a TI permite que se monitore passo a passo, caso a caso. Isto possibilita ainda que se desenvolva um controle maior dos custos de mão-de-obra e outros recursos, mesmo em situações em que haja uma complexidade de rotas que os clientes podem fazer no processo.

- Acesso a dados do paciente em tempo real (via WEB)

O acesso, via WEB, ao prontuário do paciente em que poderão ser lançados e acessados dados pelas pessoas devidamente autorizadas por senha, permite prescrever, a qualquer hora, medicamentos e outras alterações, quando necessário. A enfermagem, por sua vez, lançará apenas o que foi efetivamente utilizado no local de atendimento do paciente. O mesmo acontece com as prescrições da enfermagem, as quais são lançadas e alteradas pela própria enfermagem. 
A flexibilidade de lançar e alterar dados em qualquer local e a qualquer momento tanto pelos médicos como pela enfermagem faz com que a operação fique mais ágil e atualizada. Os medicamentos, ao serem prescritos, já saem no prontuário, devidamente fracionados, na medida em que deverão ser ministrados. Isto facilita na montagem pela empresa (nas operações de retaguarda) dos medicamentos e materiais (kits) que serão utilizados, no dia pelo paciente. Os kits (conjunto de itens para se realizar um procedimento) são entregues à enfermagem para serem levados às casas dos pacientes, facilitando o processo e eliminando erros de dosagem.

Como a intensidade de informação no processo de prestação de serviços de saúde é substancial, ter acesso aos dados a qualquer local a qualquer momento é importante para flexibilizar as atividades dos profissionais de saúde. Os ganhos de produtividade com a redução de deslocamentos são evidentes, em especial em locais onde o trânsito é mais intenso. Por fim, pode-se ainda flexibilizar a capacidade versus a demanda, pois a maior parte dos serviços é terceirizada e, portanto, acionada na medida em que houver demanda e, dessa forma, reduzem-se estoques de segurança (filas) em relação a equipes, a equipamentos, a insumos e outros.

D- Otimização do processo empresarial (reengenharia do processo do negócio).

Obs. Este subitem será dividido em duas partes: reengenharia do processo do negócio e novos negócios gerados pela TI ou em processo de gestação.

\section{D1 - Reengenharia do processo do negócio}

- Uso do equipamento móvel (smarthphone) em substituição ao prontuário médico convencional

Uso de equipamento móvel (smarthphone) para lançar, gerenciar e controlar dados do paciente (evolução, prescrição, requisição de materiais e medicamentos, serviços terceirizados, outros) substitui o tradicional prontuário médico de papel. O uso de formulário eletrônico orienta as tarefas e os procedimentos requeridos pelo paciente. O formulário contém mecanismos à prova de falhas, os quais minimizam erros na operação. A disponibilização de informações, em tempo real via WEB, integra os profissionais, facilitando a gestão sistêmica.

As atividades aumentam a velocidade de resposta da central da empresa na realização dos serviços de retaguarda (envio de insumos, outros profissionais e 
serviços), reduzem controles administrativos, eliminam-se papéis, concentram as informações e as disponibilizam aos participantes da rede de valor que se estende até a fonte pagadora. Esta, por sua vez, pode controlar a evolução do paciente e os custos de cada caso. Quanto mais rápida e completa a visão do profissional de saúde sobre o diagnóstico e os cuidados com o paciente, melhor se desenvolve o tratamento. A análise do todo, em tempo real, elimina retrabalhos, duplicidade de exames e de procedimentos, reduzindo custos e gerando maior conforto e resolutividade para o paciente.

Esta operação se beneficia de uma série de vantagens: o tempo de contato com o cliente é otimizado, pois com o equipamento a operação torna-se mais rápida e pode-se despender mais tempo ouvindo o cliente. Possibilita a melhora na compreensão quanto à expectativa do cliente, pois permite acessar o histórico do paciente e entender detalhes de seu tratamento que são importantes para o contato e para a operação. Atender de forma personalizada melhora o relacionamento, consegue-se lealdade na medida em que se desenvolvem melhores soluções. Por um outro ponto de vista, o equipamento em si denota qualidade de serviços e contribui para tangibilizar a promessa de realização da operação com qualidade. Também atribui qualidade por ser um elemento diferenciador. Os ganhos com produtividade, gerenciamento e controle dos recursos humanos também são observados na autonomia que o processo propicia. As tarefas rotineiras, devidamente especificadas, contam com mecanismos à prova de falhas que inibem erros e agilizam a operação. Os controles dos processos das operações de serviços, em especial dos profissionais em campo, são automatizados e podem ser monitorados, via $W E B$, pela supervisão. Isto facilita eventuais interferências a distância, já que, com todo o controle da operação, há uma diluição das responsabilidades dos gerentes de operações, com o conseqüente aumento de procedimentalização.

- Gestão inteligente por meio de formulário eletrônico

A padronização dos procedimentos de avaliação por paciente, utilizando formulário eletrônico específico (a ficha eletrônica está contida na operação anterior). Este instrumento é fundamental na gestão de pacientes, em especial no que diz respeito à priorização dos esforços. Trata-se de mais de uma centena de itens que o profissional de enfermagem deverá colher no momento que chega à casa do 
paciente. A avaliação é obtida e fornecida para uma central em tempo real, paciente a paciente. Estas informações são consolidadas na central da empresa, onde saem as indicações de quais pacientes precisam ser priorizados em relação aos atendimentos de outros profissionais da saúde: médicos, fisioterapeutas, outros.

A velocidade de resposta aos pacientes, em especial os que estão em situação crítica, pode tornar a operação de serviços mais resolutiva, gerando, ao mesmo tempo, eficiência e eficácia. A análise ou o gerenciamento clínico é feito pelas enfermeiras supervisoras (que estão na sede da empresa), que ao receberem as informações, tomam as decisões. O monitoramento integral busca reproduzir as formas de gerenciamento e cuidados realizados em um hospital.

Além das atividades citadas no item anterior, pode-se dizer que a ficha eletrônica realiza um diagnóstico, controles rotineiros para interface com o cliente, otimizando o envolvimento na linha de frente e também nas operações de retaguarda.

- Mecanismos à prova de falhas

Nas consultas e lançamento de dados nas fichas eletrônicas dos pacientes há inúmeros elementos à prova de falhas e inclusive codificações. No primeiro caso, pode-se, por exemplo, informar horários e dosagens de medicamentos ou ainda protocolos para realização de exames. No segundo caso, podem-se instituir códigos, informando a falta de um determinado item ou a urgência de se realizar um procedimento qualquer com o paciente.

Os mecanismos à prova de falhas eliminam erros e reduzem custos além de resguardarem o paciente de informações ou procedimentos que não agregam em sua experiência com o serviço prestado. A codificação de itens e de kits facilita e simplifica o entendimento do receptor (retaguarda na empresa) na dispensa de medicamentos e materiais ou nas atividades relacionadas a faturamento, entre outras.

Conforme explicado, os mecanismos à prova de falhas inibem erros e agilizam as operações de serviços.

- Envio eletrônico de dados

O envio eletrônico de dados referente à evolução do tratamento do paciente utiliza o equipamento móvel para central da empresa. 
A enfermagem pode fazer a operação da prescrição de onde estiver atendendo o paciente: prescrição médica, prescrição de enfermagem, envolvendo requisição de medicamento, materiais e outros, sem que seja necessário retornar para a empresa ao final das atividades de atendimento domiciliar.

O tempo recuperado com o uso da TI é dedicado a uma maior atenção ao paciente, à família do paciente e a outras atividades. Esta aproximação melhora o relacionamento com a equipe e com a organização, aliás, otimiza a solução de problemas. O aumento do contato com os clientes também permite ampliar 0 marketing "boca a boca".

- Integrar operações de serviços em tempo real

Consolidar informações das operações de serviços em tempo real para otimizar a gestão da operação. Ocorre a integração de toda operação de serviços em tempo real para que se possam prover recursos humanos, materiais, medicamentos e equipamentos e, principalmente, informações, objetivando oferecer resultados semelhantes ao de um hospital.

A consolidação dos dados em um único local permite que se analisem as necessidades e contingências do tratamento, convertendo os locais de trabalho (residência dos pacientes), do ponto de vista da informação, em um minihospital virtual.

A consolidação e a disponibilização dos dados em tempo real melhora a produtividade, gerenciamento e controle dos recursos-chave da empresa. Com isto, conseguem-se reduzir custos e melhorar o desempenho nas operações. Conforme comentado anteriormente, a disponibilidade de informações permite operar com estruturas hierárquicas mais achatadas, pois os profissionais municiados de informação têm melhores condições de tomada de decisão. A capacidade produtiva pode ser otimizada, pois há mais flexibilidade para alocação de equipes nos serviços.

- Banco de dados do paciente

A conversão de todas as informações para o formato digital. Todos os documentos que não são originalmente digitais (RX, eletrocardiograma, ultrassom, exames clínicos, outros) são digitalizados e enviados para o banco de dados do paciente, juntamente com as outras informações originalmente digitais. 
A eliminação de papéis e a facilidade de busca de informações do paciente por categorias e até de forma evolutiva trazem ganhos de tempo para todos os profissionais envolvidos no processo de tratamento domiciliar. A organização dos dados permite que os profissionais façam uma melhor interpretação da evolução do paciente, gerando melhores possibilidades de eficiência e eficácia no atendimento.

Esta operação de inteligência nos negócios facilita o entendimento sobre o tratamento dos pacientes e, assim, otimiza a especificação de tarefas a cada paciente. Considerando a co-produção dos pacientes nos serviços, as especificações são ajustadas a cada perfil de paciente, o que contribui muito com o contato com o cliente. O mesmo ocorre quanto à flexibilidade no atendimento nos requisitos do paciente (tempo, local e posse). Como o paciente é um co-produtor do serviço, o adequado é entender suas preferências e suas expectativas. Com isto, aprimora-se o relacionamento e a conseqüente solução de problemas específicos. Em relação aos controles, a inteligência da empresa permite desenvolver melhor os processos, tornando-os mais ágeis e seguros, facilitando os controles das tarefas.

\section{- Acesso remoto a informações dos pacientes e processos}

Informações no local de trabalho (residência dos pacientes), utilizando o equipamento móvel, amplia a autonomia dos profissionais em campo e propicia que tomem mais decisões, permitindo redução de níveis hierárquicos.

É por meio da consulta aos equipamentos móveis que se tem as informações do paciente e também auxiliado pelo apoio, a distância, dos supervisores de plantão.

Nas operações em campo, a dificuldade de se acompanhar os profissionais são imensas, tanto por parte de quem contrata o serviço, quanto para a supervisão da empresa. A autonomia para estes profissionais apresenta duas características: uma é o descontrole, e a outra é a agilidade na operação. O equipamento móvel permite que se resolvam estas duas questões e ainda informa, em tempo real, a fonte pagadora o que está ocorrendo.

\section{- Aconselhamento e/ou apoio a distância}

Apoio a distância aos profissionais em campo e aconselhamento aos pacientes pelas enfermeiras supervisoras da central de atendimento.

Apoio por telefone ou Internet da supervisão, o que gera uma retaguarda importante aos profissionais de campo e agilizam o contato e eventuais explicações 
e acordos com os auditores dos tomadores de serviço. Também é utilizada como apoio ao paciente que, em situação de desconforto ou dúvida de se dirigir a um hospital ou solicitar um profissional da saúde, liga para a central e resolve o problema ou realiza o aconselhamento.

Esta ferramenta melhora o relacionamento tanto com os profissionais em campo, que são na maioria terceirizados com vínculo restrito à empresa, como para os clientes. Estes últimos recebem atendimento personalizado, pois os atendentes conhecem todo o histórico do paciente com base nas informações do banco de dados da empresa e podem aconselhá-los melhor. Alias, evita-se, inclusive, que procurem outros recursos (hospitais, pronto-atendimentos, outros) gerando incômodo e maiores custos à fonte pagadora.

\section{- Banco de dados de profissionais da saúde}

O desenvolvimento de um banco de talentos na saúde com identificação do perfil dos profissionais envolvidos no processo de atendimento domiciliar permite rastrear quais profissionais estão mais aptos para determinado serviço. Na medida em que cresce o número de funcionários, torna-se difícil conhecer o perfil técnico e comportamental e outras questões pessoais de cada um, que são importantes para a qualidade do serviço. É fundamental identificar as especificidades de cada profissional que, em geral, são autônomos. Dados pessoais, como peso, idade, experiência (habilidades técnicas) das pessoas facilita na dispensa para os locais de trabalho, adequando o perfil de um funcionário com o perfil do paciente. Por exemplo, uma criança com enfermeiro especializado em pediatria. Competências técnicas, flexibilidade, desenvoltura, segurança; local de moradia, etnia e religião são também importantes para esta adequação às necessidades dos pacientes, as quais são identificadas na avaliação dos pacientes nas fichas eletrônicas.

A TI contribui para que a partir de um banco de dados de prestadores de serviço se possa conciliar com informações das fichas eletrônicas dos pacientes avaliados e, a partir disto, escolher o profissional mais adequado, de acordo com as necessidades do paciente, personalizando o atendimento.

O valor nesta operação está em adequar a prestação de serviços ao cliente. Neste caso, a TI permite que o cliente participe da especificação do serviço, ainda que ele não saiba disto. Desenvolve-se uma customização/personalização do serviço. Quanto mais especializado e direcionado for o profissional para o paciente, 
melhor a qualidade do serviço em diversos aspectos, em especial no que se refere à co-produção deste, que gera maior resolutividade e redução de custos.

- Gestão a vista da escala de trabalho

O mapa eletrônico da disponibilidade dos profissionais para a realização da escala de trabalho que, em geral, é complexo em operações de serviço na saúde. A complexidade aumenta quando se desenvolvem atividades com algumas centenas de profissionais terceirizados e com carga horária e local de trabalho que mudam com muita freqüência. A oscilação da demanda é bastante grande, pois se tem variações de cobertura de atendimento que podem chegar a 24 horas por dia, 7 dias por semana. A heterogeneidade das patologias, procedimentos, diferentes formas de tratamento, entre outros, contribuem com a complexidade. Pacientes crônicos e pacientes de alta complexidade também diferem em relação à operacionalização do serviço.

O sistema indica quais os funcionários disponíveis e mais aptos para cada caso, com base nos dados do paciente.

A operação obtém maior produtividade, pois os mapas são eletrônicos e podem ser atualizados via WEB. Os mapas apontam a demanda e a oferta de serviços em tempo real, flexibilizando oferta e demanda do trabalho tanto para quem oferece como para quem contrata o serviço. Isto facilita o preparo das escalas de trabalho em uma situação de complexidade de profissionais, patologias, regiões e outras variáveis. Esta forma de se gerenciar as escalas de trabalho otimizam a capacidade produtiva da mão-de-obra disponível, reduzindo custos, contribuindo para adequar a oferta às variações da demanda.

- Discussão de casos a distância (segunda opinião médica)

A segunda opinião em tempo real pode ser útil em diversas circunstâncias, por exemplo, pacientes com ferimentos podem ser fotografados com o equipamento móvel e enviado a distância para uma segunda opinião. Esta segunda opinião pode ser por parte da enfermagem, por médicos ou de qualquer outra especialidade, para que possa ser discutido em tempo real, em que poderá ser recomendada uma conduta alternativa. As imagens também serão anexadas ao relatório do paciente, que será encaminhado à fonte pagadora: plano de saúde, empresas, particular, outros. 
Este processo reduz o tempo de atendimento, custos de transação, otimizando os cuidados com o paciente. A transparência desta operação facilita 0 relacionamento com as fontes pagadoras, que podem tomar decisões consistentes e com maior assertividade (manter o paciente em internação domiciliar ou encaminhar para um hospital, por exemplo) em relação ao tratamento do paciente. No momento da análise dos relatórios dos casos, as imagens facilitam o entendimento do caso e das justificativas das condutas realizadas.

Nesta operação, o fato principal é flexibilizar o atendimento ao paciente em relação a tempo e a local que também se aplica aos profissionais que estão atuando no caso. Ganha-se tempo para o paciente com a otimização do tempo para o enfermeiro, pois se agiliza o possível diagnóstico ou sugestão de tratamento, melhorando a resolutividade.

\section{D2 - Novos negócios gerados pela TI ou em processo de gestação}

- Sistema de controle para programa preventivo para pacientes crônicos

O programa preventivo para pacientes crônicos, utilizando a TI, possibilita que os profissionais envolvidos no caso, fonte pagadora, assim como o paciente, possam controlar os procedimentos de seu tratamento e acompanhar a evolução do caso. Os dados também podem ser consolidados, em que se pode analisar a situação de pacientes crônicos de uma determinada população. Todas as informações são disponibilizadas via WEB para que os participantes do programa possam acompanhar as obrigatoriedades de cada parte, o desenvolvimento das ações e os resultados. Cada parte desta rede de valor possui acesso a informações específicas.

Monitorar o tratamento e entender de que forma os casos estão evoluindo, no caso do paciente, este efeito aumenta o comprometimento e contribui para que ele participe dos esforços relacionados aos cuidados. O monitoramento é uma ferramenta importante para que haja uma continuidade no tratamento, para que não haja interrupções, causando retrabalhos.

Esta operação dedica esforços específicos de prevenção em grupos de risco. Os efeitos são melhora na qualidade de vida do paciente e redução de custos ao evitar que os casos se agravem. A TI contribui para segmentar os grupos e direcionar esforços específicos aos grupos, tratando principalmente em relação à prevenção, antes que os casos se agravem. 


\section{- Educação a distância}

A educação, na área da saúde, pelas dimensões continentais do país e a carência de especialização em muitas regiões, fazem com que a TI seja uma alternativa nos locais mais distantes. Outro fato importante é a dificuldade de levar alunos nas casas dos pacientes, ou fica muito difícil e dispendioso. Colocar uma câmera na casa de um paciente permitiria que muitos alunos vivenciassem situações de atendimento domiciliar. As diferenças entre trabalhar em um ambiente hospitalar e na casa de um paciente são muito grandes.

Podem-se realizar estas atividades de várias formas, entre elas: a Internet, a videoconferência, ou ainda o CD ROM, os DVDs, outros.

A área de atendimento domiciliar não oferece cursos em quantidade ou na qualidade que o mercado possa absorver. A TI contribuiria para suprir estas formas de ensino menos convencionais, flexibilizando tempo, local e posse para alunos e professores. A questão da co-participação também poderia ser amenizada com o treinamento com as imagens. A questão da variabilidade, que assume proporções muito mais difíceis de serem previstas, poderia se fortemente procedimentalizada. Em um ambiente hospitalar, muitas operações são realizadas na retaguarda; em um atendimento domiciliar, isto fica mais difícil. Esta última peculiaridade reforça ainda mais a importância de um curso nestes termos já que não há formação acadêmica específica na área.

- Banco de dados com perfil detalhado de profissionais

Para o agenciamento e o fornecimento de profissionais para o mercado é necessário que os recursos humanos que atuam na empresa façam parte de um banco de dados (mapeamento criterioso para atuar de forma personalizada). Este banco de dados deve conter o perfil profissional e comportamental, além de endereço e outros dados que vão ao encontro de necessidades de pacientes. Estes profissionais são utilizados pela empresa, mas também podem ser direcionados a outras empresas prestadoras de serviço de saúde, de acordo com a necessidade da empresa e de seus clientes.

A TI pode gerar um novo negócio na saúde ao permitir que o banco de dados utilizado para seleção de seus profissionais seja utilizado para contratar pessoas para outras empresas. 
Esta operação é semelhante ao cadastramento de profissionais para atuação na empresa, anteriormente citados. Ajusta-se o perfil do paciente, com o perfil do profissional e faz-se o encaminhamento.

- Intermediação em transações comerciais

Intermediação de transações comerciais entre pacientes, planos de saúde, seguradoras, outras fontes pagadoras, empresas de materiais médicos, medicamentos, laboratórios de exames clínicos e por imagem, empresas de equipamentos médicos em geral, como cadeira de rodas, muletas, macas, respirador artificial e outros.

Ao utilizar a $\mathrm{TI}$ para se relacionar com toda a rede de valor desde fornecedores à fonte pagadora, a empresa poderia assumir a intermediação destas atividades relacionadas à internação domiciliar que vão além da atividade atual de cuidados com o paciente. Esta atividade aumentaria ainda mais o relacionamento com os fornecedores e fonte pagadora de fornecedores, tornando-se uma fonte de indicação para prestação de serviços enviados pelos participantes da rede de valor.

Esta operação é semelhante à anterior, porém amplia a atuação para insumos e outros prestadores de serviços especializados.

\section{E - Redes de valor e alianças entre empresas}

- Complementar pacote de benefícios ao cliente e também competências ausentes

A TI propicia a integração de diversos prestadores: serviços de análises clínicas e serviços de diagnóstico por imagem, além de insumos e outros serviços que podem complementar o conjunto de informações utilizados por $\mathrm{C} 1$ e fornecer resultados dos exames como também, imagens, gráficos e qualquer outra informação que possa ser útil na definição da hipótese diagnóstica do paciente.

A integração temporária ou permanente, por meio da $\mathrm{TI}$, com os parceiros, cria um canal de distribuição para seus participantes. A aliança elege e direciona os parceiros para o fornecimento de informações, serviços e insumos. No caso de informações, dispor destas - como exames e diagnósticos realizados por terceiros pode ser um diferencial competitivo tanto para a empresa que fornece a informação quanto para quem realizou o exame, para ficar com apenas um exemplo. 
Ao unificar as informações do paciente, tanto o paciente como a fonte pagadora se beneficia. O primeiro, pelo fato de permitir um melhor diagnóstico de quem está analisando seu caso; o segundo, por evitar duplicidade de procedimentos e, conseqüentemente, redução de custos. As alianças favorecem os relacionamentos de longo prazo, que propiciam soluções específicas de um prestador para outro. Favorecem, ainda, melhores controles dos recursos-chave: humanos, equipamentos, processos, estoques, filas, que extrapolam os limites da empresa. Permitem otimizar a capacidade produtiva, ao informar aos participantes a previsão da produção com base no cliente final. Isto flexibiliza a capacidade ao encontro da demanda.

\section{F - Comércio eletrônico e redes de informação}

- Realização de transações comerciais eletrônicas

Requisição de materiais, medicamentos e serviços diversos em campo (casa do paciente), utilizando equipamento móvel (PDA). O pedido/requisição de medicamento para a farmácia interna da empresa é realizado por meio do PDA. A enfermagem acessa o equipamento e busca nos itens de farmácia o medicamento solicitado pelo médico. Ao encontrar o medicamento adequado, ela faz a solicitação clicando no item que, por sua vez, já é debitado na conta do paciente e creditado na conta da empresa. Esta operação também dispara a solicitação de reposição de compra do material utilizado aos fornecedores.

A TI permite a realização de transações de empresa para empresa $(B 2 B)$ ou de empresa para clientes $(B 2 C)$, faturando ou recebendo eletronicamente, via WEB, do local onde está sendo realizado o atendimento. Os itens demandados (materiais, medicamento, outros) são acessados por uma lista de itens disponíveis. Na tela do equipamento móvel, aparece o produto, a embalagem do produto e também a dosagem. Neste caso, a enfermagem confirma se o medicamento é o que está sendo solicitado, além de verificar se o produto vem fracionado de acordo com o pedido do médico ou se ela deverá buscar a marca de outro fabricante que forneça dosagem diferente ou em outro formato: comprimidos, cápsula, drágea, injetável, outros. Este fato reduz erros, facilita a operação e também lança os dados na conta.

Os clientes, tanto pacientes como os planos de saúde em geral, adquirem um serviço de intermediação, em que contam com o apoio de uma empresa que, além 
de escala de produção, está bem desenvolvida na curva de aprendizagem nesta operação. A parceria melhora o relacionamento e as soluções para os clientes, não apenas nas operações eletrônicas de compra, mas em toda a cadeia que fazem parte.

\subsubsection{Outras Considerações}

Alguns pontos importantes surgiram durante as entrevistas em relação ao uso da TI que se acredita sejam valiosos para este trabalho, ou para outros estudos relacionados. Entre eles, podem-se citar quanto aos pacientes que têm informação em relação ao uso da TI pela empresa e, inclusive, sobre os benefícios.

Conforme a empresa, os planos de saúde, seguros saúde e outros, principais compradores dos serviços, todos têm pleno conhecimento das ferramentas utilizadas, porém os pacientes têm conhecimento discreto das vantagens da TI. Os pacientes conheciam a tecnologia móvel, por perceber o uso no dia-a-dia e também da central de aconselhamento médico. Neste caso, uma hipótese que pode ser levantada é se o paciente conhecesse todos os benefícios da $\mathrm{TI}$, ele passaria a exigir mais de seu convênio. Desta forma, as empresas de internação domiciliar que oferecessem este diferencial conseguiriam mais vantagens competitivas em relação aos concorrentes.

Conforme a empresa, o maior valor nas suas operações de serviço advém do uso da TI na gestão das informações que gira em torno do paciente. Todo o processo, desde captação de pacientes, profissionais, insumos, tarefas e controles, são realizados, fortemente amparados pela $\mathrm{TI}$, que põe ao centro os dados do paciente. A questão da mobilidade aos profissionais de campo e a disponibilização de informações em tempo real facilitou as operações tanto de retaguarda como de linha de frente. Mais do que isto, a questão da mobilidade e das informações em tempo real permitiu um monitoramento das tarefas, não apenas pela empresa, mas principalmente pela fonte pagadora (planos de saúde, seguros em geral), tornando o relacionamento transparente, fundamental em situações de serviços, em especial nos serviços na saúde.

Segundo a empresa, existem limitações na tecnologia, mas nas estratégias da empresa, não. Os processos da empresa têm uma história. Iniciou-se com a adaptação do que já existia na área hospitalar para o domicílio, para justificar a 
quantidade de horas de enfermagem, durante as $24 \mathrm{~h}$ do dia. Pretendia-se entender quais eram as intervenções presentes, que necessitavam de 12, 8 ou 4 horas. Depois em uma tese de doutoramento, desenvolveu-se o dimensionamento do pessoal de enfermagem. Tudo isto foi formatado e transformado em um programa utilizado pela empresa.

\subsubsection{Resumo da análise de C1}

A TI criou valor (eficiência e/ou eficácia) em diversas circunstâncias, entre elas, podem-se citar:

- denotando maior inovação como empresa no uso da Tl;

- contribuindo para fidelizar clientes;

- consolidando informações;

- integrando operações e empresas;

- monitorando, priorizando e controlando tarefas;

- tangibilizando serviços;

- enviando dados eletronicamente (reduzindo custos de transação);

- instituindo mecanismos à prova de falhas (minimizando erros, aumentando a qualidade);

- disponibilizando informações em tempo real;

- desenvolvendo banco de dados para pesquisa (transformando dados em informação);

- criando novos negócios;

- flexibilizando operações de serviços;

- solucionando problemas a distância;

- mapeando a disponibilidade de funcionários;

- permitindo a supervisão a distância;

- realizando transações comerciais de compras e de pagamento via WEB;

- requisitando materiais para trabalho em campo;

- outros.

Por que a TI cria valor? As respostas foram diversas, mas observou-se uma maior incidência do ponto de vista da eficácia, nas seguintes circunstâncias: 
- flexibilizando o atendimento com base nos requisitos do cliente;

- adequando o tempo de contato com o cliente;

- considerando a co-produção do cliente e a forma com ele gostaria de participar;

- associando o uso da TI, como sinônimo de maior qualidade no serviço;

- criando oportunidades para maior diferenciação. Conforme será explicado abaixo, este ainda é um item pouco explorado pela empresa e mesmo assim é bastante relevante.

Do ponto de vista da eficiência, observou-se que a TI teve maior contribuição nas seguintes circunstâncias:

- aumentando a produtividade;

- favorecendo o gerenciamento e controle dos recursos-chave, em especial os recursos humanos;

- aumentando o índice de reprodução em série de uma mesma solução em serviços (desenvolvendo e instituindo controles de roteiros scripts) para interface com o cliente;

- otimizando o envolvimento na linha de frente e/ou nas atividades de retaguarda;

- aumentando a previsibilidade nas operações de serviços, permitindo uma melhoria no índice de padronização e especialização e conseqüentemente da produtividade.

Quadro 7 - Resumo da Análise de C1

\subsection{EMPRESA 2 (C2) - HOSPITAL GERAL DE ALTA COMPLEXIDADE}

\section{Dados da empresa}

\begin{tabular}{|l|r|}
\hline Faturamento anual da empresa: & $\mathrm{R} \$ 750.000 .000,00$ \\
\hline $\begin{array}{l}\text { Número de funcionários da } \\
\text { empresa: }\end{array}$ & 5.500 \\
\hline Funcionários terceirizados: & $\mathrm{ND}$ \\
\hline Funcionários de TI da empresa: & 65 \\
\hline Funcionários de TI terceirizados: & 0 \\
\hline
\end{tabular}




\begin{tabular}{|l|l|}
\hline $\begin{array}{l}\text { Área de aplicação da TI estudada } \\
\text { que gera vantagem competitiva } \\
\text { para empresa: }\end{array}$ & $\begin{array}{l}\text { Sistema móvel, prontuário eletrônico e } \\
\text { digitalização e arquivo digital. }\end{array}$ \\
\hline $\begin{array}{l}\text { Estratégia competitiva genérica e } \\
\text { escopo de atuação da empresa no } \\
\text { mercado: }\end{array}$ & $\begin{array}{l}\text { A empresa oferece serviços diferenciados } \\
\text { com escopo amplo, abrangendo as mais }\end{array}$ \\
\hline
\end{tabular}

ND - não declarado.

\section{Principais Características da Empresa}

C2 é um dos principais centros de excelência de medicina no país está posicionado no mercado como de alta tecnologia e complexidade. O que dá respaldo a este posicionamento é sua infra-estrutura composta por suas instalações, equipamentos, corpo clínico e a reconhecida capacidade de resolver casos graves e insolúveis.

A instituição conta com mais de 4.500 médicos cadastrados, dos quais 500 são funcionários contratados. Estes profissionais recorrem às instalações da empresa para realizar consultas, exames, internações, cirurgias, entre outros.

Tem como principais clientes: planos, seguradoras e cooperativas de saúde do país. O hospital foi fundado na década de $70 \mathrm{e}$, atualmente, fatura mais de $\mathrm{R} \$$ 750 milhões por ano.

A Instituição coloca à sua disposição todo o conforto e a variedade de serviços, desde a prevenção e a orientação em saúde, passando por consultas, exames diagnósticos e intervenções de alta e baixa complexidade, até a reabilitação.

\section{Uso da TI}

Um dos importantes projetos do hospital está relacionado ao uso de um equipamento móvel sem fio (PDA). Este projeto, apesar de focar apenas questões administrativas do ambiente médico hospitalar, tem contribuído para ganhos de qualidade e de produtividade, melhorando o trabalho dos médicos e funcionários do hospital, assim como o de pacientes em geral.

O sistema móvel trata-se de um terminal sem fio, em que se pode obter, em tempo real, toda lista de tarefas dos pacientes. Durante ou imediatamente após os procedimentos serem executados, prescrevem-se as informações no terminal. Estas 
informações são inseridas de forma rápida e precisa em qualquer local do hospital e os dados coletados são transmitidos para o sistema central que irá processá-los para os devidos fins.

Os ganhos advindos deste novo sistema estão relacionados, por exemplo, aos erros de contabilização e lançamento de dados nas contas dos pacientes, custos de materiais e medicamentos, evasão de medicamentos e garantia da acuracidade nas informações, sem contar nas questões de inventário e outros ganhos de estoques e armazenagens. Pelo lado da eficácia, este sistema permite que os funcionários e médicos estejam mais informados e possam executar suas funções na linha de frente, com mais qualidade e dedicação ao paciente.

O hospital também desenvolve outros projetos de $\mathrm{TI}$, entre eles citam-se: prontuário eletrônico, digitalização de imagens e arquivo digital com as informações dos clientes, entre outros.

\subsubsection{Formas de Contribuição da TI - Categorias}

\section{A - Sistemas estratégicos}

- Conjunto de ferramentas de TI (qualidade no atendimento)

A infra-estrutura de $\mathrm{TI}$ dá respaldo à estratégia de complexidade e tecnologia utilizada pela empresa, reafirmando o posicionamento da empresa no mercado. As ferramentas utilizadas permitem explorar oportunidade para o negócio ou mesmo gerar novas competências para se disputar mercado em função do uso conjunto delas.

As ferramentas de $\mathrm{TI}$ utilizadas tendem a estreitar o relacionamento entre os elos da cadeia de valor da empresa. Isto permite aumento de qualidade e segurança. Qualidade, pois facilita as discussões, tem-se histórico de informações de forma mais facilitada, conseguem-se mecanismos de controle dos processos; segurança, pois está relacionada com a minimização de erros e isto melhora o tratamento, reduz tempo de internação e de utilização de medicamentos e exames, diminuindo o custo e melhorando a qualidade para o paciente.

Nas operações analisadas em C2, a TI contribuiu para aumentar a produtividade, facilitou a gestão, propiciando melhores controles dos recursos humanos, equipamentos e processos. A TI ajudou na melhora das especificações das tarefas pelos clientes, antes que elas acontecessem. Permitiu aumentar a 
previsibilidade de algumas operações, melhorando o índice de padronização e especialização e, conseqüentemente, a produtividade; propiciou maior controle das operações por meio de procedimentalização, com isto se podem reduzir níveis hierárquicos e outros custos em geral.

\section{B - Foco no cliente e no serviço}

- Banco de dados (informações de pacientes, médicos e fonte pagadora)

As ferramentas de $\mathrm{TI}$ da empresa visam a estreitar o relacionamento com os diversos clientes da empresa: pacientes, médicos e fonte pagadora.

Ao utilizar um banco de dados (histórico dos pacientes), a empresa consegue, de forma muito veloz, entender suas necessidades e antecipar-se a elas. O cadastro de mais de 4500 médicos permite manter contato regular com eles e esporadicamente informá-los sobre as novidades oferecidas pela instituição e outras formas de relacionamento. Com a fonte pagadora, a empresa disponibiliza todas as informações referente às contas dos pacientes, via WEB, tornando transparente o relacionamento entre as partes, otimizando-o.

A operação, usando a TI, define melhor a expectativa do cliente, favorecendo a produção simultânea, antecipando-se as suas necessidades. Também se consegue um melhor relacionamento com o contato contínuo, facilitando as soluções de problemas aos clientes.

\section{C - Esforço contínuo de melhorias}

- Automação das operações do laboratório de análises clínicas

Todo o processo de operações de serviço do laboratório, desde o atendimento inicial, coleta, realização dos exames e entrega dos resultados, estão integrados em um único sistema.

O aumento da produtividade do laboratório de análises clínicas e da qualidade das operações de serviços torna mais ágeis os processos e minimizam os erros. Quando se faz o pedido do exame no sistema, a informação vai para a conta do paciente. Quando sai o resultado do exame, os valores são confirmados na conta do paciente.

Esta operação é totalmente automatizada, os eventuais erros de informação dos exames e lançamentos na conta do paciente são duplamente analisados e confirmados. 
- Equipamento móvel (PDA) nos lançamentos de dados dos pacientes

Após a prescrição pelo médico, os dados são lançados automaticamente na conta do paciente. Esta informação vai também para a farmácia, que faz a dispensa do que foi solicitado pelo médico. O pedido recebido pela farmácia orienta quando e como disponibilizar o medicamento. Faz-se a baixa no estoque e a emissão do pedido para os fornecedores.

Este sistema evita gargalos e estoques desnecessários, permitindo um balanceamento das operações de serviço em tempo real.

Aumento da produtividade melhora o gerenciamento e o controle dos recursos-chave. O controle dos custos e da rentabilidade, inclusive em operações com complexidade de rotas, que os pacientes podem fazer. Melhoria das especificações nas alas de internações, farmácia e suprimentos em geral. O histórico destas operações favorece o aprendizado e a reprodução em série de uma mesma solução de serviços, propiciam assim padronizações de tarefas.

- Entender as necessidades dos parceiros para melhor atendê-las

Uso da TI na integração dos processos na rede de valor, em que envolvem relacionamentos de longo prazo, no sentido de entender as necessidades dos parceiros e antecipar-se a elas.

Avaliar tendências de consumo de materiais, medicamentos, equipamentos, tipos de procedimentos. Estas informações são utilizadas para amparar negociações com fonte pagadoras e acordos com fornecedores em geral. O processo de coleta de informações ainda é muito mais desenvolvido que a transformação destas em informações gerenciais.

Esta operação contribui para que se desenvolvam relacionamentos de longo prazo entre a empresa, os fornecedores e a fonte pagadora. O relacionamento amplia o conhecimento entre os participantes e o entendimento de suas necessidades, o que facilita soluções de problemas para o grupo.

- Estruturação de dados para inteligência nos negócios

Desenvolvimento e manutenção de banco de dados digital com informações de todos os clientes da instituição para compreender melhor o comportamento e demanda nas operações de serviços destes públicos. 
Ao disponibilizar todo material em formato digital (digitado e digitalizado), obtém-se mais produtividade e qualidade nas operações por meio de acesso mais rápido e preciso de procedimentos, intervenções e tudo que foi ministrado no paciente.

Conhecer melhor os clientes propicia o entendimento de suas expectativas e permite antecipar ações para atender suas necessidades o que leva ao aumento do relacionamento, fidelizando o cliente.

- Digitalização e gerenciamento de exames de diagnóstico por imagem.

Estas imagens são laudadas por especialistas e ficam à disposição do médico que a solicitou, tanto internamente em estações dentro da estrutura hospitalar, quanto na WEB.

A TI facilita o acesso às imagens, em várias circunstâncias, caso haja, necessidade de segunda opinião médica ou de uma conferência entre médicos para dar um veredicto sobre um laudo, isto pode ser feito de qualquer local do mundo onde haja um computador conectado a Internet. Além das imagens pela Internet, os médicos recebem também um CD com essas imagens gravadas, que poderão ser levadas e acessadas off-line, na medida em que o médico achar necessário ou em uma das estações de trabalho espalhadas nos andares do hospital. O paciente também recebe este material. Em ambos os casos eliminam-se a necessidade de se transportar os tradicionais filmes fotográficos.

Esta operação facilita o atendimento com base nos requisitos do cliente (paciente, médico, planos de saúde em geral) em relação a tempo, a local e à posse dos serviços prestados. Estas facilidades otimizam o tempo dos clientes e aumentam o benefício oferecido, criando maior valor.

- Uso da TI como suporte à decisão médica

Esta ferramenta permite, por exemplo, ao médico fazer uma prescrição de um medicamento, após consultar uma base de dados. A base de dados informa se não há contra-indicação em utilizar um medicamento junto a outro e até mesmo se o medicamento indicado é o mais correto.

Facilita a tomada de decisão e aumenta o grau de assertividade nas prescrições médicas. 
Esta operação contribui para melhora das especificações das tarefas, instituindo mecanismos à prova de falhas.

\section{- Equipamento móvel}

Uso de equipamento móvel no controle do processo de ministração de medicamentos.

Esta ferramenta permite identificar se os medicamentos estão sendo ministrados nos horários prescritos pelos médicos. Ao ministrar o medicamento, a enfermagem registra, por meio de um código de barras do paciente, no pulso do paciente, o horário que foi ministrado.

O uso do equipamento móvel em si já denota maior qualidade na operação, demonstrando diferenciação no serviço. Por outro lado, esta ferramenta permite também um maior gerenciamento dos recursos e dos insumos (materiais, medicamentos e outros) que são ministrados. O equipamento determina a ordem da dispensação, descreve os procedimentos, melhora o contato na linha de frente. Por possuir todas as informações do processo e dos pacientes, aumenta a produtividade e qualidade dos serviços.

D- Otimização do processo empresarial (reengenharia do processo do negócio)

Obs. Este subitem será dividido em duas partes: reengenharia do processo do negócio e novos negócios gerados pela TI ou em processo de gestação.

D1 - Reengenharia do processo do negócio

A empresa não apresentou nenhum processo que utiliza $\mathrm{Tl}$ e que pudesse ser considerado nesta categoria.

D2 - Novos negócios gerados pela TI ou em processo de gestação

- Desenvolvimento de vários novos negócios

O uso da TI permitiu diversas novas atividades como: videoconferência, segunda opinião médica a distância, internação domiciliar monitorada, análise de exames por imagem a distância, outros.

A TI permite reduzir custos de transação ao tornar possível a realização destas atividades em qualquer local que tenha infra-estrutura para recebê-la. 
Esta operação cria valor ao flexibilizar o atendimento com base nos requisitos do cliente com relação a tempo e a local. A TI permite otimizar a capacidade produtiva na mão-de-obra disponível, assim como dos equipamentos e também flexibilizar a capacidade ao encontro das variações da demanda, oferecendo o excedente de produção de forma remota.

\section{E - Redes de valor e alianças entre empresas}

\section{- Controle de operações de serviço interempresas}

O uso da TI é para unificar fontes de informações, facilitando controles e para integrar áreas médicas, administrativas de suporte, pacientes, outros. Um hospital é um conjunto de empresas que desenvolvem atividades complementares. Estas atividades vão desde fornecimento de insumos, serviços de laboratório, centro cirúrgico, farmácia outros. Nas atividades administrativas, tem-se: recursos humanos, comercial, operações de serviços de manutenção, financeiro, suprimentos, outros.

A integração das áreas traz para o hospital benefícios relacionados ao controle e ao gerenciamento dos processos em geral e também do fluxo de caixa e de suprimentos. Isto facilita o planejamento da produção dos serviços, reduzindo a perecibilidade, adequando a oferta e a demanda.

As operações de serviços hospitalares são predominantemente complexas. O uso da TI no gerenciamento dos recursos-chave (recursos humanos, equipamentos e outros) são vitais para o funcionamento de toda a estrutura em função da complexidade. As tarefas de linha de frente e retaguarda, ao serem mais bem especificadas no equipamento móvel, permitem a repetição com menor variabilidade. A TI permite também estruturas hierárquicas mais achatadas, pois ao subsidiar os profissionais de saúde com informações em tempo real, tornam desnecessários controles rígidos. A procedimentalização ganha maior ênfase com o uso da TI, atenuando a necessidade de julgamento profissional, controle de custos sobre a mão-de-obra e também controle da lucratividade individual dos serviços, mesmo em complexidade de rotas. Por fim, a TI permite flexibilizar as operações de serviços relacionadas à negociação de entrega, rotação de equipes de trabalho e outros ajustes.

- Controle de estoques e pedidos 
O uso da $\mathrm{Tl}$ contribui para controlar os estoques e os pedidos. O sistema realiza emissão de pedidos, planejamento de forma automática, cálculo de lotes ou de utilização do lote comprado.

Os controles tornam a produção dos serviços mais flexível e evitam quebras de estoques.

Na medida em que a operação está totalmente automatizada, tem-se maior produtividade e qualidade. Inventários e outras atividades burocráticas são totalmente desnecessários, evitando desperdício de tempo.

- Interface com clientes (fonte pagadora)

O uso da TI permite interface com fonte pagadora (planos de saúde, seguradoras, outros). Este procedimento propicia a padronização dos protocolos de comunicação entre as empresas da cadeia produtiva na saúde.

A ação permite realizar a autorização para os atendimentos e pagamentos eletrônicos entre instituições de saúde. O compartilhamento de informações reduz a duplicidade de procedimentos entre prestadores de serviços, a falta de clareza, o aumento de rapidez e a transparência nas operações de serviço.

A TI otimiza as operações de serviço de linha de frente e retaguarda, controlando roteiros pré-determinados (scripts) e outros acordos e protocolos que possam ser monitorados entre a empresa e a fonte pagadora.

$F$ - Comércio eletrônico e redes de informações

- Aquisição de insumos via WEB

Uso da TI na aquisição de medicamentos direto da indústria farmacêutica.

As empresas trabalham de forma integrada. Todo o procedimento é eletrônico, eliminando o uso de papéis e/ou fax, seguido de confirmação por telefone, comum neste segmento. Os ganhos são mútuos: redução do tempo de pedido e de atendimento do pedido, redução de erros nos pedidos e retrabalhos de digitação das duas partes. A integração permite o recebimento do pedido e depois a fatura, tudo por meio eletrônico, inclusive a nota fiscal.

Automação do processo de compras, eliminando custos de transação. $\mathrm{Na}$ medida em que as baixas acontecem no estoque, os fornecedores são informados e na medida em que se consolidada um pedido mínimo previamente acordado, os insumos são enviados para a empresa solicitante. 


\subsubsection{Outras Considerações de C2}

Alguns pontos importantes surgiram durante as entrevistas em relação ao uso da $\mathrm{TI}$ que se acredita ser valioso para este trabalho, ou para outros estudos relacionados, entre eles, podem-se citar: o médico é um dos principais clientes de um hospital, juntamente com o cliente, que geralmente subordina sua escolha hospitalar às indicações do primeiro. Como em geral o médico é um profissional liberal, que trabalha em diversas instituições, seu vínculo é bastante discreto com cada uma delas. Assim, o imediatismo é bastante constante nas suas escolhas de formas de trabalho e, neste caso, mudanças envolvendo a $\mathrm{TI}$, por exemplo, nem sempre são bem aceitas ou assimiladas.

No caso da TI e as operações de serviço na saúde, foi explicado que o médico não era o suficiente informado, sobre as vantagens de se utilizar a TI, para ele e para a instituição. Conforme a empresa, também sobre o ponto de vista do paciente, em geral não se percebem as vantagens da TI. Não há uma fonte de informação formal ou informal sobre o assunto. O hospital informa as sofisticações diretamente relacionadas com os equipamentos e tratamentos. As questões relacionadas à $\mathrm{TI}$, parte importante em um tratamento médico, nunca é discutida $\mathrm{e}$ pode ser definitiva para um paciente quando bem utilizada, segundo o hospital. A abordagem pode ser tanto do ponto de vista da segurança, quanto da velocidade e do acesso a informações em geral, aumentando a resolutividade do caso, além dos custos, os quais podem ser mais bem controlados pela empresa.

Um outro ponto para a adoção da $\mathrm{Tl}$ está relacionado à cultura. Conforme a instituição, profissionais que nasceram após 1965, em geral são menos resistentes a mudanças; os mais antigos, médicos já consagrados no mercado, com maior poder de barganha, junto ao hospital e também às fontes pagadoras, tornam-se mais resistentes a evoluções. Embora haja todo um aparato para o uso da TI nas prescrições médicas do prontuário eletrônico, o que predomina é o processo manual. Existe um grupo de transcritores (enfermeiros, farmacêuticos, outros) que lançam os dados no sistema. Outro ponto importante, também relacionado à cultura, é a questão de poder. No processo digital, as informações ficam mais facilmente acessíveis e isto pode causar constrangimento e inclusive questionamento de determinados procedimentos, por parte de auditores externos de fontes pagadoras, 
por exemplo. Por fim, quando se tem um hospital cujo corpo clínico é aberto, permitindo que qualquer médico utilize a instituição quando desejar, sem que haja vínculo com a instituição, também acarreta dificuldades. A autonomia do médico gera um descomprometimento quanto às inovações relacionadas à $\mathrm{TI}$, dificultando a adoção.

\subsubsection{Resumo da Análise de C2}

A TI criou valor (eficiência e/ou eficácia) em diversas circunstâncias, entre elas, podem-se citar:

- oferecendo um conjunto de ferramentas, ampliando a qualidade no atendimento a seus clientes;

- disponibilizando informações dos pacientes em formato digital, incluindo prontuário médico com exames de análises clínicas e por imagem;

- utilizando equipamento móvel (PDAs) nas operações de serviços médicos;

- otimizando a gestão de processos;

- criando ferramentas de suporte à decisão;

- controlando processos de ministração de medicamentos;

- integrando operações entre parceiros da empresa;

- controlando estoques e pedidos de compras;

- automatizando o processo de compras e de faturamento;

- interfaceando o contato com fonte pagadora (convênios);

- outros.

Por que a TI cria valor? As respostas foram diversas, mas observou-se uma maior incidência do ponto de vista da eficácia, nas seguintes circunstâncias:

- flexibilizando o atendimento com base nos requisitos do cliente relacionados a tempo e local e outras especificidades pessoais.

- outros.

Do ponto de vista da eficiência, observou-se que a TI teve maior contribuição nas seguintes circunstâncias:

- aumentando o índice de reprodução em série de uma mesma solução em serviços (desenvolvendo e instituindo controles de roteiros scripts) para 


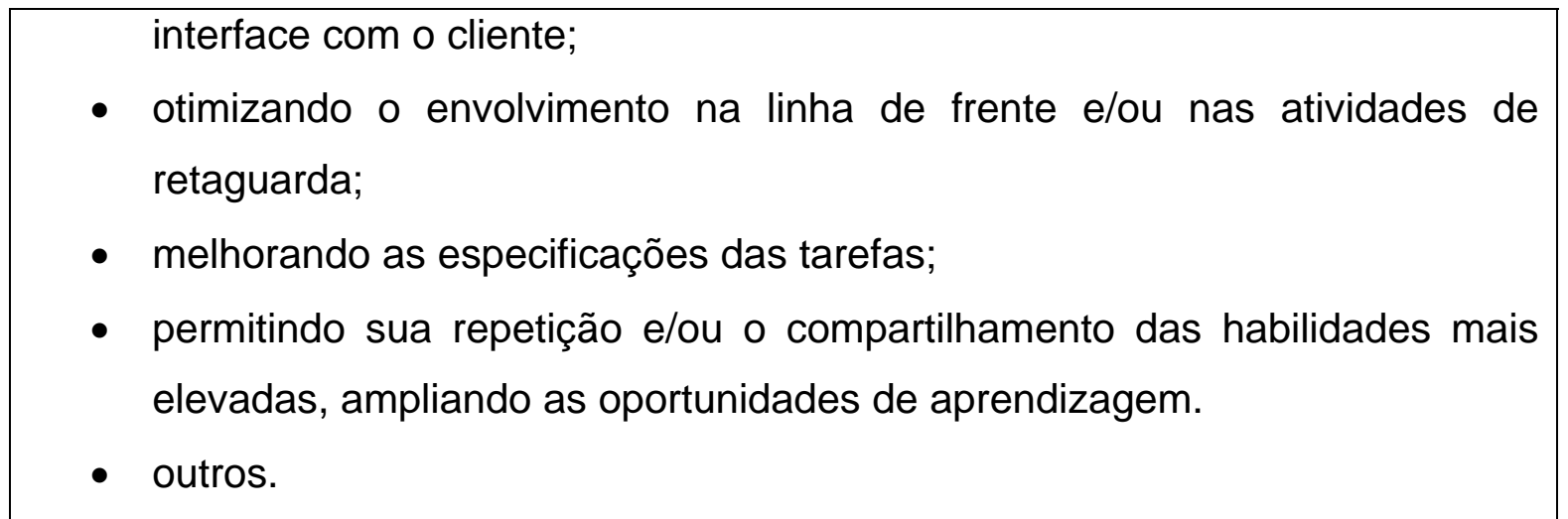

Quadro 8 - Resumo da Análise de C2

\subsection{EMPRESA 3 (C3) - HOSPITAL ESPECIALIZADO DE ALTA COMPLEXIDADE}

\section{Dados da empresa}

\begin{tabular}{|c|c|}
\hline Faturamento anual da empresa: & $\mathrm{R} \$ 150.000 .000,00$ \\
\hline $\begin{array}{l}\text { Número de funcionários da } \\
\text { empresa: }\end{array}$ & 1600 \\
\hline Funcionários terceirizados: & 400 \\
\hline Funcionários de TI da empresa: & 15 \\
\hline Funcionários de TI terceirizados: & 6 \\
\hline $\begin{array}{l}\text { Área de aplicação da } \mathrm{TI} \text { estudada } \\
\text { que gera vantagem competitiva } \\
\text { para empresa: }\end{array}$ & $\begin{array}{l}\text { Sistema móvel e controle de dispensa de } \\
\text { medicamentos e gerenciamento de } \\
\text { imagens de exames de diagnóstico. }\end{array}$ \\
\hline $\begin{array}{l}\text { Estratégia competitiva genérica e } \\
\text { escopo de atuação da empresa no } \\
\text { mercado: }\end{array}$ & $\begin{array}{l}\text { A empresa oferece serviços diferenciados } \\
\text { com enfoque em cardiologia. }\end{array}$ \\
\hline
\end{tabular}

\section{Principais Características da Empresa}

C3 é um dos principais centros de tratamento de doenças cardiovasculares da América Latina, em especial cirurgias cardíacas e análise diagnóstica por imagem.

Atua há mais de cinco décadas como pioneiro em cardiologia, compartilhando recursos tecnológicos e conhecimentos com outras especialidades, associando 
ensino e pesquisa clínica. Tem como clientes: planos, seguradoras, cooperativas de saúde e autogestões.

Conta, ainda, com uma equipe multidisciplinar formada por médicos, enfermeiros, fisioterapeutas, nutricionistas, psicólogos e assistentes sociais e oferece o que há de melhor em tecnologia aliado à humanização com apoio das voluntárias.

Outro dado significativo é que, desde 1998 até o presente, foi prestado atendimento ambulatorial de cardiopediatria a mais de 4000 crianças, sendo o número de internações superior a 2000, das quais 1500 cirurgias foram custeadas pela C3, demonstrando sua forte preocupação com a questão "Responsabilidade Social".

\section{Uso da TI}

A C3 é uma empresa totalmente integrada, qualquer funcionário, desde que autorizado, acessa os dados de qualquer área da empresa, de acordo com sua necessidade. Desde 2001, a instituição mudou o ambiente tecnológico e está totalmente integrada no que se refere ao sistema de informações.

A empresa tem um processo na parte de medicamentos, onde se faz a dispensação dos medicamentos com a utilização de um PDA, com códigos barras, com horários predeterminados. Os PDAs contribuem para que os usuários realizem suas atividades de forma ágil e segura, favorecendo o contato com o cliente.

A empresa utiliza também um sistema de gerenciamento de imagens que contribui para aumentar a qualidade e a produtividade dos serviços prestados.

\subsubsection{Formas de Contribuição da TI - Categorias}

A - Sistemas estratégicos.

- Agilizando processos e desburocratizando o serviço para os médicos

A TI contribui para controlar e tornar mais ágeis os processos, possibilitando que os médicos dediquem maior tempo aos seus pacientes que foram encaminhados por eles para um determinado hospital.

Os médicos, um dos principais clientes em um hospital, em geral trabalham em mais do que uma instituição e, neste caso, quando podem optar, a preferência recai sobre instituições mais eficientes e seguras. Quanto mais eficiente for o 
hospital, maior será o tempo para se despender com o paciente. Quanto mais seguros, maiores serão as possibilidades de recuperação do paciente. A premissa qualidade, portanto, contribui para se captar os melhores médicos e, conseqüentemente, mais negócios.

A TI contribui para facilitar a avaliação da qualidade dos serviços prestados (percepção do cliente). Os equipamentos, a padronização dos relatórios, a clareza, a segurança e a velocidade de resposta das informações tornam tangíveis os serviços da instituição e geram maior confiança nos serviços que serão prestados.

$B$ - Foco no cliente e no serviço.

- Aprimoramento do monitoramento dos pacientes

O uso da TI no monitoramento de casos e atualização dos dados do paciente. Como as pessoas e processos estão em constante transformação, a TI permite processar melhor as informações, tornando possível um atendimento mais personalizado.

Os dados dos pacientes permitem programar contatos de acordo com o seu tratamento.

A integração do paciente com a empresa é fundamental para que as intervenções que ele irá sofrer estejam relacionadas com sua expectativa, garantindo maior qualidade à sua experiência com os serviços. Esta operação amplia o relacionamento e contribui na solução de problemas.

\section{C - Esforço contínuo de melhorias}

- Desenvolvendo procedimentos e ferramentas da qualidade

O uso da TI nos processos para acreditação hospitalar (certificação de qualidade no setor da saúde) para execução e controle. Com o processo totalmente digitalizado, a armazenagem e o histórico dos dados ficam facilmente disponíveis para pesquisas. As pesquisas podem apresentar dados importantes como, por exemplo, liberações de laudos mais rápidos, agilizando a alta de pacientes.

O uso da TI na execução e controle diário dos processos aumenta a produtividade (tornando-os padronizados e comuns a todos) e a qualidade (aumento da transparência e acesso às informações). As fontes pagadoras, mobilizadas na redução de custos, por exemplo, acatam satisfatoriamente, argumentos que 
demonstram altas hospitalares antecipadas, por não ter de esperar laudos demorados.

O uso da TI nestas operações aumenta a produtividade e a segurança nos serviços prestados, atraindo mais clientes.

- Equipamento móvel (PDA)

Uso de tecnologia móvel nas alas de internação no controle dos medicamentos dispensados pela farmácia.

A TI pode indicar a ordem adequada para se iniciar a dispensação por paciente e até se existe algum caso urgente que tenha prioridade ou aviso sobre alguma especificidade do paciente. Quanto mais correta for a dispensação do medicamento em relação ao horário, melhor será a ação deste.

A tecnologia móvel, nesta operação, contribui para flexibilizar o atendimento, com base nas necessidades dos clientes em relação a tempo e a local. Facilita a avaliação da qualidade dos serviços prestados tanto para o paciente como para o médico do paciente.

- Identificação de pacientes e controles por código de barras

Uso de pulseiras com código de barras no paciente, facilitando o processo de controle de dispensação de medicamentos e outros cuidados.

Na medida em que ocorre a ministração dos medicamentos, os pacientes são informados do motivo de utilizarem a pulseira com código de barras. Ao tomar conhecimento e consciência das diferenças promovidas pela $\mathrm{TI}$, o paciente sente-se mais seguro, porém torna-se mais exigente.

Nesta operação, o uso da TI facilita na avaliação dos serviços prestados (tangibiliza o serviço) e também faz com que o cliente associe seu uso como sinônimo de qualidade, criando oportunidade para diferenciação.

- Redesenhando processo de prescrição e solicitação de materiais e medicamentos nas alas de internação

Digitalização das prescrições médicas (escaneamento) nas alas de internação e encaminhamento, via sistema interno para a farmácia, para realizar a separação e o envio para ser ministrados nos pacientes. 
A farmácia controla o processo de análise do medicamento e a dispensação. Ao receber as solicitações, ela se programa sempre com uma hora de antecedência. O processo de escaneamento, além de eliminar a tradicional entrega de papéis, que aumenta substancialmente o ciclo de serviços e os fluxos na empresa, permite que os pedidos sejam direcionados para diretórios específicos, separados por unidade e por paciente. De posse desta informação, a farmácia faz o trabalho de dispensação. Um fato relevante é: o prontuário não sai do posto de enfermagem, que é local correto deste documento.

Esta operação contribui para otimizar o tempo dos funcionários para que eles se dediquem mais tempo ao cliente, com aumento da produtividade, gerência e controle dos recursos-chave. Finalmente, contribui para a melhora nas especificações das tarefas, aumento do índice de reprodução em série, uma mesma solução em serviços para interface com o cliente.

\section{D- Otimização do processo empresarial (reengenharia do processo do negócio)}

Obs. Este subitem será dividido em duas partes: reengenharia do processo do negócio e novos negócios gerados pela TI ou em processo de gestação.

\section{D1 - Reengenharia do processo do negócio}

- Interfaceando processos entre diversas áreas no hospital Interface entre operação nas alas de internação e a farmácia do hospital, facilitando a execução e o controle das operações, utilizando equipamento móvel $(P D A)$. Neste caso, a TI pode contribuir de várias formas: a dispensação dos medicamentos é realizada a partir dos dados recebidos pelo sistema. Estes dados são baixados em um PDA; o equipamento faz a opção de coleta de medicamentos para a próxima distribuição nas alas de internação. A partir destas informações, o farmacêutico realiza a separação dos medicamentos individualizado e fracionado para aquele horário. O equipamento informa o medicamento e quando é recolhido em um escaninho específico para um determinado paciente. Utilizam-se códigos de barra para dar entrada e saídas nos produtos (baixas de estoque, pedidos de compra, lançamento na conta do paciente, outros); a TI também pode informar a falta de medicamento ou medicamento errado. Neste caso, há um bloqueio realizado pelo leitor ótico ao não separar um determinado item ou item errado. Este bloqueio evita erros e informa que faltam itens e que estes devem ser supridos ou 
substituídos; o recebimento e a conferência dos insumos nos andares pela enfermagem utilizando leitor ótico. Quando o medicamento do paciente chega ao andar, a enfermagem confere, utilizando um leitor ótico e, quando houver problema, retorna a informação à farmácia; a ministração do medicamento, utilizando o PDA. De posse dos materiais e dos medicamentos e respectivas dosagens e horários que deverão ser ministrados nos pacientes, a enfermagem realiza a ministração junto aos pacientes.

Além de ajudar no lançamento dos dados, o leitor de código de barras e a prescrição eletrônica são confrontadas, eliminando possíveis erros de interação de dosagem ou até de prescrição. O PDA funciona como um mecanismo de interface. Por exemplo, indica que se tem segurança com o código de barra, que foi feita a leitura correta do medicamento. O equipamento permite maior mobilidade para recolher os medicamentos e fazer a leitura ótica, e, se houver erro na prescrição, o código de barra acusa que se trata da medicação incorreta. Ex: O paciente está com dor de cabeça, está indicado o medicamento X para dor; aparece no equipamento, 0 medicamento. O operador desloca-se até a prateleira e retira o medicamento $\mathrm{X}$ e, por meio do PDA, é feita a leitura do código de barra deste medicamento; coloca-se em um recipiente plástico (físico) e o envia para a enfermagem. A baixa do estoque é feita no momento da dispensação, não quando da utilização do $P D A$, que se refere apenas à leitura do medicamento físico. Ao se finalizar a coleta de medicamentos no recipiente plástico de um determinado paciente, é necessário lacrá-la com uma etiqueta, para dar maior segurança, evitando troca de nomes ou medicamentos incorretos. Com o PDA, em mão, o operador desloca-se até a impressora, aciona o código de barra, que emite a etiqueta daquele paciente. O comando é feito pelo PDA; depois, retira-se a etiqueta e lacra-se o recipiente. Sem este lacre, não há o fechamento do sistema e ele não consegue ir para outro paciente, ou seja, ele só fecha o processo no momento da emissão da etiqueta e, no momento, do lacre. Com isto, consegue-se reduzir o erro de separação dos materiais e medicamentos a zero. Evitam-se retrabalhos. Neste caso, ganha-se mais eficiência e evita-se que seja ministrado um medicamento de forma incorreta, mas com maior eficácia. Para que se possa finalizar o processo, é necessário gerar uma informação ao sistema, referente ao remédio que estava faltando ou estava incorreto. Assim, insere-se a informação: quantidade zero e entende-se que o medicamento não foi usado, passase para o próximo e o sistema entende que não dispensou o medicamento. Este 
bloqueio evita erros e informa que faltam itens e que estes devem ser supridos ou substituídos. Esta ferramenta tem uma interação menor, mas é à prova de falhas, pois, para que haja falhas, a cadeia inteira teria de falhar: a farmácia, a enfermagem e outros. O ponto de controle principal é a farmácia: os outros devem acompanhar e checar com o PDA. Na medida em que a enfermagem ministra os medicamentos nos pacientes, é dada baixa nestes insumos, por meio da leitura do código de barras da pulseira de cada paciente. A validação do sistema permite que a enfermagem saiba qual o tempo real do processo e a farmácia também pode rastrear se está tudo conforme o especificado. Mais uma vez eficiência do processo e segurança (eficácia) para o paciente.

Esta operação contribui para otimizar o tempo dos funcionários, permitindo que eles dediquem mais tempo aos pacientes, possibilitando, ainda, que o cliente perceba maior qualidade na operação. A TI melhora a produtividade e ajuda a focar os esforços; melhora as especificações das tarefas, permitindo repetição em série de uma mesma solução; aumenta ainda o índice de previsibilidade, facilitando as interações nas co-produções dos pacientes; contribui para o controle organizacional, possibilitando estruturas hierárquicas mais achatadas, tornando desnecessários controles rígidos de chefia; automatiza o controle dos processos; dilui a responsabilidade dos gerentes e contribui no controle dos custos.

- Envio de resultados de exames via celular dos pacientes

O uso da TI para informações de exames de laboratório e imagens em geral, para o celular dos pacientes (SMS). Os avisos informam sobre a disponibilidade dos resultados dos exames e se os pacientes preferem retirá-lo no formato convencional, recebê-los via e-mail ou por acesso ao site da instituição. Também se utiliza a mesma ferramenta (SMS) para marcação dos exames e indicar os preparos que devem ser realizados para fazer o exame.

Pacientes, médicos e hospital têm se beneficiado desta forma de comunicação relacionada com os exames. Os pacientes têm a comodidade de serem avisados e podem optar sob qual forma querem receber os exames e, antes disto, sobre a data de realização dos exames e ainda sobre o preparo para os exames. Os médicos também estão satisfeitos, pois estes cuidados com o paciente reduzem os resultados e até mesmo repetições de exames. A instituição prestadora de serviços, além de racionalizar as despesas com papéis e outros custos para 
enviar o material ao paciente, ao oferecer estas alternativas, melhoram o relacionamento com seus clientes, fidelizando-os.

Nesta operação, o cliente participa da especificação do processo e determina de que forma o serviço será realizado. Assim, flexibiliza o atendimento com base nos requisitos dos clientes em relação a tempo, a local e a posse. A TI amplia a produtividade, melhora as especificações, aumenta o índice de reprodução de uma das tarefas, reduzindo a variabilidade nas operações; reduz também incertezas, pois a TI melhora a previsibilidade nas operações. Pode contribuir para otimizar a capacidade da mão-de-obra.

- Equipamento de reconhecimento de voz

O processo de reconhecimento de voz utilizado na análise e diagnóstico de imagens permite reduzir o tempo para se expedir um laudo de três dias para um dia. A redução de tempo nos laudos tem feito com que o processamento das imagens realizadas pelos técnicos, que finalizam o processo, seja realizado de forma mais veloz. Neste caso, a possibilidade que o paciente receba seus exames, assim que sair da sala de exames, é reduzido de um dia para alguns minutos. Isto poderá ser factível em breve.

Os ganhos de eficiência e qualidade são muito claros, para todos os participantes do processo. A fonte pagadora, de posse de laudos mais rápidos pode acelerar o tratamento de seus pacientes. Os pacientes tornar-se-ão mais exigentes, exigindo do mercado este tipo de serviço, pois poderão ter tratamentos mais resolutivos. A importância destes procedimentos está diretamente relacionada com a competitividade da empresa, pois com a paridade dos resultados dos diagnósticos, a disputa será na disponibilização dos resultados, em especial, nos casos mais urgentes. Isto também cria barreiras de entradas em alguns seguimentos específicos e permite a cobrança de preços diferenciados.

Dessa forma, flexibiliza o atendimento com base nos requisitos do cliente em relação a cumprimento de prazos. Por um lado, além da comodidade do paciente, também pode ser observada a maior resolutividade no tratamento, sendo importante para o paciente e também para a fonte pagadora, que reduz custos.

- Gerenciamento de exames no centro de diagnóstico por imagem 
Alguns pontos devem ser ressaltados: aspecto funcional (produtividade, facilidade e interação entre os agentes do processo: pacientes, médicos radiologistas, médicos clínicos, enfermeiras e pessoal administrativo); aspecto gerencial (controle das imagens e dos laudos) e a confiabilidade; controle de imagens digitais e laudos com gravação digital (reconhecimento de voz), utilizando a TI.

$\mathrm{Na}$ operação utilizando a TI, o médico radiologista analisa a imagem, grava o laudo (voz digitalizada), interage se houver necessidade de corrigir o texto (após digitação) e finaliza o laudo. Finalmente, ocorre a entrega para o médico clínico que solicitou o exame ou para o paciente. Esta ferramenta permite eliminar os controles manuais, retrabalhos e outros problemas relacionados com área física para se guardar insumos de filmes, além do estoque de filmes.

Assim sendo, flexibiliza o atendimento com base nos requisitos do cliente em relação a cumprimento de prazos. Isto por um lado além de comodidade do paciente também pode ser observado como maior resolutividade no tratamento. É importante para o paciente que aumenta o benefício e também para a fonte pagadora, que reduz custos.

- Interface em tempo real em operações de serviço com o paciente Interface em tempo real, entre paciente e sistema de marcação de consultas e exames e do serviço de sugestões e reclamações pelo cliente, quando é encaminhado um retorno para o cliente a posteriori.

A empresa disponibiliza um site para os pacientes e para os médicos que podem fazer as marcações de consultas e exames. Este serviço também é disponibilizado via telefone.

A interface com o cliente permite que ele participe da especificação do serviço antes de incorporá-lo ao processo. Isto permite flexibilizar o atendimento com base em seus requisitos de tempo, de local e de posse em uma operação totalmente automatizada.

D2 - Novos negócios gerados pela TI ou em processo de gestação

- Diagnóstico (laudo) para terceiros a distância 
O sistema utilizado para processamento e gerenciamento das imagens pela empresa permite viabilizar processos para diagnóstico (laudos de exames por imagem) a distância. Para tanto, basta que também haja infra-estrutura para realizar o exame no local.

Podem-se concentrar especialistas radiologistas em uma central de análise e várias bases para captação e realização dos exames, apenas com técnicos e outros médicos (para casos especiais de exames contrastados e outros procedimentos mais complexos), mas não necessariamente médicos radiologistas. Como o radiologista não tem necessidade de ver o paciente, podem ficar em locais distintos em qualquer ponto do planeta, basta que seja possível a transmissão destas imagens por satélite, fibra ótica, outros.

A TI contribui para flexibilizar o atendimento com base nos requisitos do cliente em relação à conveniência espacial. A TI também contribui para que o cliente associe a operação de serviços como sinônimo de maior qualidade no serviço prestado, ou seja, maior diferenciação.

\section{E - Redes de valor e alianças entre empresas}

- Diagnóstico por imagem (laudo a distância)

A TI permite que se disponibilizem as informações na rede de valor na saúde, tanto a montante quanto a jusante, facilitando a tomada de decisão. As decisões, neste caso, estão relacionadas ao consumo de insumos, marcação de consultas, exames, cirurgias e outros procedimentos que poderão gerar capacidade ociosa ou filas. Na medida em que os prestadores de serviço e fornecedores em geral estão integrados e operando em uma única rede de valor, obtém-se menor custo e/ou maior benefício.

A saúde é um setor de difícil padronização e procedimentalização, pois os casos são únicos, diferentes uns dos outros. A informação contribui para que se aperfeiçoe o planejamento, facilitando o processo de tomada de decisão. A informação permite ainda que o processo de gestão seja compartilhado, ampliando os poderes entre os elos da rede de valor, para que gerem respostas adequadas.

O uso da $\mathrm{Tl}$, nestas circunstâncias, torna as operações de serviços mais flexíveis (tempo, local e posse) em relação às empresas que participam da rede de valor e às transações realizadas entre elas. A TI também amplia o relacionamento entre os participantes e, como conseqüência, obtém-se melhores soluções e 
maiores ganhos. Estes ganhos tanto podem vir da redução de estoques e filas, frutos de informação mais adequada, quanto do aumento do número de transações entre os participantes. Portanto, ganham-se também na produtividade, no gerenciamento e no controle dos recursos-chave, evitando retrabalhos e facilita-se a previsibilidade nas operações, o que favorece a padronização de tarefas; permite um melhor controle de custos sobre a produção dos recursos; otimiza-se a capacidade produtiva em função de se conhecer melhor uns aos outros. Por fim, permite-se flexibilidade nas operações de serviços relacionadas a datas de entrega, à rotação em equipes de trabalho e outros ajustes de pessoal e até de equipamentos.

F - Comércio eletrônico e redes de informações

- Compra de insumos via WEB

As compras da instituição são realizadas automaticamente junto aos fornecedores, via WEB, conforme são geradas baixas nos estoques.

A TI permite que este processo seja realizado sobdemanda, enviando informação para o fornecedor enquanto o estoque é consumido, até se gerar um pedido. Esta demanda pode ainda ser prevista com bases históricas e também por meio da previsão da demanda por parte dos médicos que utilizam o hospital.

Ocorre aumento na eficiência nas operações de compra, por meio da automação, eliminando processos morosos.

\subsubsection{Outras Considerações de C3}

Um ponto interessante a ser citado é a prescrição médica digital, a qual só acontece em função do processo de transcrição dos dados. Ainda que haja todo aparato técnico disponível para os médicos realizarem esta operação, não é o suficiente. A explicação está na praticidade do modelo e até se os mecanismos são suficientemente amigáveis ou ainda no hábito, pois larga maioria dos médicos preferem não fazê-lo, recorrendo aos transcritores. Por outro lado, ao se observar tecnologias por comando de voz, por exemplo, a adesão às novas tecnologias fica evidente. No caso, o laudo de exames de diagnóstico por imagem é a atividade-fim para o médico radiologista, ou seja, seu trabalho se encerra com esta operação. Diferentemente de outras especialidades como a dos médicos clínicos, em que o prontuário é apenas um meio de registrar a evolução do paciente e exceto pela 
questão do registro, que embora seja importante não faz parte do tratamento. Talvez esta seja a razão por que os profissionais se envolvem e utilizam mais a TI na medida em que esta sai do campo administrativo e passa a fazer parte da operação deste profissional.

O que se conclui, neste caso, é que há um apoio importante da direção da empresa para que se utilize a TI cada vez mais e em todas as circunstâncias possíveis. A empresa entende que na medida em que os convênios tendem a verticalizar-se, a sensibilidade a preço aumenta. As operadoras acabam integrando a montante, crescendo a rivalidade, no que se refere à especialização, havendo uma disputa mercadológia e o emprego da TI deve ser decisivo neste processo. Por outro lado, os médicos, outro cliente importante da empresa, realizam suas escolhas em hospitais que propiciem maior produtividade nos serviços. Esta opção permite que os médicos possam dedicar maior tempo ao paciente e também pela segurança eles querem contar com processos que melhorem a resolutividade (contribuam no restabelecimento do paciente). Conforme se observou, estes são os principais motivos para a utilização da TI nesta empresa.

\subsubsection{Resumo da Análise de C3}

A TI criou valor (eficiência e/ou eficácia) em diversas circunstâncias, entre elas, podem-se citar:

- padronizando processos, ampliando nível de serviços, reduzindo a burocracia e oferecendo maior segurança e eficiência nas operações de serviços, aumentando o poder de barganha com os médicos clientes;

- utilizando equipamento móvel (PDAs) em diversas atividades: controle e ministração de medicamentos, identificação de pacientes, outros;

- disponibilizando informações em formato digital;

- controlando o processo de solicitação, separação, priorização e ministração de medicamentos;

- interfacendo processos entre diversas áreas do hospital;

- favorecendo a padronizando de processos;

- utilizando vias alternativas (SMS) para comunicar resultados de exames, reduzindo o tempo para divulgação de laudos de exames; 
- personalizando o monitoramento de pacientes;

- utilizando equipamentos com reconhecimento de voz em operações de laudo médico;

- gerando laudo de exames de diagnóstico por imagem a distância;

- integrando parceiros em uma rede de valor;

- comprando insumos via WEB;

- outros.

Por que a Tl cria valor? As respostas foram diversas, mas observou-se uma maior incidência do ponto de vista da eficácia, nas seguintes circunstâncias:

- flexibilizando o atendimento, com base nos requisitos do cliente;

- otimização do tempo do funcionário, para que ele dedique maior tempo ao cliente;

- outros.

Do ponto de vista da eficiência, observou-se que a TI teve maior contribuição nas seguintes circunstâncias:

- aumentando a automação no controle de processos de serviços;

- aumentando a previsibilidade nas operações de serviços, permitindo uma melhoria no índice de padronização e especialização e conseqüentemente da produtividade;

- gerenciamento e controle dos recursos-chave da empresa: recursos humanos e/ou dos equipamentos e processos;

- aumento do índice de reprodução em série de uma mesma solução em serviços (desenvolvendo e instituindo controles de roteiros scripts) para interface com o cliente;

- otimizando o envolvimento na linha de frente e/ou nas atividades de retaguarda;

- outros.

\subsection{EMPRESA 4 (C4) - HOSPITAL-DIA}

\section{Dados da empresa}




\begin{tabular}{|c|c|}
\hline Faturamento anual da empresa: & $\mathrm{R} \$ 4.500 .000,00$ \\
\hline $\begin{array}{l}\text { Número de funcionários da } \\
\text { empresa: }\end{array}$ & 42 \\
\hline Funcionários terceirizados: & 55 \\
\hline Funcionários de TI da empresa: & Não há. Somente corporativo \\
\hline Funcionários de TI terceirizados: & 0 \\
\hline $\begin{array}{l}\text { Área de aplicação da TI estudada } \\
\text { que gera vantagem competitiva } \\
\text { para empresa: }\end{array}$ & $\begin{array}{l}\text { Sistema integrado de gestão do hospita- } \\
\text { dia. }\end{array}$ \\
\hline $\begin{array}{l}\text { Estratégia competitiva genérica e } \\
\text { escopo de atuação da empresa no } \\
\text { mercado: }\end{array}$ & $\begin{array}{l}\text { A empresa atua com escopo estreito, } \\
\text { atendendo especificamente a cirurgias de } \\
\text { pequeno e médio porte, oferecendo } \\
\text { serviços altamente diferenciados, tanto } \\
\text { para os médicos, quanto aos pacientes. }\end{array}$ \\
\hline
\end{tabular}

\section{Principais Características da Empresa}

C4 é uma empresa de origem nacional, que atua no país, como hospital há quatro anos. A empresa pertence a um grupo tradicional no segmento de análises clínicas e de diagnósticos por imagem.

A instituição oferece infra-estrutura especializada para realização de procedimentos cirúrgicos de baixa e média complexidade, para que transcorram com agilidade e total segurança para o paciente. Os procedimentos, em geral, demandam períodos curtos de internação.

O hospital-dia é um modelo de negócio que segue uma tendência de deshospitalização do setor da saúde. Cada vez mais a área de saúde conta com técnicas que agridem menos o organismo e, portanto, permitem um restabelecimento mais rápido e eficaz. Atualmente, em muitas cirurgias, é possível voltar para casa no mesmo dia, o que evita gastos desnecessários para o cliente e seu plano de saúde, além de diminuir o risco de infecção hospitalar.

Os principais clientes da empresa são os grandes planos de saúde e seguro saúde. Estes podem oferecer mais vantagens a seus associados, em função da flexibilidade e qualidade do atendimento. Por outro lado, contam com preços 
reduzidos, em função da estrutura enxuta, porém de alto padrão com equipamentos de última geração, oferecida pela empresa.

\section{Uso da TI}

O hospital-dia C4 foi inaugurado, originalmente, com todas suas operações de serviços, administrativas e relacionadas aos cuidados médicos, integrados em um único sistema. Os gestores da empresa contam com um sistema de inteligência de negócios que permite monitorar todas as operações de serviços em tempo real, via WEB.

Os procedimentos cirúrgicos são padronizados com base em protocolos definidos previamente pelos médicos cirurgiões. Assim, para cada procedimento, tem-se uma lista de todos os recursos necessários em um sistema. O sistema informa os materiais, medicamentos, instrumentais, equipes médicas, outros profissionais, conforme definido pelo médico e, com base nestas informações, realizam-se as operações de serviços.

Nas operações de serviços relacionadas ao centro cirúrgico, pode-se contar ainda com salas inteligentes com equipamentos que respondem ao comando de voz. Além disto, diversos monitores de vídeo além de apresentar os sinais vitais e outras informações referentes ao paciente no ato cirúrgico, apresentam também prontuário eletrônico do paciente. As salas contam ainda com câmeras digitais para gravação e transmissão das imagens e do áudio para um auditório na instituição ou para qualquer local via WEB.

\subsubsection{Formas de Contribuição da TI - Categorias}

\section{A - Sistemas estratégicos.}

- Sistema de gestão (inteligência nos negócios)

A empresa possui um sistema integrado que abrange todas as áreas da empresa, desde compra de insumos, agendamento, internação, faturamento, financeiro e outros. Juntamente com este sistema existe uma ferramenta de inteligência nos negócios que pode ser acessada inclusive via WEB, que facilita todo processo de gestão do hospital-dia.

A TI está presente em todas as áreas da empresa e foi implantada de uma só vez, desde a implantação do hospital-dia. Este fato favoreceu para que todos os 
processos fossem padronizados, minimizando a variabilidade nas operações de serviço. Os relatórios gerenciais permitem avaliar rapidamente o andamento do negócio e definir ajustes, otimizando a gestão.

Este modelo de organização propiciou maior produtividade e qualidade, permitindo flexibilidade na formação de preços, com uma oferta de serviços diferenciados. A TI contribuiu com o gerenciamento e controle dos recursos-chave da empresa. Contribuiu também para melhoria das especificações das tarefas, permitindo um aumento no índice de reprodução em série de uma mesma solução em serviços, além de aumentar o controle organizacional e o controle de custos.

B - Foco no cliente e no serviço

- Mapa de agendamento do centro cirúrgico

O centro cirúrgico utiliza um mapa de agendamento eletrônico que realiza todo processo logístico relacionado à cirurgia a ser realizada: reserva de sala, limpeza, insumos, solicitação de anestesistas, outros.

O sistema faz desde a reserva da sala, assim como dos equipamentos e materiais e equipamentos que serão utilizados. Cada médico cirurgião possui informações cadastradas (protocolos) sobre as condições que ele deseja para cada tipo de cirurgia. Nestes protocolos personalizados, também são incluídas informações sobre a fonte pagadora, as operadoras de saúde e quanto à cobertura de materiais e de medicamentos.

Além da personalização do atendimento aos médicos, muitos procedimentos, que fazem parte da cirurgia, são realizados na retaguarda, trazendo maior segurança e qualidade para a linha de frente. Nesta ficam apenas as operações de serviços essenciais, inerentes ao ato cirúrgico.

- Alta do paciente pelo anestesista, via informações do sistema

O médico cirurgião especifica alguns detalhes do paciente e da cirurgia no sistema e programa um horário para que um outro profissional médico observe o paciente e lhe dê alta.

O sistema informa aos médicos anestesistas de plantão contratados pelo hospital sobre os pacientes e os horários que deverão ser visitados. Os médicos plantonistas recebem a informação do sistema, analisam as recomendações e avaliam o paciente. Caso esteja tudo correto, o médico gera alta ao paciente. 
O procedimento é conveniente para o médico cirurgião, que não necessita retornar para liberar o paciente. Também é bom para o paciente que pode ser liberado no mesmo dia. Finalmente, é bom para o convênio que reduz custos de internação. O médico participa da especificação do serviço antes de utilizá-lo. Este fato adequa as características do hospital-dia às suas necessidades, além de tornar o atendimento mais flexível para os médicos e pacientes.

\section{C - Esforço contínuo de melhorias}

- Prontuário eletrônico do paciente / prescrição eletrônica

O prontuário eletrônico consolida as informações do paciente de todos os atendimentos realizados em qualquer data anterior. Estas informações são armazenadas em um banco de dados da empresa e podem ser acessadas a qualquer momento pelos médicos e pelo paciente. Os médicos podem ainda acessar o prontuário eletrônico via WEB, caso seja necessário.

O acesso às informações do paciente, no ambiente hospitalar, torna o processo mais ágil e seguro. O armazenamento das informações, a rastreabilidade, tudo é feito com mais confiança.

Conforme explicado anteriormente, têm-se diversas vantagens com 0 aumento da qualidade das informações, entre elas: as ferramentas à prova de falhas, eliminação de pedidos em duplicidade, outros. O prontuário eletrônico pressupõe a prescrição eletrônica, por si também traz muitas vantagens, entre elas a padronização do formato do prontuário, facilitando o entendimento das informações pelos outros profissionais da saúde, envolvidos no tratamento do paciente. Os procedimentos cirúrgicos são muito semelhantes e, neste caso, pode-se utilizar o preenchimento dos comandos, copiando de uma ficha para outra, facilitando o processo. Há circunstâncias em que esta operação ainda sofre restrições por parte dos médicos. Nestes casos, utiliza-se um profissional da saúde, em geral um enfermeiro ou um farmacêutico, para transcrever os dados. A TI contribui fundamentalmente nesta operação de serviços na produtividade e controle dos recursos-chave e também na melhoria das especificações das tarefas, permitindo sua repetição e, conseqüentemente, maior aprendizagem. 
O processo de internação é realizado pelo sistema da empresa, que avalia todos os dados do paciente, relacionados a questões administrativas e clínicas. A avaliação de admissão do paciente utiliza várias ferramentas à prova de falhas, relacionadas, por exemplo, à cobertura que o plano do paciente dá direito, sobre o quadro clínico do paciente e pré-requisitos para realizar os procedimentos de internação assim como cirúrgicos e outros.

Ao cadastrar o paciente no sistema, este envia informações a várias áreas da empresa para que se libere o kit de internação deste paciente.

Uma preparação antecipada conta com recomendações do médico do paciente, que estão contidas no mapa de agendamento do centro cirúrgico. O médico participa da especificação do serviço antes de integrá-lo. Conta, ainda, com informações do paciente e envolvem alguns medicamentos que serão utilizados durante o dia e inclusive sobre a alimentação, entre outros, contribuindo com a operação na linha de frente. Todas estas informações são enviadas automaticamente para a conta do paciente, em que se pode observar um melhor controle organizacional e de custos.

- Pré-faturamento eletrônico

O sistema recebe todas as informações do paciente desde o processo de admissão até a alta do paciente. Esta conta é auditada pela enfermeira da instituição antes de ser enviada eletronicamente para as operadoras.

O processo de pré-faturamento permite que se analisem eventuais falhas ou erros de lançamento nas contas dos pacientes, antes que a conta seja enviada à fonte pagadora. Com este processo, a conta do paciente pode ser fechada em minutos, facilitando a liberação do paciente no hospital-dia.

A TI contribui para aumentar a previsibilidade nesta operação, permitindo uma melhoria no índice de padronização e especialização e, provavelmente, da produtividade.

A TI coopera, ainda, para uma melhora no controle de custos da mão-de-obra e de outros recursos, mesmo quando existe uma complexidade de rotas que os clientes podem fazer no processo.

- Faturamento eletrônico e envio aos clientes (operadoras) 
O faturamento da empresa é realizado eletronicamente e enviado, via WEB, aos convênios.

A empresa conta com um fornecedor que oferece serviços de conectividade entre o hospital-dia e os convênios.

Esta operação reduz procedimentos em duplicidade como preenchimento de vários formulários: aumenta a transparência da operação, torna mais fácil o processo de envio e conferência das contas médicas; gera maior produtividade e qualidade para o hospital-dia e para quem recebe as informações, na medida em que produz e envia contas em um formato padronizado, que utilizou diversos mecanismos à prova de falhas. O sistema também traz um ganho importante para a contabilidade da empresa, que importa todos dados e consegue realizar o fechamento, a qualquer momento que desejar e em poucos minutos, sem a necessidade de inventários. Conforme explicado anteriormente, os mecanismos à prova de falhas são construídos com base nos acordos e exigências da fonte pagadora e, neste caso, minimizam erros de cobrança.

- Informações sobre kits para procedimentos cirúrgicos por médico

Os kits para procedimentos cirúrgicos (conjunto de materiais e medicamentos que serão utilizados em uma cirurgia) são montados com base nos protocolos do médico. Cada médico determina as regras relacionadas a materiais e a medicamentos que deverão ser utilizados, por tipo de paciente e por convênio.

Esta preparação antecipada do que será utilizado durante o ato cirúrgico, como, por exemplo, tipo de fio cirúrgico, permite com que o retrabalho de devolução à farmácia seja mínimo ou inexistente.

A TI permite estruturar as informações e dispô-las aos médicos e aos tipos de convênios, garantindo uma melhoria nas especificações das tarefas. Este fato racionaliza as operações de serviço de retaguarda em vários pontos, desde a farmácia, centro cirúrgico, faturamento, outros. Conforme explicado anteriormente, os kits são personalizados com base nas necessidades dos médicos, pacientes e convênios.

- Informações da consulta pré-anestésica 
Todos os dados do paciente, antes de sua admissão para os procedimentos cirúrgicos, são lançados na ficha pré-anestésica, que faz parte do prontuário eletrônico do paciente.

Estes dados serão acessados em diversas circunstâncias por várias outras áreas do hospital-dia: processo de internação, farmácia, enfermagem, centro cirúrgico, outros.

$\mathrm{Na}$ medida em que todas estas áreas acessam as informações, muitos problemas e dúvidas são resolvidos de forma mais ágil. Por parte do paciente, suas experiências nos serviços prestados, também ganham maior qualidade, pois ele percebe a segurança que o serviço está sendo desenvolvido. O modelo tradicional ainda adota cadernos ou blocos de anotações, em que só o médico anestesista tem conhecimento, o que pode causar diversos problemas, entre eles a falta de informações no momento adequado para a realização dos procedimentos. A TI contribui, em várias circunstâncias, que vão desde as especificações dos serviços por parte do paciente e do médico antes de se incorporar ao este, passando pela organização das tarefas na linha de frente, até o aumento da previsibilidade nas operações de serviços.

D- Otimização do processo empresarial (reengenharia do processo do negócio).

Obs. Este subitem será dividido em duas partes: reengenharia do processo do negócio e novos negócios gerados pela TI ou em processo de gestação.

\section{D1 - Reengenharia do processo do negócio}

- Sala cirúrgica inteligente

A TI permite que a organização e o controle do centro cirúrgico sejam otimizados, facilitando o trabalho dos profissionais da saúde e aumentando a produtividade dos serviços realizados.

As informações para organização das salas, desde a oferta de horário para as cirurgias até a higienização são integradas ao restante do hospital, facilitando a programação dos equipamentos e dos recursos humanos nesta área. Para tanto, ganha-se tempo entre uma cirurgia e outra com soluções como: equipamentos e papel suspensos, cabeamento embutido e braço mecânico para locomoção dos monitores. O controle de todos os equipamentos é realizado em um único monitor. Os equipamentos como mesa cirúrgica, foco, bisturi, entre outros podem ser 
acionados por comando de voz. A TI ainda informa os períodos de manutenção preditiva, que deverão ser realizados nos equipamentos. Além destas vantagens, ainda pode-se contar com vários geradores de sinal, como: câmera endoscópica, câmera de sala, raios-X, ultra-som, que transmitem as informações aos monitores na sala cirúrgica e até para o auditório da instituição ou para outros locais, via WEB. As filmagens são gravadas em DVD; os cirurgiões saem levando a mídia e a cirurgia fica protocolada, conferindo maior segurança ao processo.

A TI contribui para facilitar a avaliação da qualidade dos serviços prestados e também para que associe seu uso como sinônimo de maior diferenciação. Em relação à eficiência das operações, a TI permite também que se aumente o índice de procedimentalização.

D2 - Novos negócios gerados pela TI ou em processo de gestação

- Sala cirúrgica inteligente (transmissão de imagens)

A sala cirúrgica inteligente conta com toda a infra-estrutura para transmissão dos procedimentos cirúrgicos em tempo real, além de equipamento para gravação das imagens em DVD.

As imagens e procedimentos poderão servir para DVDs educativos na área da saúde ou ainda para transmissão de cirurgias em tempo real para instituições de ensino ou outras instituições de saúde. Por fim, pode-se utilizar a TI, para realizar segunda opinião médica, durante o ato cirúrgico.

Na mesma linha que o item anterior, a TI contribui para facilitar a avaliação da qualidade dos serviços prestados e também para que associe seu uso como sinônimo de maior diferenciação. Além disto, pode-se flexibilizar a capacidade operacional com as variações da demanda e ampliar as fontes de flexibilização de serviços, atendendo pacientes a distância.

\section{E - Redes de valor e alianças entre empresas}

- Relacionamento com parceiros

O sistema da empresa que integra o almoxarifado está interligado com a farmácia que também está interligado ao agendamento e ao setor de compras. Com isto, a empresa informa a seus fornecedores, em tempo real, a demanda por serviços e insumos. 
Os fornecedores de materiais, medicamentos e serviços médicos e de apoio, recebem informações relacionadas à demanda do hospital-dia e, com isto, atendem prontamente as solicitações. A velocidade das informações permite que toda a cadeia opere com estoques mínimos e com estimativa da demanda bastante próxima da realidade.

A TI possibilita flexibilizar o tempo, o local e a posse entre os participantes desta rede na saúde, na medida em que consente que todos possam contar com informações da última camada de demanda, que é o paciente. As vantagens se estendem até os controles de recurso-chave de cada participante, permitindo que otimizem a capacidade produtiva, flexibilizem a capacidade operacional e finalmente tenham custos menores.

- Rede interna de informações e inteligência do negócio

A rede interna de informações e inteligência do negócio é um sistema que recebe informações de processos de cada profissional (verticalização do conhecimento) em sua área específica, para que seja disseminada para toda a empresa.

Todas estas informações colhidas são dispostas horizontalmente, apresentando a todos os colaboradores de que forma suas atividades vão repercutir nas atividades dos outros colaboradores.

Estes ações aprimoram o processo de conhecimento da empresa e criam maior sinergia entre as áreas. Por exemplo, a enfermeira, que irá conhecer o módulo de centro cirúrgico, de internação, da solicitação de materiais, de todos os módulos que ela vai usar dia-a-dia. Esta enfermeira irá entender os outros módulos e a estratégia que a empresa está desenvolvendo. Além do processo educativo que está sendo reforçado, esta pessoa passa a ser uma auditora interna, que pode auditar outras áreas. Estas informações e conhecimento sobre a empresa devem gerar maiores oportunidades de melhoria no dia-a-dia, racionalizando operações e permitindo que os funcionários dediquem maior tempo aos clientes (médicos e pacientes).

F - Comércio eletrônico e redes de informação

- Compra de insumos sobre demanda 
Os fornecedores recebem eletronicamente informações, via WEB, sobre o nível de estoques do hospital-dia e também a solicitação de pedidos de itens específicos que não fazem parte do estoque básico da empresa.

Os fornecedores recebem os pedidos e realizam o faturamento eletrônico com base na solicitação recebida via $W E B$, sem necessidade de papéis ou confirmações por telefonemas ou fax. O processo de precificação dos insumos é realizado com base na última cotação, que é atualizada trimestralmente.

Ao atualizar os dados, as cotações são comparadas às de outros fornecedores pré-qualificados para também atender as solicitações da empresa. Neste caso, o sistema informa para qual fornecedor o pedido deverá seguir, com base nas melhores condições propostas e consegue ainda manter o estoque com um baixo volume.

\subsubsection{Outras Considerações}

Conforme a empresa pesquisada, cem por cento das prescrições realizadas na instituição são realizadas eletronicamente, porém nem sempre é o médico cirurgião quem a realiza neste formato. Em alguns casos, outros profissionais da saúde, como enfermeiros e farmacêuticos, fazem a transcrição do que foi prescrito pelo médico no prontuário convencional. O que se percebe é que a natureza do relacionamento do cirurgião com o hospital se restringe ao ato cirúrgico, ou seja, o cirurgião realiza os procedimentos e finaliza o vínculo naquele momento, quando não há internação. Observou-se que outros médicos da instituição, por exemplo, anestesistas, que têm um vínculo maior com a instituição e cuja atividade envolve um número maior de procedimentos administrativos, têm maior adesão ao uso da TI.

O processo de aculturação dos médicos com as ferramentas de TI tem sido lento. Uma rotina, por exemplo, na oncologia, para preenchimento do prontuário eletrônico no sistema, apresenta uma complexidade diferente de procedimentos pediátricos mais simples. Um médico pode optar fazer dez a doze casos seguidos e, depois, preencher o prontuário. Neste ato, há limitações do sistema para que ele faça um a um, o que impede o médico de parar a cada caso. O que se percebe é que o tempo dos médicos varia. Médicos clínicos que atendem em consultório apresentam um perfil de utilização diferente de um cirurgião, que, por sua vez, é diferente de um anestesista. 
Mesmo com problemas, houve um grande esforço de treinamento no processo de implementação da $\mathrm{TI}$ na empresa. Os funcionários do setor administrativo e os profissionais da saúde, envolvendo enfermeiros, farmacêuticos e inclusive médicos, diretamente relacionados com o negócio, rapidamente assimilaram as vantagens da TI, entretanto o problema maior tem se apresentado na adesão dos médicos externos à instituição. As pessoas envolvidas percebem rapidamente as vantagens de se trabalhar de forma integrada. As vantagens de demonstrar o conhecimento individual de cada área ampliam o conhecimento da instituição e, depois, ao apresentar este conhecimento horizontalizado para todos, permitem-se ganhos importantes na cadeia de valor da empresa, conforme se constatou.

Com todas estas características, ainda se percebe que existe uma forte tendência dos profissionais de saúde, em especial profissionais de destaque, em valorizar a humanização do tratamento, em detrimento da TI. A alegação de que o paciente não sabe e não precisa saber das vantagens da TI, que o mais importante é a humanização do processo, ficou constatada em várias situações durante o estudo de caso. Por outro lado, também se percebeu que o médico cirurgião, que também é um importante cliente da instituição, tem sido fortemente informado sobre as vantagens da $\mathrm{Tl}$ e da segurança que esta implementação pode gerar e isto tem aumentado o poder de barganha da instituição.

\subsubsection{Resumo da Análise de C4}

A TI criou valor (eficiência e/ou eficácia) em diversas circunstâncias, entre elas, podem-se citar:

- integrando operações de serviço, propiciando otimização da gestão;

- oferecendo soluções personalizadas para os médicos nos processos cirúrgicos;

- programando a alta dos pacientes, otimizando capacidade produtiva;

- disponibilizando acesso à Internet a pacientes e médicos;

- permitindo prescrição eletrônica, prontuário eletrônico e disponibilização de informações via WEB;

- integrando processo de internação de pacientes; 
- realizando pré-faturamento eletrônico, minimizando eventuais falhas e erros de lançamento de dados nas contas dos pacientes;

- faturando eletronicamente;

- personalizando e padronizando kits para procedimentos cirúrgicos por médicos;

- prevenindo falhas na operação de serviços, por meio da disponibilização de ficha eletrônica pré-anestésica, para o ato cirúrgico e outros procedimentos necessários;

- automatizando o controle de equipamentos na sala cirúrgica;

- transmitindo imagens e fazendo gravações digitais dos procedimentos no centro cirúrgico;

- interligando parceiros: fornecedores e prestadores de serviço em geral;

- criando rede de informações interna, aumento do conhecimento sobre o negócio;

- automatizando a compra de insumos;

- outros.

Por que a TI cria valor? As respostas foram diversas, mas observou-se uma maior incidência do ponto de vista da eficácia, nas seguintes circunstâncias:

- contribuindo para que o cliente participe das especificações dos serviços;

- flexibilizando as operações de serviços;

- aumentando a diferenciação dos serviços oferecidos;

- personalizando o atendimento aos pacientes e médicos;

Do ponto de vista da eficiência, observou-se que a TI teve maior contribuição nas seguintes circunstâncias:

- aumentando o gerenciamento e controle dos recursos-chave;

- melhorando as especificações das tarefas;

- aumentando o índice em reprodução em série de uma mesma solução.

Quadro 10 - Resumo da Análise de C4

\subsection{EMPRESA 5 (C5) - LABORATÓRIO DE ANÁLISES CLÍNICAS E DIAGNÓSTICO POR IMAGEM}


Dados da empresa

\begin{tabular}{|c|c|}
\hline Faturamento anual da empresa: & $\mathrm{R} \$ 400.000 .000,00$ \\
\hline $\begin{array}{l}\text { Número de funcionários da } \\
\text { empresa: }\end{array}$ & 2.000 \\
\hline Funcionários terceirizados: & 400 \\
\hline Funcionários de TI da empresa: & 60 \\
\hline Funcionários de TI terceirizados: & 20 \\
\hline $\begin{array}{l}\text { Área de aplicação da TI estudada } \\
\text { que gera vantagem competitiva } \\
\text { para empresa: }\end{array}$ & $\begin{array}{l}\text { Não se estudou uma área específica, mas } \\
\text { várias ferramentas, em que a empresa } \\
\text { utiliza a TI, tanto para atender melhor o } \\
\text { cliente, aumentando a percepção de } \\
\text { benefícios dos serviços prestados, como na } \\
\text { redução de custos e controles em geral. }\end{array}$ \\
\hline $\begin{array}{l}\text { Estratégia competitiva genérica e } \\
\text { escopo de atuação da empresa no } \\
\text { mercado: }\end{array}$ & $\begin{array}{l}\text { A empresa atua no mercado de prestação } \\
\text { de serviços de saúde de alto padrão, } \\
\text { enfocando em diferenciação. }\end{array}$ \\
\hline
\end{tabular}

\section{Principais Características da Empresa}

C5, empresa fundada há mais de 80 anos, atua nos mercados nacional e internacional de forma diferenciada, no setor de análises clínicas e por imagem entre outros negócios. É um dos maiores e mais complexos laboratórios de análises clínicas e por imagem do país.

A empresa se embasou como um dos seus preceitos éticos, de não estimular a demanda. Seu lema, em todas as frentes que atua são a saúde e a qualidade de vida aos seus usuários. Sua atuação se pautou pela qualidade nos serviços prestados, juntamente com o relacionamento e o atendimento personalizado, sendo estas principais formas das empresas se apresentarem ao mercado.

A empresa conta com um quadro de cerca de 300 profissionais médicos contratados, que contribuem fundamentalmente para dar retaguarda à estratégia de qualidade e à infra-estrutura. A equipe assessora profissionais médicos em todo o país no que se refere aos tipos de exames oferecidos e, inclusive, na interpretação dos resultados. 
Seus principais clientes são os planos de saúde, as seguradoras, as cooperativas e as autogestões. Além da prestação de serviços para os clientes acima descritos, também mantém unidades hospitalares, prestando serviços diagnósticos em exames de análise clínicas e por imagem, em grandes hospitais do país e também atende a mais de 700 laboratórios, espalhados pelo país. A empresa mantém outras unidades de negócios na área da saúde, como pesquisa clínica e serviços de promoção à saúde. O faturamento anual de C5 é cerca de R\$400 milhões por ano.

\section{Uso da TI}

A TI tem um papel importante e está totalmente alinhada com a estratégia da empresa. Conforme explicado, tanto sob o ponto de vista da qualidade, como das questões relacionadas com produtividade, a TI está sempre relacionada. A empresa apresenta diversas ferramentas, buscando a eficácia e a eficiência.

Desde a humanização no atendimento aos pacientes, automação de processos, segurança, confidencialidade e disponibilidade nas informações entre outros, até na gestão do negócio, tudo está fortemente apoiado pela TI, nesta empresa.

A empresa possui técnicas avançadas para processamento e análise de exames. Oferece soluções, via WEB, para pacientes e médicos, facilitando o contato entre estes públicos. Também dispõe de ferramentas modernas de TI, para apoio à decisão na avaliação dos resultados de exames, a qual amplia ainda mais a qualidade de seus serviços.

\subsubsection{Formas de Contribuição da TI - Categorias}

A - Sistemas estratégicos.

- Aumento da diferenciação (maior benefício) nos serviços prestados aos pacientes, médicos, fonte pagadora, fornecedores e outros clientes pessoa jurídica.

O uso da TI permite que a empresa apresente maior diferenciação a seus diferentes públicos de interesse: pacientes, médicos, convênios, fornecedores, clientes jurídicos (laboratórios, institutos de pesquisa, outros). A diferenciação 
abrange diversos aspectos que vão desde a velocidade de resposta a seus clientes até a forma com que as informações são encaminhadas e apresentadas.

A empresa utiliza as mais variadas ferramentas de TI que contribuem para estreitar o relacionamento com clientes, reduzir custos de transação, aumentar a confiabilidade nos serviços prestados, entre outros. O composto de serviços que utilizam a TI é amplo e aborda desde a apresentação de resultados via WEB, passando pela gestão logística e o controle de agendamento de exames, estendendo-se a sistemas complexos de apoio à decisão na análise de resultados de exames, utilizando algorítimos, entre outros.

As ferramentas de TI utilizadas pela empresa dão retaguarda à sua estratégia de diferenciação em diferentes circunstâncias, entre elas: contribuindo com que o paciente e o médico particípe da especificação do processo de serviços, antes de incorporar-se a este processo; adequando sua estrutura operacional de acordo com a necessidade dos pacientes; flexibilizando o atendimento do cliente em relação ao tempo, ao local e a posse de seus serviços, reduzindo custos de transação para pacientes e médicos; aumentando o relacionamento com pacientes, médicos, fornecedores e parceiros; demonstrando maior capacidade tecnológica, enfim envolve um conjunto de elementos da TI, gerando maior diferenciação para empresa. No campo da eficiência, a empresa também utiliza a TI de forma bastante satisfatória. Podem-se citar as seguintes vantagens: maior controle da produtividade, gerenciamento e controle dos recursos-chave, melhorando as especificações na linha de frente e da retaguarda, aumentando as possibilidades de aprendizagem; padronizando operações; procedimentalizando e gerando maior qualidade; controlando os custos da mão-de-obra e outros recursos; otimizando a capacidade produtiva e flexibilizando as operações.

\section{B - Foco no cliente e no serviço}

- Instruções personalizadas para o cliente

$\mathrm{O}$ ato do agendamento dos exames é suportado por um sistema que interrelaciona os dados e gera um relatório, que são as instruções para o paciente realizar os exames. Itens como: local, sala, data, horário, preparo para cada exame, entre outros devem constar neste relatório. 
As instruções personalizadas para o cliente são enviadas por telefone ou por e-mail no ato do agendamento e, depois, são confirmadas na véspera do exame, por telefone, e-mail ou por SMS.

O sistema de agendamento permite a participação do paciente na especificação do processo de serviço e também flexibiliza o atendimento com base nos requisitos deste paciente, podendo proceder a execução desta operação pelo telefone ou pela Internet e inclusive confirmar via SMS. O uso da TI melhora o relacionamento e a lealdade dos clientes na medida em que possibilita resolver os problemas dos clientes ao adequar suas necessidades diárias à agenda proposta. A TI contribui fortemente para a especificação das tarefas, melhorando o índice de reprodução em série de uma mesma solução e ainda flexibiliza a capacidade operacional em prol da demanda.

- Central de atendimento telefônico, ou via Internet, para assessoria a médicos em todo o país.

A equipe de médicos da empresa realiza um serviço de assessoria a outros profissionais médicos de todo o país.

O suporte destes profissionais é realizado por meio de uma central telefônica e também pela Internet (e-mail) e contribui para esclarecer dúvidas sobre tipos de exames, sobre a necessidade de solicitar outros exames e outros serviços oferecidos pela empresa e também sobre a interpretação de resultados dos exames.

O trabalho realizado pela central é uma espécie de apoio a distância aos médicos, flexibilizando o atendimento para eles. Com o tempo, as recomendações e trocas de informações criam um vínculo maior e na medida em que o serviço colabora para resolver os problemas, aumenta a lealdade do médico com a empresa. A empresa, para tanto, desenvolve roteiros para interface com os médicos, reproduzindo em série uma mesma solução.

\section{C - Esforço contínuo de melhorias}

- Central data center com informações dos clientes

A empresa mantém um data center que consolidada as informações dos clientes de todas as unidades da empresa. Cada cliente tem um cadastro unificado, independentemente de onde ele for acessado, pois o sistema inibe que sejam abertas outras fichas. 
Todas as unidades, inclusive os hospitais têm abertura de fichas e alguns dados de internações em tempo real. Os resultados dos exames e outras informações do paciente, como alergia, contra-indicações com contrastes, outros, podem ser observados em qualquer unidade, caso haja necessidade do médico ou de outro profissional da saúde.

A centralização das informações de todos os clientes em um banco de dados unificado permite maior flexibilidade ao cliente e à operação. Com isto, torna-se desnecessário o preenchimento de documentos quando o paciente for atendido pela segunda vez em unidade diferente da primeira. Assim, ganha-se tempo para o cliente e para o laboratório. O banco de dados permite que se personalize o atendimento, quanto ao nome do paciente e às suas preferências em geral e também em relação às contra-indicações, com medicamentos e outros. Com isto, tem-se maior produtividade e controle dos recursos da instituição, eliminando procedimentos desnecessários e riscos ao pacientes.

- Comunicação com parceiros (clientes, fornecedores), utilizando voz sobre IP.

O sistema de comunicação da empresa com seus parceiros é totalmente estruturado no sistema de voz sobre IP.

Esta opção de comunicação tem gerado uma economia substancial para esta empresa de diagnóstico e para toda sua rede de mais de 700 laboratórios terceirizados e também um grande número de fornecedores, que se relacionam diariamente.

O sistema adotado reduz fortemente as despesas com telefonia na empresa.

- Call Center (central de atendimento telefônico)

O Call Center tem uma função importante nos relacionamentos com seus parceiros e clientes no que se referem às reclamações, aos elogios, às dúvidas, aos pedidos, e às outras operações de serviços de retaguarda.

O Call Center subdivide suas operações em marcação de exames e resultados dos exames. O cliente marca o exame e depois recebe um relatório com as instruções personalizadas, via e-mail ou telefone. Os resultados dos exames são fornecidos via e-mail, ou telefone, ou ainda, impresso, se o cliente desejar. As informações sobre preparo para os exames seguem em um relatório de instruções personalizadas e são enviadas por telefone e e-mail. 
O sistema utiliza várias ferramentas à prova de falhas: primeiro, para marcar corretamente os exames e, segundo, para ter certeza de que o cliente compareça aos locais de exames, conforme protocolos preestabelecidos. Variáveis como: peso, sexo, idade, e diversas outras regras, são parametrizados no sistema, evitando que se encaminhe um paciente, que não tenha pré-requisitos ou não tenha autorização para um determinado exame. Um novo aviso, na véspera do exame ou $48 \mathrm{~h}$ antes, por telefone, e-mail ou SMS, é enviado, confirmando os horários marcados e os preparos necessários para o exame, para que ele não perca a data do exame ou para não precise voltar outro dia, porque, porventura, tenha se esquecido de vir em jejum. Estas ferramentas à prova de falhas evitam perda de tempo para o cliente e desperdício da capacidade produtiva para a empresa. Todo o trabalho de retaguarda, utilizando a $\mathrm{TI}$, permite que as operações de linha de frente realizem apenas o indispensável em relação ao contato com o cliente. Este fato minimiza os efeitos da imprevisibilidade das operações de linha de frente.

- Sistema de agendamento de exames, sincronizando operações de serviços para atendimento do cliente.

O uso da TI no sistema de agendamento é indispensável, pois envolve uma rede complexa de operações, que devem estar sincronizadas, para atender o cliente com qualidade.

Além das questões do preparo dos pacientes, o agendamento deve considerar toda a logística para que o cliente possa realizar um conjunto de exames, geralmente mais do que cinco em um mesmo dia.

Os exames têm preparos específicos e demandam equipamentos e profissionais diferentes, tornando o conjunto de variáveis enorme. As informações realizam os bloqueios de sala, requisitam os insumos que serão utilizados, escalam os profissionais e ajustam os horários para o exame, entre outros. Como a empresa oferece mais de 2000 tipos de exames diferentes, a complexidade do sistema e a quantidade de ferramentas à prova de falhas que estão embutidas, para minimizar os erros, torna-se fundamental para a qualidade do serviço. Tudo isto contemplado permite que o paciente realize os exames, com o menor tempo de espera possível. Assim, o sistema de agendamento, utilizando a TI, propicia vantagens de várias formas: permitindo que o paciente participe da especificação do serviço; flexibilizando o atendimento com base nos requisitos do cliente relacionados a 
tempo; pré-selecionando os pacientes para compreender melhor suas expectativas; controlando os recursos-chave da empresa; controlando os custos; adequando a capacidade produtiva; flexibilizando o trabalho das equipes envolvidas no processo de prestação de serviços; outros.

- Gestão de exames (diagnóstico por imagem) e entrega de resultados aos pacientes pela Internet ou em CDs.

A empresa possui um sistema de armazenamento e distribuição de imagens de exames. Os exames que envolvem diagnóstico por imagem são os seguintes: ultra-sonografia, raios- $X$, tomografia e ressonância.

Os resultados dos exames são enviados aos pacientes via WEB. Os exames que contêm diagnóstico por imagem seguem apenas com imagens ilustrativas via WEB, pois não servem para fim diagnóstico. Neste caso, as imagens são fornecidas em $C D$, em função do tamanho dos arquivos. $O$ paciente retira o $C D$ com os resultados e leva até o médico.

Com a entrega dos resultados dos exames pela Internet, é flexibilizado o atendimento do paciente em relação a tempo e a local de entrega dos exames. $\mathrm{O}$ sistema facilita o diagnóstico, reduzindo custos e aumentando a produtividade, pois se podem comparar os exames de maneira rápida. A automação da entrega dos exames também contribui para redução de custos dos recursos humanos, de papel, correio, entre outros.

D- Otimização do processo empresarial (reengenharia do processo do negócio).

Obs. Este subitem será dividido em duas partes: reengenharia do processo do negócio e novos negócios gerados pela TI ou em processo de gestação.

D1 - Reengenharia do processo do negócio.

- Sistema de apoio à decisão (uso de algoritmos para simulação do raciocínio médico)

Uso da TI em um sistema de apoio à decisão que, por meio de algoritmos, simula o raciocínio médico e contribui para a qualidade do serviço prestado.

Algumas patologias, associadas à idade e a sexo do paciente, entre outras variáveis, sugerem hipóteses de resultados de exames. Esta lógica geralmente faz parte dos conhecimentos dos profissionais médicos que, com sua experiência, inter- 
relacionam os dados sobre o paciente. $\mathrm{Na}$ medida em que um exame apresenta resultados fora do previsto, considera-se o histórico do paciente. Envia-se uma informação ao médico que contribui para seu raciocínio em relação ao caso. Desta forma, pode-se solicitar um novo exame, confirmando o primeiro, um outro exame, abordando outro aspecto correlacionado ao problema ou, ainda, até encaminhar a um especialista. Qualquer uma destas alternativas busca reduzir erros e aumentar a qualidade do resultado final para o paciente.

O sistema de apoio à decisão contribui para que se desenvolva relacionamento entre o médico e equipes de funcionários do laboratório. Na medida em que estes contribuem para solucionar os problemas do médico, aumenta-se a lealdade com a empresa.

- Laudo evolutivo via WEB.

O laudo evolutivo, via $W E B$, é uma ferramenta que permite que todos os resultados de exames realizados pelo paciente (nesta ou em outras instituição) sejam disponibilizados em um banco de dados que pode ser acessado via WEB, mediante uma senha.

As informações são consolidadas em um relatório e apresentadas em ordem cronológica. Os resultados são apresentados em gráficos, que facilitam ainda mais a leitura da evolução do quadro do paciente. Os acessos são da ordem de 10.000 por dia e apresentam uma curva ascendente desde que foi instituída esta ferramenta.

A TI contribui para flexibilizar a entrega com base nos requisitos do cliente em relação a tempo e a local e também contribui para reduzir despesas da empresa. Além da redução de despesas com papel e com o envio dos resultados pelo correio, a satisfação do cliente com a facilidade de acesso aos resultados e todo aparato tecnológico é facilmente observada.

D2 - Novos negócios gerados pela TI ou em processo de gestação.

- Bioinformática - software para análise do seqüenciamento de DNA

Sistema para leitura e análise automática de exames da área de biologia molecular (seqüenciamento de DNA). Esta área que se preocupa com o estudo da estrutura biológica do indivíduo vem substituindo algumas formas tradicionais de diagnóstico (Genômica). 
Os exames realizados pelo processo convencional, sem o uso de software, demandam esforços dos analistas de cerca de 30 minutos, para se realizar a leitura e a interpretação do exame manualmente. Com o processo automatizado, além de aumentar a qualidade dos resultados, aumenta-se significativamente a produtividade, reduzindo o tempo do exame para 20 segundos. Ao se desenvolver neste campo, a empresa entra em um novo segmento, que foca prioritariamente a prevenção na saúde.

O sistema contribui para aumentar a produtividade da mão-de-obra e de equipamentos da empresa. A automação dos processos otimiza a capacidade produtiva da mão-de-obra especializada da empresa.

- Sistema para prevenção na saúde - questionário inteligente.

Uso da TI por meio de um questionário inteligente, desenvolvido para mapear o estado da saúde de empresas.

O questionário inteligente é suportado por algoritmos que realizam uma série de análises para realizar um diagnóstico de uma determinada população, do ponto de vista da saúde.

A utilização do questionário inteligente flexibiliza o atendimento do paciente ou médico com base em seus requisitos de tempo e local.

- Laudo evolutivo via WEB.

Este item faz parte da categoria D1 - Reengenharia do processo do negócio, porém com a inclusão de resultados de exames de outras instituições, pode-se criar um novo negócio para ser explorado futuramente.

$E$ - Redes de valor e alianças entre empresas.

- Gestão das informações em tempo real

$\mathrm{O}$ uso da TI permite que se obtenham informações sobre a quantidade de fichas abertas por unidade, movimento das unidades e outras informações que podem ser comparadas com o orçado e permite, ainda, que se faça um rebalancemento nas operações do grupo. Também se podem realizar algumas consultas de informações específicas sobre pacientes, médicos ou exames, que contribuem para tornar o processo mais transparente e ágil. 
Com as informações disponíveis em vários níveis, podem-se fazer ajustes rápidos nas operações de serviços, evitando desperdícios como capacidade ociosa das unidades ou filas, comprometendo a qualidade dos serviços, por exemplo.

A TI permite uma maior flexibilidade nas operações de serviços ao dispor as informações em tempo real permitindo que se tomem decisões de forma mais ágil. As decisões mais ágeis aumentam a produtividade, gerenciamento e o controle dos recursos-chave da empresa (recursos humanos e equipamentos). Pode-se, para tanto, obter ganhos com a otimização da capacidade produtiva e com a flexibilização da capacidade operacional, adequando oferta à demanda.

- Extranet.

A empresa mantém uma extranet que possibilita contato com todos seus parceiros: laboratórios (cerca de 700), hospitais, indústria farmacêutica e fornecedores em geral.

A maior parte da comunicação da empresa é realizada pela extranet. Em função das facilidades e baixo custo deste canal e do uso intenso tem-se excelentes resultados em relação à qualidade do fluxo de informações e da produtividade.

A flexibilidade da extranet na troca de informações entre os participantes de uma rede de valor, faz com que haja vantagens a todos os participantes. As vantagens se referem à velocidade de respostas em um ambiente onde há um grande número de prestadores de serviços que desenvolvem operações de serviços de forma interdependente. Juntamente a estas facilidades, podem-se acrescentar os custos reduzidos desta ferramenta em relação aos resultados que se proporciona.

- Pesquisa clínica, utilizando a TI para reduzir custos de transação.

O aparato para desenvolvimento e testes faz parte do dia-a-dia da empresa, porém o fato que permitiu a empresa entrar neste novo negócio foram os baixos custos de transação, proporcionados pela TI.

A empresa testa protocolos para medicamentos novos da indústria farmacêutica, para o produto entregue (dados estatísticos) intenso de informação, porém facilmente entregues via WEB.

Como a empresa possui competência técnica e capacidade instalada para realizar exames de diagnóstico, a TI permitiu que a parceria se efetivasse na medida 
em que os serviços podiam ser entregues eletronicamente a milhares de quilômetros de distância, via WEB.

F - Comércio eletrônico e redes de informação.

- Equipamento móvel para atendimento domiciliar

O equipamento móvel para atendimento domiciliar permite que se leve uma infra-estrutura de qualidade, para atender o paciente em um ambiente reservado (casa ou na empresa).

O conjunto de equipamentos é composto por um notebook com acesso online, possibilitando acesso à ficha do paciente e ao lançamento de dados, à impressora com código de barras, a recibos e à possibilidade de pagamento on-line entre outros.

Além de atender pacientes que não podem locomover-se, esta opção também garante ao cliente a realização de exames de forma totalmente privativa.

- Site com Informações sobre saúde em geral

Site com informações sobre saúde em geral. O público-alvo é prioritariamente os profissionais médicos, mas também é consultado por pacientes.

O laboratório desenvolve e disponibiliza um vasto conteúdo sobre saúde, entre eles, podem-se citar: artigos, aulas multimídia, e outros. Além da produção interna, a empresa realiza parcerias com outras instituições na produção de conteúdo.

Esta ferramenta permite que a empresa desenvolva institucionalmente sua marca no mercado, além de informar seus produtos e serviços oferecidos.

\subsubsection{Outras Considerações}

Mais uma vez se identificou que diversos benefícios, utilizando a TI, que são utilizados tanto na linha de frente quanto nas operações de serviços de retaguarda e que aumentam a qualidade, a segurança e reduzem os custos, tornando alguns exames viáveis, não são de conhecimento dos clientes no geral. Alguns destes benefícios são apenas apresentados aos médicos e instituições. Esta é uma lacuna que se observa no que se refere à educação e à sofisticação dos pacientes-clientes, também neste segmento. 


\subsubsection{Resumo da Análise de C5}

A TI criou valor (eficiência e/ou eficácia) em diversas circunstâncias, entre elas, podem-se citar:

- aumentando o benefício nos serviços prestados aos pacientes, médicos e fornecedores em geral;

- personalizando os serviços (agendamento e instruções específicas por paciente);

- assessorando outros profissionais médicos (pós-venda);

- melhorando as operações de serviços por meio da consolidação, centralização e disponibilização das informações dos clientes;

- racionalizando despesas de comunicação em geral;

- apoiando operações de retaguarda, atenuando o contato na linha de frente de atendimento;

- $\quad$ sincronizando operações para melhorar a prestação de serviços ao cliente e também otimizar a capacidade operacional;

- reduzindo custos de transação via entrega de serviços pela WEB;

- fornecendo sistemas de apoio à decisão, aumentando a qualidade dos serviços prestados;

- ampliando os benefícios dos clientes com alternativas para recebimento e acompanhamento dos serviços recebidos;

- desenvolvendo ferramentas que aumentam a produtividade e também a qualidade e permitem que a empresa ingresse e permaneça em novos negócios;

- minimizando o efeito da perecibilidade de serviços, adequando a oferta de serviços da empresa e a demanda de mercado;

- viabilizando a entrada em novos mercados, inclusive fora do país;

- flexibilizando o atendimento de pacientes em domicílio ou fora das instalações da empresa;

- informando e causando interação com pacientes, médicos e clientes em geral, via WEB;

- outros. 
Por que a $\mathrm{Tl}$ cria valor? As respostas foram diversas, mas observou-se uma maior incidência do ponto de vista da eficácia, nas seguintes circunstâncias:

- permitindo que pacientes e médicos participem das especificações do processo de serviços antes de se incorporar a este;

- adequando sua estrutura operacional de acordo com a necessidade dos pacientes;

- flexibilizando o atendimento do cliente em relação ao tempo, ao local e da posse de seus serviços, reduzindo custos de transação para pacientes e médicos;

- aumentando o relacionamento com pacientes, médicos, fornecedores e parceiros;

- demonstrando maior capacidade tecnológica.

Do ponto de vista da eficiência, observou-se que a TI teve maior contribuição nas seguintes circunstâncias:

- aumentando a produtividade, gerenciamento e controle dos recursoschave;

- melhorando as especificações das tarefas na linha de frente e da retaguarda, ampliando as possibilidades de aprendizagem;

- aumentando a previsibilidade das operações, permitindo aumento de padronização;

- procedimentalizando e gerando maior qualidade;

- controlando os custos da mão-de-obra e outros recursos;

- otimizando a capacidade produtiva e flexibilizando as operações.

Quadro 11 - Resumo da Análise de C5

\subsection{EMPRESA 6 (C6) - EMPRESA DE SERVIÇOS MÉDICOS}

\section{Dados da empresa}

\begin{tabular}{|l|r|}
\hline Faturamento anual da empresa: & $\mathrm{R} \$ 1.500 .000,00$ \\
\hline $\begin{array}{l}\text { Número de funcionários da } \\
\text { empresa: }\end{array}$ & 30 \\
\hline Funcionários terceirizados: & 150 \\
\hline Funcionários de TI da empresa: & 1 \\
\hline
\end{tabular}




\begin{tabular}{|l|l|}
\hline Funcionários de TI terceirizados: & \\
\hline $\begin{array}{l}\text { Área de aplicação da TI estudada } \\
\text { que gera vantagem competitiva } \\
\text { para empresa: }\end{array}$ & $\begin{array}{l}\text { Gerenciamento de custos e de recursos } \\
\text { para empresa do setor da saúde (terceiros), } \\
\text { utilizando mapeamento de risco (softwares) } \\
\text { e outras ferramentas de intermediação de } \\
\text { transações comerciais. A empresa também } \\
\text { presta serviços de cuidados à saúde em } \\
\text { especial para internação domiciliar. }\end{array}$ \\
\hline $\begin{array}{l}\text { Estratégia competitiva genérica e e e } \\
\text { mercado: }\end{array}$ & $\begin{array}{l}\text { A empresa desenvolve suas atividades na } \\
\text { cidade de São Paulo, no setor da saúde. A } \\
\text { TI, associada à forma de conduzir seus } \\
\text { negócios e os trabalhos permite que a } \\
\text { mesma atue com enfoque em custos. }\end{array}$ \\
\hline
\end{tabular}

\section{Principais Características da Empresa}

C6, uma empresa recente no mercado, iniciou suas atividades em 2005. Seus sócios são remanescentes de empresas do setor da saúde, onde desenvolveram atividades por mais 15 anos.

A empresa conta, no momento, com trinta funcionários contratados e cerca de 150 prestadores de serviços da saúde (médicos, enfermeiros, fisioterapeutas, fonoaudiólogos, outros) terceirizados.

É uma empresa especializada em gerenciar custos e recursos na saúde, por meio de ferramentas de mapeamento de riscos e gerenciamento de condições crônicas (softwares).

Além do gerenciamento, a empresa também realiza atividades relacionadas a cuidados médicos em hospitais e em internações domiciliares. Este serviço é decorrente dos diagnósticos realizados pela empresa que também utiliza fortemente a TI para serem operacionalizados e controlados.

A empresa ainda oferece um serviço de consultoria, em que é feita uma análise dos sinistros, ou seja, da utilização dos recursos pelos usuários do plano de saúde. Com uma visão estatística e clínica, a C6 pode estratificar a população em níveis de utilização de serviços de saúde, identificar riscos e facilitar o planejamento de ações no setor. 
A C6 tem como principais clientes: os planos de saúde, as seguradoras de saúde e as cooperativas de saúde. A empresa apresenta um faturamento anual de cerca de um milhão e meio de reais.

\title{
Uso da TI
}

A empresa conta com:

\author{
$\checkmark$ banco de dados próprio; \\ $\checkmark$ software de Análise de Sinistros (acesso WEB); \\ $\checkmark$ software de Mapeamento de Risco (acesso WEB); \\ $\checkmark$ software de gerenciamento de pacientes em assistência (prontuário \\ eletrônico com acesso WEB).
}

Todos dão suporte a todos os serviços oferecidos pela empresa.

\subsubsection{Formas de Contribuição da TI - Categorias}

A - Sistemas estratégicos.

- Utilização de software para mapeamento e diagnóstico da saúde de uma determinada população

A proposta de valor da empresa C6 é utilizar a TI para oferecer aos seus clientes um diagnóstico de suas operações de serviços na saúde. A empresa utiliza vários softwares próprios ou ainda produtos de empresas de terceiros para realizar os serviços. Após a execução do serviço, todas as informações são consolidadas e demonstram-se as ações, os controles e os resultados em uma determinada população ou negócio.

A operação de serviços integrada pela TI possibilita analisar o problema de uma forma sistêmica. Segmentam-se os grupos de pacientes e se desenvolvem objetivos e ações específicas para cada grupo. O diagnóstico da saúde de uma determinada população pode gerar programas preventivos que são mais eficientes do ponto de vista das despesas e mais eficazes do ponto de vista do tratamento do cliente. Além dos serviços de diagnóstico, a empresa também realiza a operação dos serviços, conforme as necessidades de seus clientes. $O$ foco e especialização 
garantem à C6 ganhos importantes de escala e uma posição vantajosa na curva de aprendizagem.

O envolvimento entre as empresas, inerente ao tipo de serviço oferecido por C6, favorece o relacionamento de longo prazo. Quanto maior o envolvimento, melhor o desenvolvimento dos serviços, em especial os serviços de diagnóstico de uma população, e, assim sendo, melhor as alternativas para a solução de problemas.

\section{B - Foco no cliente e no serviço.}

- Personalização do atendimento e de soluções

O uso da TI permite personalizar o atendimento e as soluções aos clientes. A empresa está alicerçada em três bases: a) estabelecer conta por cliente; b) fazer com que a operação se desenvolva dentro do mínimo esperado pelo cliente e c) ter como regra superar as expectativas do cliente. Em todos estes casos, são utilizadas ferramentas de TI para controlar e monitorar os serviços realizados.

Em todas as atividades, têm-se informações específicas sobre o negócio, ou seja, uma gestão inteligente para dar retaguarda à operação realizada. Os profissionais envolvidos: médicos, enfermeiros, entre outros, trabalham com protocolos predefinidos, que são avaliados pelo gestor da conta do cliente. Este acompanhamento analisa os resultados das operações realizadas, identifica deficiências e permite a tomada de decisões de acordo com cada cliente.

Cada empresa possui especificidades e formas diferentes de operar. A TI permite compreender melhor as diferenças dos clientes para que se gerem soluções personalizadas. $\mathrm{Na}$ medida em que se compreende melhor cada cliente, desenvolvem roteiros (scripts), aumentando a padronização de tarefas e também a procedimentalização.

- Relacionamento no Pós-venda para fidelização.

A TI é uma importante ferramenta para relacionamento pós-venda. Depois de realizado o trabalho, a empresa disponibiliza uma senha de acesso para os usuários (fonte pagadora: planos de saúde, seguros saúde, cooperativas, autogestões, outros) para acessarem as informações referentes aos serviços adquiridos. Eventualmente, são enviados e-mails, avisando aos clientes sobre itens de interesse deles como, por exemplo, um prontuário ou casos de racionalização de despesas, entre outros, que estão fora da média ou das situações especiais. 
Manter o cliente informado, principalmente de eventos que otimizam sua cadeia de valor, é uma forma de manter ativo o relacionamento e, ao mesmo tempo, demonstrar de que forma o produto adquirido traz vantagens sobre outras alternativas. Esta é uma auto-análise do trabalho prometido e, de certa forma, o cumprimento da promessa.

Quanto mais se desenvolve o relacionamento, mais se conhecem as formas de operar de cada um e isto possibilita soluções específicas. Estas soluções chegam ao ponto de informar o cliente sobre desvios no processo, em casos pontuais. Isto reforça a importância da ferramenta e a sua qualidade. Esta operação também permite otimizar a mão-de-obra, equipamentos e processos e até flexibilizar a capacidade produtiva, adequando-a às variações da demanda.

C-Esforço contínuo de melhorias.

- Integração das operações de serviços para aumentar sinergia

As operações de serviços, ao serem integradas pela TI, permitem que se elimine estoque desnecessário entre os participantes. Todos integrantes possuem um nível de informação maior, principalmente sobre a demanda, ficando mais fácil estimar os recursos humanos e os insumos que serão utilizados, reduzindo perdas desnecessárias.

A TI contribui para reduzir as filas e/ou adequá-las de acordo com a oferta. A integração de toda a cadeia, utilizando a TI, faz com que o negócio se desenvolva como se fosse uma única empresa, facilitando os ajustes em cada estágio da cadeia e criando elos que otimiza a interação entre os participantes. Adequar o número de profissionais que saem a campo para atender vários pacientes pode ser uma medida importante para que a empresa racionalize suas despesas. Por outro lado, os pacientes também não gostam de ficar esperando por mais tempo do que o determinado.

O uso da $\mathrm{TI}$, nesta operação, permite que se otimize a capacidade produtiva da mão-de-obra e dos equipamentos, evitando filas, comprometendo a qualidade do serviço e das perdas. Contribui, ainda, para flexibilizar as operações de serviços em relação à realização do serviço e a outros ajustes e acertos da mão-de-obra envolvida.

- Flexibilidade nos recursos humanos da empresa 
A TI possibilita velocidade e especificidade na busca de profissionais de saúde terceirizados. Este fato permite que se desenvolva uma estrutura modular, com um número restrito de profissionais fixos. Quando novos clientes/projetos são incorporados, profissionais terceirizados são contratados e passam a fazer parte das operações de serviços do grupo.

Identificam-se e requisitam-se profissionais com competências específicas, em um banco de dados da empresa, que é constantemente atualizado pela empresa e diretamente pelos profissionais do mercado. Este fato permite estender a abrangência da empresas e manter o padrão de soluções de serviços aos clientes em geral.

O uso da TI aumenta a flexibilidade da empresa para fazer opções em seu quadro de colaboradores. Despende-se menos tempo (custos de transação) para se encontrar os profissionais certos.

- Segmentação da população para otimizar as formas de tratamento

A TI permite agrupar e analisar uma determinada população em relação à freqüência de uso, cruzando com dados como: faixa etária, localização, tipo de patologia e outros.

Há várias formas para se fazer esta análise, por exemplo: analisar o valor total de despesas de um paciente por mês, item a item para entender melhor os desvios; analisar se a região que o paciente reside tem alta incidência de certa patologia para que se possa agir preventivamente; segmentar por grupos de diagnósticos, definindo o melhor tratamento para cada grupo. A complexidade do setor da saúde dificulta que se trabalhe com médias, pois existem muitos desvios.

Esta operação segmenta a população e torna possível direcionar esforços de acordo com a necessidade do paciente, gerando melhores resultados. $O$ direcionamento refere-se a utilizar recursos no atendimento da linha de frente ou na retaguarda, com o objetivo de adequar o serviço às necessidades, principalmente às de prevenção à saúde.

- Tornar tangível a proposta de valor da empresa

As habilidades de $\mathrm{TI}$ desenvolvidas pela empresa C6, juntamente com softwares específicos e equipamentos diferenciados, tangibilizam a proposta da empresa para que gerem vantagens na negociação. Ainda no que se refere à 
argumentação na negociação, o uso da TI tem permitido que sejam desenvolvidas diversas publicações científicas envolvendo saúde e tecnologia.

O efeito da TI e as vantagens propostas pela empresa são avaliados desde as apresentações, em que alguns tangíveis como equipamentos em geral passam uma idéia do poder tecnológico da empresa, no que concerne, inclusive, às suas publicações científicas, as quais possuem pesos especiais, denotando qualidade e conhecimento superior, que são fatores diferenciadores relevantes neste setor.

O uso da TI, na realização de diagnóstico de uma população, ajuda a tangibilizar a proposta de valor do serviço, por meio de gráficos, dados estatísticos, cruzamentos, concentrações, outros. Estes elementos facilitam o processo de gestão de uma determinada população, reduzindo custos ao minimizar perdas com tratamentos inadequados e ineficientes ou superestimar formas de tratamento e ao aumentar o nível de qualidade dos serviços ao resolver, mais rapidamente, o problema do cliente.

D- Otimização do processo empresarial (reengenharia do processo do negócio).

Obs. Este subitem será dividido em duas partes: reengenharia do processo do negócio e novos negócios gerados pela TI ou em processo de gestação.

D1 - Reengenharia do processo do negócio.

- Identificação de grupos (segmentos) para prescrição de procedimentos padronizados

Utilizar a TI para se desenhar uma pirâmide de risco com perfil da saúde de uma determinada população, identificando os diferentes grupos para realizar as intervenções adequadas.

Identificação dos grupos, seguida de prescrição de procedimentos e oferta de operacionalização. Uma pirâmide de risco é dividida da seguinte forma: na base, são apresentados os pacientes que demandam prevenção primária (promoção à saúde para que o indivíduo não fique doente: fumantes, alcoólatras, obesos, sedentários) e serviço de orientação. Os serviços são realizados para entender o problema do doente para poder atender a análise do sinistro (passado), o mapeamento de risco (questionários da saúde), o acompanhamento prospectivo (medir depois de algum tempo os resultados), a análise atuária, outros. Na prevenção secundária, o diagnóstico é precoce (indivíduos que não sabem que estão doentes, ou melhor, são 
diabéticos silenciosos, hipertensos silenciosos, ou seja, nunca tiveram sintomas da doença e vão descobrir quando tiverem uma crise). Na prevenção terciária, o indivíduo já está doente, e tem-se de evitar que ele piore, então há o gerenciamento de plano presencial junto ao paciente na residência, com aconselhamento (higiene, nutrição, outros) e apoio de central telefônica 24h. Estas atitudes fidelizam o paciente com os funcionários que os está atendendo, evitando que ele se dirija aos hospitais e recomece toda a investigação sobre seus problemas, o que seria dispendioso e também incomodaria muito o paciente. Por último, existe a prevenção assistencial (indivíduos internados, com altos custos). Quando necessário, o paciente tem tratamento domiciliar, medicamentos injetáveis, transfusões, quimioterapia, raios- $X$, oxigênio, outros. Além do diagnóstico, a empresa oferece ainda muitas opções de prestação de serviços para atender a população diagnosticada. Na prevenção primária, ocorrem palestras, workshops, treinamentos, teatros temáticos, orientação para aposentadoria, outros. Na secundária, existe diagnóstico precoce, com check-up para população específica, campanhas de prevenção, em que existem casos de mulheres acima de 40 anos, que não fazem exames ginecológicos e de mama há muito tempo. Nestes dois casos, a TI permite criar banco de dados e filtrar quais serviços devem ser designados para quais tipos de pacientes, reduzindo despesas e aumentando a qualidade de vida dos clientes. $\mathrm{Na}$ fase terciária, a proposta é cuidar destas pessoas, assistencialmente, ao gerenciar as despesas de suas contas médicas. Nesta fase, utiliza-se um prontuário eletrônico que integrará todos os procedimentos realizados com os pacientes, integrando todos os profissionais da saúde, a empresa e a fonte pagadora, tornando mais ágil e transparente todo o tratamento.

A TI, nestas operações de serviços, contribui de diversas formas: compreendendo melhor os grupos de clientes ao facilitar a definição da expectativa deles, ao atender estas expectativas, com a melhora do relacionamento e que com as melhores soluções para problemas individuais e de grupos. Pode-se, ainda, otimizar os recursos-chave, como pessoas ou equipamentos, aumentando a produtividade. Ao se conhecer melhor os grupos, pode-se aumentar o índice de reprodução em série de uma mesma solução. Na mesma linha, pode-se, ainda, aumentar a previsibilidade nas operações de serviços, aprimorando a padronização das respostas e as tarefas aos clientes, tornando-se mais especializado e mais produtivo. Por último, o uso da TI pode ser importante no controle de custos e na 
avaliação dos resultados individuais de serviços, mesmo onde houver complexidade de rotas percorridas pelos clientes ao longo do processo.

- Mapeamento de risco, via WEB e identificação de concentrações e tendências de uma população, apoiando decisões operacionais.

Desenvolver serviços de diagnóstico de uma determinada população a distância, utilizando questionários via WEB. Existem programas utilizados por empresas de análise de risco (mapeamento para avaliação do sinistro no futuro), contendo itens como análise de antecedentes pessoais e familiares do indivíduo. Estes dados, somados às informações como peso, altura, pressão arterial, hábitos de vida, entre outros, geram um relatório individual do risco (baixo, médio ou alto), para determinadas doenças.

Além de esta ferramenta possibilitar o mapeamento individual, ela também permite entender as tendências quanto à saúde daquela população. Por exemplo, em vez de começar um programa de qualidade de vida, trabalhando estresse, se fosse identificado que existe um alto risco cardiovascular, é melhor iniciar um programa preventivo atacando o problema maior. Na medida em que se fazem estas análises juntamente com as despesas das contas médicas, despesas com medicamentos entre outros, faz-se uma análise periódica em que se consegue um monitoramento e uma avaliação das ações (primárias, promoção à saúde; secundárias, diagnóstico precoce; e terciária, cuidados com o pacientes com problemas, para que não se agravem) implementadas em relação ao início do trabalho no tempo zero.

Esta operação flexibiliza o atendimento com base nos requisitos do cliente, quanto ao tempo, ao local e à posse. Todas as vantagens no item imediatamente anterior podem ser observadas nesta operação.

\section{- Desenvolvimento de alianças com outras empresas}

Fornecer serviços de TI a empresas concorrentes na prestação de serviços de saúde. Muitas das atividades desenvolvidas pela empresa, utilizando a TI, estão formatadas para substituir atividades tradicionais como compras (insumos e serviços), controle de estoques e inventários, faturamento, outros. Todas estas atividades são oferecidas a outros prestadores de serviços concorrentes. 
Por ser uma empresa que já nasceu com todos os processos utilizando a TI de forma integrada, fica mais fácil absorver o serviço de outras empresas. A curva de aprendizagem, a escala, o conhecimento entre outros contribuem para aumentar a eficiência e a eficácia das empresas.

Para esta operação, o uso da TI traz vários benefícios, comentadas nos dois itens anteriores, porém, esta ainda conta com todas as vantagens de custo que a curva de aprendizagem e a escala possibilitam, pois os serviços são realizados para diversas outras empresas e as situações são semelhantes.

D2 - Novos negócios gerados pela TI ou em processo de gestação

- Central de aconselhamento médico e de apoio aos profissionais de campo

Apoio ao serviço de campo dos enfermeiros e médicos e também central de aconselhamento ao paciente. Este serviço também é oferecido para outras empresas concorrentes.

O atendimento a distância, tanto para aconselhar profissionais que estão em campo, quanto para aconselhar pacientes, reduz custos de transação, mas reduz principalmente o custo total dos cuidados com a saúde, pois os casos são analisados a partir de uma base conhecida. Os pacientes em vez de procurar serviços em um hospital, por exemplo, entrarão em contato com o aconselhamento, em que serão atendidos de forma personalizada, por um profissional que possui seu histórico.

O atendimento a distância flexibiliza o atendimento para o paciente em relação a tempo e ao local e amplia sua avaliação de qualidade do serviço prestado. Muitos dos pacientes são crônicos ou de alta complexidade e já mantêm relacionamento de longo prazo com a empresa: este fato facilita o diagnóstico e aumenta a resolutividade do caso. Reduz-se, portanto, o custo do tratamento, aumentando a produtividade da mão-de-obra que, sem deslocar-se, resolveu o problema do paciente e ampliam as fontes de flexibilidade na operação, que pode atender um número maior de casos a partir de uma única base.

- Gestão de compras (interna e terceirização destes serviços)

O processo de compra desenvolvido para atender as necessidades internas da empresa também opera como um intermediador de transações entre o mercado e os prestadores de serviços ou tomadores de serviços. 
As empresas recebem um software que permite a inclusão dos itens que necessitam, por exemplo, uma prótese ortopédica para uma intervenção cirúrgica. Por outro lado, os fornecedores de prótese fazem suas ofertas de venda. No final, a empresa C6 faz a intermediação, optando pela melhor proposta (custo x benefício) e fecha a negociação entre, por exemplo, a operadora de planos de saúde e o fornecedor. O sistema consegue ser mais eficiente e mais eficaz que o processo de aquisição convencional, pois, além de trabalhar com escala maior, os mecanismos de busca e de efetivação da compra são muito mais especializados.

Nesta operação, os clientes são outras empresas que adquirem um serviço de intermediação, em que participam da especificação do processo antes de se incorporar a ele. Com isto, esta empresa obtém maior flexibilidade em suas operações de compra. Com a efetivação da parceria, ampliam-se o relacionamento e as soluções para a empresa. As operações de compras sofrem uma melhora nas especificações, permitindo repetições nas tarefas, com oportunidade de aprendizagem. A operação torna-se mais automatizada e também mais procedimentalizada, reduzindo a variabilidade na prestação de serviços.

- Serviço de suporte: as empresas que realizam corretagem para planos de saúde, seguro saúde, cooperativa e outras empresas de medicina de grupo.

As empresas de corretagem estão tornando-se cada vez mais empresas de consultoria na saúde. Os vendedores estão agregando os serviços de diagnóstico e monitoramento da utilização dos benefícios saúde.

Do ponto de vista comercial, esta é uma nova forma de abordar as empresas compradoras de planos de saúde. Na medida em que a empresa compra um plano de saúde, ela compra também um instrumento que ajudará no controle do sinistro de sua carteira de associados. A corretora repassa parte do comissionamento vitalício, para pagar este gerenciamento da carteira, que garantirá a retenção do cliente por mais tempo. Quanto melhor o monitoramento e controle, menores serão as despesas com o plano ao longo do ano, facilitando os acordos de reajuste anual com a empresa de plano de saúde.

A oferta deste serviço permite que a empresa estenda suas competências a novos mercados, oferecendo serviços de diagnóstico a populações entre outros. 
- Uso da TI para diagnosticar carteiras de beneficiários para aperfeiçoar a gestão.

A empresa oferece quatro tipos diferentes de serviços: análise de sinistro (base no passado, histórico das contas médicas - titulares ou dependentes); análise de risco (mapeamento para avaliação do futuro); gestão do paciente (prontuário eletrônico) e cálculo atuarial. Estas ferramentas permitem coletar dados e possibilitam disponibilizar os resultados das análises via WEB.

Os softwares são disponibilizados via WEB (maior penetração e adesão), permitindo que clientes de qualquer ponto do país realizem suas operações e acessem o sistema para inserir os dados. A gestão integrada é realizada na sede da empresa (escala, especialização, outros), gerando respostas aos usuários de onde eles estiverem. O monitoramento permanente da rede de valor da empresa analisada e a redução de custos é a fonte de recursos para manter a aliança.

Nestas operações, são desenvolvidos acordos com planos de saúde e outras fontes pagadoras em geral e até com prestadores de serviços, para que as empresas atuem conjuntamente e obtenham ganhos, conforme se maximizam os resultados da empresa analisada. Estas operações possibilitam que os clientes participem da especificação dos serviços, antes de se incorporar a eles adequandose à sua realidade.

F - Comércio eletrônico e redes de informação.

- Integração com fornecedores nas operações de compra

Os fornecedores de medicamentos, materiais, equipamentos, serviços em geral e outros ao receberem o pedido dão prosseguimento e o encaminham eletronicamente os avisos informando que já foi atendida a solicitação. O sistema central da empresa recebe esta informação e informa que já foi feita a validação (aprovação do processo de compra requerido). No final, as faturas dos fornecedores são controladas com base na validação em que se pode auditar, se tudo esta de acordo com o solicitado anteriormente.

A TI cria valor em duas circunstâncias: primeiro reduzindo o custo de transação ao buscar os insumos e recebê-los onde o cliente necessita, e segundo, racionalizando a operação de validação e faturamento que em geral é bastante complexa no setor da saúde. 
Para esta operação, o uso da TI traz vários benefícios, conforme comentado anteriormente: o cliente pode participar da especificação do processo, assim ele adquire algo na medida de suas necessidades. Institui-se, para tanto, um melhor relacionamento com o cliente. A operação torna-se mais automatizada, reduzindo a variabilidade na prestação de serviço e contando, ainda, com todas as vantagens de custo que a curva de aprendizagem e a escala possibilitam, pois os serviços são realizados para diversas outras empresas e as situações são semelhantes.

\subsubsection{Outras Considerações de C6}

A proposta de valor desta empresa é o processamento de dados na saúde e geração de informações para tomada de decisão. Conforme se constatou, algumas empresas clientes sabem que este serviço é fundamental para seus negócios, pois se perdem em uma imensidão de dados. Mesmo assim, algumas destas empresas, que adquiriram o serviço, impediram que fosse desenvolvido. Seus sistemas possuem tantas "travas" de segurança que preferem relatórios em papel, fazendo eles próprios os lançamentos de dados dentro da empresa. Foi relatado, ainda, que empresas do setor, clientes potenciais de C6, preferem declinar de promoções ou oferta de serviços de menor custo, pois, para aceitar isto, teriam de alterar tabelas e regras internas. Resumindo, pode-se dizer que políticas de $\mathrm{TI}$, em algumas empresas definidas no passado, impedem que se desenvolvam alternativas que podem ser interessantes, porém a TI dificulta que se faça isto.

Conforme a empresa, este negócio nasceu com o propósito de preencher uma lacuna do ponto de vista tecnológico que as operadoras (planos de saúde em geral) não puderam preencher. As empresas têm necessidades diversas, porém não conseguem identificar o problema e, neste caso, surgem oportunidades: primeiro, oferecendo consultoria para diagnosticar o problema, e segundo, oferecendo soluções utilizando a TI. Este é o espaço onde a empresa esta inserida e desenvolve atualmente sua proposta de valor.

\subsubsection{Resumo da Análise de C6}

A TI criou valor (eficiência e/ou eficácia) em diversas circunstâncias, entre elas, podem-se citar: 
- intermediando transações entre parceiros;

- $\quad$ propiciando maior relacionamento e fidelização de clientes;

- criando soluções personalizadas;

- permitindo gestão a vista;

- criando novas formas de treinamento;

- controlando tarefas e equipes;

- flexibilizando recursos humanos;

- melhorando argumentação comercial;

- dando apoio a distância aos profissionais;

- permitindo aconselhamento médico a distância para pacientes;

- gerindo processo de compras da empresa e para terceiros;

- criando soluções de consultoria para planos de saúde, seguradoras, cooperativas, autogestões, corretoras, grandes empresas e outros.

- outros.

Por que a TI cria valor? As respostas foram diversas, mas observou-se uma maior incidência do ponto de vista da eficácia, nas seguintes circunstâncias:

- aumentando o relacionamento e conseqüentemente a lealdade (otimizando os resultados) na empresa, na medida em que ajuda na solução de problemas do cliente;

- definindo melhor a expectativa do cliente, por meio de pré-seleção (segmentação ) entre outros;

- outros.

Do ponto de vista da eficiência, observou-se que a TI teve maior contribuição nas seguintes circunstâncias:

- aumentando o índice de reprodução em série de uma mesma solução em serviços (desenvolvendo e instituindo controles de roteiros scripts) para interface com o cliente;

- otimizando o envolvimento na linha de frente e/ou nas atividades de retaguarda;

- melhorando as especificações das tarefas, permitindo sua repetição e/ou o compartilhamento das habilidades mais elevadas, ampliando as oportunidades de aprendizagem; 
- atenuando a necessidade de julgamento profissional rotineiro, diluindo a responsabilidade dos gerentes no controle de qualidade, permitindo um aumento na procedimentalização;

- otimizando a capacidade produtiva da mão-de-obra disponível e/ou dos recursos e equipamentos nas empresas de serviços;

- outros.

Quadro 12 - Resumo da Análise de C6

\subsection{EMPRESA 7 (C7) - PLANO DE SAÚDE}

\section{Dados da empresa}

\begin{tabular}{|c|c|}
\hline Faturamento anual da empresa: & $\mathrm{R} \$ 160.000 .000,00$ \\
\hline $\begin{array}{l}\text { Número de funcionários da } \\
\text { empresa: }\end{array}$ & 2.500 \\
\hline Funcionários terceirizados: & ND \\
\hline Funcionários de TI da empresa: & 60 \\
\hline Funcionários de TI terceirizados: & 0 \\
\hline $\begin{array}{l}\text { Área de aplicação da TI estudada } \\
\text { que gera vantagem competitiva } \\
\text { para empresa: }\end{array}$ & $\begin{array}{l}\text { Operações de serviço do plano de saúde } \\
\text { em geral. }\end{array}$ \\
\hline $\begin{array}{l}\text { Estratégia competitiva genérica e } \\
\text { escopo de atuação da empresa no } \\
\text { mercado: }\end{array}$ & $\begin{array}{l}\text { A empresa atua com estratégia genérica de } \\
\text { custo com escopo amplo, abrangendo } \\
\text { diversos segmentos do mercado. O número } \\
\text { de associados lhe garante importantes } \\
\text { ganhos de escala. o nível de } \\
\text { informatização da empresa, nas mais } \\
\text { diferentes áreas, permite um controle sobre } \\
\text { suas operações e inclusive uma } \\
\text { produtividade acima da média do mercado. } \\
\text { Além disto, a empresa conta com uma } \\
\text { infra-estrutura bastante verticalizada e } \\
\text { eficiente. }\end{array}$ \\
\hline
\end{tabular}

ND - não declarado. 


\section{Principais Características da Empresa}

Fundada na década de 60, C7 está entre as 5 maiores empresas de plano de saúde do país. Atualmente, é uma das organizações no setor de planos de saúde que mais utiliza a TI, em suas operações de serviços. Seu quadro de colaboradores conta com 2500 funcionários, 400 médicos e, ainda, com uma rede credenciada de 2000 médicos.

A empresa possui uma carteira de mais de meio milhão de beneficiários (pessoa física e jurídica). Tem como principais clientes as empresas de grande porte em São Paulo. Com mais de 40 anos de experiência na prestação de serviços médicos e hospitalares, a C7 proporciona aos seus Clientes, a excelência na prestação de serviços de prevenção, manutenção e do restabelecimento da saúde.

A corporação entende que a ciência médica e a tecnologia na saúde devam ser adequadamente organizadas e administradas. Tem como diretriz atender seus clientes de modo eficiente, dentro de princípios humanitários/éticos e de respeito às pessoas, disponibilizando moderna tecnologia e garantindo a melhor qualidade de serviços médicos e hospitalares.

\section{Uso TI}

C7 é uma empresa totalmente integrada, quase todos os controles internos, em suas instalações, que incluem 5 hospitais, 27 centros médicos, serviços de prevenção, laboratório de análise clínicas e rede credenciada são eletrônicos, tornado suas operações muito ágeis.

A empresa utiliza muitas ferramentas que são fortemente amparadas pela TI, entre elas, podem-se citar: prontuário eletrônico, ficha clínica ambulatorial eletrônica, conectividade com rede de fornecedores e rede credenciada, utilizando recursos como: Internet, POS e identificação por biometria, gerenciamento de benefícios de farmácia, SMS (serviço de mensagem no celular para confirmação de consultas e exames), outros. O código de barras, por exemplo, é utilizado em todas as circunstâncias em que pode ser útil, incluindo materiais, medicamentos, doses unitárias, outros. O processo de devolução de materiais e medicamentos solicitados nos andares de internação nos hospitais é totalmente monitorizado. Desde o momento em que o médico prescreve, ocorre a solicitação na farmácia. Na hora que 
a farmácia atende ao pedido é dada baixa. Quando ocorre a devolução, ocorre o estorno eletronicamente.

A empresa dispõe de uma central telefônica de atendimento para agendamento de consultas, exames, cirurgias, outros, como 120 pontos de atendimento, que funciona $24 \mathrm{~h}$ por dia, 7 dias por semana. Também possui uma central de aconselhamento médico, onde os profissionais médicos, ao telefone ou pela Internet, munidos de um software de apoio à decisão realizam recomendações aos pacientes, evitando que eles recorram desnecessariamente à rede de atendimento.

A área comercial "vendas" também está integrada com as corretoras. A empresa distribui PDAs para sua equipe comercial interna e de marketing. Os PDAs são utilizados tanto nas operações de vendas como no relacionamento com seus clientes, servindo para estruturar propostas em tempo real, ao levar informações e anotar solicitações dos clientes.

\subsubsection{Formas de contribuição da TI - Categorias}

A - Sistemas estratégicos.

- O uso da TI na gestão clínica e administrativa dos centros médicos

O conjunto de ferramentas de $\mathrm{TI}$, nos centros médicos, permite que se realize gerenciamento e controle, em um local que historicamente consome mais de $50 \%$ dos custos de um plano de saúde.

O sistema permite um gerenciamento não apenas das questões clínicas, mas também das questões administrativas. Com isto, podem-se identificar problemas como doentes crônicos, casos de difícil solução, clientes insatisfeitos, entre outros.

A TI aumenta a qualidade da gestão, por meio da maior velocidade de respostas ao cliente, segurança, confiabilidade das informações, entre outros. Permite reduzir a sinistralidade, apontando os casos que devem ser priorizados ou monitorados mais ostensivamente. Também contribui para reduzir custos, eliminando retrabalhos, despesas com papel, tinta, mão-de-obra, falhas no processo, filas e outros, gerando maior vantagem competitiva. A TI contribui na produtividade, gerenciamento e controle dos recursos-chave. Na preparação das tarefas da linha de frente e retaguarda, minimizando os efeitos da inseparabilidade e co-produção do 
cliente, variabilidade e perecibilidade dos serviços, no controle organizacional, controle da qualidade e controle de custos em geral.

$B$ - Foco no cliente e no serviço

- Informação completa do paciente

A TI propicia que se tenha um acompanhamento de todos os procedimentos em que o paciente teve envolvimento com o prestador de serviço. As ferramentas de TI permitem saber, por exemplo, se o paciente comprou ou não um medicamento, permite que ele obtenha descontos, entre outros e, neste caso, atendê-lo de forma personalizada.

Com as fontes de informação propiciadas pelas ferramentas de $\mathrm{Tl}$ da empresa, o médico pode saber detalhes do tratamento de um paciente, por exemplo, o dia que ele comprou um medicamento.

De posse das informações sobre o paciente, pode-se realizar um tratamento personalizado, demonstrando que realmente a instituição presta atenção às necessidades do cliente. A TI contribui também para tangibilizar a proposta de valor do plano de saúde, com o uso e a apresentação da infra-estrutura e a TI, denotando maior qualidade. O paciente observa os equipamentos, a velocidade no atendimento, as formas de auto-serviço, e outros fatos que criam oportunidade de diferenciação. As informações permitem um controle maior do paciente e da gestão, ajuda ainda na previsibilidade das operações de serviços, permitindo um maior índice de padronização e, conseqüentemente, um aumento da produtividade.

C - Esforço contínuo de melhorias.

- Serviço de aconselhamento médico

O serviço de aconselhamento médico é realizado em uma central, em que profissionais médicos, munidos de softwares de apoio à decisão (árvore de decisão) esclarecem dúvidas e aconselham os pacientes.

O serviço funciona $24 \mathrm{~h}$ por dia, 7 dias por semana. Esta operação de serviços contribui para que os pacientes resolvam ou esclareçam problemas imediatos ou que causam constrangimento, entre outros. Estes casos podem ser esclarecidos por telefone ou pela Internet.

Muitos dos atendimentos esclarecem dúvidas básicas e evitam que os associados se desloquem até a rede credenciada, flexibilizando o atendimento com 
base nos requisitos do cliente em relação a tempo, a local e à entrega do serviço. Outras vantagens como melhoria das especificações das tarefas, permitindo repetição e aprendizagem e ainda aumento da reprodução em série de uma mesma solução, também são observadas. Estes procedimentos, além de contribuírem para eficácia do atendimento, aprimorando a qualidade dos serviços para o cliente, são também eficientes, pois seu custo é inferior em relação a uma consulta presencial.

- Serviço de mensagens curtas (SMS) para confirmação de consultas e exames As consultas e exames são agendadas por telefone pelos próprios clientes. A confirmação da consulta é realizada por meio de uma mensagem enviada ao celular do cliente. Este, por sua vez, deverá confirmar ou não o agendamento do procedimento a ser realizado.

Quanto mais distante uma consulta é agendada, a possibilidade do nãocomparecimento é maior. Neste caso, a confirmação da consulta, além de lembrar o paciente, passa a sensação de proximidade do serviço agendado, reduzindo o nãocomparecimento. Por outro lado, os casos não confirmados podem ser substituídos por outros agendamentos que estavam marcados em datas mais distantes, reduzindo ainda mais o não-comparecimento. Ao receber a mensagem, o cliente opta por: "1" - confirmar e "0" - cancelar. Na confirmação do procedimento, o sistema valida os dados físicos, clínicos e administrativos: contrato, coberturas, outros. A partir deste momento, uma ficha clínica (eletrônica) é enviada ao prestador que realizará o procedimento. Além da marcação e validação, analisa-se a posteriori qual o comportamento deste cliente.

A TI contribui para que o cliente participe da especificação do processo dos serviços, antes de incorporar-se a ele. A operação adequa as necessidades do cliente com o serviço oferecido. Por outro lado, a operação também gera mais eficiência, pois aumenta a produtividade, contribui para adequar a oferta, a demanda, otimizando a capacidade produtiva da empresa.

- Cartão eletrônico de identificação do paciente e encaminhamento para sala do médico

Quando o paciente chega ao centro médico (com a consulta previamente marcada), passa seu cartão eletrônico de identificação em um leitor ótico, que informa qual sala ele deverá dirigir-se para ser atendido. 
Esta operação é semelhante a um auto-serviço no varejo. O cliente realiza parte da sua experiência com aquele serviço fortemente apoiado pela tecnologia. $O$ processo é simples e ágil.

A TI contribui para facilitar a avaliação da qualidade dos serviços prestados em função da infra-estrutura utilizada. Ajuda também nas tarefas de linha de frente na interface com o cliente.

\section{- Ficha clínica eletrônica}

Quando o paciente chega ao centro médico, passa seu cartão de identificação em um leitor ótico, que já informa qual sala ele deverá dirigir-se para ser atendido. Este procedimento também envia automaticamente um arquivo com sua ficha clínica para o computador do consultório onde será atendido.

O paciente será chamado pelo médico na ordem em que a ficha clínica chegar ao seu computador. Neste caso, os erros de filas e troca de papéis e outras informações de pacientes são minimizadas. O médico realizará todo o atendimento e a evolução do paciente na ficha clínica no seu computador. Assim que for preenchida, a ficha clínica estará atualizada e disponível para ser novamente utilizada em qualquer uma das unidades da empresa, a qualquer momento. Em nenhum destes procedimentos, é utilizado papel: tudo é feito eletronicamente.

A TI contribui no controle dos recursos-chave; neste caso, recursos humanos e processos. A contribuição na melhoria das especificações das tarefas, tanto para linha de frente como retaguarda, são evidentes. O controle dos serviços favorece a previsibilidade, permitindo aumento do índice de padronização e especialização e certamente da produtividade. Também se percebe um alto índice de automação no controle dos processos.

- Prescrição de medicamentos e controle de uso no cartão eletrônico de identificação

Com base na consulta realizada e com as informações da ficha médica que consta o histórico do paciente, com evolução, exames e outros procedimentos, o médico realiza o diagnóstico e prescreve um medicamento. A prescrição é transferida para o cartão de identificação do paciente, para que ele se dirija até uma farmácia conveniada e realize a aquisição dos medicamentos. 
Ao realizar a prescrição, o médico conta com o apoio de um banco de dados que informa em detalhes as ações medicamentosas das drogas, assim como as contra-indicações, entre outras informações importantes. Uma lista privilegiada de medicamentos faz parte de parcerias com farmacêuticas e com a rede de farmácias credenciadas, que geram descontos de até $60 \%$ nos medicamentos.

No ato da compra na rede credenciada de farmácias, o cliente passa o cartão, para que se identifiquem os medicamentos e se efetue a compra, no tempo e local que o paciente achar mais adequado. Estas informações de hora e data da compra são enviadas eletronicamente para a ficha médica do paciente. Na próxima consulta do cliente, o médico saberá se o paciente comprou e quando comprou o medicamento, obtendo subsídios complementares para realizar sua atividade profissional. O cartão dá credito ao cliente e envia as informações de cobrança para a empresa que ele trabalha, para que seja debitado em sua folha de pagamento. $O$ conteúdo e o formato das informações da ficha médica eletrônica, assim como o receituário médico, são padronizados. Não há procedimentos manuscritos, que podem causar erros de entendimento. As vantagens são diversas e abrangem questões relacionadas à eficácia, adequando a prestação de serviços às necessidades do paciente e à eficiência, controlando os processos em geral.

- Gestão das consultas nos centros médicos

Todas as consultas e procedimentos realizados nos consultórios são enviados eletronicamente para um banco de dados. Estes dados são consolidados e transformados em relatórios que auxiliam na gestão do negócio.

Os relatórios informam as especialidades mais procuradas, os pacientes e as empresas que mais utilizaram o plano de saúde, entre outras informações. Há também uma variedade de outros itens que auxiliam na análise do sinistro de uma determinada carteira de clientes e, por outro lado, também se podem identificar tendências e concentrações e até pacientes crônicos.

As informações permitem que se tomem decisões mais acertadas, facilitando o processo de gestão. A TI, neste caso, contribui desde o processo de definição da expectativa do cliente, até na co-produção dos serviços. Permitem melhores controles dos recursos-chave, em especial os recursos humanos e os processos. Contribuem, ainda, nos controle dos serviços, favorecendo previsibilidade, que permite maior padronização, e levando a maior produtividade. 
D- Otimização do processo empresarial (reengenharia do processo do negócio).

Obs. Este subitem será dividido em duas partes: reengenharia do processo do negócio e novos negócios gerados pela TI ou em processo de gestação.

\section{D1 - Reengenharia do processo do negócio}

- Relatórios de utilização do plano de saúde para os clientes Pessoa Jurídica

A TI permite a elaboração de relatórios com as informações de utilização do plano de saúde pelos beneficiários das empresas. Estas informações podem ser apresentadas juntamente com indicadores, curva de utilização, tendências e outros.

O relatório indica, por exemplo, número de consultas marcadas e o número de faltas nas consultas, exames realizados, cirurgias e outros procedimentos.

Estas informações contribuem em várias circunstâncias. Em primeiro lugar, ajuda a estabelecer uma parceria entre as duas instituições, pois quanto maior for o controle das partes, reduz-se o custo e as condições de negociação, as quais podem ser melhoradas. Outra contribuição importante, também na parte da prevenção, é que de posse destas informações a empresa pode desenvolver um programa de medicina preventiva, controle de crônicos, outros.

Observação: alguns dos itens listados em C - Esforço contínuo de melhorias poderiam ser classificados na categoria D1 - Reengenharia do processo do negócio. Embora eles apresentem o aprimoramento de atividades que já eram realizadas, analisado por outro ponto de vista, sobre o conjunto das atividades, pode-se dizer que é uma forma totalmente nova de se desenvolver o negócio e, portanto, uma reengenharia do processo do negócio.

\section{D2 - Novos negócios gerados pela TI ou em processo de gestação}

- Assinatura digital do médico na ficha clínica por biometria Assinatura digital do médico na ficha clínica por meio de biometria. Este procedimento permitirá que as fichas clínicas se tornem prontuários eletrônicos. No momento, ainda não há uma autorização que as empresas utilizam apenas prontuários digitais. A legislação obriga que se mantenha o prontuário físico, de papel, assim todas as fichas clínicas eletrônicas devem ser impressas e assinadas pelos médicos e arquivadas como prontuários. 
O prontuário médico e a assinatura digital trarão muitas facilidades, incluindo questões de controle de qualidade e rastreabilidade, quando necessário. No momento em que houver a autorização, a empresa já estará apta para implementála.

Independentemente da autorização, pode-se dizer que as fichas eletrônicas já são úteis, pois apresentam muitas vantagens, conforme foi explicado anteriormente.

- Utilização de Equipamento móvel (PDAs) na operações de serviços de medicina preventiva

Os PDAs são utilizados pelos agentes de medicina preventiva nas visitas nas residências dos pacientes.

Os equipamentos servem para que os dados sejam lançados diretamente da residência do paciente e sejam disponibilizados em tempo real. $O$ equipamento também permite que sejam realizadas pesquisas a outros dados do paciente que estão arquivadas.

A TI facilita o envio e o acesso às informações e elimina a necessidade de se transportar papéis (exames, fichas e cópias de prontuários) nas visitas. Além das informações individuais de cada cliente, o equipamento traz um roteiro personalizado (protocolos) dos procedimentos que devem ser realizados com os pacientes. $O$ cliente participa das especificações dos serviços na medida em que programa as visitas do pessoal de campo e determina outras peculiaridades do tratamento quando envolve mais de uma opção como, por exemplo, tipo de medicamento ou até alimentação. $O$ equipamento móvel flexibiliza o trabalho dos agentes de saúde, assim como o atendimento ao paciente, pois permite que o atendimento seja realizado em qualquer local, sem perda de informações. Na medida em que se têm as informações do paciente, podem-se segmenta-los em grupos e obter um melhor entendimento da expectativa do paciente. Quanto aos controles dos recursos-chave, as vantagens são: a portabilidade, o acesso às informações e a velocidade na tomada de decisão. Além disto, outras vantagens de preparação para linha de frente e retaguarda também são possíveis em função da facilidade das informações, conforme explicado.

- Utilização de Equipamento móvel (PDAs) na operação comercial 
Os PDAs são utilizados pelos vendedores que contam com formulários para cadastro dos clientes e pessoal de relacionamento com o cliente.

Os vendedores podem formatar os produtos (planos de saúde) e apresentar proposta comercial, em tempo real. No que tange ao atendimento de clientes atuais, muitas informações sobre a carteira de associados e as estatísticas de utilização do plano de saúde pela empresa como um todo podem ser apresentados.

A TI facilita para que seja feito um diagnóstico da carteira do cliente que juntamente com a formatação do produto e a proposta de venda tornará o processo mais ágil. Além destas vantagens, o equipamento em si e a forma que ele está sendo programado para ser utilizado já denotam as afinidades do plano de saúde com a TI, o que é favorável no setor da saúde. As vantagens são semelhantes às apresentadas no item anterior.

\section{E - Redes de valor e alianças entre empresas}

\section{- Total integração dos parceiros}

O uso da TI permite que todos os participantes da rede de valor de um plano de saúde se integrem e possam ter uma visão sistêmica do negócio e também do paciente.

Conforme foi apresentado, podem ser citadas várias circunstâncias em que a TI integra as operações de serviço e, com isto, amplia a qualidade e a produtividade. O processo se inicia na marcação de consultas, utilizando central de atendimento, por telefone ou Internet. Esta operação se ramifica em duas alternativas, caso o cliente busque a central de aconselhamento e pode até resolver seu problema, sem precisar utilizar o sistema de saúde presencialmente e ao ser atendido. Neste caso, ele receberá uma informação via celular (SMS), confirmando sua consulta e que enviará sua ficha médica (via arquivo eletrônico) para o local onde ele será atendido. No dia da consulta, ele será identificado pelo seu cartão de identificação. Sua ficha eletrônica segue automaticamente para a sala do médico que irá atendê-lo. Este envio já determina e organiza automaticamente as filas. Ao ser atendido, o médico utiliza as informações da ficha médica e prescreve outras informações também na ficha médica. Estas informações servirão para dar seqüência a um próximo atendimento e também serão anexadas em seu cartão eletrônico de identificação, para que ele faça suas compras na rede credenciada de farmácias. Na farmácia, um leitor identifica o cliente e também os medicamentos prescritos e informam o 
convênio quando ele comprou o medicamento. Este cartão também permite que suas compras sejam debitadas em folha de pagamento e, neste caso, as informações também são enviadas para empresa em que ele trabalha. Depois disto, ainda se tem a gestão destas consultas, procedimentos, medicamentos prescritos, outros, que colaboram com a inteligência da gestão do negócio. Ainda poderia ser mencionada a integração com o laboratório de análises clínicas e até as informações referentes à internação hospitalar do paciente, quando houver.

Uma operação de serviço por si já apresenta características não lineares e, no caso da saúde, esta fragmentação é ainda mais evidente. O baixo nível de previsibilidade das operações, considerando que cada paciente é um caso, diferente do outro, faz com que cada operação de serviço seja diferente da outra. A TI, portanto, permite que a operação, independentemente da heterogeneidade seja observada como uma linha de produção, separando os usuários em segmentos. A forma com que ela foi estruturada torna mais previsível a operação para todos os participantes, o que evita problemas de qualidade e aumenta a produtividade. Enquanto todos os participantes têm a informação, não apenas da demanda, que já seria útil, mas da forma que o sistema funciona, todos colaboram como se fosse um processo único, uma única empresa.

- Ampliação dos ambulatórios para dentro das empresas clientes

Algumas empresas que mantêm ambulatórios de atendimento dentro de suas instalações utilizam as ferramentas de TI cedidas pelo plano de saúde, para gerenciarem melhor seus recursos e também controlar melhor o histórico de seus pacientes.

As empresas conseguem realizar um trabalho profissionalizado, pois o sistema é completo.

A instalação de um sistema similar ao do plano de saúde na empresa contratante se justifica, pois o custo é zero e os controles são os mesmos do plano de saúde. Com isto, estabelecem-se relações permanentes entre as instituições, aumentando o grau de fidelização da empresa nos clientes.

F - Comércio eletrônico e redes de informação

- Rede credenciada externa (prestadores de serviço - terceirizados) 
O acesso de pacientes e a autorização para utilizar a rede externa terceirizada, com cerca de 2000 prestadores, são realizados, utilizando a cartão eletrônico de identificação.

Ao receber o paciente, o prestador de serviços verifica todos os dados do paciente, inclusive os procedimentos que ele tem direito e libera ou não o atendimento. O cartão eletrônico de identificação do paciente além de permitir acesso ao atendimento também gera um débito para o convênio que contratou os serviços. A documentação eletrônica deste débito servirá para que seja feito o faturamento eletrônico e a glosa eletrônica.

A TI contribui para flexibilizar o atendimento com base nos requisitos do cliente em relação a cumprimento de prazos (a operação é mais ágil), conveniência espacial (local do atendimento) e entrega dos serviços (permite a posse do serviço, realizando uma transação eletrônica). A operação permite ainda que se realize um maior controle dos recursos (mão-de-obra, processos e equipamentos). Os controles afetam os custos, minimizando-os. A TI contribui para a completa automação desta operação de serviços.

\subsubsection{Outras Considerações}

Uma questão importante na empresa C7 está relacionada com a adoção às novas tecnologias. Como a empresa é fortemente verticalizada, a implementação da TI não foi algo facultativo, mas sim uma imposição. A empresa instalou os equipamentos, treinou os usuários e explicou as vantagens do uso da TI. Pode-se dizer que a adesão foi $100 \%$, principalmente pelo fato de que a empresa não teve escolhas. Segundo relatos, a aprovação tem sido muito grande, pelas facilidades que o sistema apresenta, tanto no lançamento dos dados, quanto na busca e, principalmente, pela visão integrada dos casos: fichas de atendimento ambulatorial, exames, dados sobre internação, outros. Outro fato interessante trata-se da facilidade para se entender as prescrições, a padronização das informações. Tudo isto tem aumentado a segurança nos processos e essencialmente aumentado a confiança e a adesão na nova forma de trabalhar. Uma última variável que pode ter influenciado a velocidade das mudanças trata-se do perfil dos médicos que atuam na empresa estudada. Neste caso, são médicos contratados pela empresa que, mesmo que sejam autônomos, têm tarefas predeterminadas para realizar. Outra 
variável é a faixa etária: médicos não muito experientes (jovens) e, na maioria, clínicos. Mesmos os cirurgiões, no momento do uso da TI, estavam realizando trabalho de gabinete, ou seja, atendendo consultas.

\subsubsection{Resumo da Análise de C7}

A TI criou valor (eficiência e/ou eficácia) em diversas circunstâncias, entre elas, podem-se citar:

- diagnosticando processos, operações, demanda entre outros, facilitando a gestão clínica e administrativa da empresa;

- propiciando informações consolidadas em ficha eletrônica, dos procedimentos realizados pelo paciente na empresa;

- atendendo pacientes a distância (aconselhamento médico), via telefone e e-mail, utilizando softwares de apoio à decisão (árvore de decisão);

- identificando e encaminhando pacientes para procedimentos, por meio de cartão eletrônico;

- prescrevendo medicamentos e controlando o uso, utilizando cartão eletrônico;

- gerando relatórios a clientes empresariais, sobre os índices de utilização do plano de saúde por parte de sua carteira de usuários;

- instituindo formas de controle por biometria;

- utilizando equipamento móvel (PDAs) nas operações de campo de medicina preventiva e operações de campo da equipe comercial;

- integrando parceiros em uma rede valor;

- estendendo as ferramentas de TI utilizadas nos ambulatórios do plano de saúde até os ambulatórios das empresas clientes;

- autorizando o acesso e o débito dos procedimentos realizados, nos pacientes conveniados na rede credenciada externa, utilizando cartão eletrônico;

- outros.

Por que a TI cria valor? As respostas foram diversas, mas observou-se uma maior incidência do ponto de vista da eficácia, nas seguintes circunstâncias:

- minimizando os efeitos da inseparabilidade e co-produção do cliente; 
- contribuindo para tangibilizar a proposta de valor da empresa;

- facilitando a avaliação da qualidade dos serviços prestados em função da infra-estrutura utilizada;

- criando oportunidades de demonstrar maior diferenciação;

- outros.

Do ponto de vista da eficiência, observou-se que a TI teve maior contribuição nas seguintes circunstâncias:

- aumentando a produtividade, gerenciamento e controle dos recursoschave;

- melhorando as especificações das tarefas e otimizando as operações de linha de frente e de retaguarda;

- $\quad$ padronizando processos e reduzindo a variabilidade nos serviços;

- adequando a oferta à demanda, reduzindo a perecibilidade dos serviços;

- outros.

Quadro 13 - Resumo da Análise de C7

\subsection{EMPRESA 8 (C8) - EMPRESA FARMACÊUTICA}

\section{Dados da empresa}

\begin{tabular}{|c|c|}
\hline Faturamento anual da empresa: & $\mathrm{R} \$ 800.000 .000,00$ \\
\hline $\begin{array}{l}\text { Número de funcionários da } \\
\text { empresa: }\end{array}$ & 2.500 \\
\hline Funcionários terceirizados: & ND \\
\hline Funcionários de TI da empresa: & ND \\
\hline Funcionários de TI terceirizados: & ND \\
\hline $\begin{array}{l}\text { Área de aplicação da TI estudada } \\
\text { que gera vantagem competitiva } \\
\text { para empresa: }\end{array}$ & $\begin{array}{l}\text { Programa de marketing digital da empresa } \\
\text { que envolve principalmente } \\
\text { relacionamento com seus diversos tipos de } \\
\text { clientes: pacientes, médicos e farmácias. }\end{array}$ \\
\hline $\begin{array}{l}\text { Estratégia competitiva genérica e } \\
\text { escopo de atuação da empresa no } \\
\text { mercado: }\end{array}$ & $\begin{array}{l}\text { Pelo seu tamanho, estrutura e abrangência } \\
\text { em diversos mercados e segmentos, com } \\
\text { uma extensa linha de produtos, a empresa }\end{array}$ \\
\hline
\end{tabular}


atua no mercado com estratégia genérica de custos com escopo amplo.

ND - não declarado.

\section{Principais Características da Empresa}

C8 é uma das maiores farmacêuticas do mundo e usa fortemente a TI para relacionar-se com seu principal público (médicos) e também com o cliente final (paciente). É uma empresa de origem européia que procura diferenciar-se, na forma de interagir com seus clientes. O faturamento anual da empresa é cerca de $R \$ 800$ milhões.

A empresa ainda conta com uma área de pesquisa e desenvolvimento eficaz, que Ihe assegura um crescimento sustentável, um abrangente portfólio de medicamentos e vacinas para atender às principais demandas da saúde pública, incluindo tanto remédios inovadores quanto medicamentos consagrados pela medicina, que constituem a base da prescrição médica mundial.

A empresa possui uma cultura organizacional pautada na ética, qualidade, segurança e cidadania, que formam a base de seu compromisso perante a sociedade.

\section{Uso da TI}

A empresa oferece um leque de serviços utilizando a TI, que vão desde sites específicos para determinadas patologias, softwares gratuitos para controle de doenças, depoimento de doenças crônicas, informações sobre patologias diversas em "português", até um dicionário de especialidades farmacêuticas on-line. Também realiza rastreamento de medicamentos em farmácias, com a identificação de pacientes e respectivos médicos.

A empresa oferece uma série de serviços distribuídos diretamente a seus pacientes pelo seu portal na WEB. Por exemplo, para pacientes com diabetes, a empresa possui um software que ele pode baixar no computador ou PDA, para fazer a contagem de carboidratos. Desta forma, o paciente identifica a quantidade de insulina que deverá tomar. Possui ainda fóruns de debates com outros pacientes, seção de entrevistas atualizadas de médicos e pacientes, entre outros.

Para os médicos, existem diversas ferramentas para auxiliá-los no dia-a-dia, entre eles, podem-se citar: agenda de eventos; atualização científica; dicionário de 
especialidades farmacêuticas on-line; informações para doutorandos e residentes; educação continuada; materiais para download; notícias de saúde; oncologia on-line; seção Palm; seu consultório; outros: arte e cultura, concursos culturais, compras, curiosidades, empregos, enogastronomia, promoções e descontos, revista digital.

\subsubsection{Formas de Contribuição da TI - Categorias}

A - Sistemas estratégicos.

- Programa de marketing digital envolvendo médicos e pacientes

Conjunto de ferramentas disponibilizadas principalmente via WEB para médicos e pacientes. Entre as ferramentas, no caso dos médicos, podem-se citar: eventos médicos, atualização científica, bulas, concursos culturais, informações sobre vagas para doutoramento e residência médica, dicas para consultórios, softwares para PDAs, outros; no caso de pacientes, são diversos sites com informações sobre patologias, envolvendo depoimentos, fóruns de discussão, informações variadas sobre doenças, entre outras.

A TI ajuda no quesito informação ao paciente ou médico sobre patologias diversas. Como as informações sobre medicamentos são proibidas no país, uma das formas de criar um relacionamento com médicos e pacientes é informando sobre as patologias e suas características.

Ao dispor todas estas ferramentas, a empresa cria um vínculo com seus principais públicos: médicos e pacientes. Como o acesso direto aos pacientes, utilizando canais de comunicação não é permitido para empresas do setor farmacêutico, a empresa desenvolve um programa de relacionamento com os médicos e estes, por sua vez, influenciam os pacientes. A TI contribui para flexibilizar o atendimento com base nos requisitos dos médicos e pacientes, em relação a tempo, a local e à posse de informações e outras vantagens oferecidas pela empresa farmacêutica para estes públicos. O programa de marketing digital contribui entre outros para segmentar os públicos envolvidos com a empresa e dedicar esforços direcionados a eles.

B - Foco no cliente e no serviço

- Gerenciamento do relacionamento com clientes (Linha direta com médicos) 
A empresa conta com um banco de dados com mais de 50 mil médicos cadastrados que recebem informativos e por meio de uma senha acessam conteúdo de diversos sites.

O banco de dados estratifica os médicos por especialidade, endereço e outras informações que contribuem para compreender o perfil do médico.

Com base no perfil dos médicos e um trabalho de mineração de dados, podese realizar uma customização de massa. Assim, são encaminhadas informações específicas de interesse (agenda de eventos, artigos científicos, enciclopédia ilustrada, outros), otimizando o relacionamento entre médico e empresas farmacêuticas.

- Uso de software para determinar a quantidade de insulina por paciente

Distribuição de software para PDA ou computador, para controle de diabetes.

O software ajuda o paciente a fazer a contagem de carboidratos, que é a fórmula que se tem para saber qual a quantidade de insulina que ele deverá tomar. O programa também apresenta um despertador, que avisa os horários que o medicamento deve ser ministrado.

A TI contribui para que o cliente participe da especificação do processo de serviço antes de se incorporar a ele; e contribui para flexibilizar o atendimento ao paciente, para que ele não necessite se deslocar fisicamente até um ambulatório ou centro médico para realizar o acompanhamento; ajuda ainda a segmentar os pacientes, identificando suas patologias e grau de criticidade.

- Uso de software para produzir gráfico de curva de glicemia

Distribuição de Software para PDA ou computador, para controle de curva de glicemia.

O paciente realiza os testes (furo no dedo para medir glicemia) e vai registrando os dados e gerando um gráfico. O gráfico da curva de glicemia é fornecido ao médico que determinará qual ação tomar, se deve ou não ajustar a insulina do paciente.

Idem ao item anterior.

- Site específico sobre a saúde da mulher 
O objetivo deste site é informar às mulheres, em geral, sobre os mais variados assuntos, como, por exemplo, gravidez, estresse, cólica menstrual, tensão pré-menstrual, outros.

Informam-se, inicialmente aos médicos os benefícios que as informações podem trazer para as mulheres. Posteriormente, os médicos fazem as recomendações, que vão contribuir para aperfeiçoar seu tempo no consultório e oferecer um valor agregado, aumentando o nível de serviço prestado.

A TI contribui para que a empresa farmacêutica desenvolva relacionamentos de longo prazo com o médico e o paciente. Na medida em que este relacionamento contribui com a solução de problemas, cria-se uma maior lealdade entre estes públicos. De posse do conteúdo das informações, médicos e pacientes podem discutir mais facilmente sobre uma determinada patologia, o que facilita 0 tratamento, melhorando a eficácia e a eficiência nas operações de serviços.

- Apoio à decisão para os médicos por meio do DEF - Dicionário de especialidades farmacêuticas on-line e outras ferramentas envolvendo a TI

Disponibilização de Dicionário de especialidades farmacêuticas on-line para médicos cadastrados.

O dicionário é utilizado para que os médicos se informem sobre interações de medicamentos, princípio ativo e outras informações que contribuem para apoiar a decisão. Este serviço oferecido evita que o médico despenda esforços e recursos para adquirir estes conhecimentos. Ainda podem-se incluir, nesta mesma linha, calculadoras médicas, que contribuem para calcular riscos de infecção ou de traumas num determinado paciente, Código Internacional de Doenças (CID) on-line, para facilitar no preenchimento de formulários médicos.

Nestes casos, aumenta-se o interesse pelas informações da empresa e, possivelmente, o relacionamento com o médico e, advindo deste contato, a proximidade do médico com o paciente. Com as ferramentas, os médicos podem otimizar seu tempo, e dedicar maior atenção ao paciente, aumentar a qualidade na prestação de seus serviços ao fornecer ferramentas atualizadas.

C - Esforço contínuo de melhorias.

- Programa de conscientização e educação continuada para patologias crônicas 
Canal de informação via WEB (em português) para pacientes, subdividido em diversos sites que abordam variados aspectos de doenças crônicas. O objetivo dos sites é informar os pacientes sobre determinada doença. O que é a doença? Por que o paciente tem a doença? A doença tem cura ou não? O site apresenta outras informações que geralmente os pacientes queiram saber sobre a doença. A ferramenta também utiliza fóruns de discussão, depoimentos e outras possibilidades de troca de informações entre pacientes e médicos.

Além de informar, os sites também educam os pacientes sob diversos aspectos relacionados com sua doença. Os pacientes mais informados permitem com que o médico ganhe tempo e possa ser mais direto e objetivo no encaminhamento do tratamento. Assim, o que se faz é avisar primeiramente ao médico sobre a disponibilidade destas informações para os pacientes. O médico é quem faz a recomendação aos pacientes, sobre as características do site e os benefícios.

A TI contribui com o médico e o paciente, gerando facilidades em relação ao acesso a informações que podem ajudar o paciente na compreensão de sua patologia. Este fato cria um maior relacionamento do médico com a farmacêutica. Por exemplo, pacientes crônicos necessitam de medicamento de uso contínuo (osteoporose, diabetes). Os esforços da comunicação são para que os pacientes se conscientizem e não abandonem o tratamento, investe-se, portanto, na prestação de serviços para a população. Ao reconhecer os esforços da empresa, nesta prestação de serviços, e tomar conhecimento que o medicamento ajudará a resolver o problema de seu paciente, o médico pode optar em prescrever este medicamento ou não. Assim, além da TI contribuir indiretamente para o aumento das vendas da empresa, contribui-se também para que todo mercado cresça.

\section{D- Otimização do processo empresarial (reengenharia do processo do negócio)}

Obs. Este subitem será dividido em duas partes: reengenharia do processo do negócio e novos negócios gerados pela TI ou em processo de gestação.

D1 - Reengenharia do processo do negócio

- Uso de ferramentas de TI da empresa como diferencial competitivo para força de vendas 
O conjunto de ferramentas de TI da empresa (Programa de Marketing Digital) contribui para que a força de vendas (propagandistas e representantes de vendas) apresente argumentos diferenciadores em relação a seus concorrentes.

As ferramentas de TI apresentadas, cujo alvo são os pacientes, os médicos e os farmacêuticos, colaboram com o dia-a-dia destes públicos.

Com a melhora na qualidade do serviço para o médico, melhora também o relacionamento com a empresa farmacêutica, aumentando o poder de barganha do segundo em relação ao primeiro.

- Software de controle de estoques em farmácias (aumento do poder de barganha)

As farmácias recebem um software para realizarem controle de estoques e reposição automática de pedidos e, com isto, passam a negociar diretamente com o fabricante do medicamento.

Os distribuidores de medicamento são intermediários que apresentam grande poder de barganha com a indústria farmacêutica, pois compram em grande quantidade, assumem o risco dos estoques e levam o produto ao ponto de venda. $O$ distribuidor detém o poder no mercado, influenciando inclusive a precificação e os descontos nos medicamentos. Para o farmacêutico, quanto menor o risco melhor; neste sentido, ele acata as determinações dos distribuidores, que vendem os produtos que mais Ihes convêm, da forma que Ihes convêm.

O software de controle de estoques permite que o farmacêutico reduza os riscos e opte em trabalhar diretamente com a indústria farmacêutica, objetivando aumentar seu poder de barganha com o ponto de venda. Para o farmacêutico, contar com uma ferramenta que contribui para o controle de estoques e que permita negociar diretamente com as empresas farmacêuticas, é importante, pois amplia suas possibilidades de negociação e de flexibilidade. A ferramenta propicia um melhor relacionamento entre os farmacêuticos e empresas farmacêuticas, reduzindo o poder de barganha dos distribuidores de medicamentos. A ferramenta também contribui com os controles nos recursos-chave nas farmácias, controle dos custos e a flexibilização na operação, que colaboram com o dia-a-dia do farmacêutico.

D2 - Novos negócios gerados pela TI ou em processo de gestação.

Obs. Não foi observado nenhum item nesta categoria. 
E - Redes de valor e alianças entre empresas.

- Programa de relacionamento com planos de saúde (fármaco-economia)

Serviço de diagnóstico aplicado aos beneficiários das carteiras de clientes de planos de saúde. Para se fazer o diagnóstico, utiliza-se um software que analisa o perfil das carteiras, incluindo os pacientes internados.

Com base no diagnóstico, a empresa demonstra os benefícios e possibilidades de redução de sinistro, caso os beneficiários recebessem determinados medicamentos.

Houve aumento da eficiência, ao eliminar os problemas, antes que se complicassem; aumento da eficácia, pois o cliente recebe maiores cuidados e fica mais saudável. Neste caso, a TI contribui para que o cliente participe das especificações do processo do serviço antes de se incorporar a ele. $O$ desenvolvimento de relacionamentos de longo prazo, na medida em que se solucionam os problemas, contribui para aumentar a lealdade dos clientes. $\mathrm{O}$ uso da TI e os ganhos com eficiência são evidentes, pois os esforços são direcionados à produtividade, gerenciamento e controle dos recursos-chave.

- Programa de conscientização e educação continuada para patologias crônicas

Este item já foi comentado na categoria $C$ - Esforço contínuo de melhorias e também pode ser incluído nesta categoria. Uma das características conforme foi explicado, são os fóruns de discussão sobre determinadas doenças crônicas. Estas discussões formam comunidades virtuais, envolvendo pacientes e médicos.

$\mathrm{O}$ arranjo em formato de redes propicia um número maior e mais variado de informações a um custo baixo e de fácil acesso. Há também as vantagens relacionadas a questões qualitativas como, por exemplo, permitir que alguém, de forma anônima, fale um pouco sobre sua doença e tenha alguma satisfação em saber que existem outras pessoas interessadas em saber, ou que isto possa ajudar outras pessoas.

Este item já foi comentado na categoria $C$ - Esforço contínuo de melhorias, com as explicações por que a TI cria valor.

F - Comércio eletrônico e redes de informações. 
- Reciclagem profissional / geração de conteúdo para médicos

Informações divididas por especialidades e disponibilizadas nos sites ou enviadas por e-mail em formato compatível para computador ou equipamento móvel (PDAs).

As informações contribuem para a atualização dos médicos sobre assuntos de interesse, relacionados com sua especialidade. Há médicos que freqüentam congressos mais habitualmente e, outros, de forma mais discreta. Muitos médicos recorrem a assinaturas de revistas científicas, despendendo recursos próprios para a aquisição. As informações disponibilizadas pela empresa farmacêutica, quando não são originalmente em português, são traduzidas e entregues eletronicamente, contribuindo no processo de reciclagem dos profissionais, sem custo para os médicos. No momento, a empresa tem disponibilizado mais de duas centenas de artigos científicos por mês. Existe também a possibilidade de solicitação de artigos sob demanda, que são traduzidos e enviados aos médicos. Tem-se, ainda, nesta mesma linha de serviços, conteúdo em formato de resenhas de artigos, tornando possível que os médicos possam atualizar-se diariamente sobre novidades científicas no campo da saúde.

A criação de valor nas operações de serviços e uso da TI está relacionada principalmente com a conveniência espacial e entrega dos serviços. Os médicos solicitam e recebem o material eletronicamente de qualquer local onde haja acesso à Internet. Outras vantagens acerca do relacionamento com a empresa farmacêutica também podem ser atribuídos a esta operação usando a TI.

\subsubsection{Outras Considerações}

Pôde-se notar que, além deste caso, várias outras empresas estudadas, independentemente da área de atuação estão dando ênfase na prevenção. Seja pelo histórico do paciente, pelo perfil atual, pelos diagnósticos elaborados, pelo mapeamento genético, pelos medicamentos que ele toma ou pelos medicamentos que ele deixou de tomar, existe uma tendência de evitar que as doenças se agravem ou que o índice de sinistro aumente. Neste e nos casos anteriores, a TI foi utilizada fortemente para identificar as situações, informando para poder formar melhor os públicos envolvidos. 
caminho escolhido, neste estudo de caso, foi estabelecer vínculos com seus públicos-alvos por meio do fornecimento de informações e aumentando o nível de serviços prestado, buscando aumentar o relacionamento. A proposta foi tornar o mais transparente possível tudo que se sabe sobre determinada patologia, educando o paciente, prestando um serviço de utilidade pública. Também se identificaram controvérsias quanto às informações aos pacientes. Se por um lado, elas ensinam e tem-se um paciente mais preparado para compreender o problema e colaborar com ele; por outro lado, podem-se encontrar leigos questionando condutas médicas e até protocolos internacionalmente reconhecidos.

Inferiu-se, no estudo, que o médico cada vez tem menos tempo para explicar ao paciente sobre a doença dele. Diante disto, a TI tem contribuído para que o paciente fique mais informado, facilitando as interações entre médicos e pacientes. Mesmo assim, segundo se constatou, ainda há ainda muitos médicos que preferem o modelo anterior, onde se dizia ao doente o que ele tinha e não era necessário contra-argumentações.

Independentemente das percepções ou atribuições de valor às novas formas de se lidar com os pacientes, percebe-se pelo crescente número de acessos aos sites da empresa estudada e pela forma que os têm utilizado as ferramentas de $\mathrm{TI}$ disponíveis, que esta demanda está tornando-se mais sofisticada e exigente, demonstrando uma tendência de uso cada vez mais intenso.

\subsubsection{Resumo da Análise de C8}

A TI criou valor (eficiência e/ou eficácia) em diversas circunstâncias, entre elas, podem-se citar:

- ampliando o relacionamento com clientes (médicos e pacientes);

- desenvolvendo ferramentas que facilitam o controle de doenças e da utilização de medicamentos;

- informando, via WEB, características de doenças em geral;

- apoiando a decisão do médico com diversas ferramentas eletrônicas de informações da saúde;

- propiciando educação continuada a médicos em geral;

- gerando retaguarda e diferencial competitivo, para equipe comercial no 


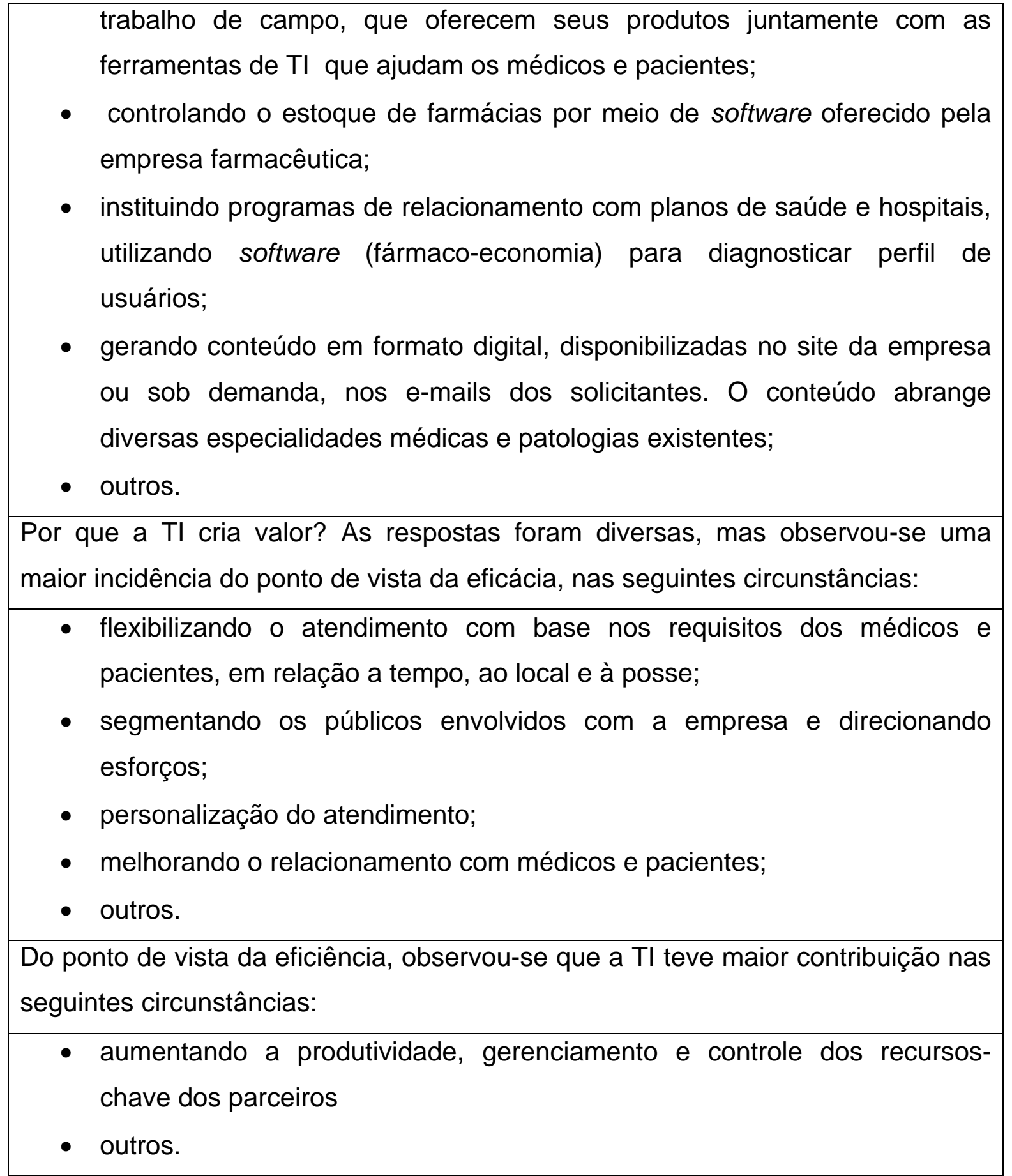

Quadro 14 - Resumo da Análise de C8

\subsection{EMPRESA 9 (C9) - EMPRESA DE SISTEMAS}

\section{Dados da empresa}

\begin{tabular}{|l|r|}
\hline Faturamento anual da empresa: & $\mathrm{R} \$ 35.000 .000,00$ \\
\hline $\begin{array}{l}\text { Número de funcionários da } \\
\text { empresa: }\end{array}$ & 320 \\
\hline
\end{tabular}




\begin{tabular}{|c|c|}
\hline Funcionários terceirizados: & 60 \\
\hline Funcionários de TI da empresa: & 110 \\
\hline Funcionários de TI terceirizados: & 40 \\
\hline $\begin{array}{l}\text { Área de aplicação da TI estudada } \\
\text { que gera vantagem competitiva } \\
\text { para empresa: }\end{array}$ & $\begin{array}{l}\text { Banco de dados, com informações } \\
\text { ambulatoriais, unificando todas as } \\
\text { informações do paciente em um único local } \\
\text { e que pode ser acessado pela WEB, em } \\
\text { qualquer hora e local onde houver acesso à } \\
\text { Internet. }\end{array}$ \\
\hline $\begin{array}{l}\text { Estratégia competitiva genérica e } \\
\text { escopo de atuação da empresa no } \\
\text { mercado: }\end{array}$ & $\begin{array}{l}\text { O escopo de atuação da empresa é } \\
\text { bastante amplo, abrangendo diversos } \\
\text { setores. A empresa conta com uma } \\
\text { quantidade expressiva de clientes que lhe } \\
\text { garante escala, entre outras vantagens } \\
\text { relacionadas a custo. Entre estas outras } \\
\text { vantagens, podem-se citar: curva de } \\
\text { aprendizagem, compartilhamento de } \\
\text { despesas entre as unidades, alto nível de } \\
\text { informatização, treinamento intensivo, } \\
\text { outros. }\end{array}$ \\
\hline
\end{tabular}

\section{Principais Características da Empresa}

C9 é uma empresa que oferece sistemas para racionalizar a assistência médica, envolvendo: médicos, clínicas, hospitais, laboratórios, farmácias e clínicas de diagnósticos. A proposta diferenciadora da empresa é centralizar e disponibilizar, em tempo real, todas as informações do paciente em um único banco de dados. $A$ empresa pertence a um grupo com mais de 20 anos de presença no Brasil. Atua fortemente no mercado corporativo e mantém contrato atualmente com mais de 350 clientes. Está classificada entre as 100 maiores empresas de TI do país e vem apresentando crescimento de 60\% ao ano nos últimos 3 anos.

O grupo mantém três Data Centers interligados e conta ainda em sua infraestrutura com telefonia IP, monitoramento por câmeras, gerador de energia, help desk, treinamento, outros. 


\section{Uso da TI}

A proposta de valor, com o uso da TI, para esta empresa é no seu banco de dados ambulatorial, o qual unifica todas as informações do paciente em um único local e que pode ser acessado pela WEB, em qualquer hora e local onde houver acesso à Internet.

O sistema para racionalizar a saúde, desenvolvido por C9, apresenta um prontuário eletrônico ambulatorial e apresenta as seguintes ferramentas: sistema antifraude (autenticação do paciente), validação do paciente, compartilhamento de informações, padronização de atendimento, protocolos de atendimentos médicos, contas médicas, redução de investimento em $\mathrm{TI}$, outros. Estas ferramentas servem para que seus usuários, as operadoras (planos de saúde, seguros saúde, autogestões, cooperativas e outros) reduzam seus custos.

\subsubsection{Formas de Contribuição da TI - Categorias}

A - Sistemas estratégicos.

- Banco de dados com histórico da saúde do paciente (acesso via WEB)

O banco de dados com histórico da saúde do paciente reúne todas as informações do paciente como se fosse um extrato bancário. Esta ferramenta mantém os dados do paciente de forma padronizada e em séries históricas. Neste caso, facilita que se observe a evolução do tratamento ou mesmo procedimentos da saúde do paciente que podem contribuir com novos tratamentos.

A apresentação do histórico, constando medicamentos utilizados, tempo de internação, intervenções cirúrgicas, exames de análises clínicas ou por imagem e outros procedimentos médicos, contribuem para o tratamento tanto do ponto de vista do paciente como do ponto de vista do convênio médico. Ao evitar duplicidade de exames ou solicitação de exames que ainda estejam com validade, reduz custos para o convênio e diminui o incômodo do paciente em realizar outros exames. Ganha-se tempo e, com isto, pode-se aumentar a resolutividade do tratamento. Aperfeiçoa o trabalho dos médicos ao apresentar em detalhes e de forma padronizada o que os outros especialistas já fizeram, contribuindo para sua hipótese-diagnóstica. Além destas vantagens, ainda não é necessário reiniciar o tratamento, cada vez que um especialista assume ou passa a participar do caso, 
seja porque o paciente foi encaminhado por outro médico, seja porque o paciente resolveu trocar de médico.

O acesso, via WEB, às informações do paciente contribui para flexibilizar o tempo, local e posse por parte do médico, podendo acompanhar a evolução do paciente de qualquer local que tenha acesso à Internet. Isto também favorece o paciente, que poderá dispor de seus dados em qualquer local do planeta. Na medida em que houver necessidade de novos profissionais médicos se incorporarem ao processo de tratamento deste paciente, por troca do médico ou por mudança de local de tratamento, troca de convênio, mudança do paciente de região, o histórico do paciente continuará facilmente sendo acessado. Este fato traz vantagens para o paciente, para o médico e para a fonte pagadora. O paciente terá continuidade no tratamento iniciado; os médicos poderão levantar melhores hipóteses-diagnósticas para tratamento que estão iniciando e os convênios poderão reduzir custos, eliminando a repetição de serviços que já foram realizados.

B - Foco no cliente e no serviço.

- Aumentar o contato do médico e do convênio com o cliente

Aumento do contato do médico e do convênio com o cliente por meio de comunicação eletrônica. O banco de dados permite realizar análises sofisticadas do perfil da carteira de cada convênio, possibilitando uma espécie de personalização em massa.

O convênio e o médico obtêm estas informações e as dispõem para seus clientes, quando julgarem adequado, quando localizam grupos de risco em cardiologia, por exemplo, e, nestas situações, recomendam protocolos preventivos desta especialidade. Além deste tipo de informação, pode-se contatar o paciente para avisar sobre um exame, ou consulta marcada, ou até desejar-lhe feliz aniversário, usando ferramentas do prontuário eletrônico.

A TI permite uma melhora no relacionamento do paciente com o médico e/ou com a organização. Este contato cria maiores possibilidades de fidelização dos pacientes e margens mais significativas para a empresa.

C - Esforço contínuo de melhorias.

- Redução do custo administrativo utilizando a TI 
O custo administrativo de uma transação realizada, utilizando a TI, é cerca da metade do valor de uma transação realizada no modelo tradicional.

As despesas com papel, mão-de-obra, espaço para armazenagem de papéis, custos de procura de informações, duplicidade nas solicitações de consultas, exames, procedimentos, outros, encarecem o processo tradicional, além de reduzirem muito o nível de serviços oferecidos.

Com o aumento da padronização e procedimentalização propiciado pelas ferramentas de TI, aumenta-se a qualidade e reduzem-se perdas desnecessárias e, dessa forma, a operação torna-se mais eficiente. Estes ganhos permitem que os funcionários dediquem maior tempo ao cliente, aumentando também a eficácia nas operações de serviços.

- Visão sistêmica do atendimento em relação ao paciente

O uso da $\mathrm{TI}$ possibilita que se avaliem quantos médicos, quantos especialistas, quantos outros recursos são oferecidos pela empresa para um determinado paciente em um espaço de tempo. Esta análise não apenas permite entender melhor os problemas do paciente como também contribui para uma análise da qualidade do atendimento que o paciente está recebendo dentro da rede.

Pode-se, por exemplo, realizar uma análise estatística e descobrir que o paciente está utilizando os recursos acima ou abaixo da média. No primeiro caso, pode-se concluir que há uma insatisfação no atendimento e o paciente está buscando alternativas. No segundo caso, o paciente pode estar mal informado sobre seu retorno a um especialista ou qualquer outro motivo que faça com que ele postergue uma visita ao médico, portanto, nesta situação, também é importante contatá-lo, pois ações preventivas são mais eficientes, de menor custo aos convênios e geram mais satisfação aos clientes.

A forma com que as informações ficam dispostas, utilizando a TI, permite uma análise mais abrangente e sistêmica sobre a saúde do paciente, uma melhor compreensão acerca de seus problemas, gerando as melhores soluções. O paciente tenderá a aumentar o relacionamento com as organizações que contribuem para o atendimento de sua saúde, mais do que com as que apenas cuidam de sua doença. Melhorando a saúde, aumenta-se a produtividade no tratamento e reduzem-se as despesas nesse tratamento. Esta visão mais abrangente das operações de serviços 
com o paciente ainda propiciam a otimização da capacidade produtiva e maior flexibilidade operacional em geral.

- Protocolos médicos no prontuário eletrônico como apoio a decisão

Utilizar ferramentas de busca dentro do prontuário médico, em que o médico possa consultar e orientar-se com base em protocolos médicos internacionais, contribui para aprimorar a qualidade no atendimento.

Ao apresentar protocolos relacionados a procedimentos, medicamentos e a outros, os protocolos contribuem no apoio a decisão do profissional médico. Isto minimiza erros que impactam em custos desnecessários e na qualidade de atendimento dos pacientes.

Os protocolos médicos orientam os médicos e permitem uma maior especificação na operação de serviços, mesmo em uma situação clássica de serviço profissional. Além desta vantagem, os protocolos são espécie de trabalho de retaguarda que pode ser utilizado na linha de frente, quando for necessário. Por fim, os protocolos, dispostos com o prontuário eletrônico para consulta, também aumentam a previsibilidade das operações, permitindo um aumento no índice de padronização e especialização e produtividade.

- Rastreabilidade dos procedimentos no paciente

O sistema permite rastrear quais médicos, exames, medicamentos, datas e circunstâncias em que foram realizadas as ações, além de outras informações importantes. Estas informações podem ser úteis tanto para questões relacionadas ao pagamento das faturas, glosas, auditoria, como para outras questões legais relacionadas à conduta médica ou à conduta do paciente, entre outros.

Os pacientes possuem um número de registro e uma senha de acesso, em que as pessoas autorizadas podem analisar os dados de qualquer local, via WEB. Esta operação reduz o deslocamento de profissionais, torna mais ágil o processo de respostas, de verificação de custos; de procura em geral, facilita questões administrativas, assim como questões relacionadas ao tratamento do paciente.

A TI cria valor ao flexibilizar as operações de serviços, no que se refere ao tempo de procura e ao local onde se encontram as informações do paciente, facilitando este acesso. Isto, de certa forma, aumenta a percepção do cliente em 
relação à qualidade do serviço prestado, reduz as despesas com gerenciamento e com controle dos recursos-chave da empresa.

- Ganhos de escala no banco de dados

A TI permite que os custos de acesso às informações para beneficiários, convênios, prestadores de serviço e outros sejam viáveis e possam ser oferecidos da mesma forma que um estrato bancário.

A infra-estrutura tecnológica para dispor as informações em formato padronizado, assim como todas as ferramentas que garantem a qualidade do serviço, só é possível em função do fracionamento dos custos entre os participantes.

As vantagens logísticas relacionadas a tempo, a local e à posse das informações são elementos fundamentais na gestão de carteiras de associados e isto só é possível, no que tange ao plano econômico, quando se reúne um número expressivo de associados, conforme caso apresentado. Outras possibilidades de ganhos podem ser observadas no gerenciamento e no controle de custos ao se consolidarem as informações e ao se analisarem as mais variadas situações de um ponto de vista mais completo.

D- Otimização do processo empresarial (reengenharia do processo do negócio).

Obs. Este subitem será dividido em duas partes: reengenharia do processo do negócio e novos negócios gerados pela TI ou em processo de gestação.

D1 - Reengenharia do processo do negócio.

- Acesso a informações em qualquer local e em tempo real

O banco de dados permite que as informações estejam disponíveis em tempo real em qualquer local que se tenha acesso à WEB.

Esta operação permite que se reduzam custos de transação entre fornecedores, clientes, pacientes e todos os participantes da rede de valor em que o paciente está inserido. Os médicos, por exemplo, poderão analisar resultados de exames e prescreverem diretamente no prontuário e o paciente e outros envolvidos na operação poderão usufruir destas vantagens.

A flexibilização, com base nos requisitos do cliente, seja ele o médico ou o paciente, é total, pois o acesso ao banco de dados, via WEB, trazem vantagens importantes no que se refere ao tempo e ao local para acesso às informações dos 
pacientes. Pode-se observar também uma maior flexibilidade nas operações de serviços envolvendo datas de entrega, ajustes nas equipes de trabalhos, entre outros. Como conseqüência, ainda pode-se obter maior utilização da capacidade produtiva, ao flexibilizar o paciente que receberá o serviço como o prestador do serviço.

D2 - Novos negócios gerados pela TI ou em processo de gestação.

- Explorar segmentos ou negócios específicos de mercado

O banco de dados permite que as informações estejam disponíveis em tempo real em qualquer local que se tenha acesso à WEB. E, conforme foi explicado anteriormente, esta operação reduz custos de transação, entre outras vantagens relacionadas à acessibilidade a informações em situações específicas. Este diferencial pode gerar novos negócios para as empresas.

Alguns segmentos na sociedade como, por exemplo, executivos, profissionais liberais, atletas e outros que viajam com certa freqüência, precisam de suas informações sobre saúde, onde estiverem, portanto, são mais "sensíveis" a este tipo de serviço.

O benefício oferecido pela TI permite explorar segmentos específicos por meio de uma oferta diferenciada de serviços. Este fato criará um vínculo maior com o prestador de serviço, trazendo soluções para esta peculiaridade relacionada ao trabalho ou estilo de vida do paciente.

E-Redes de valor e alianças entre empresas.

- Alianças de cooperação e padronização de procedimentos

A TI permite que se desenvolvam alianças de cooperação entre empresas, que propiciam vantagens mútuas. Tanto as empresas tomadoras de serviço, os convênios, quanto às fornecedoras de serviço, os prestadores, melhoram a qualidade e ampliam suas fontes de vantagem competitiva no mercado.

$\mathrm{Na}$ medida em que os prestadores de serviço se dispõem a utilizar o prontuário eletrônico e a trabalhar, seguindo procedimentos preestabelecidos, consegue-se reduzir a variabilidade nas operações de serviços.

A redução da variabilidade nas operações de serviços denota maior qualidade e ampliam o valor do serviço oferecido. Com o aumento da previsibilidade nas 
operações de serviços entre os prestadores de serviços em uma rede de valor, pode-se aumentar o índice de padronização, especialização e, conseqüentemente, a produtividade.

- Parcerias entre os prestadores de serviço, melhorando o nível de serviços ao cliente

O banco de dados permite que as informações estejam disponíveis em tempo real em qualquer local que se tenha acesso a WEB. Os médicos recebem informações de resultados de exames encaminhados pelos laboratórios de análises clínicas, por exemplo. Poderão acionar outras áreas da rede de valor, afetando positivamente os membros desta rede.

Ao analisar um diagnóstico de um exame que foi enviado digitalmente para o prontuário eletrônico do paciente (banco de dados na saúde), o médico pode gerar uma receita de um medicamento ao paciente. Esta informação pode gerar uma solicitação de compra em uma farmácia próxima à residência do associado, podendo ser entregue em casa o produto solicitado, descontado, inclusive em folha de pagamento, da empresa em que o paciente trabalha.

Com o acesso de um grupo de prestadores de serviço a um mesmo banco de dados via WEB, cada prestador pode realizar sua parte nos serviços de forma interdependente. Este fato reduz custos de espera e de procura, permitindo maior flexibilidade para o cliente, e também para o prestador de serviços, o qual flexibiliza ainda sua capacidade operacional com base nas informações mais rápidas e atualizadas.

F - Comércio eletrônico e redes de informação.

- Parcerias entre os prestadores de serviço melhorando o nível de serviços ao cliente

Obs. No item $E$ - Redes de valor e alianças entre empresas, é apresentado o exemplo acima, o qual também ilustra o item comércio eletrônico.

\subsubsection{Outras Considerações}


Mais uma vez se constatou, por meio das informações obtidas na pesquisa com a empresa, que o usuário final ainda desconhece os benefícios e vantagens que a TI pode oferecer. Acredita-se que na medida em que os usuários tiverem mais informações e confiabilidade no processo passarão a pedir e isto pode ser uma fonte importante de vantagem competitiva para a empresa que utilizar este diferencial, além das vantagens de custo anteriormente explicadas.

Também se constatou, com base nas informações obtidas no estudo de caso, que os médicos muitas vezes são uma barreira de entrada às novas tecnologias e este fato tem causado morosidade e dificultado o processo de divulgação, de venda e de implementação desta ferramenta.

\subsubsection{Resumo da Análise de C9}

A TI criou valor (eficiência e/ou eficácia) em diversas circunstâncias, entre elas, podem-se citar:

- permitindo que se observem dados históricos da evolução do tratamento dos pacientes;

- melhorando o relacionamento entre médicos, convênios e empresas;

- reduzindo custo administrativo com os cuidados com a saúde;

- visão sistêmica do atendimento em relação ao atendimento;

- apoiando a decisão médica;

- facilitando a rastreabilidade de informações;

- permitindo escalabilidade para algumas operações;

- facilitando acesso a informações a qualquer hora e local;

- aumentando as oportunidades de comercialização de produtos para nichos específicos;

- $\quad$ permitindo alianças e cooperação entre empresas;

- disponibilizando informações em tempo real e melhorando o nível de serviços;

- outros.

Por que a TI cria valor? As respostas foram diversas, mas observou-se uma maior incidência do ponto de vista da eficácia, nas seguintes circunstâncias:

- flexibilizando o tempo, o local e a posse para pacientes, médicos e outros 


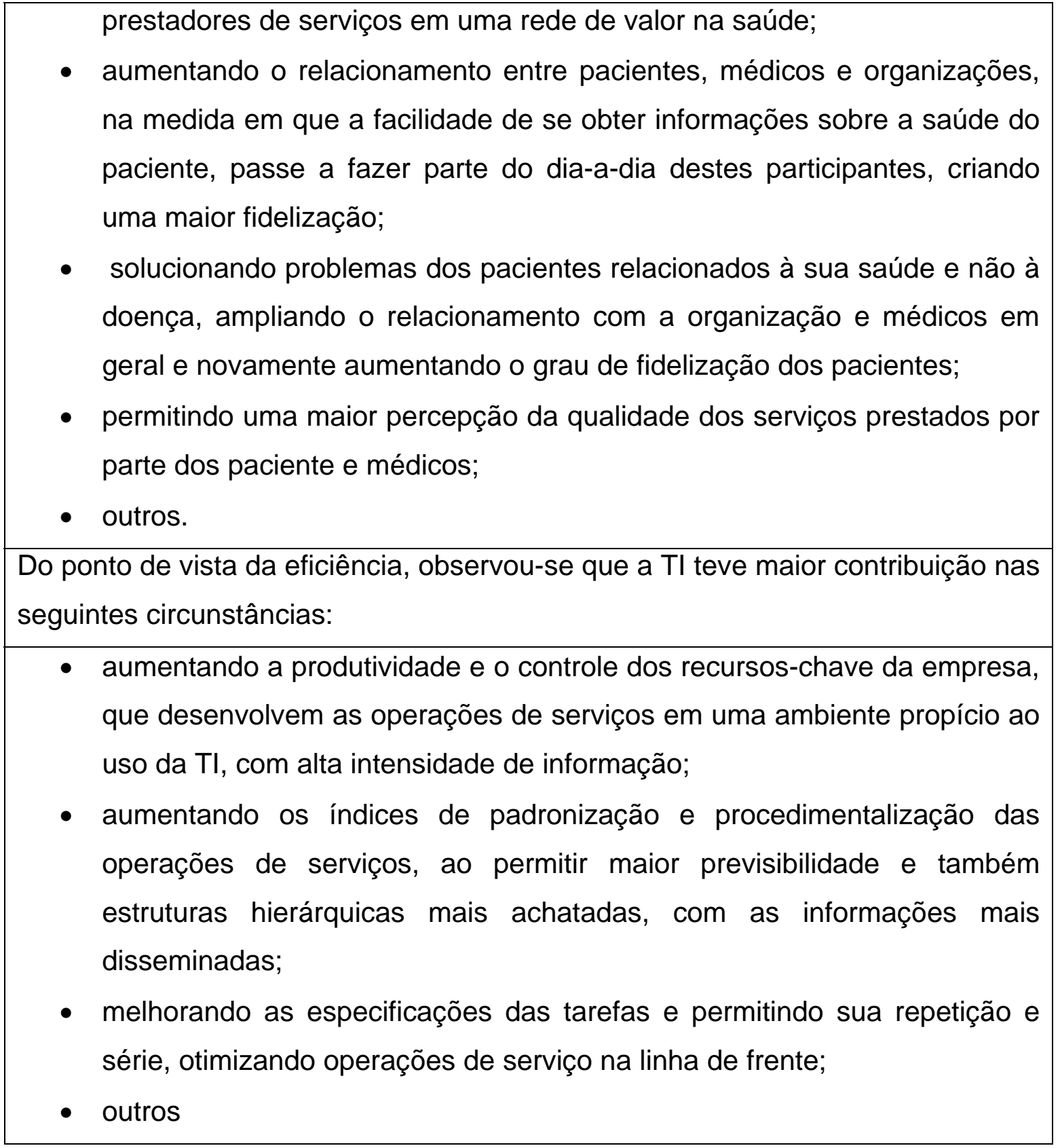

Quadro 15 - Resumo da Análise de C9

\subsection{EMPRESA 10 (C10) - EMPRESA DE GERENCIAMENTO DE BENEFÍCIOS DE MEDICAMENTOS}

\section{Dados da empresa}

\begin{tabular}{|l|r|}
\hline Faturamento anual da empresa: & $\mathrm{R} \$ 30.000 .000,00$ \\
\hline $\begin{array}{l}\text { Número de funcionários da } \\
\text { empresa: }\end{array}$ & 100 \\
\hline
\end{tabular}




\begin{tabular}{|l|lr|}
\hline Funcionários terceirizados: & & 0 \\
\hline Funcionários de TI da empresa: & & 12 \\
\hline Funcionários de TI terceirizados: & & 4 \\
\hline $\begin{array}{l}\text { Área de aplicação da TI estudada } \\
\text { que gera vantagem competitiva } \\
\text { para empresa: }\end{array}$ & $\begin{array}{l}\text { Foram estudadas diversas ferramentas } \\
\text { oferecidas pela empresa relacionadas à } \\
\text { gestão de benefícios de medicamento }\end{array}$ \\
\hline $\begin{array}{l}\text { Estratégia competitiva genérica e } \\
\text { escopo de atuação da empresa no } \\
\text { mercado: }\end{array}$ & $\begin{array}{l}\text { A infra-estrutura tecnológica da empresa e } \\
\text { a escala existente permitem que se } \\
\text { desenvolva uma estratégia genérica de } \\
\text { enfoque em custo. A empresa atua } \\
\text { fortemente nas operações de serviços que } \\
\text { envolvem medicamentos. A partir de } \\
\text { informações sobre o uso de medicamentos, } \\
\text { a empresa desenvolve informações para } \\
\text { gestão clínica e administrativa de uma } \\
\text { determinada carteira de clientes. }\end{array}$ \\
\hline
\end{tabular}

\section{Principais Características da Empresa}

C10 é uma empresa nacional que surgiu no mercado em 1999, como uma empresa de gerenciamento de benefícios de medicamentos (PBM). A operação engloba a conexão eletrônica de uma rede de farmácias a um banco de dados que deve possibilitar a disponibilidade de medicamentos a uma lista referencial, a elegibilidade do beneficiário, autorização da operação e conseqüente armazenamento e disponibilização de informações para as empresas contratantes.

Tem como principais clientes: laboratórios farmacêuticos, planos de saúde, seguradoras, autogestões, cooperativas e empresas de grande porte. No momento, a empresa conta com uma carteira de 6 milhões de associados.

A empresa trabalha com um banco de dados sempre relacionados a medicamentos. Com base histórica do consumo de medicamentos da carteira analisada, a empresa faz um diagnóstico da situação, apontando o perfil das doenças, tipos de patologias, entre outros.

C10 também intermedia transações entre plano de saúde, empresas e farmácias, fornecendo um cartão eletrônico aos beneficiários, que permite que façam compras em farmácias e obtenham desconto em folha de pagamento em suas 
empresas. As informações referentes à compra, como data e horário, são enviadas ao plano de saúde, que incluirá na ficha médica ou prontuário do paciente.

\section{Uso da TI}

A operação de serviços da empresa utiliza intensamente os serviços anteriormente citados, como gerenciamento de benefícios de medicamento, conexão entre farmácias e planos de saúde, serviços de atendimento telefônico e outros. Todos estes serviços podem ser desenvolvidos independentes ou estar contidos em uma opção mais ampla que é a gestão de risco na saúde. A gestão de risco na saúde utiliza fortemente a $\mathrm{TI}$, que identifica, estratifica os usuários de risco e dá suporte para monitoramento de programas preventivos com base na utilização dos medicamentos entre outras características em uma determinada população.

Toda a operação é realizada por um software de autorização que processa, autoriza e armazena a dispensação de medicamentos em tempo real.

A empresa opera com diversos produtos, entre eles podem-se citar:

- assistência farmacêutica on-line - serviço de atendimento telefônico supervisionado por farmacêuticos e apoiado por médicos destinados aos associados dos programas de benefícios de medicamentos, profissionais e entidades de saúde;

- cartão de descontos básico - empresas com cartões de descontos, seguradoras, corretoras e demais carteiras, que desejam acrescentar serviços de benefícios de medicamentos;

- gestão de benefícios de medicamentos para carteira de associados controles, segurança nas operações, redução de custos, controle de reembolso, flexibilidade de subsídios e possibilidade de desconto em folha de pagamento dos funcionários;

- rede nacional de farmácias credenciadas - benefício destinado à pessoa física, rede de farmácias credenciadas que vendem medicamentos com descontos de até 60\%;

- gestão de risco na saúde - identificação e estratificação de usuários de risco e suporte de monitoramento de programas preventivos, utilizando ferramentas como central de relacionamento e WEB. 


\subsubsection{Formas de Contribuição da TI - Categorias}

A - Sistemas estratégicos.

- Gerenciamento de benefícios de medicamentos integrado a outras fontes de informação administrativa e clínica.

A operação utiliza a TI de várias formas. Inicialmente, identificam-se os pacientes e classificam-os por categorias. Na seqüência, procura-se estratificar os pacientes por grupos de risco, para suporte, monitoramento de programas preventivos, e outros, utilizando ferramentas como central de relacionamento e WEB. A gestão abrange as questões clínicas e administrativas, criando regras, sistemas à prova de falhas, padronização dos serviços, outros.

No caso da gestão clínica, a TI contribui para mapear o perfil das carteiras de usuários de planos de saúde, de seguradoras, de autogestões, de cooperativas e outros, com base no histórico de medicamentos utilizados por estes pacientes em seus planos. Por exemplo, qual o percentual de diabéticos de uma determinada carteira. Utilizando-se indicadores de saúde, sabe-se que essa é uma doença que representa em média $X \%$ das despesas de uma carteira que, por sua vez, consome em média Y\% da despesa total de um plano de saúde. Hipoteticamente falando, se juntar com outras patologias, com, por exemplo, hipertensão, neoplasia, obesidade, outros, tem-se $20 \%$ da carteira que corresponde de 70 a $80 \%$ de toda a sinistralidade.

O processo de diagnóstico identifica não apenas as patologias, mas também quais os pacientes que estão em situação de risco. Com este diagnóstico, pode ser feita uma gestão clínica da carteira, atuando principalmente de forma preventiva nas doenças de alto custo. Estas informações permitem que os planos de saúde, em geral, tracem planos de ação em sua carteira de beneficiários e consigam reduzir custos, por meio da melhoria da saúde de seus associados, aumentando sua eficiência e eficácia.

Dentro do plano de ação, existem alternativas, utilizando a TI e envolvendo o uso de medicamentos, que podem ser utilizados, que vão desde o processo de compras até informações sobre o efeito de determinados medicamentos, entre outros. O controle das informações, em alguns casos, está estendendo-se para outras bases de dados como, por exemplo, o prontuário eletrônico dos pacientes, 
protocolos médicos e outros, criando mais alternativas de inteligência para a gestão clínica.

No campo administrativo, os itens relacionados à legibilidade do usuário, se ele tem direito a um determinado medicamento ou procedimento, se o médico está autorizado a fazer determinada prescrição, também estão sendo incorporados ao sistema de informações, tornando os controles mais completos.

As ferramentas de $\mathrm{TI}$ são fundamentais para identificar segmentos de usuários e desenvolver operações de serviços que vão ao encontro de suas expectativas. O mapeamento dos grupos de risco permite que se direcionem esforços na solução dos problemas dos pacientes. A conseqüência destes efeitos é a realização de serviços mais eficientes e eficazes. Eficazes, pois o mapeamento de risco permite agir de forma preventiva, o que é bom para o paciente; eficiência é bom para o paciente que apresentará menor sinistro assim como para o convênio que aumentará sua eficiência e reduzirá custos ao sobre a gestão de seus pacientes.

$B$ - Foco no cliente e no serviço.

- Mapeamento do perfil dos clientes e personalização em massa

As ferramentas de TI contribuem para juntar os dados dos pacientes e transformá-los em informações que permitem a personalização em massa, favorecendo o aumento da previsibilidade nas operações de serviços. Estas informações geram recomendações de como agir sobre determinado grupo de pacientes, para torná-los mais satisfeitos.

Conhecendo-se o perfil do paciente, pode-se, por exemplo, evitar que ele utilize medicamentos incompatíveis com outras drogas ou que causem problemas colaterais.

A personalização em massa cria grupos homogêneos, que ao controlar melhor os custos como mão-de-obra e outros recursos, dedicam-se esforços de forma mais específica. A adequação da mão-de-obra e dos recursos também tem a capacidade otimizada na medida em que prevê com mais assertividade quais os grupos de risco e seu tamanho.

C - Esforço contínuo de melhorias.

- Sistema autorizador para compra de medicamento e controle de uso 
Sistema autorizador para compra de medicamento por meio de cartão de identificação do paciente, para que ele se dirija até uma farmácia conveniada e realize a aquisição dos medicamentos.

O cartão eletrônico recebe as informações dos médicos dos convênios e o paciente leva até a farmácia para fazer a solicitação. No ato da prescrição, o médico utiliza uma lista de medicamentos que faz parte de parcerias com farmacêuticas e com a rede de farmácias credenciadas, que geram descontos de até $60 \%$ nos medicamentos. No ato da compra na rede credenciada de farmácias, o cliente passa o cartão, para que se identifiquem os medicamentos e efetue a compra. Estas informações de hora e data da compra são enviadas eletronicamente para a ficha médica do paciente, assim como o débito dos valores, que serão enviados para o plano de saúde e depois para a empresa, que descontará os valores em folha de pagamento.

O serviço realizado, utilizando a TI, denota maior qualidade e diferenciação do prestador e contribui na compra de medicamentos para o paciente, flexibilizando tempo, local e posse. Ao indicar medicamentos de menor custo, aumenta-se a probabilidade do paciente adquiri-lo, tornando mais eficiente o tratamento. Este fato reduz despesas com os recursos-chave da empresa.

- Sistema autorizador para compra de medicamento subsidiados pelas empresas

Sistema autorizador para compra de medicamento por meio de cartão de identificação do paciente, para que ele se dirija até uma farmácia conveniada e realize a aquisição dos medicamentos.

Este sistema, semelhante ao anteriormente apresentado, determina as farmácias conveniadas e sugere os medicamentos em uma lista privilegiada. Estes controles permitem comprar medicamentos com preços menores e ainda evitam fraudes. Como os medicamentos são pagos pelas empresas, ou algumas vezes subsidiados, os ganhos com redução nas despesas são automáticos.

A TI cria valor basicamente da mesma forma que o item anterior, porém podese acrescentar que os controles são muito mais eficientes que no modelo tradicional. Toda a compra é realizada de forma automática, com descrição dos itens adquiridos. Conforme explicado, isto evita fraudes, de majoração de preços ou de itens que não são relacionados a medicamentos. 
- Mapeamento de utilização dos recursos médicos (empresa e plano de saúde) e alerta de risco

Relatório constando volume de utilização por usuário, participação por medicamentos mais utilizados e incidência por patologias.

Ao apresentar uma curva abc de utilização de medicamentos, inicia-se um processo de identificação de tendências e concentrações, que pode apontar áreas de maior incidência em uma empresa ou em regiões, entre outras variáveis (alerta 1). Os consumos de medicamentos, por tipo e quantidade indicam que os pacientes podem estar tomando mais medicamentos para sistema nervoso central, cardiologia, diabetes, outros (alerta 2). Estes medicamentos podem ser divididos em subgrupos, trazendo informações detalhadas. Uma terceira abordagem é uma análise sobre as patologias mais utilizadas, como hipertensão e diabetes, por meio das drogas consumidas relacionadas a estas patologias (alerta 3). Estes exemplos de alertas servem para se desenvolver programas preventivos nas empresas e em carteira de associados em planos de saúde e são realizados periodicamente, para que se possam medir os resultados das ações e/ou planos preventivos.

O mapeamento diagnostica os grupos de incidência por patologia, que permite uma melhor prescrição preventiva ou curativa, favorecendo a solução dos problemas dos pacientes. Com isto, aumenta-se o relacionamento, a solução de problemas e consegue-se maior fidelização. Por outro lado, o mapeamento também permite um ganho importante no controle dos recursos-chave, mão-de-obra e equipamentos. Favorece sobremaneira o desenvolvimento tanto de retaguarda, como na linha de frente, por meio de especificações mais detalhadas para cada tipo de tratamento. Contribui para aumentar o índice de reprodução em série de uma mesma solução de serviços. As operações de serviços, ao dedicar esforços a grupos específicos, tornam-se mais previsíveis e aumentam o grau de procedimentalização, aumentando a qualidade. Tudo isto contribui para o controle de custos da operação.

D- Otimização do processo empresarial (reengenharia do processo do negócio).

Obs. Este subitem será dividido em duas partes: reengenharia do processo do negócio e novos negócios gerados pela TI ou em processo de gestação. 
- Controle de medicamento em nível ambulatorial

A TI, por meio da análise dos medicamentos, identifica os pacientes graves e crônicos e a empresa ou plano de saúde que o paciente pertence subsidia os medicamentos. O uso destes medicamentos pelos pacientes é monitorado por uma central de atendimento telefônico. Periodicamente, analisa-se a evolução do tratamento do paciente.

$\mathrm{Na}$ medida em que a TI identifica pacientes graves ou crônicos e monitora o uso de medicamentos, reduzem-se despesas com contas de alta complexidade no futuro. As despesas com medicamento ambulatorial, para estes casos, podem ser pagas pelas empresas e também pelos planos de saúde.

A segmentação e a pré-seleção, permitidas pela $\mathrm{TI}$, contribuem para definir melhor a expectativa do cliente, conforme foi explicado. Isto gera um melhor relacionamento e fidelização, além de todos os controles de custo e produtividade conseguida nas operações de serviços.

- Monitoramento e controle de utilização de medicamentos otimizando a gestão clínica

A TI permite que se identifiquem quais pacientes estão utilizando determinado tipo de medicamentos, no ato da compra nas farmácias, utilizando ferramentas de controle e monitoramento da carteira. Com estes dados, pode-se extrair informações, de utilização de medicamento que podem indicar tendência para uma doença no futuro.

Ao identificar que tipo de medicamento um paciente está tomando, no ato da compra na farmácia, por exemplo, uma droga para hipertensão, sabe-se que ele poderá tornar-se um diabético crônico. Primeiramente, ele apresentará complicações urinárias, comprometimento do rim e até utilização de procedimentos de alto custo como Hemodiálise, entre outros.

A identificação precoce permite que se trabalhe de forma preventiva, minimizando custos e melhorando a qualidade de vida do paciente, aumentando a eficácia e eficiência do tratamento.

- Gestão individual da saúde 
Com base no diagnóstico do paciente, desenha-se um protocolo com procedimentos e datas para realização, que será controlado, utilizando a TI.

Utiliza-se a TI para controlar o desenvolvimento destes protocolos e datas. $\mathrm{Na}$ medida em que o paciente se conscientiza dos benefícios do programa, ele passa a utilizá-lo espontaneamente, ampliando os índices de resolutividade dos casos.

Além das vantagens anteriormente apresentadas, a TI permite que o paciente participe da especificação do serviço antes de se incorporar a ele. Neste caso, o paciente autoriza o monitoramento e complementa com outras informações e procedimentos que ajudam em seu tratamento. Estas informações adicionais favorecem para que o tratamento seja ainda mais personalizado e atinja melhores resultados.

- Gestão de pacientes graves

A TI é utilizada para identificar estes pacientes e depois monitorar os procedimentos que serão determinados para sua recuperação.

$\mathrm{Na}$ medida em que não se desenvolveram programas preventivos no passado, as carteiras apresentam em média $2 \%$ de pacientes graves de alto risco. Utiliza-se uma central de atendimento telefônico, para ligar nas casas dos pacientes, para informar sobre um programa de recuperação, ou para fazer alguma operação de serviço reacional ou para questionar por que não compareceu na consulta.

Estes mecanismos evitam que se perca o contato com estes pacientes e só reencontre com eles quando o caso for crônico, em uma situação de internação ou outras. A TI, neste caso, contribuiu para flexibilizar o tempo e o local de atendimento, por meio da central telefônica ativa, que também favorece um maior relacionamento com o paciente. Contribui para aumentar a produtividade e custos em geral.

- Atualização continuada dos médicos utilizando protocolos na Internet

A TI contribui para disseminar informações que contribuem com a boa prática médica, divulgando protocolos baseados em evidência, validados pelas sociedades de especialidades, aos médicos que cuidam de uma determinada população.

Os protocolos devem ser inseridos nos programas de prevenção e tratamento das doenças, padronizando e facilitando o tratamento e a resolutividade nos casos.

$\mathrm{Na}$ medida em que os médicos sejam mais bem atendidos pelas empresas contratadas, tendem a melhorar seu relacionamento com elas, o que favorece na 
solução de problemas. O tempo ganho pelo médico pode ser dedicado com o paciente que, por sua vez, fará uma melhor avaliação do serviço prestado.

D2 - Novos negócios gerados pela TI ou em processo de gestação.

- Modelo facilitador para a indústria farmacêutica e para planos de saúde

Programa de monitoramento de utilização de um determinado medicamento em pacientes de risco. Evitar que o paciente pare de tomar o medicamento e apresente retrocesso no tratamento.

Com o monitoramento, a indústria farmacêutica demonstra aos planos de saúde ou as empresas que o paciente pertence, as vantagens de não descontinuar a utilização das drogas. Este efeito poderia torná-lo suscetível a complicações, a riscos de uma nova cirurgia, para alguns casos, que gerariam maiores custos e redução da qualidade de vida do paciente.

A TI ajuda a identificar os casos e também incentiva os usuários participarem da especificação dos serviços antes de se incorporar a este. Outras vantagens observadas com o uso da TI nas operações de serviços, como resserviços e outras despesas relacionadas ao agravamento do tratamento dos pacientes, podem ser evitadas.

- Modelo facilitador para a indústria farmacêutica e setor público

Uso da TI para controle de um programa de monitoramento e distribuição de pós-medicamento em pacientes transplantados. O uso inadequado ou não uso de medicamentos compromete a recuperação do paciente e todo o investimento da fase pré-operatório.

Com o monitoramento, identifica-se o medicamento correto, para o paciente certo, na dose certa, inibindo também fugas dos pacientes.

- Idem ao Modelo facilitador para a indústria farmacêutica e para planos de saúde

- Modelo facilitador para a indústria farmacêutica direto com o usuário final Uso da TI para incluir e controlar um programa de monitoramento de utilização de medicamento. O programa tem a anuência do médico e do paciente, que recebe descontos no valor dos medicamentos por fazer parte de um programa. 
O monitoramento identifica a compra do medicamento pelo paciente e depois uma central de atendimento telefônico verifica se ele comprou novamente na data prevista. Quando isto não ocorre, contata-se o paciente para perguntar os motivos. A central de atendimento telefônico também realiza outros tipos de contato com o paciente, verificando se ele está tomando o medicamento e também quanto à nova consulta com o médico, entre outras coisas. O sistema tem diversas alternativas à prova de falhas que servem para facilitar a vida do paciente e ampliar as vendas na indústria farmacêutica.

- Idem ao Modelo facilitador para a indústria farmacêutica e para.planos de saúde

- Parceria público-privada para distribuição de medicamentos

$\mathrm{O}$ item acima está descrito em detalhes no item $\mathrm{F}$ - Comércio eletrônico e redes de informação. Ele foi incluído também nesta categoria por ser um novo negócio gerado pela TI para a empresa.

E - Redes de valor e alianças entre empresas

- Monitoramento e controle de utilização de medicamentos otimizando a gestão clínica em uma rede de valor

A TI permite que se identifiquem problemas com pacientes, cruzando várias fontes de informação. As empresas de conectividade vêm disseminando a utilização dos modelos de autorizadores eletrônicos, atuando em quatro frentes: consultórios médicos, hospitais, serviços de análise diagnóstico e de terapêutica e nas farmácias. Este fato vem tornando cada vez mais as informações em formato digital, o que possibilita filtrar, selecionar, segmentar os pacientes de uma determinada carteira. Com estes dados, podem-se extrair dados de utilização de medicamento que podem indicar tendência para uma doença no futuro.

A integração das informações dos pacientes em um único banco de dados e o cruzamento destes dados permite identificar e confirmar o diagnóstico de um paciente mais precocemente. Por exemplo, se um médico não identificar uma tendência, as outras partes envolvidas poderão fazê-lo. Unindo os esforços, uma parte controla o consumo dos medicamentos; a outra; a evolução do paciente; a 
outra; os resultados de exames, tornando assim, mais efetiva a recuperação do paciente com a finalidade de consolidar uma parceria entre clientes e fornecedores.

A integração de uma rede de valor na saúde gera importantes vantagens aos participantes. Inicialmente, pode-se estabelecer entre os participantes a potencialidade de cada empresa e também suas limitações, facilitando que as solicitações de serviços sejam adequadas ao perfil de cada participante. Todas as outras variáveis relacionadas a relacionamento, à solução de problemas, à sinergia nas operações, à padronização, à procedimentalização e outros ficam evidenciadas e facilitam o trabalho do ponto de vista de uma rede de valor.

F - Comércio eletrônico e redes de informação.

- Parceria público-privada para distribuição de medicamentos

Uso da TI para dar legibilidade ao usuário, para que ele se dirija a um caixa de uma farmácia e retire uma nota fiscal do medicamento solicitado, assine um cupom vinculado e pague apenas $10 \%$ do valor. Os meios de pagamento entre as farmácias e o governo federal são intermediados pelo sistema da empresa C10.

O sistema utilizado mesclou o modelo do sistema financeiro com o modelo de assistência farmacêutica. O usuário vai até uma farmácia, apresenta o número do cadastro pessoa física (CPF), a receita do médico, compra o medicamento e paga $10 \%$ do valor. Por meio da ferramenta de gerenciamento de benefícios do medicamento, gera-se um documento ao DataSUS, que valida a transação. O modelo permitiu ao Ministério da Saúde desenvolver um de seus programas de saúde utilizando a rede pública de farmácias. Com isto, ampliou o número de farmácias para distribuição de medicamentos no país. Evitou-se que o governo realizasse operações de distribuição dos medicamentos que aumentava muito o custo do medicamento para distribuir em um número reduzido de pontos.

A TI permitiu aumentar a flexibilidade do atendimento com base nos requisitos dos pacientes e também do governo, que subsidia o projeto. A TI permitiu ainda um aumento substancial de produtividade na operação de distribuição de medicamentos pelo governo à população carente. A automação no controle das operações de serviços foi fundamental para que fosse viabilizado. A capacidade produtiva ampliouse e permitiu maior adequação com as variações da demanda, que foi realmente fundamental neste projeto, considerando a complexidade e as dimensões continentais do país. 


\subsubsection{Outras Considerações}

Conforme sensibilidade da empresa estudada, existem ainda muitas barreiras quanto ao uso da TI na saúde, que dificultam que ela seja difundida mais rapidamente, que não está apenas relacionada com custo. A primeira, e mais forte, talvez seja a crença de que a tecnologia só aumenta o custo dos serviços. Percebese que a falta de profissionalização do setor acentua ainda mais esta avaliação.

Há outras variáveis e peculiaridades no modelo de saúde no Brasil, que vão somando-se e tornando o quadro ainda mais complexo. A medicina privada no país segue o modelo norte-americano, enquanto a saúde pública segue o modelo europeu. A existência desta dualidade constitui um problema, que reflete nas operações de serviços, na padronização e nas formas de organizar-se como um todo. Quanto ao uso da TI, sabe-se que, nos dois modelos, ela é uma ferramenta importante de integração. Existe uma transparência muito grande entre tomadores e prestadores de serviços.

No mercado de medicina privada no país, as despesas com internação domiciliar, por exemplo, continua sendo uma das maiores despesas e, apesar disto, a interação com prestador e fonte pagadora é muito rudimentar, pode-se dizer que é um cheque em branco na mão do prestador. Enquanto isto o tomador de serviços espera ansioso, contando com a sorte, para que a conta do paciente seja a menor possível.

Do ponto de vista da informação e acesso aos medicamentos, sabe-se que muitos pacientes apresentam complicações, por não tomarem medicamento ou por fazerem automedicação e acabam morrendo. Antes de morrerem, apresentam complicações, são internados e geram custo altíssimo, tanto para o sistema público, quanto para o sistema privado. O conflito de interesses entre planos de saúde e empresas é muito grande, pois juntas, poderiam, por exemplo, subsidiar os medicamentos de pacientes crônicos que fossem identificados em suas carteiras; aumentaria a qualidade de vida dos pacientes e haveria uma redução dos custos futuros. Porém, muitas vezes é difícil se fazer compreender estes mecanismos, dificultando que se chegue a acordos, sobre quem pagará a conta.

Os pacientes, que têm acesso a ferramentas de controle e à distribuição de medicamentos que, por sua vez, melhoram sua qualidade de vida, afirmam que não 
têm o menor conhecimento de como funciona o sistema. Não sabem a contribuição que a TI traz para o sistema. Se o doente souber que está ganhando vantagem, sendo atendido mais rápido, mais racionalmente, com mais zelo, exigirá mais do seu prestador de serviço. Na medida em que o paciente torna-se mais sofisticado, ainda que ele não seja o decisor sore as alternativas de usar ou não a $\mathrm{Tl}$, certamente haverá uma alavancagem na utilização da TI, nos serviços de saúde.

\subsubsection{Resumo da Análise de C10}

A TI criou valor (eficiência e/ou eficácia) em diversas circunstâncias, entre elas, podem-se citar:

- diagnosticando o perfil da carteira de clientes para gestão e controle de custos administrativos e clínicos;

- realizando análise para customização em massa;

- intermediando transações de autorização de procedimentos de negócio a negócio;

- mapeando utilização de recursos médicos em uma determinada carteira de clientes;

- controlando e monitorando a utilização de medicamentos em pacientes crônicos;

- criando protocolos personalisados por pacientes;

- gerindo a evolução do tratamento em pacientes crônicos;

- atualizando continuadamente profissionais da saúde em relação a patologias, com base em protocolos de sociedades médicas;

- monitorando a utilização de medicamentos em pacientes de risco (transplantados e outros), para setor público e privado;

- aumentando o controle da gestão clínica por meio do cruzamento de informações entre diversos prestadores de serviços na saúde;

- outros.

Por que a Tl cria valor? As respostas foram diversas, mas observou-se uma maior incidência do ponto de vista da eficácia, nas seguintes circunstâncias:

- contribuindo para que os clientes participem da especificação do processo de serviço antes de se incorporar a ele; 
- flexibilizando o atendimento com base nos requisitos do cliente em relação a tempo, a local e à posse dos serviços;

- segmentando a carteira de usuários de empresas e planos de saúde, permitindo customização em massa;

- contribuindo para que sejam desenvolvidos relacionamentos de longo prazo entre pacientes, médicos e organizações, ampliando as opções para solução de problemas e aumentando a fidelização;

- outros.

Do ponto de vista da eficiência, observou-se que a TI teve maior contribuição nas seguintes circunstâncias:

- aumentando a produtividade, gerenciamento e controle dos recursoschave da empresa;

- melhorando as especificações de retaguarda e de linha de frente;

- aumentando a previsibilidade das operações, permitindo maior procedimentalização e qualidade nos serviços;

- controlando custos;

- outros.

Quadro 16 - Resumo da Análise de C10

\subsection{EMPRESA 11 (C11) - EMPRESA DE EQUIPAMENTOS E SOFTWARES MÉDICOS}

\section{Dados da empresa}

\begin{tabular}{|l|r|r|}
\hline Faturamento anual da empresa: & $R \$ 6.000 .000 .000,00$ \\
\hline $\begin{array}{l}\text { Número de funcionários da } \\
\text { empresa: }\end{array}$ & 12.000 \\
\hline Funcionários terceirizados: & 500 \\
\hline Funcionários de TI da empresa: & 200 \\
\hline $\begin{array}{l}\text { Funcionários de TI terceirizados: } \\
\text { que gera vantagem competitiva } \\
\text { para empresa: }\end{array}$ & Sistemas de informações para saúde \\
\hline Estratégia competitiva genérica e & A empresa atua de forma diferenciada e \\
\hline
\end{tabular}




\begin{tabular}{|l|l|}
\hline $\begin{array}{l}\text { escopo de atuação da empresa no } \\
\text { mercado: }\end{array}$ & $\begin{array}{l}\text { com escopo amplo, abrangendo diversos } \\
\text { setores. Nos diversos setores em que atua, } \\
\text { assim como no mercado da saúde, seus } \\
\text { produtos e soluções tem sido pioneiros. }\end{array}$ \\
\hline
\end{tabular}

\section{Principais Características da Empresa}

C11 é uma empresa multinacional centenária de origem européia. Sua trajetória no país tem sido marcada pelo crescimento e superação de desafios em diversos segmentos, inclusive na saúde. É reconhecida por seus produtos inovadores e soluções completas que se aplicam de forma integrada a todas as fases da vida do paciente. A empresa oferece soluções em equipamentos e softwares, utilizados desde diagnóstico por imagens, equipamentos para terapia e cuidados intensivos a soluções de TI voltados ao fluxo de trabalho.

A empresa ainda conta com excelentes colaboradores que é a chave para 0 sucesso de uma empresa, concentra esforços para assegurar que todo colaborador possa contribuir com o melhor de seus conhecimentos e habilidades, independentemente de onde ele esteja. Com mais de 7000 invenções por ano, a instituição é uma das empresas mais inovadoras no mundo.

\section{Uso da TI}

A empresa é conhecida por oferecer tecnologias médicas inovadoras, sistemas de informações para saúde, consultoria gerencial e serviços de suporte para auxiliar o cliente a obter resultados clínicos e financeiros sustentáveis. As aplicações de seus produtos e serviços são utilizadas em diversas áreas da saúde, em especial, hospitais, clínicas e em serviços de análise e diagnóstico. A empresa utiliza a tecnologia da informação aplicada à saúde, nos seguintes produtos e serviços:

- solução de gerenciamento e arquivamento de imagens;

- sistemas de gestão em serviços de saúde;

- gestão de processos;

- consultoria em TI e infra-estrutura;

- sistemas de gestão hospitalar;

- sistemas de informações de radiologia. 


\subsubsection{Formas de Contribuição da TI - Categorias}

A - Sistemas estratégicos.

- Soluções integradas para empresas da saúde

O conjunto de ferramentas de TI, desenvolvidas pela empresa, dá retaguarda para as empresas que utilizam imagens e outras informações para a prevenção, tratamento e cura, por meio de armazenamento seguro e resgate rápido de informações. As soluções foram construídas em módulos de forma que os produtos se integrem uns aos outros. A padronização e o uso destas plataformas facilitam a integração dos sistemas e, por outro lado, mantêm uma mesma linha ou formato para os usuários, facilitando a operação dos serviços.

As ferramentas utilizadas permitem um melhor gerenciamento das informações e, conseqüentemente, indicadores e controles, facilitando o trabalho de médicos e outros profissionais da saúde. A estruturação das informações faz com que aumentem a praticidade e a transparência das operações de serviços. Uma das alternativas destas ferramentas, por exemplo, é comparar exames realizados há vários anos com exames atuais, analisar o tratamento que o paciente foi submetido, promover videoconferência com outros profissionais médicos, tendo acesso a todas as informações clínicas do paciente. Dessa forma, ganha-se tempo e evitam-se retrabalhos. As soluções, portanto, aumentam a segurança no processo, assim como a qualidade e a produtividade nas operações de serviços.

As ferramentas flexibilizam o atendimento com base nos requisitos do paciente, com relação a cumprimento de prazos e local de entrega dos exames. Além do enfoque na paciente, as ferramentas geram maior produtividade, gerenciamento e controle dos recursos-chave da empresa.

\section{B - Foco no cliente e no serviço.}

- Fornecimento de imagens em formato digital aos pacientes

Após realização dos exames nos pacientes, os arquivos são enviados para Estação de trabalho que centraliza todas as imagens para radiologia: raios- $X$, ressonância, tomografia e outros. As imagens e os respectivos laudos, realizados pelos radiologistas, são gravados em um CD e fornecidos aos pacientes.

No processo convencional, a paciente recebe do local onde foram realizados os exames, vários filmes em diferentes formatos. Neste caso, ele recebe um CD com 
as imagens e o laudo do exame, para entregar ao seu médico. Uma outra cópia das imagens e laudo também poderá ser enviada ao médico do paciente.

O paciente pode se incorporar ao processo de serviços e especificar qual a melhor forma de receber os resultados dos exames. A operação também flexibiliza o atendimento ao paciente, entre outras vantagens, que vão desde processo mais ágil, portabilidade do exame, arquivamento digital, outros, apresentando uma maior diferenciação no serviço. Além de racionalizar o processo, reduz também os custos com filmes, reduz riscos de saúde com o material químico utilizado para revelar os filmes, entre outros para a empresa que realizou o exame.

- Agendamento de exames com sistema à prova de falhas

A TI contribui para que se faça o agendamento dos exames e informe aos pacientes alguns preparos para que o realize.

Ao se preencher o formulário para exames e se especificar o exame, o sistema gera uma lista de pré-requisitos que o paciente deve ter para realizar o exame. Um caso comum é o paciente vir fazer um determinado exame e quando lhe perguntam se ele fez o preparo, o paciente não sabe informar. Por exemplo: "O senhor está de jejum? O paciente diz: "Ninguém me disse nada".

Primeiramente, flexibiliza-se 0 atendimento, com base nos requisitos do cliente em relação a tempo e a local. Evita-se perda de tempo do paciente e se otimiza a capacidade produtiva da empresa. Com sistemas à prova de falhas, avisase o paciente no momento em que ele solicita a autorização para o exame ou quando ele faz o agendamento. Também se podem instituir avisos um ou dois dias antes, lembrando o paciente sobre o exame e sobre os preparos. Estes procedimentos melhoram as operações de retaguarda e de linha de frente.

C - Esforço contínuo de melhorias.

- Redução de lead-time na entrega de exames de diagnóstico por imagem

O sistema de gestão de imagens permite que se reduza o tempo de entrega de exames para em média em 50\%, aumentando a resolutividade do tratamento médico do paciente.

Com o gerenciamento das imagens, arquivamento, recuperação e entrega em formato digital, racionaliza-se o processo, permitindo maior agilidade de respostas aos clientes. 
Aumento no controle dos recursos-chave, otimização da capacidade produtiva e flexibilização da capacidade operacional são as principais explicações do porquê a TI cria valor, nesta operação. Em um ambiente competitivo com alta rivalidade como é a saúde, a questão da velocidade de respostas é um diferencial importante, em especial, nos casos de pacientes graves, em que o resultado de exame é fundamental para que se decida rapidamente sobre outros procedimentos que 0 paciente deverá fazer. Por exemplo, no caso de um paciente internado, que espera alta ou não, em função do resultado de um exame. Assim, quanto mais rápido for liberado, mais rápido ele terá alta ou será encaminhado para outros procedimentos gerando menos custos.

- Soluções de gerenciamento e arquivamento de imagens

Estação de trabalho que centraliza todas as imagens para radiologia: raios- $X$, ressonância, tomografia e outros, que, em alguns casos, chegam a centenas de milhares de arquivos digitais.

O gerenciamento de imagens, por meio de um servidor e software específico, contribui para que as imagens sejam arquivadas e distribuídas aos locais onde serão utilizadas.

O sistema aumenta a qualidade nas operações de serviços (percepção do médico), reduzindo a variabilidade, entre outros. O gerenciamento permite um controle mais eficaz das imagens e também aumenta a racionalização nos processos, melhorando a produtividade.

- Sistema de acompanhamento e gestão de pacientes internados via WEB Todas as informações sobre os pacientes que estão em seus prontuários eletrônicos ficam disponíveis, via WEB, possibilitando que se façam intervenções do ponto de vista das operações de serviços clínicas e administrativas.

Ao avaliar o quadro de pacientes, número e horário de altas, tipo de pacientes, patologias, entre outros, o gestor pode tomar decisões como, por exemplo, solicitar que entrem em contato com um determinado médico e questione por que ele ainda não deu alta ou encaminhou para determinado procedimento ou ainda para que se contate um determinado convênio para negociação. 
O sistema permite ao usuário a definição de quais os itens mais importantes que devem ser gerenciados. Além disto, o sistema atende os requisitos dos clientes no que se refere ao tempo e o local de utilização. Por outro lado, pode-se aumentar o gerenciamento dos recursos-chave, reduzindo custos. Aumentam-se, ainda, os controles organizacionais, facilitando a tomada de decisões em diversos níveis hierárquicos, que desenvolvem seus serviços a partir de instruções colocadas no sistema.

D- Otimização do processo empresarial (reengenharia do processo do negócio).

Obs. Este subitem será dividido em duas partes: reengenharia do processo do negócio e novos negócios gerados pela TI ou em processo de gestação.

D1 - Reengenharia do processo do negócio

- Gestão a vista de processos utilizando a TI

Com o apoio da TI, faz-se o mapeamento dos processos, seguido da reestruturação e de controles. Estes controles ajudam a avaliar filas de espera e outros gargalos na operação.

A TI analisa os processos e avalia como está o fluxo das operações de serviços. A análise apresenta indicadores em vermelho, amarelo ou verde de acordo com o andamento do fluxo. Esta ferramenta informa o tempo de espera dos pacientes, controla todo processo do início ao fim, desde a admissão até o momento do laudo final. Ao se identificar, por exemplo, um problema na enfermagem, pode-se avaliar se é falta ou excesso de pessoal, falta de especialização dos profissionais, problemas com equipamentos, entre outros.

A utilização da TI, nesta operação, contribui ainda para melhoria das especificações das tarefas e para o aumento do índice de reprodução em série de uma mesma solução. Também aumenta a previsibilidade das operações de serviços, permitindo maior padronização e aumento da produtividade.

D2 - Novos negócios gerados pela TI ou em processo de gestação.

- Software de gestão da TI para terceiros ( setor público)

Uso do software para gestão da TI e dos equipamentos médicos dos clientes.

O trabalho inicia-se com um mapeamento dos processos e identificação dos problemas. Para realizar esta atividade, utiliza-se um software (workflow) para fazer 
um levantamento da situação e/ou eventuais ajustes nos processo e controles. Ao se utilizar um software no mapeamento e controle de todas as ferramentas de $\mathrm{TI}$ e equipamentos, consegue-se ter uma visão integrada da empresa. Este diagnóstico contribui para que se dimensionem a quantidade de equipamento, as estações de trabalho, locais centralizados para cópias de arquivos digitais entre outros.

O software permite desenvolver os serviços de forma personalizada, atendendo as necessidades específicas dos clientes. Flexibiliza o atendimento (tempo e local) aumenta o relacionamento entre tomador e prestador de serviços, ao se resolvem os problemas dos clientes e outros possíveis.

- Utilização de etiquetas eletrônicas (RFID) em pacientes

Uso de etiquetas eletrônicas nas pulseiras de identificação dos pacientes, com controle de localização por rádio freqüência.

As etiquetas eletrônicas dão maior liberdade aos pacientes para que desde que autorizados possam deambular por algumas áreas de um hospital ou clínica. As etiquetas também ajudam a localizar os pacientes, informando quando eles não estão em uma área autorizada. Existem muitas situações em que a localização de um paciente é importante e não é tão óbvia assim. No caso de um paciente que está realizando vários procedimentos e exames e precisa ser localizado para uma visita de um especialista ou um familiar. Existem ainda casos de fugas de pacientes de hospitais, em que a identificação eletrônica ajudaria a controlar ou localizar pacientes que se perdem, entre outros.

As etiquetas favorecem um controle maior de segmentos de risco. Pode-se pré-selecionar alguns pacientes e monitorá-los mais ostensivamente.

\section{E - Redes de valor e alianças entre empresas}

- Redução de cliques e movimentação do mouse utilizando menus personalizados

A empresa vem desenvolvendo estudos com grandes centros de pesquisa no mundo, para que as ferramentas que desenvolve sejam cada vez mais fáceis de manusear; utilizando procedimentos mais amigáveis, com maior satisfação dos clientes e, espera-se com maior a fidelização.

Entre os estudos desenvolvidos, podem-se citar a redução de cliques e movimentação do mouse, utilizando menus personalizados. Constatou-se que, em 
determinados exames, o número de cliques e a quantidade de quilômetros percorridos pelo mouse eram substanciais, causando muito cansaço ao médico.

Neste caso, desenvolveu-se uma ferramenta, similar a um menu personalizado, reduzindo o esforço dos usuários e aumentando a produtividade.

F - Comércio eletrônico e redes de informação.

- Cartão inteligente (chip)

Uso de cartões inteligentes (chip) com histórico do paciente: quais tipos de doenças ele já teve, qual medicamento está tomando, se está fazendo algum controle periódico, se tem algum exame agendado, outros. O cartão também pode ser utilizado para compras.

Com o cartão inteligente, pacientes, médicos e estrutura de atendimento, farmácias e outros, obtêm, de forma clara e rápida, informações sobre o paciente. As informações contribuem para entender melhor o quadro do paciente e acelerar o processo de atendimento e solução de seus problemas.

$\mathrm{Na}$ medida em que o paciente leva suas informações em um cartão para um determinado médico, evita que o profissional se desloque até um determinado hospital ou necessite falar com algum outro especialista sobre este paciente, pois as informações estão todas ali. O cartão também serve como um cartão de descontos, pois ele possui créditos que permitem que o usuário realize compras em farmácias, acesse a Internet ou TV a cabo, quando estiver internado em algum hospital e outros.

\subsubsection{Outras Considerações}

Conforme C11, ainda existe resistência no uso da TI por muitos profissionais, pois, segundo esta empresa, a transparência das informações põe em evidência as decisões dos médicos e muitos não querem isto. Há uma espécie de diluição do poder, causado pelo compartilhamento das informações. Isto se torna ainda mais claro quando se instituem indicadores de desempenho e se podem comparar profissionais e serviços realizados.

Uma outra corrente consegue ver benefícios no uso da TI em diversas circunstâncias, como: geração de arquivos de pesquisas, possibilidade de segundas opiniões, estatísticas, divulgação de informações, outros. 
Aparentemente os primeiros são os médicos com menor envolvimento administrativo, que atuam mais fortemente em centros cirúrgicos ou com procedimentos médicos. O segundo caso é formado por médicos com perfil clínico que trabalham mais fortemente em consultórios ou intensivistas de UTI, que utilizam muito a $\mathrm{TI}$ para desenvolverem seus relatórios. Utilizam também a TI como uma ferramenta que pode ajudá-lo a ser mais atualizado e também o ajuda a informar seus pacientes acerca de diversos assuntos que podem contribuir com a recuperação dos pacientes. Há, ainda, um terceiro caso, formado por médicos que utilizam a TI como atividade-fim, por exemplo, um radiologista ao fazer um laudo. A TI ajudou a analisar o exame realizado e vai ajudar e transmitir as informações do laudo realizado, sendo isto, para o médico, a atividade-fim. Neste caso, aparentemente este é o segmento que mais tem se envolvido e assimilado mudanças trazidas pela TI.

\subsubsection{Resumo da Análise de C11}

A TI criou valor (eficiência e/ou eficácia) em diversas circunstâncias, entre elas, podem-se citar:

- gerando soluções integradas, em especial na gestão de imagens relacionados a diagnósticos por imagem;

- propiciando maior portabilidade e flexibilidade na entrega de resultados de exames, fornecendo cópia de exames em CDs;

- instituindo sistemas à prova de falhas nas operações de agendamento e de preparo dos pacientes para exame;

- reduzindo o tempo de entrega de exames;

- gerenciando o arquivamento e a busca de exames;

- propiciando acompanhamento e gestão de pacientes a distância;

- propiciando gestão a vista (controle de filas e outros);

- desenvolvendo ferramentas de TI para gerenciar equipamentos de terceiros;

- utilizando novas formas (etiquetas eletrônicas) de identificação e rastreabilidade de pacientes;

- $\quad$ racionalizando operações, por meio de menus personalizados; 
- utilizando cartões inteligentes com histórico do paciente, entre outras informações;

- outros.

Por que a TI cria valor? As respostas foram diversas, mas observou-se uma maior incidência do ponto de vista da eficácia, nas seguintes circunstâncias:

- flexibilizando o atendimento com base nos requisitos do paciente, do médico e do hospital;

- apresentando maior diferenciação no serviço prestado;

- reduzindo a variabilidade nas operações de serviços (maior qualidade);

- personalizando o atendimento a pacientes e médicos;

- pré-selecionando (segmentando) pacientes;

- outros.

Do ponto de vista da eficiência, observou-se que a TI teve maior contribuição nas seguintes circunstâncias:

- aumentando a produtividade e controle dos recursos-chave (recursos humanos e equipamentos).

- racionalizando processos (maior produtividade);

- otimizando a capacidade produtiva;

- aumentando os controles organizacionais, permitindo estruturas hierárquicas mais achatadas;

- melhorando as especificações e permitindo reprodução em série de uma mesma solução

- outros.

Quadro 17 - Resumo da Análise de C11

\subsection{EMPRESA 12 (C12) - EMPRESA DE GESTÃO DE DOCUMENTOS}

\section{Dados da empresa}

\begin{tabular}{|l|r|r|}
\hline \multicolumn{2}{|l|}{ Faturamento anual da empresa: } & $\mathrm{R} \$ 80.000 .000,00$ \\
\hline $\begin{array}{l}\text { Número de funcionários da } \\
\text { empresa: }\end{array}$ & & 1.600 \\
\hline
\end{tabular}




\begin{tabular}{|c|c|}
\hline Funcionários terceirizados: & 0 \\
\hline Funcionários de TI da empresa: & 14 \\
\hline Funcionários de TI terceirizados: & 16 \\
\hline $\begin{array}{l}\text { Área de aplicação da TI estudada } \\
\text { que gera vantagem competitiva } \\
\text { para empresa: }\end{array}$ & $\begin{array}{l}\text { Gestão de documentos e soluções } \\
\text { relacionadas à engenharia da informação, } \\
\text { relacionados ao prontuário médico do } \\
\text { paciente. }\end{array}$ \\
\hline $\begin{array}{l}\text { Estratégia competitiva genérica e } \\
\text { escopo de atuação da empresa no } \\
\text { mercado: }\end{array}$ & $\begin{array}{l}\text { A empresa atua de forma diferenciada, com } \\
\text { escopo amplo, abrangendo diversos } \\
\text { setores econômicos de diversas regiões do } \\
\text { país. }\end{array}$ \\
\hline
\end{tabular}

\section{Principais Características da Empresa}

C12 é uma empresa de origem nacional, que atua no país desde 1992, no setor de armazenagem de arquivos e documentos de terceiros. Vem sendo reconhecida no mercado em que atua por utilizar processos de gestão e tecnologia de última geração. Oferece soluções customizadas para a gestão de processos documentos e informações, tomando sempre como base os requisitos e necessidades dos seus clientes.

No final da década de 1990, a empresa iniciou a oferta de gestão eletrônica de documentos, com foco no tratamento individual do documento. Por volta de 2003, a empresa começou a oferecer serviços especializados de apoio em processos de gestão e controle de documentação, em que seus clientes definem o escopo das atividades a serem assumidas pela empresa, que possa a atuar como extensão da organização do cliente na execução de processos de análise e formalização de documentação em geral.

Seus principais clientes são os bancos e outras empresas do sistema financeiro. Tem os hospitais de grande porte da Cidade de São Paulo, que possuem grande volume de documentos, entre eles, o prontuário médico do paciente, como seus principais clientes no setor da saúde.

Os principais serviços oferecidos da empresa são:

- gestão eletrônica e guarda de documentos;

- gestão e guarda de caixas de arquivo; 
- execução de processos de análise, formalização, controle e apoio para as atividades de gestão de documentação e informações do cliente;

- organização de arquivos e documentos;

- digitalização de documentos;

- gestão e guarda de mídias eletrônicas.

\section{Uso da TI}

É reconhecida no mercado em que atua pela ênfase no atendimento diferenciado. Um dos principais itens do atendimento diferenciado é a utilização de tecnologia de última geração que facilita as operações de serviços relacionadas à gestão de processos e de documentação de seus clientes.

O serviço prestado inclui armazenagem física e digital, além de digitalização e disponibilização de documentos, via WEB, sob demanda.

A empresa também armazena dados originalmente digitais de seus clientes na saúde e oferece o mesmo sistema de disponibilização, via WEB.

As ferramentas oferecidas pela empresa que dão retaguarda à utilização da TI são as seguintes:

- digitalização de documentos de alta performance e qualidade, com tratamento de imagens, reconhecimento de código de barras, controle de documentos e imagens, e facilidade de customização;

- automação na indexação de imagens e documentos;

- possibilidade de integração com os sistemas da empresa

\subsubsection{Formas de Contribuição da TI - Categorias}

A - Sistemas estratégicos.

- Gestão de documentos utilizando a TI

Os serviços oferecidos pela empresa estão relacionados à gestão de documentos e à engenharia da informação. Utiliza-se a TI de forma intensa no composto de serviços da empresa, que inclui guarda e o gerenciamento de documentos. 
A TI é utilizada tanto para diagnosticar e propor processos racionalizados para o fluxo de informações dos clientes quanto para produzir conteúdo digital (digitalização dos documentos) e ainda para entregar estes serviços via WEB.

As ferramentas de TI, utilizadas pela empresa, trazem benefícios de escala, sem perder a vantagem da customização aos clientes. As ferramentas agregam tratamento ás informações, qualificando, quantificando e consolidando dados e, principalmente, recuperando os dados quando solicitados. Na medida em que a empresa soluciona os problemas relacionados à engenharia da informação para seus clientes, aumenta o relacionamento e, possivelmente, a lealdade. Estas vantagens geram redução de despesas e/ou aumentam a diferenciação dos clientes em suas operações de serviços.

$B$ - Foco no cliente e no serviço.

- Operações de serviços e gestão de documentos

A empresa oferece soluções personalizadas a cada cliente. Todo o processo que envolve o arquivamento físico e digital é previamente desenhado, para que depois se façam as transferências dos documentos e informações que serão arquivadas.

A empresa conta com uma equipe de profissionais que, utilizando softwares específicos, realizam um mapeamento do processo das informações dos clientes (fluxo dos documentos). Após o mapeamento, propõem-se um novo formato para o fluxo de documentos do cliente e até de fornecedores deste cliente, estendendo-se até $\mathrm{C} 12$. O cliente pode determinar se prefere o documento físico ou digital. Necessita-se apenas da guarda do documento ou precisa-se de análises estatísticas e outros serviços oferecidos pela empresa.

As soluções personalizadas (cliente participa da especificação do processo do serviço antes de se incorporar a ele), oferecidas pela empresa, buscam adequar a infra-estrutura do cliente às oportunidades de racionalização de processos e de documentos de seus parceiros.

C - Esforço contínuo de melhorias

- Arquivamento e digitalização de prontuários médicos e outros documentos 
C12 recebe os documentos das instituições de saúde (prontuário médico), passa para o processo de digitalização e, depois, envia o material para o arquivo físico.

A empresa conta com equipamentos para digitalizar documentos em grande escala que processam até 400 páginas por minuto. Os documentos são digitalizados e disponibilizados, via WEB, para serem acessados na medida em que os clientes solicitam. Possui servidores com grande capacidade de armazenagem de aproximadamente três terabytes de dados e utiliza, ainda, um Data Center externo.

Com os documentos disponíveis na WEB, podem-se acessá-los a qualquer momento de qualquer local, flexibilizando o atendimento ao cliente. Esta operação evita que se perca tempo fazendo solicitação de prontuários e permite que o médico avalie o prontuário do paciente quando quiser, tornando mais ágeis as ações a respeito dos pacientes. Alguns hospitais, clientes deste serviço, estão fornecendo parte do material em formato digital, registrando as prescrições dos médicos no prontuário, deixando apenas os exames para serem digitalizados. Este fato torna ainda melhor o processo de disponibilização via WEB. Além destas vantagens, este processo libera espaço físico nos hospitais, pois além do volume de documentos serem substanciais, os documentos devem ser arquivados por, pelo menos, vinte anos, conforme determina a lei. A TI garante a organização e a segurança aos processos do cliente, informando quem as solicitou, quem retirou os documentos, em que data, entre outras informações.

- Arquivamento e digitalização de prontuários médicos sob demanda

O processo é semelhante ao descrito acima. A empresa recebe os documentos das instituições de saúde e os enviam para um arquivo físico, ou seja, apenas os arquivos solicitados são digitalizados e ficam disponíveis via WEB. Quando a empresa envia um documento para o arquivo, ela recebe um protocolo que será anexado aos registros do paciente no hospital. Este número de protocolo servirá para identificar os documentos do paciente que estão na empresa de arquivos.

No caso de digitalização sob demanda, despende-se aproximadamente uma hora para atender o cliente. Os documentos serão localizados no arquivo físico e, na seqüência, são digitalizados e ficam disponíveis para o cliente via WEB. No modelo 
convencional, mesmo com as informações disponíveis dentro das instituições, despende-se em média 36h.

A velocidade de resposta desta operação permite que os médicos aumentem a resolutividade no tratamento de seus pacientes e os convênios possam analisar prontamente os documentos solicitados. Nos dois casos, estreitou-se o relacionamento entre os colaboradores. Outro ganho é a manutenção da integridade dos documentos que, no formato tradicional, deterioravam-se rapidamente, dificultando a interpretação. Portanto, ganha-se mais especificamente com a personalização (o cliente especifica o que necessita), com a flexibilidade no atendimento e com a automação nas solicitações de serviços em geral.

D- Otimização do processo empresarial (reengenharia do processo do negócio).

Obs. Este subitem será dividido em duas partes: reengenharia do processo do negócio e novos negócios gerados pela TI ou em processo de gestação.

D1 - Reengenharia do processo do negócio

- Mapeamento do fluxo de informações / documentos

A empresa utiliza a TI em vários aspectos para desenhar o processo das informações nos clientes (fluxo de documentos) e simular as vantagens de utilizar o modelo proposto.

A operação de arquivamento físico e digital, neste caso, é precedida por estudos de processos, que determinarão como deve ser o fluxo de documentos para que a empresa desenvolva suas atividades de forma mais racionalizada.

O mapeamento dos fluxos conta fortemente com as recomendações da empresa contratante, na definição do que ela espera em relação aos seus documentos. Também se podem citar os ganhos que o mapeamento propiciará às operações de linha de frente e de retaguarda, apenas melhorando as especificações e a reprodução em série das soluções que serão implantadas.

- Ficha eletrônica no banco de sangue

Digitalização das fichas de doadores e receptores e arquivo das informações em CDs. Os CDs são enviados à empresa de arquivos que disponibiliza o conteúdo via Internet, sob demanda. 
Os arquivos eletrônicos garantem maior velocidade e qualidade na operação de recuperação das informações, tanto dos doadores de sangue quanto dos receptores. Informações relacionadas ao histórico do paciente como doenças, medicamento, entre outros, podem ser facilmente levantadas.

Esta operação gera respostas mais rápidas aos usuários do banco de sangue e, conseqüentemente, ao tratamento de pacientes.

- Ferramenta de busca de conteúdo em documentos digitalizados

A empresa conta com tecnologia (ECR) que reconhece as informações dos documentos por meio de imagens. O software trata, reconhece e faz qualquer tipo de busca nos documentos.

Esta ferramenta permite que se realizem buscas nos documentos digitalizados, facilitando o trabalho tanto no campo clínico como no administrativo.

Cria-se valor, flexibilizando o atendimento com base nos requisitos de tempo para o cliente. Este, por sua vez, permite que tanto áreas clínicas como administrativas tenham maior produtividade.

D2 - Novos negócios gerados pela TI ou em processo de gestação

- Gestão de documentos da área de recursos humanos nas empresas de saúde

Gestão de documentos dos recursos humanos nas empresas de saúde é outra solução ofertada pela empresa, para a racionalização nas operações de serviços nesta área.

Como as empresas de saúde utilizam mão-de-obra intensiva em suas operações de serviços e os documentos e informações nesta área são substanciais, C12 passou a oferecer a gestão também nestas áreas. O gerenciamento destes documentos abrange, entre outros, atestados médicos, exames periódicos, outros.

O cliente participa da especificação do serviço, determinando qual a situação ideal para desenvolver suas operações de serviços. O formato digital e as soluções, anteriormente comentadas, flexibilizam o atendimento com base nos requisitos de tempo e de local para o cliente. Com a ajuda nas soluções dos problemas, aumentam-se o relacionamento e a lealdade dos clientes.

E - Redes de valor e alianças entre empresas. 


\section{- Parcerias com colaboradores}

Os arquivos, em formato digital, ficam à disposição da empresa contratante com a possibilidade de que sejam enviadas diretamente a alguns parceiros.

No processo de internação ou procedimentos mais complexos, são comuns as operadoras solicitarem os prontuários para análise da conta. Neste caso, o detentor da informação (prontuário eletrônico) é um hospital, que solicita a C12 a liberação das informações diretamente ao plano de saúde, via WEB ou por e-mail.

Neste processo, o cliente participa das especificações, antes de se incorporar a este. Isto flexibiliza o atendimento em relação ao tempo, conveniência espacial e entrega do serviço. Ao facilitar o fluxo de informações, reduz-se o tempo de procura para os convênios e para o hospital.

\section{F - Comércio eletrônico e redes de informação.}

- Portal de documentos - controle e solicitação dos documentos via WEB

Os documentos são identificados por meio de um número de protocolo que é fornecido no site de C12. O sistema permite que o cliente defina o tipo de arquivo desejado, tipo de caixa a ser utilizado, data do início da guarda e data em que o documento deve ser destruído. Este número de protocolo será utilizado para recuperar as informações, quando a empresa necessitar.

Antes de serem enviados para o arquivamento, os documentos são cadastrados no site de $\mathrm{C} 12 \mathrm{e}$, a partir, disto gera-se um protocolo para controle deste documento. Ao chegar em $\mathrm{C} 12$, o número do protocolo é transformado em uma etiqueta com código de barras que será anexado aos documentos. Em alguns clientes, as caixas de documentos ou os documentos recebem o código de barras, antes de serem enviados a C12. No processo para recuperação de documentos, o cliente acessa o site, faz a busca dos documentos que necessita e ao encontrá-los coloca o pedido em um carrinho de compras eletrônicas. Este processo aciona o pedido do documento e também gera o processo de compra eletrônica dos serviços. A solicitação, por parte do cliente, pode envolver o envio tanto do documento físico, como o envio do documento digitalizado.

Todo o processo é determinado pelo cliente, antes de se incorporar ao serviço. As facilidades de acesso em relação a tempo, a local e à posse dos serviços são evidentes. Muitos problemas são solucionados mais facilmente ao utilizar-se este mecanismo. Isto melhora o relacionamento e aumenta a fidelização por parte do 
cliente. Os ganhos de produtividade e controle com os recursos-chave e, ainda, a melhoria das atividades de linha de frente e retaguarda, complementam as vantagens de se desenvolver este tipo de operação de serviços, por meio de um portal de documentos.

\subsubsection{Outras Considerações}

Conforme a empresa existe uma forte pressão por diversos segmentos no país, para que a certificação digital seja aceita integralmente, em especial em algumas áreas relacionadas ao sistema financeiro e também na saúde. Este fato deverá gerar grande volume de serviços especializados para gestão de documentos utilizando a TI. No caso da saúde, quando não for mais uma exigência legal, o arquivamento de prontuários físicos, pelo prazo de vinte anos, haverá um aumento substancial para transformar estes documentos no formato digital.

Ainda, no campo da saúde, a empresa estima que por volta do ano 2015 a 2020, muitas barreiras referentes à produção dos documentos na saúde, que ainda oferecem uma resistência, serão fortemente reduzidas, em função da nova geração de médicos no mercado. Para fazer esta afirmação, a empresa se baseia em estatísticas de documentos processados por ela, os quais demonstram que médicos recém-formados têm-se utilizado de ferramentas de TI de forma mais evidente.

\subsubsection{Resumo da Análise de C12}

A TI criou valor (eficiência e/ou eficácia) em diversas circunstâncias, entre elas, podem-se citar: 
- otimizando a gestão de documentos e informações;

- oferecendo soluções personalizadas de guarda e busca de documentos, acordo com as necessidades dos clientes;

- digitalizando documentos e facilitando o tráfego de informações;

- instituindo ferramentas de busca em material digitalizado;

- entregando informações sob demanda (portal WEB);

- mapeando fluxo de informações e documentos e desenvolvendo processos;

- aumentando a velocidade de recuperação de informações;

- ampliando os campos de atuação da empresa;

- compartilhando informações em uma rede de valor;

- outros.

Por que a TI cria valor? As respostas foram diversas, mas observou-se uma maior incidência do ponto de vista da eficácia, nas seguintes circunstâncias:

- aumentando o relacionamento e, conseqüentemente, a lealdade dos clientes;

- aumentando a diferenciação dos serviços oferecidos;

- implementando soluções personalizadas;

- flexibilizando o atendimento com base nos requisitos do cliente em relação a tempo, a local e à posse;

- outros.

Do ponto de vista da eficiência, observou-se que a TI teve maior contribuição nas seguintes circunstâncias:

- racionalizando operações;

- aumentando a produtividade;

- otimização das operações de linha de frente e retaguarda;

- outros.

Quadro 18 - Resumo da Análise de C12

\subsection{EMPRESA 13 (C13) - EMPRESA DE SISTEMAS E SERVIÇOS PARA INSTITUIÇÕES DE SAÚDE}


Dados da empresa

\begin{tabular}{|c|c|}
\hline Faturamento anual da empresa: & $\mathrm{R} \$ 40.000 .000,00$ \\
\hline $\begin{array}{l}\text { Número de funcionários da } \\
\text { empresa: }\end{array}$ & 350 \\
\hline Funcionários terceirizados: & 0 \\
\hline Funcionários de TI da empresa: & 200 \\
\hline Funcionários de TI terceirizados: & 70 \\
\hline $\begin{array}{l}\text { Área de aplicação da TI estudada } \\
\text { que gera vantagem competitiva } \\
\text { para empresa: }\end{array}$ & Sistemas integrados para hospitais \\
\hline $\begin{array}{l}\text { Estratégia competitiva genérica e } \\
\text { escopo de atuação da empresa no } \\
\text { mercado: }\end{array}$ & $\begin{array}{l}\text { Pelo seu tamanho e pela maneira que a } \\
\text { empresa organiza seus negócios, pode-se } \\
\text { dizer que esta é uma empresa voltada para } \\
\text { custo. Seu escopo de atuação é amplo, } \\
\text { abordando vários segmentos do setor da } \\
\text { saúde, em todo território nacional. É a } \\
\text { maior empresa nos país neste segmento. } \\
\text { Trabalha com os melhores profissionais, os } \\
\text { quais são constantemente treinados em } \\
\text { áreas específicas de atuação. }\end{array}$ \\
\hline
\end{tabular}

\section{Principais Características da Empresa}

C13 é uma empresa nacional, fundada em 1987, atua como fornecedora de sistemas e serviços para instituições dos diferentes segmentos do setor da saúde: hospitais, atendimento domiciliar, planos, e incluindo o setor de saúde pública; prestadora de serviço hospitalar.

Seus principais clientes são os hospitais (públicos, privados, filantrópicos e universitários), os quais atendem mais de 400 empresas. C13 é a maior empresa do país neste segmento, desenvolve toda a solução na saúde, desde a parte do agendamento de consultas, cirurgias, exames até prestação de contas.

Comprometida com a qualidade e evolução dos seus produtos, a C13 investe continuamente no desenvolvimento de novos recursos e tecnologias, garantindo aos 
clientes a segurança de contar com sistemas que estão sempre respondendo às suas necessidades.

\section{Uso da TI}

Utiliza a Internet como sendo outro grande diferencial dos seus sistemas, possibilitando o acesso do usuário a partir de qualquer estação conectada à rede. Possui aproximadamente 100 mil usuários, sendo 15\% médicos e cerca de 20 a $25 \%$ enfermeiros, espalhados no Brasil inteiro.

Esta empresa possui a mais completa e abrangente linha de Sistemas de Informação e Serviços para aperfeiçoar a gestão de pequenas, médias e grandes instituições da área da saúde. As soluções organizacionais desenvolvidas pela empresa possibilitam que hospitais planejem e gerenciem suas atividades de forma eficiente, organizada e lucrativa.

A C13 possibilita o acesso do usuário a partir de qualquer estação conectada à rede.

Os produtos oferecidos pela empresa são:

- gestão hospitalar;

- informações gerenciais;

- gestão de custos e resultados;

- captura e gestão de imagens;

- prontuário eletrônico do paciente;

- gestão de secretarias de saúde;

- gestão de laboratórios.

\subsubsection{Formas de Contribuição da TI - Categorias}

\section{A - Sistemas estratégicos.}

- Sistema integrado para gestão em hospitais

A TI permite que se desenvolvam sistemas integrados que possibilitam que toda a empresa desenvolva suas atividades conjuntamente e sinergicamente. $\mathrm{Na}$ área hospitalar, existe o paciente, o médico, as operadoras de planos e o seguro saúde, os prestadores de serviços médicos e outros prestadores de serviços de apoio, que contribuem de alguma forma para criar valor na experiência do paciente na instituição. Criar valor para o paciente é um caminho importante para se criar 
valor para o plano de saúde, que é o responsável pela compra de serviços ou pelo pagamento dos serviços a este paciente. Outra forma de se criar valor com a fonte pagadora é apresentar maior produtividade na solução dos casos, ou seja, mais resolutividade. O uso da TI na integração das atividades de um hospital consegue ao mesmo tempo aumentar a eficiência e a eficácia da instituição.

As instituições que não utilizam $\mathrm{TI}$, ou não são totalmente integradas, necessitam de muitas interfaces, as quais geram muitos erros e redução da produtividade. Ao desenvolver atividades com sistema de informações integrado, é possível, por exemplo, antecipar as necessidades dos clientes e atendê-los de forma mais humanizada. Pode-se informar às pessoas que estarão envolvidas com o tratamento do paciente, se ele já foi internado na instituição, qual sua preferência em termos de alimentação, outros. Por outro lado, podem-se analisar questões mais específicas do tratamento como, por exemplo, se o paciente é alérgico a algum medicamento, se tem pressão alta, entre outros, gerando mais segurança no tratamento. Há também as questões relacionadas com a velocidade de resposta ao atendimento, que envolvem entrega de medicamentos nas alas de internação, coleta de material para exames, entrega de resultados de exames e toda natureza de serviços logísticos que uma estrutura hospitalar demanda e que a TI contribui, distribuindo serviços, horários, insumos, escalas de trabalho, outros.

Os sistemas oferecidos por C13 são customizados de acordo com as necessidades dos clientes. O sistema integra toda a estrutura hospitalar e é dividido em módulos, permitindo que sejam acrescentados, quando houver necessidade. A TI contribui principalmente com a produtividade, gerenciamento e controle dos recursos-chave. As tarefas de linha de frente e retaguarda podem ser mais bem especificadas, permitindo repetição e melhor aprendizagem. O sistema facilita o controle organizacional, que pode desenvolver operações de serviços com maior autonomia dos funcionários. O controle de custos é um dos principais atributos do sistema, que desenvolve atividades, mesmo com a complexidade de rotas que fazem parte do processo em operações de serviços na saúde.

$B$ - Foco no cliente e no serviço.

- Agendamentos de cirurgias e utilização de protocolos personalizados por médico 
A TI auxilia para que o nível de serviços logísticos de uma determinada cirurgia sejam realizados, conforme a solicitação do médico, com reservas de sala cirúrgica, equipamentos, materiais, medicamentos, equipes de anestesia, entre outras coisas.

Os médicos podem realizar cirurgias, utilizando diferentes técnicas que, por sua vez, utilizam infra-estrutura e insumos diferentes, ou por causa da técnica, ou por preferência pessoal. Neste caso, existe um banco de dados com informações personalizadas de cada médico, o que facilita para que se obtenha maior qualidade nos serviços oferecidos ao médico.

Os médicos participam da especificação do serviço, por meio de protocolos, antes de se incorporarem a este processo. O sistema identifica o perfil dos pacientes e propicia um melhor entendimento de sua expectativa e, conseqüentemente, facilita a produção simultânea ao consumo. Do ponto de vista da eficiência, podem-se obter ganhos tanto na linha de frente (preparando antecipadamente os locais onde o paciente será atendido), como na retaguarda (realizando serviços sem a presença do paciente ou médico, quando está não é requerida) entre outros.

- Questionário eletrônico com perfil do paciente para planejamento da internação

O uso da TI nas internações eletivas, além da informatização do processo de admissão do paciente, contribui ainda para entender e atender melhor algumas peculiaridades de sua internação, que serão fundamentais para a qualidade do atendimento.

O questionário, com perfil do cliente, faz parte de um banco de dados do paciente que fica em um banco de dados do hospital. Mesmo antes de o paciente ser internado, ele é abordado pela equipe de internação, que faz algumas perguntas para que se possa conhecer o paciente. O médico do paciente também contribui para que se faça este levantamento prévio.

A TI pode identificar que um paciente que será internado em um determinado dia e hora possui uma prótese, por exemplo. Neste caso, já se providencia uma cadeira de rodas, para que, na chegada do paciente, ele possa dispor deste benefício como um diferencial importante na prestação de serviços. A TI, neste caso, contribui para que se possa planejar uma operação de serviço objetivando ser 
desenvolvida totalmente na retaguarda, deixando para a hora de contato com o cliente somente o indispensável, minimizando erros e tornando o processo mais ágil.

\section{C - Esforço contínuo de melhorias}

- Prescrição eletrônica

A prescrição eletrônica é uma ferramenta importante para tornar as atividades do hospital mais sincronizadas e integradas.

O texto digitado, o formato padronizado das fichas ou prontuário, os dispositivos à prova de falhas, entre outras, trazem vantagens de produtividade e qualidade em diversos aspectos, como: redução de estoques, racionalização de operações, monitoramento de dados, controles, relatórios e outros.

A prescrição eletrônica gera maior segurança para o médico, porque ninguém vai deixar de entender a letra dele. O sistema faz toda a parte de interação, se o paciente é alérgico, se um medicamento interagiu com o outro, tudo isso é alertado ao médico na hora da prescrição, pelos vários sistemas à prova de falhas. As regras de convênios são bastante complexas e também são explicitadas para que os itens que não tiverem cobertura sejam apresentados. A alta do paciente é automática, pois assim que o médico libera o paciente, ele pode passar na recepção que sua conta está pronta; acelera o processo de liberação do leito, faturamento, cobrança, outros e também mais satisfação ao cliente; garante um registro de dados em tempo real, com apuração de seus custos, para negociação a posteriori com os convênios ou para controle da rentabilidade. Os dados da prescrição eletrônica vão para o prontuário eletrônico, consolidando todas as informações do paciente, fazendo um histórico que deverá ser arquivado, pois é um documento que deve ser guardado, por exigência legal. A prescrição eletrônica contribui fundamentalmente para os gerenciamento e controle dos recursos-chave, para a melhoria das especificações das tarefas e para o controle dos serviços em geral.

- Prontuário eletrônico e disponibilidade das informações, via WEB

O prontuário eletrônico consolida todas as informações do paciente de todos os atendimentos realizados naquele hospital em qualquer data anterior e ainda disponibiliza as informações para consulta, via WEB.

O acesso às informações do paciente, tanto no ambiente hospitalar quanto pela $W E B$, torna o processo mais ágil e seguro, assim como o aumento da qualidade 
das informações, pela questão da padronização dos formulários eletrônicos, pelo texto digitado, pelos filtros e também as ferramentas à prova de falhas, entre outros.

Ganhos de produtividade: facilidade de acesso às informações, dentro ou fora do hospital, eliminação de pedidos em duplicidade (quando um paciente retorna a um hospital, três dias após ter sido internado, não há necessidades de se pedir determinados exames, por que o prontuário eletrônico mostra o que foi feito, diferentemente do modelo tradicional, em que se solicitam novos exames, pois a informação não está à disposição) entre outros exemplos. Da mesma forma que o item anteriormente comentado, pode-se obter melhor gerenciamento e controle dos recursos, melhoria nas especificações de tarefas, controle dos serviços em geral e ainda contribuir para flexibilizar o atendimento com base nos requisitos do paciente e do médico, em relação a tempo, a local e à entrega dos serviços.

- Ministração de medicamentos utilizando equipamento móvel (PDAs)

Assim que o médico prescrever eletronicamente, as informações vão simultaneamente para o prontuário eletrônico do paciente e para outras áreas que estiverem relacionadas, entre elas, a farmácia do hospital. A farmácia recebe um arquivo com as informações sobre como deverá separar detalhadamente os medicamentos, os materiais e outros.

A farmácia separa o medicamento que deverá ser ministrado pelos pacientes por meio da informação que recebeu na tela do computador. O computador gera uma lista e uma etiqueta com código de barras. A lista servirá para separar o medicamento e para outras instruções de como ministrar, além da identificação do paciente. No horário que o medicamento deverá ser ministrado, ele é enviado à respectiva ala de internação onde o paciente se encontra. O enfermeiro recebe as informações sobre os medicamentos, doses, forma de ministrar, leito do paciente e horário, em seu equipamento móvel (PDA), automaticamente, por meio de uma rede sem fio. $O$ enfermeiro dirige-se até os quartos dos pacientes, identificam-os com suas pulseiras demarcadas com código de barras, confere o medicamento que está levando, refazendo a leitura no código de barras e administra a ministração do medicamento.

Estes procedimentos permitem eliminar problemas de ministração errada de medicamentos (melhor controle). Ao mesmo tempo em que ele ministra os medicamentos, a farmácia e o prontuário do paciente recebem informações 
eletrônicas sobre o horário que o paciente recebeu o medicamento. Também são enviadas informações dos valores dos medicamentos para a conta do paciente, que, depois, serão faturados eletronicamente para os convênios (maior controle de custos). Todo o processo é automático e com mecanismos à prova de falhas, aumentando a qualidade e a produtividade (automação no controle de processos de serviços).

- Ferramentas de TI utilizadas na operação de faturamento

O conjunto de ferramentas de TI (prescrição eletrônica, prontuário eletrônico, utilização de equipamento móvel, compras automatizadas, outros) facilita o faturamento e permite reduzir perdas no processo de apuração dos procedimentos realizados, assim como na comprovação destes.

Os convênios em geral apresentam um grande e complexo número de regras, o que torna difícil o controle e a cobrança das atividades realizadas. Um exemplo que pode ser citado é a cobrança pelo uso de gases medicinais nos pacientes internados. Por quanto tempo ele utilizou o aparelho? Como controlar e depois comprovar que foi utilizado? Quando se solicita que se ministre um medicamento qualquer, como cobrar pela agulha, seringa e pela dose do medicamento, se o produto não estiver fracionado e já em formato de kit ou pacote no sistema? Será cobrado o kit ou o pacote. Os convênios só aceitam que sejam repetidos alguns procedimentos após determinado período; caso contrário, estes não serão pagos. Existem muitas possibilidades de se realizar as cobranças dentro de um mesmo convênio que variam de tipo de plano, pois as coberturas e as tabelas acordadas são diferentes. Comparar um plano com outro plano torna esta complexidade ainda maior, sem controles específicos, pois perde mais tempo provando o que deve ser cobrado do que efetivamente no foco do negócio: o atendimento médico.

A TI contribui no controle dos recursos-chave (mão-de-obra, equipamentos, outros) para que estes sejam utilizados dentro do planejado, minimizando perdas. $O$ controle organizacional favorece trabalho com estruturas mais achatadas, tornando desnecessário controle rígido dos gerentes e equipes. Por fim, o controle de custos permite que se monitore toda a operação para que se possam comprovar os valores cobrados aos convênios.

- Controle de processos e indicadores de desempenho utilizando a TI 
O processo de implantação de sistemas integrados em hospitais ou em qualquer empresa supõe que se realize um estudo dos processos, para que se chegue à melhor solução em sistemas de informação. Ao desenhar estes processos, podem-se implantar os indicadores de desempenho, conforme recomendam as empresas certificadoras de qualidade.

As instituições que trabalham com certificação de qualidade estão fazendo parcerias com empresas de sistemas e também certificações destas empresas, pois entendem que existe sinergia e afinidade entre os propósitos destas empresas.

Os indicadores de desempenho são fundamentais para monitorar a gestão do negócio e corrigir quando ocorrem falhas, melhorando, portanto, os resultados da empresa. Podem-se citar casos de CCIH (Comissão de Controle de Infecção Hospitalar), em que o sistema permite que se fique sabendo quando o paciente começou a tomar um antimicrobiano, após uma cirurgia de grande porte e, neste caso, monitorar para evitar imprevistos, complicações com o paciente. Em locais onde não se têm este controle informatizado, os profissionais vão ficar sabendo disso dias depois, após lerem o prontuário. O atraso pode causar danos irreparáveis para a recuperação do paciente, além de gerar custos.

- Criação de formulários eletrônicos personalizados

O uso da TI para manter determinados formulários que contribuem para os controles das operações de serviços. Estes formulários são específicos de algumas áreas ou departamentos e contribuem pontualmente com as operações de serviços de uma determinada área.

Os formulários deixam de ser impressos em papel e passam a ser utilizados no sistema, com o controle automático, sem despesas de papel e outros inconvenientes de padronização, erros e perdas, entre outros fatores.

A TI permite que o cliente determine como desenvolverá seus formulários, antes de incorporá-lo ao serviço.

D- Otimização do processo empresarial (reengenharia do processo do negócio).

Obs. Este subitem será dividido em duas partes: reengenharia do processo do negócio e novos negócios gerados pela TI ou em processo de gestação. 


\section{D1 - Reengenharia do processo do negócio}

- Acordos comerciais baseados em resolutividade no tratamento dos pacientes

A TI permite que se acompanhem os principais indicadores de desempenho em um hospital de forma precisa e ágil. Uma delas é a questão da infecção hospitalar, que devidamente monitorada e controlada, facilita o tratamento dos pacientes, evitando que haja complicações com infecção hospitalar. A redução de custos com o controle de infecção é um instrumento importante de barganha dos hospitais com os convênios em geral.

Alguns convênios estão negociando suas tabelas com base em indicadores de desempenho relacionados à infecção hospitalar. O processo funciona da seguinte forma, na medida em que se reduz o índice de infecção hospitalar, o hospital recebe um valor maior. Quando os índices de infecção aumentam, aplica-se um redutor para os valores das tabelas negociadas, ou o contrário, de acordo com o nível de infecção, aplica-se um percentual a maior nos valores cobrados.

Esta operação, amparada pela $\mathrm{TI}$, faz o processo tornar-se mais rápido e transparente com maiores chances de êxito. Os ganhos são para todos os participantes: para o paciente, maior segurança; para o hospital, maiores esforços para obter maior qualidade e, para a fonte pagadora, um preço prêmio para os maiores índices de resolutividade, que por sua vez, apresentam menor custo analisando proporcionalmente. Além da $\mathrm{CCIH}$ (Comissão de Controle de Infecção Hospitalar) bem documentada, gera valor para o hospital, pois isto também ocorre com outras áreas do hospital, onde se possam demonstrar controles e resolutividade. Portanto, na mesma linha que os itens anteriores, as vantagens do uso da TI trazem maior eficácia, observando os ganhos para o paciente e uma maior eficiência para hospitais e convênios (gerando melhores controles em geral).

- Prescrição eletrônica de exame, com liberação parcial, condicionado aos resultados dos primeiros exames.

Prescrição eletrônica de exames de análises clínicas e de diagnósticos por imagem, com liberação parcial, após resultado de exames anteriores.

Na medida em que se obtêm os resultados dos exames, novos exames são liberados ou não, dependendo da necessidade.

A velocidade que a $\mathrm{TI}$ propicia aos processos permite que os resultados e os exames sejam analisados e, depois, outras solicitações sejam realizadas, se for 
necessário. Diferentemente do modelo tradicional, onde se prescrevem vários exames e, mais tarde, se descobre que eram desnecessáriom, quando um deles já deu resultado negativo, por exemplo. Este processo permite que o médico e paciente participem das especificações dos serviços antes de se incorporá-los. Permite também uma maior flexibilidade no atendimento com base nos requisitos do cliente e, ainda, controle de custos e adequação da capacidade produtiva.

- Resumo das informações do paciente via WEB

Resumo das informações do paciente disponíveis via WEB, em que o médico pode consultar a evolução do paciente em qualquer local que haja acesso à Internet.

Ao acessar as informações sobre o paciente a distância, o médico pode tomar decisões como, por exemplo, pedir que algum colega, médico, prescreva um exame ou procedimento (as prescrições médicas só podem ser realizadas de forma presencial), tornando mais rápidas as ações sobre o paciente. Pode, ainda, estabelecer prioridade de visitas, optando em realizá-las de acordo com a gravidade dos pacientes, entre outros.

Nesta operação de serviços, a TI permite uma grande flexibilidade no que se refere ao cumprimento de prazos, conveniência espacial e entrega dos serviços. Além disto, pode-se desenvolver o controle dos serviços, controle organizacional, controle dos custos e flexibilizar também a capacidade operacional, reduzindo custos.

- Informações Gerenciais (inteligência nos negócios para o hospital)

Uso da TI para dispor um conjunto de informações, indicadores e controles, para serem analisados dentro ou fora da instituição, via WEB.

As informações gerenciais abordam, por exemplo, quantos pacientes já tiveram suas prescrições realizadas às 11 horas. Neste caso, têm-se uma das formas de gerir, uma delas é instituindo sinalizadores verde, amarelo e vermelho (indicadores), informando como este processo, que dá suporte para que se tomem decisões de qualquer local que estiver o gestor.

Por que a TI cria valor? É semelhante ao item anterior. 
- Desenvolvimento de um prontuário ambulatorial (ficha médica) para planos de saúde

Transferência do conhecimento e tecnologia utilizada nos prontuários eletrônicos hospitalares para um prontuário ambulatorial.

Este novo produto está sendo desenvolvido junto a um plano de saúde, portanto, um novo mercado que a empresa está apresentando-se.

Os principais atributos desta nova ferramenta são contribuir com a produtividade e o gerenciamento dos recursos-chave, melhorar as especificações de linha de frente e de retaguarda, reproduzindo em série uma mesma solução e outras vantagens anteriormente apresentadas em relação ao prontuário eletrônico hospitalar.

\section{E - Redes de valor e alianças entre empresas}

- Sistema hospitalar integrado e a organização em redes

O sistema hospitalar integrado faz parte dos sistemas estratégicos que podem dar vantagem competitiva à empresa, e também é importante para a efetivação das redes e das alianças entre as empresas, que permitem o funcionamento adequado de um hospital. O sistema cobre as mais diversas áreas do hospital, desde agendamento de consultas, exames ou cirurgia, apuração de custos e resultados, passando pelo centro cirúrgico, nutrição, manutenção, zeladoria, área fiscal, outros. Além das áreas internas, o sistema também aciona prestadores de serviços e fornecedores, formando uma rede de valor.

$\mathrm{Na}$ medida em que se agenda uma cirurgia, por exemplo, todas as áreas envolvidas são comunicadas de forma integrada: reserva de um leito de internação; reserva de um leito na UTI, para pós-cirúrgico; solicitação de insumos para a cirurgia, ou seja, equipamentos, medicamentos, materiais, outros. Todas as operações de serviços são realizadas eletronicamente, assim como todas as áreas são comunicadas conjuntamente. Além das áreas internas do hospital, os parceiros externos também são acionados: fornecedores de materiais (próteses, orteses, pinos, fios, outros); distribuidores de medicamento (medicamento especial que não tenha no estoque, outros); especialistas diversos (médicos, fisioterapeutas, outros).

Tudo o que estiver relacionado com o procedimento que o paciente está envolvido é acionado automaticamente, informando toda a rede, com base nas informações recebidas. Quanto mais precisas forem as informações, melhor a 
programação e, conseqüentemente, menores serão as falhas, os retrabalhos e as perdas desnecessárias. Quanto a perdas, inclui-se o tempo dos profissionais de saúde, que precisam estar em diversos locais ao longo do dia e, quanto melhor a programação, mais bem utilizada será sua capacidade produtiva. Isto também se aplica às reservas de equipamentos, leitos, salas cirúrgicas, que são altamente perecíveis na medida em que são reservadas e não utilizadas, ocupando um espaço de outra cirurgia que poderia ter sido agendada, entre outros fatores. O controle de custos se estende a toda cadeia produtiva, flexibiliza-se a capacidade operacional ao encontro da demanda, especialmente em circunstâncias com esta que envolve muitos parceiros autônomos.

F - Comércio eletrônico e redes de informação.

- Compra de insumos pela Internet

Compra de insumos pela Internet, com todo processo automatizado.

A partir da prescrição eletrônica realizada pelo médico, uma informação é enviada eletronicamente para a farmácia. A farmácia separa os medicamentos e envia para as alas de internação ou de pronto-atendimento. Nas alas de internação, os enfermeiros fazem a ministração nos quartos dos pacientes, utilizando um equipamento móvel. Neste momento, uma informação eletrônica é enviada para várias partes do hospital: o faturamento, debitando o medicamento na conta do paciente e no estoque do hospital. No estoque do hospital, são regitrados eletronicamente os pedidos com base em lote mínimo, prazo ou qualquer outro parâmetro estabelecido pela instituição. Este pedido é enviado, pela $W E B$, para os fornecedores, que emitirão uma nota fiscal eletrônica e enviarão o pedido solicitado.

Com este processo, consegue-se manter um estoque mínimo. Não há retrabalho dos pedidos, pois eles são acionados após a ministração, ou seja, de fato o medicamento foi consumido, pois não houve devolução. O aumento da produtividade e a redução de erros é facilmente observável. A TI flexibiliza o atendimento com base nos requisitos do cliente, em relação a tempo, a local e à posse, ajuda também no controle dos recursos-chave, no caso, profissionais de saúde e equipamentos. Finalmente, contribui para aumentar a automação nas operações de compra dos hospitais. 


\subsubsection{Outras Considerações}

A questão do baixo índice de profissionalização nas empresas de saúde no país (muitas empresas familiares) dificulta a introdução de ferramentas de TI, muitas vezes por desconhecer as vantagens que esta pode gerar. Podem-se citar alguns poucos exemplos de cidades, principalmente capitais, onde é possível discutir as vantagens de se utilizar um sistema integrado com uma instituição hospitalar. Estas são as poucas instituições que apresentam excelência em gestão, porém são exceções. Larga maioria dos hospitais do país vive à margem de sistemas de TI e de gestão. A indústria da saúde, em especial os hospitais, está muito atrasada em relação a outras áreas no país. Para citar um exemplo, pode-se citar a questão da gestão de custos hospitalares. O que se percebe é que poucas instituições têm noção de quanto custa uma determinada cirurgia, por exemplo. Então, como saber se ela dá lucro ou prejuízo. Além de não se ter uma cultura voltada à gestão e de desprezar ferramentas que poderiam auxiliar a gestão como é o caso da TI, muitas destas instituições não conseguem perceber a diferença entre obter uma informação em tempo real e tentar atuar concomitantemente, do que só ficar sabendo muito depois e não poder fazer nada. Muitas indústrias aprenderam com os sistemas e filosofias desenvolvidas pelas montadoras ou outras indústrias. O setor da saúde aparentemente ficou alheio, preferiu fechar-se e desenvolver sua própria forma de conduzir os negócios. Este fato causou uma distância desta indústria em relação às demais, no que se refere à gestão e também às aplicações da TI. Por último, constatou-se, mais uma vez, que as ferramentas apresentadas e utilizadas pelos hospitais não são fator de diferenciação para os pacientes que, segundo se constatou, por meio de fontes secundárias, um hospital é melhor que outro, mas os hospitais não apontam a TI como fator da diferenciação.

\subsubsection{Resumo da Análise de C13}

A TI criou valor (eficiência e/ou eficácia) em diversas circunstâncias, entre elas, podem-se citar:

- gerando soluções integradas para gestão hospitalar; 
- realizando agendamentos para prestação de serviços personalizados (protocolos específicos, conforme determinação do médico usuário);

- instituindo questionário eletrônico para o paciente, para facilitar o planejamento no processo de internação hospitalar;

- permitindo o processo de prescrição eletrônica nos prontuários e disponibilização dos dados na WEB;

- aumentando o controle na ministração de medicamentos, por meio de equipamentos móvel (PDAs);

- favorecendo a operação de faturamento da empresa;

- controlando processos e indicadores de desempenho da empresa;

- criando formulários eletrônicos personalizados;

- propiciando acordos comerciais mais vantajosos na medida em que se apresentam melhores resultados (resolutividade) no tratamento de pacientes;

- racionalizando o processo de solicitação de exames em geral;

- propiciando, para o médico, a gestão clínica de pacientes a distância;

- propiciando para os gestores a gestão clínica e administrativa de hospitais a distância;

- $\quad$ integrando parceiros, fornecedores e prestadores de serviços médicos, na operação hospitalar;

- comprando insumos via WEB;

- outros.

Por que a TI cria valor? As respostas foram diversas, mas observou-se uma maior incidência do ponto de vista da eficácia, nas seguintes circunstâncias:

- personalização no atendimento;

- flexibilizado o atendimento com base nos requisitos do cliente;

- outros.

Do ponto de vista da eficiência, observou-se que a TI teve maior contribuição nas seguintes circunstâncias:

- aumentando a produtividade e controle dos recursos-chave;

- aumentando o controle organizacional;

- aumentando o controle dos custos; 
- melhorando as especificações das tarefas (linha de frente e de retaguarda);

- controlando serviços em geral;

- automatizando processos;

- outros.

\subsection{EMPRESA 14 (C14) - EMPRESA DE SERVIÇOS DE INFORMÁTICA (CONECTIVIDADE)}

\section{Dados da empresa}

\begin{tabular}{|c|c|}
\hline Faturamento anual da empresa: & $\mathrm{R} \$ 3.600 .000,00$ \\
\hline $\begin{array}{l}\text { Número de funcionários da } \\
\text { empresa: }\end{array}$ & 45 \\
\hline Funcionários terceirizados: & 0 \\
\hline Funcionários de TI da empresa: & 13 \\
\hline Funcionários de TI terceirizados: & 0 \\
\hline $\begin{array}{l}\text { Área de aplicação da TI estudada } \\
\text { que gera vantagem competitiva } \\
\text { para empresa: }\end{array}$ & $\begin{array}{l}\text { C14 é uma empresa de outsourcing que } \\
\text { oferece conectividade para outras } \\
\text { empresas. As soluções que a empresa } \\
\text { oferece permitem que seus clientes } \\
\text { reduzam custos de transação, por meio de } \\
\text { transações eletrônicas, em vez do modelo } \\
\text { tradicional. }\end{array}$ \\
\hline $\begin{array}{l}\text { Estratégia competitiva genérica e } \\
\text { escopo de atuação da empresa no } \\
\text { mercado: }\end{array}$ & $\begin{array}{l}\text { A empresa atua especificamente no setor } \\
\text { da saúde, oferecendo opções de serviços } \\
\text { relacionados à conectividade. O foco de } \\
\text { atuação em conectividade permitiu uma } \\
\text { maior especialização para empresa. Ao } \\
\text { estreitar o escopo de atuação, a empresa } \\
\text { conseguiu bons resultados de escala e na } \\
\text { curva de aprendizagem, reduzindo seus }\end{array}$ \\
\hline
\end{tabular}


custos.

\section{Principais Características da Empresa}

C14 é uma empresa de origem nacional que atua como uma prestadora de serviços de informática para o setor da saúde com operações no Brasil e América do Sul, desde 1998. Desenvolve soluções que permitem a automação da administração da saúde pela aplicação de tecnologias que melhoram a eficiência e reduzem os custos de gestão.

A empresa fornece serviços de processamento de transações eletrônicas (conectividade) por meio de diferentes canais e tecnologias.

Atualmente, seus produtos são utilizados por mais de uma dezena das maiores empresas de medicina suplementar e por mais de 500 prestadores de serviços de saúde.

A empresa conecta uma rede de mais de 560 prestadores institucionais e 2000 consultórios no Brasil por meio de suas plataformas.

\section{Uso da TI}

Mediante sua plataforma de conectividade, a empresa oferece opções para as empresas manterem um constante fluxo de informações sobre a gestão e a administração diária com a rede de prestadores, usuários e clientes. A empresa desenvolve soluções que permitem a automação da administração da saúde pela aplicação das tecnologias que melhoram a eficiência e reduzem os custos de gestão.

A empresa conta com serviço de faturamento eletrônico que vem a ser um processo de envio de faturamento, ou seja, um paciente passa no médico, na clínica, no hospital ou laboratório, que pertença a um convênio, automaticamente isso gera uma guia, e essa guia é faturada para o convênio, ao invés de ele mandar o processo (preenchendo toda a guia), simplesmente ele gera um arquivo eletrônico e envia isso na data do envio do faturamento do convênio. Além deste serviço, podem-se citar outros que o complementam e cujo processo é semelhante. Um deles é o sistema autorizador, utilizado para permitir que um serviço médico seja prestado, a um suposto beneficiário. Outras ferramentas, como auditoria on-line e glosa eletrônica, que validam os procedimentos que foram realizados nos pacientes e liberam as contas para que sejam faturadas. 


\subsubsection{Formas de Contribuição da TI - Categorias}

A - Sistemas estratégicos.

- Serviços de conectividade

A empresa utiliza a TI para oferecer soluções de conectividade a seus clientes, cobrando pelas transações realizadas.

Entre estes serviços, podem-se citar: faturamento eletrônico e sistema autorizador (para consultas, exames e outros procedimentos médicos em geral), incluindo toda infra-estrutura para que compradores (planos de saúde, seguros e outros) e fornecedores (consultórios médicos, serviços de análise, diagnóstico e terapia, hospitais e outros) possam comunicar-se eletronicamente.

A operação aumenta a produtividade e a qualidade do serviço, pois substitui processos administrativos controlados por guias de papel, por arquivos eletrônicos. Os arquivos eletrônicos são enviados automaticamente na data do faturamento determinado pela fonte pagadora (convênios, outros), gerando grande flexibilidade em relação a tempo e a local em que a operação é realizada. O modelo tradicional demanda diversos controles e retrabalhos relacionados à classificação, à separação, à contabilização, à expedição deste material, e outros. A utilização da TI favorece o controle de todo o processo de faturamento, em especial quanto à autorização de procedimentos, ao envio, à auditoria, à cobrança de contas e outros.

$B$ - Foco no cliente e no serviço.

- Redução do tempo de atendimento aos pacientes

O processo de conectividade facilita a comunicação entre as empresas prestadoras de serviços médicos e os convênios médicos. As facilidades geradas pelo processo eletrônico relacionadas à padronização de procedimentos, sistemas à prova de falhas, entre outros, minimizam os erros e agilizam o processo de atendimentos aos pacientes.

O processo de atendimento no modelo convencional exige que os pacientes tragam guias de autorização para alguns casos e/ou que as autorizações sejam realizadas junto ao convênio por telefone no momento em que forem utilizar o sistema. 
Estes fatos, além de causarem um número maior de erros por parte dos funcionários, pois realizam a operação na linha de frente, ainda incomodam os clientes pelo maior tempo de espera para ser atendido. No processo, utilizando a TI, além da flexibilidade, em relação aos requisitos do cliente, quanto a tempo, a local e à entrega do serviço, anteriormente explicada, há também a questão do controle da expectativa do cliente, por receber mais rapidamente as contas. Há, ainda, vários ganhos com produtividade, relacionados aos controles inerentes a um sistema digital.

C - Esforço contínuo de melhorias.

- Faturamento eletrônico

A operação de faturamento eletrônico permite que seja realizada uma préanálise nas contas dos pacientes. Este procedimento minimiza erros ou inconsistências no processo. A TI introduz procedimentos à prova de falhas que bloqueiam o envio do faturamento. Isto faz com que o prestador tenha de arrumar a conta, antes que seja enviada, evitando glosas futuras (cobrança indevida ou incorreta) e qualquer outro tipo de retrabalho.

Entre as inconsistências que podem ser evitadas na pré-análise, podem-se citar as seguintes: códigos de carteirinha inválida, serviços contratados não cadastrados, preenchimento inadequado dos códigos relacionado ao procedimento que será realizado, número do CRM (Conselho Regional de Medicina) do médico que solicitou o procedimento, valor de acordo com que foi contratado, falta de senhas de autorização, falta de algum tipo de laudo, que deve anteceder um determinado tratamento, outros.

Podem-se exemplificar mais de uma centena de possibilidades de erros que geram bloqueio no faturamento. Na medida em que se utiliza esta forma padronizada de realizar a operação de faturamento, ganha-se produtividade na operação e reduzem-se perdas de diversas naturezas.

\section{- Sistema autorizador}

O sistema autorizador vem antes do faturamento eletrônico, funciona da seguinte forma: o paciente chega ao local de atendimento e, por meio de biometria (controle de acesso por partes do corpo humano, por exemplo, digitais do dedo), POS (máquina que faz leitura em cartões) ou sistema legado (banco de dados dos 
beneficiários), que identificam o usuário e os procedimentos que ele tem direito, para autorizar o atendimento.

Estas ferramentas permitem identificar o usuário, qual seu convênio, data de validade de seu contrato, qual procedimento está sendo solicitado, entre outros, gerando ou não a autorização para realizar o procedimento solicitado pelo médico.

Além do aumento da velocidade de atendimento, o sistema minimiza erros de digitação, inibe fraudes com falsos associados. O sistema autorizador permite ainda que se faça direto no site dos convênios uma pré-autorização, entre outras peculiaridades, que permitem que o cliente especifique, antes de se incorporar ao serviço. A pré-autorização, por exemplo, gera um código, para que os usuários apresentem no local de atendimento, para que seja confirmado. Esta operação elimina ligações telefônicas ou deslocamento dos pacientes para retirar guias de autorização. As autorizações, por sua vez, abrem uma conta corrente do prestador de serviços de saúde na fonte pagadora, indicando quanto o convênio terá de pagar para aquele prestador. Esta atividade poderia inclusive eliminar o faturamento eletrônico, anteriormente comentado. A TI contribui de várias maneiras: melhorando o controle nos recursos-chave, nas tarefas de linha de frente ou na retaguarda, no controle organizacional, possibilitando vantagens relacionadas à qualidade, para reduzir custos, entre outras.

\section{D- Otimização do processo empresarial (reengenharia do processo do negócio).}

Obs. Este subitem será dividido em duas partes: reengenharia do processo do negócio e novos negócios gerados pela TI ou em processo de gestação.

\section{D1 - Reengenharia do processo do negócio}

- Processo de glosa eletrônica

A glosa eletrônica é um processo de avaliação das contas enviadas pelos prestadores de serviço aos convênios, utilizando a TI. Este processo consiste em analisar as contas dos fornecedores e gerar arquivo que é disponibilizado para cada prestador na WEB.

Os prestadores, por sua vez, recebem esta informação, fazem uma análise e, por meio de relatórios, documentos complementares, como laudos entre outros, buscam justificar os valores faturados que foram glosados pela fonte pagadora. 
Esta operação substitui a tradicional operação de glosas, que gera um consumo substancial de papel, impressão, correio, pessoal, outros. O prestador retira o demonstrativo da glosa no site e, no mesmo local, apresenta o recurso, item por item, conta por conta, em que foram apontados os problemas. Os prestadores, em geral, têm, em média, 30 dias para fazer recurso das glosas apresentadas pelos convênios. No caso da glosa eletrônica, torna o processo mais transparente, mais fácil de ser controlado. A operação de serviço fica mais flexível em relação a cumprimento de prazos, a local e a entrega do serviço e ainda pode ser fortemente personalizado de acordo com as necessidades dos tomadores e prestadores de serviços.

- Auditoria médica on-line utilizando PDA

Utilização de PDA (on-line ou off-line) com formulário do convênio em que são especificadas as operações que devem ser realizadas. Entre as operações, o formulário eletrônico especifica valores e coberturas que o paciente tem direito. $\mathrm{O}$ formulário traz, inclusive, protocolos relacionados à permanência média em relação a determinadas patologias, em que o auditor pode vir a questionar o médico que solicitou o tratamento. As auditorias médicas são operações de serviços em hospitais que acontecem entre a operação do sistema autorizador e a operação de faturamento. Trata-se de avaliar as contas enquanto o paciente está sendo tratado. No modelo convencional, os auditores médicos portando pastas, tabelas e diversos outros documentos, percorrem os leitos nos hospitais, analisando prontuários médicos, para verificar os procedimentos realizados no pacientes. Depois desta operação, retornam com um relatório ao escritório da empresa, onde lançam os dados no sistema, aprovando ou glosando os procedimentos.

A utilização do PDA permite que se avaliem os procedimentos realizados no paciente e que serão lançados na conta dele, no local onde está sendo realizado o trabalho de auditoria. Quando a operação é on-line, transferem-se as informações em tempo real para o convênio e também para o prestador de serviços; na operação off-line, utiliza-se um terminal com acesso à Internet, para enviar os arquivos.

Os auditores médicos avaliam se os materiais, medicamentos, procedimentos, entre outros estão sendo utilizados e cobrados adequadamente, consultando e lançando dados no PDA. Neste caso, torna-se desnecessário o transporte de documentos e outros comprovantes anteriores de operação e também 
se torna desnecessário retornar ao escritório para levar o trabalho realizado. Tudo pode ser descarregado em um terminal e enviado pela $W E B$, quando a próxima operação não fizer isto automaticamente. $O$ trabalho é realizado uma única vez. Não é necessário retrabalhos e, portanto, obtém-se maior produtividade e qualidade na operação. As vantagens são semelhantes às apresentadas no item anterior.

D2 - Novos negócios gerados pela TI ou em processo de gestação.

- Banco de dados sobre tendências de consumo de materiais e medicamentos Quando as empresas de conectividade realizam as transações entre os convênios e seus prestadores de serviço, são gerados dados destas operações. Estes dados podem ser transformados em informações sobre tendências de consumo de matérias e medicamentos, entre outros, utilizados pelas instituições de saúde, que podem ser valiosos.

As informações de consumo podem ser úteis de diversas formas para diferentes públicos. A indústria farmacêutica, ou a indústria de materiais, pode beneficiar-se destes dados, por exemplo, ao conhecerem quais são os insumos mais utilizados, oferecendo condições especiais de seus produtos, conseguindo vantagem sobre seus concorrentes.

As informações, indicando tendências, contribuem para compreender melhor os pacientes e, conseqüentemente, adequar-se à oferta de serviços. Conhecendo melhor o cliente, pode-se, por outro lado, aumentar o índice de previsibilidade, ampliando as oportunidades de padronização e da produtividade.

E - Redes de valor e alianças entre empresas.

- Informação uniforme na rede de valor adequando oferta e demanda

A conectividade supõe que todo o processo de tráfego de dados seja digital e, em seguida, transformado em informações.

Estas informações, analisadas conjuntamente, incluindo os fornecedores e clientes, permitem uma visão sistêmica do negócio, facilitando a gestão.

As informações difundidas a fornecedores e a clientes contribuem para adequar oferta e demanda. Com isto, é possível aos parceiros reduzirem estoques, adequarem à capacidade produtiva de equipamentos e aos serviços médicos, por exemplo. 
- Parcerias entre empresas de TI

O uso da $\mathrm{Tl}$ oferece oportunidades para que empresas consigam mais mercado, atuando como parceiras. As empresas fazem alianças para oferecer soluções de serviços que se complementam e resolvem o problema do cliente por inteiro.

No processo eletrônico, supõe-se uma empresa para integrar as áreas da instituição (por exemplo, empresa que fornece sistemas para hospitais) e, outra, para conectividade (que integrará o hospital a um plano de saúde, por exemplo). A primeira obtém seus resultados por meio da venda de sistemas integrados e, a segunda, por meio das transações que realizará com a conectividade.

Empresas que oferecem sistemas integrados para hospitais, por exemplo, unem-se às empresas de conectividade e desenvolvem conjuntamente um layout em que o sistema das duas empresas se adequem e resolvam problemas de integração e conectividade da empresa contratante. A um só tempo, solucionam-se dois problemas: maior satisfação do cliente e vantagem competitiva para as empresas parceiras.

F - Comércio eletrônico e redes de informação.

- Gestão de benefícios de farmácia

O uso da TI no processo de compra de medicamento em farmácias pelos pacientes beneficiários dos convênios. Os convênios oferecem às empresas cartões para que seus beneficiários comprem medicamentos com descontos nas farmácias. Estes cartões, além de permitirem descontos nos medicamentos, também funcionam como cartões de crédito, permitindo que os associados dos planos de saúde comprem medicamentos e que estes valores sejam debitados diretamente em suas folhas de pagamento.

Cada associado tem um limite de crédito para gastar com medicamento. Após a operação de compra, a farmácia envia um arquivo para o convênio, informando a compra realizada pelo beneficiário.

Ao facilitar o processo de compra dos medicamentos, os convênios propiciam uma percepção de maior qualidade aos seus beneficiários, facilitando o atendimento com base nos requisitos do paciente, em relação a tempo, a local e à entrega do serviço. Além deste benefício, também se pode considerar que ao tomar os medicamentos indicados pelo médico, os pacientes, em geral, recuperam-se mais 
rapidamente, reduzindo despesas potenciais de tratamento deste beneficiário pela fonte pagadora.

\subsubsection{Outras Considerações}

Alguns pontos levantados neste caso levam a crer que a conectividade entre as empresas poderia ser mais bem explorada, trazendo ganhos a todos os participantes. Um dos pontos importantes que foram levantados trata-se da falta de padronização em relação às empresas que atuam neste setor. Neste caso, um prestador de serviços como um hospital, por exemplo, pode utilizar diferentes processos para realizar conexão entre seus clientes, planos de saúde, seguradoras, autogestões, cooperativas e outros. Considerando-se que alguns convênios utilizam redes de prestadores de serviços que ultrapassam 2000 pontos de atendimentos e que, apenas na Cidade de São Paulo, se tem mais de 100 diferentes convênios, percebe-se a complexidade e perdas nesta indústria, apenas com problemas administrativos, que não relacionados ao foco do negócio.

\subsubsection{Resumo da Análise de C14}

A TI criou valor (eficiência e/ou eficácia) em diversas circunstâncias, entre elas, podem-se citar:

- conectando empresas para que realizem transações operacionais e comerciais;

- reduzindo no tempo de atendimento a clientes em geral;

- faturamento eletrônico;

- autorizando procedimentos médicos, envolvendo pacientes, prestadores de serviços e convênios;

- avaliando contas médicas, que são enviadas por prestadores de serviços, antes do processo de faturamento eletrônico (glosa eletrônica);

- auditando contas médicas dos prestadores de serviços, antes de serem enviadas às fontes pagadoras;

- analisando tendências de consumo de materiais e medicamentos;

- $\quad$ permitindo uma visão sistêmica entre participantes de uma rede de valor; 
- instituindo parceiras entre empresas para prestação a um mesmo cliente;

- facilitando o processo de compras de medicamentos e materiais para pacientes em farmácias;

- outros.

Por que a TI cria valor? As respostas foram diversas, mas observou-se uma maior incidência do ponto de vista da eficácia, nas seguintes circunstâncias:

- aumentando a qualidade nos serviços;

- flexibilizando o atendimento;

- controlando a expectativa do cliente;

- permitindo parcerias entre empresas;

- outros.

Do ponto de vista da eficiência, observou-se que a TI teve maior contribuição nas seguintes circunstâncias:

- aumentando a produtividade;

- automatizando processos;

- racionalizando despesas;

- adequando a capacidade produtiva às oscilações da demanda;

- outros. 


\subsection{SÍNTESE DA ANÁLISE DOS CASOS (PROCESSOS POR CATEGORIAS)}

A análise dos casos (Quadro 21 - Síntese da Análise dos Casos), quando observada pelo ponto de vista dos processos por categorias, contribui para que se observem de que forma as empresas estão utilizando a $\mathrm{Tl}$ em suas operações de serviços. Conforme foi explicado, as empresas foram questionadas quanto às formas de se utilizar a TI que Ihes davam vantagem competitiva no mercado. Neste caso, não se deve comparar um caso com outro em relação ao número de processos analisados e muito menos comparar os processos entre categorias, pois, embora o estudo tenha utilizado o mesmo roteiro para a investigação, as operações, algumas vezes, podem ter sido sintetizadas em um número menor de processos ou o contrario, dependendo do entrevistado.

De forma geral, pode-se dizer que a $\mathrm{TI}$, nestas empresas, foram utilizadas mais fortemente no esforço contínuo para melhorias e na reengenharia do processo do negócio (50\% dos processos estavam concentrados nestas duas categorias).

Em uma análise caso a caso, pode-se notar o impacto da TI por categorias, o que facilita o entendimento da vantagem competitiva destas empresas no mercado e observar as formas de desenvolver as estratégias de negócios de cada uma.

Analisando empresa por empresa, usuárias e fornecedoras de $\mathrm{TI}$, o que se percebe é que a tendência apresentada acima é a mesma com um discreto desvio entre elas. 


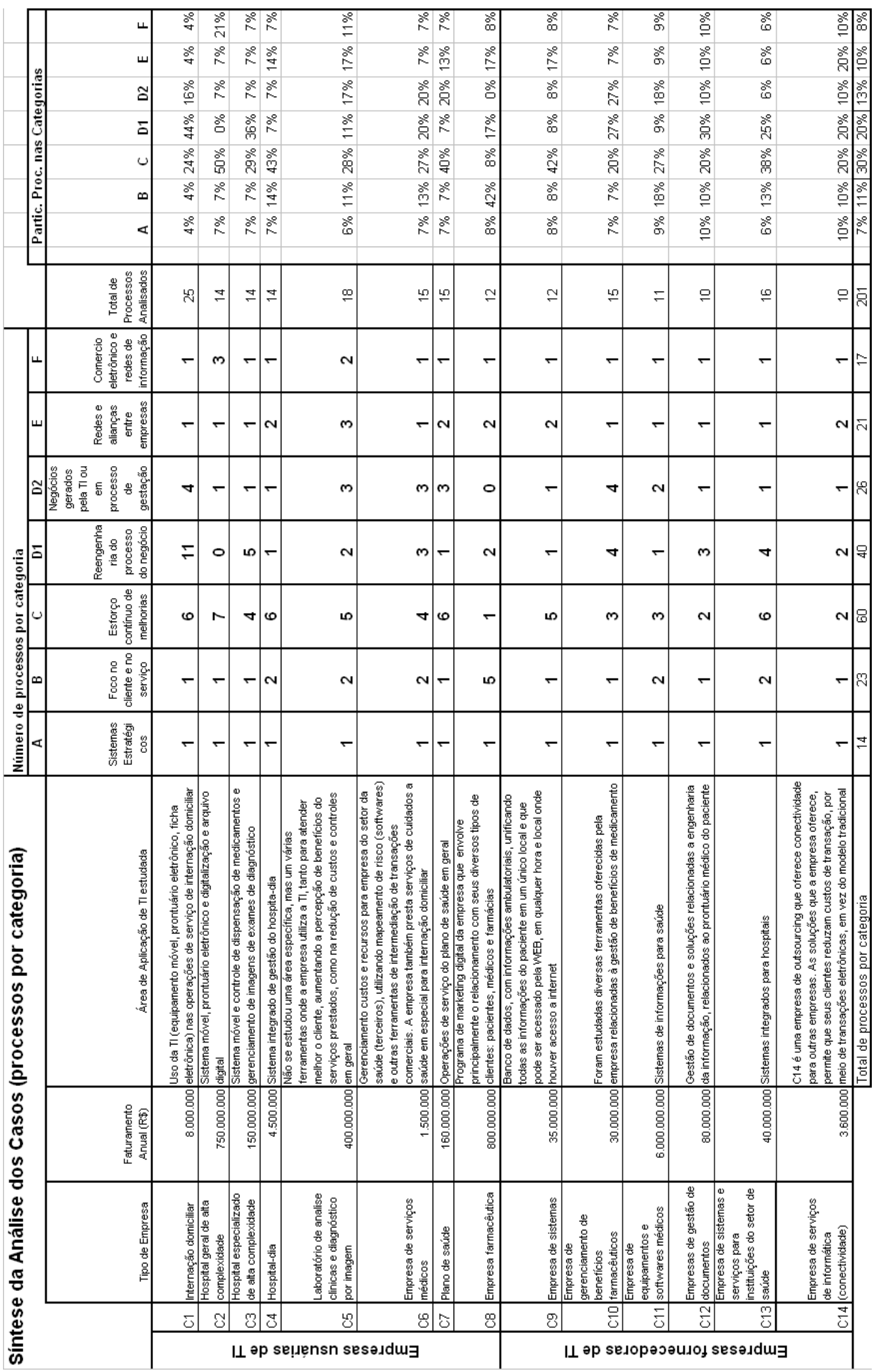

Quadro 21 - Síntese da Análise dos Casos 


\section{INTERPRETAÇÃO DOS DADOS DA PESQUISA}

\subsection{AVALIAÇÃO DAS CONTRIBUIÇÕES DA TI EM RELAÇÃO ÀS OPERAÇÕES DE SERVIÇOS, UTILIZANDO ESCALAS (BAIXO, MÉDIO E ALTO) GRAU DE CONTRIBUIÇÃO NAS OPERAÇÕES DE SERVIÇOS}

Para avaliação das variáveis dependentes em relação às variáveis independentes, utilizaram-se escalas baseadas no método de Lickert. Conforme (LAKATOS e MARCONI, 1982, p.94), o método Licket permite realizar avaliações sobre o grau de concordância e/ou favorabilidade em relação a uma determinada situação ou questão. As questões utilizadas nas avaliações foram divididas em dois grupos distintos: eficácia e eficiência. Estes, por sua vez, estão divididos em três subgrupos. Cada subgrupo contém vários itens (questões), somando um total de vinte variáveis independentes.

As respostas a esta avaliação, realizadas por meio de escalas, explicam como as operações em serviços que utilizam a TI, criam valor. A proposta é partir de uma situação em que se cria vantagem competitiva, utilizando a TI (Etapa 1). A partir disto, classificar, sob o ponto das reações das empresas como elas utilizaram a $\mathrm{TI}$ no mercado (Etapa 2). Na Etapa 3, utilizaram-se situações em que operações de serviço criam mais ou menos valor com o uso da TI nas operações de serviços (avaliação utilizando escalas).

Os dados e análises das etapas, comentadas acima, serão demonstrados a seguir.

Os casos apresentados (total de 14) fazem parte de uma rede de valor na saúde, delimitada para este estudo. Conforme poderão ser observadas, as tabelas trazem as seguintes informações:

A - casos: tipos de empresas estudadas e referência (C1 a C14) na rede de valor na saúde;

B - categorias: sete categorias em que foram classificadas as operações de serviços (itens) para serem analisadas;

C - características dos serviços (variáveis independentes - base prognóstica): variáveis de (1 a 20) em que se questiona a contribuição da TI (avaliação) em relação aos processos analisados; 
D - processos analisados (variáveis dependentes): número de processos analisados;

E - avaliação: avaliação utilizando escalas de 1 a 9 (baixo = 1, 2 ou 3, médio = 4, 5 ou 6 e alto: 7, 8 ou 9 ) grau de concordância e/ou favorabilidade em relação à contribuição da $\mathrm{TI}$ e o processo analisado. Conforme explicado anteriormente na metodologia, a análise e as notas referentes ao grau de favorabilidade, foram obtidas a partir da pesquisa de campo, com os entrevistados;

F - índices encontrados para eficiência e para eficácia.

Na seqüência, será apresentada uma análise consolidada por meio do Quadro 22 - Análise Geral dos Casos - Tabela Consolidada. A apresentação individual dos casos (C1 a C14) encontra-se no apêndice deste trabalho. Após os comentários e a interpretação do Quadro 22 - Análise Geral dos Casos - serão apresentados ainda alguns gráficos de análise da eficácia e da eficiência utilizando a TI.

Todos os quadros apresentados e também os gráficos apresentam a média das avaliações. Como se trata de uma abordagem qualitativa, as médias apresentadas referem-se ao grau de concordância e/ou favorabilidade em relação à contribuição da TI para aquele conjunto de processos em um determinado caso. Não se deve, portanto, considerar com uma representação estatística. 
11.1.1 Avaliação das Contribuições da TI - Análise Geral dos Casos - Tabela Consolidada.

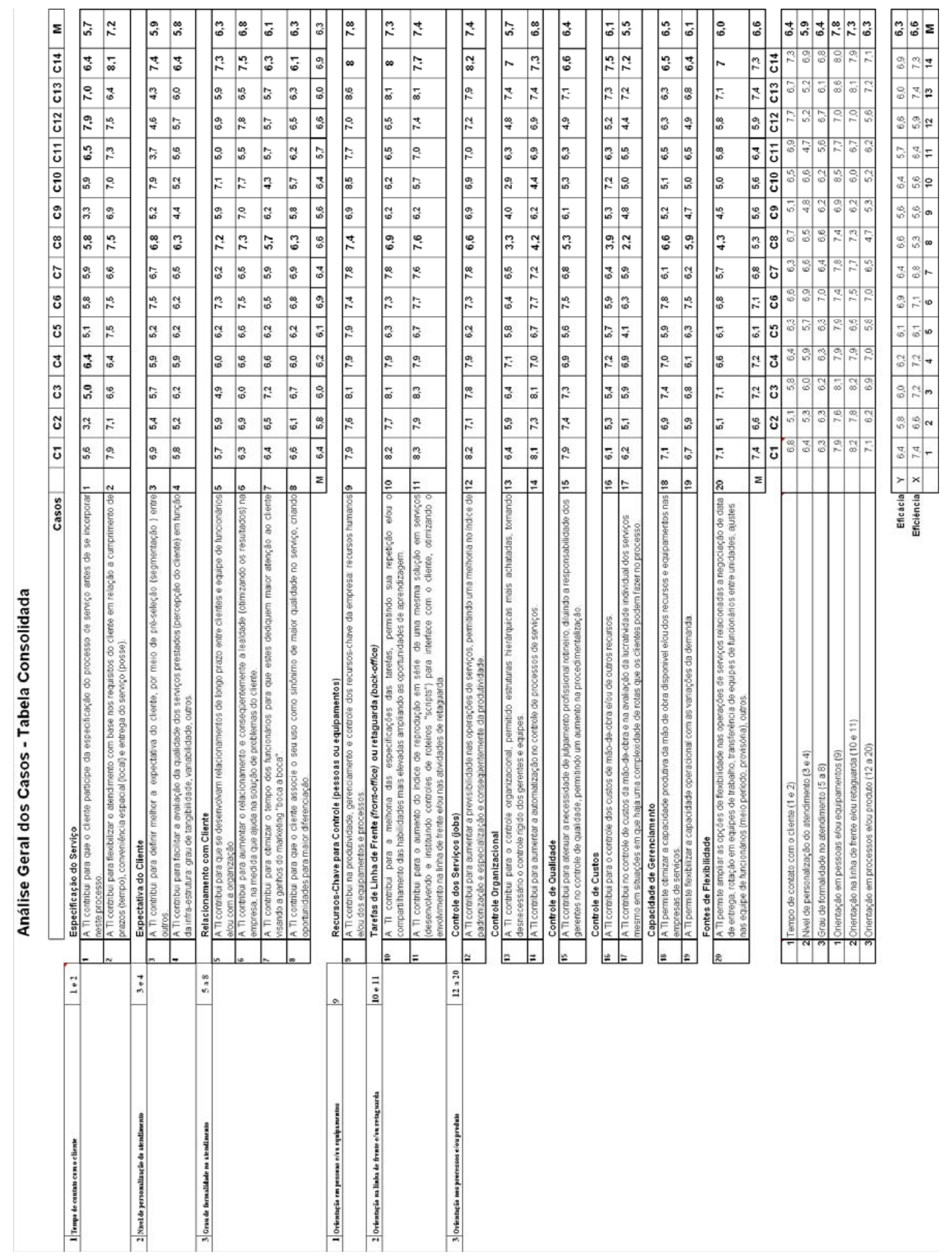

Quadro 22 - Análise Geral dos Casos - Tabela Consolidada. 
A análise dos 14 casos foi baseada na média das avaliações dos casos. As variáveis dependentes (operações de serviços que utilizam a TI) foram escolhidas na pesquisa de campo, por meio do roteiro da pesquisas, pois contribuíam para se criar valor (eficiência e/ou eficácia) nas operações de serviços em uma rede de valor na saúde. As pontuações (escalas) permitem compreender a ordem de grandeza, o grau de concordância e/ou favorabilidade em que a TI contribui com a criação de valor, sobre as variáveis dependentes.

Do ponto de vista da eficácia, que se subdivide em: tempo de contato com o cliente, nível de personalização do atendimento e grau de formalidade no atendimento, foram obtidas respectivamente as seguintes avaliações média: 6,4; 5,9 e 6,4 e média igual a 6,3 em uma escala de 1 a 9.

Conforme explicado, este valor representa o grau de favorabilidade em relação ao uso da TI e às operações de serviços. Quer se dizer que a TI contribuiu para que se obtivesse o grau de eficácia na intensidade apresentada.

Do ponto de vista de eficiência, que se subdivide em orientação em pessoas e/ou equipamentos, orientação na linha de frente e/ou retaguarda, orientação em processos e/ou produtos, obteve-se a respectiva avaliação: 7,8, 7,3 e 6,3, com uma média de 6,6, em uma escala de 1 a 9, conforme citado acima.

Tanto do ponto de vista da eficácia como da eficiência, a TI apresentou uma contribuição de média a alta. O importante, neste caso, não é a confirmação destes resultados, já que foram escolhidas situações em que a TI gerava vantagem competitiva para as empresas estudadas. O mais importante é a correlação da TI sobre as variáveis independentes que, por sua vez, sugere onde a TI pode criar mais valor nas operações de serviços, e de que forma. Conforme exposto anteriormente, a estruturação da pesquisa nos moldes que foi montada propicia que se faça uma engenharia reversa nas operações de serviços e se descubram as formas de se criar valor utilizando a TI.

\subsubsection{Avaliação das Contribuições da TI para a Eficácia.}

Nesta linha de raciocínio, pode-se dizer que na análise das variáveis independentes associadas à TI, a de número 2: - A TI contribui para flexibilizar o atendimento com base nos requisitos do cliente em relação a cumprimento de prazo (tempo), conveniência espacial (local) e entrega de serviço (posse). O subitem do 
Tempo de contato com o cliente recebeu a melhor avaliação. Isto significa que, para esta variável, a TI apresentou a maior contribuição, obtendo avaliação de 7,2 (em uma escala de 1 a 9$)$.

Para Silvestro (1999), esta variável independente é uma dos importantes características a serem consideradas nas operações de serviços. Lovelock e Wright (2006), Bowen e Ford (2002) e Gianesi e Correa (1996) corroboram com esta abordagem e acrescentam a importância do tempo de contato com o cliente, que envolve elementos como a co-participação, a produção simultânea ao consumo, a participação na especificação dos serviços antes de se incorporar a ele, a flexibilização no atendimento em relação a tempo, a local e à posse, entre outros.

Pode-se, então, fazer a seguinte leitura: as empresas utilizaram mais a TI para aumentar a flexibilidade no atendimento com base nos requisitos do cliente, para conseguirem vantagem competitiva, por parte da eficácia. Por si, já é um dado relevante, mas, por outro, pode-se também analisar o lado oposto, ou seja, analisar onde estão os problemas. Conhecendo-os, podem-se direcionar os esforços de TI. Por exemplo, o item 4 - A TI contribui para facilitar a avaliação da qualidade dos serviços prestados (percepção do cliente) em função da infra-estrutura: grau de tangibilidade, variabilidade, outros. Este item obteve uma das menores avaliações; neste caso, o gestor poderia direcionar os esforços de TI para aumentar este índice, melhorando as operações de serviços da empresa.

No Gráfico 1 - Análise da Eficácia nas Operações de Serviços Utilizando a TI I, pode-se observar o desempenho de cada empresa em relação às variáveis independentes, quanto à eficácia. Com este diagnóstico, podem-se tomar decisões de investir em determinadas áreas, direcionar os esforços em $\mathrm{TI}$, pode-se optar em distribuir melhor os esforços e contemplar as características de serviços em várias frentes como, por exemplo, as relacionadas com nível de personalização dos serviços ou em relação à formalidade no atendimento.

No Gráfico 2 - Análise da Eficácia nas Operações de Serviços Utilizando a TI II, pode-se observar todas as empresas analisadas em relação aos 8 itens que compõem as variáveis independentes que formam a eficácia. Aqui se pode analisar caso a caso, item a item, qual a contribuição da TI na eficácia da empresa.

Conforme apresentado, cada um destes casos corresponde a empresas diferentes que desenvolvem atividades em camadas diferentes em uma rede de valor na saúde. Assim, embora a média de desempenho entre os itens não 
apresente uma variação expressiva, observa-se que o impacto é diferente na medida em que as variáveis dependentes são diferentes. Em uma mesma empresa, pode-se descobrir operações em que a TI traz um forte impacto para uma determinada operação em relação a uma variável independente e pode trazer um impacto discreto, em relação a outra variável independente.

Com isto, pode-se dizer que não se encontraram muitas variações de empresa para empresa, variações nas operações de serviços dentro de uma mesma empresa, na medida em que os processos e a forma de se utilizar a TI eram diferentes.

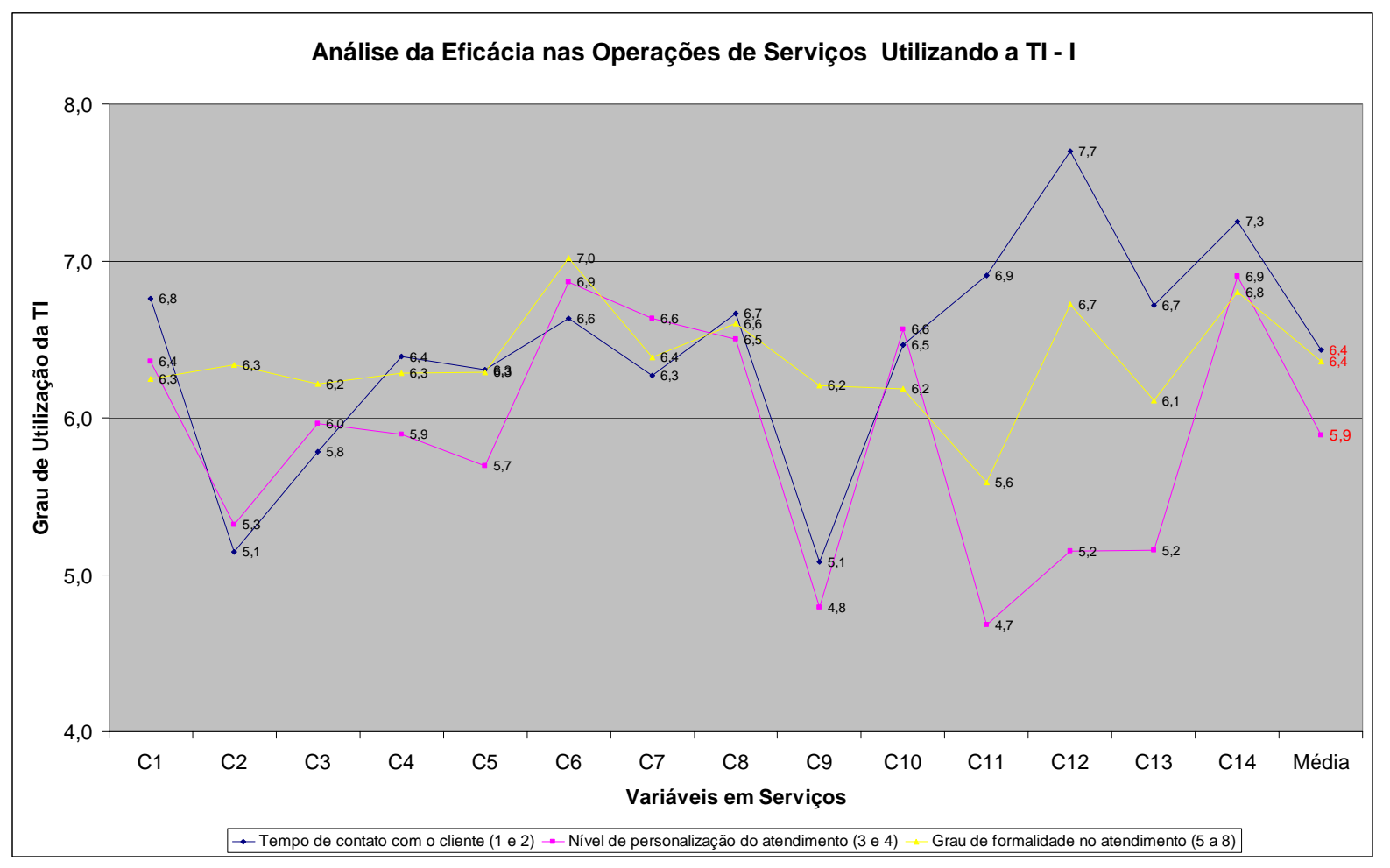

Gráfico 1 - Análise da Eficácia nas Operações de Serviços Utilizando a TI - I 


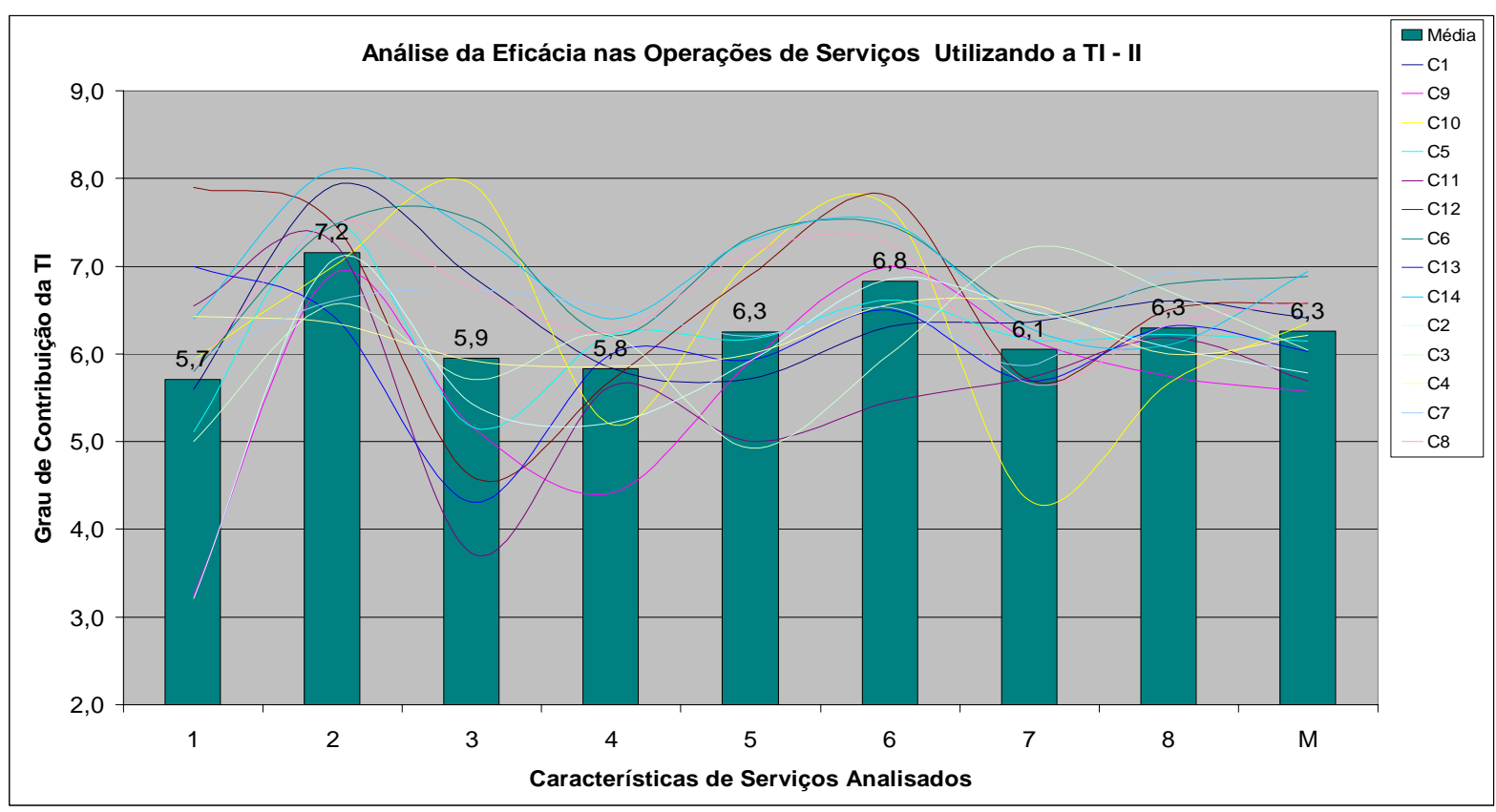

Gráfico 2 - Análise da Eficácia nas Operações de Serviços Utilizando a TI - II

\subsubsection{Avaliação das Contribuições da TI para a Eficiência.}

$\mathrm{Na}$ análise das variáveis independentes associadas à TI, a de número 9: - A TI contribui na produtividade, gerenciamento e controle dos recursos-chave da empresa: recursos humanos e/ou equipamentos e processos. O subitem da Orientação em pessoas e/ou equipamentos recebeu a melhor avaliação. Isto significa que, para esta variável, a TI apresentou a maior contribuição, obtendo avaliação de 7,8 (em uma escala de 1 a 9) para a eficiência.

Esta variável independente é uma dos importantes características a serem consideradas nas operações de serviços, conforme Silvestro, 1999, Lovelock e Wright (2006), Bowen e Ford (2002) e Gianesi e Correa (1996), entre outros. Estes autores relacionam diversas variáveis independentes que contribuem com a eficiência da empresa. Estes elementos, conforme foi demonstrado, tornam-se ainda mais evidentes com o incremento da TI. Entre estas variáveis, podem-se citar: controles de recursos-chave, estruturação das tarefas de linha de frente ou de retaguarda, repetição de tarefas, reprodução em série de uma mesma solução, aumento da previsibilidade das operações, padronização, procedimentalização, automação, flexibilidade na produção dos serviços, otimização da capacidade produtiva, adequação da oferta e da demanda. 
Da mesma forma que a análise da eficácia acima, pode-se então fazer a seguinte leitura: as empresas utilizaram mais a TI para aumentar a produtividade, 0 gerenciamento e o controle dos recursos-chave, para conseguirem vantagem competitiva, por parte da eficiência. Por si, isto é um dado relevante, mas é possível analisar os outros itens que foram menos favorecidos e direcionar ou adequar os esforços em TI, para que também apresentem desempenho exemplar.

No Gráfico 3 - Análise da Eficiência nas Operações de Serviços Utilizando a TI - I - pode-se observar o desempenho de cada empresa em relação às variáveis independentes, quanto à eficácia. Com este diagnóstico, podem-se tomar decisões de investir em determinadas áreas, direcionar os esforços em TI. Pode-se optar em distribuir melhor os esforços e contemplar as características de serviços em várias frentes como, por exemplo, as relacionadas com nível de personalização dos serviços ou em relação à formalidade no atendimento.

No Gráfico 4 - Análise da Eficiência nas Operações de Serviços Utilizando a TI - II - podem-se observar todas as empresas analisadas em relação aos 12 itens que compõem as variáveis independentes que formam a eficiência. Aqui, pode-se analisar caso a caso, item a item, qual a contribuição da TI na eficiência da empresa.

Igualmente à análise da eficácia, e conforme apresentado, cada um destes casos correspondem a empresas diferentes que desenvolvem atividades em camadas diferentes em uma rede de valor na saúde. Assim, embora a média de desempenho entre os itens não apresente uma variação expressiva, observa-se que o impacto é diferente na medida em que as variáveis dependentes são diferentes. Em uma mesma empresa, podem-se descobrir operações em que a TI traz um forte impacto para uma determinada operação em relação a uma variável independente e pode trazer um impacto discreto, em relação a outra variável independente. Com isto, pode-se dizer que não se encontraram muitas variações de empresa para empresa, mas variações nas operações de serviços dentro de uma mesma empresa, na medida em que os processos e a forma de se utilizar a TI eram diferentes. 


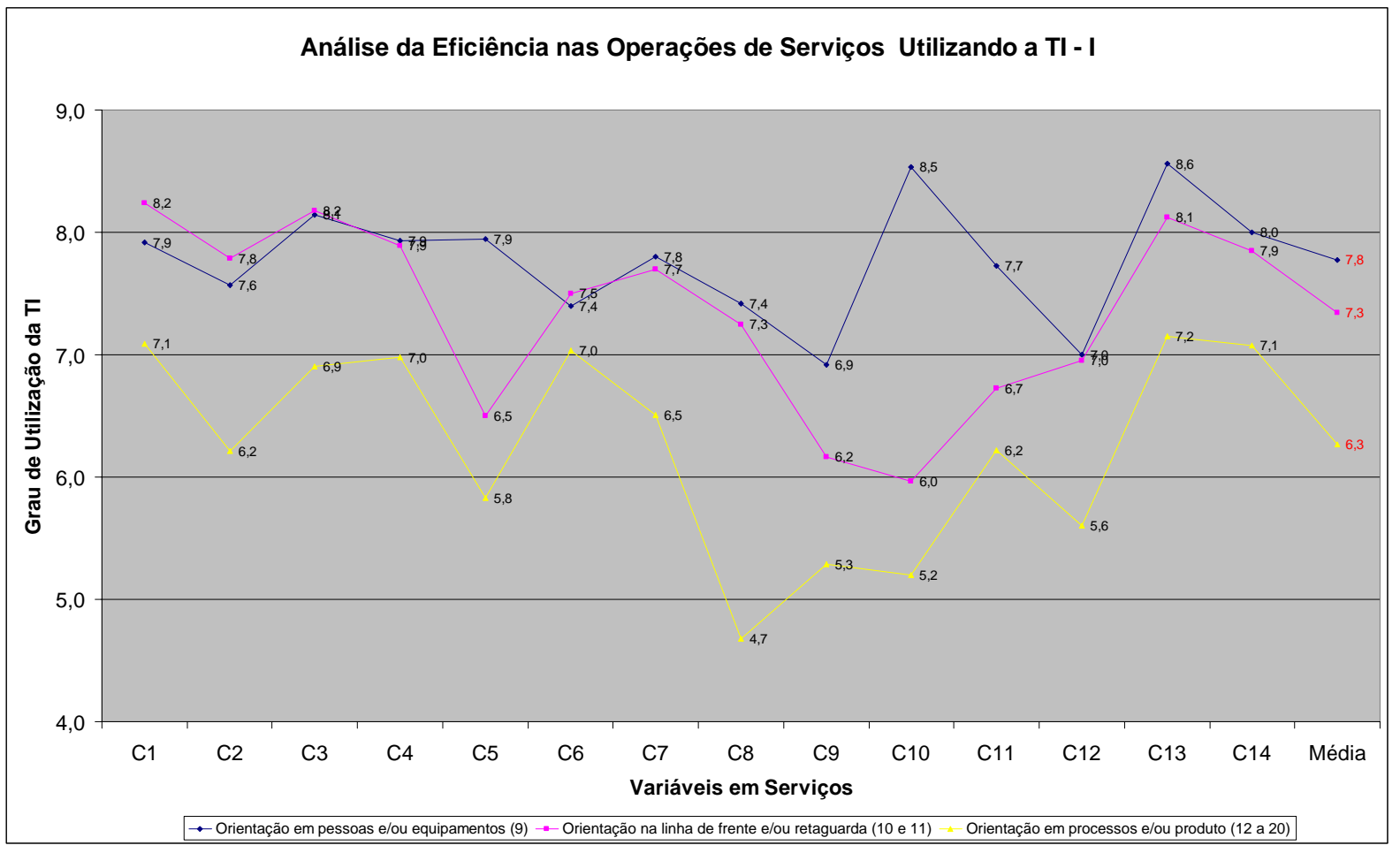

Gráfico 3 - Análise da Eficiência nas Operações de Serviços Utilizando a TI - I

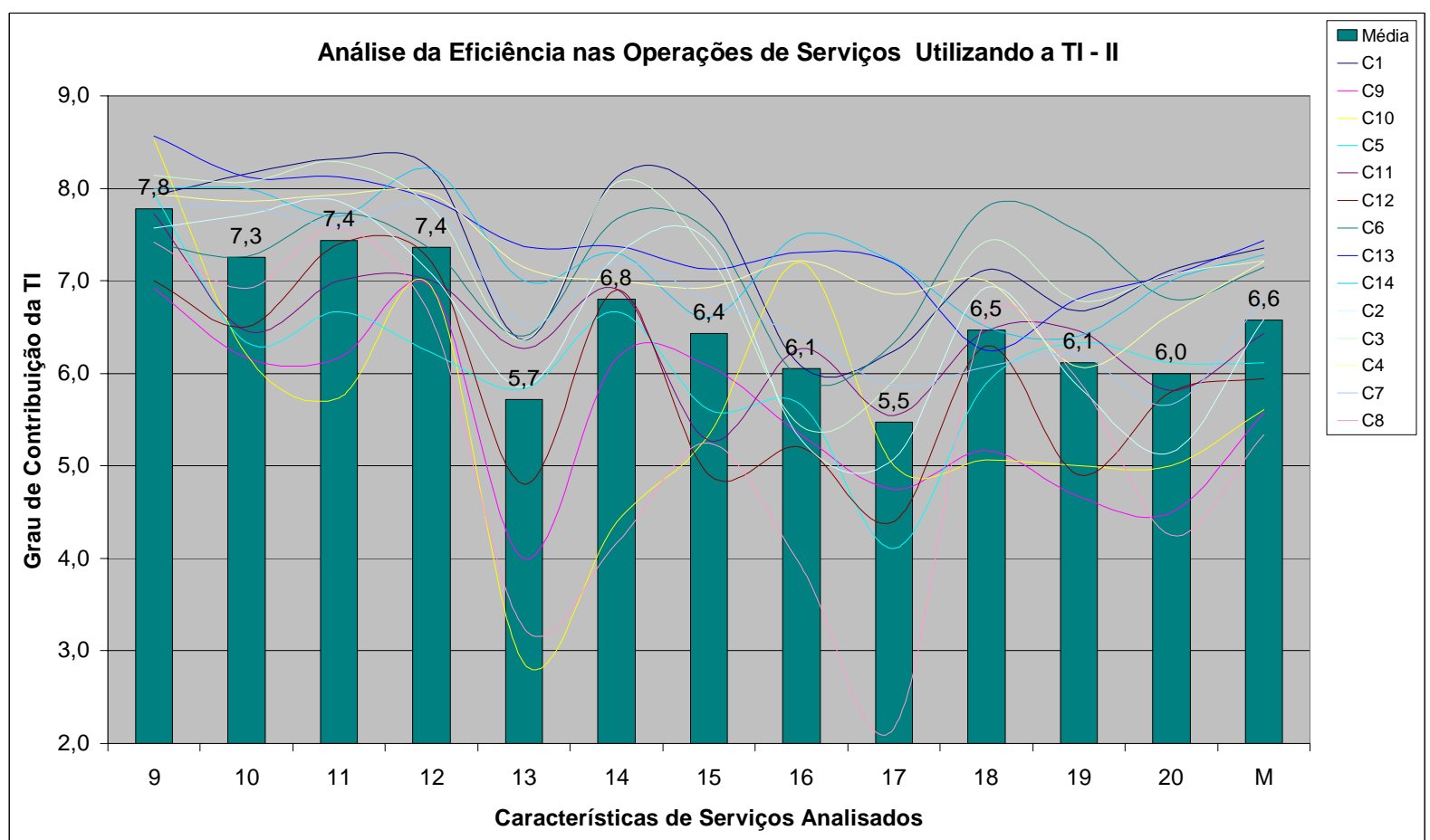

Gráfico 4 - Análise da Eficiência nas Operações de Serviços Utilizando a TI - II

\subsection{MATRIZ DE CRIAÇÃO DE VALOR EM SERVIÇOS}

A Figura 18 - Matriz de Criação de Valor (Eficácia e Eficiência) em Operações de Serviços II, adaptado de (OLIVEIRA, SILVA E LAURINDO, 2005) 
apresenta o resultado da avaliação dos casos estudados: C1, C2, C3, C4, C5, C6, C7, C8, C9, C10, C11, C12, C13 e C14.

A análise de dados da pesquisa seguiu o roteiro utilizado na pesquisa a qual divide o estudo em dois blocos para análise e que darão respaldo para quantificar as variáveis dos eixos $X$ e $Y$ da Matriz $3 \times 3$, são eles:

1. tempo de contato com o cliente; nível de personalização e grau de formalidade no atendimento (8 subitens);

2. orientação em pessoas e/ou equipamentos; orientação na linha de frente e/ou retaguarda e orientação nos processos e/ou produtos (12 subitens).

Conforme os autores acima citados, a análise propicia que se avalie cada item e se faça um diagnóstico, o qual permite uma prescrição futura. Este fato facilita a gestão do serviço, tornando mais ágil o processo de decisão estratégica. Muitos dos itens analisados permitiram observar como a $\mathrm{Tl}$ altera as questões relacionadas à eficiência e à eficácia em empresas no setor da saúde.

Do ponto de vista da criação de valor, fica evidente, no caso das empresas estudadas, que existem ganhos que podem vir inclusive a transformar-se em novos modelos de negócios advindos da utilização da TI no serviço de saúde. Para ficar apenas em um exemplo, a utilização de equipamento móvel deverá substituir, por exemplo, o tradicional prontuário médico, com o histórico do paciente, o que poderá ser não apenas de uma determinada instituição. Por um lado, não será preciso mais papel para escrever, e nem pastas para acondicioná-los, nem arquivos físicos e nem arquivistas, apenas empresas que arquivam dados e os disponibilizam aos seus clientes. Ainda neste ponto sem ampliar o escopo, podem-se imaginar empresas que armazenam dados, não apenas de instituições de saúde, mas de pessoas físicas, que poderão disponibilizá-los a qualquer hora em qualquer lugar. Tudo isto, de forma reservada, de forma que o paciente autorize o acesso a quem desejar. Estas empresas podem oferecer seus dados aos próprios pacientes, aos planos de saúde e às seguradoras, às empresas empregadoras. Enfim, há diversas formas de se utilizar dados sobre a vida do paciente, muito mais seguros e precisos do que os atuais prontuários de papel, haja vista que algumas empresas já estão fazendo isto. 

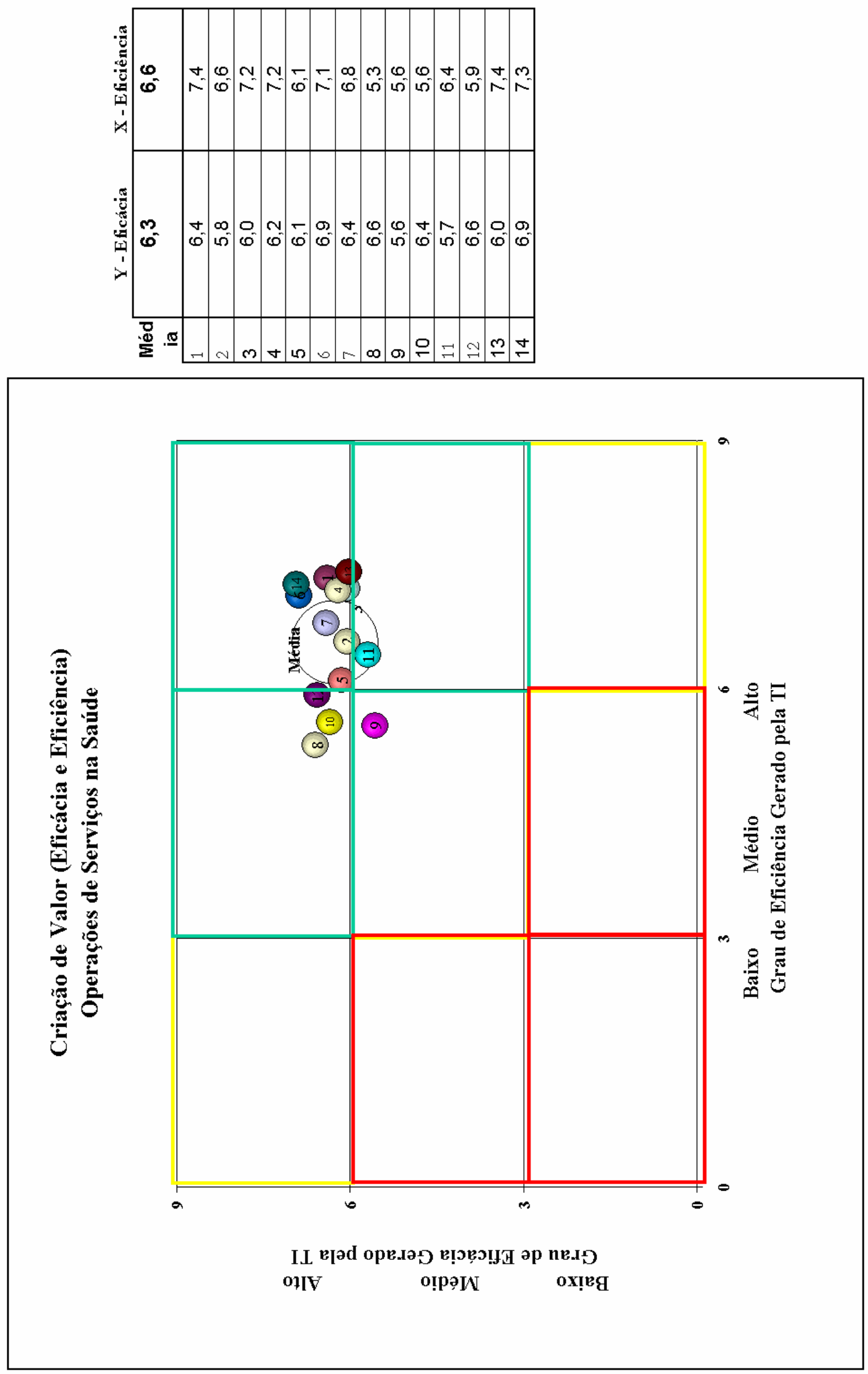

Figura 18 - Matriz de Criação de Valor (Eficácia e Eficiência) em Operações de Serviços II 
O gráfico demonstra, de forma simplificada, a criação de valor (eficiência e eficácia) com o uso da TI. Além da facilidade de se visualizarem os dados, o diagnóstico também pode servir para que se comparem empresas concorrentes ou serviços de uma mesma empresa e se monitore a evolução das variáveis no mercado.

Com os dados referentes à análise dos casos, pode-se atuar pontualmente em cada um dos itens e utilizar como controle de desempenho nas empresas. Podem-se desdobrar os dados e plotar cada operação de serviços, medir e controlar uma a uma.

O estudo em questão analisou diversas empresas de sucesso no mercado, o qual apontou a forma como utilizavam a TI em suas operações de serviços. Os resultados na Matriz de Criação de Valor em Serviços (Fig. 18) demonstram este viés, mostrando a forte concentração das empresas nos quadrantes de maior eficiência e maior eficácia.

Com isto, pode-se dizer que qualquer empresa de serviço pode ser avaliada pelo modelo e, inclusive, comparada com outras empresas. Um fato relevante que não pode ser negligenciado neste diagnóstico, para que se obtenha qualidade na análise, é o acesso a informações. Uma análise superficial prejudicaria muito o estudo e certamente impossibilitaria uma avaliação adequada.

\subsection{MODELO DECORRENTE DA ANÁLISE QUALITATIVA (APLICAÇÕES E COMENTÁRIOS)}

O modelo decorrente da análise qualitativa (Vide Fig. 17 - capítulo 9) apresentou-se muito útil para a execução do trabalho. Conforme citado na introdução, uma das contribuições destes deveria ser no campo do conhecimento metodológico: fornecer uma linha de raciocínio que pode ser replicada. Aparentemente, o intento foi alcançado e, mais do que isto, o modelo propiciou também que se conseguisse conhecimento prático das situações. Esta última também faz parte das contribuições listadas neste trabalho.

A identificação dos pontos-chave, que se baseou no roteiro da pesquisa, foi uma fase importante de campo, que demandou tempo e paciência. Foram estudados 14 casos, com diferentes tipos de empresa. Nesta fase, foi realizada uma média de 
três visitas por empresa com, pelo menos $2 \mathrm{~h}$, de entrevista cada uma delas. As entrevistas eram gravadas e, depois, transcritas. A partir das transcrições, surgiam novas dúvidas, que eram abordadas na entrevista seguinte, juntamente com a seqüência do processo de investigação. Esta forma de conduzir foi dispendiosa, porém, altamente compensadora do ponto de vista do conhecimento das operações de serviço e do negócio como um todo.

A formação das unidades de significado, que permitiu o agrupamento dos assuntos levantados, também foi um trabalho bastante extenso, pois a quantidade de dados levantada foi enorme. Para facilitar a formação dos grupos buscaram-se, na literatura, situações semelhantes ao problema estudado, que favoreceu a realização dos agrupamentos;

$\mathrm{Na}$ formação das categorias, segue-se o mesmo caminho realizado pelas unidades de significado, pois as evidências levantadas facilitaram identificar categorias na bibliografia apresentada.

A análise das unidades de significado contrapondo às variáveis independentes (base prognóstica), foi um estudo que envolveu o trabalho de campo realizado e, em algumas situações, foi necessário retomar as investigações para se obter uma melhor qualidade de respostas às indagações. As variáveis independentes, as quais foram contrapostas às variáveis dependentes, nem sempre eram fáceis de interpretar, dependiam da operação analisada e mudavam de significado de empresa para empresa. Pode-se dizer que esta fase foi bastante morosa e demandava revisões para enquadrar e avaliar as variáveis dependentes estudadas.

Por último, utilizou-se uma matriz 3×3, Matriz de Criação de Valor (Eficácia e Eficiência) em Operações de Serviços (OLIVEIRA, SILVA e LAURINDO, 2005), para facilitar a compreensão do diagnóstico realizado. Esta fase foi simplificada, pois contou com a pesquisa de trabalhos anteriormente desenvolvidos com algumas adaptações. 


\section{ANÁLISE DOS RESULTADOS DA PESQUISA}

A análise dos resultados tem como base a análise das proposições, conforme explicado na metodologia. Para realizar a análise das proposições, utilizaram-se as seguintes pontuações: "0" - refuta e "1" - corrobora com a proposição em relação às variáveis dependentes. No final, apresenta-se um quadro, demonstrando os percentuais com as proporções em que as proposições foram corroboradas ou refutadas.

\section{Análise das proposições:}

Proposição 1 - O uso da TI amplia as oportunidades, por meio de um monitoramento participativo entre empresas em uma rede de valor na saúde, causando integração do grupo, melhoria do nível de serviços e/ou redução de custos de transação;

Proposição 2 - O uso da $\mathrm{Tl}$ aumenta os pontos fortes do negócio da empresa em uma rede de valor na saúde e possibilita gerar vantagem competitiva por meio do aumento da qualidade e/ou produtividade;

Proposição 3 - As diversas formas de aplicação da TI, principalmente em setores como a saúde em que a intensidade de informação nos processos e nos serviços oferecidos é substancial, tem tornado a demanda exigente. Este fato exige formas alternativas de atuação das empresas para se criar valor (eficiência e/ou eficácia) no mercado com a finalidade de novos negócios.

A seguir, no Quadro 23 - Análise das Proposições, apresentando o perfil de cada um dos casos estudados e também a média. 


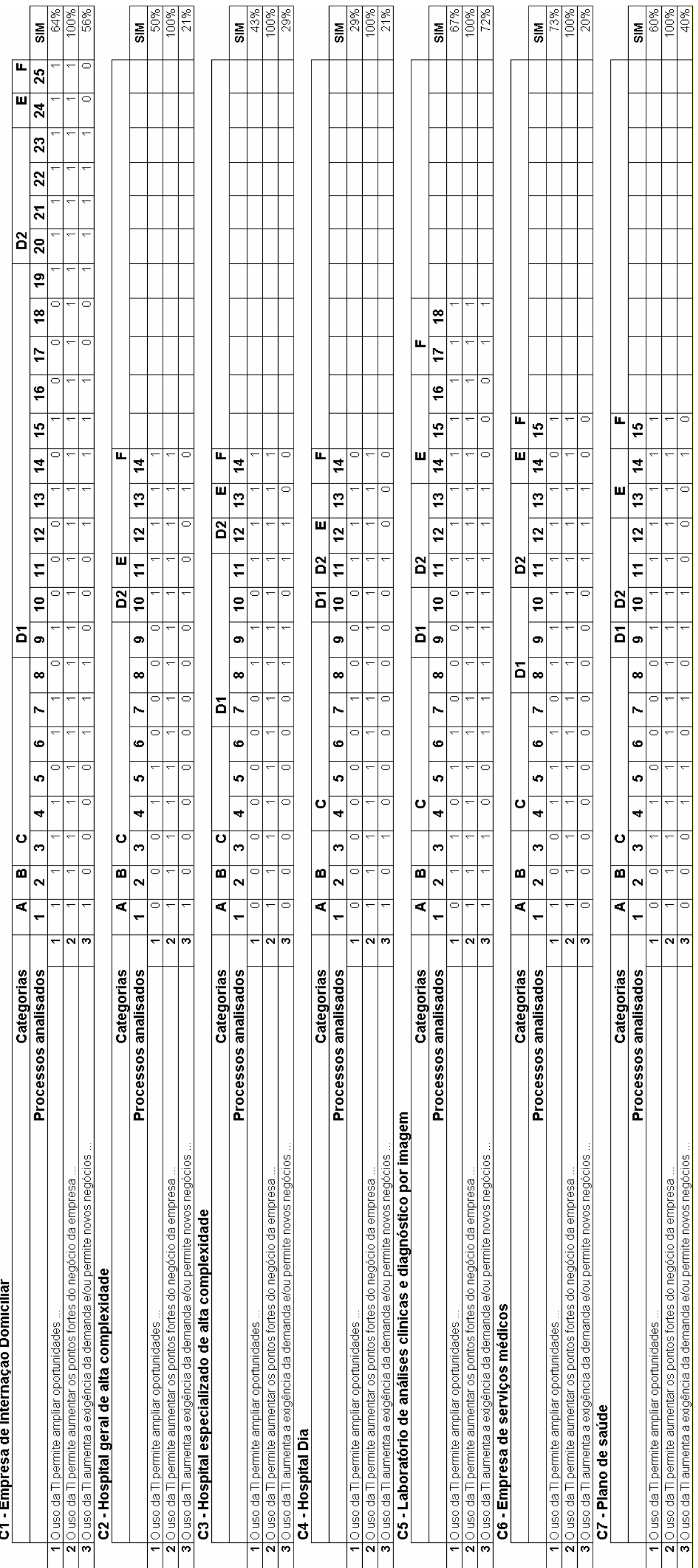




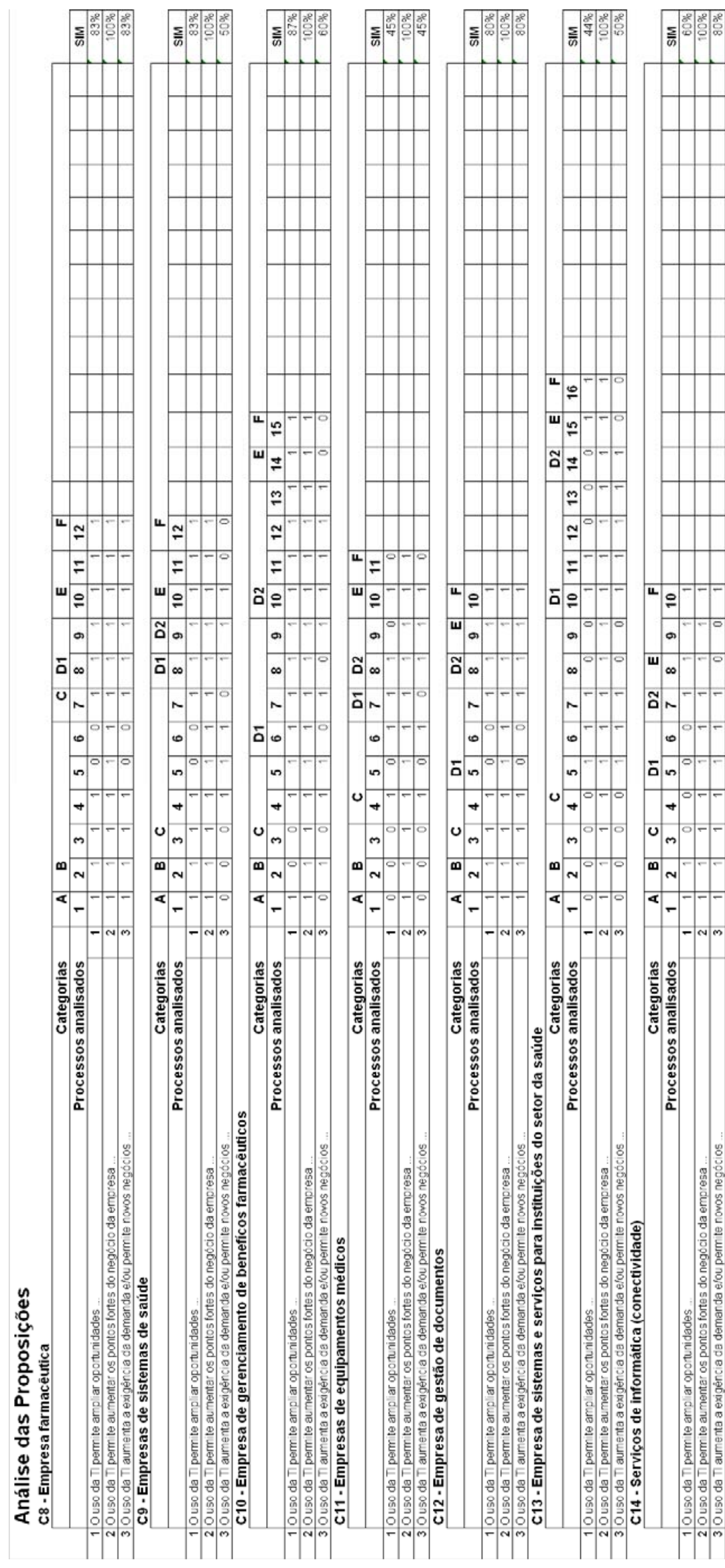

Quadro 23 - Análise das Proposições 
A proposição 1 (ampliar as oportunidades de atuação no mercado) e a proposição 2 (aumentar os pontos fortes no negócio da empresa), são fortemente confirmadas em larga maioria dos processos analisados.

No caso da proposição 1, um número expressivo de situações corroboram com a afirmação da proposição. Novamente, deve-se dizer que as empresas variam umas das outras em relação ao uso da TI e isto gera maior ou menor grau de concordância com as proposições. Além da variação entre empresas, elas apresentam também uma variação interna, entre seus processos. Mesmo com a variação nos itens analisados, de que as empresas obtêm maiores oportunidades de mercado ao usar a TI, a pior das situações ainda corroborou com 29\% de seus itens analisados, que a TI amplia as oportunidades de mercado para seu negócio. Quer se dizer que entre os itens analisados quase um terço das situações a TI aumenta as oportunidades de atuação no mercado nas operações de serviços na saúde.

No caso da proposição 2, todos os itens analisados corroboram com a proposição de que a TI aumenta os pontos fortes no negócio da empresa. Nota-se que as operações de serviços levantadas caso a caso exigiam que as empresas apresentassem elementos que davam vantagem competitiva para as empresas no mercado. Neste caso, o que se constatou é que realmente a utilização da TI ampliava os pontos fortes do negócio da empresa. Em nenhum momento da pesquisa, a TI foi apresentada como algo que não criava valor para o negócio ou como algo que não gerava força para empresa.

A proposição 3 também apresenta fortes indícios de que a demanda está tornando-se cada vez mais exigente e sofisticada, impulsionados pela própria TI. Isto propicia um ambiente para geração de novos negócios. Demonstra, por outro lado, que o paciente, que está no centro da rede de valor na saúde, carece de maiores informações sobre os benefícios que recebem advindos da TI. Este fato gera um efeito em cascata fazendo com que os prestadores de serviços que utilizam a TI ampliem seu poder de barganha na rede de valor na saúde corroborando com a proposição 1 e 2.

Quando se diz exigência e sofisticação da demanda (PORTER, 1999a), devese ter em conta que esta demanda é ampla e bastante diversificada. Em alguns casos, a demanda pode ser entendida como o paciente; em outros casos, o médico. Para os hospitais, a demanda são os convênios, as empresas, os particulares e 
outros. Para as empresas farmacêuticas, a demanda são as farmácias, os hospitais, os distribuidores, os pacientes e os médicos. O que se quer dizer é que, em uma rede de valor na saúde, existem as mais variadas formas de demanda, que a cada dia tornam-se mais exigentes na medida em que as empresas oferecem diferenciais para os clientes em geral. A exigência, a que se refere, abarca tanto o campo dos custos, como o campo dos benefícios. Exigem-se preços menores em que, por exemplo, algumas formas de utilizar a TI podem propiciar, aumentando a produtividade, controlando custos e outros. Por outro lado, também se exigem serviços diferenciados. A TI apresenta as mais diversas alternativas para diferenciar as operações de serviços a pacientes, a médicos, e a instituições de saúde em geral. Então, formas de melhorar o relacionamento, flexibilizar o tempo com base nos requisitos do cliente e diversas outras vantagens melhoram o poder de barganha com os clientes.

Em síntese, o que se constata é que em todos os processos analisados, a TI aumentou os pontos fortes, corroborando, portanto com 100\% da proposição 2 . Como a análise das proposições abordou sua relação com cada um dos processos, constatou-se que além de aumentar os pontos fortes da empresa, a TI também ampliou as suas oportunidades no mercado (proposição 1) e a exigência da demanda e/ou geração de novos negócios (proposição 3). Nestes dois casos (proposição 1 e 3), constatou-se que, em mais da metade dos processos analisados, as proposições foram confirmadas. Assim, a superposição, apresentada na análise das proposições, facilita a compreensão de que a TI contribuiu nas operações de serviços na saúde e para a competitividade da empresa de várias formas.

\subsection{REDE DE VALOR NA SAÚDE E O USO DA TI}

Na Figura 19 - Rede de Valor na Saúde e o Uso da TI, podem-se observar algumas possibilidades de interação encontradas entre os casos estudados. A figura demonstra que as formas de relacionar-se são inúmeras e também como a TI pode criar oportunidades para negócios, ampliar os pontos fortes do negócio da empresa e criar novos negócios, conforme demonstrado na análise das proposições.

A figura apresentada é adaptada do modelo de rede de valor proposto por Bovet e Martha (2001). Conforme estes autores, as redes de valor apresentam cinco características que distinguem os negócios da rede de valor sobre o modelo de 
negócios tradicional, baseado no conceito da cadeia de suprimento. São eles: alinhada com o cliente, cooperativa e sistemática, ágil e flexível, fluxo rápido e digital. A figura 19 demonstra estas características observadas nos estudos de caso que utilizam a $\mathrm{TI}$ em seus modelos de negócios.

Conforme explicado anteriormente, Bovet e Martha (2001) apresentam algumas características que fazem parte das redes de valor e são semelhantes às vantagens apresentadas por Silva Junior (2004), são elas: 1) cliente alinhado com a empresa; 2) ambiente de colaboração entre fornecedores e clientes; 3) agilidade e escala - produção flexível, distribuição e fluxos de informação; 4) fluxo rápido ciclos curtos do pedido à entrega, inexistência de inventários, datas de entrega segura; 5) digital - sistema de informação interligado de forma eficiente e eficaz em toda a rede. Estas vantagens também foram observadas no estudo desenvolvido. 


\section{Rede de Valor na Saúde e o Uso da TI}

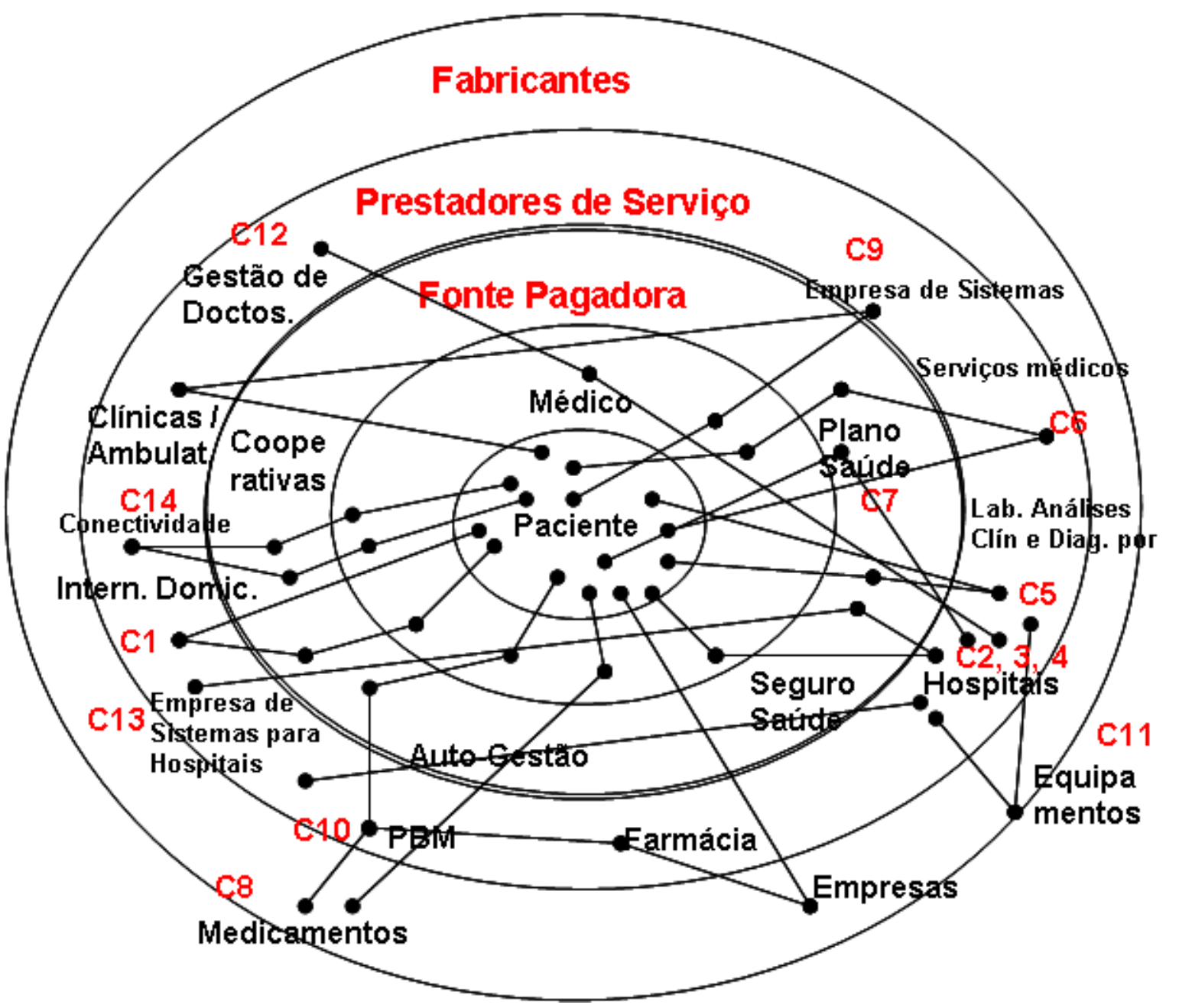

Caso 1 (C1) - Internação domiciliar (estudo de caso-piloto)

Caso 2 (C2) - Hospital geral de alta complexidade

Caso 3 (C3) - Hospital especializado de alta complexidade

Caso 4 (C4) - Hospital-dia

Caso 5 (C5) - Laboratório de análises clínicas e diagnóstico por imagem

Caso 6 (C6) - Empresa de serviços médicos

Caso 7 (C7) - Plano de saúde

Caso 8 (C8) - Empresa farmacêutica

Caso 9 (C9) - Empresa de sistemas

Caso 10 (C10) - Empresa de gerenciamento de benefícios farmacêuticos

Caso 11 (C11) - Empresa de equipamentos e softwares médicos

Caso 12 (C12) - Empresas de gestão de documentos

Caso 13 (C13) - Empresa de sistemas e serviços para instituições do setor de saúde

Caso 14 (C14) - Empresa de serviços de informática (conectividade)

Figura 19 - Rede de Valor na Saúde e o Uso da TI

Obs. Os casos C1 a C8 são empresas usuárias de TI. Os casos C9 a C14 são empresas fornecedoras de TI. 
Ao se observar o estudo dos casos por completo, também se pode observar que muitas empresas realizam operações de serviços que se complementam e que poderiam ter maior sinergia. Por outro lado, existem outras empresas que concorrem entre si, oferecendo soluções semelhantes por meio de produtos substitutos, ou de base tecnológica diferente (PORTER, 1986). Neste caso, nem sempre o mercado consegue diferenciar as proposta de valor entre elas. O fato é que a TI, de uma forma ou de outra, interfere nas operações de serviços na saúde. Na seqüência, apresentar-se-á uma breve comparação entre as formas de se utilizar a TI de cada um dos participantes e algumas possíveis sobreposições e características.

O Caso 1 (C1) é uma empresa de internação domiciliar e uma de suas importantes ferramentas é a utilização de um equipamento móvel (smartphone), juntamente com um prontuário eletrônico e ficha de alerta. Estas ferramentas permitem que os profissionais em campo realizem os procedimentos de prescrição de dados, faturamento, solicitação de materiais e medicamentos e outros. Outras empresas como, por exemplo, C9, que oferece um prontuário eletrônico em nível ambulatorial e que conta inclusive com um Data Center, onde se podem armazenar as informações e disponibilizá-las via $W E B$, apresenta fortes afinidades, tanto em relação ao prontuário, quanto no armazenamento das informações. C10, que realiza gerenciamento de benefícios de farmacêuticos, poderia acrescentar mais um serviço e mais uma forma de controle às já realizada por C1. C5, por exemplo, poderia realizar uma parceria, utilizando uma das ferramentas que é o laudo evolutivo de exames, disponibilizando-o nos equipamentos móveis de C1, agregando valor para as duas empresas. C12, empresa de arquivos digitais, que também oferece um Data Center, característica semelhante à $\mathrm{C9}$, a sua especialidade é exclusivamente na guarda e busca de documento de seus clientes, complementando a oferta de C1. C13, empresa que oferece sistemas para hospitais, poderia ter uma conexão com C1, compartilhando os dados do prontuário hospitalar, juntamente com os dados do paciente em internação hospitalar. No Caso de C2, C3 e C4, são empresas que oferecem estrutura hospitalar e que utilizam prontuário eletrônico entre outras ferramentas de $\mathrm{TI}$, sendo que as possibilidades seriam semelhantes ao caso anteriormente explicado. C7, também conta com prontuário em nível ambulatorial, poderia ter conexão também com C1. Como se viu, os casos C1, C2, C3, C4, C9 e C13 oferecem ou utilizam ferramentas muito semelhantes, para citar apenas um caso. 
Para que não fiquem repetitivas as explicações já apresentadas em capítulos anteriores, será apresentado no Quadro 24 - Formas de Utilizar a TI que Concorrem Entre $\mathrm{Si}$ ou que se Complementam, as empresas e algumas possibilidades de interação ou até de sobreposição nas operações de serviços, utilizando a TI na saúde.

\section{Formas de utilizar a TI que concorrem entre si ou que se complementam}

\begin{tabular}{|c|c|c|c|c|c|c|c|c|c|c|c|c|c|c|}
\hline & $\mathrm{Cl}$ & C2 & $\mathrm{C} 3$ & $\mathrm{Cl}$ & C5 & $\mathrm{C6}$ & C7 & 18 & $\mathrm{Cg}$ & $\mathrm{C} 10$ & C11 & $\mathrm{C} 12$ & $\mathrm{Cl3}$ & $\mathrm{C14}$ \\
\hline Caso 1 (C1) - Internaçäo domiciliar & & $x$ & $x$ & $X$ & $x$ & $x$ & $x$ & & $x$ & 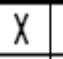 & & $X$ & $X$ & $X$ \\
\hline Caso 2 (C2) - Hospital geral de alta complexidade & $x$ & & & & $x$ & $x$ & $x$ & $x$ & $x$ & $x$ & $x$ & $X$ & $X$ & $X$ \\
\hline Caso 3 (C3) - Hospital especializado de alta complexidade & $x$ & & & & $x$ & $x$ & $x$ & $x$ & $x$ & $x$ & $x$ & $x$ & $x$ & $x$ \\
\hline Caso 4(C4) - Hospital Dia & $x$ & & & & $x$ & $x$ & $x$ & $x$ & $x$ & $x$ & $x$ & $x$ & $x$ & $x$ \\
\hline Caso 5 (C5) - Laboratório de análises clínicas e diag. imagem & $x$ & $x$ & $x$ & $x$ & & $x$ & $x$ & & $x$ & & $x$ & $X$ & & $x$ \\
\hline Caso 6 (C6) -Empresa de serviços médicos & $x$ & $x$ & $x$ & $x$ & $x$ & & $x$ & & $x$ & $X$ & & $x$ & & $x$ \\
\hline Caso 7 (C7) - Plano de saúde & $x$ & $x$ & $x$ & $x$ & $x$ & $x$ & & $x$ & $x$ & $x$ & & $x$ & $X$ & $x$ \\
\hline Caso 8 (C8) -Empresa farmacêutica & & $x$ & $x$ & $x$ & & & $x$ & & & $x$ & & & & $x$ \\
\hline Caso 9 (C9) -Empresa de sistemas & $x$ & $x$ & $x$ & $x$ & $x$ & $x$ & $x$ & & & & & $x$ & $x$ & $x$ \\
\hline Caso 10 (C10) - Empresa de gerenc. de beneficios farmacêuticos & $x$ & $x$ & $x$ & $x$ & & $x$ & $x$ & $x$ & & & & $X$ & & $x$ \\
\hline Caso 11 (C11) - Empresa de equipamentos e softwares médicos & & $x$ & $x$ & $x$ & $x$ & & & & & & & & $X$ & \\
\hline Caso 12 (C12) - Empresas de gestäo de documentos & $x$ & $x$ & $x$ & $x$ & $x$ & $x$ & $x$ & & $x$ & & & & $X$ & \\
\hline Caso 13 (C13) -Empresa de sistemas hospitalares & $x$ & $x$ & $x$ & $x$ & & & & & $x$ & & $x$ & $x$ & & $x$ \\
\hline Caso 14(C14) - Serviços de informática (conectividade) & $x$ & $x$ & $x$ & $x$ & & $x$ & $x$ & $x$ & $x$ & & & & $x$ & \\
\hline
\end{tabular}

Quadro 24 - Formas de Utilizar a TI que Concorrem Entre Si ou que se 


\section{CONCLUSÕES E RECOMENDAÇÕES FINAIS}

O tema estudado foi bastante enriquecedor na medida em que pode demonstrar as possibilidades de se criar valor (eficiência e/ou eficácia) ao se utilizar a TI nas estratégias de negócios em empresas, em uma hipotética rede de valor na saúde. Ao se abordar um grupo de empresas que atuam independentes em uma rede de valor na saúde, podem-se perceber muitas possibilidades de utilizar a TI de forma a criar valor, aumentando a eficiência e/ou a eficácia destas empresas. Apesar de em algumas circunstâncias estas empresas concorrerem entre si em alguma operação de serviços, na maioria das vezes o foco de do negócio (core business) eram diferentes. Este fato demonstra que quanto mais ajustado o foco, mais estas empresas poderiam cooperar entre si, principalmente valendo-se das vantagens da TI.

O problema da pesquisa que aborda as novas formas para as operações de serviço na saúde, utilizando a TI em um cenário onde a demanda esta cada vez mais exigente e os recursos mais escassos, foram exaustivamente estudados. Aparentemente, pode-se afirmar que a TI contribui tanto para a redução de custos quanto para tornar a demanda mais sofisticada e exigente. Neste caso, procurou-se responder às perguntas da pesquisa, cujas respostas apresentam em que circunstâncias o problema pode ser resolvido ou minimizado, são elas: 1 - Como e por que utilizar a TI para criar maior valor (eficiência e/ou eficácia) e 2 - Como e por que a TI amplia as oportunidades e/ou competências. De que forma este efeito pode aumentar as possibilidades de êxito competitivo nestas empresas, minimizando os problemas relacionados às exigências da demanda e da escassez de recursos. Os estudos abordaram 14 casos de empresas que conseguiram obter vantagem competitiva, utilizando a TI em suas operações de serviços. Foram mais de duas centenas de situações em que a TI apresentou contribuições nas operações de serviços. Em cada uma destas situações, realizouse uma análise que respondia às questões acima perante uma escala que cobria várias abordagens relacionadas à eficiência e à eficácia nas operações de serviços. O que se pode dizer é que a pesquisa cobriu um vasto campo nas operações de serviços em uma rede de valor na saúde e apresentou várias possibilidades de se reduzir custos. Por outro lado, mostraram que se podem melhorar também os 
benefícios dos serviços, atendendo às solicitações da demanda. Ainda que se saiba das limitações, quanto à quantificação dos resultados $e$, conseqüentemente, do subjetivismo das abordagens, entende-se que o problema da pesquisa foi solucionado, demonstrando evidências e abrindo um campo importante para que outras sejam levantadas.

Os objetivos da pesquisa eram: compreender como a TI contribui para o desenvolvimento de estratégias de negócios, envolvendo inter-relação e cooperação entre empresas no setor da saúde; identificar, a partir da vantagem competitiva das empresas, o nível de contribuição da TI na criação de valor (eficiência e/ou eficácia) em operações de serviços; compreender como a tecnologia da informação contribui para o desenvolvimento de estratégias de negócios, envolvendo inter-relação e cooperação entre empresas no setor da saúde.

A partir deles, consideram-se os objetivos específicos: analisar formas para a organização das operações de serviços utilizando a TI em uma rede de valor na saúde, e compreender como desenvolver estratégias de negócios de maior valor, que propiciem vantagem competitiva aos seus executores. Estes também foram amplamente alcançados. Como se observaram na descrição dos casos, as operações de serviço que utilizam a TI em uma rede de valor na saúde, passaram por um processo de engenharia reversa, possibilitando perceber em que circunstâncias a TI pôde trazer maior contribuição para a eficiência e para a eficácia delas.

A justificativa ou as contribuições no que tange ao conhecimento (PEREZ, 2006), para o desenvolvimento do trabalho, apresenta três frentes distintas que se complementam, são elas:

- em nível prático: entender as operações de serviço que criam valor e direcionam esforços a elas no sentido de maximizar os resultados da empresa. Neste campo, foram apresentadas inúmeras situações, que poderão ser desenvolvidas em outras empresas em suas operações de serviços;

- em nível metodológico: fornecer uma linha de raciocínio que possa ser replicada. Também se criou um modelo decorrente da análise qualitativa, cuja riqueza de detalhes permite sua aplicação em outras situações, envolvendo operações de serviços e o uso da TI;

- em nível teórico: apresentar diversos autores e abordagens que se complementam e que juntos ganhem formas diferentes ao compreender o 
problema apresentado. O conjunto dos conceitos e a forma com que foram arranjados propiciaram uma análise com profundidade sobre os assuntos. Podese, com isto, raciocinar em, pelo menos, três frentes conjuntamente como se fosse apenas um assunto: TI, operações de serviços e estratégias de negócios.

Este trabalho, que explorou TI, operações de serviços e estratégias de negócios, pode apresentar outros desdobramentos, pois, conforme observado, o campo da saúde é bastante amplo, complexo e pouco explorado. Notou-se que o aporte de recursos em TI em operações de serviços nem sempre obedece a critérios ou a recomendações comuns na literatura de negócios. Estas práticas, largamente utilizadas em outros setores, inclusive de serviços, muitas vezes passam à margem do setor de saúde. Pior que isto, assuntos como operações de serviços e estratégias de negócios, muitas vezes apresentaram-se como uma seara desconhecida a profissionais de $\mathrm{TI}$, demonstrando que eles poderiam argumentar muito mais e melhor sobre as vantagens das ferramentas que possuem e às que estão desenvolvendo para suas empresas. Recomenda-se ainda um esforço em compreender ou demonstrar aos pacientes o verdadeiro valor de se utilizar a TI nas operações de serviços na saúde. Como se viu, já existe um nível ótimo de desenvolvimento da TI nas empresas. Não seria ainda melhor se os favorecidos tomassem mais conhecimento de suas vantagens e suas formas de uso e passassem a utilizá-la em toda sua potencialidade ou ainda se assumissem que seus tratamentos foram otimizados graças ao apoio da TI? Desta forma o avanço poderia ser muito maior. Uma outra abordagem seria realizar um exercício de simulação ou o desenvolvimento de uma rede de valor hipotética na saúde, em que os participantes pudessem maximizar os elos entre si, buscando maior qualidade e produtividade para o conjunto.

Por fim, há também as questões relacionadas com a privacidade das informações e as questões culturais. Embora não faça parte do escopo deste trabalho, entende-se que são pontos importantes para estudos futuros, que poderão contribuir para melhor compreender a criação de valor e o uso da TI no setor da saúde. As informações sobre a saúde do paciente são confidenciais e devem ser restritas aos pacientes e seu respectivo médico. A possibilidade de que estas informações possam ser consultadas por terceiros, pode ser um fato inibidor em relação ao uso da $\mathrm{TI}$, para os médicos e pacientes. Quanto às questões culturais, 
seria providencial, compreender o papel do médico e o uso da TI. Compreender melhor por que algumas áreas e especialidades tendem a utilizar mais a $\mathrm{TI}$ do que outras. Analisar também o impacto da TI para as novas gerações de médicos, os quais deverão utilizar cada vez mais e com menos restrições estas novas ferramentas de criação de valor. Todas estas considerações demonstram que o setor da saúde apresenta um vasto e fértil campo a ser estudado, no que se refere ao uso da TI e as estratégias de negócios das empresas deste setor. 


\section{REFERÊNCIAS BIBLIOGRÁFICAS}

ALBERTIN, A. L. Comércio Eletrônico, 2. ed.- São Paulo: Atlas, 2002.

ANDAL-ANCION, Angela, CARTWRIGHT, Phillip A., YIP, George S. The Digital Transformation of Traditional Businesses. MIT Sloan Management Review, 15329194, Summer 2003, Vol. 44, Issue 4.

ANSOF, H. Igor; MCDONNELL, Edward J. Implantando a administração estratégica. São Paulo: Atlas, 1993.

ASSUMPÇÃO. Silvana. Texanos investem em rede hospitalar. Revista Carta Capital. São Paulo, 19 de janeiro de 2000.

BARATA, Luiz Roberto Barradas. A relação Estado-Saúde, como fator de desenvolvimento social. São Paulo. Palestra proferida aos professores e alunos da Faculdade de Ciências Médicas da Santa Casa de São Paulo, 03 de maio de 2006.

BARNEY, Jay. Looking inside for competitive advantage. The Academy of Management Executive, Ada, V. 9, n. 4, p. 49-61, nov. 1995.

. Is the resource-based "view" a useful perspective for strategic management research? Yes. Academy of Management Review, 03637425, jan 2001, Vol. 26, Issue 1.

BETHLEM, Agricola de Souza. Estratégia Empresarial: conceitos, processo e administração estratégica. São Paulo: Atlas, 1999.

BOOZ ALLEN e WHARTON SCHOOL. Strategy + Business. Disponível em: http://knowlwdge.wharton.upenn.edu. Acesso em: 15-05-2005.

BOVET, David; MARTHA, Joseph. Value nets: Reinventing the rusty supply chain for competitive advantage. Strategy e leadership. Chicago: jul-ago 2000. Vol. 28, n.4, p 21.

. Redes de Valor: Aumente os lucros pelo uso da Tecnologia da Informação na cadeia de Valor. São Paulo: Negócios Editora, 2001.

BOWEN, J.; FORD, R.C. Managing service organizations: does having a "thing" make a diference" Journal of Management. Vol. 28, n.3, 2002, pp. 447-469.

BRANDÃO, Nilson; FLACH, Marcelo. Fusões e aquisições chegam aos hospitais Jornal Gazeta Mercantil. Rio de Janeiro e Porto Alegre, 15 de outubro de 1999. Saúde Total.

BURNS, L.R. and Wharton Scholl Colleagues. The Health Care Value Chain Producers, Purchasers, and Providers. Jossey-Bass, San Francisco, CA, 2002. 
CALOGHIROU, Yiannis; PROTOGEROU, Aimilia; SPANOS, Yiannis; PAPAGIANNAKIS, Lefteris. Industry - Versus Firm - specific Effects on Performance: Contrasting SMEs and Large-sized Firms. European Management Journal, Vol.22, no. 2, pp. 231-243, 2004.

CARVALHO, Marly Monteiro de; LAURINDO, F. J. B. Estratégias para a competitividade. 1. ed. São Paulo: Editora Futura, 2003. v. 1. 272 p.

CASTELLS, Manuel. A Galáxia da Internet. Reflexões sobre a Internet, os Negócios e a Sociedade, Rio de Janeiro: Jorge Zahar, 2003.

CHANDRASHEKAR, Ashok; SCHARY, Philip B. Toward the virtual suply chain: the convergence of IT and organization. International Journal of Logistics Management; 1999; 10, 2; ABI/INFORM Global. p. 27.

CHAO LW. Modelo de ambulatório virtual (cyber ambulatório) e tutor eletrônico (cyber tutor) para aplicação na interconsulta médica e educação à distância mediada por tecnologia. [tese de livre docência] apresentada à Faculdade de Medicina, Universidade de São Paulo; São Paulo, 2003.

CHRISTENSEN, Clayton M. O Dilema da inovação - Quando novas tecnologias levam empresas ao fracasso. São Paulo: Makron Books, 2001.

CONNER, Kathleen R. A historical comparison of resource-based theory and five schools of thought within industrial organization economics: do we have a new theory of the firm? Journal of Management, 1991, Vol. 17, No. 1, pp. 121-154.

CONTADOR, José Celso. Comparação entre o modelo de campos e armas da competição e o modelo de Porter - Fórum Especial - Estratégias em ambientes turbulentos: velhas fórmulas, novas narrativas? - jan 2004.

CORRÊA, Henrique L.; CAON, Mauro. Gestão de Serviços: lucratividade por meio de operações e de satisfação dos clientes - São Paulo: Atlas, 2002.

Relatório Global sobre Corrupção 2006. Corrupção priva milhões de pessoas de cuidados médicos. Disponível em:

http://www.mni.pt/destaques/?cod=8036\&cor=azul\&MNI=6e71826b9be98281c972b7 78bba7026c Acesso: 28.03.2006

CORTÉS, Enrique Calver; AZORÍN, José Francisco Molina. Determinantes de la rentabilidad de lãs empresas manufatureiras de la comunidade valenciana. Revista Valenciana D’Esudis Autonomics. Número 36 - Tercer Trimestre de 2001.

COSTA FILHO, Bento Alves da; TOLEDO, Geraldo Luciano. Marketing estratégico e a criação de unidade de negócios. Caderno de Pesquisa em Administração, São Paulo, v.1, no. 10. $3^{\circ}$ Trim./99.

COUTO FILHO, Antonio. A realidade da saúde no Brasil. Jornal do Brasil. 20.6.2005. Disponível em: < http://clipping.planejamento.gov.br/Noticias.asp?NOTCod=200956> Acesso em: 15.03.2006. 
DE SORDI, José Osvaldo. Tecnologia da Informação Aplicada aos Negócios. São Paulo: Atlas, 2003.

DORNAS, Guilherme: MILAGRES, Rosileia. Competitividade na Cadeia Produtiva. MG: Fundação Dom Cabral, ClO 508 agosto 2005.

DRUCKER, Peter. F. The information executives truly need. Harvard Business Review, p.54-62, jan/feb 1995.

53-60, 1963.

Managing for business effectiveness. Harvard Business Review, may/june,

DUHAN S; LEVY, M; POWELL, P. Information systems strategies in knowledgebased SMES: the role of core competencies. European Journal of Information Systems, v.10, p.25-40, 2001.

ELLRAM, Lisa, TATE, Wendy, BILLINGTON, Corey. Understanding and Managing the Services Supply Chain Journal of Supply Chain Management. Autumn 2004.Vol.40, Num. 4; p. 17, 16.

EISENHARDT, K. M. (1989). Building theories from case study research. Academy of Management Review, Vol. 14, No. 4, pp. 532-550.

EUSTACE, Clark. A New perspective on the knowledge value chain. Journal of Intellectual Capital, 2003, 4, 4; ABI/INFORM Global p. 588.

FACHIN, Odília. Fundamentos de metodologia. São Paulo: Atlas, 1993.

FARRELL, Diana. The Real New Economy. Harvard Business Review - Boston: Oct 2003.Vol.81, Num. 10; p. 104.

FAY, John. Competitive advantage in internacional services: a resource-based view. International Studies of Management \& Organization, 00208825, Summer 1996, Vol. 26 , Issue 2.

FIGUEIREDO, A. Dias de. Os Sistemas de informação vistos do ponto de vista do negócio - gestão, estratégia e sistemas de informação - Departamento de Engenharia Informática - Universidade de Coimbra, 1997, 1998.

FISCHMANN, Adalberto A.; ALMEIDA, Martinho Isnard R. de. Planejamento estratégico na prática. 2.ed. - São Paulo: Atlas, 1991.

FITZSIMMONS, J.; FITZSIMMONS, M. Administração de serviços. 2. ed.- Porto Alegre, Bookmam, 2000.

FLEURY, A. C. C. ; FLEURY, M. T. L. . Em busca de metodologias para o estudo de cadeias de valor. In: Leda Gitahy, Márcia de Paula Leite. (Org.). Novas tramas produtivas: uma discussão teórico-metodológica. $1^{\text {a }}$ ed. São Paulo: SENAC, 2005, v. , p. 121-148. 
GADREY, J. Emprego, produtividade e avaliação de desempenho dos serviços. In: SALERNO, Mario Sergio (organizador). Relação de Serviço. Produção e Avaliação. São Paulo: SENAC, 2001.

GADREY, Jean; GALLOUJ, Faiz; WEINSTEIN, Olivier. New modes of innovation: How services benefit industry. International Journal of Service Industry Management; 1995; 6,3; ABI/INFORM Global, p. 4.

GAGNON, Joseph; CHU, Julian. Os que realmente mandam - 2. HSM Management. Número 55, Ano 10, Vol 2, 76. março-abril 2006.

GALBREATH. Jeremy. GALVIN, Peter. Which resourses matter? A fine-grained test of the resource based view of the firm. Academy of Management Best conference Paper 2004 BPS: L1.

GIANESI, Irineu G. N.; CORRÊA, Henrique Luiz. Administração estratégica de serviços: operações para a satisfação do cliente. - São Paulo: Atlas, 1994.

GILBERT, Clark. The disruption opportunit. MIT Sloan Management Review Summer 2003 - pp. 27 a 32.

GOODE, Willian Josiah \& HATT, Paul K. Métodos em pesquisa social - São Paulo: Nacional, 1968.

GOULART, Linda; ARRUDA, Carlos. Alianças como instrumento de renovação Eficaz. Nova Lima, MG: FUNDAÇÃO DOM CABRAL. CI0309, setembro 2003a.

GOULART, Linda; ARRUDA, Carlos. Parcerias, inovação eficaz de uma organização - Jornal Valor Econômico, 06.06.2003.

HAMEL, Gary. Strategy as Revolution. Harvard Business Review, p.69-82, jul.-aug., 1996.

HAMEL, Gary; PRAHALAD, CK. Competindo pelo futuro. Rio de Janeiro: Campus, 1995.

HAMEL, Gary; VÄLIKANGAS, Liisa. The Quest for Resilience. Harvard Business Review - Boston: Sep 2003.Vol.81, Num. 9; p. 52.

HESKET, J. L., SASSER, Jr. \& SCHLESINGER, L. A. The service profit chain. New York: The Free Press, 1997.

HILL, Peter. On Goods and services. The review of income and wealth, no. 4, Dec. 1977, pp. 315-338.

HITT, Michael A.; IRELAND, R. Duane; HOSKISSON, Robert E. - Administração Estratégica. Tradução de José Carlos Barbosa dos Santos e Luiz Antonio Pedroso Rafael - São Paulo: Pioneira Thompson Learning, 2003. 
IANSIT, M.; LEVIEN, R. - Strategy as Ecology - Harvard Business Review - march 2004, p.69.

JOHNSON, Steven. Cultura de Interface: Como o computador transforma nossa maneira de criar e comunicar; trad. Maria Luísa X. de A. Borges; revisão técnica, Paulo Vaz. - Rio de janeiro: Jorge Zahar, 2001.

JOHNSON, Steven. Emergência: A vida integrada de formigas, cérebros, cidades e softwares; trad. Maria Carmelita Pádua Dias; revisão técnica Paulo Vaz. - Rio de Janeiro: Jorge Zahar, 2003.

KANAMURA, A. Tecnologia da informação. As inovações melhorando os processos em saúde. Revista Hospitais Brasil, Ano II, no. 9 setembro/outubro 2004.

KANITZ, Stephen. Estamos Emburrecendo. Veja. São Paulo, ano $36-\mathrm{n}^{\circ} 31$, 06.08.2003, p. 20, agosto de 2003.

KEDROVSKY, Paul. Tendência: A hora do feed. Harvard Business Review - Impact media, junho 2004.

KIM, W.C. \& MAUBORGNE, R. Value innovation, and knowledge economy. Harvard Business Review - p.77-83, june 2002.

KINGMAN-BRUNDAGE, J.; GEORGE, W. R. \& BOWEN, D. E. (1995) Service logic: achieving service system integration. (revised in 1994). International Journal of Service Industry Management, vol.6 No. 4, pp. 20-39.

KLENK, Lorena Aubrift. Setor hospitalar vive momento de fusões. Gazeta Mercantil Paraná, 19 de abril de 2000.

LAURINDO, F. J. B.; Tecnologia da Informação como Suporte às Estratégias Empresariais. In: João Amato Neto. (Org.). Redes de Empresas. São Paulo: Atlas, 2005a, v., p. 1-15.

$\overline{2002 .}$

Tecnologia da informação: eficácia nas Organizações. São Paulo: Futura,

LIEBER, H. Stephen. Can IT Transform Healthcare? Frontiers of Heath Services Management; Spring 2003; 19, 3; ABI/INFORM Global p. 31.

LOVELOCK, Christopher; WRIGHT, Lauren. Serviços: marketing e gestão - São Paulo: Saraiva, 2006.

MACGEE, James V.; PRUSAK, Laurence. Gerenciamento estratégico da informação: aumente a competitividade de sua empresa utilizando a informação como ferramenta estratégica. Rio de Janeiro: Campus, 1994.

MAGRETA, Joan \& STONE, Nan. O que é gerenciar e administrar. Rio de Janeiro: Campus, 2002. 
MARKIDES, Constantino C. A Dynamic view of strategy. Sloan Management Review Spring 1999.

MARKIDES, Costas. What strategy is e how do you know if you have one? Business Strategy Review. Vol 15. Summer 2004.

McFARLAN, F. Warren. A Tecnologia da informação muda a sua maneira de competir. In: MONTGOMERY, Cynthia A.; PORTER, Michael E. - Estratégia: a busca da vantagem competitiva. - trad. Bazán Tecnologia e Lingüística. - Rio de Janeiro: Campus, 1998.

MCGAHAN, Anita M.; PORTER, M. E.; How much does industry matter, really? Strategic Management Journal, Vol. 18 (Summer Special Issue), pp. 15-30 (1997).

MINTZBERG, Henry; AHLSTRAND, Bruce; LAMPEL, Joseph. Safári de Estratégia: Um roteiro pela selva do planejamento estratégico; trad. Nivaldo Montingelli Jr. Porto Alegre: Bookman, 2000.

MONTGOMERY, Cynthia A.; PORTER, Michael E. - Estratégia: a busca da vantagem competitiva. - trad. Bazán Tecnologia e Lingüística. - Rio de Janeiro: Campus, 1998.

MORATH, Julie. Changing the healthcare culture: the consumer as part of the system of care. Frontiers of Heath Services Management; Summer 2003; 19, 4; ABI/INFORM Global p. 17.

NETO, João Amato, (org.) Redes entre Organizações: Domínio do conhecimento e da Eficácia Operacional - São Paulo: Atlas, 2005.

NOBREGA, Clemente. Antropomarketing. Rio de Janeiro: SENAC, 2002.

Disponível

O inventor da administração e o desafio brasileiro. Portal Exame, 2006. <http://portalexame.abril.uol.com.br/revista/exame/edicoes/0766/gestao/m0043382.h tml> Acesso em: 09.04.2006.

NORMANN, Richard; RAMÍREZ, Rafael; Da Cadeia de Valor à Constelação de Valor - A criação da estratégia interativa. In: RODRIGUES, Martius Vicente Rodrigues y; Gestão Estratégica. - Rio de Janeiro: Elsevier, 2005.

O ESTADO DO PARANÁ - http://www.doctorsac.com.br

O'BRIEN, James. Sistemas de Informação e as decisões estratégicas na era da Internet - trad. Cid Knipel Moreira - São Paulo: Saraiva, 2003.

OHMAE, Kenichi. Gerenciando em um Mundo sem Fronteiras. In: MONTGOMERY, Cynthia A.; PORTER, Michael E. - Estratégia: a busca da vantagem competitiva. trad. Bazán Tecnologia e Lingüística. - Rio de Janeiro: Campus, 1998. 
. Concentra-se nos fatores básicos. In: O estrategista em ação. São Paulo, Pioneira, 1985.

OLAVE, Maria Elena Leon.; NETO, João Amato. A formação de redes de cooperação e clusters em países emergentes: uma alternativa para PMEs no Brasil. In: NETO, João Amato, organizador. Redes entre Organizações: Domínio do conhecimento e da Eficácia Operacional - São Paulo: Atlas, 2005.

OLIVEIRA, Macir Bernardo de; SILVA, Marcia Terra da; LAURINDO, F. J. B. A tecnologia da informação e a criação de valor (eficiência e eficácia) nos serviços na saúde. In: SIMPEP - SIMPÓSIO DE ENGENHARIA DE PRODUÇÃO, XII SIMPEP Bauru, SP, Brasil, 07 a 09 de novembro de 2005.

OLIVEIRA, Macir Bernardo de; LAURINDO, F. J. B. Utilização da Tecnologia da Informação no Setor da Saúde no Desenvolvimento de Estratégias de Negócios. In: 10. CONTECSI - Congresso Internacional de Gestão de Tecnologia e Sistemas de Informação -, 2004, São Paulo. Anais do CONTECSI 2004. São Paulo: TECSI/FEA/USP, 2004. v. 1. p. 1-21.

PECK, Helen; JUTTER, Uta. Strategy and relationships: defining the interface in supply chain contexts. International Journal of Logistics Management; 2000; 11, 2; ABI/INFORM Global pp. 33-44.

PEREZ, Gilberto. Adoção de inovações tecnológicas: um estudo sobre o uso de sistemas de informação na área da saúde. Tese de doutorado apresentada a Faculdade de Economia, Administração e Contabilidade da Universidade de São Paulo. São Paulo, 2006.

PITTA, Dennis, LARIC, Michael V. Value chains in helth care. The Journal of Consumer Marketing; 2004; 21, 7; ABI/INFORM Global p. 451.

PORTER, Michael E. Strategy and the Internet. Harvard Business Review - march, Boston, 2001.

A vantagem competitiva das nações. In: - Competição: on competition: estratégias competitivas essenciais. Tradução de Afonso Celso da Cunha Serra. Rio de Janeiro: Elsevier, 1999a - $13^{a}$ reimpressão.

. Como as forças competitivas moldam a estratégia. In - Competição: on Competition: estratégias competitivas essenciais. Tradução de Afonso Celso da Cunha Serra. - Rio de Janeiro: Elsevier, 1999b - 13ª reimpressão.

. Competição = On Competition: estratégias competitivas essenciais. Tradução de Afonso Celso da Cunha Serra. - Rio de Janeiro: Elsevier, 1999c - 13a reimpressão.

What is Strategy? Harvard Business Review, p.61-78, nov-dec, 1996.

. Vantagem competitiva: criando e sustentando um desempenho superior"; RJ: Campus, 1989. 
. Estratégia competitiva. Técnicas para análise da indústria e da concorrência. RJ: Campos, 1986.

PORTER, Michael E., TEISBERG, Elizabeth Olmsted. Repensando a saúde: estratégias para melhorar a qualidade e reduzir os custos. Porto Alegre: Bookman, 2007.

PORTER, Michael E. MONTGOMERY, Cynthia. Da Vantagem competitiva à estratégia corporativa. In: Estratégia: a busca pela vantagem competitiva. Rio de Janeiro: Campus, 1998. pp. 237-269.

PORTER, Michael E. MILLAR, V. E.; - How information gives you competitive advantage. - Harvard Business Review, V.63, nº 4, pp. 149 - 160, jul/ago.1985.

PRAHALAD, CK e HAMEL, Gary. The core competence of the corporation. Harvard Business Review - Boston, v. 68, n.3, p. 79-91, may/june 1990.

Prevenção: preocupação para os planos de saúde. O Estado do Paraná. Disponível em: <http://www.doctorsac.com.br> Acesso em: 15.03.2006.

QUINN, James Brian, BAILY, Martin Neil, HERBERT, Glenn R, WILLET, Doug; et al. Information technology: Increasing productivity in services. The Academy of Management Executive; aug 1994; Vol.8, 3; ABI/INFORM Global, p. 28.

QUINN, James Brian, BAILY, Martin Neil.; Information technology. The Brookings Review: Summer 1994; Vol.12, 3: ABI/INFORM Global, p. 36.

RANGAN, Subramarian.; Lições de estratégia que a Internet nos oferece. Encontro Temático Comunidade Ampliar e CTE - São Paulo. Trad. Linda Goulart. Comunidade das Parcerias Ampliar - Fundação Dom Cabral, Minas Gerais, Jan 2003. Disponível em: $\quad$ <ttp://www.fdc.org.br/parcerias/upload/artigo/Sub\%20Rangan\%20.doc>. Acesso em: 27 set 2004.

RANGAN, Subramanian; ADNER, Ron. Profits and the Internet sevem misconceptions. MIT SLOAN MANAGEMENT REVIEW, 15329194, Summer 2001,Vol.42, Issue 4.

RASIEL, Ethan M. O jeito Mckinsey de ser. São Paulo: Makron Books, 2000.

ROCKART, J.F. Chief executives define their own data needs. H.B.R.,V. 57.n.2, pp.81-92, mar./apr. 1979.

ROTHENBERG, Ronald L. Using information networks for competitive advantage. Healthcare Financial Management. Westchester: Jan 1995. Vol. 49, Num. 1, p. 73.

RUMELT, R. How much does industry matter? Strategic Mangement Journal, 1991. Vol. 12, no. 3, pp. 167-185.

SALERNO, M. Relação de serviço: produção e avaliação. São Paulo: SENAC, 2001.

SCHMALESEEE, R. Do markets differ much? American Economic Review, 1985. Vol. 75, no. 3, pp. 341-351. 
SCOTT. Cheryl M. STRUDER, Quint.; The impact of the consumer on healthcare delivery. Frontiers of Heath Services Management; Summer 2003; 19, 3; ABI/INFORM Global, p. 41.

SELLTIZ, Claire et all. Métodos de pesquisa nas relações sociais. E.P.U. São Paulo, 1984.

SEYBOLD. P.; MARSHAK, Ronni T. Clientes.com. São Paulo: Makron Books, 2000.

SILVA JUNIOR, Antonio Batista. Parceria: uma estratégia de desenvolvimento empresarial 20.05.2004. Disponível em: <http: // www.fdc.org.br/parcerias/area_fechada/comunidade_conhecimento/artigo/default.as p? IndiceParceria=0\&CodEspaco=30\&NumeroPagina=4 < Acesso em: 19 de Julho de 2004.

SILVESTRO, R. Positioning services along the volume-variety diagonal. International Journal of operations and production management, vol.19, n.4, 1999, pp. 399-420.

SILVESTRO, R., FITZGERAL, L., JOHNSTON, R.; VOSS, C. Towards a classification of service processes. International Journal of Service Industries Management, Vol. 3 No. 3, pp. 62-75, 1992.

SKINNER, Richard I. The value of information technology in heathcare. Frontiers of Health Services Management; Springs 2003; 19, p. 3.

SLACK, Nigel, CHAMBERS, Stuart, Johnston. Administração da produção. São Paulo: Atlas, 2002.

Strategy + Business. Can a national healthcare information network work? 15/06/2005. Disponível em: <http://www.strategybusiness.com/sbkwarticle/sbkw050615?pg=all< Acesso em: 06.06.2006.

TAPSCOTT, Don; TICOLL, David. A Empresa Transparente: Como a Era da Transparência Revolucionará os Negócios. São Paulo: Makron Books, 2005.

TAPSCOTT, Don; TICOLL, David. LOWY, Alex. Capital Digital: Dominando o Poder das Redes de negócios. Tradução: Ruth Gabriela Bahr; revisão técnica: Jaci Corrêa Leite. São Paulo: Makron Books, 2001.

TAPSCOTT, Don. Rethinking strategy in a networked world. Strategy + Business, issue 24, 8p., 2001.

. Growing up digital: the rise of the net generation. McGraw Hill - NY, 1998.

. Economia digital: promessa e perigo na era da inteligência em rede. São Paulo: Makron Books, 1997.

TEISBERG, Elizabeth Olmsted; PORTER, Michael E.; BROWN, GREGORY B. A competição na área da assistência médica. In: PORTER, Michael E. Competição = 
On Competition: estratégias competitivas essenciais - tradução de Afonso Celso da Cunha Serra - Rio de Janeiro: Elsevier, 1999 - 13ª reimpressão.

TOLEDO, Geraldo Luciano de. COSTA, Bento Alves Filho. Marketing estratégico e a criação de unidades de negócios. Caderno e Pesquisas em Administração, São Paulo, v.1, no. 10, $3^{\circ}$ Trim./1999.

TURBAN, Efraim; RAINER JR, R. Kelly; POTTER, Richard E. Administração da Tecnologia de Informação: Teoria e Prática. Tradução de Teresa Cristina Felix de Souza. Rio de Janeiro: Elsevier, 2003 - 3ª reimpressão.

VILLELA, Adriana. Fusões chegam com força ao setor hospitalar. Acordos Logísticos e aquisições de unidades por empresas de seguro saúde e grupos estrangeiros reforçam lado empresarial da atividade. Jornal Gazeta Mercantil - São Paulo, 30 de março de 2000.

VOSS, C. et al. Case research in operations management. International Journal of Operations and Production Management, V. 22, N. 2, p. 195-219, 2002.

WADE, Michael; HULLAND, John. The resource-based view and information systems research: review, extension, and suggestions for future research. MIS Quarterly; Mar2004, Vol. 28 Issue 1, pp. 107-142, 36p, 5 charts, 1 diagramDocument Type:ArticleSubject.

WERTHEIM, Margaret. Uma História do Espaço de Dante à Internet; trad. Maria Luiza X. de A. Borges; revisão técnica Paulo Vaz. - Rio de Janeiro: Jorge Zahar, 2001.

WILLCOCKS, L; LESTER, S. Beyond the IT Productivity Paradox. European Management Journal, vol. 14, n. 3, pp. 279-290, 1996.

YANAZE, Mitsuru Higuchi. Gestão de Marketing: avanços e aplicações. São Paulo: Saraiva, 2007.

. Gestão de Mercado e Comunicação: Dos conceitos à sua aplicação - Escola de Comunicações e Artes - São Paulo: USP, 2004.

YIN, Robert K. Case study research: design and methods. California, USA, SAGE. 1998.

ZACCARELLI, Sérgio Baptista. Estratégia Moderna nas Empresas. - São Paulo: Zarco, 1996.

ZARIFIAN, Philip. Mutação dos sistemas produtivos e competências profissionais: a produção industrial de serviço. In: SALERNO, Mario Sergio (organizador). Relação de Serviço. Produção e Avaliação. Editora SENAC - São Paulo, 2001.

. Valor, organização e competência na produção de serviço - esboço de um modelo de produção de serviço. In: SALERNO, Mario Sergio (organizador). Relação de Serviço. Produção e Avaliação. SENAC - São Paulo, 2001a. 


\section{GLOSSÁRIO}

$B 2 B$

Business to Business (B2B) é o nome dado ao comércio praticado por fornecedores e clientes empresariais, ou seja, de empresa para empresa. O conceito do e-commerce B2B, ou comércio eletrônico entre empresas, pode ser definido como a substituição dos processos físicos, que envolvem as transações comerciais, por processos eletrônicos.

B2C

Business-to-consumer (B2C) é o comércio efetuado diretamente entre a empresa produtora, vendedora ou prestadora de serviços e o consumidor final. É a forma de ecommerce que conecta empresa com consumidores, mais relacionada com as áreas de varejo e comércio direto, onde o consumidor final é o alvo que se busca pela Internet.

Back office

Back office ou retaguarda, está associado aos departamentos administrativos de uma empresa, que mantêm nenhum ou pouco contato com os clientes. Por exemplo, os departamentos de informática, contabilidade e recursos humanos.

Biometria

Os sistemas chamados biométricos baseiam o seu funcionamento em características de diversas partes do corpo humano, por exemplo: os olhos, a palma da mão, as digitais do dedo, a retina ou íris dos olhos. A premissa em que se fundamentam é a de que cada indivíduo é único e possui características físicas e de comportamento (a voz, a maneira de andar, etc.) distintas.

B-webs

Redes de negócios que utilizam a Internet para facilitar a interação entre as partes envolvidas. 
Data Center

Download

Downsizing

Engenharia reversa

Extranet
Local onde são concentrados computadores e sistemas (softwares) responsáveis pelo processamento de dados de uma empresa ou organização, assim como os arquivos digitais da empresa.

É a transferência de dados de um computador remoto para um computador local.

É uma técnica aplicada nas abordagens contemporâneas da administração, voltada a eliminar a burocracia corporativa desnecessária. Trata-se de um projeto de racionalização planejado em todas as suas etapas, que deve estar consistente com o planejamento do negócio e cuja meta principal é construir uma organização mais eficiente.

A engenharia reversa consiste em usar a criatividade para, a partir de uma solução pronta, retirar todos os possíveis conceitos novos ali empregados.

A Extranet de uma empresa é a porção de sua rede de computadores, que faz uso da Internet, para partilhar com segurança parte do seu sistema de informação. Tomado o termo em seu sentido mais amplo, o conceito confunde-se com Intranet. Uma Extranet também pode ser vista como uma parte da empresa que é extendida a usuários externos ("rede extra-empresa"), tais como representantes e clientes.

Fonte pagadora / Termo empregado para designar empresas que realizam operadoras de aquisição de serviços, neste caso específico no setor da saúde saúde. Estes grupos são divididos em planos de saúde, seguros saúde, cooperativas de saúde, autogestões e outros.

Front office Front office, ou linha de frente, são atividades de uma 
empresa que tem alto contato com o cliente.

Gaps

Help desk

Intranet

Kit ou pacote

On-line
Termo é utilizado para descrever as lacunas (gaps) existentes entre o serviço esperado pelo cliente e o serviço percebido.

Help Desk, termo inglês que designa o serviço de apoio a usuários para suporte e resolução de problemas técnicos em informática, telefonia e tecnologias de informação. Este apoio pode ser tanto dentro de uma empresa (profissionais que cuidam da manutenção de equipamentos e instalações dentro da empresa), quanto externamente (prestação de serviços a usuários).

Uma intranet é uma rede de computadores privada que assenta sobre a suíte de protocolos da Internet. Conseqüentemente, todos os conceitos da Internet, aplicamse também numa intranet como, por exemplo, o paradigma de cliente-servidor. Resumidamente, o conceito de intranet pode ser interpretado como "uma versão privada da Internet", ou uma mini-Internet, confinada a uma organização.

Conjunto de itens para se realizar um procedimento. Normalmente, as empresas de saúde juntam medicamentos, materiais, procedimentos e outros para formar um kit ou pacote para facilitar a solicitação destes itens no momento da utilização e também para efetuar o faturamento destes valores.

No contexto de um web site, significa estar disponível para acesso em tempo real. $\mathrm{Na}$ comunicação instantânea, significa estar disponível para a comunicação. Num contexto de um outro sistema de informação, significa estar 
operacional nas funções que desempenha nesse sistema. "em linha", mas com o significado mais claro de "ao vivo", "conectado" ou "ligado".

De modo oposto, estar offline (ou off-line) traduz-se na indisponibilidade da entidade perante o sistema.

Out-sourcing Out-sourcing designa a ação que existe por parte de uma organização em obter mão-de-obra de fora da empresa, ou seja, mão-de-obra terceirizada. Está fortemente ligado à idéia de subcontratação de serviços. Em outras palavras, "Outsourcing" é a transferência das atividades conhecidas como atividades meio, e nunca as atividades fins (produto final), para uma empresa terceirizada.

Pagers Dispositivo eletrônico usado para contatar pessoas mediante de uma rede de telecomunicações.

PDA (on-line ou Personal digital assistants (PDAs ou Handhelds), ou off-line) Assistente Pessoal Digital, é um computador de dimensões reduzidas, dotado de grande capacidade computacional, cumprindo as funções de agenda e sistema informático de escritório elementar, com possibilidade de interconexão com um computador pessoal e uma rede informática sem fios - wifi - para acesso a correio eletrónico e Internet.

POS (point of POS ou PoS é a abreviatura de ponto de venda ou ponto de sale) serviço (do inglês Point of Sale ou Point of Service). Pode ser uma loja varejista, um caixa em uma loja, ou um local onde uma transação financeira ocorre neste tipo de ambiente. Um POS também pode se referir ao sistema de caixa registradora usado em um estabelecimento. Sistemas de POS são usados em restaurantes, hotéis, estádios, hospitais, clínicas, além de lojas de varejo. O POS utiliza apenas uma 
linha telefônica para comunicação, e os cupons das vendas são impressos pelo próprio $P O S$, não sendo necessário o uso de um $P C$ ou qualquer outro sistema de automação comercial.

Sistema Legado Sistema legado é o termo utilizado em referência aos sistemas computacionais de uma organização que, apesar de serem bastante antigos, fornecem serviços essenciais. Geralmente utilizam bancos de dados obsoletos. São aplicações complexas, de difícil manutenção e que pelo grau de criticidade e custo para modernização, continua ativo.

Smartphone

Smartphone é um telefone celular com funcionalidades estendidas por meio de programas que podem ser carregados para rodarem no seu Sistema Operacional. Numa tradução livre, do inglês "smartphone" - "telefone inteligente". Usualmente um smartphone possui características mínimas de hardware, sendo as principais: conexão por infravermelho e bluetooth, capacidade de sincronização dos dados do organizador com um computador pessoal e câmera para fotos e vídeos.

SMS

Serviço de mensagens curtas ou Short message service (SMS). É um serviço disponível em telefones celulares (telemóveis) digitais que permite o envio de mensagens curtas (até 255 caracteres em GSM e 160 em CDMA) entre estes equipamentos e entre outros dispositivos de mão como palm e handheld, e até entre telefones fixos (linha-fixa).

Tomadores de Empresas que adquirem serviços de saúde junto a hospitais, serviço na saúde clínicas, empresas de diagnóstico e outras. 
em inglês; também conhecida como Web e WWW é um sistema de documentos em hipermídia que são interligados e executados na Internet. Os documentos podem estar na forma de vídeos, sons, hipertextos e figuras. 


\section{APÊNDICE}

APÊNDICE A - Roteiro para realização dos estudos de casos para o projeto: A Utilização da Tecnologia da Informação e a Criação de Valor (eficiência e eficácia) nas Estratégias de Negócios na Indústria da Saúde

O Estudo de Casos a ser conduzido visa a avaliar a utilização da $\mathrm{TI}$ em operações de serviço na indústria da saúde e de que forma esta pode criar valor. Para este estudo, conforme conceituado, criar valor significa propiciar maior eficiência e/ou eficácia. Consideram-se que as empresas podem obter lucratividade a partir do ambiente interno, por meio de seus recursos (BARNEY, 1995) e/ou a partir do ambiente externo, gerando oportunidades (PORTER, 1986). Nos dois casos, interno e externo, quando as empresas obtêm maior eficiência (menor custo) e/ou maior eficácia (qualidade, ou melhor, benefício), estas obtêm vantagens competitivas sustentáveis, que Ihes permitem rentabilidade, crescimento e sustentabilidade.

As estratégias de negócios que utilizam a TI para desenvolver novas formas de abordar o mercado são o objeto de estudo deste trabalho. O que se pretende compreender é como e por que a utilização da TI cria maior valor nas operações de serviço na saúde.

A coleta de dados será feita via entrevistas semi-estruturadas aplicadas pelo pesquisador.

O público interno alvo é composto por profissionais das áreas de negócio, operações de serviço e TI.

As questões e itens listados abaixo orientaram as entrevistas e a coleta de dados:

\section{1 - Questões gerais sobre a organização da empresa, as estratégias de negócios e o relacionamento com a TI:}

- Qual é(são) o(s) negócio(s) da empresa?

- Quais são os principais produtos?

- Qual (ou quais) a estratégia do(s) negócio(s) na visão da empresa? 
- Qual a estrutura da empresa (como ela é dividida)?

- Como é a operação da empresa (de modo geral)?

- A empresa é dividida em áreas de negócios?

\section{2 - Questões específicas sobre a estratégia de negócio e a TI}

Classificar a empresa em relação ao Modelo de Negócios (TAPSCOTT, 2001)

( ) Ágora. É um tipo de rede de negócio em que compradores e vendedores se encontram para negociar livremente e atribuir valor aos bens.

( ) Aliança. Tipo de rede de negócio em que compradores e vendedores se encontram para negociar livremente e atribuir valor aos bens.

( ) Agregação. Tipos de redes de negócios que oferecem grande variedade de produtos e serviços, com integração de valor.

( ) Cadeia de Valor. O provedor de contexto estrutura e dirige uma rede " $b$-web" para produzir uma proposta de valor altamente integrada.

( ) Rede Distributiva. Empresas que permitem o tráfego, a armazenagem, o tratamento de dados e outros serviços que dão suporte às redes de negócios.

Classificar o negócio/empresa: Formas de abordar o mercado usando a TI. Vide modelo de Rangan (2003)

( ) $1^{\circ}$. Quadrante: A empresa possui produtos e clientes e encontra novos modos de oferecer conveniências utilizando a TI.

( ) 2 $2^{\circ}$ Quadrante: Novos produtos para clientes já existentes. Ampliação da oferta do produto.

( ) 30. Quadrante: Novos clientes para produtos já existentes. Ampliação dos clientes por meio de novas formas de utilização.

( ) $4^{\circ}$. Quadrante: Produtos novos para clientes novos. Esta é a maior área de incerteza nos negócios utilizando a TI.

\section{3 - Diagnóstico Estratégico do Ambiente Externo}

Na seqüência, deverão ser aplicados os modelos estratégicos nos estudos de casos, analisando o impacto da utilização da TI no negócio em comparação ao formato tradicional. 


\section{- Aplicação do Modelo do Diamante (PORTER, 1999)}

o Fatores de Produção

- Condições da Demanda

o Setores Correlatos e de Apoio

o Estrutura e estratégia

Os itens, a seguir, orientarão quais características deverão ser abordadas no modelo estratégico citado acima. Os resultados da aplicação dos modelos estratégicos auxiliarão na compreensão das oportunidades do ambiente externo, propiciadas pela utilização da TI. Cada um dos itens deverá abordar o formato tradicional em relação ao formato utilizando a TI nas empresas.

\section{Macroambiente}

\section{o Condição dos Fatores de Produção}

o Dinâmica da mudança, transformação do ambiente produtivo, enquanto fator que propicia o desenvolvimento sustentado.

o Condições da Demanda

o Sofisticação da Demanda.

- Sofisticação, grau de exigência e especificidade da demanda no sentido de possibilitar o amadurecimento e desenvolvimento por parte da oferta.

o Fornecedores/Parceiros com Padrão Internacional

o Existência de fornecedores/parceiros dotados de competitividade internacional, oferecendo vantagens à jusante.

o Infra-Estrutura

o Competição estruturada

- Estrutura e rivalidade que contribui para o desenvolvimento do setor, gerando renovação não predatória, experimentação contínua e experiência continuada.

\section{o Outros Fatores Macroambientais}

o Economia

- Distribuição de renda

- Poupança, endividamento e disponibilidade de crédito 
- Inflação

- Câmbio

- Outros

o Demografia

- População

- Composição da população

- Etnias

- Nível instrução

- Outros

o Tecnologia

- Oportunidades de inovação

o Político-Legal

- Legislação regularizando os negócios

o Sociocultural

- Persistência a valores culturais

- Existência de subculturas

- Aplicação do Modelo das Cinco Forças (PORTER, 1986)

o Concorrência (rivalidade)

o Novos Entrantes

o Produtos Substitutos

o Compradores

o Fornecedores

Os itens, a seguir, orientarão quais características deverão ser abordadas no modelo estratégico citados acima. Os resultados da aplicação dos modelos estratégicos auxiliarão na compreensão das oportunidades do ambiente externo propiciadas pela utilização da TI. Cada um dos itens deverá abordar o formato tradicional em relação ao formato utilizando a TI nas empresas.

\section{Ambiente Externo: Ambiente Tarefa}

o Propensão dos negócios da empresa

o Negócios em Geral

- Expansão do foco do negócio da empresa 
- Explorar novos segmentos de mercado

- Ampliar campo de atuação do produto

- Estender vantagem de diferenciação ou custo

- Expansão do mercado de exportação

- Entrar em negócios relacionados

- Possibilitar integração vertical (jusante e montante)

- Ampliar portifólio corporativo

- Buscar mercados em rápida expansão

- Crescimento do mercado atual

\section{o Microambiente}

- Concorrência

- Rivalidade do setor

- Intensidade da rivalidade

- Competidores numerosos no segmento

- Competidores regionais

- Competidores internacionais

- Crescimento lento da indústria

- Potenciais incorporadores

- Possibilidade de novos entrantes (barreiras entrada custo/diferenciação) e (barreiras de saída)

- Custo (escala, capital, custos de mudança, tecnologia, acesso à matéria-prima, localização, curva aprendizagem, curva experiência, subsídios, outros)

- Diferenciação (diferenciação do produto, acesso a canais diferenciados, outros)

- Ativos especializados/específicos, alto custo de saída, barreiras emocionais, restrições governamentais.

\section{- Possibilidade de Produtos Substitutos}

- Novas formas de competição da indústria

- Mudança nos hábitos de consumo

- Fornecedores

- Poder de barganha com fornecedores 
- Quantidade de fornecedores na indústria

- Dependência dos fornecedores

- Insumo do fornecedor é essencial para a empresa

- Ameaça do fornecedor integrar a jusante

- Empresa não é um cliente importante para o fornecedor

- Compradores

- Poder de barganha com compradores

- Quantidade de compradores da indústria

- Dependência dos compradores

- Dependência de um comprador específico

- Ameaça do comprador integrar a montante

- Comprador tem total informação (demanda, custos, preço)

3 - Diagnóstico Estratégico Ambiente Interno (estratégia de negócio: tradicional versus $\mathrm{TI}$ )

- Aplicação do Modelo das Competências Essenciais (HAMEL e PRAHALAD, 1995)

o A competência essencial da empresa permite...

- Acessar quais (novos) mercados;

- Oferecer que tipo de contribuição significativa (custos ou benefícios);

- Oferecer uma complexa combinação de tecnologias individuais e conhecimentos especiais de produção de difícil imitação.

- Aplicação do Modelo das Fontes e Capacitações (BARNEY, 1995)

o Os recursos da empresa (financeiros, físicos, humanos, organizacionais, outros) pesquisada podem ser considerados ...

- Valiosos

- Raros

- Difíceis de imitar

- A empresa tem organização para se capitalizar com os recursos 
O Quadro 25 (Fontes e Capacitações) apresenta alguns recursos divididos em subitens, que orientam na análise do modelo:

\begin{tabular}{|l|l|l|l|l|l|}
\hline & & V & R & I & O \\
\hline Recursos Financeiros & Capacidade de Investimento & & & & \\
\hline & Relacionamento com Bancos & & & & \\
\hline & Endividamento Atual & & & & \\
\hline Recursos Físicos & Máquinas & & & & \\
\hline & Instalações & & & & \\
\hline & Construção & & & & \\
\hline Recursos Humanos & Experiência & & & & \\
\hline & Conhecimento & & & & \\
\hline & Propensão a correr riscos & & & & \\
\hline & Sabedoria das Pessoas & & & & \\
\hline Recursos Organiz. & História / Tradição & & & & \\
\hline & Relacionamento & & & & \\
\hline & Confiança & & & & \\
\hline & Cultura & & & & \\
\hline
\end{tabular}

Adaptado de Barney (1995)

Quadro 25 - Fontes e Capacitações

Na seqüência, serão apresentados outros itens do ambiente interno, os quais colaboram para compreender os pontos fortes do negócio das empresas ao utilizar a TI e complementam a análise dos modelos estratégicos acima. Estas questões estão divididas em níveis 1, 2 e 3 e devem ser questionadas considerando o uso da TI comparado ao modelo tradicional, quando isto se aplicar.

\section{Ambiente Interno: Desempenho Interno da Empresa}

\section{- Corporação}

o Reputação da empresa

- Participação no mercado

- Satisfação do cliente

- Retenção do cliente

o Organização 
- Unidades dos valores e clareza de propósitos da organização

- Fadiga da organização devido a exigências constantemente cobradas

- Consistência dos arranjos organizacionais com a estratégia

- Consistência no aprimoramento funcional

- Marketing

o Reputação / Qualidade do produto / Serviço

- Amplitude e profundidade da linha de produtos

- Lançamento de Novos produtos no mercado

Efetividade das inovações

Uso conjugado de produtos

o Efetividade da distribuição

- Cobertura e qualidade do canal

- Cobertura e qualidade do canal

- Intensidade das relações com o canal

- Capacidade de atendimento aos canais

- Cobertura geográfica

o Precificação adequada

- Eficiência na precificação

- Eficácia na precificação

o Impacto das promoções

- Efetividade na divulgação

- Efetividade na força de vendas

- Treinamento e capacitação da força de vendas

- Cobertura geográfica da força de vendas

- Finanças

o Finanças

- Custo ou disponibilidade de capital

- Fluxo de caixa

- Estabilidade financeira

- $\quad$ Operações/Produção

o Operações/Produção

- Instalações 
- Localização, incluindo custos de transportes e mão-de-obra

- Economia de escala

- Posição no custo de fabricação

- Curva de aprendizagem

- Novidade do equipamento

- Flexibilidade das instalações e dos equipamentos

- Capacidade

- Força de trabalho capaz e dedicada

- Capacidade de produzir no prazo

- Habilidades técnicas de fabricação

- Acesso e custo de matéria-prima

- Grau de integração vertical

- Recursos Humanos

o Recursos Humanos

- Liderança visionária e capaz

- Funcionários dedicados

- Orientação empreendedora

- Flexibilidade ou boa capacidade de resposta

- Outros

o Pesquisa e Engenharia

- Patentes e direitos autorais

- Capacidade própria de pesquisa e desenvolvimento (pesquisa básica, produto, processo, etc.)

- Acesso a fontes externas de pesquisa e engenharia (fornecedores, clientes, contratantes)

- Flexibilidade ou boa capacidade de resposta

\section{4 - Direcionadores de Negócios Utilizando a TI}

No Quadro 26 - Direcionadores de Negócios Utilizando a TI, são apresentados direcionadores que contribuem para avaliar se a estratégia de negócio utilizada nas operações de serviço na saúde tem maior ou menor possibilidade de êxito.

1 - Entrega eletrônica

2 - Intensidade da informação 


\begin{tabular}{|l|}
\hline 3 - Customização \\
\hline 4 - Efeitos da agregação \\
\hline 5 - Custo de procura \\
\hline 6 - Interface em tempo real \\
\hline 7 - Risco do contratante \\
\hline 8 - Efeitos da rede (eficiência) \\
\hline 9 - Benefícios de padronização \\
\hline 10 - Competências ausentes \\
\hline
\end{tabular}

Adaptado de Andal-Ancion et al. (2003)

Quadro 26 - Direcionadores de Negócios Utilizando a TI

\section{5 - Diagnóstico - Avaliação do Valor (eficiência / eficácia)}

- Cadeia de Valor

- Cadeia de Suprimentos

- Redes de Valor

Obs. Utilizar direcionadores de custo e condutores de singularidade (abaixo) de forma a avaliar os três itens listados: cadeia de valor, cadeia de suprimentos e redes de valor.

Direcionadores de Custo na Cadeia de Valor

- $\quad$ Economia de escala (tecnologia, tamanho lote)

- $\quad$ Aprendizagem (aumento eficiência)

- Padrão utilizado da capacidade

- $\quad$ Elos (grau de integração das áreas)

- Inter-relações (compartilhar atividades com empresas do mesmo grupo)

- Integração (grau de verticalização)

- Momento oportuno (custo oportunidade)

- Políticas discricionárias (arbitrárias)

- $\quad$ Localização (afetando o custo)

- Custos em geral 
- Escolhas de políticas (atividades a serem executadas e como serão executadas). Desempenho e característica, serviços fornecidos, intensidade de uma atividade adotada.

- $\quad$ Elos (fornecedores e canais)

- $\quad$ Oportunidade (10. a adotar X, pioneirismo)

- Localização (acessibilidade)

- Inter-relações (compartilhar atividades com empresas do mesmo grupo)

- $\quad$ Aprendizagem (know-how superior)

- $\quad$ Integração (nível de verticalização tornando singular)

- $\quad$ Fatores institucionais (marca) 
APÊNDICE B - Avaliação das Contribuições da TI - Casos C1, C2, C3, C4, C5, C6, C7, C8, C9, C10, C11, C12, C13 e C14

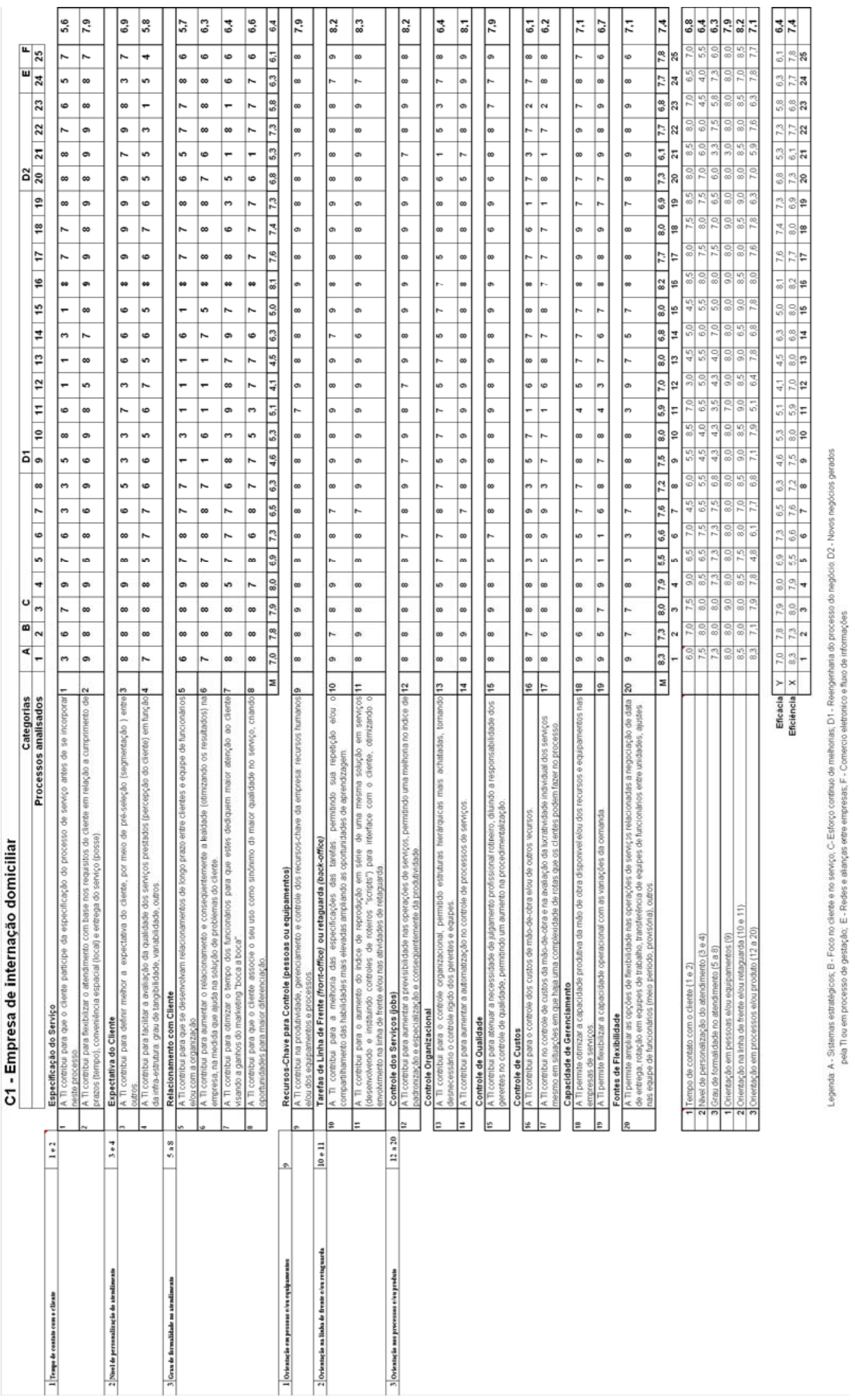




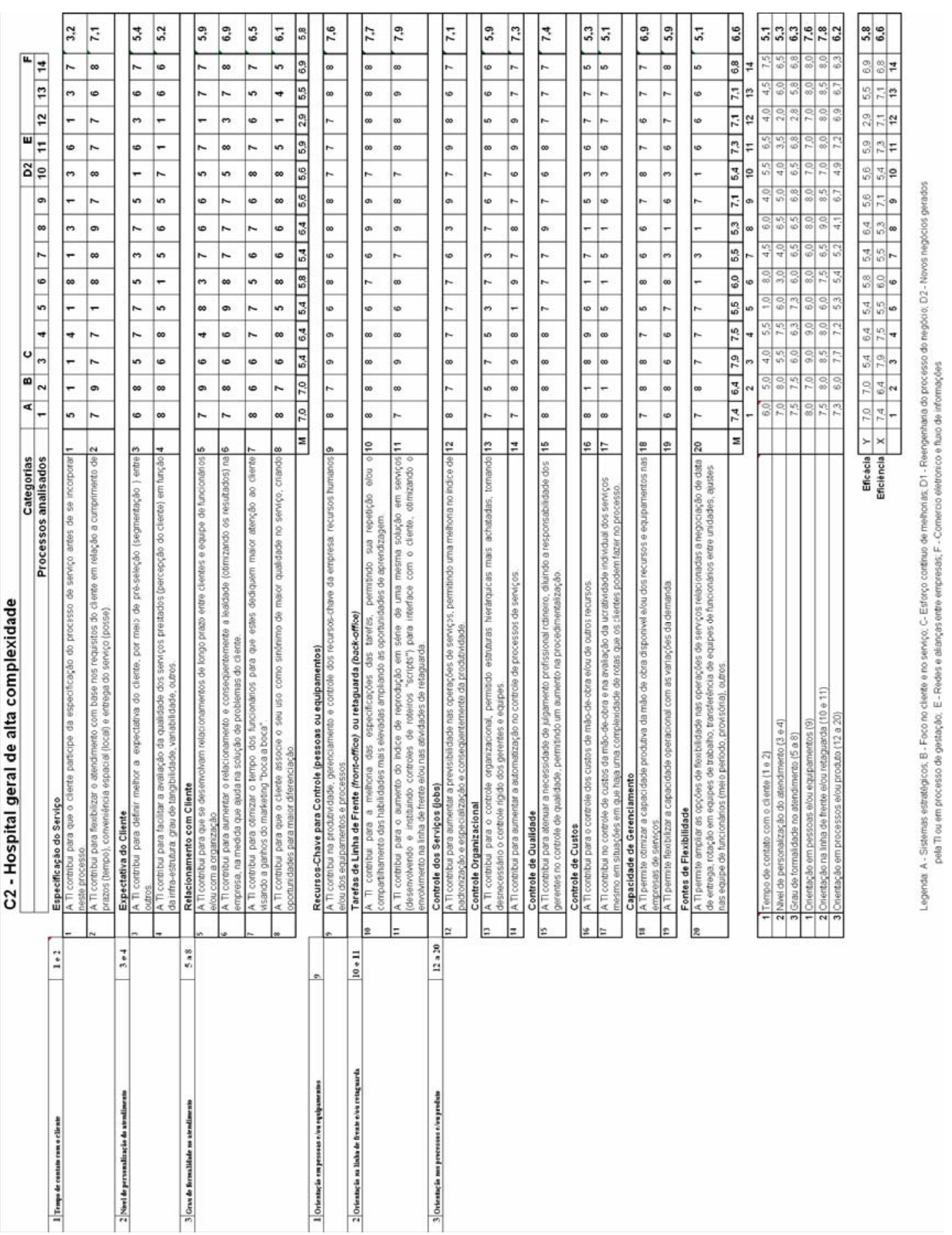




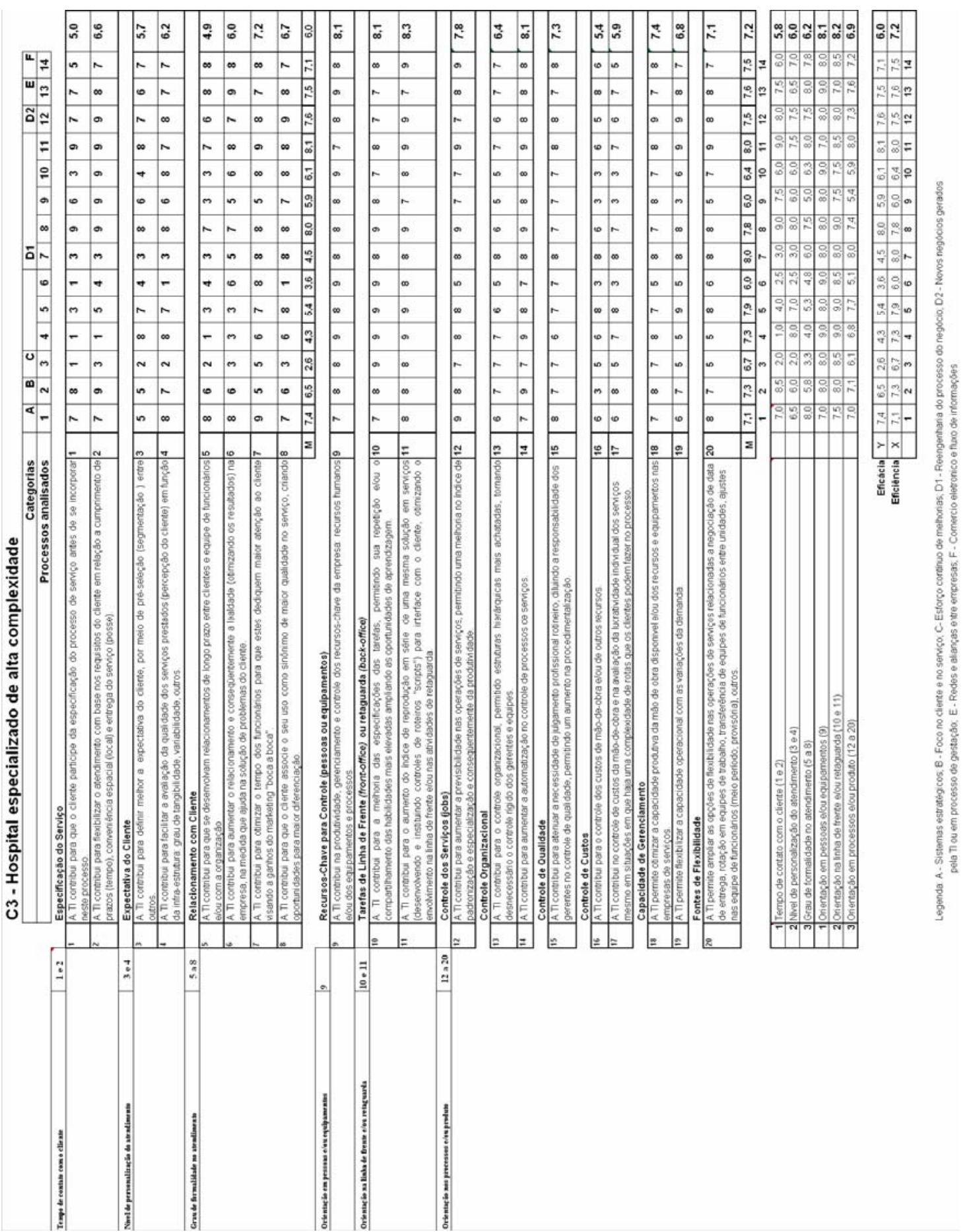




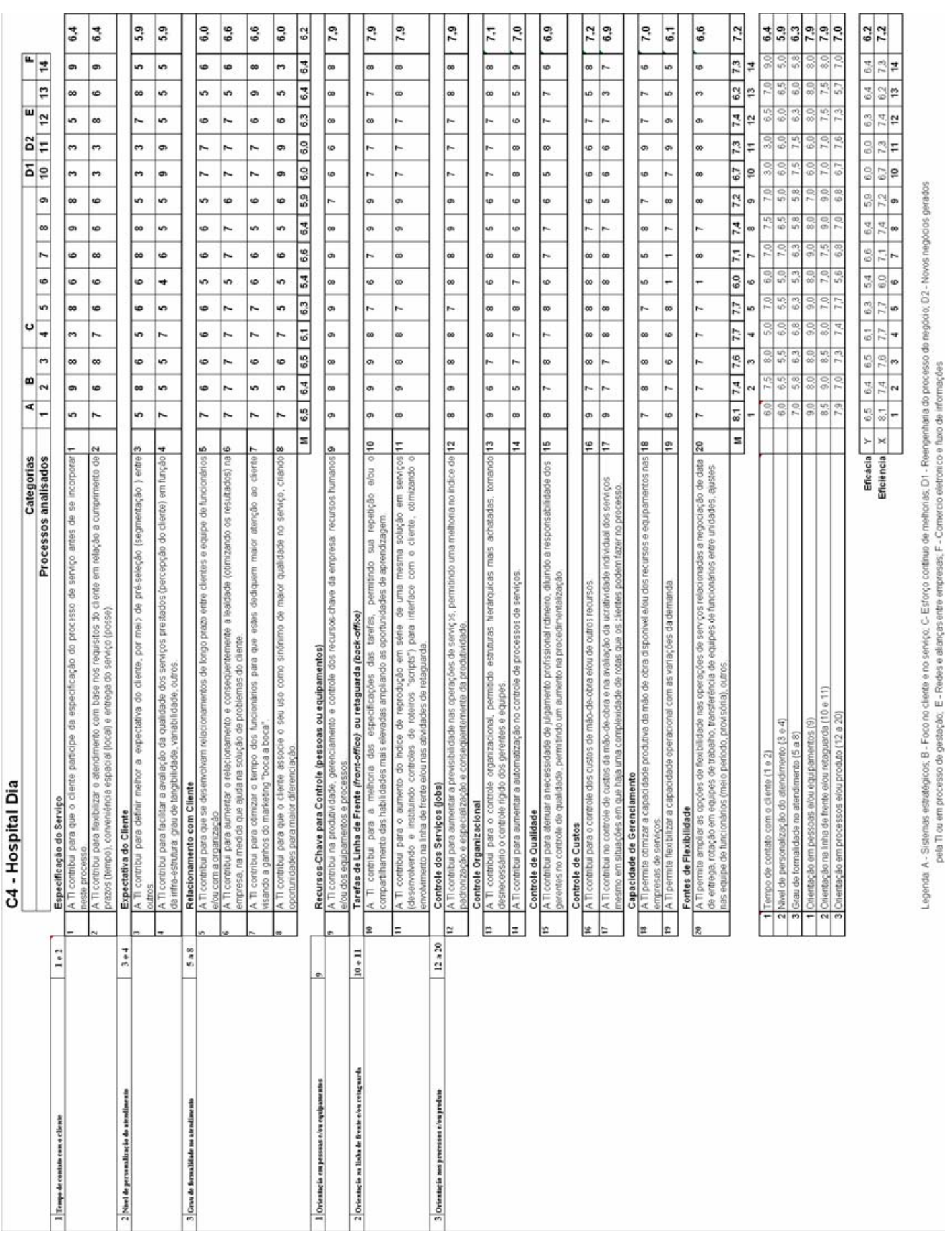




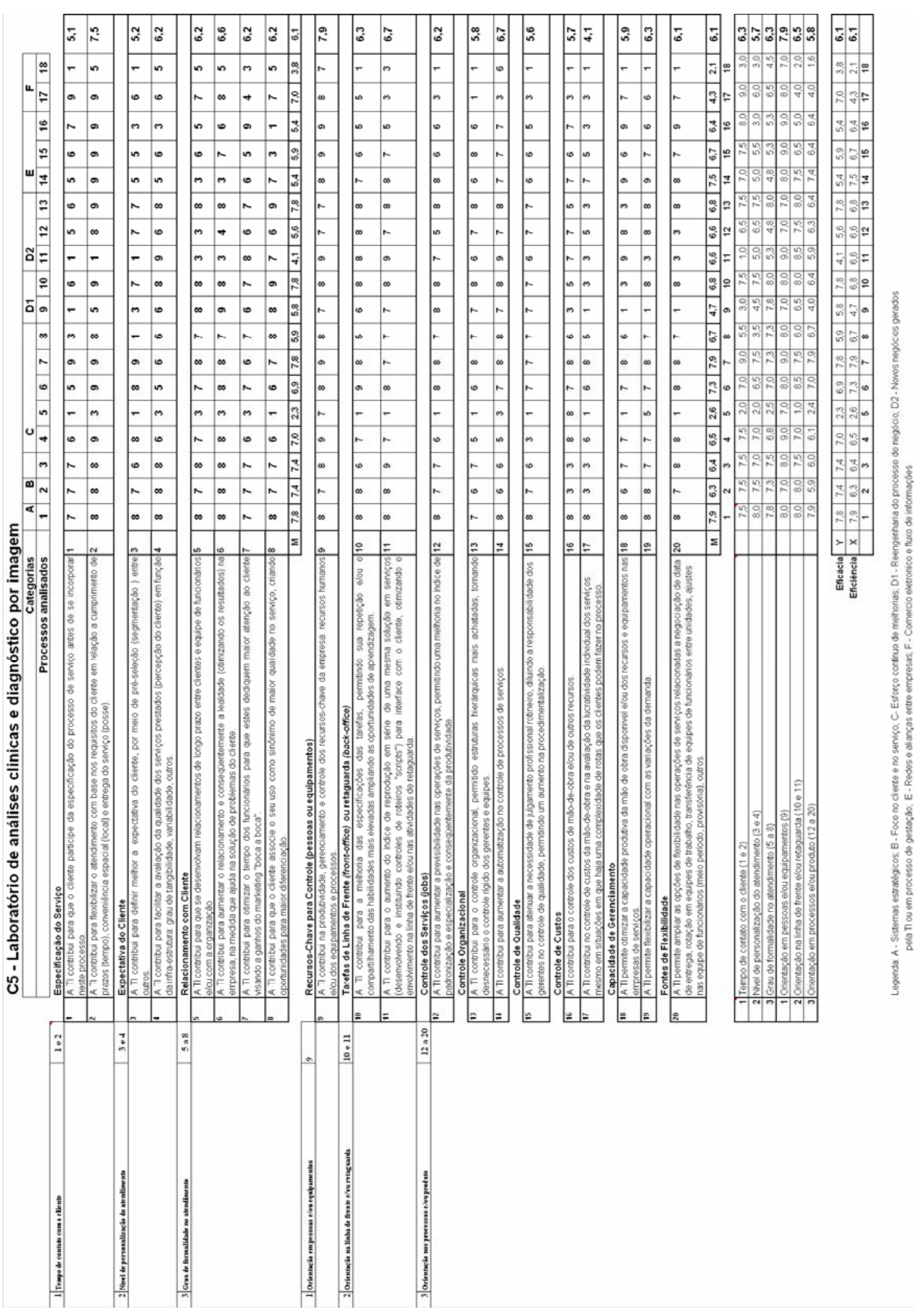




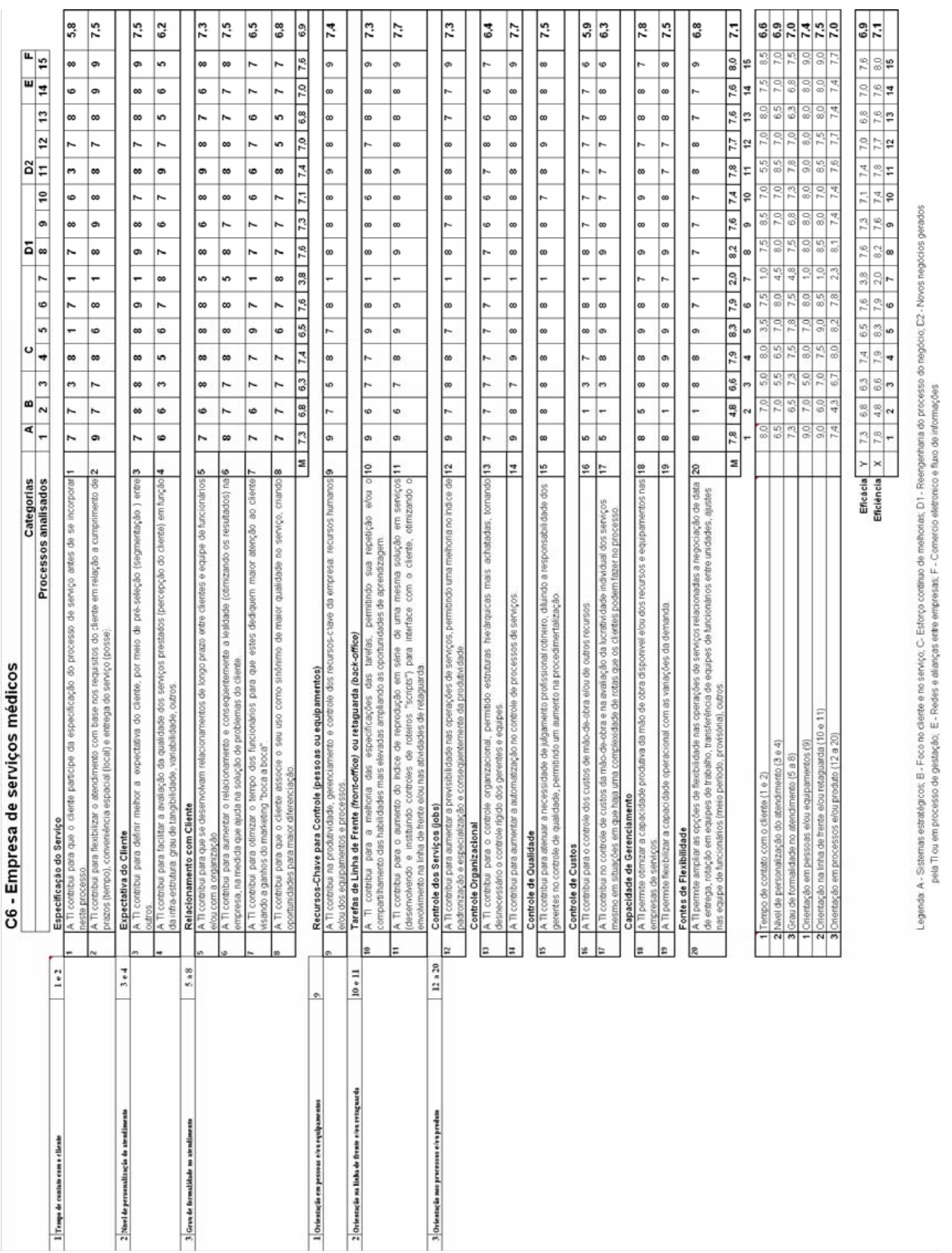




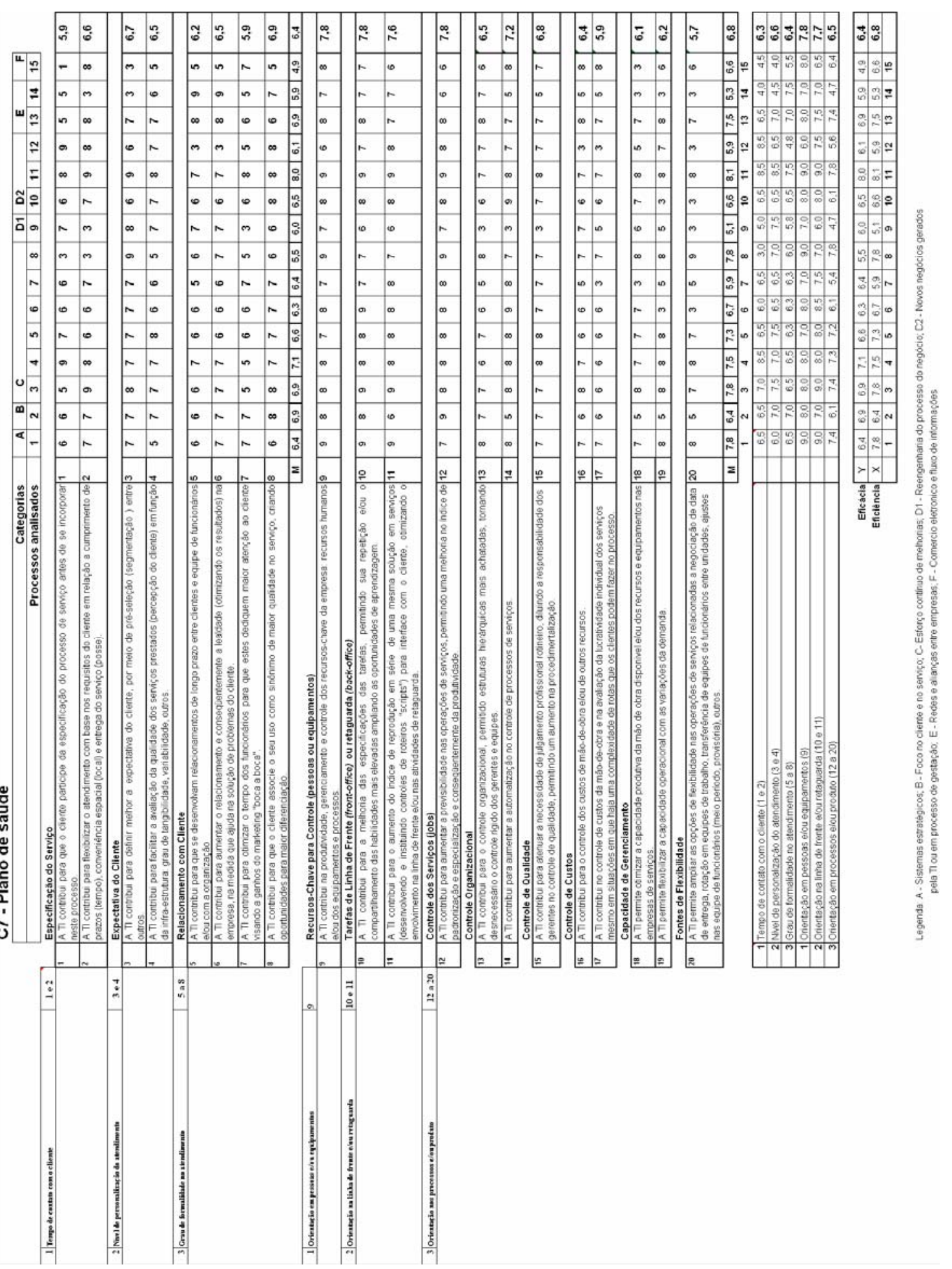




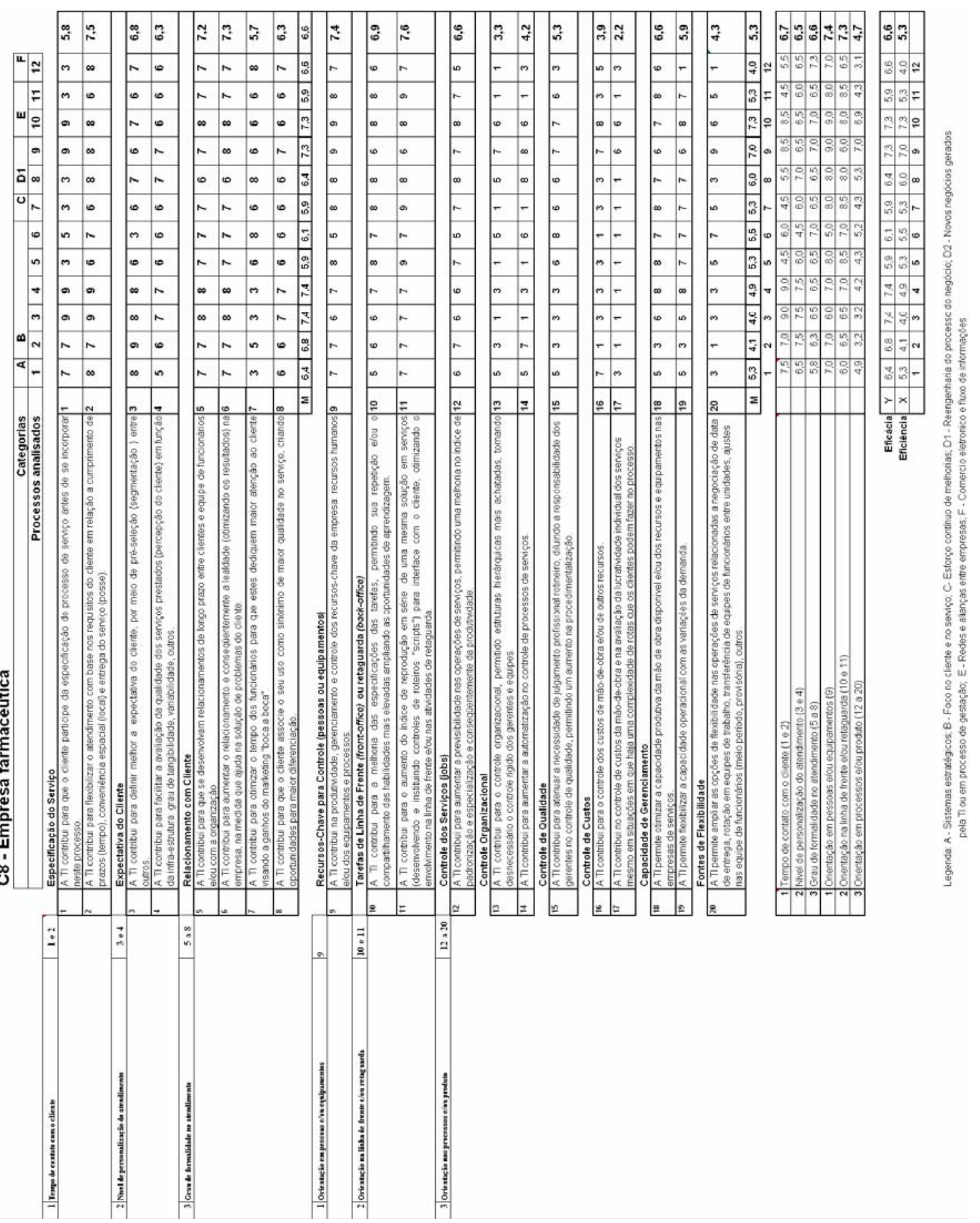




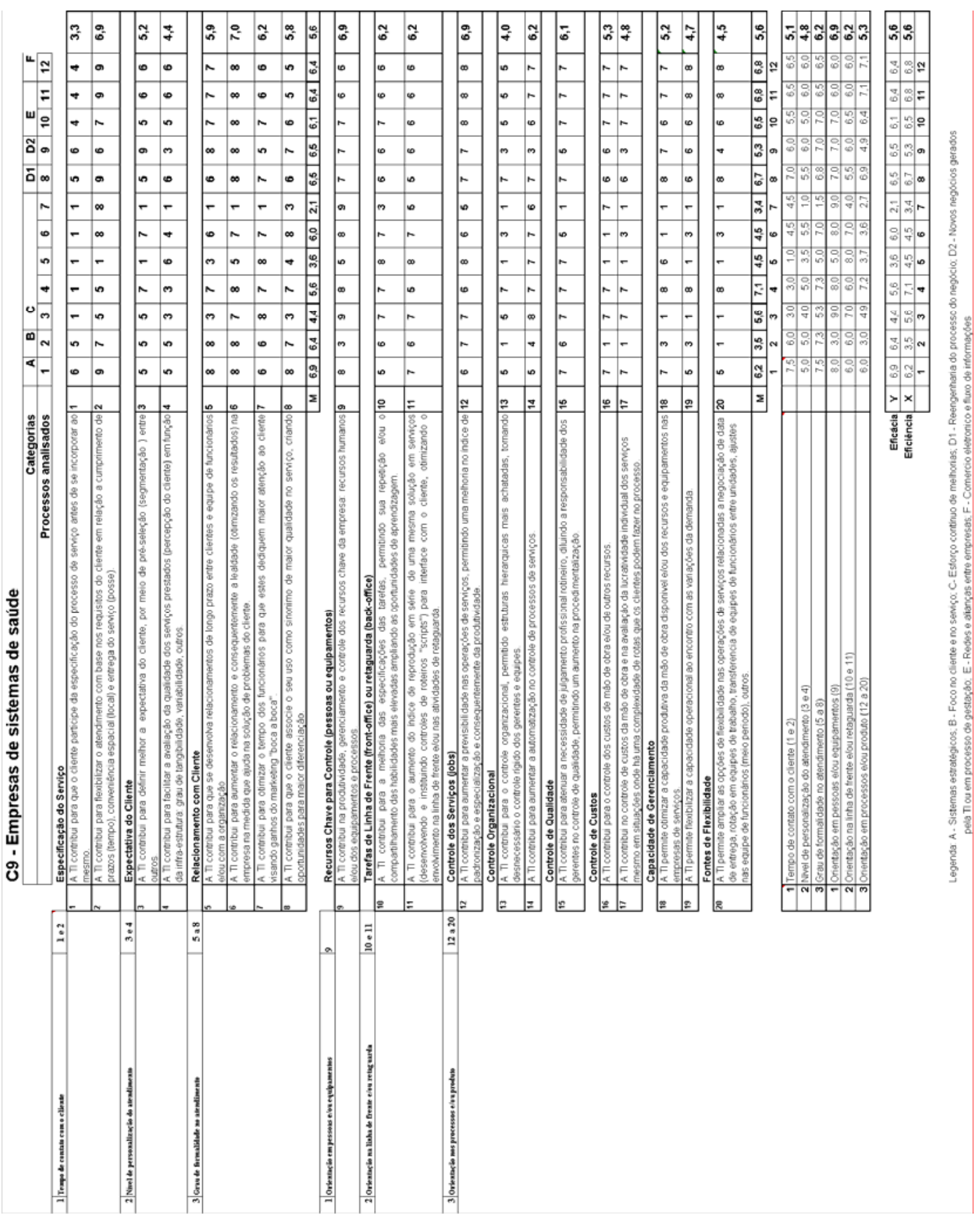




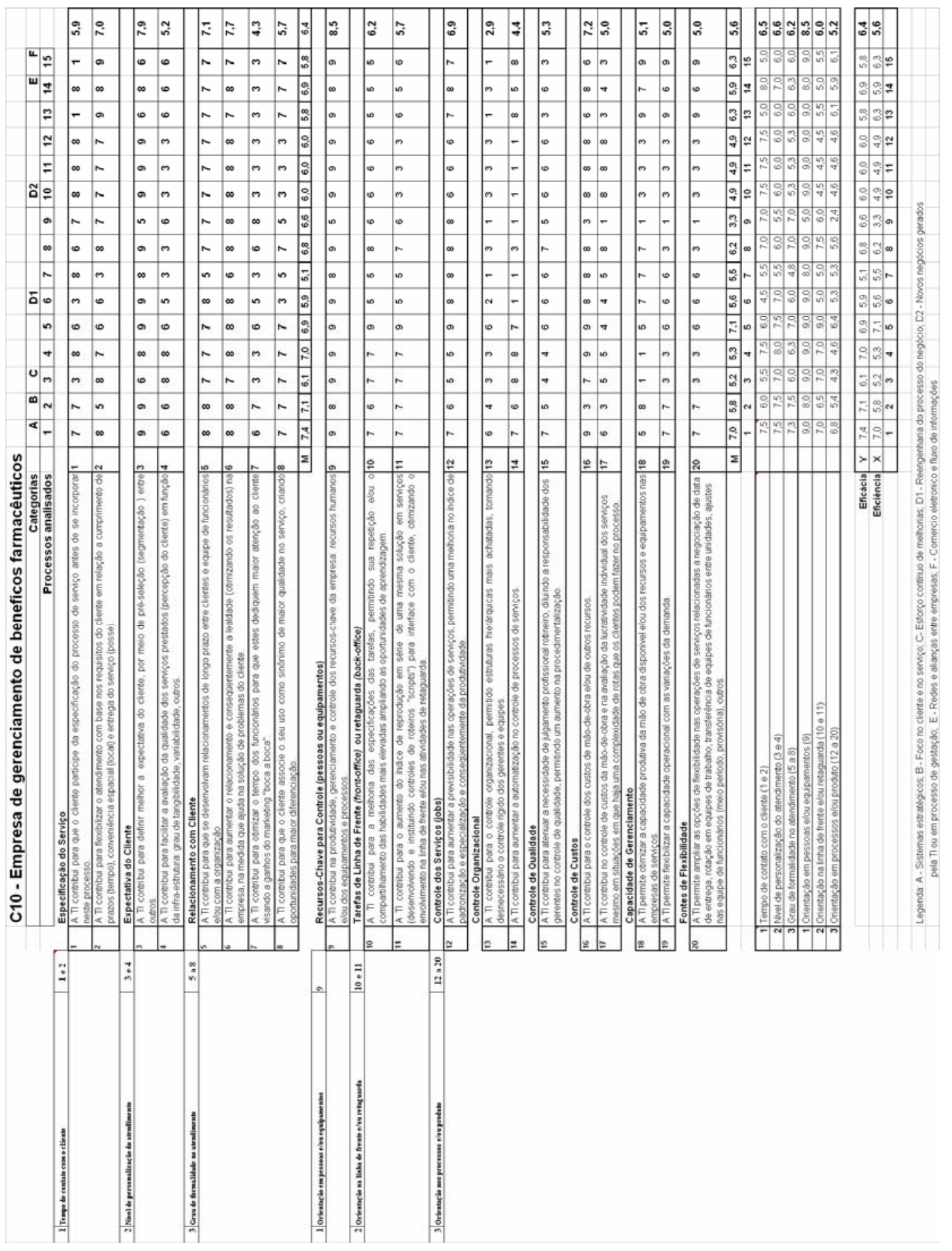




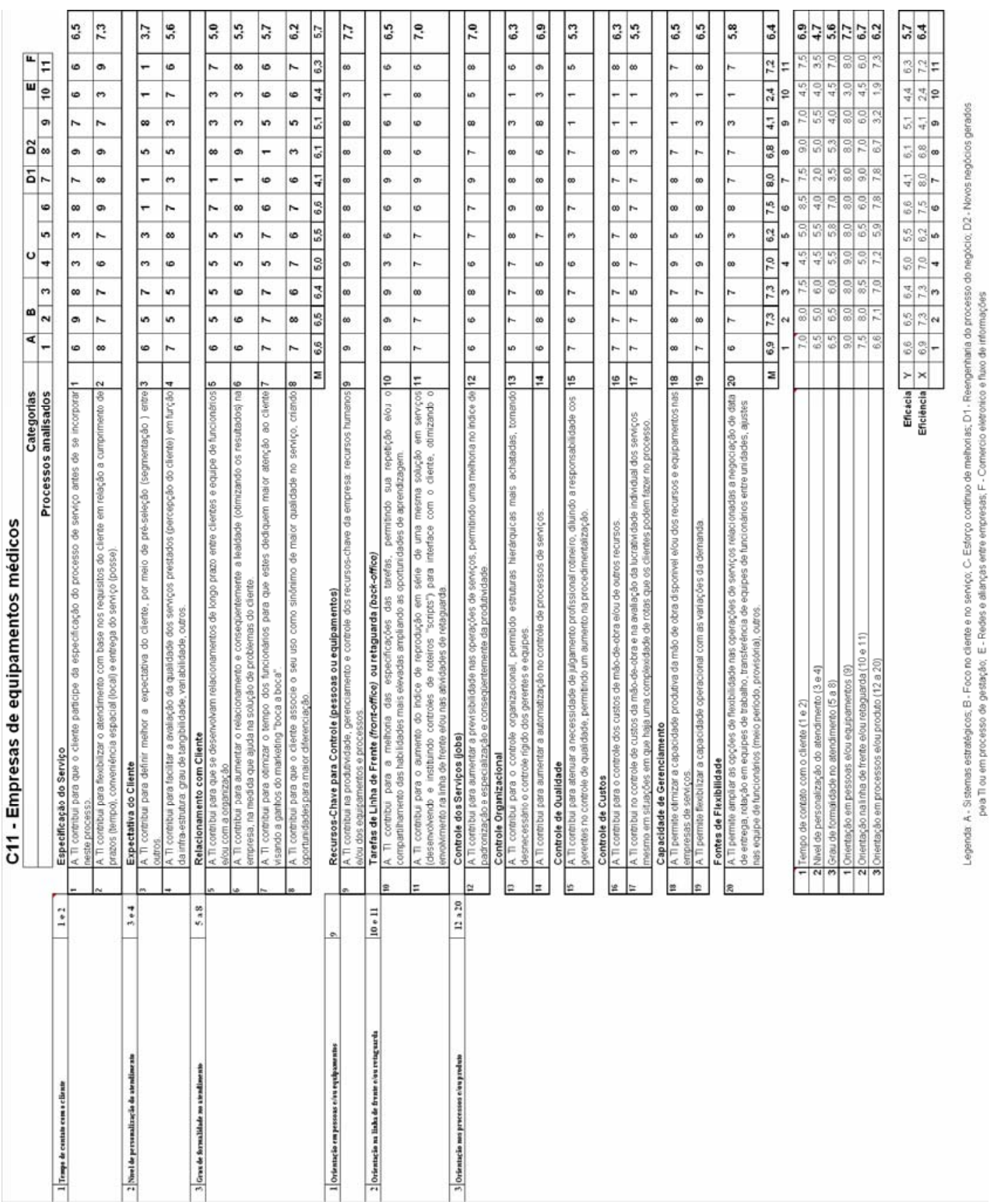




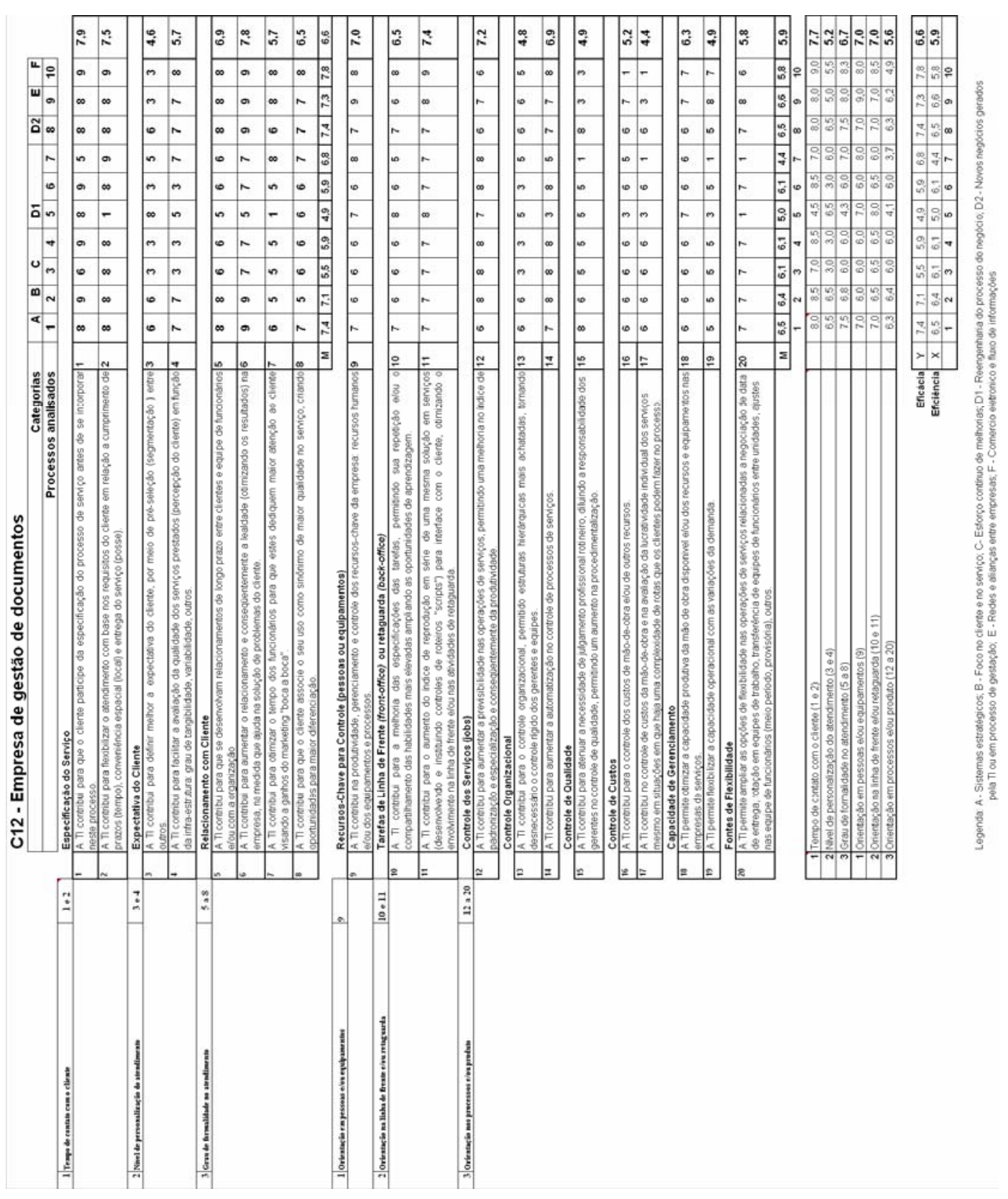




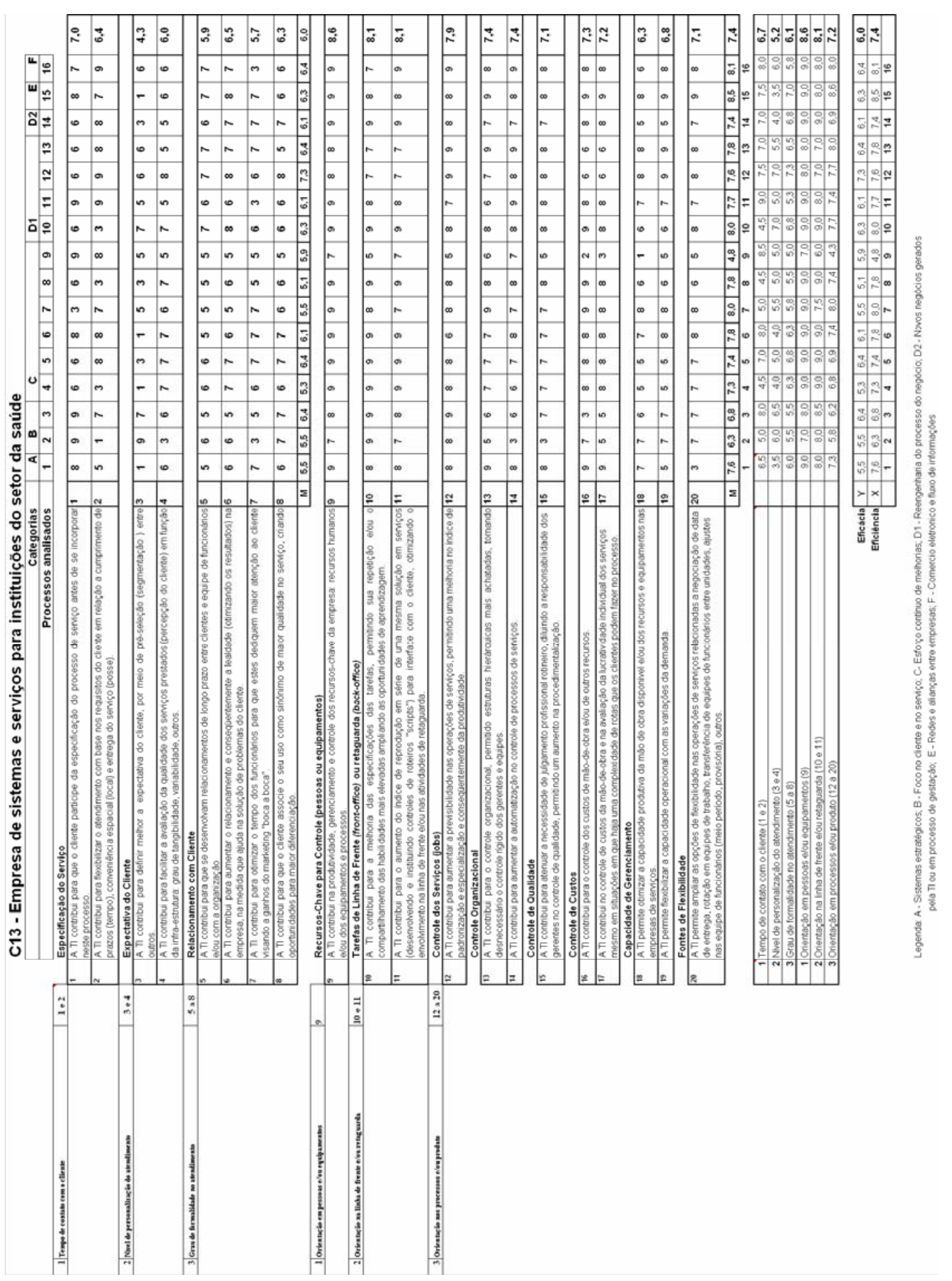




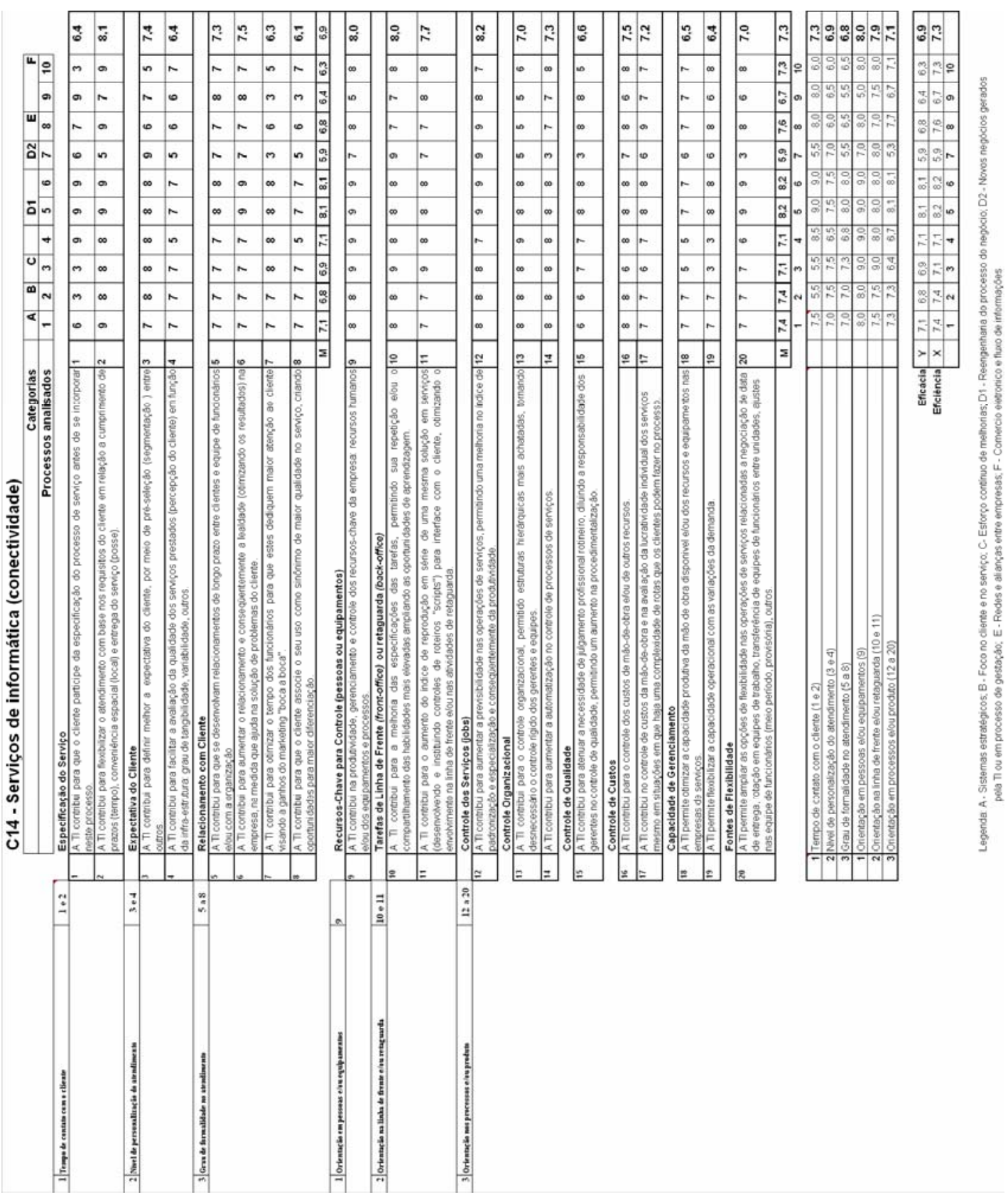

